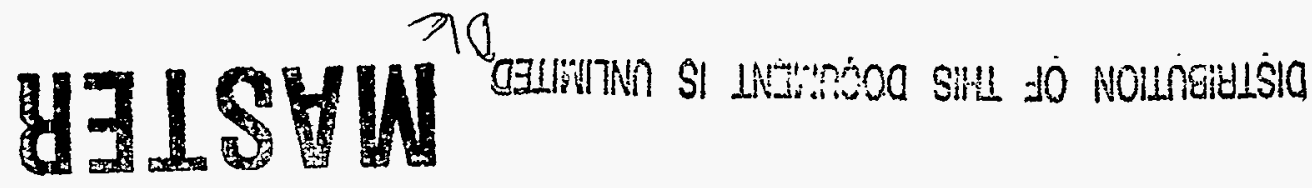

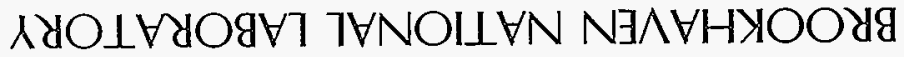

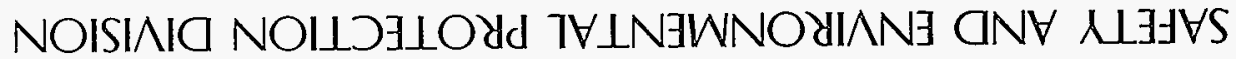

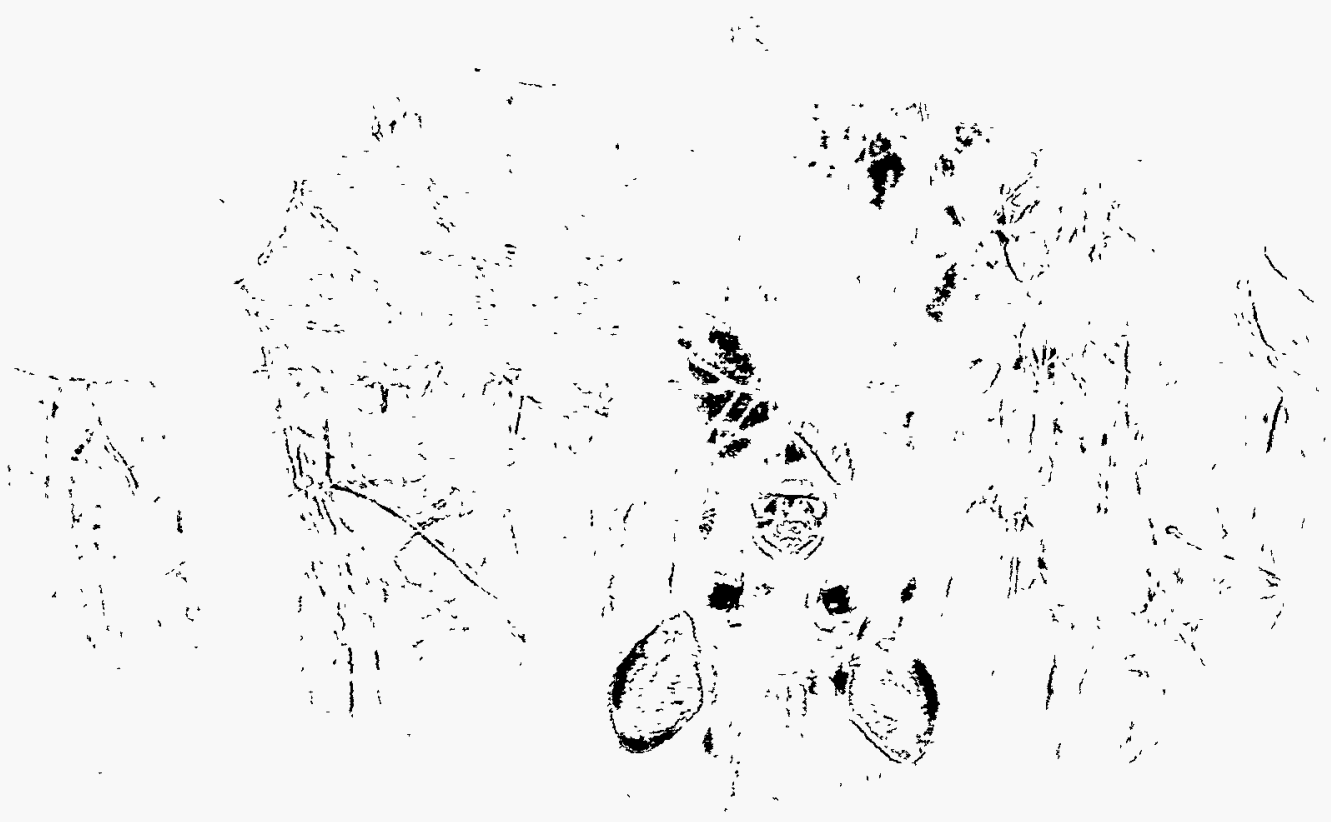

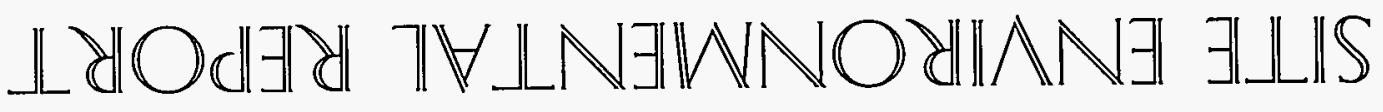
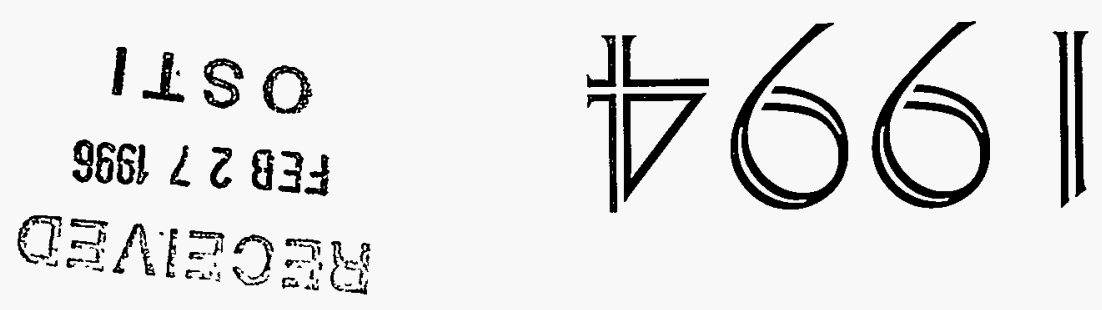


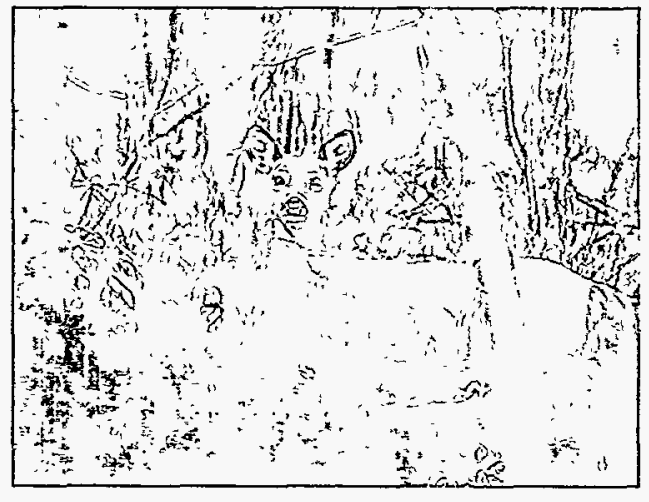

White-tailed deer Odocoileus virginianus Zimmerman

The white-tailed deer or Virginia deer has long and varied history on Long Island. Archaeological finds and early Colonial records show that for centuries this was the principal big game species hunted by Long Island Indians and was one of their important sources of food. In the early 1800 s, the number of deer declined with the spread of white settlers throughout the area; this was followed by enactment of various laws to conserve the deer herd. One of them especially designed to protect the deer during breeding season and the strict enforcement of game laws allowed the deer to spring back to its natural population. In addition, the extirpation of wolves further allowed the deer to rebound in their population. Thus the deer have spread widely over much of the island, although the expanding metropolitan area restricts their numbers in the western portion. At the present time deer are numerous on the eastern half of Long Island, where there is suitable cover, which coupled with mild winters, abundance of food absence of large predators except dogs, and the regulated hunting have favored deer abundance in the more thinly settled areas of Long Island.

Deer are encountered in all kinds of woods, including the Island's Pine Barrens, where they are numerous, and around fields, ponds and bogs. At Hither Hills, deer are common in oak woods and other habitats. In Peconic bay, deer were seen on Jesup Neck, and are also present on Robins island. On the north shore they are present locally in deciduous woods overlooking Long Island sound, and east to the vicinity of Orient. In the western Suffolk County, deer are regular but uncommon in the vicinity of Dix hills but are numerous in Heckscher State park on great South Bay. Deer are also seen on Gardiners Island, Shelter Island, and Fire Island. Controlled marketing is practiced on Gardiner's Island where deer are abundant. Gardiner's Island incidentally, has had a uniquely long record of one-family ownership, and the deer are carefully protected in the days when they were reduced significantly elsewhere on eastern Long Island.

Deer population, like many animals, are affected by climatic changes, conflicts with agricultural interests, land developers and reduction of their natural habitats, which in turn results in dramatic impacts on vegetation, inhibiting forest regeneration, affecting species composition and amount of ground cover, the latter in turn affects the habitat of many wildlife species. Deer/vehicle accidents are also a major concern.

With species such as the white-talled deer whose populations are not self limiting and can cause serious damage to their own range, orderly annual removal of animals is necessary to maintain populations in balance with carrying capacity and at levels where conflicts with man's use of the land can be tolerated. Some deer populations should be reduced, other populations stabilized, while some deer populations should be increased. The programs in place through proper regulation as evidenced on Long Island have allowed this delicate balance to survive. This has allowed hunting within limits, has allowed the deer population to be maintained at natural levels, and has allowed us to enjoy seeing them and recreating in what can be considered a wild setting. 


\title{
BROOKHAVEN NATIONAL LABORATORY SITE ENVIRONMENTAL REPORT FOR CALENDAR YEAR 1994
}

\author{
J.R. Naidu and B.A. Royce, Editors
}

May 1995

SAFETY AND ENVIRONMENTAL PROTECTION DIVISION

BROOKHAVEN NATIONAL LABORATORY

ASSOCIATED UNIVERSITIES, INC.

UPTON, LONG ISLAND, NEW YORK 11973

UNDER CONTRACT NO. DE-AC02-76CHO0016 WITH THE UNITED STATES DEPARTMENT OF ENERGY

Brookhaven National Laboratory Upton, Long Island, New York 11973

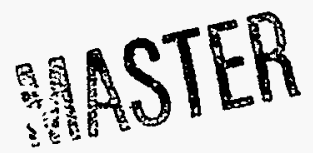

DISTRIBUTION OF THS DOCUIAENT IS LNLIAITED 


\section{DISCLAIMER}

This report was prepared as an account of work sponsored by an agency of the United States Government. Neither the United States Government nor any agency thereof, nor any of their employees, nor any of their contractors, subcontractors, or their employees, makes any warranty, express or implied, or assumes any legal liability or responsibility for the accuracy, completeness, or usefulness of any information, apparatus, product, or process disclosed, or represents that its use would not infringe privately owned rights. Reference herein to any specific commercial product, process, or service by trade name, trademark, manufacturer, or otherwise, does not necessarily constitute or imply its endorsement, recommendation, or favoring by the United States Government or any agency, contractor or subcontractor thereof. The views and opinions of authors expressed herein do not necessarily state or reflect those of the United States Government or any agency, contractor or subcontractor thereof.

Printed in the United States of America Available from

National Technical Information Service

U.S. Department of Commerce

5285 Port Royal Road

Springfield, VA 22161

NTIS price codes:

Printed Copy: A13; Microfiche Copy: A01 
The U.S. Department of Energy order 5400.1, "General Environmental Protection Program", establishes the requirement for environmental protection programs. These programs ensure that Department of Energy operations comply with applicable federal, state, and local environmental laws and regulations, executive orders, and department policies. Brookhaven National Iaboratory has established a plan for implementing this order, Environmental Protection Implementation Plan. This plan is updated annually.

The Brookhaven National Laboratory Site Environmental Report is prepared annual.1y pursuant to Department of Energy order 5400.1 to summarize environmental data, characterize the Brookhaven National Laboratory site, demonstrate compliance status, provide an assessment of the impact of Brookhaven National Laboratory's operations on the environment, and document the efforts made by Brookhaven National Laboratory Management to mitigate environmental impacts. More detailed environmental compliance, monitoring, surveillance, and study reports may be of value, therefore, to the extent practical, these additional reports have been referenced in the text.

This report is prepared for the Department of Energy by the safety and Environmental Protection Division at Brookhaven National Laboratory. The document is the responsibility of the Environmental Management section of the Safety Environment \& Protection Division. Within this section, the sampling \& Analysis Group is responsible for preparing the sampling plan, collecting environmental and facility samples, analyses of samples, interpretation of results, performing impact analysis of the emissions and effluents from Brookhaven National Laboratory, and compiling of this information presented here. In this effort, other groups of the section/Division: Compliance, Groundwater, and Quality Assurance played key roles in addressing the regulatory aspects, review and interpretation of data, and documentation of data.

Although this report is written to meet Department of Energy requirements and guidelines, it is also intended to meet the needs of the public. The Executive summary has been written with a minimum of technical information, and a condensed version of this site Environmental Report, titled summary Report, has also been prepared for Public distribution. In addition, the Appendices provides a list of acronyms, abbreviations, and other useful information. Also, the accompanying tables in the text represents a summary of corresponding data, whereas the 1994 Brookhaven National Laboratory site Environmental Report Compendium presents the analytical data in full detail for those who need to review the data in toto.

Inquiries regarding this report and the summary Report may be directed to the Public Affairs Office, Brookhaven National Laboratory, Upton, New York 11973 (516 282-2345). 



\section{Abstract}

This report documents the results of the Environmental Monitoring Program at Brookhaven National Laboratory and presents summary information about environmental compliance for 1994. To evaluate the effect of Brookhaven National Laboratory's operations on the local environment, measurements of direct radiation, and a variety of radionuclides and chemical compounds in ambient air, soil, sewage effluent, surface water, groundwater, fauna and vegetation were made at the Brookhaven National Laboratory site and at sites adjacent to the Laboratory.

Brookhaven National Laboratory's compliance with all applicable guides, standards, and limits for radiological and nonradiological emissions and effluents to the environment were evaluated. Among the permitted facilities, two instances of $\mathrm{pH}$ exceedances were observed at recharge basins, possibly related to rain-water run-off to these recharge basins. Also, the discharge from the Sewage Treatment Plant to the Peconic River exceeded on ten occasions, one each for fecal coliform and 5-day Biochemical oxygen Demand (avg.) and eight for ammonia nitrogen. The ammonia and Biochemical oxygen Demand exceedances were attributed to the cold winter and the routine cultivation of the sand filter beds which resulted in the hydraulic overloading of the filter beds and the possible destruction of nitrifying bacteria. The on-set of warm weather and increased aeration of the filter beds via cultivation helped to alleviate this condition. The discharge of fecal coliform may also be linked to this occurrence, in that the increase in fecal coliform coincided with the increased cultivation of the sand filter beds.

The environmental monitoring data has identified site-specific contamination of groundwater and soil. These areas are subject to Remedial Investigation/Feasibility Studies under the Inter Agency Agreement. Except for the above, the environmental monitoring data has continued to demonstrate that compliance was achieved with applicable environmental laws and regulations governing emission and discharge of materials to the environment, and that the environmental impacts at Brookhaven National Laboratory are minimal and pose no threat to the public or to the environment.

This report meets the requirements of Department of Energy Orders 5484.1, Environmental Protection, safety, and Health Protection Information reporting requirements and 5400.1, General Environmental Protection Programs. 


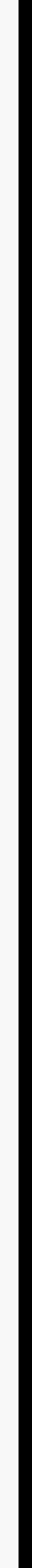




\section{Acknowledgment}

There are many individuals who assisted in the collection of data, and preparation of this report. The editors express their gratitude to all these individuals. However, the following individual efforts require special acknowledgment.

Monitoring and surveillance data were obtained through the combined efforts of the Sampling Team and the Analytical Team (Radiological and Nonradiological). special recognition is reserved for the dedication and professionalism of the Sampling \& Analysis staff: M. Bero, R. Lagattolla, and L. Lettieri; the Analytical Laboratory staff: C. Decker, R. Gaschott, P. Hayde, A. Meier, L. Muench, J. Odin and M. Surico.

The editors further extend their appreciation to the authors of the main sections of this report, which has included review of data, preparation of text, and in some cases, even participating in the collection of data. These individuals are:

\section{Environmental Management Section}

$\begin{array}{ll}\text { S. Chalasani } & \text { Nonradiological Analysis and Data Review } \\ \text { M. Clancy } & \text { Hazardous Waste } \\ \text { G. Goode } & \text { Waste Minimization and Pollution Awareness Plans } \\ \text { R. Lee } & \text { Compliance - Surface Water and Potable Water } \\ \text { D. Paquette } & \text { Groundwater Management } \\ \text { G. Schroeder } & \text { Radiological Data Assay, National Emission standards for } \\ & \text { Hazardous Air Pollutants, and Radiological Surveys } \\ \text { K. Shurberg } & \text { Compliance - Resource Conservation Recovery Act } \\ \text { T. Sperry } & \text { Compliance - National Environmental Policy Act } \\ \text { J. Williams } & \text { Compliance - Air }\end{array}$

Other S\&EP Contributors:
G. Adams
Asbestos
H. Bowen
S. Briggs
Data Base and Data Reports
R. Thompson
Quality Assurance
Thermo Iuminescent Dosimeter Assays
Contributors from other Departments:

W. Gunther and Staff, principally R. Howe and K. Geiger, office of Environmental Restoration, Comprehensive Environmental Response, Compensation, and Liability Act activities.

Finally, the Editors would like to extend a special thanks to Marie De Angelis and Rosemary Taylor for their infinite patience and quality of work in typing, reviewing, and finalizing this report. 


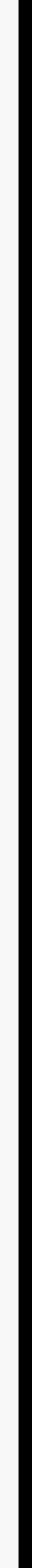


Preface . . . . . . . . . . . . . . . . . . . . . . iii

Abstract . . . . . . . . . . . . . . . . . . . . . v v

Acknowledgment . . . . . . . . . . . . . . . . . . . . . vii

Executive summary ......................... . . . . s-1

1.0

INTRODUCTION . . . . . . . . . . . . . . . . . 1-1

Site Mission . . . . . . . . . . . . . . . $1-1$

Site Characteristics ... . . . . . . . . . . . 1-1

1.2

Existing Facilities.................. . 1-11

2.0

2.1

COMPLIANCE SUMMARY . . . . . . . . . . . . . . . . . 2-1

2.2

2.2 .1

2.2 .2

2.3

2.3 .1

2.3 .1 .1

2.3 .1 .2

2.3 .2

2.3 .3

2.3 .4

2.3 .4 .1

2.3 .5

2.4

2.4 .1

2.4 .2

2.4 .2 .1

Environmental Permits. . . . . . . . . . . . . . . . 2-1

Groundwater Compliance Monitoring. . . . . . . . . . 2-1

Current Landfill . . . . . . . . . . . . . . . . 2-1

Major Petroleum Facility . . . . . . . . . . . . . 2-4

Clean Water Act . . . . . . . . . . . . . . . . . . . . 2-4

State Pollution Discharge Elimination System Permit. . . . 2-4

Recharge Basins . . . . . . . . . . . . . . . . 2-5

Sewage Treatment Plant Effluent . . . . . . . . . . 2-6

State Pollution Discharge Elimination system

Inspections and Audits . . . . . . . . . . . . . . . . . 2-9

National Pollutant Discharge Elimination system

Analytical Quality Assurance .. . . . . . . . . . . 2-9

Major Petroleum Facility . . . . . . . . . . . . . . 2-10

Spill Prevention, Control, and Countermeasures Plan . . . 2-11

oil/Chemical spills.................. 2-11

Clean Air Act . . . . . . . . . . . . . . . . . . 2-18

Conventional Air Pollutants............. 2-18

National Emission Standards for Hazardous Air

Pollutants . . . . . . . . . . . . . . . . . 2-21

National Emission Standards for Hazardous Air Pollutants . 2-21

2.4.2.2 Asbestos Emissions . . . . . . . . . . . . . . . . . 2-22

2.5 Suffolk County Sanitary Codes . . . . . . . . . . . . . 2-22

2.6 Safe Drinking Water Act . . . . . . . . . . . . . . 2-23

2.6.1 Applicability to Brookhaven National Laboratory . . . . . . 2-23

2.6.2 Potable Water Monitoring Requirements . . . . . . . . . 2-23

2.7 Toxic substance Control Act ............... . 2-30

2.7.1 Toxic Substance Control Act Program at Brookhaven

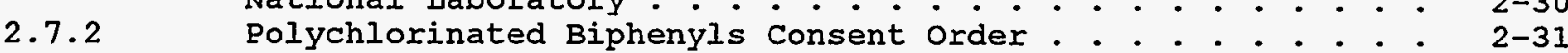

2.7.3 Environmental Protection Agency Authorized

$2.8 \quad$ New York State Department of Environmental Conservation $\cdot{ }^{\cdot} \cdot{ }^{2-32}$

2.9 Resource Conservation and Recovery Act . . . . . . . . . 2-33

2.9.1 Facility Upgrades .. . . . . . . . . . . . . . . . 2-33

2.9.2 Resource Conservation and Recovery Act Part B Permit: 6

2.9.3 90-Day Accumulation Areas and Satellite Areas . . . . . . . . $2-33$

2.9.4 Facility Audits . . . . . . . . . . . . . . . . 2-34

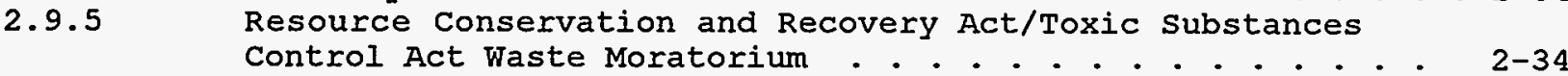

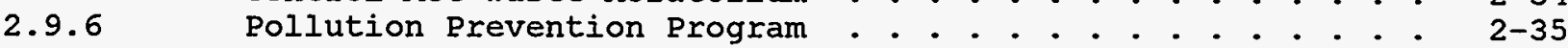


2.9. 7

2.9.8

2. 10

2. 11

2.12

2.13

2. 14

2.15

2.16

2.16 .1

2.17

2.18

2. 18.1

2.18 .2

2.18 .3

2.19

3. 0

3.1

3. 1.1

3.1. 2

3.1. 3

3.2

3.3

3. 4

3.5

3. 5.1

3. 5.2

4. 0

4.1

4. 1.1

4.1.2

4. 1.3

4. 1.4

4.1. 4.1

4.1. 4.2

4. 1.4 .3

4. 1. 4.4

4.1. 4.5

4. 1.4 .6

4. 1.5

4. 1.5 .1

4.1.5.2

4.1 .5 .3

4.1.5. 4

4.1.5. 5

4.1 .5 .5 (a)

4.1 .5 .6

4.1.5.7

4.1.5.8

4.1 .5 .9

4.1 .5 .9 (a)

4.1 .5 .9 (b)
Waste Disposal

$2-35$

Federal Facility Compliance Act . . . . . . . . . . . . 2-36

Comprehensive Environmental Response, Compensation

and Liability Act . . . . . . . . . . . . . . . . . 2-36

Superfund Amendments and Reauthorization Act of 1986 . . . 2-38

National Environmental Policy Act . . . . . . . . . . . . 2-38

Federal Insecticide, Fungicide, and Rodenticide Act . . . . 2-39

Endangered Species Act . . . . . . . . . . . . . . . . . 2-39

National Historic Preservation Act . . . . . . . . . . . . 2-39

Floodplain Management . . . . . . . . . . . . . . . 2-39

New York Wild, Scenic, and Recreational

River Systems Act . . . . . . . . . . . . . . . . . . . . 2-40

Protection of Wetlands . . . . . . . . . . . . . . . . 2-40

Environmental Compliance Audits . . . . . . . . . . . . . . 2-40

Tiger Team Issues... . . . . . . . . . . . . . . . . . 2-40

Environmental Protection Agency National Emission standards

for Hazardous Air Pollutants Audit 1994 . . . . . . . . . . 2-41

Department of Energy Chicago Environmental

Safety and Health Appraisals . . . . . . . . . . . . . 2-42

Quality Assurance Program . . . . . . . . . . . . . . . 2-42

ENVIRONMENTAL PROGRAM INEORMATION . . . . . . . . . . . . . 3-1

Program Organization . . . . . . . . . . . . . . . . . . . 3-1

Environmental Compliance Group . . . . . . . . . . . . . . . 3-2

Sampling and Analysis Group . . . . . . . . . . . . . . . . 3-2

Engineering and operations Group . . . . . . . . . . . . . . 3-2

Environmental Programmatic Changes in 1994 . . . . . . . . . 3-3

Environmental Restoration . . . . . . . . . . . . . . 3-5

Waste Minimization and Pollution Prevention Programs . . . . 3-5

Environmental Audits . . . . . . . . . . . . . . . . 3-6

Tier III Assessment . . . . . . . . . . . . . . . . 3-6

Other Audits . . . . . . . . . . . . . . . . . 3-6

ENVIRONMENTAL PROGRAM DESCRIPTION . . . . . . . . . . . . . . 4-1

Effluent Emissions and Environmental Surveillance . . . . . . 4-1

Airborne Effluent Emissions - Radioactive . . . . . . . . . . 4-2

Airborne Effluent Emissions - Nonradioactive . . . . . . . . 4-5

Liquid Effluents . . . . . . . . . . . . . . . . . . . 4 4-5

Liquid Waste Management . . . . . . . . . . . . . . . . . 4-5

Sanitary System Effluents... . . . . . . . . . . . . . 4-6

Radiological Analyses . . . . . . . . . . . . . . . . . . . 4-8

Sanitary System Nonradiological Analyses . . . . . . . . . . 4-8

Recharge Basins . . . . . . . . . . . . . . . . . . . 4-16

Recharge Basins - Radiological Analyses . . . . . . . . . . 4-22

Recharge Basins - Nonradiological Analyses . . . . . . . . 4-22

Environmental Measurements and Analyses . . . . . . . . . . 4-26

External Radiation Monitoring . . . . . . . . . . . . . . . 4-26

Atmospheric Radioactivity . . . . . . . . . . . . . . . . 4-26

Tritium Analyses . . . . . . . . . . . . . . . . . . 4-26

Radioactive Particulates . . . . . . . . . . . . . . . 4-31

Terrestrial Ecological studies . . . . . . . . . . . . . . 4-31

Radioactivity in Soil, Vegetation and Fruits . . . . . . . . 4-31

Peconic River Aquatic Surveillance - Radiological Analyses . 4-34

Peconic River Aquatic Surveillance - Nonradiological Analyses 4-34

Aquatic Biological Surveillance. . . . . . . . . . . . . . 4-39

Biomonitoring of the Liquid Effluent . . . . . . . . . . . . 4-39

Biomonitoring: Fish Species . . . . . . . . . . . . . . . . 4-39

Biomonitoring: Chronic Toxicity Tests . . . . . . . . . . . 4-45 
5.0

GROUNDWATER PROTECTION . . . . . . . . . . . . . . 5-1

5.1

5.1 .1

Groundwater Surveillance . . . . . . . . . . . . . . 5-1

5.1 .1 .1

5.1 .1 .2

5.1 .2

5.1 .2 .1

Potable Water and Process Supply Wells

$5-1$

Radiological Analyses .. . . . . . . . . . . . . 5-13

Nonradiological Analyses . . . . . . . . . . . . 5-13

Groundwater Monitoring . . . . . . . . . . . . . . 5-19

Nonradiological Analyses . . . . . . . . . . . . . 5-19

5.1 .2 .2

Radiological Analyses...

$5-69$

6.0

OFF-SITE DOSE ESTIMATES . . . . . . . . . . . . . . . 6-1

6.1

6.2

6.3

6.4

Dose Equivalents due to Airborne Effluents . . . . . . . . 6-1

Dose Equivalents due to Iiquid Effluents . . . . . . . . . 6-1

Maximum Individual Effective Dose Equivalent . . . . . . 6-8

Collective (Population) Dose Equivalent . . . . . . . . 6-8

7.0

7.1

LABORATORY QUALITY ASSURANCE . . . . . . . . . . . . . . . 7-1

Radiological Analyses . . . . . . . . . . . . . . . . 7-1

Nonradiological Analyses . . . . . . . . . . . . 7-7

7.2

Contractor Laboratories . . . . . . . . . . . . 7-16

Appendix A.1 Appendix A.2 Appendix B Appendix C Appendix D Distribution

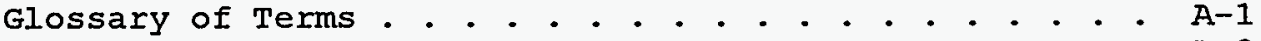

Glossary of Units.. . . . . . . . . . . . . . A-3

Methodologies . . . . . . . . . . . . . . . . . B-1

Instrumentation and Analytical Methods . . . . . . . . C-1

References .. . . . . . . . . . . . . . . . . D-1

$D-4$ 
1-1 Resident Population 1994 within an 80-km Radius of the Brookhaven National Laboratory . . . . . . . . . . . . . . . . . 1-2

1-2 Brookhaven National Laboratory Local and On-site Population Distribution . . . . . . . . . . . . . . . . . . . 1-3

1-3 Major Facilities . . . . . . . . . . . . . . . . . . . . 1-4

1-4 Annual wind Rose for 1994. . . . . . . . . . . . . . . . . . . 1-6

1-5 Climatology for the Brookhaven National Laboratory Site - Annual Temperatures - 1994 . . . . . . . . . . . . . . . 1-7

1-6 Climatology for the Brookhaven National Laboratory Site - Annual Precipitation - 1994 . . . . . . . . . . . . . . . . 1-8

1-7 Precipitation Trend Data for the Brookhaven National Laboratory 1949 - 1994 . . . . . . . . . . . . . . . . . . . . 1-9

1-8 Site Water Table Map - September 1994 . . . . . . . . . . . . . 1-10

4-1 Brookhaven National Laboratory Effluent Release Points and On-site Environmental Monitoring Stations . . . . . . . . . . . 4-3

4-2 Sewage Treatment Plant - Sampling stations . . . . . . . . . . . . 4-7

4-3 Gross Beta Concentration Data: Sewage Treatment Plant and Peconic River 1987 - 1994 . . . . . . . . . . . . . . . 4-11

4-4 Tritium Concentration Data: Sewage Treatment Plant and Peconic River - 1987 - 1994 . . . . . . . . . . . . . . . . 4-12

4-5 Tritium Activity Discharged to the Peconic River from the Brookhaven National Laboratory 1971 - 1994 . . . . . . . . . . . . 4-13

4-6 Maximum Effluent Concentration of Copper - Discharged from Brookhaven National Laboratory's Sewage Treatment Plant, 1989 - 1994 . . . . . . . . . . . . . . . . . . . . . . 4-17

4-7 Daily Average Loading of Copper at Brookhaven National Laboratory's Sewage Treatment Plant, 1989 - 1994 . . . . . . . . . 4-17

4-8 Maximum Effluent Concentration of Lead Discharged from Brookhaven National Laboratory's Sewage Treatment Plant, 1989 - 1994 . . . . . . . . . . . . . . . . . . . . . . 4-17

4-9 Daily Average Loading of Lead at Brookhaven National Laboratory's Sewage Treatment Plant, 1989 - 1994 . . . . . . . . 4-17

4-10 Maximum Effluent Concentration of Silver Discharged from Brookhaven National Laboratory's sewage Treatment Plant, $1989-1994$. . . . . . . . . . . . . . . . . . . 4-18

4-11 Daily Average Loading of Silver at Brookhaven National Laboratory's Sewage Treatment Plant, 1989 - 1994 . . . . . . . . 4-18 
4-12 Maximum Effluent Concentration of zinc Discharged from Brookhaven National Laboratory's Sewage Treatment Plant,

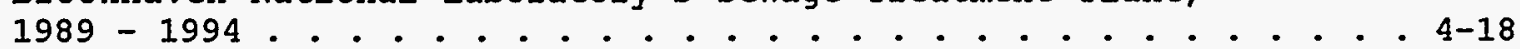

4-13 Daily Average Loading of zinc at Brookhaven National Laboratory's Sewage Treatment Plant, 1989 - 1994 . . . . . . 4-18

4-14 Maximum Effluent Concentration of Iron Discharged by Brookhaven National Laboratory's Sewage Treatment Plant, 1989 - 1994 . . . . . . . . . . . . . . . 4-19

4-15 On-site: Potable and Supply Wells and Recharge Sumps . . . . . . 4-20

4-16 Brookhaven National Laboratory Schematic of Water Use and Flow for 1994 . . . . . . . . . . . . . . 4-21

4-17 Brookhaven National Laboratoxy Location of On-site Thermoluminescent Dosimeters . . . . . . . . . . . 4-29

4-18 Brookhaven National Laboratory Location of off-site Thermoluminescent Dosimeters . . . . . . . . . . . 4-30

4-19 Peconic River Sampling Stations . . . . . . . . . . . . . . 4-40

4-20 Liquid Flow Data - Sewage Treatment Plant and Peconic River: 1971 - 1994 . . . . . . . . . . . . . 4-41

4-21 Cesium-137 Distribution in the Peconic River and Fish . . . . . . 4-42

5-1 Monitoring Wells, Pumping Wells, supply Wells and Piezometers .................. . . . 5-2

5-2 Monitoring Wells: Noṛth Boundary - Upgradient Background Wells . • 5-3

5-3 Monitoring Wells: North Boundary and Sewage Treatment Plant . . . 5-4

5-4 Monitoring Wells: Western Supply Wells, Alternating Gradient Synchrotron, Waste Concentration Facility . . . . . . . . . . 5-5

5-5 Monitoring Wells: Sewage Treatment Plant area, Peconic River Area, Building 830 spill Site Recharge Basins . . . . . . . . . . . . . . 5-6

5-6 Monitoring Wells: Peconic River, Upland Recharge . . . . . . . . . 5-7

5-7 Monitoring Wells: Western Supply Area, Water Treatment Plant,

5-8 Monitoring Wells: Building 650, Central steam Facility, Major Petroleum Facility, Current Iandfill . . . . . . . . . . . 5-9

5-9 Monitoring Wells: Biology Experimental Fields, Meadow Marsh . . . 5-10

5-10 Monitoring Wells: Southwest Boundary Area . . . . . . . . . . . . 5-11

5-11 Monitoring Wells: Southern Boundary . . . . . . . . . . . . . . . 5-12

5-12 Time History of DCA Downgradient of the Current Landfill . . . . . 5-32

5-13 Time History of Iron Downgradient of this Current Iandfill . . . . 5-33 
5-14 Time History of Manganese Downgradient of the Current Landfill . 5-34

5-15 Time History of Gross Beta Downgradient of the

Hazardous Waste Management Facility . . . . . . . . . . . . . . . 5-40

5-16 Time History of TCA/PCE Downgradient of the Central steam

Facility/Major Petroleum Facility . . . . . . . . . . . . . . . 5-46

5-17 Time History of TCA Downgradient of the

Waste Concentration Facility . . . . . . . . . . . . . . . 5-56

5-18 Time History of TCA Downgradient of Supply \& Materiel Area . . . . 5-62

5-19 Time History of TCA Downgradient of the

West Sector/Southwestern Boundary . . . . . . . . . . . . . . 5-68

5-20 Time History of Tritium Downgradient of the

Sewer Treatment plant. . . . . . . . . . . . . . . . 5-82

5-21 Time History of Tritium Downstream. of the

Sewer Treatment Plant Along Peconic River . . . . . . . . . . . . . 5-83

5-22 Time History of Gross Beta Downgradient of the

Current Landfill/Old Landfill Area . . . . . . . . . . . . . . 5-84

5-23 Time History of Strontium-90 Downgradient of the

Current Landfill/Old Irandfill Area . . . . . . . . . . . . . 5-85

5-24 Time History of Tritium Downgradient of the

Current Landfill/Old Landfill Area . . . . . . . . . . . . . . 5-86

5-25 Time History of Gross Beta Downgradient of the

Hazardous Waste Management Area . . . . . . . . . . . . . . . 5-91

5-26 Time History of strontium-90 Downgradient of the

Hazardous Waste Management Area . . . . . . . . . . . . . . . 5-92

5-27 Time History of Tritium Downgradient of the

Hazardous Waste Management Area . . . . . . . . . . . . . . . 5-93

6-1 Collective Dose-Nuclide Specific 1994 Airborne Emissions . . . . . 6-5

6-2 Fraction of Collective Dose by Facility - 1994 . . . . . . . . . . 6-6

7-1 1994 Calibration Standard Summary (Alpha, Beta, Tritium) . . . . . 7-5

7-2 1994 Gamma Calibration Standard Summary (Cesium-137 Energy) . . . . 7-6

7-3 1994 strontium-90 Calibration Summary . . . . . . . . . . . . . . 7-8

7-4 1994 Linear Regression of Tritium Data . . . . . . . . . . . . . 7-9

7-5 1994 Reference Check Sample Summary - Inorganic Analysis . . . . . 7-12

7-6 1994 Reference Check Sample Summary - Organic Analysis . . . . . . 7-13

7-7 1994 surrogate and spike Recoveries Summary - Organic Analysis . . 7-14

7-8 1994 Spike Recoveries Summary - Inorganic Analysis . . . . . . . . 7-15 
2-1 Brookhaven National Laboratory Environmental Permits . . . . . . 2-2

2-2 State Pollution Discharge Elimination system Compliance for

Sewage Treatment Plant Effluent (Outfall 001) . . . . . . . . . . 2-7

2-3 Summary of Monthly Discharge Monitoring Report Values

for the Sewage Treatment Plant Discharge . . . . . . . . . . . . . 2-8

2-4 Summary of Chemical and oil spill Reporting Record . . . . . . . . 2-12

2-5 Bacteriological, Inorganic Chemical, and Radiological

Analytical Data . . . . . . . . . . . . . . . . . . . 2-25

2-6 Principal Organic Compounds, synthetic Organic Compounds,

Pesticides \& Micro-extractables . . . . . . . . . . . . . . . 2-26

4-I Atmospheric Effluent Release Iocations and Radionuclide

Activity . . . . . . . . . . . . . . . . . . . . . . . . . . 4-4

4-2 Radiological Analysis Results of Sewage Treatment Plant

Influent and Effluent . . . . . . . . . . . . . . . . . . . . . 4-9

4-3 Gamma spectroscopy and strontium-90 Results. . . . . . . . . . 4-10

4-4 Sewage Treatment Plant - Average Water quality and

Metals Data. . . . . . . . . . . . . . . . . . . . . . 4-15

4-5 Radiological Analysis of Recharge Basin Water Annual

Radionuclide Concentrations . . . . . . . . . . . . . . . . 4-23

4-6 Water Quality Data for On-site Recharge Basins . . . . . . . . . 4-24

4-7 Average Metals Data for On-site Recharge Basins . . . . . . . . 4-25

4-8 External Dose Equivalent Rates for all Thermoluminescent

Dosimeter Locations . . . . . . . . . . . . . . . . . . 4-27

4-9 Ambient Tritium Concentrations at Perimeter and

Control Locations . . . . . . . . . . . . . . . . . . . . 4-28

4-10 Gross Alpha, Gross Beta, and Gamma-emitting Radionuclide

Concentrations for Ambient Air Monitoring stations . . . . . . . 4-32

4-1I Air station Charcoal Filter Gamma Analysis Results . . . . . . . 4-33

4-12 Radionuclide Concentrations in Vegetation and soil

around Brookhaven National Laboratory . . . . . . . . . . . . . 4-35

4-13 Annual Gross Alpha, Gross Beta, Tritium, Gamma, and strontium-90

Activity Concentrations -in Peconic River and Carmans River . • . 4-36

4-14 Water Quality Parameters for surface Water samples

Collected Along the Peconic and Carmans Rivers . . . . . . . . . 4-37 
4-15 Metals Concentration Data for Water Samples Collected Along the Peconic and Carmans Rivers . . . . . . . . . . . . . . 4-38

4-16 Radionuclide Concentrations in Eish . . . . . . . . . . . . . . . 4-43

5-1 Potable and Process Water Radionuclide Concentrations . . . . . . 5-14

5-2 Potable Water and Process supply Wells Water quality Data . . . . 5-16

5-3 Potable and Process Supply Wells Metals Data . . . . . . . . . 5-17

5-4 Potable water and Process Supply Welis Volatile

Organic Compound Data. . . . . . . . . . . . . . . . . . 5-18

5-5 Peconic River/sewage Treatment Plant and Meadow Marsh, Groundwater Surveillance Wells, Water Quality Data . . . . . . . 5-20

5-6 Peconic River/sewage Treatment Plant Area and Meadow Marsh Area, Groundwater Surveillance Wells, Metals Data. . . . . 5-21

5-7 Peconic River/Sewage Treatment Plant Area end Upland Recharge/Meadow Marsh Area, Groundwater Surveillance Wells, Chlorocarbon Data . . . . . . . . . . . . . . . . 5-22

5-8 Peconic River/Sewage Treatment Area and Upland Recharge/ Meadow Marsh Area, Groundwater Surveillance Wells, BETX Data... . . . . . . . . . . . . . . . . . . . . 5-23

5-9 Current Landfill, Former Landfill, and Ash Repository, Groundwater Surveillance Wells, Water Quality Data . . . . . . . 5-25

5-10 Current Landfill, Former Landfill, and Ash Repository, Groundwater Surveillance Wells, Metals Data . . . . . . . . . . . 5-26

5-11 Current Landfill and Former Landfill Areas, Groundwater Surveillance Wells, Chlorocarbon Data . . . . . . . . . . . . . 5-29

5-12 Current Landfill, Former Landfill, and Ash Repository, Groundwater Surveillance Wells, BETX Data . . . . . . . . . . . . 5-30

5-13 Hazardous Waste Management Facility, Groundwater Surveillance Wells, Water Quality Data . . . . . . . . . . . . . 5-36

5-14 Hazardous Waste Management Facility, Groundwater Surveillance Wells, Chlorocarbon Data . . . . . . . . . . . . . 5-37

5-15 Hazardous Waste Management Facility, Groundwater Surveillance Wells, Metals Data . . . . . . . . . . . . . . . 5-38

5-16 Hazardous Waste Management Area, Groundwater Surveillance Wells, BETX Data . . . . . . . . . . . . . . . . . 5-39

5-17 Major Petroleum Facility/Central steam Facility, Bldg. 650 and Bldg. 650 Outfall, Groundwater surveillance Wells, Water Quality Data

5-18 Major Petroleum Facility/Central steam Facility Bldg. 650 and BIdg. 650 outfall, Groundwater surveillance Wells, Metals Data. . . . . . . . . . . . . . . 5-42 
5-19 Building 650, Major Petroleum Facility, and Central Steam Facility, Groundwater Surveillance Wells, Chlorocarbon Data . . . . . . . . . . . . . . . . . 5-43

5-20 Building 650, Major Petroleum Facility, and Central Steam Facility, Groundwater Surveillance Wells,

BETX Data . . . . . . . . . . . . . . . . . . . 5-44

5-21 Alternate Gradient synchrotron, Linear Accelerator, and Relativistic Heavy Ion Collider, Groundwater Surveillance Wells, water Quality Data . . . . . . . . . 5-48

5-22 Alternate Gradient synchrotron, Linear Accelerator, and Relativistic Heavy Ion Collider, Groundwater Surveillance Wells, Metals Data . . . . . . . . . . . . . 5-49

5-23 Alternate Gradient Synchrotron, Linear Accelerator, and Relativistic Heavy Ion Collider, Groundwater Surveillance Wells, Chlorocarbon Data... . . . . . . . . 5-50

5-24 Alternate Gradient Synchrotron, Linear Accelerator, and Relativistic Heavy Ion Collider, Groundwater Surveillance Wells, BETX Data. . . . . . . . . . . . . 5-51

5-25 Waste Concentration Facility, Bldg. 830, Photography and Graphic Arts, Water Treatment Plant, Groundwater Surveillance Wells, Water Quality Data . . . . . . . . . 5-52

5-26 Miscellaneous Areas of the Brookhaven National Laboratory Site, Groundwater Surveillance Wells, Metals Data . . . . . . 5-53

5-27 Miscellaneous Areas of the Brookhaven National Laboratory Site, Groundwater Surveillance Wells, Chlorocarbon Data . . . . 5-54

5-28 Miscellaneous Areas of the Brookhaven National Laboratory Site, Groundwater Surveillance Wells, BETX Data . . . . . . . . 5-55

5-29 Supply and Materiel, Groundwater Surveillance Wells, Water Quality Data . . . . . . . . . . . . . . . 5-58

5-30 Supply and Materiel, Groundwater surveillance Wells, Metals Data.... . . . . . . . . . . . . . . 5-59

5-31 Supply and Materiel, Groundwater surveillance Wells, Chlorocarbon Data. . . . . . . . . . . . . . . . 5-60

5-32 Supply and Materiel, Groundwater Surveillance Wells, BETX Data . . . . . . . . . . . . . . . . . . . 5-61

5-33 North, West, and South Sectors, Groundwater Surveillance Wells, water quality Data . . . . . . . . . 5-64

5-34 North, West, and South Sectors, Groundwater Surveillance Wells, Metals Data ............. . 5-65

5-35 North, West, and South Sectors, Groundwater Surveillance Wells, Chlorocarbon Data... . . . . . . . 5-66

5-36 North, West, and South Sectors, Groundwater Surveillance Wells, BETX Data . . . . . . . . . . . . . . 5-67 
5-37 Radionuclide Concentrations in off-site Potable Wells..... . 5-70

5-38 Peconic River On-site/Off-site, Meadow Marsh/Upland Recharge Area, Groundwater Surveillance Wells, Radioactivity Data . . . . . . . . . . . . . . . 5-71

5-39 North Boundary, West Sector, South Boundary, and Supply \& Materiel Areas, Groundwater Surveillance Wells, Radioactivity Data . . . . . . . . . . . . . . 5-72

5-40 Miscellaneous Areas of the Brookhaven National Laboratory Site, Groundwater Surveillance Wells, Radioactivity Data . . . 5-75

5-41 Current Landfill, Old Landfill, and Ash Repository Areas, Groundwater Surveillance Wells, Radioactivity Data . . . . . . 5-78

5-42 Major Petroleum Facility and Central Steam Facility, Groundwater Surveillance Wells, Radioactivity Data . . . . . . 5-80

5-43 Hazardous Waste Management Area, Groundwater Surveillance Wells, Radioactivity Data . . . . . . . . . . . 5-88

6-1 Committed Effective Dose Equivalent at site Boundary Due to Airborne Tritium . . . . . . . . . . . . . . . . 6-2

6-2 Argon-41 and Oxygen-15 Site Boundary Dose Equivalents . . . . . . 6-3

6-3 Collective Dose - Radioactive Airborne Emissions . . . . . . . 6-4

6-4 Collective and Individual Committed Effective Dose Equivalent from the Water Pathway.............. 6-7

6-5 Collective Dose from All Pathways . . . . . . . . . . . . 6-9

7-1 Brookhaven National Laboratory Quality Assessment Program Results Environmental Measurements Laboratory . . . . . . . . . 7-2

7-2 Brookhaven National Laboratory Quality Assessment Program Results Environmental Monitoring systems Laboratory (Las Vegas) • 7-3

7-3 Brookhaven National Laboratory Potable Water Radiochemistry Proficiency Test Results Environmental Laboratory Approval Program . . . . . . . . . . . . . . . . 7-4

7-4 Brookhaven National Laboratory Non-Potable water Chemistry Proficiency Test Results Environmental Laboratory Approval Program .. . . . . . . . . . . . . . . 7-10

7-5 Brookhaven National Laboratory Potable water Chemistry Proficiency Test Results Environmental Laboratory Approval Program . . . . . . . . . . . . . . . . . 7-11

7-6 Brookhaven National Laboratory National Pollution Discharge Elimination System Performance Evaluation Report . . . 7-17

7-7 Brookhaven National Laboratory Water Pollution Performance Evaluation Study \#33 Environmental Protection Agency Environmental Monitoring systems Laboratory (Cincinnati) . . . . 7-18 
The Environmental Monitoring (EM) Program is conducted by the Environmental Management Section (EMS) of the Safety \& Environmental Protection (S\&EP) Division to determine whether operation of the Brookhaven National Laboratory (BNL) facilities have met the applicable environmental standards and effluent control requirements and assess impact of BNL operations on the environment. This program includes monitoring for both radiological and nonradiological parameters. This report summarizes the data for external radiation levels; radioactivity in air, rain, potable water, surface water, groundwater, soil, vegetation, fauna, and aquatic biota; water quality, metals, organic compounds in groundwater, surface water, and potable water.

Analytical results are reviewed by the S\&EP Division staff and when required by permit conditions are transmitted to the appropriate regulatory agencies through the Department of Energy (DOE). The data were evaluated using the appropriate environmental regulatory criteria. Data summaries for Calendar Year (CY) 1994 are presented in the text. Detailed information on analytical results, both radiological and nonradiological, are given in the 1994 BNL site Environmental Report (SER) Compendium.

\section{Airborne Effluents}

Most of the airborne radioactive effluents at BNL originate from the High Flux Beam Reactor, Brookhaven Linac Isotope Production Facility, and the Medical Research Reactor. Argon-41, oxygen-15, and tritium were the predominant radionuclides. In $1994,1,998 \mathrm{Ci}(73.9 \mathrm{TBq})$ of argon-41 were released from the MRR stack; a combined total of $390 \mathrm{Ci}(14.4 \mathrm{TBq})$ of oxygen-15 were released from BLIP, and the Alternating Gradient synchrotron (AGS) Booster, and $81 \mathrm{Ci}$ ( 3.0 TBq) of tritium in the form of water vapor was released from the HFBR stack. Much smaller quantities of airborne radioactive effluents were released from the Chemistry Building, Bldg. 801 Hot Laboratory, and the Hazardous Waste Management Facility.

\section{Liquid Effluents}

Liquid discharge limits for radiological and nonradiological parameters are subject to conditions listed in the BNL state Pollutant Discharge Elimination system Permit No. NY-0005835 as issued by the New York state Department of Environmental Conservation (NYSDEC). Radiological release concentrations for gross beta, radium, and strontium-90 are also prescribed by the SPDES permit limitations. Other radionuclide discharge concentrations are governed by the U.S. DOE specified Derived Concentration Guides (DCGs).1 Since such liquid discharges have the potential of contaminating the "Sole source Aquifer" underlying the Laboratory site, administrative controls are in place to maintain all liquid discharges at or below concentrations prescribed by the Safe Drinking Water Act (SDWA) ${ }^{3}$.

Operations at the sewage Treatment Plant (STP) were within (100\%) the radiological limits specified by the SPDES permit. Gross beta concentrations in chlorine house effluent remained higher than concentrations found in the influent by a factor of 1.1 . This condition is the result of continued low-level leaching of material adsorbed on the sand filter beds as a result of a 1988 unplanned release of cesium-137 and strontium-90 to the sanitary system. In 1994 , discharges to the Peconic River met all radioactive discharge limits of the SPDES program. The principle radionuclides released to the Peconic River from liquid effluents discharged from the STP were: $1.57 \mathrm{Ci}(58.2 \mathrm{GBq})$ of tritium, $1.16 \mathrm{mCi}$ 
(42.9 MBq) of cesium-137, and $0.037 \mathrm{mCi}(1.37 \mathrm{MBq})$ of cobalt-60. The annual average cesium-137 concentration was $0.04 \%$ of the DCG (0.15\% of the SDWA). Releases of cobalt-60 were well below the DCG and SDWA limit. The annual average tritium concentrations at the discharge point to the Peconic River was $0.09 \%$ of the DCG and $8.6 \%$ of the SDWA limit. This represents a factor of two decrease in tritium releases to the Peconic River from 1993 values.

Nonradiological parameters are monitored at the effluent of the STP in accordance with the conditions of the sPDES permit. These parameters include residual chlorine, metals, 1,1,1-trichloroethane (TCA), pH, temperature, Biochemical oxygen Demand $\left(\mathrm{BOD}_{5}\right)$, flow, suspended and settleable solids, fecal and total coliform, and ammonia-nitrogen. Although the compliance rate exceeded 99.7\%, there were ten permit deviations; one each for BOD $_{5}$ and fecal coliform and eight for ammonia nitrogen. The ammonia nitrogen exceedances were attributed to the loss of nitrifying bacteria in the STP sand filters which resulted from the cold winter and the hydraulic overloading of the filters. The on-set of warmer weather and increased aeration of the filters via cultivation proved to resolve these exceedances and repopulate the nitrifying bacteria. The cause of the fecal coliform and $B O D$ exceedances were determined to be an indirect result of the increased cultivation of the sand filters. The hydraulic overloading of the sand filters resulted from the shutting down of four of the six filter beds during a hydrogeologic investigation of groundwater in the vicinity of the STP.

Liquid effluent discharged to the on-site recharge basins contained only trace quantities of radioactivity that were all small fractions of the applicable guides or standards. If the recharge basin water were to be used as the sole source of drinking water, the resultant dose from direct ingestion at the concentrations detected would be equivalent to a dose of $0.019 \mathrm{mrem}(0.00019 \mathrm{msv})$ per year. The recharge basins function as conduits to the underlying aquifer system (i.e., groundwater recharge). Consequently the nonradiological water quality parameters used in assessing the discharges were the NYSDEC Groundwater Effluent standards as promulgated by 6 New York Code of Rules and Regulations (NYCRR) Part 703.64. With the exception of recharge basin HO and HT, discharges to the recharge basins met the NYSDEC Effluent standards. Samples collected from recharge basin Ho exhibited iron concentrations ranging from $<0.075 \mathrm{mg} / \mathrm{I}$ to 1.47 $\mathrm{mg} / \mathrm{L}$ (approximately 2.5 times the NYSDEC Effluent standard of $0.6 \mathrm{ppm}$ ) and low pH. This basin receives groundwater which is used as non-contact cooling water at the AGS. The $\mathrm{pH}$ and concentration of iron within the groundwater used by the AGS typically exceeds the NYSDEC effluent standards and are comparable to the concentration exhibited in the discharge to basin HO. A sample of water collected from recharge basin HT exhibited a pH value of 6.4 sU which exceeds the NYSDEC minimum effluent standard of $6.5 \mathrm{sU}$.

Brookhaven National Laboratory continued to collect samples from the recharge basins for organic analyses during 1994. The analytical data for these samples showed all organic compounds to be below the NYSDEC Effluent standard.

\section{External Radiation Monitoring}

Thermoluminescent dosimeters (TLDs) were used to monitor the external exposure at on-site and off-site locations. The average annual on-site integrated dose for 1994 was $65.11+/-6.2 \mathrm{mrem}(0.65+/-0.062 \mathrm{mSv})$, while the off-site integrated dose was $68.8+/-5.9 \mathrm{mrem}(0.69+/-0.059 \mathrm{mSv})$. These values are lower than ambient exposure rates typically reported for the New York City area by the Environmental Protection Agency (EPA) which predict an annual dose of about $80 \mathrm{mrem}(0.80 \mathrm{mSv})$. $^{5-8}$ The difference between the on-site and offsite integrated exposure is within the statistical uncertainty of the measurement. 9 


\section{Atmospheric Radioactivity}

Tritium was the radioactive effluent detected most frequently in environmental air samples. The maximum annual average tritium concentration at the site boundary was $4.5 \mathrm{pCi} / \mathrm{m}^{3}\left(0.17 \mathrm{~Bq} / \mathrm{m}^{3}\right)$. This concentration would result in a committed effective dose equivalent of 0.005 mrem $(0.00005 \mathrm{mSv})$ to the maximally exposed individual residing at the site boundary for the entire year. Cesium-137 was detected at stations 0702, 0420, and 1201 at least once during 1994. Cobalt-60 was also detected once at stations 0420 and 1201 . The cesium137 is attributable to atmospheric fallout and the cobalt may have been identified in these samples due to background fluctuations in the detection equipment.

\section{Soil and Vegetation}

Soil and vegetation were collected from off-site locations as part of the soil and Vegetation Sampling Program, and analyzed only for radioactivity.

The off-site soil and vegetation sampling program is a cooperative effort between BNL and Suffolk County Department of Health services (SCDHS). Local farms situated adjacent to BNL were sampled in June 1994. No radionuclides attributable to Laboratory operations were detected in any of these samples.

Surface Water - Radiological Analyses

Radiological results from samples collected at the former site boundary (Location $\mathrm{FM}$ ) indicate that the annual average gross beta concentration was 6.55 $\mathrm{pCi} / \mathrm{L}(0.25 \mathrm{~Bq} / \mathrm{L})$ or $13 \%$ of the New York state Drinking Water Standards (NYS DWS); the average strontium-90 concentration was $0.10 \mathrm{pCi} / \mathrm{L}(0.003 \mathrm{~Bq} / \mathrm{L})$ or $<18$ of the NYS DWS; the average cesium-137 concentration was $1.55 \mathrm{pCi} / \mathrm{L}(0.06 \mathrm{~Bq} / \mathrm{L})$ or $1.11 \%$ of the SDWA; and the average tritium concentration was $2566 \mathrm{pCi} / \mathrm{L}$ (95 $\mathrm{Bq} / \mathrm{L}$ ) or $12.8 \%$ of the NYS DWS. At the current site boundary (Location HQ), the annual average gross beta concentration was $11.25 \mathrm{pCi} / \mathrm{L}(0.40 \mathrm{~Bq} / \mathrm{L})$ or 22.58 of the NYS DWS and the average tritium concentration was $1795 \mathrm{pCi} / \mathrm{L}(66 \mathrm{~Bq} / \mathrm{L})$ or $9 \%$ of the NYS DWS. No nuclide specific gamma analyses were performed at this location.

The Carmans River at Yaphank and off-site locations in the Peconic River were sampled on a quarterly basis in 1994. In the Carmans River water samples, the average gross beta concentration was $1.57 \mathrm{pCi} / \mathrm{L}(0.06 \mathrm{~Bq} / \mathrm{L})$ and the average strontium-90 concentration was less than $0.1 \mathrm{pCi} / \mathrm{L}(0.0037 \mathrm{~Bq} / \mathrm{L})$. These values represent ambient background. Average gross beta concentrations in the Peconic River were uniform and ranged from $1.02 \mathrm{pCi} / \mathrm{L}$ to $2.20 \mathrm{pCi} / \mathrm{L} 10.04 \mathrm{~Bq} / \mathrm{L}$ to 0.082 $\mathrm{Bq} / \mathrm{L}$ ) or $4.4 \%$ of the NYS DWS. Tritium concentrations decrease with distance from BNL with the closest off-site sampling point (Location $\mathrm{HA}$ ) having an average concentration of $39 \mathrm{pCi} / \mathrm{I}(1.44 \mathrm{~Bq} / \mathrm{L})$, while the sample collected at the Riverhead sampling point (Location HR) had an average concentration of $-118 \mathrm{pCi} / \mathrm{L}$ $(-4.36 \mathrm{~Bq} / \mathrm{L})$. Cesium-137 was detected periodically in downstream water samples. The observations did not follow site release patterns. The average cesium-137 concentrations detected ranged from below detection limits to $0.23 \mathrm{pCi} / \mathrm{L} 10.009$ $\mathrm{Bq} / \mathrm{L})$, or $0.01 \%$ of the SDWA. Direct ingestion for one year of 2 liters of water per day containing the maximum observed cesium-137, and tritium concentration would result in a committed effective dose equivalent of less than $0.01 \mathrm{mrem}$ $(0.0001 \mathrm{mSv})$ at all locations.

Surface Water - Nonradiological Analyses

Surface water samples were collected from the Peconic River and from the Carmans River as an off-site control location. These samples were analyzed for 
water quality parameters (i.e., pH, temperature, conductivity, and dissolved oxygen), anions (i.e., chlorides, sulfates, and nitrates), metals, and volatile organic Compounds (VOCs) during CY 1994.

Review of this data indicates all water quality parameters to be consistent with the off-site control location and with historical data. Analytical data for metals showed all parameters to be consistent with historical data and all concentrations, with the exception of iron, to be below the NYS DWS. Iron is prevalent at or above the drinking water standard in all locations due to the high concentration of iron within native soils and groundwater. Volatile organic Compounds were not detected in samples of surface waters collected from the Carmans and Peconic Rivers during CY 1994.

\section{Aquatic Biological surveillance}

Fish samples were collected along the Peconic River at Donahue's Pond, and Forge Pond, at the upstream location of Swan Pond and at a control location along the Carmans River. In CY 1994, gamma spectroscopy and strontium-90 analysis were performed on these samples. The Peconic River fish contained net cesium-137 concentrations which ranged from 186 to $909 \mathrm{pCi} / \mathrm{Kg}$-wet $(7$ to $36 \mathrm{~Bq} / \mathrm{Kg}-\mathrm{wet}$ ), at Donahue's Pond and 37 to $328 \mathrm{pCi} / \mathrm{Kg}$-wet $(1.5$ to $1 ? \mathrm{~Bq} / \mathrm{Kg}-$ wet) at Forge Pond. The net strontium-90 concentrations ranged from 69 to $528 \mathrm{pCi} / \mathrm{Kg}$-wet $(2.5$ to 19.5 $\mathrm{Bg} / \mathrm{Kg}$-wet) for fishes collected in Donahue's Pond and 95 to $245 \mathrm{pCi} / \mathrm{kg}-$ wet (3.5 to $9 \mathrm{Bg} / \mathrm{kg}$-wet) in fishes collected from Forge Pond. Average concentrations found in control aquatic biota were subtracted from concentrations found in the Peconic River fish samples. Only fish collected at off-site locations were used to calculate the maximum individual and collective doses. Based on these results, the maximum individual dose was estimated to be $0.8 \mathrm{mrem}(0.008 \mathrm{mSv})$ and the collective dose was estimated to be 0.499 person-rem (0.005 person-sv). Nonradiological analyses were not performed on these samples. No sediment or aquatic vegetation samples were collected in 1994 .

\section{Potable Water Supply}

The Laboratory's potable water supply wells are screened from a depth of about $15 \mathrm{~m}$ to about $26 \mathrm{~m}$, in the Upper Glacial aquifer. During 1994, Well Nos. 4, $6,7,10,11$, and 12 were used to supply drinking water at BNL water samples collected from these wells were analyzed for radioactivity, metals, organics, and water quality. These results are discussed in the following sections.

\section{Radiological Analyses}

Gross alpha, gross beta, and tritium concentrations in samples collected from on-site potable wells were generally at or below the Minimum Detection Limit (MDL). The daily grab sample of potable water collected from a central building on site exhibited the same results. Annual average tritium concentrations in on-site potable well water were all below the MDI of $300 \mathrm{pci} / \mathrm{L}$ (11 $\mathrm{Bq} / \mathrm{L})$. Cobalt-60 was detected in FP-\#1I above MDI levels at an annual average concentration of $0.72 \mathrm{pCi} / \mathrm{L}(0.026 \mathrm{~Bq} / \mathrm{L})$. This concentration, if consumed for one year at a rate of $2 \mathrm{~L} /$ day would result in an unmeasurably small dose of $2 \mathrm{E}-6$ mrem (2E-4 mSv). This dose represents an upper limit to the dose actually received because the concentrations used to derive this dose was obtained from analyzing samples collected at individual well heads, and does not account for mixing that would occur when the water is distributed throughout the site.

\section{Nonradiological Analyses}

Metals analyses performed on potable water samples indicate that silver, cadmium, chromium, and mercury were not detected in any of the samples analyzed. Low concentrations of lead, manganese, copper, and zinc were detected in well 
water samples but at concentrations which are below their respective NYS DWS of $0.015 \mathrm{mg} / \mathrm{L}, 0.3 \mathrm{mg} / \mathrm{L}$, and $5.0 \mathrm{mg} / \mathrm{L}$. Iron was detected in water collected at the well head from well Nos. 4, 6 and 7 . Water from these wells is treated to remove excess iron at the BNL Water Treatment Plant prior to use in the domestic water distribution system. Sodium was detected in all potable wells in concentrations ranging from 8.0 to $13.9 \mathrm{mg} / \mathrm{L}$.

In order to demonstrate compliance with federal and state Drinking Water standards for organic compounds, potable water is sampled quarterly for Principal Organic Compounds (POC) and annually for synthetic organic Compounds (SOCs) and sent to an off-site New York state Department of Health (NYSDOH) certified laboratory. The POC analysis includes halogenated as well as nonhalogenated organic compounds while the SOC analysis includes chlorinated and non-chlorinated pesticides. The POC analyses indicate that organic compounds were detected in all potable wells. With the exception of Well 11, all concentrations of pocs were less than the NYSDOH prescribed drinking water standard. The maximum concentration of TCA in Well 11 ( $8 \mathrm{ppb})$ exceeded the NYSDOH standard of $5 \mathrm{ppb}^{10}$. In order to mitigate the presence of organics in water samples collected from Wells 10 and 11, these wells are equipped with activated carbon adsorption vessels. Review of treated water analyses showed all organic compounds to be within the NYS DWS.

\section{Groundwater Surveillance}

Groundwater surveillance data are compared to both DCGs and NYS DWS values in this report. The DCG for a given radionuclide represents the concentration which would yield a committed effective dose equivalent of $100 \mathrm{mrem}(1 \mathrm{mSv})$ if an individual were to consume two liters of the liquid per day for one year. Comparison of data to these concentrations permits evaluation of discharge limit impacts and provides a historic framework to evaluate past practices. Comparison of surveillance well data to EPA, NYSDEC, and NYSDOH reference levels provides a mechanism to evaluate the radiological and nonradiological levels of contamination relative to current standards.

\section{Radiological Analyses}

In 1994, 175 wells were sampled for radiological analysis. For ease of interpretation of the radiological activity in groundwater, the BNL site has been divided into sectors. In the east sector of the site (Meadow Marsh-Upland Recharge Area; Peconic River on-site including STP sand filter bed area and the Peconic River off-site), radionuclide concentrations in groundwater wells were at or below background levels except for tritium and gross beta being at $5.1 \%$ and $17.6 \%$ respectively of the NYS DWS concentration limit. ${ }^{11}$

Along the north, northwest, west, south boundary of the site, and the Supply and,Materiel areas, the only activity above background or significantly in excess of the system MDI were detected: Gross beta in Well 65-02 and Well 1803, a north boundary well.

In the center of the site, radionuclides detected in groundwater samples that were attributable to BNL operations were found in the vicinity of AGS, Building 811, Building 830, MPE, CSF and National Synchrotron Light Source. The highest annual average concentrations detected for this area expressed as a percent of the NYS DWS concentration limit were: 5.28 gross beta; 228 tritium; and $2.2 \%$ strontium-90. Radionuclides that are not regulated by concentration are regulated by dose. The highest annual average concentration detected for the remaining radionuclides expressed in percent of the drinking water dose limit were: $0.005 \%$ sodium-22; $0.003 \%$ cesium-137; and $0.002 \%$ cobalt-60. 
At the landfill areas (Current, Former, and Ashfill), the single highest average gross beta concentration observed was $52 \%$ of the applicable standard; the single highest average tritium concentration and strontium-90 concentration observed were 59\% and 62\%, respectively of the NYS DWS. Other radionuclides were detected at small fractions of the NYS DWS concentration limit. No other monitoring wells that were sampled exhibited concentrations that exceeded the NYs DWS. Given the distance to the site boundary, decay and mixing that will occur in transit, the resulting radionuclide concentrations at the site boundary are expected to be substantially below the applicable standard. This area is subject to a RI/FS as part of the IAG.

The data from groundwater surveillance wells monitored in the vicinity of the HWMF indicated the presence of tritium, fission, and activation products. The single highest average concentration of tritium, gross beta, and strontium-90 were $185 \%, 198 \%$, and $612 \%$ respectively of the NYS DWS. The highest average annual concentration for the remaining radionuclides detected expressed in percent of the NYS DWS dose derived concentration limits were: 0.03\% cobalt-60, 0.0098 sodium-22 and $0.006 \%$ cesium-137. Two of the monitoring wells that were sampled in this area exhibited concentrations that exceeded the NYS DWS for strontium-90; (Well Nos. 88-04; and 98-30). Given the distance to the site boundary decay and mixing that will occur in transit, the resulting radionuclide concentrations at the site boundary are expected to be substantially below the applicable standard. This area is subject to a RI/FS as part of the IAG.

In addition to the BNL on-site surveillance wells, 26 off-site private potable wells and one location along the Peconic River near the site boundary were sampled and analyzed for gross alpha, gross beta, tritium, and gamma emitting radionuclides as part of a cooperative program with the sCDHS. Detectable quantities of tritium were found in eight off-site sampling locations: four private potable wells and one Peconic River sampling point. The annual average tritium concentrations at the four private well locations ranged from $0.006 \%$ - 8.5\% of the NYS DWS. ${ }^{12}$ Except for naturally occurring potassium-40 and cesium-137 (a fission product), no other gamma emitting radionuclides were detected in the private well water samples. Strontium-90 analysis could not be completed in time for inclusion in this report.

\section{Nonradiological Analyses}

During 1994, a total of 234 groundwater surveillance wells were sampled during 490 individual sampling events for nonradiological analyses. Nonradiological analyses typically consist of: 1) determining water quality parameters such as $\mathrm{pH}$, conductivity, chloride, sulfate, and nitrate concentrations; 2) metals concentrations; and 3) voC concentrations. Water quality analyses conducted on groundwater samples collected site wide indicate that the $\mathrm{pH}$ of groundwater is typically within the range of 5.5 to 6.5 , which is below the New York State Ambient Water Quality Standard of 6.5 to 8.5. Chloride, sulfate, and nitrate concentrations in most areas of the site were typically below the NYs AWQS. Metals and VoCs in groundwater, however, exceed NYS DWS in a number of areas across the site, and are usually traceable to known spill or chemical waste storage areas, and former disposal areas. In several areas of the BNI site, iron is detected at levels above NYS DWS. In some cases, high iron levels appear to be the result of natural background (or ambient) concentrations within the Upper Glacial aquifer. In areas such as the Current Landfill, high iron levels are related to materials disposed of in the landfill. A summary of nonradiological analyses of groundwater samples collected during 1994 is presented below.

East sector: In the east sector of the site, two suspected contaminant source areas are monitored: the STP/Peconic River area, and the Meadow Marsh-Upland Recharge area. 
In the STP/Peconic River area, groundwater samples were collected from 18 surveillance wells for water quality, metals, and VOC analyses. The pH readings for groundwater were typically below the NYS AWQS of 6.5 to 8.5 , but were consistent with values observed at upgradient locations. All other water quality parameters were below the applicable NYS AWQS. Iron concentrations exceeded NYS DWS in five wells, with maximum concentrations ranging from $0.53 \mathrm{mg} / \mathrm{L}$ to 6.51 $\mathrm{mg} / \mathrm{L}$. Volatile organic compounds were not detected above NYS DWS in any samples.

In the Meadow Marsh-Upland Recharge area, groundwater samples were collected from ten surveillance wells for water quality, metals, and voc analyses. The $\mathrm{pH}$ readings for groundwater were typically below the NYS AWQS of 6.5 to 8.5 , but were consistent with values observed at upgradient locations. other water quality parameters were below the applicable NYs Awos. Metals analyses indicate that iron concentrations exceeded NYS DWS in two wells, with maximum concentrations ranging from $0.53 \mathrm{mg} / \mathrm{L}$ to $5.61 \mathrm{mg} / \mathrm{L}$, and lead levels exceeded NYS DWS in one well, with a maximum concentration of $0.04 \mathrm{mg} / \mathrm{L}$. Past groundwater sampling efforts in the Meadow Marsh-Upland Recharge area for vocs have detected only 1,2-dibromoethane (EDB) at concentrations exceeding the NYs DWS of $0.050 \mu \mathrm{g} / \mathrm{L}$. During 1994, for example, the maximum observed concentrations of EDB ranged from $0.06 \mu \mathrm{g} / \mathrm{L}$ to $3 \mu \mathrm{g} / \mathrm{L}$ in temporary wells installed in both onsite and off-site areas. During 1994, twelve permanent groundwater surveillance wells were installed during the oU VI Remedial Investigation to further examine the extent of EDB contamination in on-site areas. Analytical data from groundwater samples collected during the OU IV RI from the ten existing and twelve new weils on-site wells, indicate that EDB concentrations exceeded NYS DWS in four wells with maximum concentrations ranging from $0.051 \mu \mathrm{g} / \mathrm{L}$ to $0.29 \mu \mathrm{g} / \mathrm{L}$.

Southeast-South Central sector: In the southeast and south-central areas of the site, four contaminant source areas are monitored: the HWMF, the current Landfill, the Former Landfill, and Ash Repository area.

In the HWMF area, forty-five groundwater surveillance wells were monitored for water quality, metals, and vocs. The pH readings for groundwater were typically below the NYS Awes of 6.5 - 8.5, but were consistent with values observed at upgradient (background) locations. Other water quality parameters were below the applicable NYS AWQS. Results of metals analyses performed on groundwater samples from this area indicated that iron levels exceeded the NYS DWS in all three upgradient wells (maximum values ranging between $0.74 \mathrm{mg} / \mathrm{L}$ to $0.90 \mathrm{mg} / \mathrm{L}$ ) and seven downgradient wells (maximum values ranging from $0.39 \mathrm{mg} / \mathrm{L}$ to $3.56 \mathrm{mg} / \mathrm{L}$, lead and zinc levels exceeded DWS in one downgradient well at 0.05 $\mathrm{mg} / \mathrm{L}$ and $6.3 \mathrm{mg} / \mathrm{L}$, respectively. Analysis for VoCs in groundwater samples collected from the surveillance wells indicate that TCA, trichloroethylene (TCE), tetrachloroethylene (PCE), and 1,1-dichloroethane (DCA) were detected at concentrations that exceeded the NYS DWS of $5 \mu \mathrm{g} / \mathrm{L}$. The TCA was detected above NYS DWS in four surveillance wells with maximum concentrations ranging from 6 $\mu \mathrm{g} / \mathrm{L}$ to $25 \mu \mathrm{g} / \mathrm{L}$; TCE was detected in one well at a maximum concentration of 7 $\mu \mathrm{g} / \mathrm{I} ; \mathrm{PCE}$ was detected above NYS DWS in five surveillance wells with maximum concentrations ranging from $13 \mu \mathrm{g} / \mathrm{L}$ to $25 \mu \mathrm{g} / \mathrm{L}$; and DCA was detected in five wells above NYS DWS at maximum concentrations ranging from $7 \mu \mathrm{g} / \mathrm{L}$ to $110 \mu \mathrm{g} / \mathrm{L}$.

At the current Iandfill, water quality, metals, and Voc analyses were performed on groundwater samples collected from 41 surveillance wells. The pH readings for groundwater were typically below the NYS AwQS of 6.5 to 8.5 , but were consistent with values observed at upgradient (background) locations. All other water quality parameters were below the applicable NYS AWQS. At the Current Iandfill, iron concentrations exceeded NYS DWS in twenty-one wells, with concentrations ranging from $0.47 \mathrm{mg} / \mathrm{I}$ to $96.1 \mathrm{mg} / \mathrm{L}$. Lead and zinc exceeded the NYS DWS in one well at maximum concentrations of $0.34 \mathrm{mg} / \mathrm{L}$ and $5.2 \mathrm{mg} / \mathrm{L}$, respectively. All other metals concentrations were below NYS DWS. Volatile organic compound data for the current landfill area indicate that TCA was 
detected at concentrations above the NYS DWS in seven wells, with maximum observed concentrations ranging from $5 \mu \mathrm{g} / \mathrm{I}$ to $62 \mu \mathrm{g} / \mathrm{I}$; DCA was detected in twelve wells with maximum observed concentrations ranging from $6 \mu \mathrm{g} / \mathrm{L}$ to 360 $\mu \mathrm{g} / \mathrm{L} ; 1,1$-dichloroethylene (DCE) was detected above the NYS DWS in one well, with a maximum observed concentration of $34 \mu \mathrm{g} / \mathrm{L}$; TCE was detected above NYS DWS in two wells, with maximum observed concentrations ranging from $6.3 \mu \mathrm{g} / \mathrm{L}$ to $10 \mu \mathrm{g} / \mathrm{L}$; PCE was detected above DWS in one well, with a maximum observed concentration of $5.6 \mu \mathrm{g} / \mathrm{L}$; benzene was detected in four wells at or above the NYS DWS, with maximum concentrations ranging from $5 \mu \mathrm{g} / \mathrm{L}$ to $6 \mu \mathrm{g} / \mathrm{L}$; and chloroethane was detected above NYS DWS in nine wells at maximum concentrations ranging from 13 $\mu \mathrm{g} / \mathrm{L}$ to $130 \mu \mathrm{g} / \mathrm{L}$.

In the Former Landfill area, 21 groundwater surveillance wells were sampled during 1994. The $\mathrm{pH}$ readings for groundwater were typically below the NYS AwQS of $6.5-8.5$, but were consistent with the values observed at upgradient locations. All other water quality parameters were below the applicable NYS AWQS. Most metals concentrations were below the applicable NYS DWS, except for iron which was detected in two downgradient wells at maximum concentrations of $11.9 \mathrm{mg} / \mathrm{L}$ and $20.2 \mathrm{mg} / \mathrm{L}$. Volatile organic compounds were detected at concentrations slightly above NYS DWS in two wells; with TCA detected in one well at a maximum concentration of $7 \mu \mathrm{g} / \mathrm{L}$ and TCE in the second well at a maximum observed concentration of $6 \mu \mathrm{g} / \mathrm{L}$.

The Ash Repository is monitored by a single downgradient surveillance well. Water quality data indicate that the values for pH were below the NYS DWS of 6.5 - 8.5, but were consistent with the values observed in upgradient areas. All other water quality parameters, metals, and VoC concentrations were below the applicable NYS DWS and NYS AWQS.

Central sector: In the central part of the site, nine known or suspected contaminant source areas were monitored during 1994; the Central steam Facility (CSF)/Major Petroleum Facility (MPF), AGS area, the Former Building T-111 area, the Supply and Materiel area, the WCF, Building 830, and the recharge basin near the Linac. Those areas where contaminant concentrations exceeded NYS DWS or water quality parameters exceeded NYS AWQS are discussed below.

At the CSE/MPF thirty groundwater surveillance wells were monitored for water quality, metals, and vocs. The $\mathrm{pH}$ readings of groundwater were typically below the NYS AWQS of 6.5 - 8.5, but were consistent with the values observed at upgradient (background) locations. All other water quality parameters were below the applicable NYS AWQS. Results from metals analyses of groundwater from this area indicate that most metals were below the applicable NYS DWS except for iron levels in three wells located near the 1977 spill site. Maximum iron concentrations in the three wells ranged from $2.8 \mathrm{mg} / \mathrm{L}$ to $45.3 \mathrm{mg} / \mathrm{L}$. Volatile organic compound analyses of groundwater samples collected from the CSF/MPF area indicate that TCA, TCE, PCE, ethylbenzene, toluene, and xylene (total) were detected at concentrations that exceeded the NYS DWS. TCA was detected in two wells at maximum concentrations of $7 \mu \mathrm{g} / \mathrm{I}$ and $18 \mu \mathrm{g} / \mathrm{L}$; TCE was detected in two wells at maximum observed concentrations of $7 \mu \mathrm{g} / \mathrm{I}$ and $13 \mu \mathrm{g} / \mathrm{L} ;$ PCE was detected in eight wells with maximum concentrations ranging from $5 \mu \mathrm{g} / \mathrm{L}$ to $65 \mu \mathrm{g} / \mathrm{L}$; ethylbenzene was detected in two wells at maximum concentrations of $25 \mu \mathrm{g} / \mathrm{L}$ to $660 \mu \mathrm{g} / \mathrm{L}$; toluene was detected in one well at a maximum concentration of $1,300 \mu \mathrm{g} / \mathrm{L}$, and xylene (total) was detected in three wells at maximum concentrations of $14 \mu \mathrm{g} / \mathrm{L}$ to $2,140 \mu \mathrm{g} / \mathrm{I}$. As required by the MPE license, the five surveillance wells that monitor the MPF were examined for floating product (i.e., non-dissolved petroleum hydrocarbons) on a monthly basis and twice per year for dissolved voc compounds. As with previous years, no floating product or dissolved vocs that are indicative of petroleum hydrocarbons were observed during 1994. 
Within the AGS area, eleven surveillance wells were monitored for water quality, metals, and Vocs. The $\mathrm{pH}$ readings for groundwater were typically below the NYS AWQS of 6.5 - 8.5, but were consistent with the values observed at upgradient (background) locations. All other water quality parameters were below the applicable NYS AWQS. Results from metals analyses of groundwater samples from this area indicate that most metals were below the applicable NYS DWS except for iron, which was observed in two wells at maximum concentrations of $1.1 \mathrm{mg} / \mathrm{L}$ and $7.7 \mathrm{mg} / \mathrm{L}$, and zinc in one well at $5.3 \mathrm{mg} / \mathrm{L}$. Volatile organic compound analyses indicate that the NYS DWS for TCA was exceeded in one downgradient surveillance well at a maximum concentration of $15 \mu \mathrm{g} / \mathrm{L}$.

Within the WCF area, six surveillance wells were monitored for water quality, metals, and vocs. The pH readings for groundwater were typically below the NYS AWQS of 6.5 - 8.5, but were consistent with the values observed at upgradient (background) locations. All other water quality parameters were below the applicable NYS AWQS. Results from metals analyses of groundwater samples from this area indicated that all metals were below the applicable NYS DWS. Volatile organic compound analyses indicate that the NYS DWS for TCA was exceeded in one upgradient well and three downgradient wells, at maximum concentrations of $7 \mu \mathrm{g} / \mathrm{I}$ in the upgradient well and concentrations ranging from $13 \mu \mathrm{g} / \mathrm{L}$ to 19 $\mu \mathrm{g} / \mathrm{L}$ in the downgradient wells.

Within the $S \& M$ area, eight groundwater surveillance wells were monitored for water quality, metals, and vocs during 1994. The $\mathrm{pH}$ readings for groundwater were typically below the NYS AWQS of 6.5 - 8.5, but were consistent with the values observed at upgradient (background) locations. All other water quality parameters were below the applicable NYS AWQS. Results from metals analyses of groundwater samples from this area indicate that most metals were below the applicable NYS DWS except for iron, which was observed in two wells (including one upgradient well) at maximum concentrations of $0.31 \mathrm{mg} / \mathrm{L}$ and $1.0 \mathrm{mg} / \mathrm{L}$. Results from VOC analyses indicate that TCA was detected at concentrations above NYS DWS in three wells, at maximum observed concentrations of $9 \mu \mathrm{g} / \mathrm{L}, 110 \mu \mathrm{g} / \mathrm{L}$, and $470 \mu \mathrm{g} / \mathrm{L}$. DCE was detected in two wells at maximum concentrations of $8 \mu \mathrm{g} / \mathrm{L}$ and $12 \mu \mathrm{g} / \mathrm{L}$.

The Former Building T-111 (or current Photography \& Graphic Arts) area is monitored by four groundwater surveillance wells. The pH readings for groundwater were typically slightly below or within the NYS AWQS of 6.5 - 8.5. AlI other water quality parameters were below the applicable NYS AWQS. Results from metals analyses of groundwater from this area indicated that all metals were below the applicable NYS DWS. Analysis of the groundwater samples for vocs indicate that TCA and DCE were detected at or above the NYS DWS in one well at maximum observed concentrations of $11 \mu \mathrm{g} / \mathrm{L}$ and $5 \mu \mathrm{g} / \mathrm{L}$, respectively.

North Boundary, West Sector, and South Boundary: In the North Boundary area, surveillance wells monitor background or ambient groundwater quality for the site. Contaminants entering the site from off-site source areas would be detected by the North Boundary wells. Surveillance wells in the West sector of the site monitor groundwater quality in the vicinity of five BNL potable and process supply wells. South Boundary surveillance wells monitor groundwater quality downgradient of the main developed area of the site. Groundwater contaminants would be detected in the South Boundary wells prior to leaving the site.

The North Boundary area surveillance well network consists of twelve wells designed to monitor background or ambient groundwater quality. Groundwater contaminants released from off-site source areas would enter the BNL site along the Northern Boundary. The $\mathrm{pH}$ readings for groundwater samples from Upper 
Glacial aquifer wells were typically below the NYS AWQS of 6.5 - 8.5, whereas readings from a Magothy aquifer well (17-04) were typically within the range of 6.5 - 8.5. Nitrate concentrations exceeded NYS AWQS in one deep Upper Glacial aquifer well, at a concentration of $10.7 \mathrm{mg} / \mathrm{L}$. Results from metals analyses of groundwater from this area indicate that metals concentrations were typically below the applicable NYS DWS, except for iron in two wells at maximum concentrations of $0.34 \mathrm{mg} / \mathrm{L}$ and $3.43 \mathrm{mg} / \mathrm{L}$. Analysis of the groundwater samples for VOCs indicate that TCA and DCA were detected above NYS DWS in a single deep Upper Glacial aquifer well. The maximum concentration for TCA was $6 \mu \mathrm{g} / \mathrm{L}$, and for DCA the maximum concentration was also $6 \mu \mathrm{g} / \mathrm{L}$. These contaminants have migrated on to the BNL site from an upgradient source area(s).

In the West sector, nine surveillance wells were monitored for water quality, metals, and vocs. The pH readings of groundwater were typically below the NYS AWQS of $6.5-8.5$, but were consistent with values observed in upgradient areas. Results of metals analyses indicate that most metals concentrations were below NYS DWS except for iron in one well at a maximum concentration of 0.34 $\mathrm{mg} / \mathrm{L}$. Volatile organic compound results indicate that TCA was detected in concentrations that exceeded NYS DWS in a single middle Upper Glacial aquifer well designed to assess groundwater quality near BNL Supply well 4, at a maximum concentration of $11 \mu \mathrm{g} / \mathrm{L}$.

The South Boundary wells (excluding those monitoring the HWMF and current Landfill) consists of seven surveillance wells designed to monitor groundwater that is migrating off site. The $\mathrm{pH}$ readings of the south boundary groundwater samples were typically below the NYS AWQS of 6.5 - 8.5, but were consistent with values observed in upgradient areas. Other water quality parameters were below the applicable NYS AWQS. Results from metals analyses indicate that all metals were at concentrations below the NYS DWS. Analyses for VoCs in the South Boundary wells indicate that TCA and TCE were detected above NYS DWS in two middle to deep Upper Glacial aquifer wells, with maximum TCA concentrations of $7 \mu \mathrm{g} / \mathrm{L}$ and $10 \mu \mathrm{g} / \mathrm{L}$, and TCE concentrations of $6 \mu \mathrm{g} / \mathrm{L}$ and $12 \mu \mathrm{g} / \mathrm{L}$.

\section{Off-site Dose Estimates}

For the year 1994, the collective committed effective dose equivalent attributable to Laboratory operations, for the population up to a distance of 80 $\mathrm{km}$, was calculated to be 3.49 person-rem (0.035 person-Sv). This can be compared to a collective dose equivalent to the same population of approximately 290,000 person-rem $(2,900$ person-Sv) due to natural sources.

The committed effective dose equivalent to the maximally exposed individual resident at the site boundary (NE sector) from the air pathway is 0.14 mrem $(0.001 \mathrm{mSv})$. The maximum individual committed effective dose equivalent from drinking water pathway is $0.13 \mathrm{mrem} 0.001 \mathrm{mSv}$ ). The maximum individual committed effective dose equivalent from the fish pathway is $0.8 \mathrm{mrem}(0.008 \mathrm{mSv})$. The combined maximum individual dose equivalent is 1.04 mrem $(0.01 \mathrm{mSv})$. This dose represents 18 of the maximum individual annual dose limit of $100 \mathrm{mrem}(1 \mathrm{mSv})$ and $1.7 \%$ of the annual cosmic plus terrestrial external dose of about 60 mrem 10.60 $\mathrm{mSv}$ ).

\section{Quality Assurance Proqram}

Brookhaven National Laboratory has implemented DOE order $\mathrm{CH} 5700.6 \mathrm{C}^{13}$ by developing policies, responsibilities, and providing generic guidance procedures for the development of Quality Assurance programs that are appropriate to ensure the achievement of Laboratory objectives. ${ }^{19}$ The elements of this program have been adopted and adapted, as necessary, by the S\&EP Division in the development 
of the Division's QA program. ${ }^{15}$ Established protocols that document the specific activities of the EM program are described in the S\&EP EMS standard operating Procedure Manuals. The Division Quality Management Team has QA officers that have environmental expertise who review all activities within the EMS that are involved with the generation, collection, analysis, evaluation, and reporting of environmental data or waste management activities to ensure they comply with the S\&EP Division, BNL, and DOE QA objectives.

The level of quality control and quality assurance activities depend on the nature of measurements and the intended use of the data. Checks on sample collection techniques, analysis methods, and instrument performance are incorporated into SOPs and include the use of blanks, replicates, and spikes. In addition, the respective $Q A$ officer is responsible for establishing a program of internal assessments and external audits to verify the effectiveness of sampling, analysis, and data base activities and their adherence to the $Q A$ program. The analytical laboratories participate in interlaboratory $Q A$ programs organized by DOE, EPA, and NYSDEC. Contract laboratories used to augment the capabilities of the in-house laboratory are required to maintain a comprehensive QA program and are subject to audits by S\&EP Division personnel to ensure its implementation.

The results of the Analytical Services Laboratory $Q A$ performance is given in section 7.0. Overall, the S\&EP Division and contractor laboratories used to analyze data presented in this report produced acceptable results in 898 of the independent interlaboratory comparisons they participated in during 1994. The internal quality control programs maintained the analytical processes within their respective acceptance limits in all but a few isolated instances. When encountered, unacceptable results were investigated and corrective actions were implemented to improve the analytical program. 


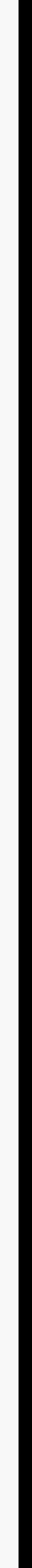




\subsection{INTRODUCTION - J. R. Naidu \\ 1.1 Site Mission}

Brookhaven National Laboratory is managed by Associated Universities Inc. under DOE Contract No. DE-AC02-76CH00016. Associated Universities, Inc. was formed in 1946 by a group of nine universities whose purpose was to create and manage a laboratory in the Northeast in order to advance scientific research in areas of interest to universities, industry, and government. on January 31, 1947, the contract for BNL was approved by the Manhattan District of the Army Corp of Engineers and BNI was established on the former Camp Upton Army camp.

The Laboratory carries out basic and applied research in the following fields: high-energy nuclear and solid state physics; fundamental material and structural properties and the interactions of matter; nuclear medicine, biomedical and environmental sciences; and selected energy technologies. In conducting these research activities, it is Laboratory policy to protect the health and safety of employees and the public, and to minimize the impact of BNL operations on the environment.

\subsection{Site Characteristics}

Brookhaven National Laboratory is a multi disciplinary scientific research center located close to the geographical center of Suffolk County on Long Island, about $97 \mathrm{~km}$ east of New York City. Its location with regard to the metropolitan area and local communities are shown in Figures 1-1 and 1-2, respectively. About 1.33 million persons reside in suffolk County ${ }^{16}$ and about 0.42 million persons reside in Brookhaven Township, within which the Laboratory is situated. Approximately eight thousand persons reside within a half $\mathrm{km}$ of the Laboratory boundary. The distribution of the resident population within $80 \mathrm{~km}$ of the BNL site is shown in Figure $1-1$ and the 1994 BNI SER Compendium, Table 1 . The population distribution within $0.5 \mathrm{~km}$ of the BNL site is shown in Figure 1-2. Although much of the land area within a $16 \mathrm{~km}$ radius remains either forested or cultivated, there has been an increase in residential housing development in the rural areas surrounding BNL (Figure 1-3), though there have been no major construction projects in the vicinity since 1978. However, detailed plans for two shopping centers, a corporate park, and several thousand single and multiple family dwellings are proposed within a $15 \mathrm{~km}$ area of BNL, predominately on the north, south, and west boundaries.

The Laboratory site is shown in Figure 1-3. It consists of 21.3 square kilometers $(2,130$ hectares [ha]), with most of its principal facilities located near the center of the site. The developed area is approximately 6.7 square kilometers $(670 \mathrm{ha})$ of which about 2.02 square kilometers $(202$ ha) were originally developed for Army use, about 0.81 square kilometers ( 81 ha) are occupied by various large specialized research facilities, and outlying facilities occupy about 2.22 square kilometers (222 ha). These include the STP, research agricultural fields, housing and fire breaks. The balance of the site is largely wooded.

The terrain of the site is gently rolling, with elevations varying between 36.6 and $13.3 \mathrm{~m}$ above sea level. The land lies on the western rim of the shallow Peconic River water shed. The marshy areas in the north and eastern sections of the site are a portion of the Peconic River headwaters. The Peconic River both recharges to, and receives water from, the groundwater aquifer depending on the hydrological potential. In times of drought the river water typically recharges to groundwater (i.e., an influent stream) while in times of normal to above normal precipitation, the river receives water from the aquifer (i.e., an 


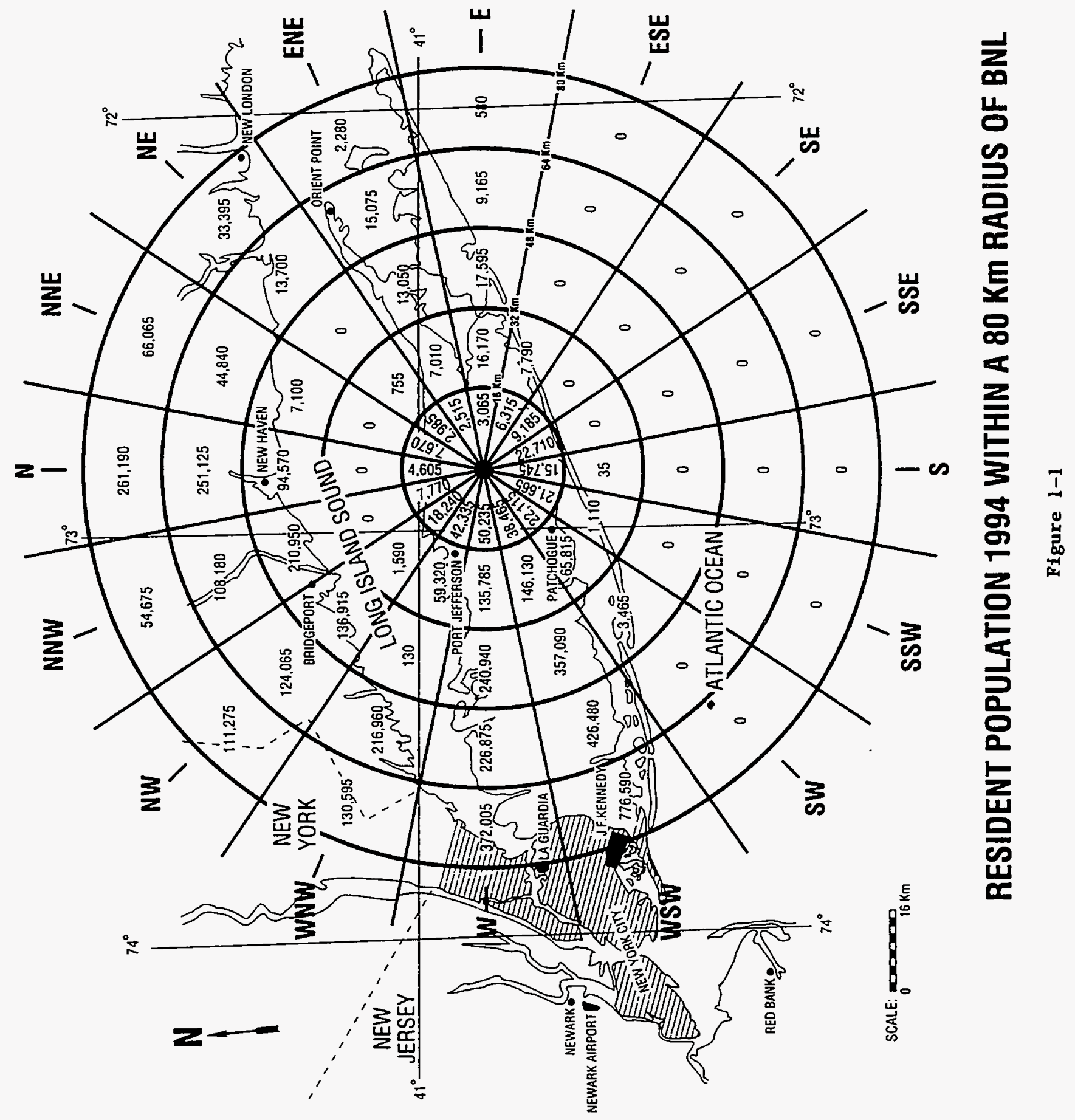


Figure 1-2

\section{BROOKHAVEN NATIONAL LABORATORY LOCAL AND ON-SITE POPULATION DISTRIBUTION}

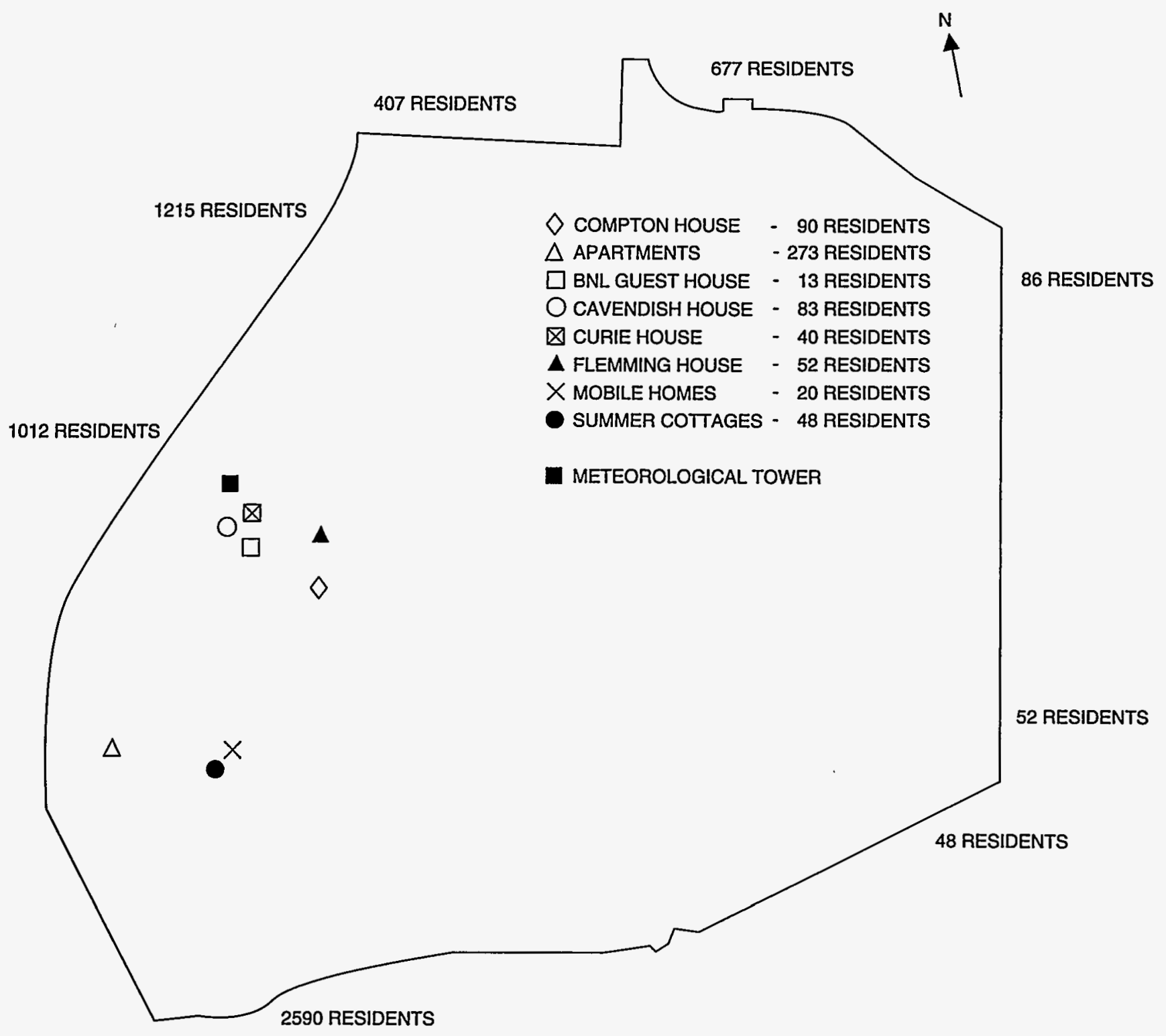

$\frac{0 \quad 180 \quad 360}{\text { SCALE }}$ METERS 
Major Facilities

Figure 1-3

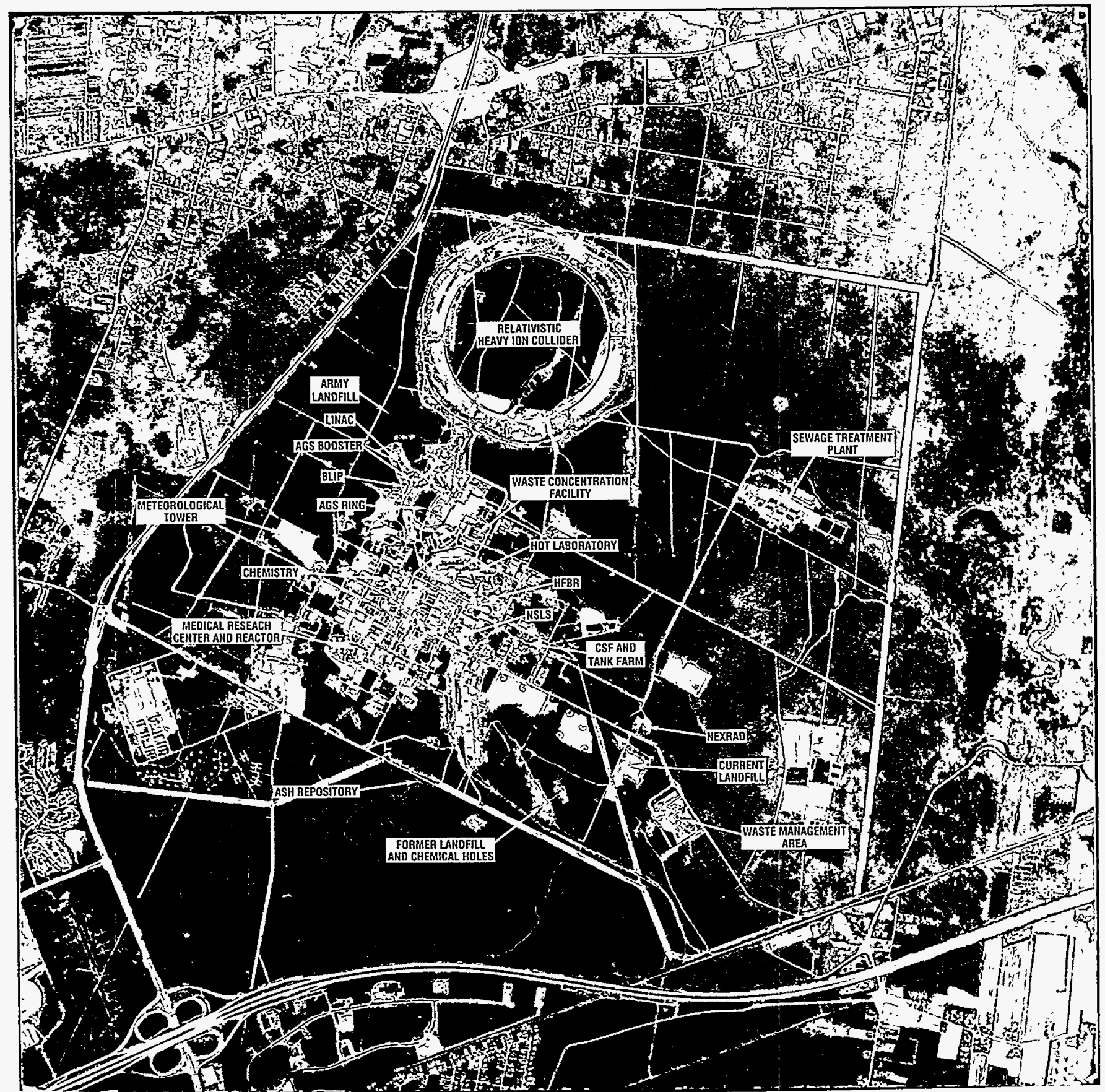


effluent stream). The river on-site is thus classified as an intermittent river. In 1994, for a significant period of the year, the Peconic River bed on-site was in a recharge mode. Consequently, virtually no flow left the site.

The Laboratory uses approximately 16.1 million liters of groundwater per day to meet potable water plus heating and cooling requirements. Approximately $70 \%$ of the total pumpage was returned to the aquifer through on-site recharge basins. About $15 \%$ is discharged into the Peconic River. Human consumption utilizes $4 \%$ of the total pumpage while evaporation (cooling tower and wind losses), cesspool plus line losses account for $9 \%$ and $2 \%$, respectively. These latter percentages are based on flow estimates and mass balance. Accuracy in such estimations is expected to be increased when flow measurement systems at the recharge basins are installed as part of the environmental monitoring upgrades in 1995 .

In terms of meteorology, the Laboratory can be characterized, like most eastern seaboard areas, as a well-ventilated site. The prevailing ground level winds are from the southwest during the summer, from the northwest during the winter, and about equally from these two directions during the spring and fall.17,18 The 1994 annual wind rose for BNL is presented in Figure 1-4. The joint frequency distribution data for the period 1993 to 1994 is presented in the 1994 BNL SER Compendium, Table 2. The average temperature in 1994 was $10.66^{\circ} \mathrm{C}$ and the range was $-2.2^{\circ} \mathrm{C}$ to $29.9 \mathrm{C}$. Monthly minimum, maximum, and average temperature data are presented in the Compendium, Table 3 and shown graphically in Figure 1-5.

Studies of Long Island hydrology and geology ${ }^{19-22}$ in the vicinity of the Laboratory indicate that the uppermost pleistocene deposits, which are between 31 - $61 \mathrm{~m}$ thick, are generally composed of highly permeable glacial sands and gravels. Water penetrates these deposits readily and there is little direct runoff into surface streams, except during periods of intense precipitation. The total precipitation for 1994 was $112.2 \mathrm{~cm}$, which is about $11 \mathrm{~cm}$ below the 40 year annual average. The 1994 monthly and historic precipitation data are presented in Eigures $1-6$ and 1-7, respectively. The monthly and annual precipitation data are also presented in the compendium, Table 4 . On the average, about half of the annual precipitation is lost to the atmosphere through evapotranspiration and the other half percolates through the soil to recharge groundwater. Run-offs form a very insignificant portion of the total rainfall, usually less than $2 \% .{ }^{23}$

Groundwater flow in the vicinity of BNL is affected by many factors. The main groundwater divide lies approximately $2-3 \mathrm{~km}$ north of BNL, and runs parallel to the Long Island Sound. This divide is known to shift $1-2 \mathrm{~km}$, north to south. ${ }^{21}$ East of BNL is a secondary groundwater divide that defines the southern boundary of the area contributing groundwater to the Peconic River. The exact location of the triple-point intersection of these two divides is not known and may be located to the northwest of BNL. South of these divides the groundwater moves southward to Great South Bay and to Moriches streams. In general, the groundwater from the area between the two branches of the divide moves eastward to the Peconic River. North of the divide groundwater moves northward to Long Island Sound. Pressure of a higher water table to the west of the BNL area generally inhibits movement towards the west. variability in the direction of flow on the BNL site is a function of the hydraulic potential and is further complicated by the presence of near surface clay deposits that accumulate perched water at several places within the site, and the pumping/ recharge of groundwater that are part of BNL daily operations. In general, groundwater in the northeast and northwest sections of the site flows towards the Reconic River. On the western portion of the site, groundwater flow tends to be towards the south while along the southern and southeastern sections of the site 


\section{Note:}

1. The arrowheads formed by the wedges indicate the direction that the wind blew towards, so the predominant wind blew towards the north-northeast and southeast in 1994.

2. Each concentric circle represents a 4 percent frequency, so wind blew from the SSW approximately $14 \%$ of the time in 1994 .

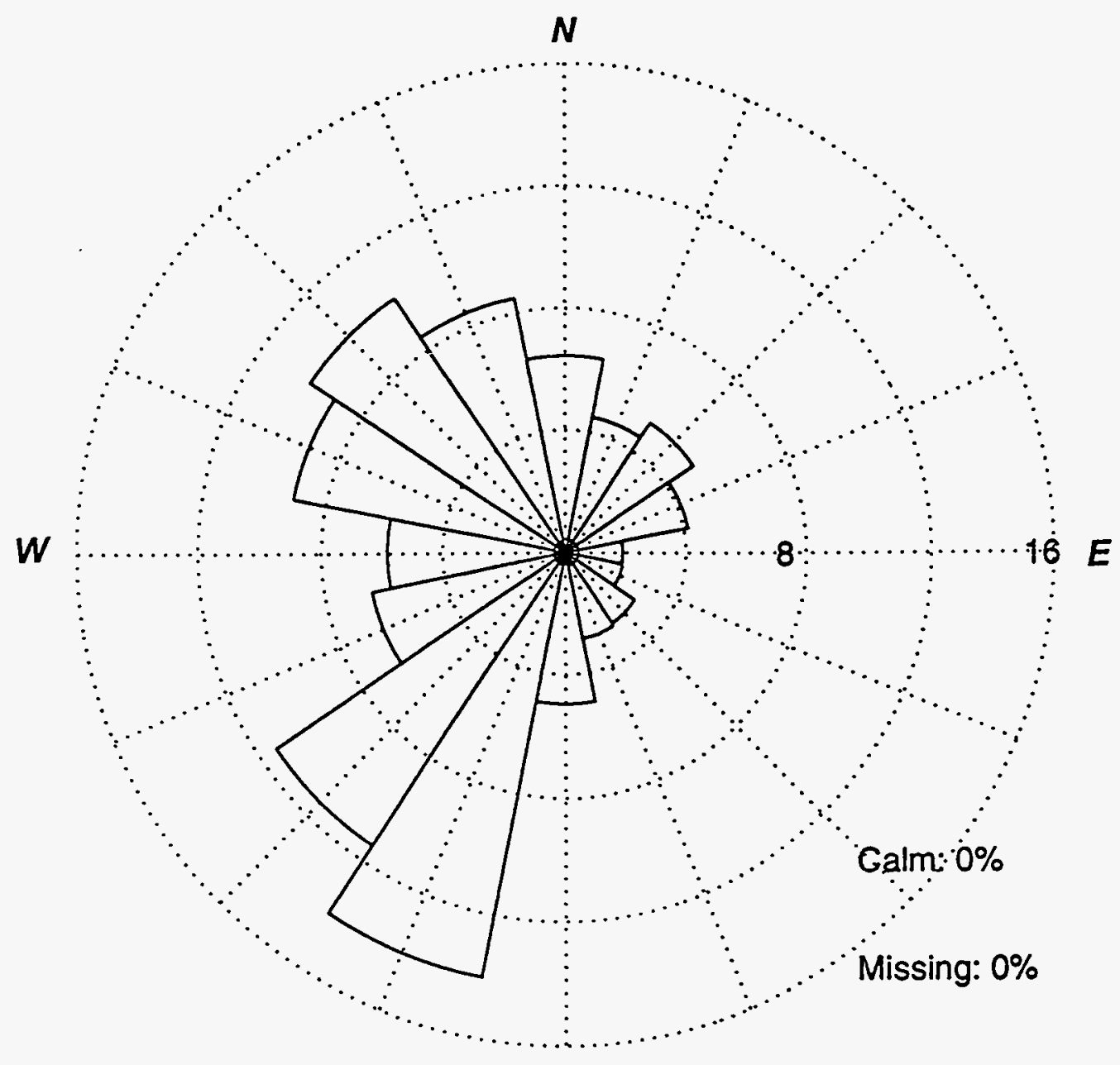

$\mathbf{S}$

Figure 1-4: Annual wind Rose for 1994 


\section{Climatology of the BNL Site}

\section{Annual Temperatures}

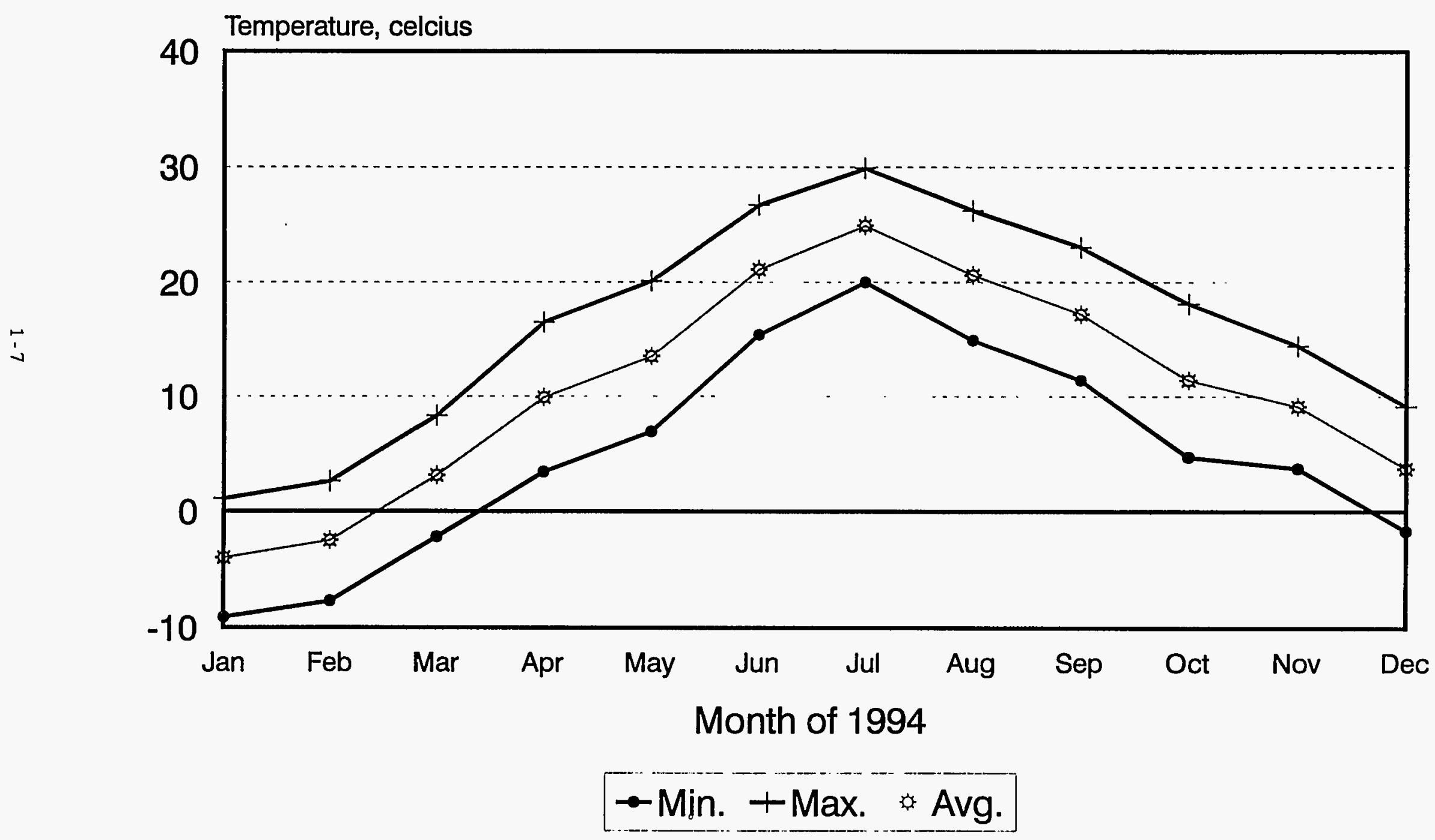




\section{Figure 1-6 \\ Climatology of the BNL Site \\ Annual Precipitation}

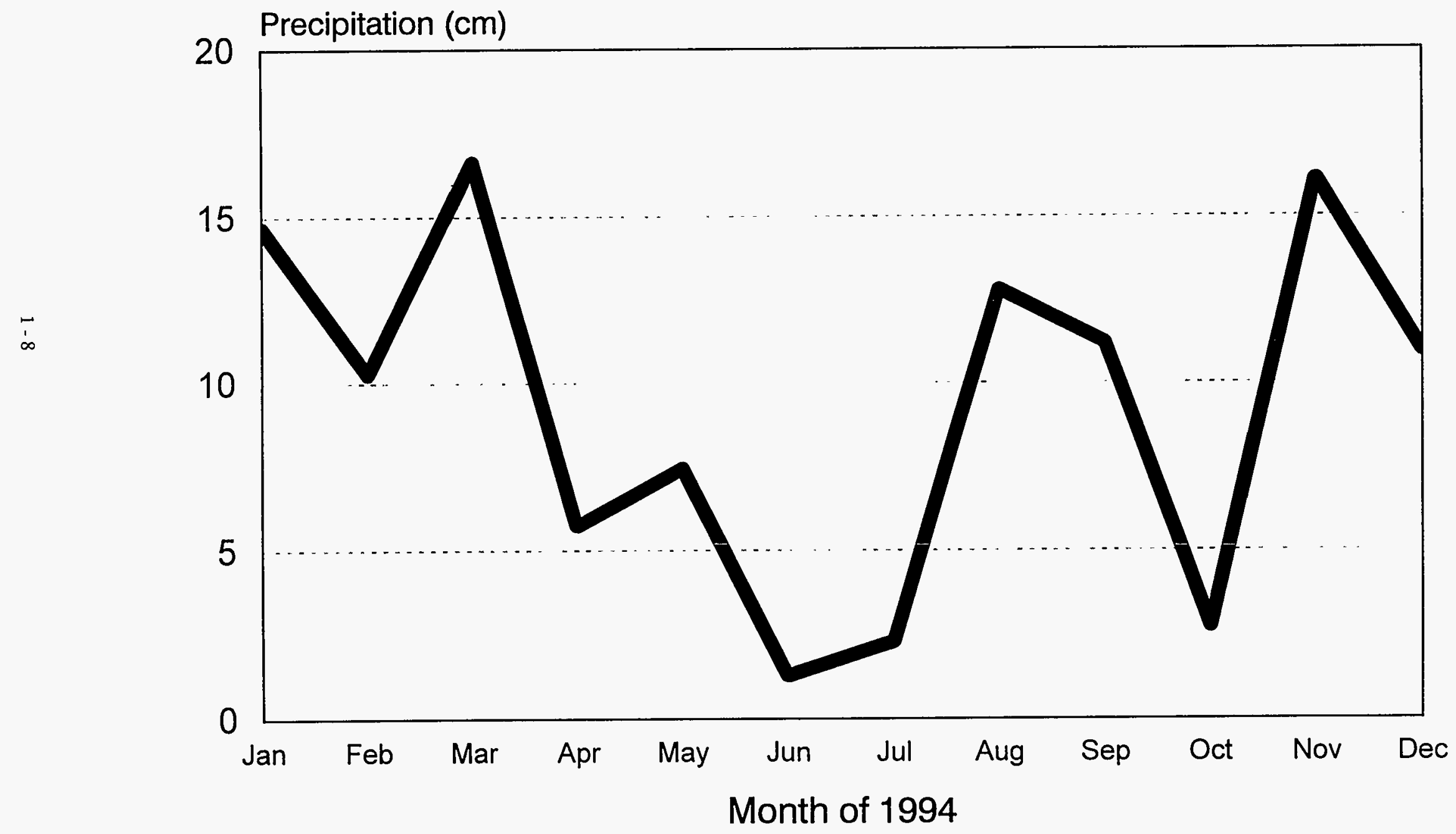




\section{Precipitation Trend Data for BNL}

(1949 to 1994)

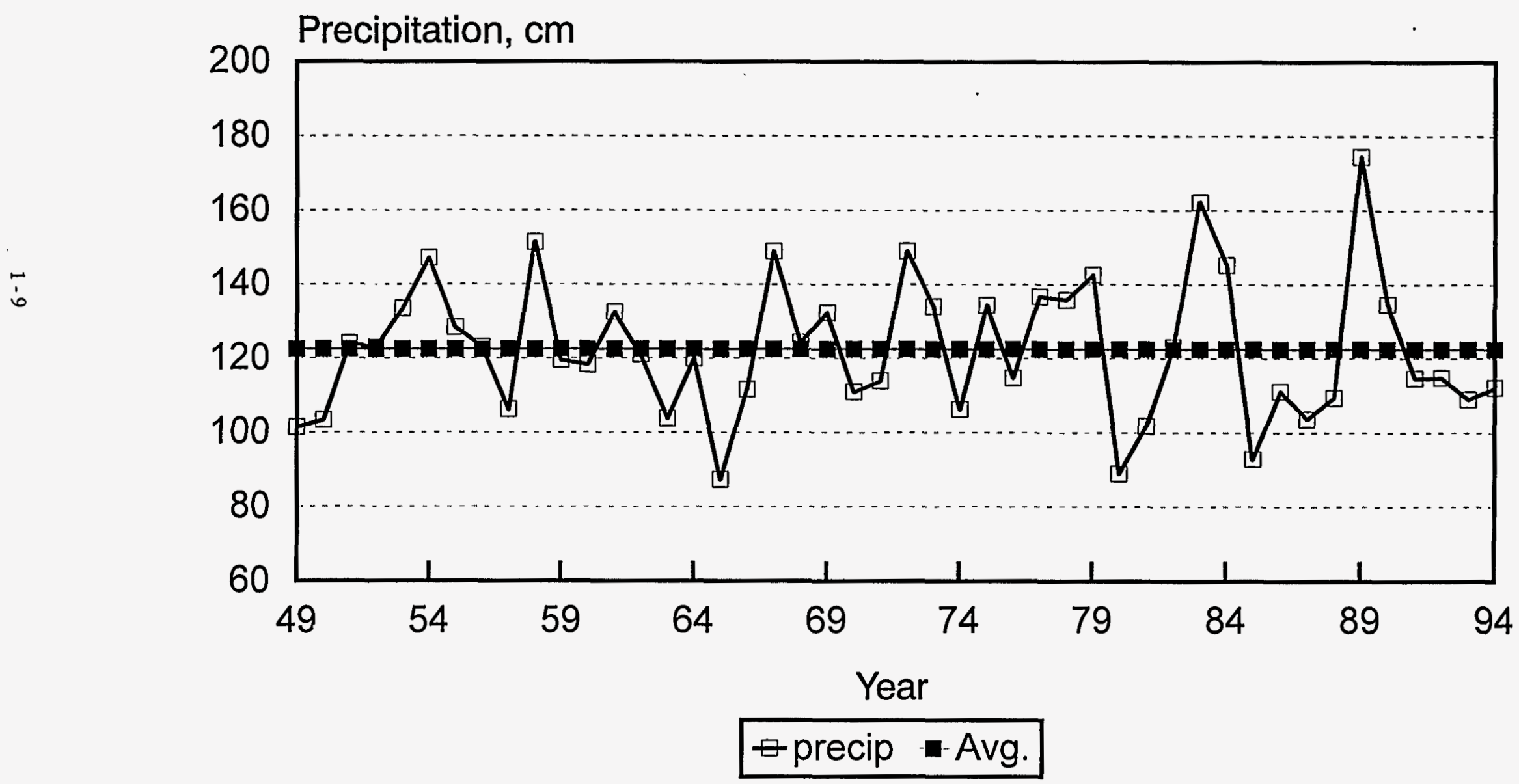




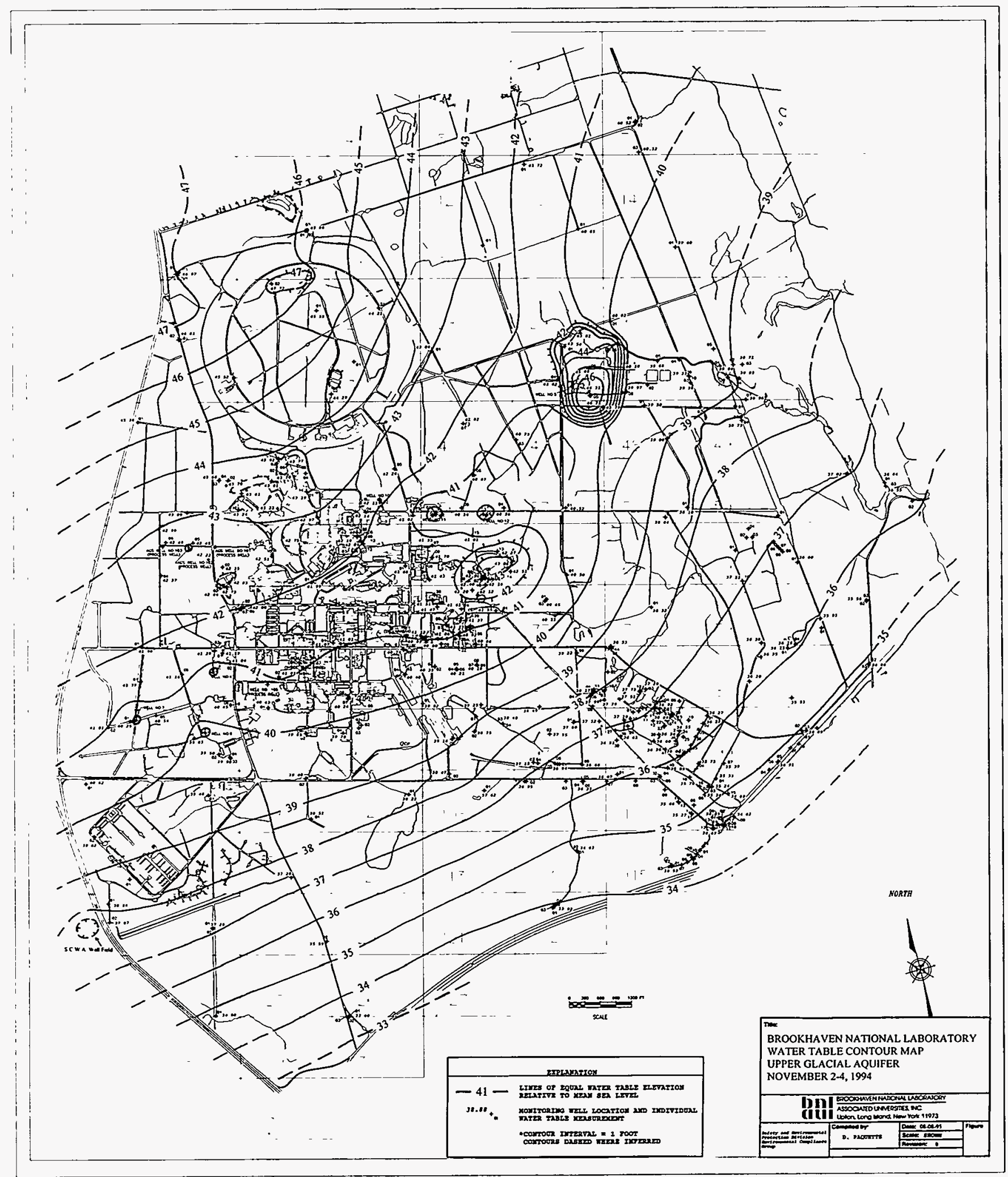

Figure 1-8: Site Water Table Map 1994 
the groundwater flow tends to be towards the south to southeast (Figure 1-8). In all areas of the site, horizontal groundwater velocity is estimated to range from 22 to $30 \mathrm{~cm} / \mathrm{d}^{19-22}$ The site occupied by BNL has been identified by the Long Island Regional Planning Board ${ }^{23}$ and Suffolk County as being over a deep flow recharge zone for long Island. This implies that precipitation and surface water which recharges within this zone has the potential to replenish the lower aquifer systems (Magothy and Iloyd) which exist below the Upper Glacial Aquifer. It is estimated that up to two fifths of the recharge from rainfall moves into the deeper aquifers. The extent to which the BNL site contributes to deep flow recharge is currently under evaluation. In coastal areas, these lower aquifers discharge to the Atlantic Ocean or the Long Island sound. ${ }^{23}$

The Laboratory is located in a section of the oak/Chestnut forest region of the Coastal Plain. Because of the general topography and porous soil, there is little surface run-off or open water. Upland soils tend to be drained excessively, while depressions form small pocket wetlands. Hence, a mosaic of wet and dry areas on the site are correlated with variations in topography and depth to the water table. In the absence of fire or other disturbance, the vegetation normally follows the moisture gradient closely. In actuality, vegetation on-site is in various stages of succession which reflects the history of disturbances to the area, the most important having been land clearing, fire, local flooding, and draining.

Mammals endemic to the site include species common to mixed hardwood forests and open grassland habitats. At least 180 species of birds have been observed at BNL, a result of its location within the Atlantic Flyway and the scrub/shrub habitats which offer food and resting opportunities to migratory songbirds. Open fields bordered by hardwood forests found at the recreation complex provide excellent hunting areas for hawks. Pocket wetlands with seasonal standing water provide breeding areas for amphibians. Permanently flooded retention basins and other watercourses support aquatic reptiles.

Except for occasional transient individuals, no Federal or New York state (NYS) listed or proposed threatened or endangered species exist within the Laboratory area. ${ }^{24,25}$ One NYS species of "special concern", which has been confirmed as an inhabitant of the Peconic River on-site, is the banded sunfish (Eanneacanthus obesus). This species occurs in New York solely within the Peconic River system. Although a final report is not yet available, preliminary data indicates use of BNL vernal ponds and some recharge basins by the NYS endangered eastern tiger salamander (Ambystoma tigrinum). A portion of the Peconic River which occurs on BNL property has been designated as "scenic" in accordance with the NYS's Wild, Scenic, and Recreational River systems Act (WSRRSA). The wide variety of wildlife resources at BNL attest to Laboratory planning practices which have clustered development to minimize habitat Eragmentation, particularly in environmentally sensitive areas such as the Peconic River corridor. Habitat fragmentation represents the greatest threat to wildlife habitats on Long Island today.

\subsection{Existing Facilities}

A wide variety of scientific programs are conducted at Brookhaven, including research and development in the following areas:

1. The fundamental structure and properties of matter;

2. The interactions of radiation, particles, and atoms with other atoms and molecules; 
3. The physical, chemical, and biological effects of radiation;

4. The production of special radionuclides and their medical applications:

5. Energy and nuclear related technology; and

6. The assessment of energy sources, transmission and uses, including their environmental and health effects.

The major scientific facilities which are operated at the Laboratory to carry out the above programs are described below:

1. The High Flux Beam Reactor is fueled with enriched uranium, moderated and cooled by heavy water. In the past, this facility operated at a routine power level ranging from 40 to $60 \mathrm{MW}$ thermal. since May 1991, it operated at a level of 30 MW thermal.

2. The Medical Research Reactor is an integral part of the Medical Research Center (MRC), is fueled with enriched uranium, moderated and cooled by light water, and is operated intermittently at power levels up to $3 \mathrm{MW}$ thermal.

3. The Alternating Gradient synchrotron is used for high energy physics research and accelerates protons to energies up to $30 \mathrm{GeV}$ and heavy ion beams to $15 \mathrm{GeV} / \mathrm{amu}$.

4. The $200 \mathrm{MeV}$ Iinear Accelerator (LINAC) serves as a proton injector for the AGS and also supplies a continuous beam of protons for radionuclide production by spallation reactions in the Brookhaven Iinac Isotope Production Facility (BLIP).

5. The Tandem Van de Graaff, Vertical Accelerator, Cyclotron, and research Van de Graaff are used in medium energy physics investigations, as well as for special nuclide production. The heavy ions from the Tandem Van de Graaffs can also be injected into the AGS for use in physics experiments.

6. The National synchrotron Iight Source (NSLS) utilizes a linear accelerator and booster synchrotron as an injection system for two electron storage rings which operate at energies of $750 \mathrm{MeV}$ vacuum ultraviolet (VUV) and $2.5 \mathrm{GeV}$ (x-ray). The synchrotron radiation produced by the stored electrons is used for VUV spectroscopy and for $\mathrm{x}$-ray diffraction studies.

7. The Heavy Ion Transfer tunnel connects the coupled Tandem Van de Graaffs and the AGS. The interconnection of these two facilities permits the injection of intermediate mass ions into the AGs where the ions can be accelerated to an energy of $15 \mathrm{GeV} / \mathrm{amu}$. These ions are then extracted and sent to the AGS experimental area for physics research.

8. The AGS Booster is a circular accelerator with a circumference of 200 meters that will receive either a proton beam from the Iinac or heavy ions from the Tandem Van de Graaff. The Booster accelerates proton particles and heavy ions prior to injection into the AGS ring. This facility became operational in 1992. 
9. The Radiation Therapy Facility operated jointly by the BNL Medical Department and State University of New York at Stony Brook, is a high energy dual $\mathrm{x}$-ray mode linear accelerator for radiation therapy of cancer patients. This accelerator has been designed to deliver therapeutically useful beams of $x$-rays and electrons for conventional and advanced radiotherapy techniques.

Additional programs involving irradiations and/or the use of radionuclides for scientific investigations are carried out at other Laboratory facilities including those of the MRC, the Biology Department, the Chemistry Department, and the Department of Applied Technology (DAT). Special purpose radionuclides are developed and processed for general use under the joint auspices of the Department of Applied Science (DAS) and the Medical Department. 

B. A. Royce, R. J. Lee, D. E. Paquette, G. I. Schroeder, T. G. Sperry, J.

K. Williams, J. R. Naidu and S. I. R. Briggs.

It is the policy of BNI to operate and maintain the site in compliance with applicable federal, state, or local regulations and DoE orders. This section provides a brief summary of the compliance status for existing facilities and operations during CY 1994.

\subsection{Environmental Permits}

There are a variety of processes and facilities at BNL which operate under regulatory permits. These permits include one spDEs permit, a MFP license, a Resource Conservation Recovery Act (RCRA) permit, a certificate from NYSDEC registering tanks storing bulk quantities of hazardous substances, seven National Emission Standards for Hazardous Air Pollutants (NESHAPS) authorizations, 50 Certificates to operate (CO) air emission sources from NYSDEC and 26 applications pending with NYSDEC either for renewals of existing COs, cancellations of existing cos, or Cos for new air emission sources. The type and status of all environmental permits issued to the DOE through December 31, 1994 is presented in Table $2-1$.

\subsection{Groundwater Compliance Monitoring}

There are two areas at BNL where groundwater monitoring is required by regulatory permits or licenses. These include the Current Iandfill which was operated under a permit issued by the NYSDEC. The second is the MPF which currently operates under a license (No. 0-1700) issued by the NYSDEC. Although the Current Iandfill ceased operation in December, 1990, in accordance with the Long Island Landfill Iaw, the Laboratory has continued to perform the groundwater monitoring requirements specified in this permit while the office of Environmental Restoration (OER) has been conducting a Remedial Investigation/Feasibility study (RI/FS) to assess the full extent of soil and groundwater contamination associated with the landfill. The monitoring results from this area for CY 94 are discussed below.

\subsubsection{Current Landfill}

The Current Landfill is approximately eight acres in size, and was in operation from 1967 to 1990. During its operation, the landfill received six to eight tons of material per work day. putrescible and non-putrescible wastes, including building debris and asbestos, were disposed of in the landfill until February 1981. After this date, all putrescible waste was taken to the Brookhaven Town Landfill. Although all authorized chemical waste disposal at the BNL site ended in 1966, the presence of VOCs in groundwater downgradient of the landfill indicates that disposal of low levels of chemical wastes did occur. Until the late 1970s, iron sludge residues from the BNL WTP and approximately 2,500 cubic feet of sewage sludge containing low level radioactivity, were disposed of in the landfill. From 1967 to 1978, the landfill also received low level radioactive laboratory waste, partially decontaminated equipment, contaminated clothing, and tritiated mouse litter. In past years, metals (principally iron), and occasionally radionuclides, have been detected in the Current Landfill monitoring wells at concentrations exceeding NYs DWS.

Assessment of the extent of groundwater contamination downgradient of the Current Landfill is presently being conducted by the BNL OER, in fulfillment of the Comprehensive Environmental Response, Compensation \& Liability ACt (CERCIA) investigation requirements for operable Unit (OU I) (see section 2.10). The CERCLA investigations at the Current Iandfill include a RI/FS, and a non-time critical Removal Action for the'proper closure of the landfill, which includes 
Table 2-1

BNL Site Environmental Report for Calendar Year 1994

BNL Environmental Permits

\begin{tabular}{|c|c|c|c|c|}
\hline $\begin{array}{l}\text { Bldg/Facility } \\
\text { Designation }\end{array}$ & $\begin{array}{l}\text { Process } \\
\text { Description }\end{array}$ & $\begin{array}{l}\text { Permitting Agency } \\
\text { and Division }\end{array}$ & Permit Number & $\begin{array}{l}\text { Expiration } \\
\text { Date }\end{array}$ \\
\hline 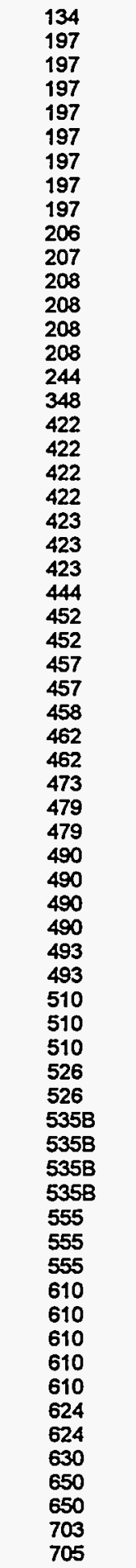 & 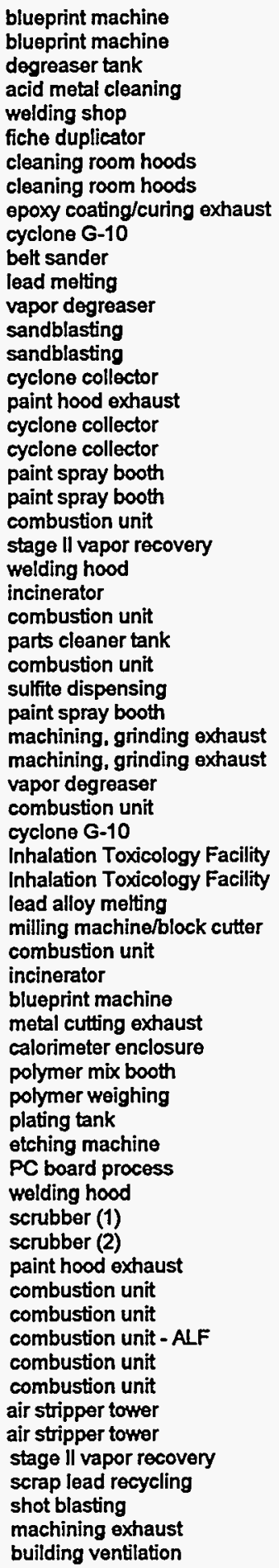 & 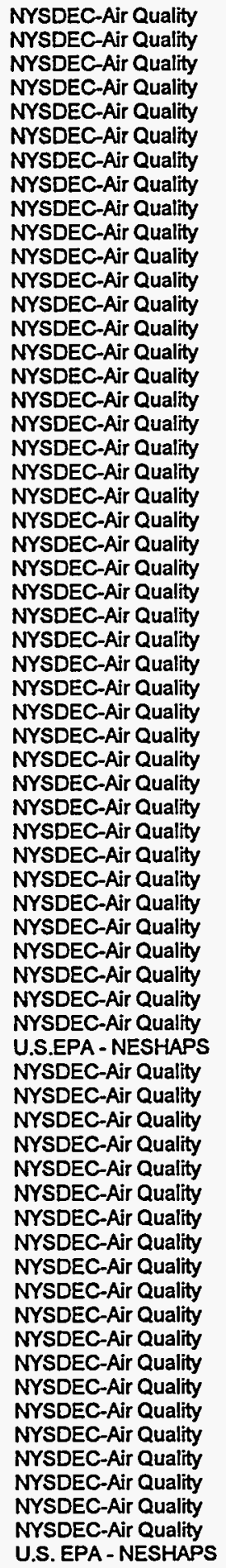 & 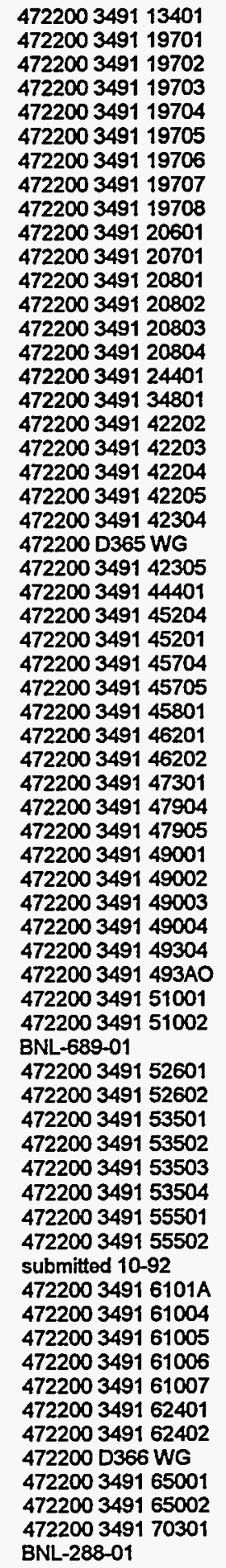 & 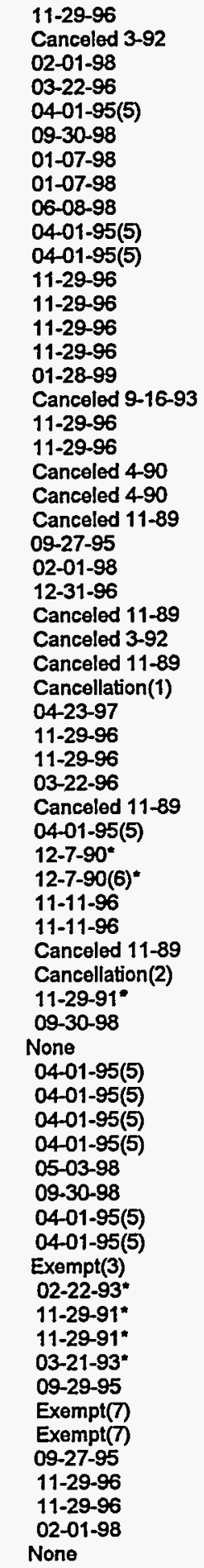 \\
\hline
\end{tabular}


Table 2-1 (Continued)

BNL Site Environmental Report for Calendar Year 1994

BNL Environmental Permits

\begin{tabular}{|c|c|c|c|c|}
\hline $\begin{array}{l}\text { Bldg./Facility } \\
\text { Designation }\end{array}$ & $\begin{array}{l}\text { Process } \\
\text { Description }\end{array}$ & $\begin{array}{l}\text { Permitting Agency } \\
\text { and Division }\end{array}$ & Permit Number & $\begin{array}{l}\text { Expiration } \\
\text { Date }\end{array}$ \\
\hline $\begin{array}{l}725 \\
815 \\
820 \\
901 \\
901 \\
902 \\
902 \\
902 \\
902 \\
902 \\
903 \\
903 \\
903 \\
905 \\
905 \\
905 \\
911 \\
911 \\
919 A \\
919 A \\
919 A \\
922 \\
923 \\
924 \\
924 \\
924 \\
930 \\
930 \\
930 \\
930 \\
\text { T30 } \\
\text { AGS Booster } \\
\text { RHIC } \\
\\
\text { CSF(d) } \\
\text { STP(a) \& RCB(b) }\end{array}$ & $\begin{array}{l}\text { blueprint machine } \\
\text { welding hood } \\
\text { accelerator test facility } \\
\text { tin lead solder } \\
\text { paint hood exhaust } \\
\text { spray booth exhaust } \\
\text { belt sander } \\
\text { sanding, cutting, drilling } \\
\text { brazing/solder exhaust } \\
\text { painting/soldering exhaust } \\
\text { blueprint machine } \\
\text { cyclone } G-10 \\
\text { brazing process exhaust } \\
\text { vapor degreaser } \\
\text { belt sander } \\
\text { machining exhaust } \\
\text { blueprint machine } \\
\text { paint spray hood } \\
\text { sandblasting } \\
\text { sandblasting } \\
\text { solder exhaust } \\
\text { cyclone exhaust } \\
\text { electronic equip. cleaning } \\
\text { spray booth exhaust } \\
\text { magnet coil production press } \\
\text { machining exhaust } \\
\text { electroplating/acid etching } \\
\text { bead blaster } \\
\text { ultrasonic cleaner } \\
\text { paint hood exhaust } \\
\text { combustion unit } \\
\text { spray aeration project } \\
\text { accelerator } \\
\text { accelerator } \\
\text { radiation therapy facility } \\
\text { radiation effects/neutral beam } \\
\text { major petroleum facility } \\
\text { sewage plant \& recharge basins }\end{array}$ & $\begin{array}{l}\text { NYSDEC-Air Quality } \\
\text { NYSDEC-Air Quality } \\
\text { U.S.EPA - NESHAPS } \\
\text { NYSDEC-Air Quality } \\
\text { NYSDEC-Air Quality } \\
\text { NYSDEC-Air Quality } \\
\text { NYSDEC-Air Quality } \\
\text { NYSDEC-Air Quality } \\
\text { NYSDEC-Air Quality } \\
\text { NYSDEC-Air Quality } \\
\text { NYSDEC-Air Quality } \\
\text { NYSDEC-Air Quality } \\
\text { NYSDEC-Air Quality } \\
\text { NYSDEC-Air Quality } \\
\text { NYSDEC-Air Quality } \\
\text { NYSDEC-Air Quality } \\
\text { NYSDEC-Air Quality } \\
\text { NYSDEC-Air Quality } \\
\text { NYSDEC-Air Quality } \\
\text { NYSDEC-Air Quality } \\
\text { NYSDEC-Air Quality } \\
\text { NYSDEC-Air Quality } \\
\text { NYSDEC-Air Quality } \\
\text { NYSDEC-Air Quality } \\
\text { NYSDEC-Air Quality } \\
\text { NYSDEC-Air Quality } \\
\text { NYSDEC-Air Quality } \\
\text { NYSDEC-Air Quality } \\
\text { NYSDEC-Air Quality } \\
\text { NYSDEC-Air Quality } \\
\text { NYSDEC-Air Quality } \\
\text { NYSDEC-Air Quality } \\
\text { U.S. EPA - NESHAPS } \\
\text { U.S. EPA - NESHAPS } \\
\text { U.S. EPA - NESHAPS } \\
\text { U.S. EPA - NESHAPS } \\
\text { NYSDEC-Water Quality } \\
\text { NYSDEC-Water Quality }\end{array}$ & $\begin{array}{l}472200349172501 \\
472200349181501 \\
\text { BNL-589-01 } \\
472200349190101 \\
\text { submitted 10-92 } \\
472200349190201 \\
472200349190202 \\
472200349190203 \\
472200349190204 \\
472200349190205 \\
472200349190301 \\
472200349190302 \\
472200349190303 \\
472200349190501 \\
472200349190502 \\
472200349190503 \\
472200349191101 \\
\text { submitted 12-90 } \\
472200349191901 \\
472200349191902 \\
472200349191903 \\
472200349192201 \\
\text { submitted 3-93, } \\
472200349192401 \\
472200349192402 \\
472200349192403 \\
472200349193001 \\
472200349193002 \\
472200349193003 \\
\text { submitted 10-92 } \\
4722003491 \text { T3004 } \\
\text { submitted 10-89, } \\
\text { BNL-188-01 } \\
\text { BNL-389-01 } \\
\text { BNL-489-01 } \\
\text { BNL-789-01 } \\
1-1700 \\
\text { NY-0005835 }\end{array}$ & $\begin{array}{l}\text { Cancellation (8) } \\
\text { Canceled 9-16-93 } \\
\text { None } \\
04-01-95(5) \\
\text { Exempt(3) } \\
09-30-98 \\
05-03-98 \\
05-03-98 \\
05-03-98 \\
05-03-98 \\
11-29-96(9) \\
04-01-95(5) \\
09-30-98 \\
03-22-96 \\
06-18-95 \\
05-03-98 \\
11-29-96 \\
\text { Exempt(4) } \\
04-23-97 \\
04-23-97 \\
02-01-98 \\
04-01-95(5) \\
\text { status pending } \\
09-30-98 \\
02-01-98 \\
05-03-98 \\
02-01-98 \\
02-01-98 \\
02-01-98 \\
\text { Exempt(3) } \\
\text { Canceled 11-89 } \\
\text { status pending } \\
\text { None } \\
\text { None } \\
\text { None } \\
\text { None } \\
03-31-95 \\
\text { I.0.5. }\end{array}$ \\
\hline$H W M F(c)$ & waste management & $\begin{array}{l}\text { NYSDEC-Hazardous } \\
\text { Waste }\end{array}$ & $\begin{array}{l}\text { NYS ID No. } \\
1-4722-00032 / 00021-0\end{array}$ & $08-31-98$ \\
\hline BNL Site & chem tanks-HSBSRC & NYSDEC & $1-000263$ & $07-27-95$ \\
\hline
\end{tabular}
(a) Sewage Treatment Plant
(b) Recharge basins
(d) Central Steam Facility
(c) Hazardous Waste Management Facility
I.O.S. = Interim Operating Status (under review for renewal)
HSBSRC = Hazardous Substance Bulk Storage Registration Certificate

"Note: Renewal application submitted more than 30 days prior to expiration date; process can continue to operate under provisions of the NYS Uniform Procedures Act.

(1) Cancellation requested 7-92, status pending.

(2) Process no longer in use, cancellation requested 11-13-90, status pending.

(3) Evaluated by NYSDEC; declared to be exempt 2-11-93.

(4) Evaluated by NYSDEC; declared to be exempt 9-16-93.

(5) Renewal applications submitted 3-9-95, approvals pending.

(6) Application for permit modification submitted 3-10-95, status pending.

(7) Evaluated by NYSDEC: declared to be exempt 9-26-94.

(8) Cancellation requested 4-95, status pending.

(9) Cancellation requested 3-93, status pending. 
construction of an impermeable landfill cap. Construction of the landfill cap, which has been designed in accordance with 6 NYCRR Part 360 (December 1988) requirements, will begin in the spring of 1995.

The Current Landfill was issued an operating permit (No. 52-S-20) by the NYSDEC on January 14, 1981. In compliance with the Iong Island Landfill Law (1990), BNL closed the landfill on December 18, 1990 due to the absence of a landfill liner. In accordance with the NYSDEC landfill permit requirements, BNL continues to collect quarterly groundwater samples from the one upgradient and six downgradient monitoring wells listed in the permit (including subsequent modifications). The groundwater samples are collected and analyzed by the BNL S\&EP Division's Sampling \& Analysis Group (SAG) for VOCs, inorganics, water quality (anions, $\mathrm{pH}$, conductivity), and radionuclides.

During 1994, BNL collected and analyzed quarterly groundwater samples obtained from the seven landfill monitoring wells listed in the NYSDEC permit. of the reportable parameters, only iron exceeded the NYS DWS limits. Iron concentrations exceeded the NYS DWS of $0.3 \mathrm{mg} / \mathrm{L}$ in all six downgradient wells, with average concentrations ranging from $5.38 \mathrm{mg} / \mathrm{L}$ to $80.98 \mathrm{mg} / \mathrm{L}$. Additionally, water quality analyses indicate that the $\mathrm{pH}$ of all groundwater samples were typically below the applicable NYS AWQS of 6.5 to $8.5 \mathrm{sU}$, with a median pH ranging from 5.68 to 6.40 . Elevated conductivity values were also detected in downgradient wells. Average groundwater conductivity for the upgradient well was $126 \mu$ mhos/cm, whereas the average groundwater conductivities for wells directly downgradient of the landfill ranged from $176 \mu \mathrm{mhos} / \mathrm{cm}$ to $876 \mu \mathrm{mhos} / \mathrm{cm}$. Complete analytical results, including VOC analyses, from all monitoring wells located at and downgradient of the Current Landfill are presented in Chapter 5 of this report.

During 1994, BNL continued to submit quarterly "BNL Landfill Monitoring Well Reports" to the NYSDEC in fulfillment of the reporting requirements contained in the landfill permit. The quarterly reports include data on groundwater quality, inorganic contaminants, radionuclides (gross alpha, gross beta, and tritium), and groundwater flow directions. Analysis and reporting requirements for VOCs was not specified in the 1981 NYSDEC permit. Under a February 1995 agreement with the NYSDEC, quarterly landfill monitoring reports will no longer be required starting in the first quarter of 1995. From this period forward, landfill monitoring well data will be reported in the annual SER and Inter Agency Agreement (IAG) related documents, which are supplied to the NYSDEC and other interested parties.

\subsubsection{Major Petroleum Facility}

Brookhaven National Laboratory operates a MPF under a license issued by the NYSDEC. This license has several special conditions associated with it which include testing of monitoring wells for free product as well as for dissolved product. The CY 1994 groundwater monitoring results for this facility are discussed in more detail in Section 2.3.4 of this Chapter.

\subsection{Clean Water Act}

\subsubsection{SPDES Permit}

Sanitary and process waste waters discharged from the operations conducted at BNL are regulated by a SPDES permit which is issued by the NYSDEC. Specifically, effluents discharged to five recharge basins and the Peconic River are currently governed by monitoring requirements and effluent limitations contained in the SPDES Permit. Deviations from the permit limitations or monitoring requirements which occurred during 1994 are described in the subsequent sections of this chapter. 
During 1994 the Laboratory continued to negotiate its SPDEs permit renewal with the NYSDEC and a redraft of the permit was received from the NYSDEC on November 28, 1994. Changes to the draft permit include slight increases in effluent concentrations for water treatment chemicals in discharges to recharge basins and the inclusion of a storm water outfall emanating from the CSF. The proposed SPDES permit will drastically change the BNL compliance sampling requirements. Increases in sampling frequency and analytical parameters for the STP discharge, biomonitoring of the STP effluent, monthly sampling and analysis for discharges to the recharge basins, and several engineering evaluations are just some of the proposed changes to the existing permit. This permit was reviewed with regard to its impact on Laboratory operations by S\&EP Division and comments were transmitted to the NYSDEC in January 1995. Comments regarding the revised permit were minor, and BNL acceptance of the permit was tentative based upon continued negotiations regarding the biomonitoring program requirements. The final permit should be received during the first quarter of 1995 .

\subsubsection{Recharge Basins}

The BNI maintains seven recharge basins for the discharge of process cooling waters, storm water run-off and, in the case of recharge basin Hx, water filter backwash from the WTP. Cooling water is discharged to basins HN, HO, HP, HS and HT and storm water is discharged to basins HN, HO, HS, HT and HW. Presently only five of these discharges are permitted under the existing BNL SPDES permit (recharge basins HN, HO, HP, HS and HT); however, the remaining two basins (recharge basins HW and HX) have been included with the November 1994 draft sPDEs permit. The draft sPDEs permit contains numerous additional monitoring requirements for discharges to the recharge basins including measurement and monthly reporting of flow, $\mathrm{pH}$ and oil and grease and quarterly monitoring for numerous analytical parameters. storm water has also been identified as a contributor to the recharge basin discharges.

Discharges of waters to recharge basins are considered Class GA groundwater discharges and are regulated by the NYSDEC as stipulated in 6 NYCRR Part 703.6. The existing BNL SRDES permit requires that BNL maintain records of $f l o w$ and $\mathrm{pH}$ to the five permitted recharge basins. These discharges are monitored quarterly for $\mathrm{pH}$ by the S\&EP Division SAG and records of flow are maintained by facility operators. Groundwater discharge regulations limit the $\mathrm{pH}$ for these effluents to the range of 6.5 to $8.5 \mathrm{SU}$ or the $\mathrm{pH}$ of the natural groundwater. On March 1 , 1994 the $\mathrm{pH}$ of grab samples collected from recharge basins HO and HT were recorded at 6.3 and $6.4 \mathrm{sU}$, respectively. These recharge basins receive predominantly cooling water discharges and storm water runoff. Much of the water discharged to recharge basin HO is used for once through cooling at the AGs. This water is pumped directly from the ground at an approximate pH of 5.8 SU and is discharged directly to this basin. Recharge basin HT receives low volumes of cooling water and storm water. Storm water which is known to have a pH of less than 6.5 is the most likely cause of the depressed pH evidenced. Due to the high ambient iron concentration in the groundwater, which is utilized for once-through cooling, water containing elevated iron concentrations was discharged to recharge basin HO in concentrations greater than the NYS groundwater discharge limitation of $0.6 \mathrm{mg} / \mathrm{L}$.

Recharge basin $\mathrm{HP}$, which received once-through cooling water from the MRR, remained out of service during CY 1994 due to TCA contamination of the process wells which previously supplied this cooling water. During 1994 all cooling water used by the MRR was supplied by the chilled water plant. While construction of an activated carbon adsorption system for the process well serving the MRR was completed in 1993, installation of the well control system was not completed untiI late 1994. The MRR should therefore revert to the weII water cooling system sometime in early 1995. 


\subsubsection{STP Effluent}

In accordance with the conditions of the BNL SPDES permit, twenty (20) parameters are reported in the monthly Discharge Monitoring Report (DMR) which is submitted to both the NYSDEC and SCDHS. Samples are collected by BNL personnel in accordance with BNL SOPs and $Q A$ protocols. Twelve parameters (nitrogen, metals, organics, $\mathrm{BOD}_{5}$, total suspended solids, fecal coliform, and total coliform) are analyzed by contractor laboratories. Gross alpha, gross beta, and tritium are analyzed by the S\&EP Division Radiological Laboratory. strontium-90 analyses were conducted by both BNL and a contractor laboratory during 1994. The remaining parameters are recorded/analyzed by the STP operators. The analytical data for the DMRs submitted in 1994 have been summarized in Tables $2-2$ and $2-3$.

Review of data presented in Tables $2-2$ and 2-3, indicates that ten exceedances of the SPDES permit discharge limits were observed at the STP effluent discharge point during 1994; eight for ammonia nitrogen and one each for fecal coliform and 5-day BOD (avg.). Eight grab samples collected between January 1, and April 30, 1994 exhibited ammonia nitrogen concentrations ranging from $2.1 \mathrm{mg} / \mathrm{L}$ to $4.6 \mathrm{mg} / \mathrm{L}$ which exceed the SPDES permit limitation of $2.0 \mathrm{mg} / \mathrm{L}$. Sources of ammonia discharged to the STP include sanitary wastes, commercial cleaners and some industrial activities (e.g., ammoniacal etching of printed circuit boards). The ammonia and BOD exceedances were attributed to the cold winter and disturbances to the sand filter beds which resulted in hydraulic overloading and the destruction of nitrifying bacteria. Nitrifying bacteria aid in the mitigation of ammonia discharged from the BNL STP by converting ammonia nitrogen to nitrate nitrogen. Concurrent decreases in the concentration of nitrates supports this theory. Monthly non-compliance reports were prepared and transmitted to the NYSDEC which discussed the ammonia exceedance and outlined measures being undertaken to correct the non-complying discharge. In addition to the non-compliance reports, the NYSDEC was contacted by telephone several times during the period of non-compliance to discuss the elevated levels of ammonia within the STP discharge and possible corrective actions. Mr. J. DiMura of the NYSDEC Albany office concurred with BNL's evaluation of the cause for the ammonia exceedances and indicated that repopulation of the nitrifying bacteria would occur with the on-set of warmer weather. A program to increase the frequency of bed cultivation was implemented to improve aeration of the filters. Increased aeration and the on-set of warmer weather proved to resolve this matter. The discharge of fecal coliform may also be linked to this occurrence in that the increase in fecal coliform coincided with the increased cultivation of the sand filters.

The BNL STP is a primary treatment system consisting of prechlorination, a primary clarifier for the separation of settleable solids and floatable materials and intermittent sand filters for the separation of suspended particulate matter. In an effort to improve the effluent water quality, the Plant Engineering Division completed preliminary design plans for upgrading the STP to an activated sludge treatment system in 1993. The first phase of the proposed plant consists of constructing two modular aeration tanks and ancillary equipment. Prior plans included the installation of an ultra-violet (UV) disinfection system; however, cost overruns have resulted in the deletion of this option. The installation of the UV disinfection system may be included during subsequent phases of construction. Other additions to this project may include the construction of rapid sand filters and a new sludge digestion system. During 1994 excavation commenced for the installation of the modular aeration tanks. Due to the presence of groundwater, construction was temporarily halted to allow the contractor time to develop a comprehensive dewatering plan. This plan will be submitted to the NYSDEC for review and approval upon it's completion. 
Table 2-2

BNL Site Environmental Report for Calendar Year 1994

SPDES Compliance for sewage Treatment Plant Effluent (Outfall 001)

\begin{tabular}{|c|c|c|c|c|c|c|c|}
\hline \multirow{2}{*}{$\begin{array}{l}\text { Parameter } \\
\text { Temperature }\end{array}$} & \multirow{2}{*}{$\begin{array}{l}\text { Permitted } \\
\text { Frequency } \\
\text { of Sample/Yr } \\
250\end{array}$} & \multirow{2}{*}{$\begin{array}{l}\text { Actual } \\
\text { Frequency } \\
\text { of Sample/Yr } \\
\qquad 250\end{array}$} & \multicolumn{2}{|l|}{$\begin{array}{l}\text { Maximum } \\
\text { Effluent } \\
\text { Value }\end{array}$} & \multicolumn{2}{|c|}{$\begin{array}{l}\text { SPDEs } \\
\text { Permit } \\
\text { Iimit }\end{array}$} & \multirow{2}{*}{$\begin{array}{l}\text { No. of } \\
\text { Exceedances } \\
\text { (per } \mathrm{Y} \text { ) }\end{array}$} \\
\hline & & & 79 & $O F$ & 90 & OF & \\
\hline Gross $\beta$ & 250 & 365 & 30.5 & $\mathrm{pCi} / \mathrm{I}$ & 1000 & $\mathrm{pCi} / \mathrm{I}$ & 0 \\
\hline $\mathrm{BOD}_{5}(\operatorname{Max})$ & 12 & 12 & 13 & $\mathrm{mg} / \mathrm{I}$ & 20 & $\mathrm{mg} / \mathrm{I}$ & 0 \\
\hline $\mathrm{BOD}_{5}$ (Avg) & 12 & 12 & 13 & $\mathrm{mg} / \mathrm{I}$ & 10 & $\mathrm{mg} / \mathrm{I}$ & 1 \\
\hline $\mathrm{pH}(\mathrm{Min})$ & 365 & 365 & 5.9 & SU & 5.8 & SU & 0 \\
\hline $\mathrm{pH}(\mathrm{Max})$ & 365 & 365 & 6.8 & SU & 9.0 & SU & 0 \\
\hline Suspended-Solids & 12 & 12 & $<6.0$ & $\mathrm{mg} / \mathrm{I}$ & 10.0 & $\mathrm{mg} / \mathrm{L}$ & 0 \\
\hline settleable solids & 250 & 250 & 0.0 & $\mathrm{ml} / \mathrm{L}$ & 0.1 & $\mathrm{ml} / \mathrm{I}$ & 0 \\
\hline Ammonia-Nitrogen & 12 & 18 & 4.6 & $\mathrm{mg} / \overline{\mathrm{L}}$ & 2.0 & $\mathrm{mg} / \mathrm{I}$ & 8 \\
\hline Cu (concentration) & 12 & 12 & 0.11 & $\mathrm{mg} / \mathrm{I}$ & 0.4 & $\mathrm{mg} / \mathrm{I}$ & 0 \\
\hline $\mathrm{Cu}$ (loading) & 12 & 12 & 0.52 & \#/day & 3.0 & \#/day & 0 \\
\hline Fe (concentration) & 12 & 12 & 0.29 & $\mathrm{mg} / \mathrm{I}$ & 0.6 & $\mathrm{mg} / \mathrm{I}$ & 0 \\
\hline $\mathrm{Pb}$ (concentration) & 12 & 12 & $<0.056$ & $\mathrm{mg} / I^{*} *$ & 0.067 & $\mathrm{mg} / \mathrm{I}$ & 0 \\
\hline $\mathrm{Pb}$ (loading) & 12 & 12 & $<0.24$ & \#/day & 0.75 & \#/day & 0 \\
\hline Ag (concentration) & 12 & 12 & 0.027 & $\mathrm{mg} / \mathrm{I}$ & 0.05 & $\mathrm{mg} / \mathrm{I}$ & 0 \\
\hline Ag (loading) & 12 & 12 & 0.11 & \#/day & 0.75 & \#/day & 0 \\
\hline $\mathrm{zn}$ (concentration) & 12 & 12 & 0.27 & $\mathrm{mg} / \mathrm{L}$ & 0.3 & $\mathrm{mg} / \mathrm{L}$ & 0 \\
\hline $\mathrm{Zn}$ (loading) & 12 & 12 & 1.68 & \#/day & 4.5 & \#/day & 0 \\
\hline Gross $\alpha$ & 250 & 365 & 3.0 & $\mathrm{pCi} / \mathrm{I}$ & 3.0 & $\mathrm{pCi} / \mathrm{L}$ & 0 \\
\hline strontium-90 & 12 & 12 & 4.0 & $\mathrm{pCi} / \mathrm{I}$ & 10.0 & $\mathrm{pCi} / \mathrm{I}$ & 0 \\
\hline Flow & 365 & 365 & 1.06 & MGD & 1.8 & MGD & 0 \\
\hline Chlorine (residual) & 250 & 250 & 0.04 & $\mathrm{mg} / \mathrm{L}$ & 0.05 & $\mathrm{mg} / \mathrm{I}$ & 0 \\
\hline Fecal Coliform & 12 & 12 & 3200 & $\mathrm{MPN} / 100 \mathrm{ml}$ & 2000 & $\mathrm{MPN} / 100 \mathrm{ml}$ & 1 \\
\hline Total Coliform & 12 & 12 & 9300 & $\mathrm{MPN} / 100 \mathrm{ml}$ & 10000 & $\mathrm{MPN} / 100 \mathrm{ml}$ & 0 \\
\hline Tritium & 250 & 365 & 7.31 & $\mathrm{nCi} / \mathrm{L}$ & 20000 & $\mathrm{pCi} / \mathrm{I}+$ & 0 \\
\hline $1,1,1-\mathrm{TCA}$ & 12 & 12 & $<5.0$ & $\mu g / L$ & 50 & $\mu g / L$ & 0 \\
\hline Total & 2799 & 3150 & & & & & 10 \\
\hline
\end{tabular}
detected concentration of lead discharged during 1994 was $0.004 \mathrm{mg} / \mathrm{L}$.

NA: SPDES permit limit not specified.

(+) EPA SDWA MCL 
TABLE $2-3$

BML Site Environmental Report for Calendar Year 1994

Summary of Monthly DMR Values for the STP Discharge

\begin{tabular}{|c|c|c|c|c|c|c|c|c|c|c|c|c|c|}
\hline PARAMETER & JAN & FEB & $\mathrm{MAR}$ & $A P R$ & MAY & JUNE & JULY & AUG & SEPT & QCT & NOV & DEC & UNIIS \\
\hline Max.Temp. & 50 & 50 & 55 & 64 & 68 & 77 & 79 & 77 & 73 & 68 & 66 & 59 & oF \\
\hline Grogs $\beta$ & 15.6 & 30.5 & 17 & 19.3 & 17.0 & 21.6 & 14.2 & 16.1 & 11.8 & 11.4 & 2.6 & 10.7 & $\mathrm{pCi} / \mathrm{L}$ \\
\hline BOD5 & 8.0 & 13 & $<3.0$ & $<3.0$ & $<3.0$ & 3.0 & $<3.0$ & 6.0 & $<3.0$ & $<3.0$ & $<3.0$ & $<3.0$ & $\mathrm{mg} / \mathrm{L}$ \\
\hline $\mathrm{pH}$ (min.) & 6.1 & 6.0 & 6.0 & 5.9 & 5.9 & 6.0 & 6.2 & 6.1 & 5.9 & 6.0 & 6.0 & 6.1 & su \\
\hline $\begin{array}{l}\text { pH (max.) } \\
\text { Suspended }\end{array}$ & 6.8 & 6.7 & 6.8 & 6.5 & 6.4 & 6.5 & 6.7 & 6.7 & 6.6 & 6.6 & 6.5 & 6.6 & su \\
\hline $\begin{array}{l}\text { Solids } \\
\text { settleable }\end{array}$ & $<6.0$ & 2.0 & 2.0 & $<4.0$ & 1.0 & $<1.0$ & 2.0 & 1.0 & $<1.0$ & 4.0 & 2.0 & 1.0 & $\mathrm{mg} / \mathrm{L}$ \\
\hline Solids & 0.0 & 0.0 & 0.0 & 0.0 & 0.0 & 0.0 & 0.0 & 0.0 & 0.0 & 0.0 & 0.0 & 0.0 & $\mathrm{ml} / \mathrm{L}$ \\
\hline $\begin{array}{l}\text { Ammonia } \\
\mathrm{Cu}\end{array}$ & 3.53 & 4.1 & 4.6 & 2.23 & 0.18 & 0.37 & $<0.05$ & $<0.05$ & $<0.05$ & 0.31 & 0.11 & 0.39 & $\mathrm{mg} / \mathrm{L}$ \\
\hline$(\max \operatorname{con} c)$ & 0.052 & 0.096 & 0.09 & 0.11 & 0.064 & 0.075 & 0.053 & 0.057 & 0.036 & 0.057 & 0.079 & 0.058 & $\mathrm{mg} / \mathrm{L}$ \\
\hline Cu (load) & 0.22 & 0.4 & 0.44 & 0.52 & 0.28 & 0.42 & 0.31 & 0.36 & 0.23 & 0.35 & 0.48 & 0.34 & */day \\
\hline $\begin{array}{l}\text { Fe } \\
(\max \operatorname{con} c) \\
\mathrm{Pb}\end{array}$ & 0.2 & 0.27 & 0.28 & 0.29 & 0.19 & 0.17 & 0.25 & 0.27 & 0.12 & 0.118 & 0.24 & 0.21 & $\mathrm{mg} / \mathrm{I}$ \\
\hline$(\max \operatorname{con} c)$ & $<0.056$ & $<0.056$ & 0.0036 & 0.0035 & $<0.003$ & $<0.003$ & 0.003 & 0.004 & $<0.003$ & $<0.003$ & 0.004 & $<0.004$ & $\mathrm{mg} / \mathrm{L}$ \\
\hline $\mathrm{Pb}$ (load) & $<0.24$ & $<0.23$ & 0.018 & 0.016 & $<0.013$ & $<0.017$ & 0.017 & 0.026 & $<0.019$ & $<0.019$ & 0.024 & $<0.022$ & */day \\
\hline $\begin{array}{l}\text { Ag } \\
(\max \text { conc) }\end{array}$ & $<0.006$ & 0.027 & 0.014 & 0.021 & 0.009 & 0.007 & 0.017 & 0.013 & $<0.007$ & 0.013 & $<0.005$ & $<0.005$ & $\mathrm{mg} / \mathrm{L}$ \\
\hline $\begin{array}{l}\mathrm{Ag} \\
\mathrm{zn}\end{array}$ & $<0.026$ & 0.11 & 0.069 & 0.099 & 0.039 & 0.039 & 0.099 & 0.081 & $<0.045$ & 0.08 & $<0.03$ & $<0.03$ & */day \\
\hline$(\max c o n c)$ & 0.051 & 0.039 & 0.04 & 0.039 & 0.047 & 0.124 & 0.083 & 0.27 & 0.034 & 0.12 & 0.056 & 0.053 & $\mathrm{mg} / \mathrm{L}$ \\
\hline Zn (load) & 0.22 & 0.16 & 0.20 & 0.18 & 0.20 & 0.70 & 0.48 & 1.68 & 0.22 & 0.74 & 0.34 & 0.31 & */day \\
\hline Gross $\alpha$ & 2.9 & 2.1 & 2.77 & 2.1 & 2.78 & 2.95 & 2.9 & 1.82 & 2.7 & 3.0 & 2.6 & 2.9 & $\mathrm{pCi} / \mathrm{L}$ \\
\hline sx 90 & $<0.2$ & 0.088 & 0.16 & 0.7 & 4.0 & 1.4 & 0.1 & -0.2 & & & & & $\mathrm{pCi} / \mathrm{L}$ \\
\hline Flow & 0.528 & 0.504 & 0.761 & 0.707 & 0.663 & 0.868 & 1.06 & 0.984 & 0.94 & 0.924 & 0.881 & 0.785 & MGD \\
\hline $\begin{array}{l}\text { Cl(res) } \\
\text { Fecal }\end{array}$ & 0.02 & 0.03 & 0.04 & 0.02 & 0.04 & 0.04 & 0.02 & 0.04 & 0.04 & 0.04 & 0.04 & 0.04 & $\begin{array}{l}\mathrm{mg} / \mathrm{L} \\
\mathrm{MPN}\end{array}$ \\
\hline $\begin{array}{l}\text { Coliform } \\
\text { Total }\end{array}$ & 840 & 280 & $<1$ & 3200 & $<1$ & 201 & 30 & $<1$ & $<1$ & $<1$ & 20 & $<1$ & $\begin{array}{l}100 \mathrm{ml} \\
\text { MPN }\end{array}$ \\
\hline $\begin{array}{l}\text { Coliform } \\
\text { Tritium }\end{array}$ & 5600 & 8000 & 600 & 9300 & 140 & 3151 & 340 & 50 & 180 & 388 & 150 & 190 & $100 \mathrm{ml}$ \\
\hline $\begin{array}{c}(\max .) \\
1,1,1 \text { TCA }\end{array}$ & $\begin{array}{l}1.9 \\
1<5.0\end{array}$ & $\begin{array}{r}1.45 \\
<5.0 \\
\end{array}$ & $\begin{array}{r}3.27 \\
<5.0 \\
\end{array}$ & $\begin{array}{r}5.0 \\
<5.0 \\
\end{array}$ & $\begin{array}{r}3.81 \\
<5.0 \\
\end{array}$ & $\begin{array}{r}5.84 \\
<5.0 \\
\end{array}$ & $\begin{array}{r}5.6 \\
\leq 5.0 \\
\end{array}$ & $\begin{array}{r}7.31 \\
\leq 5.0 \\
\end{array}$ & $\begin{array}{r}6.04 \\
-\leq 5.0 \\
\end{array}$ & $\begin{array}{r}3.08 \\
51.2 \\
\end{array}$ & $\begin{array}{r}3.92 \\
-1.0 \\
\end{array}$ & $\begin{array}{r}6.86 \\
\leq 1.0 \\
\end{array}$ & $\begin{array}{l}\mathrm{nCi} / \mathrm{L} \\
\mathrm{Ng} / \mathrm{L}\end{array}$ \\
\hline
\end{tabular}

ND: Not Detected

Due to the length of the analytical procedure there is no strontium-90 data available for $9 / 94-12 / 94$. 
The November 1994 redrafted SPDES permit contains numerous modifications to the monitoring requirements for the STP discharge including: reduced effluent limitations, deletion of radiological monitoring, deletion of mass load limitations, increase in monitoring frequency and analytical parameters, and requirements for a biomonitoring program. Starting in 1995, major changes to the BNI SPDES monitoring program are expected as a result of the modified permit.

The biomonitoring program specified in the proposed SPDES permit is a chronic Tier II Test using fathead minnows and Ceriodaphnia dubia as the test organisms. Continued biomonitoring tests conducted in 1994 have shown no acute toxicity associated with the STP effluent and that there was no chronic toxicity exhibited for the fathead minnows. Chronic toxicity tests for the Ceriodaphni dubia continued to show a negative effect on the reproduction of these organisms. Two tests were conducted to ascertain the effect of changes in water hardness on the reproduction of these organisms but proved inconclusive due to the inability to produce an acceptable control group. All biomonitoring test data and water quality analyses were forwarded to the NYSDEC in November 1994 for evaluation. Mr. E. Kuzia of the NYSDEC, Albany office, has indicated that future biomonitoring tests should be modified to discount hardness effects by using a modified EPA prescribed dilution water and that inorganic analyses should be conducted on each composite sample collected during the biomonitoring period.

In addition to the modifications to the STP effluent parameters, monitoring of specific process discharges will also be conducted under the condition of the new SPDES permit. Specifically, the effluents from the Photography and Graphic Arts Division, NSLS Acid Cleaning Facility, and the Instrumentation Division Printed Circuit Board Laboratory will be monitored quarterly for contaminants specific to these operations.

\subsubsection{SPDES Inspections and Audits}

Up until January 1993, the operations of the STP were monitored quarterly by the SCDHS. Due to reduced state funding for monitoring and inspections of local sewage treatment plants, there were no inspections conducted by the SCDHS in CY 1994 .

\subsubsection{NPDES Analytical Quality Assurance}

The Laboratory participates in the NPDES Laboratory Performance Evaluation program administered by the EPA. On February 16, 1994, proficiency check samples were received from the EPA and subsequently forwarded to the three laboratories responsible for the specific analytes. The respective parameters performed by each laboratory are listed below:

Laboratory Name and Address

NYTEST Environmental Inc. Port Washington, NY

BNL STP Operations Lab Upton, NY

Cosper Environmental Inc. Bohemia, NY

\section{Analytical Rarameters}

Copper, Lead, Iron, Zinc, $\mathrm{BOD}_{5}$, Total suspended Solids, Ammonia-N, Nitrate $-\mathrm{N}$ and $\mathrm{TKN}$

pH, Total Residual Chlorine

Tier II Chronic Toxicity

The analytical data for the proficiency check samples was forwarded to the EPA designated facility on April 13, 1994. Comments regarding the results of this 
program were not received from the EPA until January 21, 1995 . Review of these comments showed all parameters with the exception of total suspended solids (TSS) to be within EPA acceptance limits. The contractor laboratory responsible for the TSS analyses has been requested to prepare a response to this finding.

\subsubsection{Major Petroleum Facility}

The BNL CSF supplies steam for heating and cooling to all major areas of the Laboratory through an underground distribution system. The MPF is the storage area for the fuels used at the CSF. Brookhaven National Laboratory operates its MPF under a license (No. 01-1700) issued by the NYSDEC which is renewed annually. The current MPF license was issued by NYSDEC on April 14 , 1993, and has an expiration date of March 31, 1995. A renewal application for the MPF license was filed in December 1994.

The NYSDEC is required by Article 12 of the Navigation Law ${ }^{26}$ to protect and preserve the lands and waters of New York State from all discharges of petroleum and specifically from major petroleum storage facilities. In order to fulfill this responsibility, all major petroleum storage facilities are required to be registered with the NYSDEC and must have a license to operate. The license is contingent on several conditions. In addition to general groundwater monitoring conditions, additional conditions may be included from year to year.

All major petroleum storage facilities are required to install groundwater monitoring wells. The license has general conditions which include regular testing of monitoring wells for floating and dissolved product. Typically the testing for floating product can be performed by the owner of the facility; however, testing for dissolved product is required to be performed by a NYSDEC certified laboratory.

Five groundwater wells, one upgradient and four downgradient, are used for regulatory compliance monitoring of the BNL CSF. The well authorized for use by the NYSDEC as upgradient of the CSF is designated as Well ID 76-25 and is located immediately upgradient (within 50 feet) of CSF Tanks $611 \mathrm{~A}$ and $611 \mathrm{~B}$. The four downgradient wells are designated as 76-16, 76-17, 76-18, and 76-19. Their locations are shown in Figure 5-8. The well casings are constructed of polyvinyl chloride (PVC) and are four inches in diameter. These wells have PVC screens which are 20 feet in length and straddle the water table.

In accordance with conditions of the MPF license, regulatory compliance samples were collected from these wells twice during 1994 and submitted to a NYSDEC certified laboratory. The NYSDEC requested analyses for these wells include polynuclear aromatics and base neutral extractable compounds listed in EPA Method 625. The analytical results were transmitted to the NYSDEC. Another condition of the MPF license is that these wells be monitored monthly for floating product. This condition was fulfilled during CY 1994 and no floating product was found in any of these wells.

In addition to these compliance samples, these wells are also monitored several times a year as part of the BNL routine EM program. Analytical results from the routine monitoring program are discussed in Chapter 5 of this report.

On April 22, 1994 the NYSDEC performed an annual inspection of the MPF. This inspection consisted of an examination of all storage tanks and associated berms, a test of all high-level alarms and a review of operator's logs and the Spill Prevention Control and Counter Measures (SPCC) plan. Minor deficiencies noted during this inspection included a missing lock on one of the tank drainage valves, sealing of pipe penetrations through the concrete berm serving Tank No. 8 and repair of the enviro-mat liner between Tank Nos. $611 \mathrm{~A}$ and $611 \mathrm{~B}$. All repairs were completed by september 19, 1994. 


\subsubsection{Spill prevention, Control, and Countermeasures (SPCC) Plan}

Brookhaven National Laboratory has had an SPCC Plan since the early 1980 s. The early plan contained a complete listing of all oil storage tanks with capacity and building numbers. In the mid 1980 s direction from NYSDEC led to including only those storage tanks associated with the CSF and the Motor pool Fuel storage area (Building 326) on the SPCC storage tank listing. This Plan was revised in 1982, 1983, 1985, 1987, 1990 and 1993. All revisions have been submitted to the NYSDEC.

As a direct result of the Exxon Valdez, the American Trader and other waterway disasters, Congress enacted the Oil pollution Act of 1990 (OPA-90). This Act contains significant modifications to many of the provisions of the Clean Water Act (CWA). One of these requirements is that facility owners/operators must prepare response plans outlining response capability to a "Worst Case Discharge (WCD)" which is defined as the "largest foreseeable discharge in adverse weather conditions." These terms have been described in the legislative history to mean "a case that is worse than either the largest spill to date or the maximum probable spill for the facility type". The mechanism by which a facility expects to respond to the WCD must be outlined in a Facility Response Plan (FRP). The ERP also contains information regarding oil recovery capabilities of the facility and any associated Oil spill Response organizations contracted by that facility. Congress mandated that regulations implementing FRP requirements be issued not later than August 18, 1992. The original statutory deadine for submission of the FRP was February 18, 1993.

Draft regulations outlining facility response plan requirements were not issued until February 17, 1993; however, recognizing the necessity to comply with the statutory requirements of $O P A-90$, BNL contracted with an engineering consulting firm to prepare the FRP. This plan was submitted to EPA on February 18, 1993 .

On July 1, 1994 the EPA finalized the regulations outlining FRP content requirements and on October 28,1994 the Laboratory received notification from the EPA requesting revisions to the February 1993 FRP. Requested revisions included inclusion of worksheets containing calculations of the WCD and oil spill response capabilities and documentation of training programs. The revised FRP was prepared by BNL personnel and submitted to the EPA in January 1995. In addition, as required by the 1994 OPA revisions, all previous FRPs must be revised by February 18, 1995 to meet the content requirements outlined in the July 1994 final regulations. In December 1994, BNL contracted with an engineering firm to prepare these revisions.

\section{3 .5 oil/Chemical spills}

During 1994, members of the S\&EP Division EMS Environmental Compliance Group (ECG) responded to a total of 28 incidents where the potential existed for a release of oil or chemicals to the environment. Table 2-4 provides a summary of these incidents which include the date each incident occurred, the material involved, the amount of material released, and a brief explanation of the corrective actions taken. Five of these incidents involved releases which were completely contained within the building and did not reach the environment. Five of these incidents required EPA, NYSDEC, and SCDHS notifications. These spills were cleaned up and the associated contaminated absorbent and affected soil were sent off-site for disposal in an approved manner. As can be seen from Table 2-4, the remainder of these incidents involved very small quantities of material which were typically contained on asphalt, concrete, or other impervious surfaces. 
Table 2-4

BNL Site Environmental Report for Calendar Year 1994

Summary of Chemical and oil spill Reporting Record

\begin{tabular}{|c|c|c|c|c|}
\hline Date & Material & Quantity & Rpt* & $\begin{array}{l}\text { Source/Cause; } \\
\text { Corrective Actions }\end{array}$ \\
\hline $1 / 28$ & $\begin{array}{l}\text { No. } 2 \text { Fuel } \\
\text { Oil }\end{array}$ & $\begin{array}{l}5-10 \\
\text { gals }\end{array}$ & Yes & $\begin{array}{l}\text { Valve Gasket; spillage removed using absorbent pads, } \\
\text { placed in containers for offsite disposal. }\end{array}$ \\
\hline $1 / 28$ & $\begin{array}{l}\text { Hydraulic } \\
\text { Fluid }\end{array}$ & $1 q t$ & No & $\begin{array}{l}\text { Hydraulic Line; pads used to adsorb spilled product and } \\
\text { sorbent sock dike placed around downgradient storm } \\
\text { drain. All sorbent materials containerized for offsite } \\
\text { disposal. }\end{array}$ \\
\hline $2 / 3$ & Mineral Oil & $<1$ gal & No & $\begin{array}{l}\text { Transformers; oil absorbent pads/ speedi-dry placed } \\
\text { around leaking transformers. All adsorbents } \\
\text { containerized for offsite disposal. }\end{array}$ \\
\hline $2 / 10$ & $\begin{array}{l}\text { No. } 6 \text { Fuel } \\
\text { Oil }\end{array}$ & $5.5 \mathrm{gal}$ & No & $\begin{array}{l}\text { Fuel Line Strainer Gasket; visibly stained areas removed } \\
\text { and placed in drum for offsite disposal. }\end{array}$ \\
\hline $3 / 21$ & Diesel Fuel & $\begin{array}{l}\text { Approx } 1 \\
\text { pint }\end{array}$ & No & $\begin{array}{l}\text { Private Automobile; applied speedi-dry; containerized } \\
\text { for offsite disposal. }\end{array}$ \\
\hline $5 / 25$ & Hydraulic Oil & $<1$ gal & No & $\begin{array}{l}\text { Front End Loader; cardboard placed under vehicle to } \\
\text { capture drippings, contractor returned to repair machine } \\
\text { and removed all oil contaminated soils. }\end{array}$ \\
\hline $5 / 3$ & Hydraulic Oil & $2 \mathrm{gal}$ & No & $\begin{array}{l}\text { High pressure gauge blew off concrete cutting machine; } \\
\text { machine wiped down and removed for repair; speedi-dry } \\
\text { applied and removed with contaminated soil atop asphalt } \\
\text { by contractor, Whisper concrete cutting. }\end{array}$ \\
\hline $6 / 1$ & Gasoline & 1 pint & No & $\begin{array}{l}\text { Private Automobile release due to gasoline expansion } \\
\text { within filled tank; speedi-dry applied and removed for } \\
\text { offsite disposal. }\end{array}$ \\
\hline $6 / 9$ & $\begin{array}{l}\text { Diesel Fuel } \\
\text { Ethylene } \\
\text { Glycol } \\
\text { Battery Acid }\end{array}$ & $\begin{array}{l}2-3 \\
\text { gals } \\
<1 \text { pint } \\
<1 \text { pint }\end{array}$ & Yes & $\begin{array}{l}\text { Tractor fire ignited battery, and caused leaks from } \\
\text { vehicle fuel line and radiator; combination buckets \& } \\
\text { sorbent pads placed under tractor, neutralizing agent } \\
\text { and sorbent socks placed around battery; acid } \\
\text { contaminated materials \& battery removed as haz. Waste, } \\
\text { contaminated soil \& sorbent materials placed in drums } \\
\text { for offsite disposal. }\end{array}$ \\
\hline
\end{tabular}


Table 2-4 (continued)

BNL Site Environmental Report for Calendar Year 1994

Summary of Chemical and Oil spill Reporting Record

\begin{tabular}{|c|c|c|c|c|}
\hline Date & Material & Quantity & Rpt* & $\begin{array}{l}\text { Source/Cause; } \\
\text { Corrective Actions }\end{array}$ \\
\hline $6 / 20$ & $\begin{array}{l}\text { Gasoline, } \\
\text { Roof Tar }\end{array}$ & $<1$ pint & No & $\begin{array}{l}\text { Roofing tar trailer caught fire causing tar to be thrown } \\
\text { over } 6 \text { square meter area (solidified). Engine on } \\
\text { trailer had one gallon gas tank with slow leak. } \\
\text { Estimated less than one pint released. All stained soil } \\
\text { was removed and properly disposed. }\end{array}$ \\
\hline $6 / 22$ & Cooling water & $100 \mathrm{gal}$ & No & $\begin{array}{l}\text { Leaking pump flange on the IINAC RF Cavity system } \\
\text { discharged }>100 \text { gals. to floor which passed through } \\
\text { storage area with equipment exposed to low levels of } \\
\text { radiation before exiting bldg. and entering storm drain. } \\
\text { Sample analysis of water from storm drain showed } \\
\text { radionuclide levels all below NYs drinking water } \\
\text { standards. }\end{array}$ \\
\hline $6 / 20$ & PCBs & 1 oz & No & $\begin{array}{l}\text { Old power supply discovered in load lugger bucket } \\
\text { outside Bldg } 326 \text {. Power supply contained capacitors } \\
\text { which were visibly weeping (discharge confined to within } \\
\text { power supply). Power supply was removed from bucket, } \\
\text { double bagged in plastic, and stored in Bldg } 326 \text {. } \\
\text { standard wipe tests taken on } 6 / 20 \text { and analytical report } \\
\text { released } 6 / 28 \text { indicating estimated } 39,000 \text { micrograms } \\
\text { PCBs in wipe. Power supply was transferred to HWMF for } \\
\text { offsite disposal. Capacitors were believed to be pure } \\
\text { PCB containing approximately six ounces each. }\end{array}$ \\
\hline $7 / 8$ & Hydraulic Oil & 2 qts & No & $\begin{array}{l}\text { During concrete cutting operations at Bldg. } 725 \text { by } \\
\text { Whisper concrete corp., a hydraulic line broke releasing } \\
2 \text { quarts of fluid to soil. PE personnel provided a 55- } \\
\text { gallon drum and contractor removed all visibly } \\
\text { contaminated soil to drum. } \mathrm{PE} \text { delivered drum to HWME } \\
\text { for disposal. }\end{array}$ \\
\hline
\end{tabular}


Table 2-4 (continued)

BNL Site Environmental Report for Calendar Year 1994

Summary of Chemical and Oil Spill Reporting Record

\begin{tabular}{|c|c|c|c|c|}
\hline Date & Material & Quantity & Rpt* & $\begin{array}{l}\text { Source/Cause; } \\
\text { Corrective Actions }\end{array}$ \\
\hline $7 / 18$ & $\begin{array}{l}\text { Hydraulic } \\
\text { Fluid }\end{array}$ & $\begin{array}{l}3-4 \\
\text { gals }\end{array}$ & No & $\begin{array}{l}\text { During use of the Pettibone Crane behind Bldg } 919 \text {, a } \\
\text { hydraulic line ruptured causing the release of } 3-4 \text { gals } \\
\text { of hydraulic fluid. After responding to the scene, PE } \\
\text { personnel used sorbent pads to clean product from the } \\
\text { Crane carriage and to adsorb product that had mixed with } \\
\text { rain water on the ground. PE containerized contaminated } \\
\text { rainwater to prevent drainage into a downgradient storm } \\
\text { drain. Contaminated sorbent materials were collected in } \\
\text { drums and delivered to HWMF for disposal. PE personnel } \\
\text { also replaced Crane failed hydraulic hose. }\end{array}$ \\
\hline $7 / 30$ & $\begin{array}{l}\text { Lubricating } \\
\text { Oil }\end{array}$ & $1 \mathrm{gal}$ & No & $\begin{array}{l}\text { Lubricating oil leaked onto the concrete floor in Bldg. } \\
911 \text { from a loose fitting on } \mathrm{A} / \mathrm{C} \text { Compressor \# } 2 \text {. BNL } \\
\text { Fire Group used adsorbent pads to recover the spilled } \\
\text { product. Contaminated pads sent to HWMF for offsite } \\
\text { disposal. }\end{array}$ \\
\hline $8 / 3$ & Diesel Fuel & $\begin{array}{l}1-2 \\
\text { gals }\end{array}$ & No & $\begin{array}{l}\text { Fuel oil spilled onto the ground from a fuel tank on } \\
\text { equipment used to remove gravel during a roofing repair } \\
\text { job at Bldg } 463 \text {. After the roofing contractor had } \\
\text { topped off the tank, fuel began to leak from the vent } \\
\text { opening in the fill cap as the result of product } \\
\text { expansion. Fire Group personnel placed speedi-Dry onto } \\
\text { spilled product while the contractor returned later in } \\
\text { the day to sweep up the contaminated sorbent material } \\
\text { for offsite disposal. }\end{array}$ \\
\hline $8 / 9$ & $\begin{array}{l}\text { Ethylene } \\
\text { Glycol }\end{array}$ & $<1$ gal & No & $\begin{array}{l}\text { Radiator fluid discovered mixed with standing water in } \\
\text { depression behind Bldg } 488 \text {. Car from which leak } \\
\text { occurred never identified. Speedi-dry applied to } \\
\text { spillage; containerized for offsite disposal. }\end{array}$ \\
\hline
\end{tabular}


Table 2-4 (continued)

BNL Site Environmental Report for Calendar Year 1994

Summary of Chemical and Oil Spill Reporting Record

\begin{tabular}{|c|c|c|c|c|}
\hline Date & Material & quantity & Rpt* & $\begin{array}{l}\text { Source/Cause; } \\
\text { Corrective Actions }\end{array}$ \\
\hline $\begin{array}{c}8 / 26 \\
.\end{array}$ & $\begin{array}{l}\text { Ethylene } \\
\text { Glycol }\end{array}$ & $750 \mathrm{gal}$ & Yes & $\begin{array}{l}\text { Release from failed valve on portable cooler. Approx. } 3 \\
\text { cubic meters of soil removed and } 3,500 \text { gallons suspected } \\
\text { contaminated water removed from a dry well. } \\
\text { Contaminated water subsequently disposed of through an } \\
\text { offsite vendor. Contaminated soil still stored on } \\
\text { location pending final direction from NYSDEC on soil } \\
\text { clean up and disposal requirements. All liquid was } \\
\text { removed from dry well. Sediment samples taken from } \\
\text { bottom of dry well had distinct ethylene glycol odor. } \\
\text { Extent of soil contamination unknown. Clean-up } \\
\text { standards requested from NYSDEC. }\end{array}$ \\
\hline $8 / 18$ & Caustic $(50 \%)$ & $30 \mathrm{gaI}$ & No & $\begin{array}{l}\text { The } 940 \text { gallon caustic tank located in Bldg. } 93 \text { (well 1) } \\
\text { developed a leak at the drainage valve. Approx. } 30 \\
\text { gallons of caustic was released to the ground and } \\
\text { roadway outside Bldg. } 93 \text {. The roadway was flushed with } \\
\text { fresh potable water; caustic and all flush water was } \\
\text { drained to the sanitary system. Due to increased pH, } \\
\text { the sanitary system was diverted for approx. } 4 \text { hours. } \\
\text { Approx. } 20 \text { drums of soils were excavated and placed into } \\
55-\text { gallon drums for proper disposal. }\end{array}$ \\
\hline $8 / 30$ & $\begin{array}{l}\text { Lubricating } \\
\text { oil }\end{array}$ & $>1$ gal & Yes & $\begin{array}{l}\text { Leak from faulty vacuum pump } \\
\text { gasket of pump located in shed outside Bldg } 930 \text {. } \\
\text { Contaminated soil adjacent to shed and saturated speedi- } \\
\text { dry was placed in drum for offsite disposal. Leaking } \\
\text { pump was drained, disassembled and gaskets were } \\
\text { replaced. AGs also was to institute a regular vacuum } \\
\text { pump I\&M program. }\end{array}$ \\
\hline
\end{tabular}


Table 2-4 (continued)

BNL Site Environmental Report for Calendar Year 1994 Summary of Chemical and oil spill Reporting Record

\begin{tabular}{|c|c|c|c|c|}
\hline Date & Material & Quantity & Rpt* & $\begin{array}{l}\text { Source/Cause; } \\
\text { Corrective Actions }\end{array}$ \\
\hline $9 / 9$ & Diesel Fuel & $<1$ gal & No & $\begin{array}{l}\text { A contractors vehicle fuel tank overflowed spilling less } \\
\text { than one gallon of diesel fuel to the pavement. The } \\
\text { contractor applied sand to the spill and placed all } \\
\text { contaminated soil into two five gallon pails for proper } \\
\text { disposal. }\end{array}$ \\
\hline $9 / 16$ & Hydraulic Oil & $0.5 \mathrm{gal}$ & No & $\begin{array}{l}\text { Plant Engineering fork lift being used by riggers } \\
\text { developed a leak from the hydraulic system. oil spilled } \\
\text { on pavement adjacent to Bldg. } 938 \text {. speedi-dry was } \\
\text { applied to spillage; all was removed in a five-gallon } \\
\text { pail for proper disposal. }\end{array}$ \\
\hline $10 / 13$ & Battery Acid & $1 \mathrm{qt}$ & No & $\begin{array}{l}\text { Battery acid had leaked from a Lab vehicle. BNL Fire } \\
\text { Group neutralized it; PE staff cleaned up the spillage. } \\
\text { Sent for offsite disposal. }\end{array}$ \\
\hline $10 / 26$ & $\begin{array}{l}\text { Dilute } \\
\text { Ethylene } \\
\text { Glycol } \\
\text { Solution }\end{array}$ & $<5$ gal & Yes & $\begin{array}{l}\text { Technicians from the AGS connected Portable Cooling } \\
\text { Tower No. } 5 \text { to the potable water system resulting in a } \\
\text { backflow of dilute ethylene glycol into the Bldg. } 922 \\
\text { potable water system. The system was flushed resulting } \\
\text { in the discharge of glycol to the environment. Normal } \\
\text { sanitary usage also resulted in the discharge of glycol } \\
\text { to the septic system. The PE division arranged to have } \\
\text { the septic system pumped and transferred the waste to } \\
\text { the BNL Sewage Treatment Plant as directed by the } \\
\text { NYSDEC. }\end{array}$ \\
\hline $12 / 6$ & $\begin{array}{l}\text { Crankcase } \\
\text { Oil/Ethylene } \\
\text { Glycol (Rad) }\end{array}$ & $5 \mathrm{gal}$ & No & $\begin{array}{l}\text { Crane used by ENSR within tent enclosure south of Bldg. } \\
811 \text { working on } D \text { Waste Tank Removal blew a motor. } \\
\text { Approx. } 5 \text { gallons of crankcase oil and antifreeze with } \\
\text { radiation contamination was discharged to asphalt and } \\
\text { vermiculite. All spilled material was immediately } \\
\text { cleaned up and held for disposal as mixed waste. }\end{array}$ \\
\hline
\end{tabular}


Table 2-4 (continued)

BNL Site Environmental Report for Calendar Year 1994

Summary of Chemical and oil spill Reporting Record

\begin{tabular}{|c|c|c|c|c|}
\hline Date & Material & Quantity & Rpt* & $\begin{array}{l}\text { Source/Cause; } \\
\text { Corrective Actions }\end{array}$ \\
\hline $12 / 7$ & $\begin{array}{l}\text { Sodium } \\
\text { hydroxide }\end{array}$ & 1.5 qts & No & $\begin{array}{l}\text { Two of three five-gallon plastic containers with } 50 \% \\
\text { sodium hydroxide developed pinhole leaks discharging } \\
\text { approx. } 1.5 \text { qts of liquid onto and under aluminum plates } \\
\text { within Bldg T-89. Spillage was captured with speedi-dry } \\
\text { and stained areas were neutralized with vinegar (acetic } \\
\text { acid). Leaking containers were placed in overpacks for } \\
\text { removal by Hazardous Waste Management. }\end{array}$ \\
\hline $12 / 13$ & Methane & Unknown & No & $\begin{array}{l}\text { Residual gas in a methane cylinder on trailer just east } \\
\text { of Bldg. T-100 was released after a pressure relief } \\
\text { valve failed. Valves controlling other cylinders were } \\
\text { closed to prevent additional venting of residual gas. As } \\
\text { a precautionary measure the area and Bldg } \mathrm{T}-100 \text { were } \\
\text { secured while cylinder contents vented. }\end{array}$ \\
\hline $12 / 30$ & $\begin{array}{l}\text { Transformer } \\
\text { oil }\end{array}$ & $<1$ gal & No & $\begin{array}{l}\text { Transformer } 3 F \text { located in the transformer yard west of } \\
\text { Bldg. } 912 \text { A developed a leak resulting in the discharge } \\
\text { of <1 gallon of non-PCB oil to structural support pad } \\
\text { underlying the transformer. The majority of the oil was } \\
\text { contained on the concrete pad which was removed using } \\
\text { spill absorbent. A small amount of oil was sprayed onto } \\
\text { the rock ballast surrounding the transformer. All } \\
\text { contaminated rock and miscellaneous debris was removed } \\
\text { and containerized for offsite disposal. }\end{array}$ \\
\hline
\end{tabular}

*Reported to off-site regulatory agencies. 
Cleanup procedures were implemented and there were no environmental impacts as a result of these occurrences.

Notifications to off-site regulatory agencies are made based upon the type, quantity, and location of material spilled. Releases of hazardous substance in quantities equal to or greater than their reportable quantity are subject to reporting to the National Response Center under the requirements of CERCLA. Such releases are also subject to reporting to the NYSDEC as mandated in the NY Navigation Law and to the SCDHS as specified in the suffolk county sanitary Code (SCSCs). Members of the S\&EP Division ECG are on a 24-hr call list to respond to spills on-site at BNL. One of their responsibilities, as a responder, is to gather the information necessary to determine if the spill is reportable to offsite regulatory agencies. In addition, the S\&EP Division spill response personnel give guidance on the control, containment, and cleanup of the spill. They also act as the liaison with the off-site regulatory agencies in the event that they want to inspect or review any aspect of the incident.

\subsection{Clean Air Act (CAA)}

\subsubsection{Conventional Air Pollutants}

During 1994, a variety of BNL emission sources were evaluated with respect to NYS and Federal permitting requirements. The applicable regulations for these sources are the Codes, Rules and Regulations of the state of New York, Title 6, Chapter III, Part 200, New York State Air Pollution Control Regulations and the Federal clean Air Act. A summary of the sources reviewed and their current permit status is provided below:

No. of

Actions

\section{Status/Comments}

Due to anticipated delays in the construction of the new CSF boiler (designated as Boiler No. 7), a request was made to the NYSDEC in May 1994 to extend the permit to construct which had been issued in september 1993. The request was later approved in september 1994. After construction is completed, a stack test will be performed to measure emissions of $\mathrm{NO}_{x}$, carbon monoxide, total particulates, $\mathrm{PM}_{10}$ particulates and volatile organic compounds while the boiler is firing \#6 residual oil in accordance with the special conditions of the PC. The new boiler which will replace existing Boiler No. 4 will be fitted with low $\mathrm{NO}_{\mathrm{x}}$ burners capable of meeting the NYS subpart 227-2 $\mathrm{NO}_{x}$ emissions limit of $0.3 \mathrm{lbs} / \mathrm{MMBt}$. In accordance with NYS subpart 227-2 and 40 CFR 60 NSPS subpart Db requirements, the boiler will also be equipped with a continuous emissions monitoring system to measure and record $\mathrm{NO}_{\mathrm{x}}$ levels and stack gas opacity.

In April 1994, two permits to construct applications for air stripping towers designed to remove voC constituents from water drawn from potable wells 4,6 and 7 were transmitted to the NYSDEC. In september 1994, NYSDEC informed the Laboratory that, air stripping devices utilized on public drinking water supplies were exempt from operating permit requirements pursuant to latest revisions of 6 NYCRR Part 201 which became effective in June 1994. As a result, NYSDEC terminated its review of the applications.

In May 1994, NYSDEC extended the permit expiration date for the HWMF animal waste incinerator (Emission ID No. 44401) to December 1996 as 
previously requested in March 1994. Review of the revised permit revealed errors in the identification of wastes that could be burned. A request to further amend the permit so that it accurately reflects the types and quantities of wastes burned was forwarded to NYSDEC in July 1994.

In August 1994, a request was submitted to the NYSDEC to expedite the processing of pending $C O$ applications, permit renewal applications and applications to modify existing permits. The request specifically addressed: a new $C O$ application for an electronic equipment cleaning booth (Emission ID No. 92301) submitted in March 1993; Co renewal applications for Boilers Nos. $1 A, 4,5$ and 6 submitted to NYSDEC respectively in January 1993, october 1991 (Boilers 4\&5) and February 1993; a Co renewal application for a blueprint machine (Emission ID No. 51001) submitted in November 1991; and a Co modification request for an epoxy coating and curing operation (Emission ID No. 19708) submitted in May 1993. The NYSDEC had not responded to this request by the end of CY 1994. Sources with expired COs continue to operate under the provisions of the Uniform Procedures Act. ${ }^{26}$

\section{Employee Trip Reduction Plan:}

In December 1993, a workgroup was formed to address the New York state Department of Transportation (NYSDOT) rules which require employers of 100 or more employees that reside in severe ozone non-attainment areas of the state to reduce the number of single occupant vehicles entering the worksite during the morning rush hours. The workgroup was tasked with the preparation and the implementation of an Employee Trip Reduction Compliance Plan for the Laboratory.

As a first step in the preparation of an Employee Trip Reduction Plan, an employee commute options survey was distributed to all employees during the first week of February 1994 for the purpose of identifying the baseline average passenger occupancy (APO) rate for the site and also to gauge employee preferences to alternative commute options. Over 2200 completed responses were returned. A baseline APO of 1.063 was calculated from information obtained from the survey. To achieve compliance with the Employee Compute Option regional target APO of 1.46 persons/vehicle, the Laboratory must somehow reduce the number employee trips onto the site during the peak travel period from 6:00 to 10:00 AM by nearly 4070 trips per week. This is equivalent to a daily reduction of 814 single occupancy vehicles entering the site during peak travel periods.

In August 1994, the Laboratory received written confirmation from the NYSDOT and the NYS Energy Office that its Long Island Region Improving Commute (LIRIC) grant proposal had been approved and that $\$ 132,391$ will be awarded. The LIRIC program was initiated to provide non-profit and government owned or operated facilities financial assistance to develop innovative strategies to help the employer meet Clean Air Act Amendments (CAAA) employee travel reduction requirements. Grant monies will be used to: establish a Commuter Assistance and Information office to provide assistance and information to employees on carpooling and other alternative commuting options; conduct a seven month pilot on-site shuttle bus service; study the potential impacts of compressed work schedules if such schedules were offered to various segments of the Laboratory work force; and to look at the feasibility of improving site access to bicyclists via physical improvements to gate entrances and through the development of a series of bicycle paths across the site. Contract negotiations between the Laboratory and the grant sponsors had not been finalized by the end of 1994 .

In November, the Employee Trip Reduction Plan for the Laboratory was 
completed and was submitted to the suffolk County Department of Public Works in accordance with requirements of 17 NYCRR Part 38 . By submitting the plan, the Laboratory made a commitment to attempt in good faith to meet the target APo established by the NYSDOT on or before November 15, 1996. The plan discusses implementation of: a carpool/vanpool program; a bicycling program subject to the availability of funding to pay for needed site improvements to make the site conducive to safe bicycling; compressed work week schedules provided that such schedules don't negatively impact such things as laboratory operations, employee relations, employee productivity and compensation and benefits; and a dedicated commercial commuter bus service into areas where large number of employees reside.

\section{RACT Requirements:}

In March 1994, a compliance plan was submitted to NYSDEC which addressed how the Laboratory intends to comply with the reasonable available control technology (RACT) requirements of 6 NYCRR Subpart 227-2 applicable to Boilers 1A, 5 , and 6 and Boiler 7 (which is scheduled to be installed by september 1995 ). To meet the $\mathrm{NO}_{x}$ RACT emissions requirement of 0.3 lbs/MMBTU, the Iaboratory has committed to burning 0.3 percent sulfur residual fuel with a fuel bound nitrogen content of 0.3 percent or less in Boilers $1 \mathrm{~A}, 5$ and 6 . Meanwhile, Boiler 7 , which will be equipped with low $N_{x}$ burners and secondary air combustion equipment will meet the emissions limits by burning residual fuel with a sulfur content of 0.5 percent or less and a fuel bound nitrogen content of 0.3 percent or less. The plan was subsequently approved by NYSDEC on June 28 , 1994. In accordance with commitments within the plan, the Laboratory submitted a continuous emissions monitoring plans for Boilers 6 and 7 in July, and a stack test protocol for $\mathrm{NO}_{\mathrm{x}}$ emissions testing of Boilers $1 \mathrm{~A}$ and 5 scheduled to occur in January 1995, in October. A separate $\mathrm{NO}_{\mathrm{x}}$ emissions test of Boiler 7 will be scheduled after construction is completed.

\section{Halon System Phaseout Study:}

In October 1994, Hughes Associates, Inc. released their final report on the Halon System Phaseout study of existing Laboratory Halon 1301 fire suppression systems which they conducted earlier in the year. The study was initiated as a result of EPA regulations which required the cessation of all U.S. production of Halon 1301 effective January 1, 1994. The primary focus of the study was to identify alternate fire protection methods for Laboratory equipment currently protected by existing Halon 1301 systems. Under terms of the contractual agreement the contractor was tasked with: conducting a survey of existing fixed Halon 1301 systems; evaluating the need for alternative systems; estimating the costs for those systems needing replacement and making recommendations on the disposal of the halon inventory.

of the 51 systems survey, it was determined that ten systems residing in AGS facilities were no longer needed due to changes in facility fire protection needs and could be removed from service. It was also suggested that four systems in the Medical Department be replaced with automatic sprinkler systems. Recommendations for the majority of the remaining systems call for the replacement of Halon 1301 with non-ozone depleting total flooding agents. Inergen and FM-200 are the two gaseous agents recommended. Replacement of existing systems is targeted for line item funding for FY 2000 and beyond.

\section{Ozone Depleting Refrigerants:}

Refrigeration system conversions that were performed by Plant Engineering (PE) to reduce site reliance on ozone depleting refrigerants affected by the CAAA Title VI production phaseout included the conversion of a reciprocating chiller in Building 480 to $\mathrm{R}-22$ and the conversion of a centrifugal chiller in Building 
725 to R-134A. Approximately 700 pounds of $R-12$ and nearly 700 pounds of $R-500$ were recovered during these respective system conversions. During the year, approximately 250 pounds of $\mathrm{R}-22$ was recovered during the servicing and decommissioning of R-22 refrigeration equipment and roughly 70 pounds of R-12 was recovered from several small appliance units that were decommissioned.

In November 1994, work commenced on the replacement of a Carrier R-12 reciprocating chiller containing a refrigerant charge of 600 pounds with a comparably sized R-22 unit. The project is expected to be completed in February 1995. Plant Engineering also prepared a GPP request for FY 95 for $\$ 350,000$ to retrofit existing $\mathrm{R}-11, \mathrm{R}-12$ and $\mathrm{R}-502$ refrigeration equipment with equipment that utilizes EPA approved CEC alternatives. The majority of the funding is expected to be used to replace two 80 ton Carrier $\mathrm{R}-12$ reciprocating units in Building 526 with comparable R-22 units.

As of November 14, 1994, $47 \mathrm{PE}$ employees had successfully completed the Type IV Universal Technician Training Program and received a passing grade on the certification examination as required pursuant to 40 CFR Part 82 section 82.161. Two employees had successfully completed the training but were awaiting test results. Employees who complete the required universal training and pass the certification test are authorized to purchase, recycle and recover CFC and HCFC refrigerants and to service and repair all types of high and low pressure refrigeration systems.

\section{Reformulated Gasoline Program:}

To comply with $40 \mathrm{CFR}$ Part 80 subpart D reformulated gasoline requirements which became effective January 1, 1995, plans were developed in December 1994, to turnover the conventional gasoline product and refill the fuel storage tanks located at the Building 423 Fleet Vehicle Refueling Station and the Building 630 Gulf Station with reformulated gasoline by the end January. The new requirements which were enacted by the EPA as required pursuant to the Title II of the CAAA of 1990, are intended to improve air quality by reducing toxic and VOC emissions from motor vehicles.

\subsubsection{National Emissions standard for Hazardous Air Pollutants (NESHAPs)}

\subsubsection{Radioactive Airborne Effluent Emissions Governed by NESHAPs}

In 1994, BNL emissions complied with 40 CFR 61 regulations regarding radioactive airborne effluent releases. The site boundary dose resulting from BNL airborne emissions as calculated using the CAP88 model was $0.14 \mathrm{mrem}$. The radionuclide contributing the largest fraction to both the site boundary and population dose was argon-41. The total released source term of this nuclide was about 1.1 times that released in 1993. The 1994 effluent release data and dosimetric impact of these releases were transmitted to both DOE and EPA in compliance with the June 30, 1994 reporting requirements specified in 40 CFR 61, Subpart 94. Also, BNI received a facility compliance inspection by EPA in 1994 with no deficiencies reported. There were no new emission sources in 1994 that required formal NESHAPs permitting.

On March 31, 1994, the HFBR facility (Bldg. 750) experienced a minor fire on the experimental level of the facility. The cause was an electrical short in equipment being used on the H-2 beamline, known as TRISTAN. The fire generated airborne radioactive vapors inside the building which were exhausted to outdoor air via the reactor's 100 meter stack. (Note that exhausted vapors were processed through the HFBR's effluent emission control system which consists of charcoal and high efficiency particulate air [HEPA] filters.) The principal isotopes involved in the release were radioiodines, with a total released activity of approximately $54 \mathrm{\mu Ci}(2 \mathrm{MBq})$. Total off-site effective dose equivalent was 
calculated to be $2 \mathrm{E}-4$ microrem (2E-9 mSv). The magnitude of this unplanned release is quite small compared to the HFBR's normal source term output of approximately $70 \mathrm{Ci} / \mathrm{yr}(2.6 \mathrm{TBq} / \mathrm{yr})$ with an associated dose of $2 \mathrm{E}-4 \mathrm{millirem}$ (2E$6 \mathrm{mSv}$ ).

The MRR emission point is defined under NESHAPs as a "major" source and therefore requires specific equipment to perform continuous monitoring of its radioactive air effluent. Funding was received in EY 1993 for the purchase of equipment upgrades necessary to bring the facility into full compliance. A stack emissions monitoring unit capable of particulate isokinetic sampling, radioactive noble gas measurements and stack air flow recording was installed in the MRR facility in July, 1994.

\subsubsection{Asbestos Emissions}

Since 1993, BNL emissions have complied with 40 CFR 61 regulations regarding airborne fiber releases. The EPA Region II was notified on three occasions that operations required NESHAPs formal notification. Formal annual notification for nonscheduled small renovation operations for 1994 was made indicating an estimated amount of total friable asbestos material projected to be removed in small removal operations at 249 square feet of surface material, and 2,179 linear feet of pipe insulation. This information was transmitted to both DOE and EPA in compliance with the reporting requirements specified in 40 CFR 61 .

\subsection{Suffolk county Sanitary Codes}

There are over 200 storage facilities at BNL which are regulated under the suffolk County Sanitary Code Articles 7 and 12 . Since the signing of an agreement between suffolk county and BNL in 1987, the Laboratory has made significant progress toward bringing all storage facilities into compliance with these requirements. A description and status of the activities conducted during 1994 is provided below:

\section{No. $\quad$ Status/Comments}

Four existing outdoor underground storage tanks at Building 650 (BNL ID\#s 650-01, 650-02, 650-03\&650-04; SCDHS ID\#s 146, 147 , 148, \& 149) which had not been used for several years were removed in August 1994 as part of an action completed by OER. The removals were witnessed by a representative from the SCDHS. Additional details of this action are provided in a separate report entitled "Closeout Report for BNL Building 650 Tanks Removal" which was prepared in accordance with the IAG and submitted to regulatory agencies.

Two existing outdoor underground storage tanks at Building 445 (BNL ID\#S 445-02 \& 445-03; SCDHS ID\#S 43\&46) which had not been in use for several years were removed in september 1994 as part of an action completed by OER. A representative from the SCDHS witnessed the removals of both tanks. A radiological survey of the soils beneath the tanks did not indicate the presence of radioactivity above background. Additional soil samples were collected for quantitative and qualitative confirmation. Additional details of this action will be provided in a separate closeout report which will be prepared in accordance with the IAG and submitted to regulatory agencies in CY 1995.

Three existing outdoor aboveground storage tanks at Building 
811 (BNI ID\#S 811-01, 811-02 \& 811-03; SCDHS ID\#S 181, 182, \& 183) which had been previously used many years ago to store radioactive liquids were removed in December 1994 as part of an action completed by OER. These tanks have been empty of all liquids and out of service for the past several years. The action included the decontamination and dismantlement of these tanks. A report, describing the details of this project, will be prepared under the direction of the OER in accordance with the IAG and submitted to regulatory agencies in CY 1995 .

In December 1994, a SCDHS representative inspected two outdoor aboveground temporary storage tanks at Buildings 930 and 811 . The inspector was satisfied with the storage facilities, with BNL's inspection logs, and had no further requests.

Minor repairs were made to the high level alarm systems on twelve outdoor storage tanks during CY 1994.

Design plans for a project to bring twelve existing indoor tanks used to store water treatment chemicals into compliance with SCDHS requirements were completed. The work includes the removal of eight tanks (BNL ID\#s 490-13, 490-14, 490-15, 490$16,576-01,576-02,576-03, \& 634-01)$, installation of two new storage tanks (BNL ID\#s 576-04\& 634-03), and equipping four tanks with secondary containment and overfill protection (49011, 490-12, 635-01, \& 637-01). This project is anticipated to be completed during CY 1995.

In addition to the activities described above, inspections of all storage facilities at BNL were conducted by a representative from the DHs from the end of May through the end of July, 1994. The purpose of the inspections was to update the list of BNL active storage facilities maintained by the SCDHS. As a result of these inspections, one comprehensive list was compiled of all storage facilities which do not currently meet the requirements of the suffolk County Sanitary Code (SCSC) Article 12. In addition, numerous storage facilities were identified which require registration. The Laboratory submitted a registration package which addressed these facilities to the sCDHS in August 1994. A meeting was also held with various representatives from the DHS to discuss BNL's plans, schedules and cost estimates to bring the remaining storage facilities into compliance with scsc Article 12 .

\subsection{Safe Drinking water Act (SDWA)}

\subsubsection{Applicability to Brookhaven National Laboratory}

The Laboratory maintains six wells and two water storage tanks for supplying potable water to the Laboratory community. Regulations pertaining to the distribution and monitoring of public water supplies are promulgated under Part 5 of the New York state Sanitary Code which is enforced by the SCDHS as agent for the NYSDOH. These regulations are applicable to any water supply which has at least five service connections or regularly serves at least 25 individuals. The Iaboratory supplies water to a population of approximately 3,500 and must therefore comply with the provisions of these regulations.

\subsubsection{Potable Water Monitoring Requirements}

The potable water supply used at BNL was obtained from six wells during 1994. Annual minimum monitoring requirements for potable water suppliers are specified by the SCDHS. In response to these requirements, the Laboratory prepares a Potable water system Sampling and Analysis Plan which outlines sampling procedures and provides a schedule for annual monitoring of the BNL 
potable water system. The content of the BNL monitoring program was reviewed and found acceptable by the SCDHS. Routine monitoring of the potable wells and the potable water distribution system by BNL exceeded the minimum monitoring requirements prescribed by the SCDHS. Monitoring requirements for 1994 included: monthly bacteriological analyses; quarterly analyses for PoCs; an annual analysis for socs and Pesticides; semi-annual inorganic chemicals analyses and annual micro-extractables; asbestos analyses and radiological analyses. Comparison of 1994 to 1993 monitoring requirements show that due to the absence of socs and Pesticides, the frequency of these analyses was reduced in CY 1994 from quarterly to annually. Potable water samples were collected by BNL personnel and analyzed by a NYSDOH certified contractor laboratories using standard methods of analysis. AIl analytical data was submitted to the SCDHS as required by Chapter I, Part 5, of the NYS Sanitary Code. Bacteriological, inorganic, radiological and asbestos analytical data has been summarized in Table 2-5; POCs, socs, pesticides and micro-extractables analytical data has been summarized in Table 2-6.

Review of Tables $2-5$ and $2-6$ reveals that all reported bacteriological, socs, Pesticides, Micro-extractables, radiological and asbestos analytical data collected during CY 1994 were within the NYS DWS. Water obtained from Wells 4, 6 and 7 contains elevated levels of iron and color and consequently is treated for the removal of iron at the WTP. The WTP uses a calcium hydroxide water softening process for precipitating iron oxide from the water received from these wells. The precipitation of iron oxide also improves the color of the water. The potable water effluent from the WTP met all NYS DWS in CY 1994.

Further review of Table $2-6$ shows the water obtained from Well 11 to exceed the NYSDWS for TCA. Volatile organic compounds particularly TCA, have become problematic at BNL and have caused the shutdown of Potable Wells No. 4, 10, and 11 in the past. In 1992 and 1993, Potable Wells 10 and 11 were equipped with activated carbon adsorption devices for abatement of PoCs. Analysis of untreated water samples collected from Potable Well 11 showed the concentrations of TCA to be greater than the NYS DWS of $5 \mu \mathrm{g} / \mathrm{L}$, and ranged from a minimum of 5.3 to a maximum of $8 \mathrm{\mu g} / \mathrm{L}$. Analysis of treated water samples showed all TCA concentrations to be less than the NYS DWS. While the concentration of TCA in Well 10 untreated water remained less than the NYS DWS in 1994, replacement of the carbon within the carbon adsorber was required due to voc breakthrough.

The sCDHS conducted an inspection of the BNL potable water supply system on August 18, 1994. This inspection consisted of walk-through inspections of the WTP, WTP support facilities and potable well support facilities. The SCDHS inspector noted that all operations were satisfactory. Analysis of water samples collected during this visit showed all analytical parameters to meet the NYS DWS.

A second inspection was conducted on October 31, 1994 by the SCDHS, in response to a reported cross connection and potential potable water contamination incident. On October 26, 1994, report of a cross connection incident at Building 922, which resulted in the injection of dilute ethylene glycol into the BNL potable water system, was received by the S\&EP Division ECG. According to AGS personnel, while servicing a cooling tower, a connection between the cooling tower circulation pump and the potable water system was made using a garden hose. Due to the pressure differential between the cooling water circulation and the potable water systems, injection of the glycol solution occurred when the circulation pump was turned on. As the Building No. 922 water service was not equipped with a cross connection control device, the potential existed for contamination of the main water system. Flushing of the potable water mains commenced and follow-up analysis of potable water samples showed all levels of ethylene glycol to be non-detectable. The scDHs inspection focussed on the cross connection and the overall BNL Cross Connection Control Program. The SCDHS recommended that $\mathrm{BNI}$ reevaluate the status of the current program and install cross connection control devices where necessary. 
Table 2-5

BNL Site Environmental Report for Calendar Year 1994

Potable Water Wells and Potable Distribution system,

Bacteriological, Inorganic Chemical and Radiological Analytical Data

\begin{tabular}{|c|c|c|c|c|c|c|c|c|c|}
\hline Compound & $\begin{array}{l}\text { Well } \\
\text { No. } 4 \\
\text { (ED) }\end{array}$ & $\begin{array}{l}\text { We11 } \\
\text { No. } 6 \\
\text { (FE) }\end{array}$ & $\begin{array}{l}\text { Well } \\
\text { No. } 7 \\
\text { (FG) }\end{array}$ & $\begin{array}{l}\text { Well } \\
\text { No. } 10 \\
\text { (EO) }\end{array}$ & $\begin{array}{l}\text { Well } \\
\text { No. } 11 \\
\text { (FP) }\end{array}$ & $\begin{array}{l}\text { Well } \\
\text { No. } 12 \\
\text { (FO) }\end{array}$ & $\begin{array}{l}\text { Potable } \\
\text { Distribution } \\
\text { Sample }\end{array}$ & \multicolumn{2}{|c|}{$\begin{array}{c}\text { NYS } \\
\text { Drinking } \\
\text { Water Standard }\end{array}$} \\
\hline Total Coliform & ND & ND & ND & $\mathrm{ND}$ & ND & ND & ND & Negative & \\
\hline Color & $70^{2}$ & $50^{2}$ & $20^{2}$ & $<5$ & $<5$ & $<5$ & $<5$ & 15 & Units \\
\hline Odor & 0 & 0 & 0 & 0 & 0 & 0 & 0 & 3 & Units \\
\hline Cyanide & $<10$ & $<10$ & $<10$ & $<10$ & $<10$ & $<10$ & $<10$ & NS & $\mu \mathrm{g} / \mathrm{I}$ \\
\hline Conductivity & 86 & 70 & 91 & 92 & 95 & 117 & 149 & NS & umhos \\
\hline Chlorides & 21 & 15 & 20 & 17 & 12 & 15 & 17 & 250 & $\mathrm{mg} / \mathrm{I}$ \\
\hline Sulfates & 11.1 & 12.1 & 12.6 & 13.8 & 15.7 & 14.1 & 12.9 & 250 & $\mathrm{mg} / \mathrm{L}$ \\
\hline Nitrates & 0.2 & 0.2 & 0.2 & 0.5 & 0.5 & 0.5 & 0.4 & 10 & $\mathrm{mg} / \mathrm{L}$ \\
\hline Ammonia & $<0.02$ & 0.03 & 0.02 & $<0.02$ & $<0.02$ & $<0.02$ & $<0.02$ & NS & $\mathrm{mg} / \mathrm{I}$ \\
\hline $\begin{array}{l}\text { pH } \\
\text { Methylene Blue }\end{array}$ & 5.6 & 6.0 & 6.0 & 6.3 & 6.1 & 6.9 & 7.5 & NS & SU \\
\hline Active substances & $<0.04$ & $<0.04$ & $<0.04$ & $<0.04$ & $<0.04$ & $<0.04$ & $<0.04$ & 0.5 & $\mathrm{mg} / \mathrm{I}$ \\
\hline Antimony & $<5.9$ & $<5.9$ & $<5.9$ & $<5.9$ & $<5.9$ & $<5.9$ & $<5.9$ & NS & \\
\hline Arsenic & $<10$ & $<10$ & $<10$ & $<10$ & $<10$ & $<10$ & $<3.0$ & 50 & $\mu g / L$ \\
\hline Barium & $<0.2$ & $<0.2$ & $<0.2$ & $<0.2$ & $<0.2$ & $<0.2$ & $<0.2$ & 1.0 & $\mathrm{mg} / \mathrm{L}$ \\
\hline Beryllium & $<3.0$ & $<3.0$ & $<3.0$ & $<3.0$ & $<3.0$ & $<3.0$ & $<0.5$ & 4.0 & $\mathrm{mg} / \mathrm{I}$ \\
\hline Cadmium & $<5.0$ & $<5.0$ & $<5.0$ & $<5.0$ & $<5.0$ & $<5.0$ & $<5.0$ & 10 & $\mu g / L$ \\
\hline Chromium & $<0.01$ & $<0.01$ & $<0.01$ & $<0.01$ & $<0.01$ & $<0.01$ & $<0.01$ & 0.05 & $\mathrm{mg} / \mathrm{L}$ \\
\hline Fluoride & $<0.1$ & $<0.1$ & $<0.1$ & $<0.1$ & $<0.1$ & $<0.1$ & $<0.1$ & 2.2 & $\mathrm{mg} / \mathrm{L}$ \\
\hline Iron & $2.08^{2}$ & $2 \cdot 3^{2}$ & $1.74^{2}$ & $<0.02$ & $<0.02$ & 0.03 & 0.03 & $0.3^{2}$ & $\mathrm{mg} / \mathrm{L}$ \\
\hline Lead & 2.0 & $<1.2$ & $<1.2$ & $<1.2$ & 2.0 & $<1.2$ & $<1.0$ & 15 & $\mu \mathrm{g} / \mathrm{L}$ \\
\hline Manganese & 0.06 & 0.09 & 0.07 & $<0.01$ & $<0.01$ & $<0.01$ & $<0.01$ & 0.3 & $\mathrm{mg} / \mathrm{L}$ \\
\hline Mercury & $<0.2$ & $<0.2$ & $<0.2$ & $<0.2$ & $<0.2$ & $<0.2$ & $<0.2$ & 2.0 & $\mu g / L$ \\
\hline Nickel & $<0.04$ & 0.1 & $<0.04$ & $<0.04$ & $<0.04$ & $<0.04$ & $<0.04$ & 0.1 & $\mathrm{mg} / \mathrm{L}$ \\
\hline selenium & $<5.0$ & $<5.0$ & $<5.0$ & $<5.0$ & $<5.0$ & $<5.0$ & $<5.0$ & $10^{\circ}$ & $\mu g / L$ \\
\hline sodium & 10.6 & 8.4 & 11.0 & 10.1 & 10.8 & 18.9 & 19.9 & NS & $\mathrm{mg} / \mathrm{I}$ \\
\hline Thallium & $<1.9$ & $<1.9$ & $<1.9$ & $<1.9$ & $<1.9$ & $<1.9$ & $<1.9$ & 2.0 & $\mu \mathrm{g} / \mathrm{L}$ \\
\hline Zinc & 0.02 & $<0.02$ & $<0.02$ & $<0.02$ & 0.02 & 0.03 & $<0.02$ & 5.0 & $\mathrm{mg} / \mathrm{L}$ \\
\hline Gross $\alpha$ Activity & NR & $N R$ & NR & NR & NR & NR & 1.24 & 15 & $\mathrm{pCi} / \mathrm{L}$ \\
\hline Asbestos & NR & NR & NR & NR & NR & $\mathrm{NR}$ & $<0.103$ & 7 M. Ej & ibers/L \\
\hline
\end{tabular}

1. This table contains the maximum concentration (minimum pH value) reported by the contractor laboratory.

2. Due to the color and high concentrations of iron within the water produced by wells 4 , 6 , and 7 , this water is treated at the Water Treatment Plant for removal of iron and color reduction.

ND: None detected NS: DWS Not Specified NR: Analysis Not Required 
Table 2-6

BNL Site Environmental Report for Calendar Year 1994

Potable Water Wells, Analytical Data for Principal Organic Compounds, synthetic organic Compounds Pesticides and Micro-Extractables

\begin{tabular}{|c|c|c|c|c|c|c|c|c|}
\hline Compound & $\begin{array}{l}\text { WTP } \\
\text { Effluent } \\
\text { (F2) }\end{array}$ & $\begin{array}{l}\text { Well } \\
\text { No. } 4 \\
\text { (ED) }\end{array}$ & $\begin{array}{l}\text { Wel1 } \\
\text { No. } 6 \\
\text { (FF) }\end{array}$ & $\begin{array}{l}\text { Well } \\
\text { No. } 7 \\
\text { (FG) }\end{array}$ & $\begin{array}{l}\text { We11 } \\
\text { No. } 10 \\
\text { (FO) }\end{array}$ & $\begin{array}{l}\text { Wel1 } \\
\text { No. } 11 \\
\text { (FP) }\end{array}$ & $\begin{array}{l}\text { Wel1 } \\
\text { No. } 12 \\
\text { (FQ) }\end{array}$ & $\begin{array}{l}\text { NYS } \\
\text { Drinking } \\
\text { Water Standard }\end{array}$ \\
\hline Dichlorodifluoromethane & ND & ND & ND & ND & ND & ND & ND & 5 \\
\hline Chloromethane & ND & ND & ND & ND & ND & ND & ND & 5 \\
\hline Vinyl Chloride & ND & ND & ND & ND & ND & ND & ND & 2 \\
\hline Bromomethane & ND & ND & ND & ND & ND & ND & ND & 5 \\
\hline Chloroethane & ND & ND & ND & ND & ND & ND & ND & 5 \\
\hline Fluorotrichloromethane & ND & ND & ND & ND & ND & ND & ND & 5 \\
\hline 1,1-dichloroethene & ND & ND & ND & ND & ND & 0.5 & ND & 5 \\
\hline Dichloromethane & ND & ND & ND & ND & ND & ND & ND & 5 \\
\hline trans-1,2-dichloroethene & ND & ND & ND & ND & ND & ND & ND & 5 \\
\hline 1,1-dichloroethane & 0.6 & ND & ND & ND & 0.5 & 0.8 & ND & 5 \\
\hline cis-1,2-dichloroethene & ND & ND & ND & ND & ND & ND & $\mathrm{ND}$ & 5 \\
\hline 2,2-dichloropropane & ND & ND & ND & ND & ND & ND & ND & 5 \\
\hline Bromochloromethane & ND & ND & ND & ND & ND & ND & ND & 5 \\
\hline $1,1,1$-trichloroethane & 0.6 & 2.1 & 0.5 & ND & 1.8 & 8.0 & 1.1 & 5 \\
\hline Carbon Tetrachloride & ND & ND & ND & ND & ND & ND & ND & 5 \\
\hline 1,1-dichloropropene & ND & ND & ND & ND & ND & ND & ND & 5 \\
\hline 1,2-dichloroethane & ND & ND & ND & ND & ND & ND & ND & 5 \\
\hline trichloroethane & ND & ND & ND & ND & ND & ND & ND & 5 \\
\hline 1,2-dichloropropane & ND & ND & ND & ND & ND & ND & ND & 5 \\
\hline Dibromomethane & ND & ND & ND & ND & ND & ND & ND & 5 \\
\hline trans-1, 3-dichloropropene & ND & ND & ND & ND & ND & ND & ND & 5 \\
\hline cis-1,3-dichloropropene & ND & ND & ND & ND & ND & ND & ND & 5 \\
\hline 1,1,2-trichloroethane & ND & ND & ND & ND & ND & ND & ND & 5 \\
\hline Trihalomethanes & 22.9 & 25.8 & 25.1 & 0.9 & ND & 0.6 & 0.9 & 100 \\
\hline $1,1,2,2$-tetrachloroethane & ND & ND & ND & ND & ND & ND & ND & 5 \\
\hline 1,3-dichloropropane & ND & ND & ND & ND & ND & ND & ND & 5 \\
\hline Chlorobenzene & ND & ND & ND & ND & ND & ND & ND & 5 \\
\hline $1,1,1,2$-tetrachloroethane & ND & ND & ND & ND & ND & ND & ND & 5 \\
\hline Bromobenzene & ND & ND & ND & ND & ND & ND & ND & 5 \\
\hline
\end{tabular}


Table 2-6 (cont.)

BNL Site Environmental Report for Calendar Year 1994

Potable Water Wells, Analytical Data for Principal Organic Compounds,

Synthetic Organic Compounds and Maximum Principal Organic Compound Data

\begin{tabular}{|c|c|c|c|c|c|c|c|c|}
\hline Compound & $\begin{array}{l}\text { WTP } \\
\text { Effluent } \\
\text { (E2) }\end{array}$ & $\begin{array}{l}\text { Well } \\
\text { No. } 4 \\
\text { (ID) }\end{array}$ & $\begin{array}{l}\text { Well } \\
\text { No. } 6 \\
\text { (FF) }\end{array}$ & $\begin{array}{l}\text { Well } \\
\text { No. } 7 \\
\text { (EG) }\end{array}$ & $\begin{array}{l}\text { Well } \\
\text { No.10 } \\
\text { (FO) }\end{array}$ & $\begin{array}{l}\text { We11 } \\
\text { No. } 11 \\
\text { (FP) }\end{array}$ & $\begin{array}{l}\text { Wel1 } \\
\text { No. } 12 \\
\text { (FQ) }\end{array}$ & $\begin{array}{l}\text { NYS } \\
\text { Drinking } \\
\text { Water standard }\end{array}$ \\
\hline $1,1,2,2$-tetrachloroethane & ND & ND & ND & ND & ND & ND & ND & 5 \\
\hline 1,2,3-trichloropropane & ND & ND & ND & ND & ND & ND & ND & 5 \\
\hline 2-chlorotoluene & ND & ND & ND & ND & ND & ND & ND & 5 \\
\hline 4-chlorotoluene & ND & ND & ND & ND & ND & ND & ND & 5 \\
\hline 1,3-dichlorobenzene & ND & ND & ND & ND & ND & ND & ND & 5 \\
\hline 1,4-dichlorobenzene & ND & ND & ND & ND & ND & ND & ND & 5 \\
\hline 1,2-dichlorobenzene & ND & ND & ND & ND & ND & ND & ND & 5 \\
\hline $1,2,4$-trichlorobenzene & ND & ND & ND & ND & ND & ND & ND & 5 \\
\hline Hexachlorobutadiene & ND & ND & ND & ND & ND & ND & ND & 5 \\
\hline 1,2,3-trichlorobenzene & ND & ND & ND & ND & ND & ND & ND & 5 \\
\hline Benzene & ND & ND & ND & ND & ND & ND & ND & 5 \\
\hline Toluene & ND & ND & ND & ND & ND & ND & ND & 5 \\
\hline Ethylbenzene & ND & ND & ND & ND & ND & ND & ND & 5 \\
\hline m-xylene & ND & ND & ND & ND & ND & ND & ND & 5 \\
\hline p-xylene & ND & ND & ND & ND & ND & ND & ND & 5 \\
\hline o-xylene & ND & ND & ND & ND & ND & ND & ND & 5 \\
\hline styrene & ND & ND & ND & ND & ND & ND & ND & 5 \\
\hline Isopropylbenezene & ND & ND & ND & ND & ND & ND & ND & 5 \\
\hline n-propylbenzene & ND & ND & ND & ND & ND & ND & ND & 5 \\
\hline 1,3,5-trimethylbenzene & ND & ND & ND & ND & ND & ND & ND & 5 \\
\hline tert-butylbenzene & ND & ND & ND & ND & ND & ND & ND & 5 \\
\hline 1,2,4-trimethylbenzene & ND & ND & ND & ND & ND & ND & ND & 5 \\
\hline sec-butylbenzene & ND & ND & ND & ND & ND & ND & ND & 5 \\
\hline p-isopropyltoluene & ND & ND & ND & ND & ND & ND & ND & 5 \\
\hline n-butylbenzene & ND & ND & ND & ND & ND & ND & ND & 5 \\
\hline
\end{tabular}


Table 2-6 (cont.)

BNL Site Environmental Report for Calendar Year 1994

Potable Water Wells, Analytical Data for Principal Organic Compounds, synthetic organic Compounds, Pesticides and Micro-Extractables

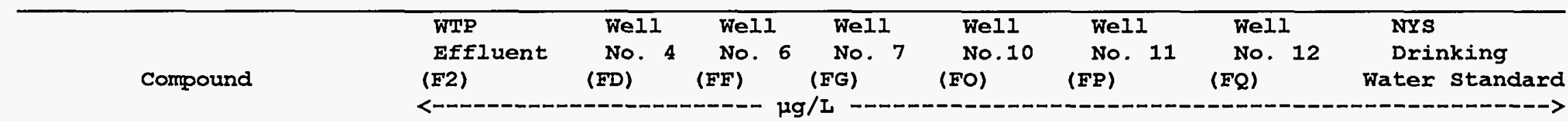

\begin{tabular}{|c|c|c|c|c|c|c|c|c|}
\hline Alachlor & ND & ND & ND & ND & ND & ND & ND & 2 \\
\hline Simazine & ND & ND & ND & ND & ND & ND & ND & 50 \\
\hline Atrazine & ND & ND & ND & ND & ND & ND & ND & 3 \\
\hline Metolachlor & ND & ND & ND & ND & ND & ND & ND & 50 \\
\hline Metribuzin & ND & ND & ND & ND & ND & ND & ND & 50 \\
\hline Butachlor & ND & ND & ND & ND & ND & ND & ND & 50 \\
\hline Lindane & ND & ND & ND & ND & ND & ND & ND & 0.2 \\
\hline Heptaclor & ND & ND & ND & ND & ND & ND & ND & 0.4 \\
\hline Aldrin & ND & ND & ND & ND & ND & ND & ND & 5 \\
\hline Heptachlor Epoxide & ND & ND & ND & ND & ND & ND & ND & 0.2 \\
\hline Dieldrin & ND & ND & ND & ND & ND & ND & ND & 5 \\
\hline Endrin & ND & ND & ND & ND & ND & ND & ND & 0.2 \\
\hline Methoxychlor & ND & ND & ND & ND & ND & ND & ND & 40 \\
\hline Toxaphene & ND & ND & ND & ND & ND & ND & ND & 3 \\
\hline Chlordane & ND & ND & ND & ND & ND & ND & ND & 2 \\
\hline Total PCB's & ND & ND & ND & ND & ND & ND & ND & 0.5 \\
\hline Propachlor & ND & ND & ND & ND & ND & ND & ND & 50 \\
\hline $2,4,-D$ & ND & ND & ND & ND & ND & ND & ND & 50 \\
\hline $2,4,5,-\mathrm{TP}$ (Silvex) & ND & ND & ND & ND & $\mathrm{ND}$ & ND & ND & 10 \\
\hline Dinoseb & ND & ND & ND & ND & ND & ND & ND & 50 \\
\hline Dalapon & ND & ND & ND & ND & ND & ND & ND & 50 \\
\hline Pichloram & ND & ND & ND & ND & ND & ND & ND & 50 \\
\hline Dicamba & ND & ND & ND & ND & ND & ND & ND & 50 \\
\hline Pentachlorophenol & ND & ND & ND & ND & ND & ND & ND & 1 \\
\hline Hexachlorcyclopentadiene & ND & ND & ND & ND & ND & ND & ND & 5 \\
\hline Di (2-ethylhexyl) Phthalate & ND & ND & ND & ND & ND & ND & ND & 50 \\
\hline Di (2-ethylhexyl) Adipate & ND & ND & ND & ND & ND & ND & ND & 50 \\
\hline Hexachlorobenzene & ND & ND & ND & ND & ND & ND & ND & 5 \\
\hline Benzo (A) Pyrene & ND & ND & ND & ND & ND & ND & ND & 50 \\
\hline Aldicarb sulfone & ND & ND & ND & ND & ND & ND & ND & NS \\
\hline
\end{tabular}


Table 2-6 (cont.)

BNL Site Environmental Report for Calendar Year 1994

Potable Water Wells, Analytical Data for Principal Organic Compounds,

Synthetic Organic Compounds, Pesticides and Micro-Extractables

\begin{tabular}{|c|c|c|c|c|c|c|c|c|}
\hline Compound & $\begin{array}{l}\text { WTP } \\
\text { Effluent } \\
\text { (F2) }\end{array}$ & $\begin{array}{l}\text { Well } \\
\text { No. } 4 \\
\text { (ED) }\end{array}$ & $\begin{array}{l}\text { Wel.1 } \\
\text { No. } 6 \\
\text { (FF) }\end{array}$ & $\begin{array}{l}\text { We1l } \\
\text { No. } 7 \\
\text { (FG) }\end{array}$ & $\begin{array}{l}\text { Well } \\
\text { No. } 10 \\
\text { (EO) }\end{array}$ & $\begin{array}{l}\text { We11 } \\
\text { No. } 11 \\
\text { (FP) }\end{array}$ & $\begin{array}{l}\text { Wel1 } \\
\text { No. } 12 \\
\text { (FQ) }\end{array}$ & $\begin{array}{l}\text { NYS } \\
\text { Drinking } \\
\text { Water standarc }\end{array}$ \\
\hline Aldicarb Sulfoxide & ND & ND & ND & ND & ND & ND & ND & NS \\
\hline Aldicarb & ND & ND & ND & ND & ND & ND & ND & NS \\
\hline Oxamy1 & ND & ND & ND & ND & ND & ND & ND & 50 \\
\hline Methomyl & ND & ND & ND & ND & ND & ND & ND & 50 \\
\hline 3-Hydroxycarbofuran & ND & ND & ND & ND & ND & ND & ND & 50 \\
\hline Carbofuran & ND & ND & ND & ND & ND & ND & ND & 40 \\
\hline Carbaryl & ND & ND & ND & ND & ND & ND & ND & 50 \\
\hline Total Aldicarbs & ND & ND & ND & ND & ND & ND & ND & NS \\
\hline Glyphosate & ND & ND & ND & ND & ND & ND & ND & 50 \\
\hline Diquat & ND & ND & ND & ND & ND & ND & ND & 50 \\
\hline Ethylene Dibromide & ND & ND & ND & ND & ND & ND & ND & 0.05 \\
\hline Dibromochloropropane & ND & ND & ND & ND & ND & ND & ND & 0.2 \\
\hline
\end{tabular}

\footnotetext{
ND: $\quad$ Not detected at minimum detection limit.

NS: $\quad$ DWS Not Specified

Notes: $\quad$ For compliance determination with NYsDOH standards, potable wells were analyzed quarterly during the year by $\mathrm{H}_{2} \mathrm{M}$ Labs, Inc., a NYS certified contract Laboratory.
}

The minimum detection limits for POC analytes are $0.5 \mu \mathrm{g} / \mathrm{L}$. Minimum detection limits for socs, Pesticides and Micro-extractables are compound specific and in all cases are less than the NYSDOH drinking water standard.

All concentrations contained in Table 2-6 are the maximum values reported by the contractor laboratory. 
The collection of first draw water samples for subsequent lead and copper analysis as required by the Federal Lead and Copper Rule, continued during 1994. This program required the collection of tap water samples from bathroom or kitchen faucets which had been unused for a period of six to twelve hours. The objective of this program was to determine the aggressiveness of the potable water to the plumbing fixtures. If the water was found to be aggressive, as evidenced by increased concentrations of lead and copper, treatment alternatives, such as the addition of corrosion inhibitors to the potable supply, were to be evaluated. Since two series of lead and copper analyses conducted in 1993 showed the BNL Potable water supply to meet the provisions of the Federal Lead and Copper Rule, the frequency and number of analyses were reduced in CY $1994 \mathrm{from}$ forty locations collected biannually to twenty locations collected annually. The Laboratory collected water samples from twenty sites during the period beginning June 1 and ending september 30, 1994 and analyzed each of these samples for lead and copper. While the analytical results for copper were all less than the EPA Federal Action Level of $1.3 \mathrm{mg} / \mathrm{L}$, the concentration of lead in the ninetieth percentile sample was found to be greater than the Federal Action Level of 15 $\mu \mathrm{g} / \mathrm{L}$. In the ensuing months resamples collected from the same facilities showed all concentrations to be less than the lead action level; however, since the original samples prove to contravene the action level the Laboratory was required to implement a public education program. This program consisted of the distribution of pamphlets, placement of newspaper articles and the posting of flyers which provided information on the toxicological properties of lead and measures being taken to reduce exposures to lead. This program was completed by December 30, 1994 .

In order to study the aggressiveness of the BNL potable water, by June 30, 1995 the Laboratory is required to perform a desk-top study which will analyze the chemical properties of the BNL potable water supply and recommend optimum conditions (e.g., calcium concentration, pH etc.) to minimize corrosion. In accordance with the Federal Lead and Copper program criteria the Laboratory will also be required to resume the monitoring of forty locations biannually in 1995 and will also conduct analysis for water quality parameters which will be evaluated during the desk-top study.

\subsection{Toxic Substance Control Act (TSCA)}

\section{7 .1 TSCA Program at BNL}

The use and disposal of specific substances, such as polychlorinated Biphenyls (PCBs), is regulated under TSCA. The requirements under this Act include labeling, inspections, record keeping, immediate notification and cleanup upon discovery of spills, and proper disposal. The Laboratory issued a Safety, Environment, and Administrative Procedures Manual (SEAPPM) for PCB management in 1992. This SEAPPM formalized the BNL policy and identified specific responsibilities to ensure that PCBS are managed in accordance with TSCA requirements. The S\&EP Division maintains a database of all Department and Division PCB equipment to ensure proper tracking and record keeping. This database is updated as information is supplied by the various Departments and Divisions. In addition, the annual PCB Report for CY 1993 was prepared in accordance with the requirements of TSCA. This report is retained on file at S\&EP Division. A copy was also submitted to the DOE-Brookhaven Area office (BHO).

The Laboratory has also been working on developing an Environment Safety and Health (ES\&H) standard on PCB management. This Standard has been reviewed by the Laboratory ES\&H Committee. It is being revised to clarify specific issues and it is anticipated that it will be issued during CY 1995 . 


\subsubsection{PCB Consent Order}

During the operation of the Alternate Liquid Fuel Program, the Laboratory received a one-time off-specification military jet fuel which contained PCBs in excess of $50 \mathrm{ppm}$ in October 1984. The Laboratory blended this material with other fuel resulting in 286,000 gallons of material with a PCB concentration above the maximum allowed. On January 21, 1986, the EPA Region II formally approved BNL's plan to incinerate this material at a 108 firing rate (concentration of $8 \mathrm{ppm}$ ) in BNL's high-efficiency Boilers 4 and $5^{28}$. The material remained in storage at BNL while negotiations continued with the NYSDEC. A final NYSDEC Order on Consent was submitted to and signed by DOE on March 12, 1992. It was then returned to NYS and signed by the Commissioner of the NYSDEC on May 15, 1992. This order on Consent authorized and required DOE to ensure that BNL burn the PCB contaminated fuel in high-efficiency Boiler 5 without obtaining permits from NYSDEC provided that the burn be performed in accordance with all conditions of the order. In addition, a report providing information on the operation of the boiler during the PCB burn was required to be submitted to NYSDEC and ERA each month.

The Laboratory commenced burning of the PCB contaminated fuel on July 7 , 1992. Approximately 164,365 gallons of this fuel were burned in Boiler 5 from the initial start up until the end of CY 1992. The burn continued during CY 1993 and was completed on April 4, 1993. Approximately 117,000 gallons of this material was burned between January 1 and April 4, 1993.

Upon completion of the burn, the Laboratory prepared a Performance Report in accordance with the conditions of the order on Consent. This report was submitted to the regulatory agencies in June 1993. It was revised to reflect comments from the NYSDEC and EPA and resubmitted in December 1993. In addition, the Laboratory prepared a plan for the decontamination of CSF Tank No. 5 as required by the conditions of the order on Consent. This plan was submitted to the regulatory agencies in April, 1993. The Laboratory submitted the revised plan, after two rounds of review and revision, to the regulatory agencies in December 1993. Notice of approval of the plan was received from NYSDEC in January 1994 and from the EPA in February 1994.

The Laboratory began implementation of the approved plan in April 1994. The sludge was removed from the bottom of CSF Tank No. 5 prior to initiation of a triple rinse procedure. Concurrently, a sample of the virgin \#2 fuel, purchased specifically to be used as the rinse material, was analyzed for PCBs by both on-site and off-site laboratories, and reported to be below the detection limit of $2 \mathrm{ppm}$. The triple rinse process was initiated on April .11, 1994. The third and final rinse was completed on June 3, 1994. In accordance with the approved plan, all rinse materials were burned in the CSF's high efficiency Boiler No. 5 using the same delivery system as was used during the initial PCB burn process. Burning of the material used for the third rinsing of the CSF Tank No. 5 was completed on November 16, 1994. All required sampling and analyses, as well as the required notifications, were performed during this rinse and burn process. The required reports, describing the performance of the boiler during these burn processes, were also prepared and submitted to the appropriate regulatory agencies.

In December 1994, the Laboratory contracted with a Professional Engineer to conduct an internal tank inspection and prepare a report certifying that CSE Tank No. 5 had been cleaned in accordance with the approved plan. This document will be submitted to the appropriate regulatory agencies during the first quarter of 1995 . 


\subsubsection{EPA Authorized PCB Research}

In 1991, ERA conducted a multi-media inspection of BNL. One of the findings from the TSCA portion of the inspection was that research involving PCBs

was being performed without EPA's authorization. The work in question was benchtop research on biodegradation of PCBs using organisms isolated from a PCB source. The Laboratory prepared the paperwork necessary to request EPA authorization to continue this work. In 1992, EPA issued a two-year approval which was subject to various conditions including marking, storage, record keeping, reporting, and disposal requirements, as well as limits to the quantity of material to be used. In 1993, the Laboratory requested that the existing agreement be modified to extend the research time period and to increase the amount of material held in stock for the research. The EPA granted approval of this request in August 1993. Notification was issued to the EPA on March 24, 1994 that research activities were to restart on April 11, 1994. Research was restarted on that date and is still in progress. On september 16, 1994, a request was made to EPA to acknowledge that the work being performed at BNL was not regulated under TSCA because the organism in use has survived over ten generations and should no longer be considered PCB or derived from PCB materials. $A$ response from EPA is still pending.

\subsection{NYSDEC Bulk Chemical Storage Registration}

Because improper storage and handling of hazardous substances are serious threats to New York's water supplies and to public safety, the New York state Legislature passed Article 40 of the Environmental Conservation Law (ECL), (the Hazardous substances Bulk storage Act of 1986). This law required the NYSDEC to develop and enforce state regulations governing the sale, storage, and handling of hazardous substances, as needed to prevent leaks and spills in New York state. A closely related law, ECL Article 37, requires the NYSDEC to issue a list of substances defined as hazardous.

The NYSDEC has implemented these hazardous substances bulk storage laws through five sets of Chemical Bulk storage (CBS) regulations as follows:

- 6 NYCRR 595 - Releases of Hazardous substances - Reporting, Response, and Corrective Action.

- 6 NYCRR 596 - Registration of Hazardous substance Bulk Storage Tanks.

- 6 NYCRR 597 - List of Hazardous Substances.

- 6 NYCRR 598 - standards for storing and Handling Hazardous substances.

- 6 NYCRR 599 - Standards for Constructing New Hazardous Substance storage Facilities.

Owners of regulated tanks were responsible for registering these storage tanks with the NYSDEC by July 15, 1989. In accordance with Part 596, ${ }^{29}$ BNL submitted application forms for the registration of Hazardous substance Bulk storage Tanks on July 13, 1989. The regulated tanks are used primarily to store water treatment chemicals. The NYSDEC issued a Hazardous substance Bulk Storage Registration (HSBSR) Certificate in August of 1989. In accordance with the NYS regulations, this certificate has been renewed every two years. The Laboratory submitted its most recent renewal request to NYSDEC on July $13,1993.1$ The Certificate was issued by NYSDEC on July 21, 1993 and has an expiration date of July 27, 1995. A total of 18 tanks are included in this certificate. 


\subsection{Resource Conservation and Recovery Act (RCRA)}

2.9.1 Facility Upqrades

Work is continuing on the design and planning of a new Hazardous Waste Management Facility. During 1994, the project entered the Title II design phase; these documents were in turn completed and approved. In addition, the Preliminary Safety Analysis Report (PSAR) has been reviewed and approved by the DOE. BNL's Plant Engineering Division has continued to provide project management services for the new facility. The architecture and engineering firm of Merrick \& Company has received all of the estimates from prospective construction contractors; these are presently being reviewed in preparation for the ground breaking, currently scheduled for Spring of 1995. The new facility will provide BNL with state of the art storage and management capabilities for radioactive, mixed, and hazardous wastes. Incorporated into the design are several decontamination processes for removal of radioactive surface contamination.

\subsubsection{RCRA Part B Permit ( 6 NYCRR Part 373 Permit)}

A major modification of the RCRA Part B Permit for the existing HWMF was submitted to the NYSDEC in July of 1994; it involved a complete reformat and update of the existing permit information. This modification was undertaken in response to BNL's need for increased storage of mixed waste (i.e., radioactive hazardous waste). In order to maintain compliance with 6 NYCRR Part 373, BNL initially applied for and was granted a temporary authorization for this increased storage. The authorization focused on utilizing storage space in BNL Building Nos. 368 and 444 for mixed waste, and in Building Nos. 360, 361, and 448 for increased storage of hazardous wastes. The temporary authorization is only valid for 180 days, with an option to renew only once (additional 180 days). During this time, BNL completed the aforementioned required permit modification for increased storage, and submitted it to the NYSDEC. Since then, BNL has responded to the NYSDEC's Notice of Incomplete Application (NIA), and has resolved all of the NYSDEC's comments. BNL expects the permit modification to be granted sometime in the first quarter of 1995.

In addition to the major modification, work also progressed on the permit application for the new facility. This application was completed and submitted to the NYSDEC on $12 / 1 / 94$ for their review and subsequent approval.

\subsubsection{0-Day Accumulation Areas and Satellite Areas}

In 1993, the Hazardous Waste Management group prepared an ES\&H Standard entitled "Accumulating RCRA Hazardous Waste." The standard is intended to clearly communicate the Federal and NYSDEC regulations governing hazardous waste storage. The standard is currently in draft and is being modified to incorporate amendments to the NYS 6 NYCRR Part 370 series. BNI expects that this standard will be approved and included in the BNI ES\&H manual sometime during the second quarter of 1995.

As part of this continuing effort, the Hazardous Waste Control Form (BNL's waste tracking form) was revised and new hazardous waste labels were issued. These upgrades to the hazardous waste management program at BNL will improve tracking waste containers (hence compliance) by better tying control form numbers to the actual waste containers.

Many SOP's for Hazardous Waste Operations were revised and issued during 1994 in order to further the BNL compliance mission. Some of these procedures included:

- "Conducting Weekly RCRA and Safety Inspections at the HWMF"

-"Review of Hazardous Waste Control Forms"

- "Pickup of Hazardous waste and Transport to the HWMF"

-"Preparation of Hazardous Waste Manifests", etc. 
Generator training for the BNL waste generator community has played a large role in emphasizing the importance of regulatory compliance, as well as the importance of pollution prevention/waste minimization. In 1994, hazardous waste generator training was given on a site-specific basis (generator training was provided at department or division's building for the generator's convenience). The generator training includes modules on Hazardous waste identification, satellite accumulation, and pollution prevention/waste minimization. This training was well-received, and will continue to be offered on an annual basis. In 1995, 90 Day Hazardous Waste Accumulation Area training will be offered at each actual accumulation areas for each respective 90 Day Area manager and his/her designee; this training will be offered annually as well.

\section{9 .4 Facility Audits}

Inspections of hazardous waste accumulation areas were conducted by the NYSDEC in June 1994. The NYSDEC observed that "No smoking" signs were not present at every accumulation area, even though BNL has designated itself as a "Smoke-Free" workplace; in response to this finding, these signs were distributed and posted in July of 1994. The NYSDEC also noted that the waste inventory maintained by the HWM facility was not sufficient; in response to this finding, BNL performed a physical inventory of waste at the HWM facility, and edited the existing inventory accordingly.

The Chicago Operations Office of the DOE also conducted ES\&H inspections of BNL (1/94\&10/94), one aspect of which concerned RCRA compliance. The audit teams found some minor instances of non-compliance, including instances of noncompliant waste labeling at the point of generation (satellite accumulation areas), and storage of containers for periods of time greater than regulatory limits allow. These findings were addressed soon thereafter (conducting more waste generator training and generation of new procedures; and subsequent shipments of wastel.

In response the Consent order/Consent Agreement (CO/CA) between AUI and the EPA (issued in response to EPA's multi-media inspection of BNL in 1991), AUI contracted the services of an independent environmental engineering firm to conduct an independent audit of BNL's RCRA program. A summary report listing deficiencies and a corrective action plan were prepared and submitted to the EPA in accordance with the $\mathrm{CO} / \mathrm{CA}$.

Internal audits and inspections of 90 Day storage Areas have revealed an increased awareness of requirements and an increased level of compliance.

The major modification of the permit, as stated earlier, is in the process of being approved by the NYSDEC (approval expected sometime during the first quarter of 1995). This document will be revised and will comprise the bulk of the Part 373 application for waste management activities at the new facility described above in section 2.9.1.

\section{9 .5 RCRA/TSCA Waste Moratorium}

The Process Knowledge Program has enabled the Hazardous Waste Management group to identify those wastes which meet the criteria of the EM document "Performance objective for the Certification of Non-radioactive Hazardous Wastes" and to ship those wastes. Wastes which are determined to have potential for added radioactivity are held by Hazardous waste Management and are managed as mixed wastes pending the approval of the final stage of $B N{ }^{\prime} s$ response to the Moratorium, the radioanalytical program for hazardous wastes. 
The development of radioanalytical procedures (Phase III) to assay wastes suspected of containing added radioactivity is continuing to proceed. The cooperative forum established by the DOE Chicago Field office, the Research and Development Working Groups (RADWG), have completed their work. BNL intends to utilize the commercial laboratory sector to perform the required analysis. A team has been established to develop a BNI specific proposal for submittal to DOE.

\subsubsection{Pollution Prevention Program.}

BNL has begun implementation of a comprehensive waste minimization and pollution prevention program to reduce the quantity and toxicity of wastes generated on site. The program is described in the BNL Waste Minimization and Pollution Prevention Program Plan.

The program is structured to evaluate waste generation, including radioactive, mixed, hazardous, and solid waste on a Department by Department basis. An interdisciplinary team, made up of waste management and compliance specialists together with departmental process specialists, performs process waste Opportunity Assessments. Ideas generated by the team are documented and an economic and technical feasibility analysis is performed. Ideas that are feasible are identified for future funding and implementation. An indication of the success of this program and the commitment of the BNL community to pollution Prevention was demonstrated in May 1994 at the Department of Energy's Tenth Annual Pollution Prevention Conference. At the conference, four BNL employees were presented with awards for their efforts in minimizing waste generation through recycling, product substitution, and affirmative procurement.

\subsubsection{Waste Disposal}

\section{Mixed Waste (Radioactive Hazardous Waste)}

BNL continues to ship many backlog "legacy wastes". Of note were BNL's first shipments of mixed waste to the Westinghouse-Hanford Company in June 1994. These shipments reduced BNL's inventory by approximately 55 percent. To address future mixed waste generation, storage, and eventual treatment, BNL developed a Draft site Treatment Plan (DSTP) as required by the Federal Facility Compliance Act (FFCA). BNL's Final site Treatment Plan (FSTP) will be submitted to the appropriate regulatory agencies for approval in 1995.

\section{Hazardous Faste}

During 1994, in addition to the 63 tons of hazardous waste disposed of at several hazardous waste treatment, storage and disposal facilities (TSDF's) around the country, BNL successfully characterized and disposed of over 350 compressed gas cylinders. Many of these cylinders had unknown contents, and most of them had hazardous contents. To facilitate cylinder disposal, BNL contracted the services of an off-site vendor (specialized in unknown gas characterization and repackaging) to characterize and repackaging the contents of cylinders which were in poor condition (i.e., not transportable as per DOT standards and/or had an inoperable valve).

\section{Radioactive Waste}

During 1994, BNL shipped approximately 12,500 cubic feet of low level radioactive waste to the Westinghouse-Hanford Company in Washington state. 


\subsubsection{Federal Facility Compliance Act (FFCA) Mixed Waste Site Treatment Plan}

BNL continued its work with DOE's Area Office and Chicago Operations Office and the NYSDEC towards developing a Mixed waste site Treatment Plan. BNI has progressed from a Conceptual site Treatment Plan (CSTP) to a DSTP with input from these agencies, and will continue to work with them to develop a ESTP in 1995 .

Potential technologies, facilities, and milestones have been identified in the DSTP to treat the mixed waste streams currently being stored and generated at BNL. These options will be implemented upon approval of the final plan by DOE and NYSDEC and the subsequent signing of a consent order between DOE/BNL and NYSDEC.

\section{Mixed Waste Inventory Report}

In 1994, BNL responded to a request for information regarding the types of mixed waste it stores and generates. This Mixed Waste Inventory Report (MWIR) compiles data from sites around the DOE complex regarding quantity and the physical, chemical, and radiological properties of their mixed wastes. This information gives DOE some insight as to the problems it may encounter with regard to available treatment capacities and may substantiate the need to construct additional treatment facilities.

2.10 Comprehensive Environmental Response, Compensation and Liability Act (CERCIA)

On November 21, 1989, BNL was included on the National Priorities list of the EPA. This is a list of hazardous waste sites that are considered high priority for cleanup under the federal superfund Program officially known as the CERCLA.

In 1991, BNL established the OER to oversee the Laboratory's Superfund activities. It is the responsibility of this office to remediate areas of known contamination, as well as identify, mitigate, and eliminate other areas of potential contamination.

In MaY 1992, an IAG between the DOE, the USEPA and the NYSDEC, became effective to insure compliance with CERCLA, the corrective action requirements of the RCRA, the National Environmental Policy Act (NEPA), as well as corresponding NYS regulations. In particular, the IAG is intended to insure that environmental impacts associated with past and present activities at BNI are thoroughly and adequately investigated so that appropriate response actions can be formulated, assessed, and implemented.

There are currently twenty-eight "Areas of Concern" (AOCs) at the BNL site to be addressed through the IAG. The AOCs consist of both active facilities, such as the STP, the HWMF, potable wells; and inactive facilities, such as the former landfills, cesspools, and radioactive waste storage tanks. The AOCs have been grouped and prioritized into Operable Units (OUs) and Removal Actions (RAs) . This prioritized grouping is documented in the BNL Response strategy Document (RSD). The RSD is undergoing revision to consolidate the seven ous into five ous for more efficient management of the investigative and cleanup work for the site.

In accordance with the IAG milestone schedules, during 1994, the following field activities have been conducted and reports have been prepared and submitted to the EPA and the NYSDEC for their review:

\section{April 1994}

Removal Action V: Groundwater screening for onsite locations completed. 
Operable Unit IV: Draft Remedial Investigation/Risk Assessment submitted to EPA/NYSDEC.

Removal Action V: Groundwater sampling for off-site locations initiated.

June 1994

Operable Unit II/VII: RI/FS Scope of Work was finalized. operable Unit III: RI/FS Work Plan submitted to EPA/NYSDEC. operable Unit IV: Engineering Evaluation Report and draft Action Memorandum for Interim Soil Removal Action submitted to EPA/NYSDEC; Interim Removal Action soils disposed of at Brookhaven Town Landfill.

\section{July 1994}

Operable Unit I: Draft EE/CA and Remedial Design Work Plan for Current Landfill submitted to DOE/EPA/NYSDEC; asphalt, surface soil and geoprobe soil boring sampling in the Hazardous Waste Management Facility completed; addendum to oU I Work Plan (including oU VI Field Investigation) submitted to EPA/NYSDEC.

- Operable Unit IV: Engineering Evaluation Report and Final Action Memorandum on the Interim Soil Removal Action was submitted to the Administrative Record.

- Removal Action II: Final Work Plan/Health and Safety Plan for Bldg. 650 UST Removal submitted to EPA/NYSDEC.

Sitewide Hydrogeological Characterization: Final Groundwater Modeling Work Plan forwarded to Groundwater. Advisory Committee.

Historical Site Review: Draft HSR Follow-up Study submitted to EPA/NYSDEC.

\section{Auqust 1994}

Removal Action I: "D" Tanks field work initiated. Sitewide Biological survey: Summer - fish, benthic, bird, amphibian, reptile, and small mammal surveys conducted.

Removal Action II: UST removal at Bldg. 650 completed.

\section{September 1.994}

- Operable Unit III: Revised Work Plans submitted to EPA/NYSDEC.

- Operable Unit IV: Draft Final Remedial Investigation/Risk Assessment Report submitted. to EPA/NYSDEC.

- Sitewide Hydrogeological Characterization: Fieldwork initiated for Phase II drilling.

- Sitewide Biological Survey: Delineation of wetlands initiated.

- Operable Unit I: UST removal at Bldg. 445 completed.

\section{October 1994}

- Operable Unit IV: Draft Final Remedial Investigation/Risk Assessment Reports approved by EPA/NYSDEC.

- .. Sitewide Biological Survey: Fall fish surveys completed.

November 1994

- Operable Unit I: Action. Memorandum for Landfill Closure Removal Action submitted to EPA/NYSDEC; Current Landfill Design Report finalized; installation of groundwater monitoring wells completed.

- Operable Unit III: RI/FS Work Plan finalized. 
Operable Unit V: RI/FS Work Plan Public Meeting held.

Removal Action V: Second round of groundwater sampling completed.

Sitewide Biological Survey: Delineation of wetlands completed.

December 1994

- Operable Unit I/VI: Round one of groundwater sampling completed; soil boring program for OU VI completed.

- Operable Unit II/VII: RI/FS Work Plan submitted to EPA/NYSDEC.

- Operable Unit III: Removal of mixed waste sludge from Bldg. 830 UST completed; Final RI/FS Work Plans submitted to Administrative Record.

- Operable Unit IV: FS/PRAP submitted to EPA/NYSDEC; final RI/RA Report submitted to Administrative Record.

- Removal Action I: "D" Tanks demolition work completed.

- Sitewide Hydrological Characterization: Phase II well installations completed.

- Sitewide Biological survey: Fall trapping completed.

\subsection{Superfund Amendments and Reauthorization Act (SARA) of 1986}

The SARA regulations require that BNL compile and submit Tier I (or the more detailed Tier II) reports to the state Emergency Response Commission (SERC), the Local Emergency Planning Committee (IEPC), and the responding fire organization. For BNL, the responding fire organization is the S\&EP Fire and Rescue Group. Under Federal SARA regulations, BNI, is required to submit the Tier II report only if requested by the SERC, LEPC, or Fire Rescue Group. In 1991, the SERC requested that BNL submit the Tier II report for 1990 and each year thereafter. The report lists the average and maximum daily amounts of each chemical on site which exceeds the threshold listed in the current EPA List of Lists. The Tier II report for CY 1994 was submitted in February 1995 to the Fire Response Group and to DOE-BHO office for transmittal to the SERC and LEPC.

\subsection{National Environmental Policy Act (NEPA)}

On October 5, 1994, the DOE Energy Research NEPA Compliance Officer (ERNCO) in conjunction with the DOE-Chicago (CH) NEPA Compliance officer conducted a training course at BNL on Environmental Assessment Preparation. This training was attended by BNL's NEPA Coordinator and several Environment, safety, and Health Coordinators from other divisions at the Laboratory. The BNL NEPA Coordinator also attended the semi-annual Energy Research Environment, Safety, and Health Conference at Gaithersburg, Maryland, October 31 - November $2,1994$. Issues discussed at this meeting were the development of new categorical exclusions, environmental justice review under NEPA, and wetland issues discussions in NEPA documents. At this meeting it was announced that BNL received one of the first ER-NCO NEPA Quality Awards. This award was presented for the preparation of quality NEPA documents.

During CY 1994, environmental evaluations were completed for 202 proposed projects in accordance with DOE order 5440.1E. Of these, 104 were considered minor actions requiring no additional documentation and 98 projects were addressed through submission of Environmental Evaluation Notification Forms to DOE. Environmental assessments were revised for a proposed new Radiation Calibration Facility, an underground vault addition to Chemistry to conduct radiation chemistry activities, the construction of a new HWMF, and programmed improvements to the AGS. Findings of No significant Impact were issued on the AGS EA in June 1994, the Radiation Chemistry EA in July 1994, and the new HWMF EA in October 1994 . 


\subsection{Federal Insecticide, Fungicide, and Rodenticide Act (FIFRA)}

Brookhaven National Laboratory has two programs where insecticides, herbicides, and pesticides are used. As per regulatory requirements, both users, the Biology Department and PE Division maintain a log of applications made and a $\log$ of the inventory at each facility. Key personnel are trained and certified by the NYSDEC for handling and application of these chemicals. Annual updating of training is required. The applicator's log books are available for inspection and verification by the regulatory agencies when required. Annual reports indicating the types and quantities of pesticides used are submitted to the NYSDEC by each certified applicator.

\subsection{Endangered Species Act}

Brookhaven National Laboratory received notification from the U. S. Fish and Wildlife Service and the NYSDEC on December 13, 1993 and December 7, 1993, respectively, that no Federal or NYS endangered or threatened species occur within the Laboratory's impact area. An ecological inventory of habitats and species found at BNL was conducted during CY 1994. Although a final report is not yet available, preliminary data indicates use of BNL vernal ponds and some recharge basins by the New York state Endangered eastern tiger salamander (Ambystoma tigrinum). Several other NYS species of special concern were also noted at BNL. This information will be considered during future planning operations that may involve habitat alterations.

\subsection{National Historic Preservation Act}

The Deputy Commissioner for Historic Preservation of the New York State office of Parks, Recreation, and Historic Preservation issued a determination April 2, 1991 that only activities which would impact the old Reactor Building (Building 701), the old Cyclotron Enclosure (Building 902), and on-site World War I era trenches require additional consultation. All other activities would have no effect upon cultural resources or eligible for inclusion in the National Register of Historic Places. The Department of the Interior Questionnaire on Eiscal Year 1993 Federal Archaeological Activities was submitted to DOE-BHO on March 24, 1994. No activities affecting cultural or historic resources were conducted during CY 1994.

\subsection{Floodplain Management}

During CY 1994 several construction actions were initiated near or within the 100-year floodplain. These actions included upgrades to the STP, rehabilitation of the berms on the tunnels holding the relativistic heavy ion collider (RHIC), and installation of new Parshall flumes in the Peconic River and its tributaries to monitor on-site flow. A request to upgrade the BNL STP was submitted on November 5, 1993 with authorization received from the NYSDEC on April 28, 1994. Although no work is located within the 100-year floodplain the upgrades will improve the quality of STP discharges to the Peconic River. Construction of the upgrades was still in progress at the close of 1994. Application to rehabilitate the berms of RHIC was made to NYSDEC on February 17, 1993. Authorization to conduct the work was issued May 18, 1994. This work, which included some work within the 100-year floodplain of the Peconic River which flows under the RHIC, was completed in the fall of 1994. Installation of environmental monitoring sheds and associated flumes was also completed in CY 1994. Authorization to construct the new sheds was received from the NYSDEC on January 20, 1993. A determination was made that replacement of the existing $V$ notch weirs and installation of flumes at new locations on the Peconic and its 
tributaries at BNL was part of environmental remediation efforts and did not require formal authorization from the NYSDEC. However, given the potential for impacts on the banded sunfish, a New York state species of Special Concern, a consultation was held with NYSDEC fisheries personnel. Recommendations to minimize impacts to the banded sunfish from construction were received July 22 , 1994 and incorporated into contract specifications. The work completed within the 100-year floodplain had no alternative viable location given the nature of the actions completed. All work was evaluated prior to construction and found to meet the needed criteria set forth in Executive order 11988 (Eloodplain Management) and all aspects of Executive order 11990 (Protection of Wetlands).

\subsubsection{New York Wild, Scenic, and Recreational River systems Act}

That portion of the Peconic River that flows through BNL is classified as "Scenic" under New York's Wild, Scenic, and Recreational River Systems Act (WSRRSA). During 1994, several actions were undertaken by BNL within this designated area. These actions included rehabilitation of berms on the RHIC tunnels, upgrades to the BNL STP, installation of new environmental monitoring stations, removal of existing V-notch weirs, and installation of Parshall flumes. Each action was coordinated with the NYSDEC. Authorizations were issued for all work except the weir and flume actions which were considered to be authorized under the CERCLA of 1980. The STP upgrades were authorized by the NYSDEC through issuance of a freshwater wetlands permit dated April 28, 1994". The RHIC berm rehabilitation work was also authorized by a freshwater wetlands permit dated May 18, 1994. Environmental monitoring station authorization was previously received on January 20, 1993. The weir and flume work was coordinated with NYSDEC wetlands and fisheries personnel. Written comments were received on July 22 , 1994 and all recommendations of the NYSDEC were incorporated into contract specifications.

\subsection{Protection of Wetlands}

other than the permitting actions described in Sections 2.16 and 2.16 .1 above, no activities conducted during CY 1994 impacted wetlands or their buffer zones. As part of the settlement of a Notice of Violation received by BNL $f r o m$ EPA for RCRA and TSCA violations, the Laboratory has proposed to conduct surveys of wetland habitats and develop protection, preservation, and possibly enhancement activities. A biological inventory of wetlands at BNL commenced in November 1993 as part of an effort to establish up-to-date knowledge on site resources to conduct impact analyses of BNL environmental remediation efforts. Detailed wetland boundary delineation commenced in october 1994. A final report on this effort is expected to be released in the second quarter of 1995 .

\subsection{Environmental Compliance Audits}

\subsection{8 .1 Tiger Team Issues}

In March and April of 1990, the DOE conducted a comprehensive ES\&H and waste operations assessment of BNL. This effort, known as the Tiger Team Assessment (TTA), was conducted in response to secretary of Energy Admiral James D. Watkins, Ret., 10-point initiative to strengthen ES\&H programs and waste management operations in the DOE community. The purpose of the TTA was to develop concise information regarding the site's status on ES\&H compliance issues, root causes for noncompliance, and the adequacy of response actions needed to address identified problems. In addition, the assessment included an evaluation of the adequacy and effectiveness of the DOE and site contractor's (AUI), management, organization, and administration of the Es\&H programs ${ }^{(30)}$. A complete documentation of the findings of this assessment has been published. The BNL Action Plan for the Tiger Team Assessment was completed and published in October $1990 .{ }^{31}$ 
In the area of compliance with environmental and waste management concerns, there were 37 findings dealing with the lack of conformance to applicable Federal and state laws and regulations, County codes, DOE orders, and 27 findings in which best management practices were not in place. By the end of 1993, 34 of the 37 environmental compliance issues were addressed. One of the unresolved compliance issue is scheduled for closure in 1995. The remaining two require substantial resources and are being addressed on a schedule determined by a risk based prioritization system. A brief description of the status on each unresolved compliance issue is listed below:

Einding

$\mathrm{SW} / \mathrm{CE}-1$

TS/CF-3

TS/CF-4

RAD/CE-1

Addressing best management practice concerns has received a lower priority due to funding and resource constraints. Several best management practice improvements are associated with upgrades to the compliance strategy. Continued improvement in this area is dependent on available resources and subject to reprioritization based on on-going audits and appraisals by DOE and EPA.

\subsection{8 .2 EPA NESHAPS Audit 1994}

On July 20, 1994, EPA inspectors conducted a 40 CFR 61, subpart H (NESHAPs) compliance inspection. The inspection team interviewed BNL and DOE staff and conducted a tour of selected facilities. Major issues covered during this inspection were a review of BNL NESHAPS QA/QC documentation, BNL's method of computing off-site dose due to diffuse emissions from the STP hold-up ponds, and the effort by New York state to assume responsibility from EPA Region II for enforcing radioactive NESHAPs regulations. The Laboratory's plan for conducting periodic confirmatory measurements of radioactive-use lab hoods was also discussed. BNL requested that it be allowed to amend the original proposal for this plan in light of recently approved plans at other DOE facilities. EPA representatives agreed to this request. No deficiencies were noted during the audit. 


\subsection{8 .3 DOE Chicago ES\&H Appraisals}

In January 1994, the DOE Chicago Operations Office performed an appraisal of the BNL environmental program for compliance with the requirements of EPA, NYSDEC, SCDHS, and DOE Orders. The scope of the appraisal included a thorough evaluation of programs related to hazardous waste, mixed waste, and radioactive waste management; PCB management; pesticide management; SDWA; and CWA. Three findings and seven recommendations were made as a result of this appraisal. In addition, one noteworthy practice was identified concerning the Tier II internal assessment program being implemented by the S\&EP Division to evaluate the state of environmental protection at various departments throughout the Laboratory. The overall rating of the BNL Environmental Program was determined to be "good" as defined in DOE Order 5000.2B, Multi program Laboratory Appraisals."

In October 1994, the DOE Chicago Operations office performed an appraisal of the BNL environmental program for compliance with the requirements of EPA, NYSDEC, SCDHS, and DOE. The functional areas that were appraised included the hazardous waste and radioactive mixed waste management programs, radioactive waste management program, underground storage tank program, NEPA requirements, and environmental restoration program. Four findings and nine recommendations were made as a result of this appraisal. In addition, two noteworthy practices were observed which included the NEPA procedural documentation program and the training on the Laboratory-wide waste minimization program. The overall rating of the BNL Environmental Program was determined to be "good" as defined in DOE order 5000.2B, Multiprogram Laboratory. Appraisals."

\subsection{Quality Assurance (QA) Program}

The objectives of the EM Section $Q A$ Program are to ensure that management provides planning, organization, direction, control, and support to achieve environmental program objectives; that the line managers achieve quality in their product or services; and that the sections overall performance is reviewed and evaluated using a rigorous assessment process. This program has been developed to ensure full compliance with $Q A$ requirements established by DOE in orders 5700.6C, ${ }^{13}$ Quality Assurance, and 5400.1, General Environmental Protection Program. ${ }^{32}$

The QA Program developed by BNL to achieve Laboratory objectives provides policies, responsibilities, and guidance procedures for the Divisions and Departments based on DOE Order 5700.6C. The S\&EP Division has adopted or adapted these program elements into the S\&EP Division Management system Manual ${ }^{14}$ and established responsibilities, methods, and controls for conducting its operations. The EM section has integrated these elements with the additional environmental $Q A$ requirements of DOE Order 5400.1 into the sampling, analysis, and data handling activities. The implementing procedures of the EM Section Standard operating Procedure Manuals on Environmental Monitoring, Radiation Measurements, Analytical Chemistry, and Regulatory Programs, in conjunction with the S\&EP Division Management System Manual and the S\&EP QA Procedures, ${ }^{15}$ comprise the EM QA Program for the environmental surveillance and effluent monitoring programs.

Responsibility for quality at BNL starts with the Laboratory Director and permeates down through the entire organization, with individuals at each level assuming their appropriate share. The BNL Quality Management (QM) office is headed by the BNL QM Manager who coordinates and evaluates the quality activities for the entire laboratory, and provides professional assistance and guidance to the departments and divisions. The S\&EP Division has appointed a QA Coordinator and Quality Management Team (QMT) to assist, assess, advise, and improve the 
implementation of the Division-wide $Q A$ program. The Division has chartered an Improvement committee, with membership from all S\&EP sections and various position levels, and is responsible for encouraging, reviewing, and evaluating employee suggestions for improvements and making recommendations to the Division Head. The EM section, because of its emphasis on quality issues, receives support from the Division QMT which has three full time QA Officers, two who have environmental expertise, with technical AsQC certification. This team is responsible for reviewing, advising, assessing, and improving EM activities.

one of the major activities for the EM Section and the S\&EP Division QMT is ensuring that sampling and analysis of environmental media are conducted in such a way as to provide representative and defensible data. The QA program fulfills this by incorporating $Q A$ elements such as field sampling plan designs, documented procedures, chain of custody, calibration/standardization program, acceptance criteria, statistical data analysis, software $Q A$, and data handling systems into the environmental surveillance and effluent monitoring programs.

Iastly, the S\&EP Division QMT is responsible for establishing a program of internal assessments and external audits to verify the effectiveness of EM sampling, analysis, and data base activities and their adherence to the $Q A$ program. Self assessments of the EM activities are performed annually by the EM group leaders to identify areas needing attention. The S\&EP Division QMT performs internal audits, as in 1994 with audits of the EM Program Management and Program Design.

Furthermore, the analytical laboratories participate in inter-laboratory performance evaluation programs organized by DOE, EPA, and NYSDOH. Contract laboratories used to augment the capabilities of the in-house laboratory are required to maintain a comprehensive $Q A$ program and are subject to audits by S\&EP Division personnel to ensure its implementation. In addition to the internal reviews, the BNL $\mathrm{QM}$ office, $\mathrm{DOE}-\mathrm{CH}$, other regulatory agencies, and other independent groups periodically audit the EM section. 


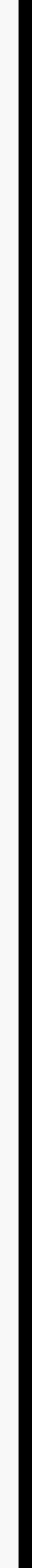




\subsection{ENVIRONDENTAL PROGRAM INEORMATION}

\section{J. R. Naidu}

Brookhaven National Laboratory is comitted to environmental compliance and accountability. The Laboratory conducts an extensive program to monitor the environment in and around the BNL site. This program, required by DOE Orders 5400.1 and 5484.1, has five major objectives:

1. To demonstrate the effectiveness of pollution control programs;

2. To demonstrate compliance with applicable environmental laws and regulations;

3. To confirm adherence to the DOE and BNL Environmental Protection policies;

4. To estimate the impact of operations on the environment; and

5. To support environmental management decisions.

\subsection{Program Organization}

The Laboratory has two organizations involved in carrying out the tasks outlined above. These are:

a. The Office of Environmental Restoration was established in response to BNL being listed on the National Priority List (NPI) on November 21, 1989 and reports directly to the Director's Office. The OER has prime responsibility for environmental restoration of areas contaminated during past spills, and the storage and disposal of hazardous and radioactive wastes.

b. The S\&EP Division EMS, which was restructured from the former Environmental Protection Section and the Hazardous Waste Management section in 1994, is organized into three groups and one team: Engineering and Operations Group, Environmental Compliance Group, Sampling and Analysis Group, and the Training and Procedures Team. The Engineering and operations Group also provides day to day $Q A$ support by a $Q A$ Officer who reports directly to the section Head.

The EMS is to support the Departments/Divisions in the implementation, of and compliance with, environmental and waste management program standards, properly manage the Laboratory's hazardous wastes, perform environmental surveillance, and provide analytical services. The section fulfills its mission by:

- Developing environmental, and waste management ES\&H SEAPPMs.

- Assisting the Departments/Divisions in complying with laws and regulations and the permit processes.

- Preparation of permit applications and renewals.

- Operating an efficient waste management facility.

- Conducting the BNI Environmental Monitoring program and operating, the Analytical Services Laboratory for radiological and non-radiological analyses.

- Providing QA, training, and Conduct of Operations (CO) support to waste operations.

- Reviewing safety Analysis Reports (SARs), performing Engineering -Design Reviews (EDR), and participating in operational Readiness Reviews (ORR), and Tier II Appraisals.

- Interacting with federal, state, and the local regulatory community, and commenting on proposed regulations. 
The assigned Quality Assurance staff oversees the functions of the section in terms of the directives on Quality Assurance, such as pertaining to environmental sampling, analytical processes and documentation, which includes review of data. Summary description of the activities conducted by the above groups are given below.

\subsubsection{Environmental Compliance Group (ECG)}

The ECG provides S\&EP Division and the Laboratory with assistance and guidance in all regulatory compliance areas, and submits appropriate compliance reports to the regulatory agencies. This Group also provides technical overview and assistance in conducting groundwater monitoring and review of data for determining impact and revisions of the Environmental Monitoring Program. The Group also reviews projects for environmental impacts and provides audit support to the Laboratory's ES\&H and environmental restoration programs. These safety and environmental reviews are performed on new construction projects as well as modifications to existing facilities. These reviews are performed from conceptual design through completion of construction and prior to final occupancy to assure that basic safety and environmental protection requirements are provided. As part of the review process, ECG staff members review these proposals and plans to assure that potential hazards are identified and potential environmental impacts are evaluated. In addition, these reviews are conducted to ensure that all necessary permits are obtained and that new construction or modifications comply with federal, state, and local regulations. Approximately 90 of these types of reviews were performed during CY 1994. Several members of the ECG are emergency responders and are on 24 hour call in the event of an oil/chemical spill at BNL.

\section{1 .2 Sampling and Analysis Group (SAG)}

The Sampling and Analysis Group is responsible for implementing the Environmental Monitoring Plan (EMP). The Group has developed the EMP and provides regular updates. The sampling effort performed by the Field Sampling Team is supplemented by the Radiological and Nonradiological Laboratories. Besides implementing the EMP, the Group also responds to emergency spills when required, preoperational investigations, and to special sampling and/or analytical requests as required. Reports based on data review and assessment are also prepared and submitted to requesting Departments and Divisions. The combination of the above three sub-groups provides the basis for writing the Annual SER, and the DMRs as required by the various environmental Permits issued by the Regulatory Agencies which oversees the Laboratory's operations.

\subsubsection{Engineering and Operations Group}

Hazardous Waste Management activities are carried out at BNL under the direction of the Engineering and Operations Group, EMS. Radioactive, hazardous, and mixed wastes generated at BNL are transported to the HWMF for processing, storage, packaging, and preparation prior to off- site disposal. The HWME has areas dedicated to the safe storage of each type of waste. In addition, all waste tracking and documentation is maintained at the HWMF.

The Hazardous Waste facilities at the HWMF received the final Part B Permit on september 27, 1993; in addition to the operational aspects of maintaining facilities sufficient to store wastes, the EMS supports the BNL hazardous waste management program in the following areas;
a. Regulatory Compliance Program
b. Waste Minimization and Pollution Program
c. Quality Assurance Program
d. Training and Procedures Program 
Summary information on monitoring activities can be found in the Executive summary. Complete details regarding individual monitoring activities, as mandated by DOE orders and implemented by BNL, can be found in specific Sections 4.0 to 5.0. The activities that are required by environmental statutes are described in section 2 (Compliance summary).

\subsection{Environmental Programmatic Changes in 1994}

In 1994, the Laboratory initiated several new programs in support of the site Environmental Monitoring Program. These were:

A) The Laboratory has been upgrading the permanently installed air and exposure rate monitoring systems, surface water sampling, and liquid effluent sampling systems. New air monitoring stations have been operational since the second quarter of FY 1994. These stations replace the existing 30 year old structures, and provide the required power and security to install real time site perimeter gamma and neutron dose monitoring systems, and upgraded the particulate and charcoal filter sampling systems which allow higher sampling rates. Additionally, new surface water flow rate and proportional sampling systems are scheduled for installation along the Reconic River by the first quarter of FY 1995. Similarly, flow monitoring and proportional sampling devices are scheduled for installation at each of the liquid effluent recharge basins within the same time frame. In addition, in anticipation of the new SPDES permit requirements to be imposed in EY 1995, a review of the sampling and analytical requirements are in progress.

B) Brookhaven National Laboratory, in conjunction with state University of New York (SUNY) Stony Brook, has expanded its Peconic River surveillance program to include metals, organics, and PCBs in fish, sediments, and vegetation. Also, the fish sampling program was expanded to two times per year to address the impact of the intermittent Peconic River on the extent of fish contamination.

c) As part of the hydrogeological site characterization and facility monitoring program, additional groundwater monitoring wells have been installed, sampled, and analyzed. This program will continue in conjunction with the CERCIA program. Also instituted is a program that coordinates S\&EP Division and OER groundwater sampling schedule, which has prevented duplication of effort and also provides a mechanism for independent verification of sampling and analysis.

D) A General Plant Project to bring storage tanks into compliance with the suffolk County Sanitary Code will continue in FY 1995 .

E) Remediation of a construction site where mercury and PCB contaminated soil was found during the excavation for the building foundation was completed during the first quarter of CY 1994 .

E) As required pursuant to Title VI, section 608 of the CAA, the Laboratory has purchased equipment to recover and recycle refrigerants ordinarily released to the atmosphere during the servicing and repair of refrigeration and air conditioning equipment. Eollowing training of BNL staff from the equipment 
manufacturers, this equipment have been placed in operation. In addition, the Plant Engineering Division has compiled an inventory of the refrigeration and air conditioning systems in operation, so that a priority ranking for the replacement or conversion of equipment to systems that utilize low or non-ozone depleting refrigerants can be made. The latter includes a search and evaluation of various alternate refrigeration and air conditioning systems that are available, and to develop an equipment replacement and conversion plan.

G) A working group was formed to prepare a guidance document covering the registration and permitting of laboratory fume hoods. This group was given the task of drafting a policy that would simplify the procedures for registration and permitting laboratory hoods for more than the 250 chemicals that the NYSDEC has identified as known or suspect carcinogens. The draft policy has been submitted to NYSDEC for review. Such a protocol will assure that the Laboratory will file for the required permits in a proactive and timely manner and thus present any violations of permit requirements.

H) Similarly, a working group was formed to identify acceptable alternate replacements for methyl chloroform and trichlorotrifluoroethane, two chlorofluorocarbon (CFC) cleaning agents that are being phased out pursuant to the provisions of Title VI of the CAAA of 1990.

I) In the first quarter of 1994, all identified radioactive effluent sources were evaluated and were found to contribute less than 0.1 mrem/yr to the site boundary dose. As a result, no formal NESHAPs applications were required to be submitted to EPA Region II.

J) Work is continuing on the new HWMF project. In 1994, the conceptual design (Title I and Title II) was completed and project funding was secured. The Preliminary safety Analysis Report (PSAR) was drafted and approved by BNL's safety Committee; this PSAR was subsequently approved by $\mathrm{DOE}-\mathrm{CH}$ as well. The NYCRR Pt. 373 permit application (RCRA Pt. B permit-equivalent) for the new facility was submitted to the NYSDEC on December 1, 1994.

During FY 1995, a Long Island contractor was awarded the contract for the construction of the new facility, and the actual groundbreaking began at the end of the third quarter of FY 1995.

K) The S\&EP Division has developed a Management system Manual, that describes S\&EP Division's program requirements to fulfill its mission, functions, and responsibilities at BNL for ES\&H issues. This program conforms to BNL and DOE regulations, including the BNL Quality Policy, and is organized in accordance with DOE 5700.6C "Quality Assurance" (see section 7). This manual, therefore, serves as a bridge between the policy of BNL and the detailed procedures of individual sections within the S\&EP Division. This manual describes in detail the Division's mission statement and primary functions, the organizational structure and the responsibilities of the S\&EP Sections, the $Q A$ and ES\&H responsibilities of each employee, the program requirements which incorporate an overview of $Q A$, Conduct of Operations, Maintenance Managements Elements as applicable to S\&EP Division activities, and finally provides the implementing procedures of the Manual and guidance on the way in which ES\&H activities should be performed. 
I) The Laboratory is in the process of developing "Guidelines for Analysis and Response to Appraisal Findings/Concerns": Principally, it is a document that will be designed to address, in a systematic manner, findings/concerns that arise from audits. It identifies an Issue Manager who will be responsible for analyzing, recommending to BNL management whether actions should be taken in response to the finding, and proposing the assignment of an Action Manager if a corrective action plan is needed. It also identifies procedures for analyzing an issue, specifically its impact on BNL ES\&H priorities and goals, BNL mission and goals, quality improvement, resource allocation, cost effectiveness, and a risk analysis. Finally, it provides a procedure for uniform documentation and reporting.

M) In order to ensure a supply of fresh potable water to the Laboratory community, the Laboratory will be expanding the current practice of pretreating groundwater prior to site-wide distribution. Currently, two potable water wells are equipped with activated carbon adsorption towers for mitigating the concentration of volatile organics found in groundwater. Monitoring of the remaining four potable water supply wells has shown these sources to meet all NYS DWS. However, as a best management practice, draft plans and specifications have been developed for pretreating the well water obtained from the remaining four potable supply wells. These plans include the construction of a carbon adsorption system at Potable Well 12 and the installation of dual air stripping towers at the water Treatment Plant. Construction of these improvements is scheduled to begin during the first quarter of 1995.

N) An environmental assessment is to be prepared which will analyze potential alternatives to the handling and on-site storage of spent reactor fuel generated by BNL's HFBR and MRR. Alternatives now under consideration include dry storage of spent nuclear fuel within a cask to be stored in a new building, reracking of the existing storage pool, and the no-action alternative. This document will tier off information presented in the final DOE Programmatic Environmental Impact statement, scheduled to be completed for the transportation and reprocessing of spent nuclear fuel.

\subsection{Environmental Restoration}

As indicated in sections 2.10 and 3.1.a, the OER has full responsibility for conducting environmental restoration activities as required under the IAG. A summary of the OER's activities are provided in section 2.10, Compliance Summary.

\subsection{Waste Minimization and Pollution Prevention Programs}

The BNL Waste Minimization and Pollution Prevention (Wmin/P2) Program Plan establishes the Wmin/P2 program at BNL. The plan has been prepared to combine the requirements for a Wmin Plan and a Pollution Prevention Awareness Plan. The plan lays out a strategy for implementation of a formal waste minimization and pollution prevention program at BNL and contains information on Wmin accomplishments.

The program plan calls for the establishment of "Waste Minimization Working Groups" within each Department/Division at BNL. The working groups combine the expertise of facility personnel and environmental professionals to evaluate waste generating processes within each department. The end result of each working 
group will be a Department Specific Waste Minimization Plan that can be used for planning, budgeting, and implementation. The two Wmin Working Groups established in the Central Shops Division and the AGS Department in 1993 have begun process waste assessments, are documenting their activities, and recommending implementation of technically and economically feasible waste reduction options.

\subsection{Environmental Audits}

\subsubsection{Tier III Assessment}

As indicated in the SER 1993, a Tier III audit was conducted between september 15th and 23rd, 1993. Three problem areas were noted: both the laboratories - radiological and nonradiological lacked space and had information management deficiencies while the Radiological Laboratory needed to formalize additional procedures. Ten improvements were also suggested by the auditors as well as noting 20 of 90 checklist items which were not addressed. Management has been attempting to resolve the space and information management issues through various channels. The response to these findings have been formalized and are being tracked by the Director's office.

\section{5 .2 other Audits}

A number of audits based on ES\&H were conducted in 1994. These are listed below:

a. Chemical waste Handling at the HWME (RCRA)

b. Low-level Radioactive Waste Management Facility

c. NYS Department of Health Environmental Laboratory Approval Program

d. DOE-CH ESH Appraisal

e. DOE-CH QA Appraisal

f. Tier I and Tier II

g. Triennial ESH Program Review Assessment

Findings resulting from the above audits/appraisals are tracked and reported on by the S\&EP Division's Office of Rlanning and Program Review Group. 


\subsection{ENVIRONMENTAI PROGRAM DESCRIPTION}

J. R. Naidu, R. J. Iee, G. I. Schroeder, B. A. Royce, and J. Williams

It is DOE policy to conduct its operations in an environmentally responsible manner and comply with applicable environmental standards. At BNI, a wide variety of environmental activities are performed to comply with federal, state, and local laws and regulations, enhance environmental quality, and monitor the impact of effluent emission from site facility operations.

Section 2.0 summarized the status of BNL's compliance with applicable regulations, activities under way to achieve compliance, and programs to manage and improve environmental quality.

This section summarizes significant activities conducted in 1994 under Environmental Monitoring, which consists of:

1. Effluent monitoring, and

2. Environmental Surveillance.

Effluent monitoring is performed as appropriate by the facility operators and/or the S\&EP Division SAG environmental sampling team at the point of release to the environment. Environmental surveillance consists of sampling and analyzing environmental media on and off the BNL site to detect and quantify potential contaminants, and to assess their environmental and human health significance.

The sampling program includes collection of airborne effluents, ambient air, sewage and facility liquid effluent, groundwater, surface water, soil, vegetation, fish, fauna, and sediment. The type of samples collected at a specific location depends on the site and the potential pollutants to be monitored. Added to this are the requirements mandated by specific permits.

A detailed description of the rationale and design criteria for the environmental surveillance and the effluent monitoring program is given in the BNL Environmental Monitoring Plan. ${ }^{33}$ This plan also discusses the extent and frequency of monitoring and measurements, procedures for laboratory analyses, $Q A$ requirements, and program implementation procedures.

Complete details regarding individual monitoring activities can be found in specific subsections grouped by environmental media.

\subsection{Effluent Emissions and Environmental Surveillance} whether:

The primary purpose of the BNL effluent monitoring program is to determine

1. Facility operations, waste treatment, and control systems functioned as designed to contain environmental pollutants; and

2. The applicable environmental standards and effluent control requirements were met.

The primary purpose of the BNL environmental surveillance program is to:

1. Quantify the presence of potential contaminants in the environment as a result of BNL operations; and

2. Assess environmental and human health impacts from BNL operations.

This annual report for CY 1994 follows the recomendations given in the DOE Order 5400.1, General Environmental Protection Program. ${ }^{32}$ 
Table 4-1

BNL Site Environmental Report for Calendar Year 1994 Atmospheric Effluent Release Locations and Radionuclide Activity

\begin{tabular}{|c|c|c|c|c|c|}
\hline $\begin{array}{l}\text { Release Pt. } \\
\text { Bldg. No. }\end{array}$ & Facility & $\begin{array}{r}\text { Release } \\
\mathrm{Ht} .(\mathrm{m})\end{array}$ & Nuclide & $\begin{array}{c}\text { Ci } \\
\text { Released } \\
\text { CY 1994 }\end{array}$ & $\begin{array}{l}\text { Annual Avg. } \\
\text { Stack Conc. } \\
\text { (uCi/cc) }\end{array}$ \\
\hline 931 & BLIP & 10 & $\begin{array}{l}\text { Cs-137 } \\
\text { H-3 } \\
\text { Mn-54 } \\
\text { O-15 } \\
\mathrm{Zr}-89\end{array}$ & $\begin{array}{r}3.58 \mathrm{E}-06 \\
9.25 \mathrm{E}-05 \\
2.54 \mathrm{E}-06 \\
3.90 \mathrm{E}+02 \\
9.58 \mathrm{E}-07\end{array}$ & $\begin{array}{l}3.51 \mathrm{E}-13 \\
9.07 \mathrm{E}-12 \\
2.49 \mathrm{E}-13 \\
3.82 \mathrm{E}-05 \\
9.39 \mathrm{E}-14\end{array}$ \\
\hline 750 & HFBR & 100 & $\begin{array}{l}\mathrm{Ba}-128 \\
\mathrm{Be}-7 \\
\mathrm{Br}-82 \\
\mathrm{Cs}-137 \\
\mathrm{H}-3 \\
\mathrm{l}-126 \\
\mathrm{l}-131 \\
\mathrm{I}-132 \\
\mathrm{I}-133 \\
\mathrm{l}-134 \\
\mathrm{l}-135\end{array}$ & $\begin{array}{l}1.60 \mathrm{E}-06 \\
6.02 \mathrm{E}-06 \\
1.22 \mathrm{E}-03 \\
4.66 \mathrm{E}-07 \\
8.08 \mathrm{E}+01 \\
2.54 \mathrm{E}-06 \\
7.40 \mathrm{E}-06 \\
1.36 \mathrm{E}-06 \\
1.56 \mathrm{E}-05 \\
1.88 \mathrm{E}-05 \\
1.32 \mathrm{E}-05\end{array}$ & $\begin{array}{l}8.89 \mathrm{E}-15 \\
3.34 \mathrm{E}-14 \\
6.78 \mathrm{E}-12 \\
2.59 \mathrm{E}-15 \\
4.49 \mathrm{E}-07 \\
1.41 \mathrm{E}-14 \\
4.11 \mathrm{E}-14 \\
7.56 \mathrm{E}-15 \\
8.67 \mathrm{E}-14 \\
1.04 \mathrm{E}-13 \\
7.33 \mathrm{E}-14\end{array}$ \\
\hline 491 & BMRR & 46 & Ar-41 & $2.00 E+03$ & 1.15E-02 \\
\hline 801 & $801 \mathrm{NA}$ & 100 & $\begin{array}{l}\text { As-74 } \\
\text { Be-7 } \\
\text { Br-77 } \\
\text { Br-82 } \\
\text { Co-60 } \\
\text { Cs-137 } \\
\text { Ga-68 } \\
\text { l-124 } \\
\text { l-126 } \\
\text { Mn-54 } \\
\text { Rb-84 } \\
\text { Sb-124 } \\
\text { Se-75 }\end{array}$ & $\begin{array}{l}2.17 \mathrm{E}-04 \\
1.47 \mathrm{E}-05 \\
9.19 \mathrm{E}-03 \\
1.42 \mathrm{E}-04 \\
1.12 \mathrm{E}-06 \\
3.90 \mathrm{E}-05 \\
1.99 \mathrm{E}-04 \\
6.15 \mathrm{E}-04 \\
2.27 \mathrm{E}-03 \\
1.26 \mathrm{E}-06 \\
9.21 \mathrm{E}-06 \\
6.64 \mathrm{E}-05 \\
1.35 \mathrm{E}-04\end{array}$ & $\begin{array}{l}2.09 \mathrm{E}-13 \\
1.41 \mathrm{E}-14 \\
8.84 \mathrm{E}-12 \\
1.37 \mathrm{E}-13 \\
1.08 \mathrm{E}-15 \\
3.75 \mathrm{E}-14 \\
1.91 \mathrm{E}-13 \\
5.91 \mathrm{E}-13 \\
2.18 \mathrm{E}-12 \\
1.21 \mathrm{E}-15 \\
8.86 \mathrm{E}-15 \\
6.38 \mathrm{E}-14 \\
1.30 \mathrm{E}-13\end{array}$ \\
\hline N/A & Incin. & 10 & $\begin{array}{l}\text { Co-57 } \\
\text { H-3. } \\
\text { l-125 } \\
\text { S-35 } \\
\text { Sr-85 }\end{array}$ & $\begin{array}{l}3.35 \mathrm{E}-04 \\
1.47 \mathrm{E}-04 \\
5.10 \mathrm{E}-04 \\
4.00 \mathrm{E}-05 \\
1.00 \mathrm{E}-06\end{array}$ & $\begin{array}{l}1.82 \mathrm{E}-08 \\
7.99 \mathrm{E}-09 \\
2.77 \mathrm{E}-08 \\
2.17 \mathrm{E}-09 \\
5.43 \mathrm{E}-11\end{array}$ \\
\hline
\end{tabular}


radionuclides in the incinerated materials during 1994 was $1.0 \mathrm{mCi}$ ( $37.0 \mathrm{MBq}$ ). Iodine-125 was the predominant radionuclide released from the incinerator at an annual rate of $510 \mu \mathrm{Ci}(18.9 \mathrm{MBq})$. Site meteorological characteristics and administrative limits on the amount of material incinerated ensure that airborne concentrations at the site boundary are small fractions of the applicable standards.

\subsubsection{Airborne Effluent Emissions - Nonradioactive}

Nonradioactive airborne emissions are generated from a variety of processes at BNL. The majority of these are defined by NYS air laws as minor sources and include processes such as welding/soldering activities, degreasers, sandblasters, machining operations, painting operations and parts cleaning units. There are two large boilers and one midsize boiler located at the CSF, which produce the largest amount of nonradioactive airborne emissions at the Laboratory. The CSF is located along the eastern perimeter of the developed portion of the BNL site. The CSF supplies steam for heating and cooling to all major facilities through the underground steam distribution and condensate grid.

The combustion units at the CSF are designated as Boiler Nos. 1A, 5, and 6. Boiler IA is a Babcock \& Wilcox FM unit which was installed in 1962 and has a heat input of 56.7 MMBtu/hr. Boiler No. 4 is a Combustion Engineering unit whicl was installed in 1961 and has a maximum heat input of 75 MMBtu/hr. Boiler No. 5 is a Combustion Engineering vU-60 unit which was installed in 1965 and has a heat input of $75 \mathrm{MMBtu} / \mathrm{hr}$. Boiler No. 6 is a Combustion Engineering 28-A-14 unit, installed in 1984, which has a heat input of $147 \mathrm{MMBtu} / \mathrm{hr}$. All of these units are monitored for opacity, oxygen, and carbon dioxide. In addition, Boiler No. 6 has low excess air burners and has a continuous emissions monitor for $\mathrm{NO}_{x}$. Emissions from these boilers are reported on a quarterly basis to the NYSDEC.

Boiler No. 4 will be dismantled in the spring of 1995 and will be replaced with Boiler No. 7, a Babcock \& Wilcox FM-117-97 unit, which has a 147 MMBtu/hr heat input. Boiler No. 7 is currently anticipated to be available for operation in the fall of 1995. This unit will be equipped with low $\mathrm{NO}_{x}$ burners, secondary air combustion equipment, and a continuous emissions monitor for $\mathrm{NO}_{\mathrm{x}}$. After this unit becomes operational, stack tests will be performed to ensure the emissions standards for $\mathrm{NO}_{x}$ are satisfied.

\subsubsection{Liquid Effluents}

The basic policy of liquid effluent management at the Laboratory is to minimize the volume of liquids requiring processing prior to on-site release or solidification for off-site burial at a licensed facility. ${ }^{35}$ Accordingly, liquid effluents are segregated by the generator at the point of origin on the basis of their anticipated concentrations of radioactivity or other potentially harmful agents.

\subsubsection{Liquid Waste Management}

Iiquid chemical wastes are collected by the Hazardous Waste Management Engineering and Operations Group (E\&OG), and subsequently packaged in accordance with Department of Transportation (DOT), EPA, and NYSDEC regulations and DOE orders for licensed off-site disposal.

The E\&OG also collects small quantities of low-level liquid radioactive wastes from waste accumulation areas throughout the site. Depending on the radionuclide and its concentration, these wastes are either directly solidified at the HWMF or processed at the WCF. Buildings where large volumes (up to several hundred liters) of low-level liquid radioactive waste are generated, have dual waste handling systems. These systems are identified as "active" (D) and 
"inactive" (F). The D-waste liquid stream is always collected for disposal through the WCF. The F-waste liquid stream is sampled, analyzed, and compared to DOE, BNL, and SPDES release criteria. If the radiological concentration meets release criteria, the liquid waste may be released to the sanitary waste stream. otherwise, the liquid waste is transferred to the WCF for processing. In 1994, authorized releases of $\mathrm{F}$-waste to the sanitary system totaled 1.9 million liters with a total gross beta activity of $0.17 \mathrm{mCi}(6.29 \mathrm{MBq})$ and a total tritium activity of $9.8 \mathrm{mCi}(0.36 \mathrm{GBq})$. The volume of material released in 1994 represents a three fold increase over 1993. The gross beta activity released decreased by a factor of 2.8, while the tritium activity released decreased by a factor of 1.5. These releases are significantly lower than pre-1989 values.

Due to the age of the WCE's evaporator system, it was temporarily taken out of service until an alternative process study for radioactive liquid waste was completed. In the interim period, a leased mobile processing system was put into operation. As a result of this operation, in 1994, approximately $4.7 \mathrm{Ci}$ (174 $\mathrm{GBq})$ of tritium was placed into the lined holding pond.

\subsubsection{Sanitary System Effluents}

Primary treatment of the sanitary waste stream to remove settleable solids and floatable materials is provided by a 950,000 liter clarifier at the STP. The liquid effluent flows from the clarifier onto sand filter beds, from which about $85 \%$ of the water is recovered by an underlying tile field. This recovered water is then released into a small stream that contributes to the headwaters of the Peconic River. This release is a SPDES permitted discharge. The Peconic River Sewage Treatment Plant - Sampling stations is an intermittent stream within the BNL site. From the mid 1980's until April of 1989, virtually all water released to this channel recharged to groundwater prior to reaching the site boundary. Beginning in April 1989 and continuing throughout 1990, heavy rains produced sufficient upstream contribution to result in the Peconic tributary on the BNL site to once again leave the site. During the period 1991 through 1994 off-site flow was intermittent with flow occurring during the spring.

The effluent not collected by the tile fields, approximately 15\%, recharges directly to groundwater under the beds and/or evaporates. A schematic of the STP and its related sampling arrangements is shown in Figure 4-2. Real time monitoring of the clarifier influent for radioactivity, $\mathrm{pH}$ and conductivity, takes place at two locations: about $1.8 \mathrm{~km}$ upstream of the STP and as the influent is about to enter the clarifier. The upstream station provides about one hour of advanced warning that liquid effluents which may exceed BNL effluent release criteria or SPDES limits have entered the system. At the clarifier, an oil monitor examines the STP influent for the presence of oil. Effluent leaving the clarifier is monitored a third time for radioactivity. Effluent that does not meet BNL and/or SPDES effluent release criteria is automatically or manually diverted to one of two lined hold-up ponds. Diversion continues until the effluent quality meets the release criteria. The effluent diverted to the holding pond is evaluated for treatment and reintroduced into the sanitary waste stream when the addition of this material will not result in exceeding BNL SPDES or administrative release criteria. ${ }^{36}$ The total combined capacity of the two holding ponds is in excess of 26.5 million liters. In addition to real time monitoring, the clarifier effluent (Location DA) and the outfall to the Peconic River (Location EA) are monitored for radiological and nonradiological parameters through a combination of volume proportional and grab samples collected routinely from each of these locations. 


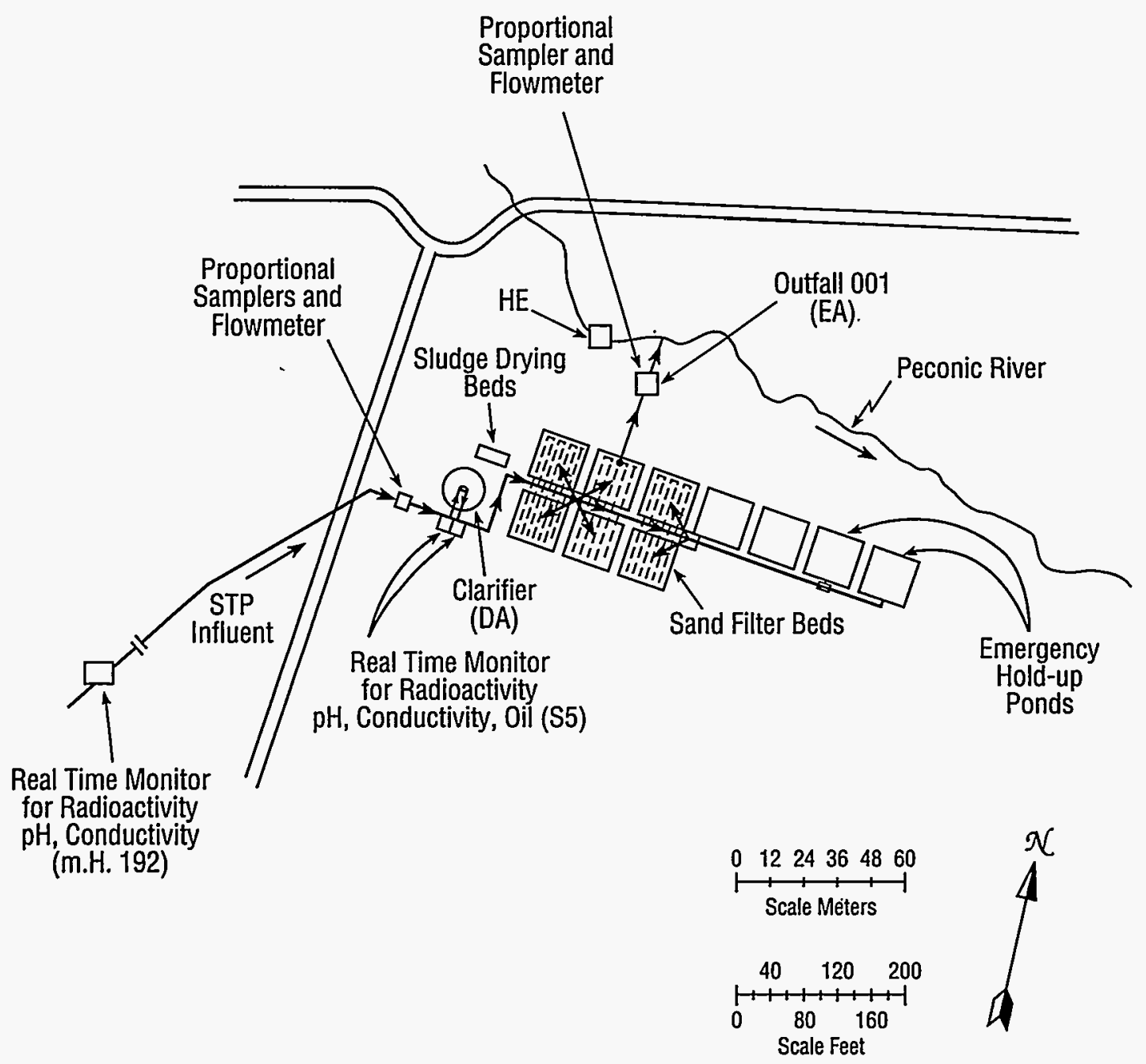

Sewage Treatment Plant - Sampling Stations.

Figure 4-2 


\subsubsection{Radiological Analyses}

The proportional samples collected at Location DA, the effluent from the STP clarifier, and Location EA, the STP discharge point into the Peconic River, are analyzed daily for gross alpha, beta, and tritium activities. An aliquot is composited for monthly strontium-90 and gamma spectroscopy analyses. The results of these measurements are reported in Tables $4-2$ and 4-3. Eight year trend plots of gross beta and tritium concentrations that were released to the Peconic River are presented in Figures $4-3$ and $4-4$. A total tritium activity trend plot from 1971 to the present is presented in Figure 4-5.

The gross alpha and gross beta data at the STP are consistent with prior year's data. All gross alpha results are essentially less than the system detection limit and have a mean value which approaches zero. This means that alpha concentration measurements for these locations are at background levels. The tritium concentrations decreased in 1994 by a factor of about 2.0 compared to 1993 levels.

Controlled releases of WCF distillate from the STP emergency holding ponds continued in 1994. The 1994 tritium concentrations discharged to the Peconic River were below regulatory standards and were within BNL administrative controls $(10,000 \mathrm{pCi} / L) .{ }^{36}$ The total tritium activity released into the sanitary system was $2.1 \mathrm{Ci}(77 \mathrm{GBq})$ as compared to $2.8 \mathrm{Ci}$ (103 GBq) in 1993 . The tritium activity discharged from Location EA was $1.6 \mathrm{Ci}$ (59 GBq), a reduction of $50 \%$ when compared to 1993. The concentrations of strontium-90 and gamma emitting radionuclides entering the STP remained at their pre-1988 levels. At Location $\mathrm{DA}$, all radionuclide concentrations were at or below pre-1988 levels. At Location EA concentrations are essentially constant with the data from prior years. ${ }^{9}$ Although cesium-137 concentrations remain slightly elevated as compared to pre-1988 values, they have almost returned to their historically typical levels. Cesium-137 continues to leach out of the sand filter beds from a deposit that occurred during an unplanned release on June 14-15, 1988. A discussion of the incident can be found in the 1988 BNL SER. ${ }^{9}$

In 1994, gross beta concentrations at Location EA were approximately 1.11 times the influent concentrations, which is consistent with previous years. Cesium-137 concentrations in water collected from Location EA were 21 times the concentration found in the clarifier. This ratio is 1.5 times higher than in 1993, but is consistent with previous years. Location EA averaged out to be near MDI concentrations (strontium-90 MDL $=0.1 \mathrm{pCi} / \mathrm{L}$ ). None of the monthly values that were positive resulted in any violation of SPDES permit. If the BNL administrative policy dose criteria of $4 \mathrm{mrem} / \mathrm{yr}$ were used for comparison, daily ingestion of water, discharged by BNL to the Peconic River, would result in an annual dose of $0.13 \mathrm{mrem}(0.0013 \mathrm{mSv})$ or less than $0.001 \%$ of BNL's current discharge policy.

\subsubsection{Sanitary System Nonradiological Analyses}

The effluent from the Laboratory STP discharges into the Peconic River at Location EA (Outfall 001) and is subject to the conditions of the SPDES Permit No. NY-0005835, which is issued by the NYSDEC. Monthly DMRs are submitted to the NYSDEC and SCDHS which provide detailed analytical results and performance information regarding the operational activities at the STP. Table 2-2 (see Chapter 2) contains the maximum concentration of contaminants observed within the STP discharge during 1994. The data collected during 1994 indicates a compliance rate of approximately $99.7 \%$ for all parameters monitored. A complete summary of monthly DMR data is presented in the Table 2-3 (Chapter 2). 
Table 4-2

BNL SIte Environmental Report for Calendar Year 1994

Radiological Analysis Results of Sewage Treatment Plant Influent and Effluent

\begin{tabular}{|c|c|c|c|c|c|c|c|}
\hline & \multirow[b]{2}{*}{$\begin{array}{l}\text { Flow } \\
\text { (liters) }\end{array}$} & \multicolumn{2}{|c|}{ Gross Alpha } & \multicolumn{2}{|c|}{ Gross Beta } & \multicolumn{2}{|c|}{ Tritium } \\
\hline & & $\begin{array}{l}\text { Avg. } \\
\text { (pCi/L) }\end{array}$ & $\begin{array}{l}\text { Max. } \\
\text { (pCi/L) }\end{array}$ & $\begin{array}{l}\text { Avg. } \\
(p C i / L)\end{array}$ & $\begin{array}{l}\text { Max. } \\
(\mathrm{pCi} / L)\end{array}$ & $\begin{array}{l}\text { Avg. } \\
(\mathrm{pCi} / \mathrm{L})\end{array}$ & $\begin{array}{l}\text { Max. } \\
(p C i / L)\end{array}$ \\
\hline \multicolumn{8}{|c|}{ Sample Location DA - Clarifier Effluent } \\
\hline January & $7.94 \mathrm{E}+07$ & 0.75 & 2.64 & 6.20 & 13.60 & 982.99 & 2850.00 \\
\hline February & $5.13 E+07$ & 0.98 & 3.25 & 5.79 & 10.00 & 547.04 & 1360.00 \\
\hline March & $8.84 E+07$ & 0.99 & 4.46 & 5.92 & 19.00 & 681.65 & 2950.00 \\
\hline April & $7.87 \mathrm{E}+07$ & 0.33 & 2.10 & 13.59 & 103.00 & 2158.29 & 4860.00 \\
\hline May & $8.05 E+07$ & 0.99 & 4.01 & 6.55 & 24.70 & 1729.77 & 4630.00 \\
\hline June & $9.76 \mathrm{E}+07$ & 1.60 & 7.92 & 13.48 & 185.00 & 3573.18 & 6290.00 \\
\hline July & $1.09 E+08$ & 0.66 & 4.00 & 4.06 & 10.10 & 3335.70 & 6390.00 \\
\hline August & $1.23 E+08$ & 1.06 & 2.94 & 5.78 & 11.80 & 2954.22 & 6420.00 \\
\hline September & $1.08 \mathrm{E}+08$ & 0.80 & 3.88 & 6.47 & 13.50 & 2169.86 & 5340.00 \\
\hline October & $1.08 \mathrm{E}+08$ & 1.23 & 3.48 & 6.33 & 15.40 & 912.52 & 2890.00 \\
\hline November & $9.82 E+07$ & 0.27 & 1.81 & 3.58 & 9.48 & 999.71 & 3540.00 \\
\hline December & 8.97E+07 & 0.49 & 3.61 & 4.58 & 10.20 & 482.95 & 1890.00 \\
\hline Annual Avg. & & 0.85 & & 6.87 & & 1714.85 & \\
\hline $\begin{array}{l}\text { Total Rel. } \\
\text { (L or mCi) }\end{array}$ & 1.11E+09 & 0.94 & & 7.19 & & 2076.94 & \\
\hline \multicolumn{8}{|c|}{ Sample Location EA - Chlorine House Effluent } \\
\hline & & \multicolumn{2}{|c|}{ Gross Alpha } & \multicolumn{2}{|c|}{ Gross Beta } & \multicolumn{2}{|c|}{ Tritium } \\
\hline & $\begin{array}{l}\text { Flow } \\
\text { (liters) }\end{array}$ & $\begin{array}{l}\text { Avg. } \\
\text { (pCi/L) }\end{array}$ & $\begin{array}{l}\text { Max. } \\
\text { (pCi/L) }\end{array}$ & $\begin{array}{l}\text { Avg. } \\
\text { (pCi/L) }\end{array}$ & $\begin{array}{l}\text { Max. } \\
\text { (pCi/L) }\end{array}$ & $\begin{array}{l}\text { Avg. } \\
\text { (pCi/L) }\end{array}$ & $\begin{array}{c}\text { Max. } \\
(\mathrm{pCi} / \mathrm{L})\end{array}$ \\
\hline January & $5.75 E+07$ & 0.44 & 2.55 & 7.10 & 24.40 & 1168.35 & 3350.00 \\
\hline February & $5.31 \mathrm{E}+07$ & 0.42 & 2.10 & 10.80 & 30.60 & 567.42 & 1450.00 \\
\hline March & $6.92 E+07$ & 1.35 & 3.76 & 11.04 & 20.50 & 714.43 & 3270.00 \\
\hline April & $6.22 E+07$ & 0.52 & 3.14 & 9.80 & 19.30 & 2032.48 & 5000.00 \\
\hline May & $6.25 E+07$ & 0.68 & 3.76 & 8.86 & 17.00 & 1708.95 & 3810.00 \\
\hline June & $7.62 E+07$ & 1.04 & 4.46 & 6.23 & 21.60 & 3369.55 & 5840.00 \\
\hline July & $7.64 E+07$ & 0.67 & 3.11 & 5.30 & 14.20 & 3269.47 & 5600.00 \\
\hline August & $9.22 E+07$ & 0.29 & 1.82 & 7.29 & 16.20 & 2735.09 & 7310.00 \\
\hline September & $8.75 E+07$ & 0.81 & 2.69 & 10.26 & 58.30 & 2183.48 & 6040.00 \\
\hline October & $8.63 E+07$ & 0.75 & 3.00 & 5.64 & 11.40 & 934.71 & 3080.00 \\
\hline November & $8.32 E+07$ & 0.50 & 2.88 & 3.71 & 10.70 & 746.21 & 6860.00 \\
\hline December & 7.17E+07 & 0.69 & 4.46 & 7.65 & 58.30 & 1726.36 & 7310.00 \\
\hline Annual Avg. & & 0.69 & & 7.65 & & 1726.36 & \\
\hline \multicolumn{8}{|l|}{ - (L or mCi) } \\
\hline SPDES Limit & & & a-226) & 1000 & & Not Listed & \\
\hline NYS Drinking & & 155 & & 50 & & 20000 & \\
\hline Typical MDL & & 2.3 & & 6 & & 1000 & \\
\hline
\end{tabular}


Table 4-3

BNL Site Environmental report for Calendar Year 1994

Sewage Treatment Plant Gamma Spectroscopy Results

\begin{tabular}{|c|c|c|c|c|c|c|c|c|}
\hline & $\begin{array}{l}\text { Flow } \\
\text { (liters) }\end{array}$ & $\begin{array}{c}\mathrm{Be}-7 \\
(\mathrm{pCi} / \mathrm{L})\end{array}$ & $\begin{array}{l}\mathrm{Na}-22 \\
(\mathrm{pCi} / \mathrm{L})\end{array}$ & $\begin{array}{l}\mathrm{Mn}-54 \\
(\mathrm{pCi} / \mathrm{L})\end{array}$ & $\begin{array}{l}-131 \\
(\mathrm{pCi} / \mathrm{L})\end{array}$ & $\begin{array}{l}\mathrm{Co}-57 \\
\text { (pCi/L) }\end{array}$ & $\begin{array}{l}\text { Co-60 } \\
\text { (pCi/L) }\end{array}$ & $\begin{array}{l}\mathrm{Cs}-137 \\
\text { (pCi/L) }\end{array}$ \\
\hline \multicolumn{9}{|c|}{ Sample Station DA - Clarifier Influent } \\
\hline January & $7.94 \mathrm{E} \div 07$ & - & - & - & - & - & - & 0.118 \\
\hline February & $5.13 E+07$ & - & 0.054 & - & - & - & - & 0.059 \\
\hline March & $8.84 \mathrm{E}+07$ & - & - & - & - & - & - & 0.205 \\
\hline April & $7.87 \mathrm{E}+07$ & - & - & - & - & 0.039 & 0.029 & 0.064 \\
\hline May & $8.05 E+07$ & 0.679 & - & - & - & - & - & 0.089 \\
\hline June & $9.76 \mathrm{E}+07$ & 0.529 & - & - & - & - & - & 0.044 \\
\hline July & $1.09 E+08$ & - & - & - & - & - & - & - \\
\hline August & $1.23 E+08$ & - & - & - & - & - & - & 0.048 \\
\hline September & $1.08 \mathrm{E}+08$ & 0.252 & - & - & - & - & 0.017 & 0.009 \\
\hline October & $1.08 E+08$ & - & 0.012 & 0.031 & - & - & - & 0.042 \\
\hline November & $9.82 E+07$ & - & - & - & 0.276 & - & - & 0.048 \\
\hline December & $8.97 E+07$ & - & - & - & - & - & - & 0.066 \\
\hline Annual Avg. & & 0.122 & 0.005 & 0.003 & 0.023 & 0.003 & 0.004 & 0.066 \\
\hline $\begin{array}{l}\text { Total Release } \\
\text { (L or } \mathrm{mCi} \text { ) }\end{array}$ & $1.11 E+09$ & 0.133 & 0.004 & 0.003 & 0.027 & 0.003 & 0.004 & 0.069 \\
\hline
\end{tabular}

Sample Station EA - Chlorine House Effluent

\begin{tabular}{|c|c|c|c|c|c|c|c|c|}
\hline January & $5.75 E+07$ & - & - & -- & -- & - & 0.078 & 1.830 \\
\hline February & $5.31 \mathrm{E}+07$ & - & - & - & - & - & 0.132 & 3.720 \\
\hline March & $6.92 \mathrm{E}+07$ & - & - & - & - & 0.029 & 0.110 & 2.300 \\
\hline April & $6.22 E+07$ & - & - & - & - & - & 0.113 & 1.020 \\
\hline May & $6.25 E+07$ & - & - & - & - & - & 0.052 & 1.210 \\
\hline June & $7.62 \mathrm{E}+07$ & - & - & - & - & - & 0.052 & 1.390 \\
\hline July & $7.64 \mathrm{E}+07$ & - & - & - & - & - & - & 0.946 \\
\hline August & $9.22 E+07$ & - & - & - & - & - & - & 0.945 \\
\hline September & $8.75 E+07$ & - & - & - & - & - & 0.039 & 1.030 \\
\hline October & $8.63 E+07$ & - & - & - & - & - & - & 0.876 \\
\hline November & $8.32 \mathrm{E}+07$ & - & - & - & - & - & - & 0.877 \\
\hline December & 7.17E+07 & - & - & - & - & - & - & 0.860 \\
\hline Annual Avg. & & 0.000 & 0.000 & 0.000 & 0.000 & 0.002 & 0.048 & 1.417 \\
\hline $\begin{array}{l}\text { Total Release } \\
\text { (L or } \mathrm{mCi})\end{array}$ & $8.78 E+08$ & 0.000 & 0.000 & 0.000 & 0.000 & 0.002 & 0.037 & 1.167 \\
\hline \multicolumn{2}{|c|}{ DOE Order 5400.5} & $1,000,000$ & 10,000 & 50,000 & 3,000 & 100,000 & 5,000 & 3,000 \\
\hline \multicolumn{9}{|c|}{$D C G s^{*}(p C i / L)$} \\
\hline \multicolumn{2}{|c|}{$\begin{array}{l}\text { SDWA Annual Dose }{ }^{\star *} \\
(\mathrm{pCi} / \mathrm{L})\end{array}$} & 40,000 & 400 & 2,000 & 120 & 4,000 & 200 & 120 \\
\hline \multicolumn{2}{|l|}{ Typical MDL } & 1.60 & 0.20 & 0.18 & 0.21 & 0.14 & 0.23 & 0.20 \\
\hline
\end{tabular}

${ }^{\star} D C G=$ Derived Concentration Guide. The DCG value represents the concentration of a radionuclide in water that would cause a committed effective dose equivalent (CEDE) of 100 mrem if 2 liters a day were ingested for one year. ${ }^{*}$ Concentration required to produce the Safe Drinking Water Act (SDWA) annual dose limit of 4 mrem. 


\section{Gross Beta Concentration Data}

\section{Sewage Plant and Peconic River}

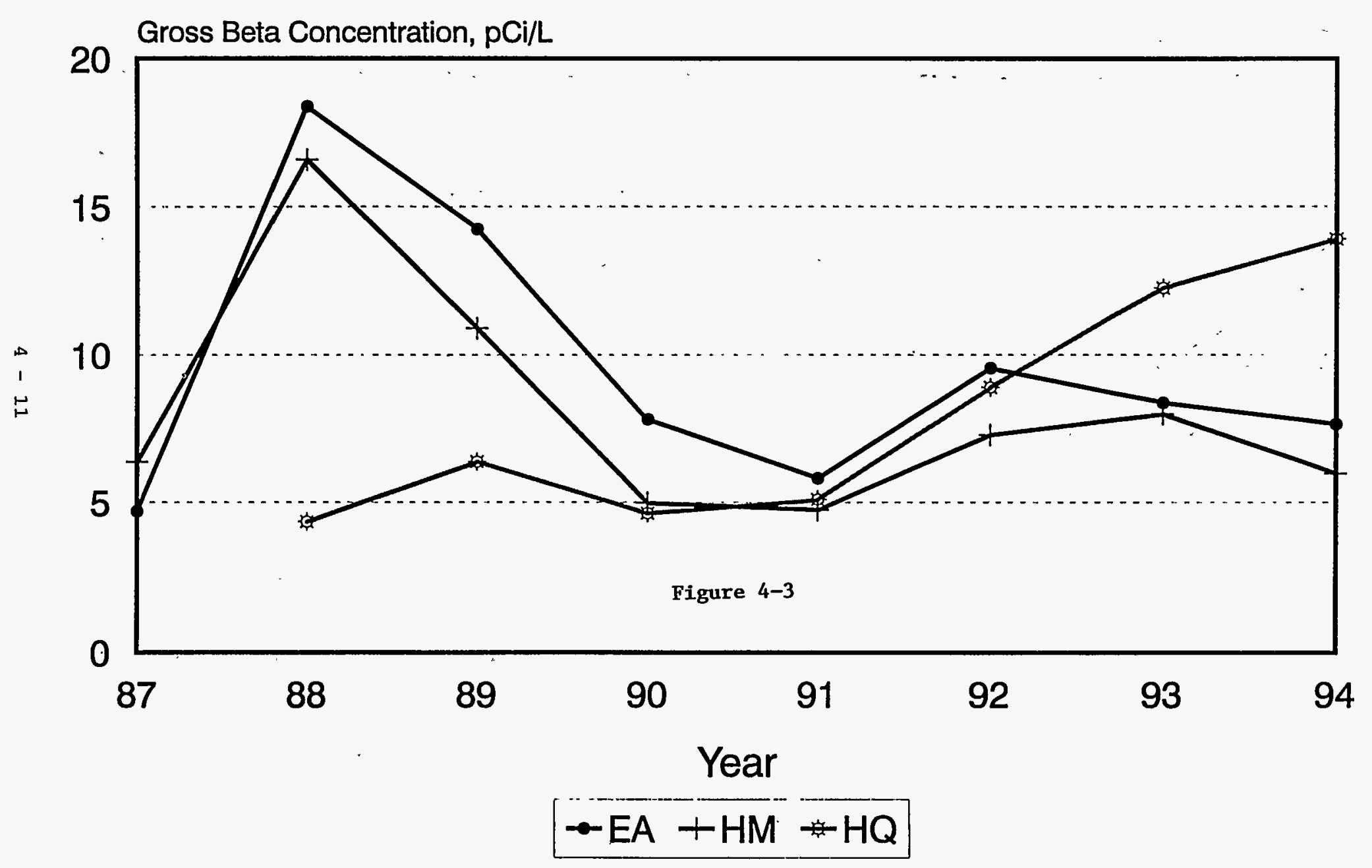




\section{Tritium Concentration Data}

\section{Sewage Plant and Peconic River}

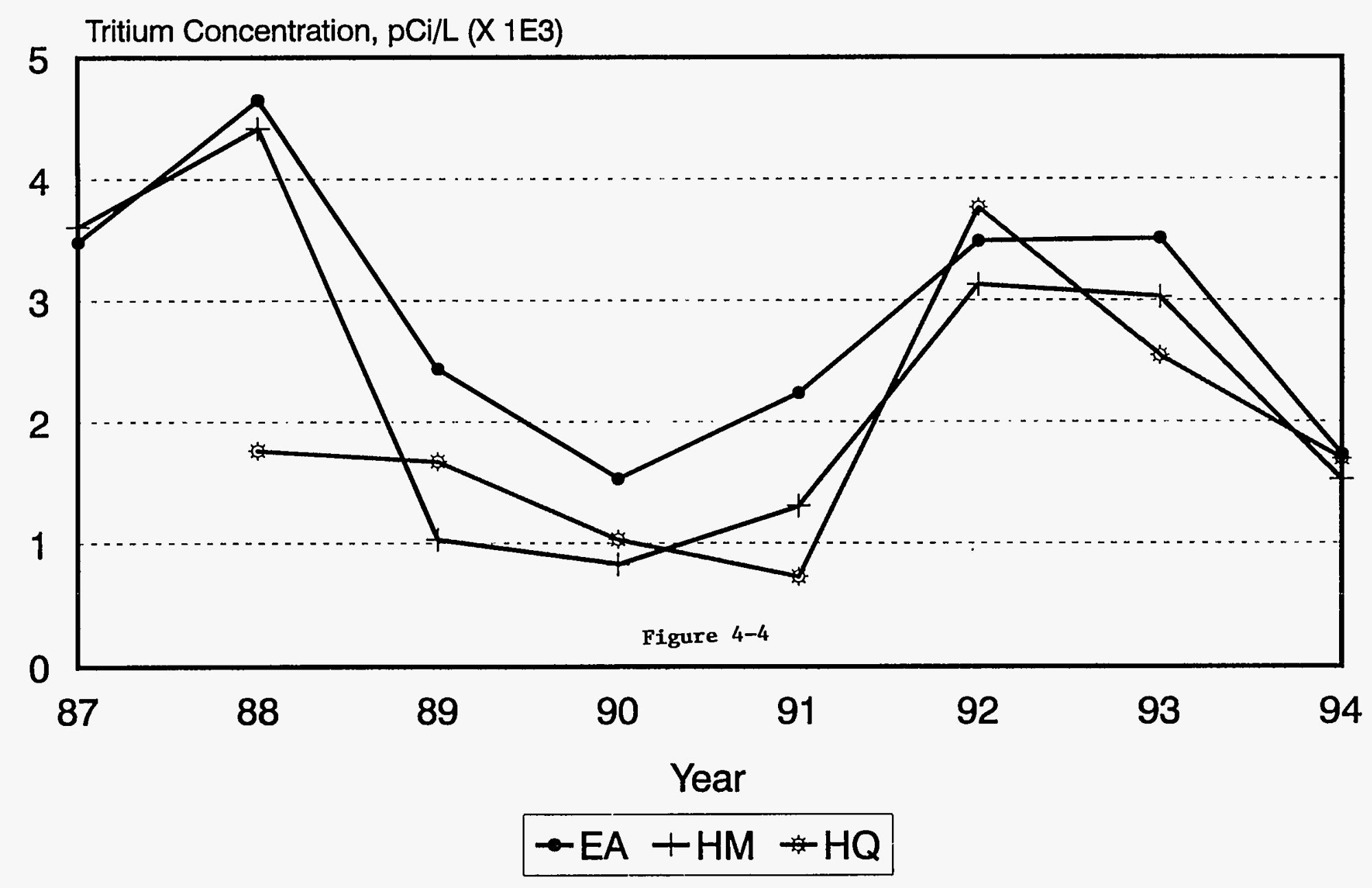

NYSDWS is $20,000 \mathrm{pCi} / \mathrm{L}$ 


\section{Tritium Activity Discharged To The Peconic River From BNL}

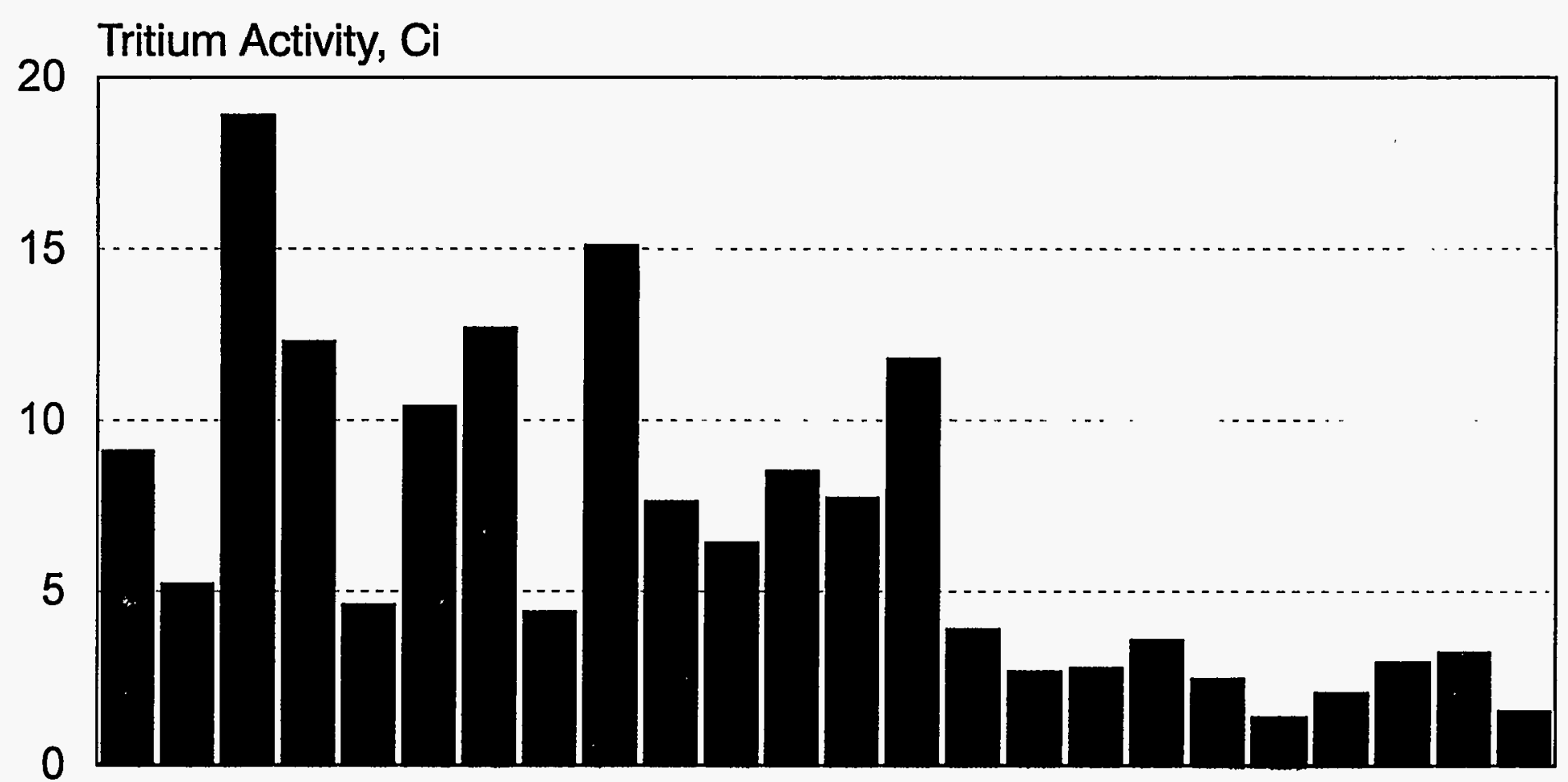

717273747576777879808182838485868788899091929394 Year 
Ten permit limitation exceedances were observed during CY 1994 . The contaminants responsible for these exceedances were $\mathrm{BOD}_{5}$ (1), ammonia nitrogen (8) and fecal coliform (1). The ammonia nitrogen exceedances occurred during the period January 1 to April 30, 1994 and were attributable to the cold winter and hydraulic overloading of the sand filter beds which occurred during preliminary studies for construction of STP improvements. In November 1993, the PE Division initiated an investigation into the cause of elevated groundwater in the vicinity of the STP. The increase in groundwater elevation had a detrimental effect upon cost estimates for construction of STP upgrades which commenced in July 1994 . During the investigation, waste water was permitted to accumulate within the eastern filter beds while the western beds were completely removed from service. Based upon review of nitrogen loadings and the proportion of nitrate nitrogen to ammonia nitrogen, it was determined that due to the accumulation of water on the sand filters and the cold winter, a loss of nitrifying bacteria in the sand filters occurred. Loss of these organisms resulted in an increase in ammonia nitrogen and concurrent decrease in nitrate nitrogen concentrations within the STP discharge. Restoration of the sand filters, increased cultivation and aeration of the sand filter media and the on-set of warmer weather resulted in repopulation of the nitrifying bacteria and the subsequent decrease in ammonia concentrations. The exceedances for $B O D_{5}$ and fecal coliform were also determined to be the result of sand filter disturbances.

In addition to the collection and analysis of the STP effluent samples for compliance purposes, the SAG monitored the STP influent and effluent routinely during 1994. Daily influent and effluent samples were collected, composited by the S\&EP Division analytical laboratory and analyzed monthly for metals. In addition, the effluent was monitored daily for $\mathrm{pH}$, conductivity, temperature, dissolved oxygen and chlorine residual and weekly for nitrates, chlorides and sulfates. Daily influent and effluent logs were also maintained by the STP operators for the parameters of flow, $\mathrm{pH}$, temperature, settleable solids, and chlorine residual.

The analytical results for the samples collected from the STP by the SAG have been summarized in Table 4-4. Comparison of the effluent data to the SPDES effluent limitations shows all concentrations to be less than the SPDES effluent release limits. This data corresponds well with the compliance data reported in Chapter 2 (Table 2-2).

The expiration date for the BNL SPDES permit was May 1, 1988 . Efforts to renew the sPDES permit, which was initiated in 1988, continued during CY 1994 . on November 28,1994 the NYSDEC reissued the BNL draft SPDES permit. The draft permit contained numerous permit modifications including: an increase in parameters requiring monitoring at the STP, an increase in monitoring frequency at the STP, addition of monitoring and reporting requirements for the recharge basins, requirements for biomonitoring of the STP discharge, addition of three outfalls, process specific monitoring requirements, preparation of best management practices for site runoff, and additional studies. This permit was reviewed with regard to its technical and economical impact on Laboratory operations and comments were prepared and submitted to the NYSDEC in January 1995 along with a conditional acceptance of the permit. Finalization of the permit was expected to be completed by the end of February 1995. The redraft sought to incorporate many of the previous BNL comments and requested modifications, including slight increases to effluent limitations for discharges of tolyltriazole and hydroxy-ethylidene-diphosphonic acid, two corrosion prevention chemicals used in cooling towers. The conditional acceptance of the permit allows the Laboratory to continue efforts to negotiate even higher effluent limits for water treatment chemicals and further negotiate biomonitoring test conditions. 
Table 4-4

BNL SIte Environmental Report for Calendar Year 1994

Sewage Treatment Plant (STP) (a)

Average Water Quallty and Metals Data

\begin{tabular}{cccccccc}
\hline & N & Minimum & $\begin{array}{c}\text { STP Influent } \\
\text { Maximum }\end{array}$ & Average & N & Minimum & $\begin{array}{c}\text { STP Effluent } \\
\text { Maximum }\end{array}$ \\
& & & & & & & \\
Average
\end{tabular}

N: No. of samples

NA: Not Applicable or Not Analyzed

(a): The locations of the monitoring stations are shown on Figure 10.

(b): The pH and temperature values reported are those recorded by the STP operators and are continuously monitored.

(c): Continuously monitored.

The average concentration has been calculated by summing all detectable concentrations then dividing the sum by the total number of samples collocted.

All non-detectable quantities have been evaluated as zero. If the average is less than than the typical Minimum Detection Limit (MDL), it is reported as less tha 
Figures 4-6 through 4-14 present five year trend plots for the maximum monthly concentrations and the average loading of copper, iron, lead, silver, and zinc in the effluent of the STP. Plotted along with the observed concentrations are the current SPDES permit limits and the November 1994 proposed limits for the SPDES permit renewal. Review of the trend plots show that the majority of the discharges comply with the existing and proposed permit conditions; however, the lower effluent limitations established under the proposed permit may require stricter source controls in order to ensure compliance.

\section{Process Specific Waste Water Assessments}

In order to prevent violation of SPDES permit limitations and the release of waste waters which exceed groundwater effluent standards, the Laboratory requires that process waste waters suspected of containing contaminants at concentrations which may exceed one or both of these standards be held, characterized, and authorized by $S \& E P$ prior to disposal.

The draft SPDES permit includes requirements for the quarterly sampling and analysis of process specific waste waters discharged from the photographic developing operations conducted within Buildings 118 and 197B, the electroplating operations conducted in Building 535 and the metal cleaning operations conducted within Building 197C. These operations will be sampled and analyzed for chemical contaminants specific to these operations such as inorganic elements (i.e., metals), cyanide, and volatile and semi-volatile organic compounds.

In an effort to further characterize the effluents discharged into the headworks of the STP, the sampling and characterization project was continued in 1994. Due to budgetary constraints, however, during 1994 only the sampling and Analysis Plan (SAP) was prepared under contract with the International Technology corporation. The SAP identifies eleven locations for future monitoring and effluent characterization as well as identifies the analyses to be conducted at each location. It is expected that the SAP will be implemented during FY 1995. Completion of this activity in conjunction with the data generated during 1993 will complete evaluation of all major contributors to the BNL STP headworks.

Process waste waters which have not been evaluated for incorporation into the SPDES permit or are not expected to be of consistent quality are held for characterization and evaluation by S\&EP prior to sewer disposal. Typical waste waters which are routinely evaluated are ion exchange column regeneration wastes, primary closed loop cooling water systems, and other industrial waste waters. In order to determine the means for disposal of these wastes, samples are collected and analyzed for contaminants specific to the process. The analyses are then reviewed and the concentrations and mass loads compared to the SPDES effluent limitations. If the concentration and/or mass load are within the effluent standard, sewer disposal authorization is granted; if not, alternate means of disposal are evaluated. In all instances, any waste which contains hazardous levels of chemical contaminants or elevated radiological contamination is remanded to the $E \& O G$ for disposal guidance.

\subsubsection{Recharge Basins}

Figure 4-15 depicts the locations of BNL recharge basins within the physical complex. An overall schematic of water use at the Laboratory is shown in Figure 4-16. After use in "once through" heat exchangers and process cooling, approximately $11.15 \mathrm{MLD}$ of water was returned to the aquifer through on-site recharge basins; 1.29 MLD to Basin HN (Outfall 002) located about $610 \mathrm{~m}$ northeast of the AGS; 9.13 MLD to Basin HO (Outfall 003) about $670 \mathrm{~m}$ east of the HFBR; 0.02 MID to Basins HS (Outfall 005); 0.23 MLD to Basin HT (Outfall 006) and 0.48 MLD 

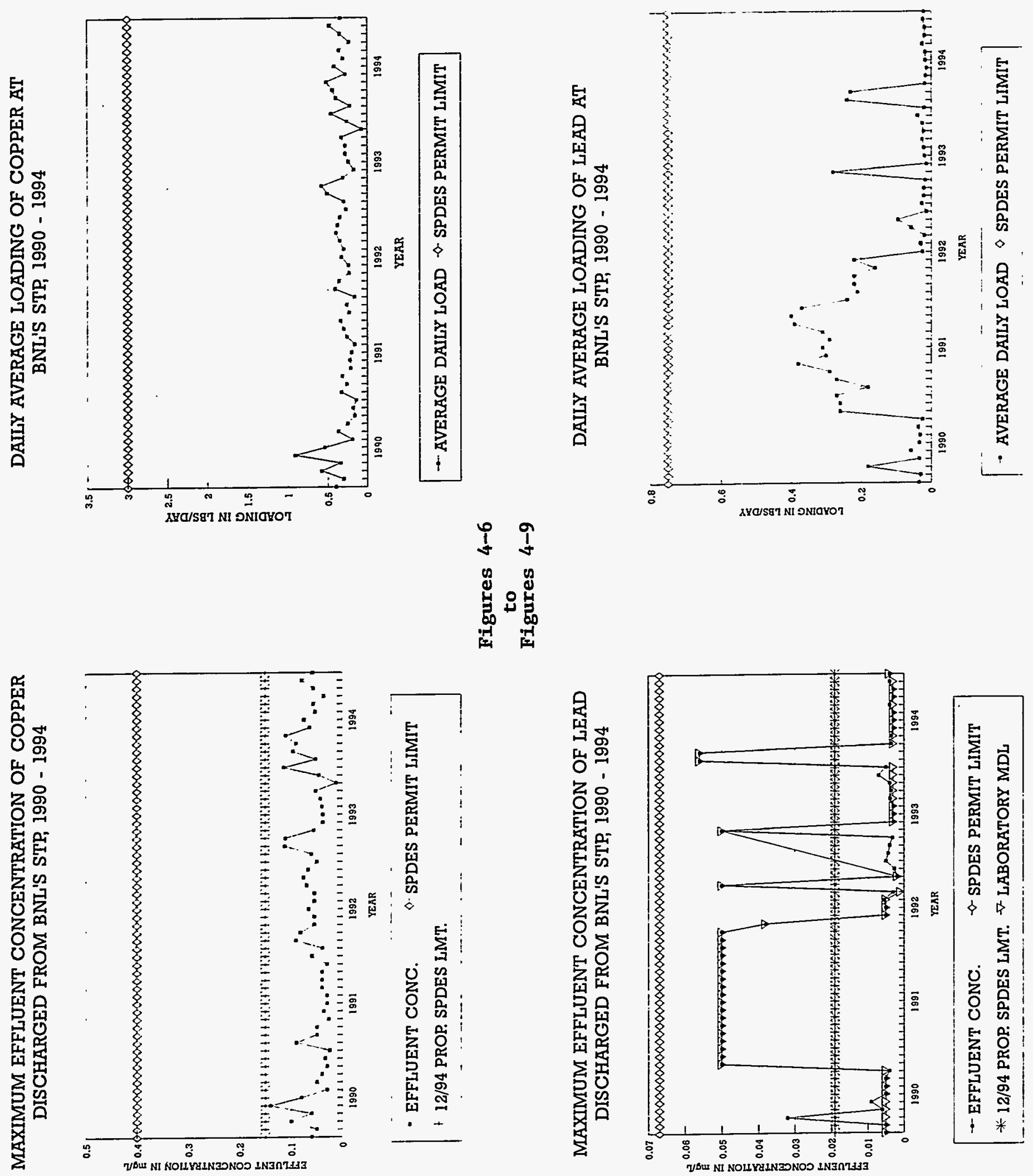
MAXIMUM EFFLUENT CONCENTRATION OF SILVER

DISCHARGED FROM BNL'S STP, 1990 - 1994

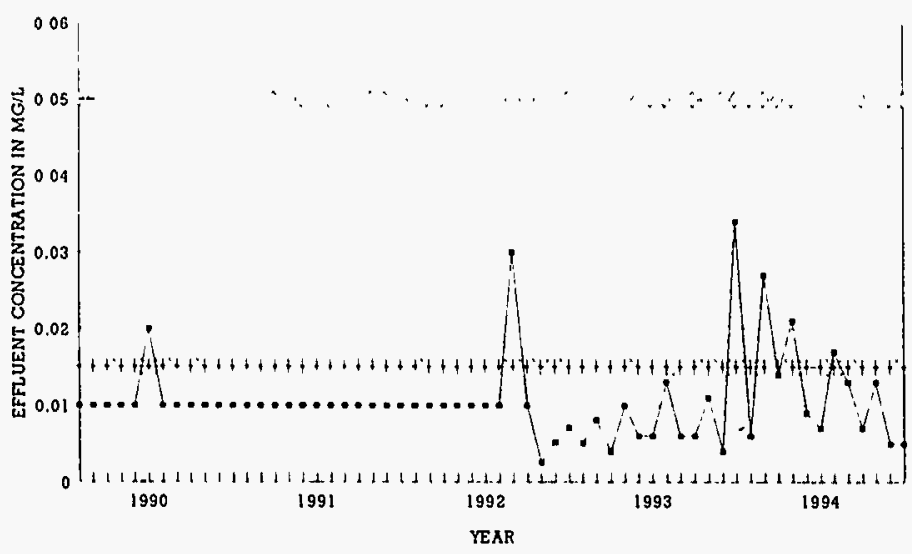

- EFFLUENT CONC. $\diamond$ SPDES PERMIT LIMIT + 12/94 PROP. SPDES LMT. DISCHARGED FROM BNL'S STP, $1990-1994$

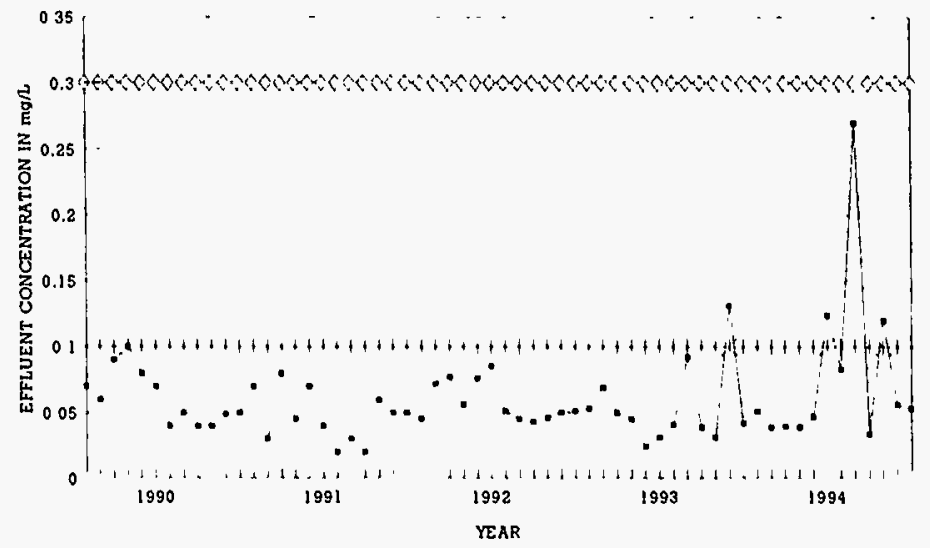

- EFFLUENT CONC.

SPDES PERMIT LIMIT

- 12/94 PROP. SPDES LMT.
DAILY AVERAGE LOADING OF SILVER AT

BNL'S STP, 1990 - 1994

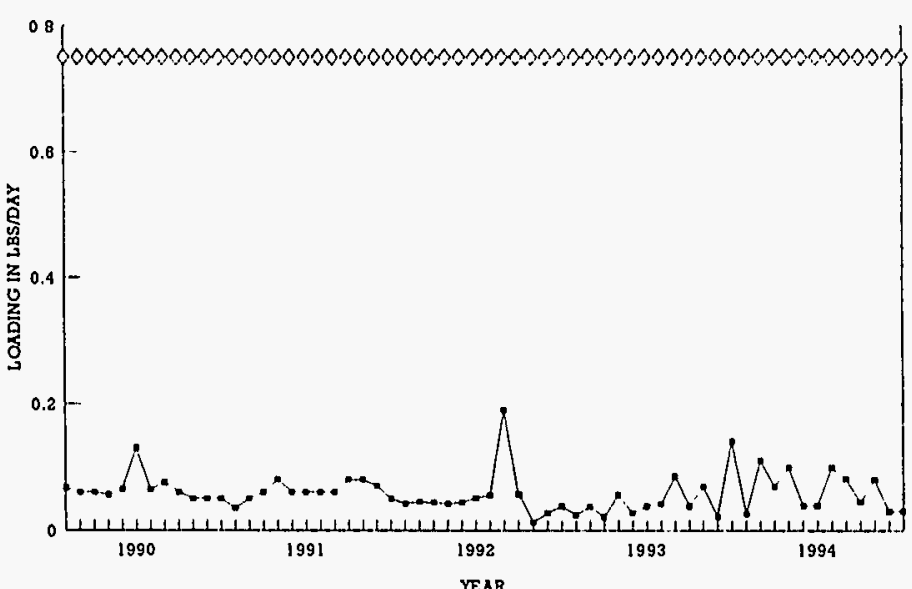

AVERAGE DAILY LOAD $\diamond$ SPDES PERMIT LIMIT

\section{Figures 4-10}

to

Figures 4-13

DAILY AVERAGE LOADING OF ZINC AT BNL'S STP, 1990 - 1994

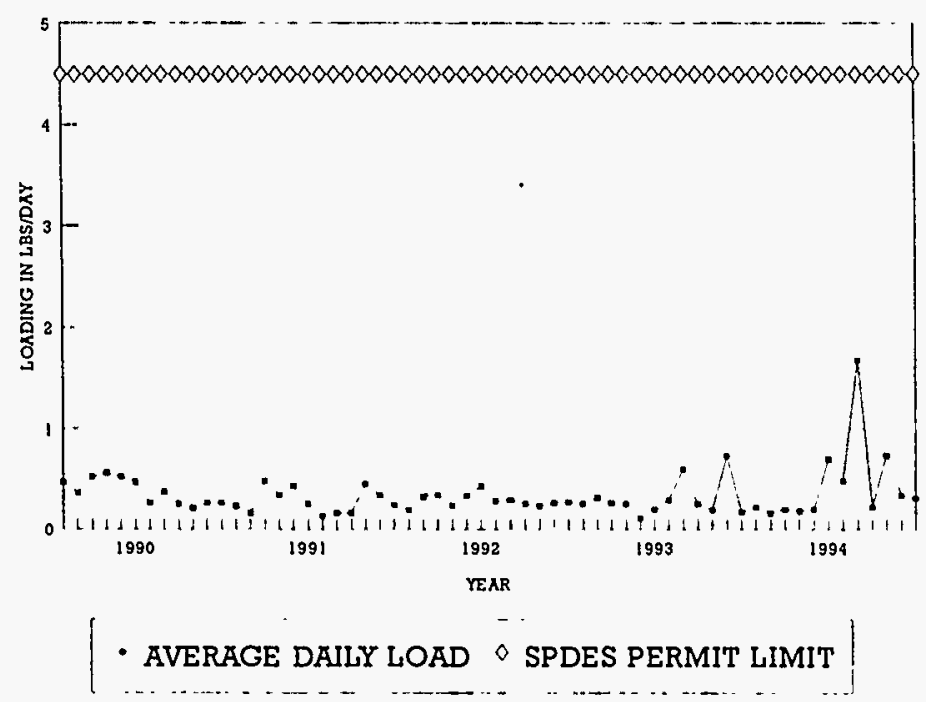


Figure 4-14

MAXIMUM EFFLUENT CONCENTRATION OF IRON DISCHARGED BY BNL'S STP, 1990 - 1994

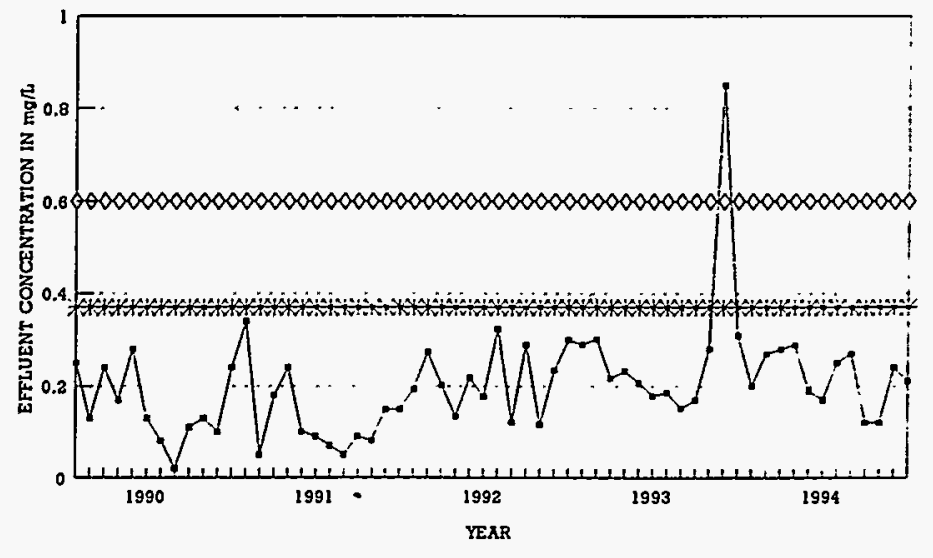

- EFFLUENT CONC. $\quad \leadsto$ SPDES PERMIT LIMIT * 12/94 PROP. SPDES LMT. 


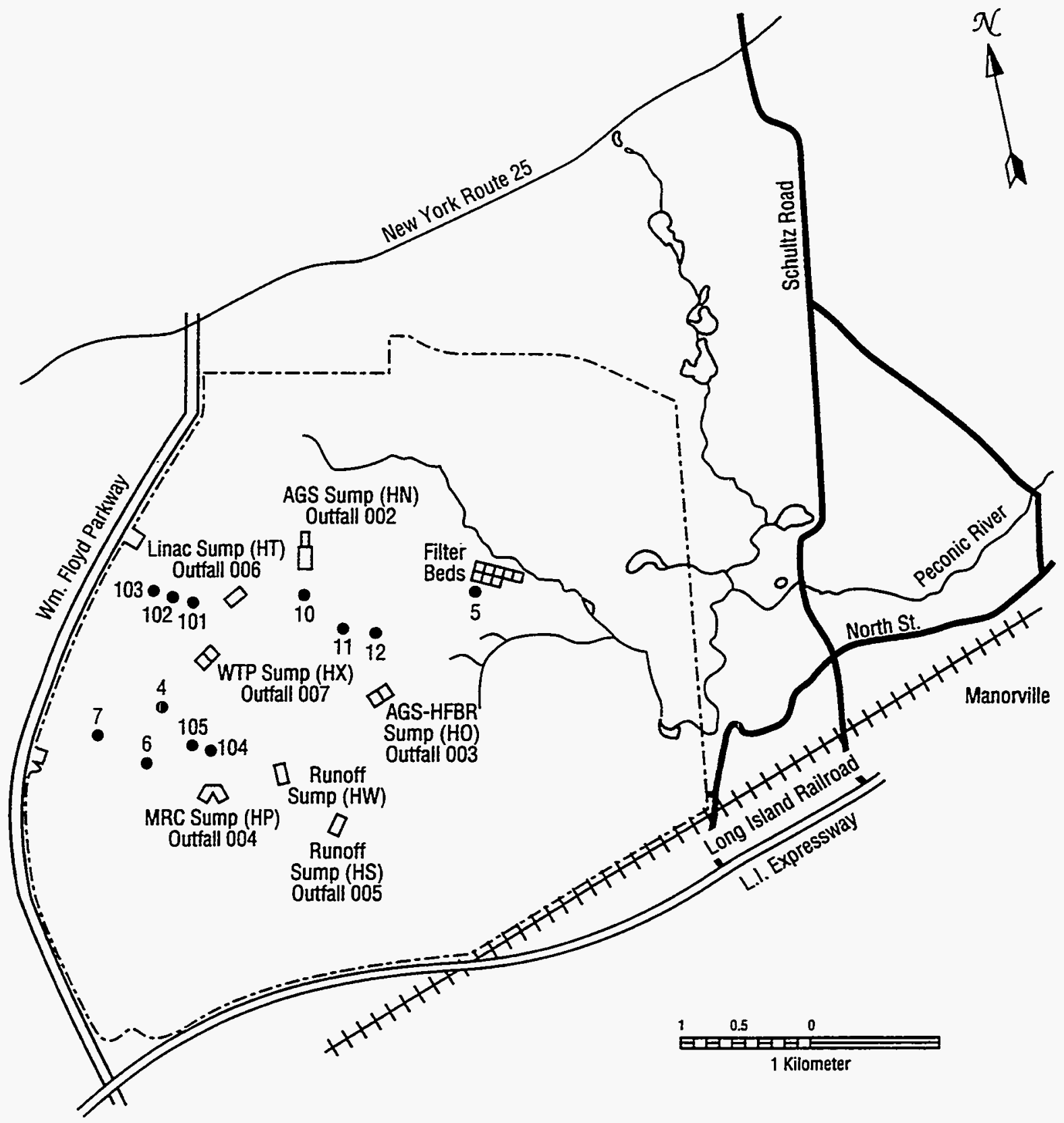

Figure 4-15 On-Site: Potable and supply wells and recharge sumps. 


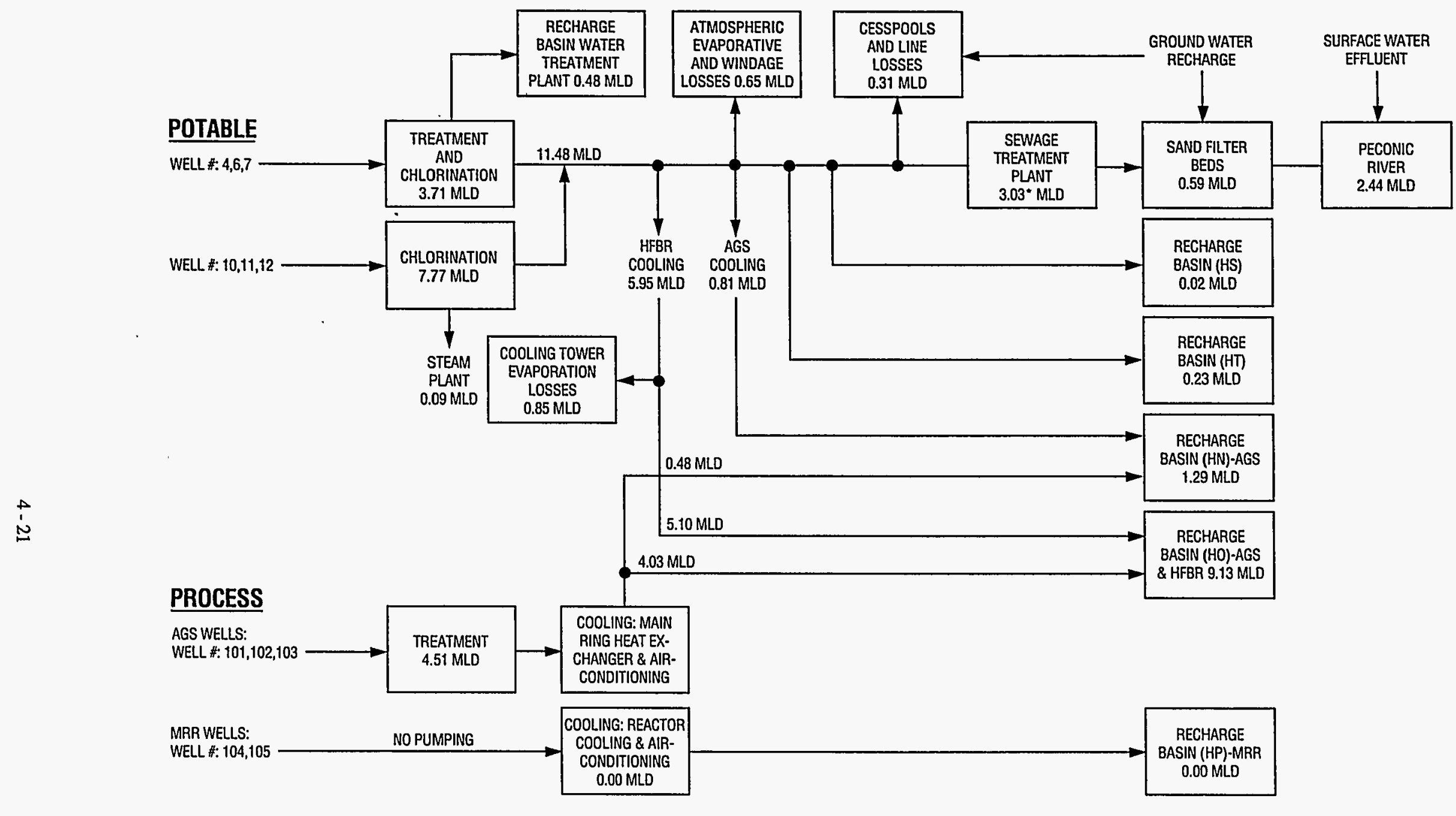

NOTE: WELL \#S: 104 \& 105 WERE NOT OPERATING.

"THIS ALSO INCLUDES STORM RUN-OFF THROUGH THE SANITARY SYSTEM.

BROOKHAVEN NATIONAL LABORATORY SCHEMATIC OF WATER USE AND FLOW FOR 1994

Figure 4-16 
to recharge basin HX. There was no recharge to Basin HP (Outfall 004) in 1994 because the MRR operated using cooling water from the Chilled water Facility.

A polyelectrolyte and dispersant was added to the AGS cooling and process water supply to keep the ambient iron in solution. of the total AGS pumpage, approximately 0.81 MLD was discharged to the HN Basin, and 4.03 MLD to the HO Basin. The HEBR secondary cooling system water recirculates through mechanical cooling towers and was treated with inorganic polyphosphate and tolytriazole to control corrosion and deposition of solids. The blowdown from this system 15.10 MLD) was also discharged to the Ho Basin. During 1994 water samples were collected from recharge basins HN, HO, HS, HT and HW. No samples were collected at recharge basin $\mathrm{HP}$ due to a lack of flow at this location. These locations are scheduled to be sampled quarterly, but due to unscheduled sampling requests, they were only sampled two times during 1994. Recharge Basin HX, which receives WTP filter backwash, was not sampled during CY 1994. This discharge will be sampled monthly under the provisions of the proposed SPDES permit. Samples collected at all recharge basins were analyzed for radiological and nonradiological parameters.

\subsubsection{Recharge Basins - Radiological Analyses}

Radiological results for recharge basin samples are reported in Table 4-5. The data indicates that trace quantities of activity were discharged to recharge basin HN. All concentrations detected were small fractions of effluent release limits. The activity detected at recharge basin HN resulted from the discharge of primary magnet rinse water into the recharge basin. The observed concentrations of Be-7 result from high energy particle interactions in the cooling water at both the AGS and LINAC facilities. The presence of the remaining radionuclides is most likely due to activation of facility components and subsequent corrosion. No samples contained strontium-90 above ambient levels and for virtually all samples the tritium concentration was at or less than the system MDL. If a person ingested water from basin HN as the sole source of drinking water for one year, this would result in a committed effective dose equivalent of less than 0.005 mrem $(5 \mathrm{E}-5 \mathrm{mSv})$.

\subsubsection{Recharge Basins - Nonradiological Analyses}

To determine the overall impact of these discharges on the environment, the analytical data for samples collected from the recharge basins is compared to groundwater discharge standards promulgated under 6NYCRR Part 703.6. Samples from the recharge basins were analyzed for water quality parameters, metals and volatile organic compounds (VoCs). The water quality and metals data have been summarized in Tables $4-6$ and 4-7, respectively. With regard to vocs analyses, only trace concentrations (i.e., 2 ppb or less) of 1, 1,1 TCA and/or chloroform were detected in the samples collected from basins HN, HO, and HT. Review of the analytical data presented in Tables $4-6$ and 4-7 shows all parameters, except for iron at recharge basin $\mathrm{HO}$ and $\mathrm{pH}$ at recharge basin $\mathrm{HT}$ and HO, to comply with the respective groundwater discharge standards. Effluents to recharge basin Ho contain elevated levels of iron and low pH due to the discharge of groundwater used in once through cooling water systems. The groundwater contains elevated concentrations of naturally occurring iron and typically has a pH less than 6.5 . recharge basin HT receives low volumes of cooling water and storm water run-off which also typically has a pH of less than 6.5 and is the most likely cause for the depressed $\mathrm{pH}$ observation.

Under the provisions of the revised draft SPDES permit, monitoring of the recharge basins will become more vigorous in CY 1995. Monthly samples will be collected for subsequent $\mathrm{pH}$ and $\mathrm{oil}$ and grease analysis and quarterly samples 
Table 4 - 5

BNL Site Environmental Report for Calendar Year 1994

Radiological Analysis of Recharge Basin Water

Annual Radionuclide Concentrations

\begin{tabular}{|c|c|c|c|c|c|c|c|c|c|c|c|}
\hline Location & $\begin{array}{c}\text { Collect } \\
\text { Date }\end{array}$ & $\begin{array}{c}\mathrm{Be-7} \\
\text { (pCi/L) }\end{array}$ & $\begin{array}{c}\mathrm{Na-22} \\
\text { (pCi/L) }\end{array}$ & $\begin{array}{l}\text { Co-60 } \\
\text { (pCi/L) }\end{array}$ & $\begin{array}{c}K-40 \\
\text { (pCi/L) }\end{array}$ & $\begin{array}{c}V-48 \\
(p C i / L)\end{array}$ & $\begin{array}{c}\text { Cr-51 } \\
\text { (pCi/L) }\end{array}$ & $\begin{array}{l}\text { Co-58 } \\
\text { (pCi/L) }\end{array}$ & $\begin{array}{l}\text { Tritium } \\
\text { (pCi/L) }\end{array}$ & $\begin{array}{l}\text { G. Alpha } \\
\text { (pCi/L) }\end{array}$ & $\begin{array}{l}\text { G. Beta } \\
\text { (pCi/L) }\end{array}$ \\
\hline \multirow{3}{*}{$\begin{array}{l}H T \\
H T\end{array}$} & 01-Mar-94 & -- & 0.28 & -- & 2.86 & - & - & - & 622.00 & -0.32 & 3.56 \\
\hline & 11-Jul-94 & -- & -- & --- & $\cdots$ & - & - & - & 38.90 & -0.26 & -4.16 \\
\hline & Avg & -- & 0.14 & $-\cdots$ & 1.43 & - & - & - & 330.45 & -0.29 & $\therefore-0.30$ \\
\hline \multirow[t]{2}{*}{ HS } & 31-Mar-94 & - & -- & 0.98 & -- & - & - & - & 687.00 & 0.28 & 0.34 \\
\hline & Avg & --- & - & 0.98 & -- & - & - & -- & 687.00 & 0.28 & 0.34 \\
\hline \multirow[t]{2}{*}{$\begin{array}{l}\mathrm{HO} \\
\mathrm{HO}\end{array}$} & $\begin{array}{r}\text { 01-Mar-94 } \\
\text { 14-Jul-94 }\end{array}$ & -- & - & $\overline{-}$ & --- & -- & $\overline{-}$ & $\overline{-}$ & $\begin{array}{r}8.08 \\
82.70\end{array}$ & $\begin{array}{l}-0.20 \\
-0.90\end{array}$ & $\begin{array}{l}1.69 \\
1.64\end{array}$ \\
\hline & Avg & -- & -- & - & -- & -- & - & -- & 45.39 & -0.55 & 1.67 \\
\hline \multirow[t]{2}{*}{$\begin{array}{l}H N \\
H N\end{array}$} & $\begin{array}{r}12-J u l-94 \\
31-\text { Mar-94 }\end{array}$ & $\begin{array}{l}12.90 \\
---\end{array}$ & 0.63 & - & $\begin{array}{l}2.09 \\
---\end{array}$ & $\begin{array}{l}2.11 \\
-\end{array}$ & 11.70 & $\begin{array}{l}0.53 \\
--\end{array}$ & $\begin{array}{r}181.00 \\
-42.80\end{array}$ & $\begin{array}{r}-0.36 \\
0.08\end{array}$ & $\begin{array}{l}9.08 \\
0.99\end{array}$ \\
\hline & Avg & 6.45 & 0.32 & - & 1.05 & 1.06 & 5.85 & 0.26 & 69.10 & -0.14 & 5.04 \\
\hline \multicolumn{2}{|c|}{ Typical MDL } & 1.60 & 0.20 & 0.23 & 3.90 & --- & 1.60 & 0.18 & 300.00 & 0.46 & 1.20 \\
\hline \multicolumn{2}{|c|}{ DOE Order 5400.5 DCG* } & $1,000,000$ & 10,000 & 10,000 & 7,000 & \multicolumn{2}{|c|}{$20,0001,000,000$} & \multicolumn{3}{|c|}{$40,0002,000,000$} & -- \\
\hline \multicolumn{2}{|c|}{ SDWA Concentration ${ }^{\star *}$} & 40,000 & 400 & 400 & 1,750 & 800 & 40,000 & 10,000 & 80,000 & & -- \\
\hline
\end{tabular}

*DCG = Derived Concentration Guide. The DCG value represents the concentration of a radionuclide in water that would cause a commi dose equivalent (CEDE) of 100 mrem if 2 liters a day were ingested for one year.

**Concentration required to produce the Safe Drinking Water Act (SDWA) annual dose limit of 4 mrem.

Note: Basin HP was dry in 1994. 
Table 46

BNL Site Environmental Report for Calendar Year 1994

Water Quality Data for On-Site Recharge Basins

\begin{tabular}{|c|c|c|c|c|c|c|c|}
\hline Location (a) & & $\begin{array}{l}\text { pH } \\
\text { su }\end{array}$ & $\begin{array}{c}\text { Temperature } \\
\text { C }\end{array}$ & $\begin{array}{l}\text { Conductivity } \\
\text { umhos } / \mathrm{cm}\end{array}$ & $\begin{array}{c}\text { Chlorides } \\
\text { mg/L }\end{array}$ & $\begin{array}{l}\text { Sulfates } \\
\text { mg/L }\end{array}$ & $\begin{array}{c}\text { Nitrate as } N(b) \\
\text { mg/L }\end{array}$ \\
\hline $\begin{array}{l}\text { HN } \\
\text { (RHIC Recharge) }\end{array}$ & $\begin{array}{c}\mathrm{N} \\
\text { Minimum } \\
\text { Maximum } \\
\text { Average }\end{array}$ & $\begin{array}{c}2 \\
7.20 \\
7.60 \\
\text { NA }\end{array}$ & $\begin{array}{c}2.00 \\
11.90 \\
27.40 \\
19.65\end{array}$ & $\begin{array}{c}2.00 \\
76.30 \\
161.60 \\
118.95\end{array}$ & $\begin{array}{c}2.00 \\
4.90 \\
21.70 \\
13.30\end{array}$ & $\begin{array}{c}2.00 \\
4.10 \\
16.10 \\
10.10\end{array}$ & $\begin{array}{l}2.00 \\
<1.0 \\
<1.0 \\
<1.0\end{array}$ \\
\hline $\begin{array}{l}\text { HO } \\
\text { (HFBR-AGS) }\end{array}$ & $\begin{array}{c}\mathrm{N} \\
\text { Minimum } \\
\text { Maximum } \\
\text { Average }\end{array}$ & $\begin{array}{c}2 \\
6.30 \\
6.70 \\
\text { NA }\end{array}$ & $\begin{array}{c}2.00 \\
12.00 \\
18.80 \\
15.40\end{array}$ & $\begin{array}{c}2.00 \\
123.10 \\
153.00 \\
138.05\end{array}$ & $\begin{array}{c}2.00 \\
19.00 \\
19.00 \\
19.00\end{array}$ & $\begin{array}{c}2.00 \\
9.50 \\
15.50 \\
12.50\end{array}$ & $\begin{array}{l}2.00 \\
<1.0 \\
<1.0 \\
<1.0\end{array}$ \\
\hline $\begin{array}{l}\text { HS } \\
\text { (Storm Water) }\end{array}$ & $\stackrel{\mathrm{N}}{\text { Concentration }}$ & $\begin{array}{c}1 \\
6.50\end{array}$ & $\begin{array}{c}1.00 \\
13.20\end{array}$ & $\begin{array}{c}1.00 \\
60.70\end{array}$ & $\begin{array}{l}1.00 \\
<4.0\end{array}$ & $\begin{array}{l}1.00 \\
<4.0\end{array}$ & $\begin{array}{l}1.00 \\
<1.0\end{array}$ \\
\hline $\begin{array}{l}\text { HT } \\
\text { (LINAC) }\end{array}$ & $\begin{array}{c}\mathrm{N} \\
\text { Minimum } \\
\text { Maximum } \\
\text { Average }\end{array}$ & $\begin{array}{c}4 \\
6.40 \\
6.70 \\
\text { NA }\end{array}$ & $\begin{array}{c}4.00 \\
8.50 \\
21.30 \\
15.70\end{array}$ & $\begin{array}{c}4.00 \\
115.40 \\
155.80 \\
135.60\end{array}$ & $\begin{array}{c}4.00 \\
15.80 \\
20.10 \\
18.30\end{array}$ & $\begin{array}{c}4.00 \\
11.00 \\
12.20 \\
11.60\end{array}$ & $\begin{array}{l}4.00 \\
<1.0 \\
<1.0 \\
<1.0\end{array}$ \\
\hline $\begin{array}{l}\text { HW } \\
\text { (Weaver Rd.) }\end{array}$ & $\stackrel{\mathrm{N}}{\text { Concentration }}$ & $\begin{array}{c}1 \\
7.10\end{array}$ & $\begin{array}{c}1.00 \\
11.80\end{array}$ & $\begin{array}{l}1.00 \\
81.80\end{array}$ & $\begin{array}{c}1.00 \\
11.80\end{array}$ & $\begin{array}{l}1.00 \\
<4.0\end{array}$ & $\begin{array}{l}1.00 \\
<1.0\end{array}$ \\
\hline $\begin{array}{l}\text { NYSDEC SPDES Effluent or } \\
\text { Water Quality Standards }\end{array}$ & & $6.5-8.5$ & (c) & (c) & 500.00 & 500.00 & 20.00 \\
\hline Typical MDL & & NA & NA & 10.00 & 4.00 & 4.00 & 1.00 \\
\hline
\end{tabular}

MDL: Minimum Detection Limit.

NA: Not Applicable.

(a): The location of the recharge basins is provided in Figure 25.

(b): The holding times specified by the USEPA were exceeded for all nitrate analyses.

(c): No effluent standard specified. 
Table 4-7

BNL Site Environmental Report for Calendar Year 1994

Metals Data for On-Site Recharge Basins

\begin{tabular}{|c|c|c|c|c|c|c|c|c|c|c|c|c|}
\hline Location (a) & $\mathbf{N}$ & & $\begin{array}{c}\mathrm{Ag} \\
\mathrm{mg} / \mathrm{L}\end{array}$ & $\begin{array}{c}\mathrm{Cd} \\
\mathrm{mg} / \mathrm{L}\end{array}$ & $\begin{array}{c}\mathrm{Cr} \\
\mathrm{mg} / \mathrm{L}\end{array}$ & $\begin{array}{c}\mathrm{Cu} \\
\mathrm{mg} / \mathrm{L}\end{array}$ & $\begin{array}{c}\mathrm{Fe} \\
\mathrm{mg} / \mathrm{L}\end{array}$ & $\underset{\mathrm{mg} / \mathrm{L}}{\mathrm{Hg}}$ & $\begin{array}{c}\mathrm{Mn} \\
\mathrm{mg} / \mathrm{L}\end{array}$ & $\underset{\mathrm{mg} / \mathrm{L}}{\mathrm{Na}}$ & $\begin{array}{c}\mathrm{Pb} \\
\mathrm{mg} / \mathrm{L}\end{array}$ & $\begin{array}{l}\mathrm{Zn} \\
\mathrm{mg} / \mathrm{L}\end{array}$ \\
\hline $\begin{array}{c}\text { HN } \\
(\mathrm{RHIC})\end{array}$ & 2 & $\begin{array}{c}\text { Minimum } \\
\text { Maximum } \\
\text { Average }\end{array}$ & $\begin{array}{l}<0.025 \\
<0.025 \\
<0.025\end{array}$ & $\begin{array}{l}<0.0005 \\
<0.0005 \\
<0.0005\end{array}$ & $\begin{array}{l}<0.005 \\
<0.005 \\
<0.005\end{array}$ & $\begin{array}{l}<0.05 \\
0.085 \\
<0.05\end{array}$ & $\begin{array}{l}0.086 \\
0.165 \\
0.126\end{array}$ & $\begin{array}{l}<0.0002 \\
<0.0002 \\
<0.0002\end{array}$ & $\begin{array}{l}<0.05 \\
<0.05 \\
<0.05\end{array}$ & $\begin{array}{c}6.2 \\
15.6 \\
10.9\end{array}$ & $\begin{array}{l}<0.002 \\
0.004 \\
0.002\end{array}$ & $\begin{array}{l}0.064 \\
0.084 \\
0.074\end{array}$ \\
\hline $\begin{array}{c}\text { HO } \\
\text { (AGS/HFBR) }\end{array}$ & 2 & $\begin{array}{l}\text { Minimum } \\
\text { Maximum } \\
\text { Average }\end{array}$ & $\begin{array}{l}<0.025 \\
<0.025 \\
<0.025\end{array}$ & $\begin{array}{l}<0.0005 \\
<0.0005 \\
<0.0005\end{array}$ & $\begin{array}{l}<0.005 \\
<0.005 \\
<0.005\end{array}$ & $\begin{array}{l}<0.05 \\
<0.05 \\
<0.05\end{array}$ & $\begin{array}{c}<0.075 \\
1.472 \\
0.74\end{array}$ & $\begin{array}{l}<0.0002 \\
0.0003 \\
<0.0002\end{array}$ & $\begin{array}{l}<0.05 \\
0.24 \\
0.12\end{array}$ & $\begin{array}{l}15.2 \\
22.1 \\
18.7\end{array}$ & $\begin{array}{l}<0.002 \\
<0.002 \\
<0.002\end{array}$ & $\begin{array}{l}<0.02 \\
0.035 \\
<0.02\end{array}$ \\
\hline $\begin{array}{c}\text { HS } \\
\text { (STORM WATER) }\end{array}$ & 1 & Concentration & $<0.025$ & $<0.0005$ & $<0.005$ & $<0.05$ & 0.1 & $<0.0002$ & $<0.05$ & 4.7 & $<0.002$ & 0.075 \\
\hline $\begin{array}{l}H T(b) \\
\text { (LINAC) }\end{array}$ & 4 & $\begin{array}{l}\text { Minimum } \\
\text { Maximum } \\
\text { Average }\end{array}$ & $\begin{array}{l}<0.025 \\
<0.025 \\
<0.025\end{array}$ & $\begin{array}{l}<0.0005 \\
<0.0005 \\
<0.0005\end{array}$ & $\begin{array}{l}<0.005 \\
<0.005 \\
<0.005\end{array}$ & $\begin{array}{c}<0.05 \\
0.134 \\
0.06\end{array}$ & $\begin{array}{c}<0.075 \\
0.13 \\
<0.075\end{array}$ & $\begin{array}{l}<0.0002 \\
<0.0002 \\
<0.0002\end{array}$ & $\begin{array}{l}<0.05 \\
<0.05 \\
<0.05\end{array}$ & $\begin{array}{l}11.1 \\
19.6 \\
15.3\end{array}$ & $\begin{array}{l}<0.002 \\
<0.002 \\
<0.002\end{array}$ & $\begin{array}{c}<0.02 \\
0.096 \\
0.05\end{array}$ \\
\hline $\begin{array}{c}\text { HW } \\
\text { (WEAVER RD.) }\end{array}$ & 1 & Concentration & $<0.025$ & $<0.0005$ & $<0.005$ & $<0.05$ & $<0.075$ & $<0.0002$ & $<0.05$ & 9.8 & $<0.002$ & 0.037 \\
\hline $\begin{array}{l}\text { NYSDEC } \\
\text { Effluent Limitation }\end{array}$ & & & 0.1 & 0.02 & 0.1 & 1 & 0.6 & 0.004 & 0.6 & (c) & 0.05 & 5 \\
\hline Typlcal MDL & & & 0.025 & 0.0005 & 0.005 & 0.05 & 0.075 & 0.0002 & 0.05 & 1 & 0.002 & 0.02 \\
\hline
\end{tabular}

N: No. of samples

MDL: Minimum Detection Limit

(a): Locations of recharge basins are shown on Figure 25.

(b): This recharge basin has two effluents which are denoted HT and HT2

(c): No effluent standard specified.

The average metals concentration has been calculated by summing all detectable quantities then dividing the sum by the total number of samples collected.

All non-detectable quantities have been evaluated as zero. If the average is less than the MDL, it is reported as less than MDL. 
will be collected for vocs and metals analyses. In addition, sampling and analysis of storm water discharges is required for several basins or discharges receiving only storm water run-off. To facilitate monitoring of flow and collection of samples, in CY 1994 the PE Division completed construction of monitoring stations at basins HT, HO, HS, and HN. These structures include a monitoring shed and a flow mensuration device (e.g., parshall or H-flume). A flow meter and chart recorder have been installed within each of the sheds for tracking daily flows to the basins. Sample collection devices manufactured by Isco have also been purchased and installed for the collection of either time or flow weighted composite samples. These devices are expected to be on-line by the end of the first quarter of 1995 .

\subsubsection{Environmental Measurements and Analyses}

\subsubsection{External Radiation Monitoring}

Dose equivalent rates from gamma radiation at the site boundary, including natural background, weapons test fallout, and that attributable to Laboratory

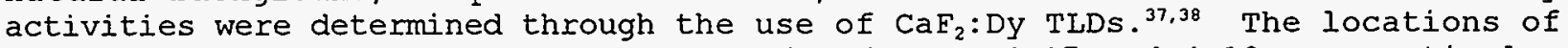
the on-site and off-site TLDs are shown in Figures 4-17 and 4-18, respectively. The TLDs were positioned using a standard 16 sector wind-rose with Sector No. 1 centering on true north. The dose equivalent rates observed are given in Table 4-8. The annual average dose equivalent rate as indicated by all TLDs was 66.9 mrem/yr $(0.67 \mathrm{msv} / \mathrm{yr})$. The dose equivalent rate at the site boundary was 65.1 $\mathrm{mrem} / \mathrm{yr}(0.65 \mathrm{mSv} / \mathrm{yr})$, while the off-site average rate was $68.8 \mathrm{mrem} / \mathrm{yr}$ (0.69 $\mathrm{mSv} / \mathrm{yr}$ ). Differences between the on-site and off-site TLD dose equivalent rate are the result of the terrestrial component of the external dose measurement and not related to BNL operations. ${ }^{9}$

The maximum dose at the site boundary due to argon-41 and oxygen-15 airborne emissions was calculated using CAP88 $8^{39}$ as 0.114 mrem (0.001 mSv). This value is not measurable using today's best available technology.

\subsubsection{Atmospheric Radioactivity}

The Laboratory's environmental air monitoring program is designed to identify and quantify airborne radioactivity attributable to natural sources, to activities unrelated to the Laboratory (e.g., above ground nuclear weapon tests), and to Laboratory activities. The predominant radionuclides measured in air at the site boundary were tritium, fission products related to weapons test, fallout, and beryllium-7 produced in the atmosphere as a result of cosmic particle interaction in the atmosphere.

\subsubsection{Tritium Analyses}

Sampling for tritium vapor was performed at eighteen different on-site stations that also match TLD locations (as shown in Figure 4-17). Air samples were also routinely collected in the analytical lab (Location 0920). The method of sampling was the collection of water vapor by drawing a stream of air through silica gel cartridges. The data collected from these stations are presented in Table 4-9. The maximum annual average tritium concentration at the site boundary was observed at station 0201 ( $\mathrm{NE}$ Location) and was $4.42 \mathrm{pCi} / \mathrm{m}^{3}\left(0.16 \mathrm{~Bq} / \mathrm{m}^{2}\right)$. This air concentration would result in whole body dose from the inhalation and submersion pathways of $0.004 \mathrm{mrem}$ (4E-5 mSv). By comparison, the National Council on Radiation Protection (NCRP) publication 91 recommends that 1 mrem $(0.01 \mathrm{mSv})$ is a dose which is below regulatory concern. ${ }^{40}$ 
Table 4-8

BNL Site Environmental Report for Calendar Year 1994 External Dose Equivalent Rates for TLD Locations

\begin{tabular}{|c|c|c|c|c|c|}
\hline Location & Historic ID & $\begin{array}{c}\text { No. of } \\
\text { Samples }\end{array}$ & $\begin{array}{c}\text { Exposure Period } \\
\text { (days) }\end{array}$ & & $\begin{array}{c}\text { Annual Dose } \\
\text { (mrem/yr) }\end{array}$ \\
\hline $000-400$ & 1 T3.0 & 4 & 364 & & 57.75 \\
\hline $000-401$ & $1 \mathrm{~T} 8.8$ & 4 & 364 & & 55.32 \\
\hline $000-402$ & $2 \mathrm{~T} 3.2$ & 4 & 340 & & 69.85 \\
\hline $000-403$ & $2 \mathrm{~T} 10.5$ & 4 & 365 & & 73.33 \\
\hline $000-404$ & $3 T 8.8$ & 4 & 367 & & 61.51 \\
\hline $000-405$ & $4 \mathrm{TT} .5$ & 4 & 367 & & 60.81 \\
\hline $000-406$ & $5 T 4.2$ & 4 & 361 & & 59.10 \\
\hline $000-407$ & $5 \mathrm{~T} 6.5$ & 3 & 265 & & 61.70 \\
\hline $000-408$ & $5 T 17.1$ & 4 & 369 & & 59.60 \\
\hline $000-409$ & $6 \mathrm{~T} 5.6$ & 4 & 358 & & 60.10 \\
\hline $000-410$ & 7T9.7 & 4 & 358 & & 60.30 \\
\hline $000-411$ & $8 \mathrm{~T} 8.0$ & 4 & 384 & & 66.06 \\
\hline $000-412$ & $9 \mathrm{~T} 8.3$ & 4 & 358 & & 73.10 \\
\hline $000-413$ & $10 \mathrm{~T} 12.0$ & 4 & 369 & & 69.33 \\
\hline $000-414$ & $10 \mathrm{~T} 9.3$ & 4 & 367 & & 69.24 \\
\hline $000-415$ & $11 \mathrm{T3.7}$ & 4 & 356 & & 60.94 \\
\hline $000-416$ & $12 \mathrm{~T} 5.0$ & 4 & 370 & & 64.87 \\
\hline $000-417$ & $12 T 7.2$ & 4 & 347 & & 69.25 \\
\hline $000-418$ & $12 T 12.5$ & 4 & 348 & & 69.67 \\
\hline $000-419$ & $13 T 8.2$ & 3 & 346 & & 63.87 \\
\hline $000-420$ & $13 T 2.6$ & 4 & 367 & & 63.33 \\
\hline $000-421$ & $14 \mathrm{~T} 5.6$ & 4 & 356 & & 79.86 \\
\hline $000-422$ & 14T3.1 & 1 & 83 & & 76.24 \\
\hline $000-423$ & $15 T 3.0$ & 4 & 356 & & 60.93 \\
\hline $000-424$ & $16 T 3.4$ & 4 & 367 & & 61.69 \\
\hline $105-400$ & ${\mathrm{~N} / \mathrm{A}^{*}}^{*}$ & 4 & 358 & & 72.82 \\
\hline $108-450$ & $N / A^{*}$ & 4 & 358 & & 76.45 \\
\hline $109-400$ & $11 \mathrm{~T} 2.1$ (P4) & 4 & 358 & & 66.84 \\
\hline $011-400$ & $1 T 2.2$ & 4 & 358 & & 62.26 \\
\hline $111-400$ & $10 T 1.8$ & 4 & 358 & & 70.75 \\
\hline $122-400$ & ${\mathrm{~N} / \mathrm{A}^{*}}^{*}$ & 4 & 358 & & 64.69 \\
\hline $123-400$ & $8 T 2.3$ & 3 & 270 & & 60.73 \\
\hline $126-400$ & 9T2.6 & 4 & 358 & & 70.89 \\
\hline $013-400$ & $2 T 2.6$ & 4 & 358 & & 63.98 \\
\hline $017-400$ & $16 \mathrm{~T} 2.1(\mathrm{P} 2)$ & 4 & 358 & & 59.09 \\
\hline $030-400$ & $3 T 2.8$ & 4 & 358 & & 65.83 \\
\hline $034-400$ & $15 T 1.7$ & 4 & 358 & & 69.44 \\
\hline $034-401$ & $15 T 1.4$ & 4 & 270 & & 76.54 \\
\hline $037-400$ & S13 & 4 & 358 & & 71.75 \\
\hline $049-400$ & $4 \mathrm{~T} 2.6$ & 4 & 358 & & 62.39 \\
\hline $053-400$ & $14 T 1.3$ & 4 & 358 & & 76.20 \\
\hline $063-400$ & $13 T$ & 4 & 358 & & 69.91 \\
\hline $073-400$ & $13 T 1.4$ & 4 & 358 & & 76.17 \\
\hline $080-400$ & $5 T$ & 3 & 274 & & 73.86 \\
\hline $082-400$ & $12 T$ & 4 & 358 & & 77.52 \\
\hline $090-400$ & 6 T2.8 (P7) & 4 & 358 & & 71.79 \\
\hline $074-450$ & BLDG 197 & 4 & 358 & & 63.41 \\
\hline $074-451$ & BLDG 907 & 4 & 358 & & 59.98 \\
\hline $075-454$ & Bkg & 1 & 91 & & 26.80 \\
\hline $075-454$ & Bkg & 3 & 284 & & 29.79 \\
\hline $075-455$ & Bkg & 1 & 99 & & 28.33 \\
\hline $075-455$ & Bkg & 3 & 338 & & 25.03 \\
\hline \multicolumn{6}{|c|}{ "New Site. Begun in 1993.} \\
\hline \multicolumn{3}{|c|}{ Annual Average, all locations: } & 66.90 & $+1-$ & mrem \\
\hline \multicolumn{3}{|c|}{ Annual Average, on-site locations: } & 65.11 & $+/-$ & mrem \\
\hline \multicolumn{3}{|c|}{ Annual Average, off-site locations: } & 68.84 & $+/-\quad 5.9$ & mrem \\
\hline \multicolumn{3}{|c|}{ Annual Average, Gun Barrel TLDs: } & 28.29 & $+/-$ & mrem \\
\hline
\end{tabular}


Table 4-9

BNL Site Environmental Report for Calendar Year 1994

Ambient Tritium Concentrations at Perimeter and Control Locations

\begin{tabular}{|c|c|c|c|c|c|}
\hline Location & $\mathrm{N}$ & $\begin{array}{c}\text { Min. } \\
\left(\mathrm{pCi} / \mathrm{m}^{\wedge} 3\right)\end{array}$ & $\begin{array}{c}\operatorname{Max} . \\
\left(\mathrm{pCi} / \mathrm{m}^{\wedge} 3\right)\end{array}$ & $\begin{array}{c}\text { Avg. } \\
\left(\mathrm{pCi} / \mathrm{m}^{\wedge} 3\right)\end{array}$ & $\begin{array}{c}\text { Flow Wt'd. } \\
\text { Avg. } \\
\left(\mathrm{pCi} / \mathrm{m}^{\wedge} 3\right)\end{array}$ \\
\hline 0101 & 42 & -1.27 & 7.22 & 1.62 & 1.60 \\
\hline 0201 & 40 & -3.71 & 53.02 & 4.42 & 4.51 \\
\hline 0302 & 50 & -2.20 & 21.34 & 2.43 & 2.44 \\
\hline 0401 & 47 & -5.83 & 12.11 & 1.94 & 1.90 \\
\hline 0501 & 39 & -2.97 & 10.08 & 2.01 & 2.01 \\
\hline 0601 & 45 & -2.88 & 40.47 & 4.31 & 4.26 \\
\hline 0602 & 45 & -21.47 & 15.97 & 1.12 & 1.45 \\
\hline 0702 & 53 & -3.15 & 85.73 & 3.43 & 3.52 \\
\hline 0803 & 45 & -4.90 & 9.83 & 1.32 & 1.31 \\
\hline 0902 & 48 & -3.04 & 33.50 & 3.51 & 3.36 \\
\hline 1001 & 45 & -2.81 & 10.87 & 1.71 & 1.59 \\
\hline 1101 & 45 & -4.39 & 8.13 & 1.33 & 1.27 \\
\hline 1301 & 47 & -2.71 & 10.43 & 1.92 & 1.80 \\
\hline 1401 & 53 & -5.17 & 10.37 & 1.52 & 1.50 \\
\hline 1501 & 46 & -3.02 & 17.42 & 1.96 & 1.79 \\
\hline 1602 & 47 & -3.11 & 11.08 & 1.57 & 1.63 \\
\hline \multicolumn{6}{|c|}{ Process Control } \\
\hline 0920 & 44 & 0.73 & 49.24 & 9.81 & 9.64 \\
\hline \multicolumn{6}{|c|}{ Background Locations } \\
\hline 1201 & 48 & -2.32 & 22.65 & 3.96 & 3.95 \\
\hline 1601 & 33 & -0.88 & 155.86 & 8.56 & 9.26 \\
\hline
\end{tabular}

$\mathrm{N}=$ number of samples collected. 


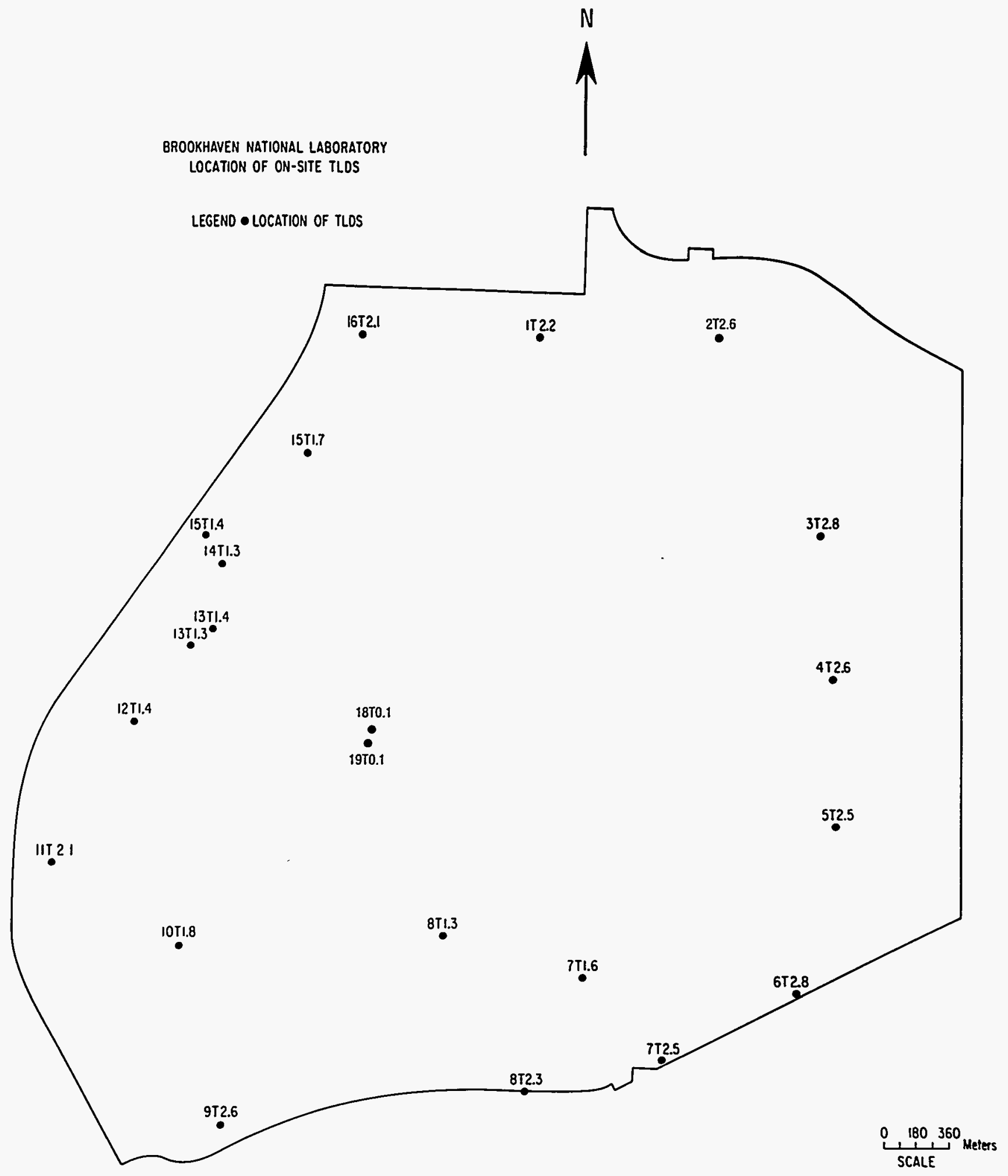

Brookhaven National Laboratory Location of On-site TLDs.

Figure $4-17$ 


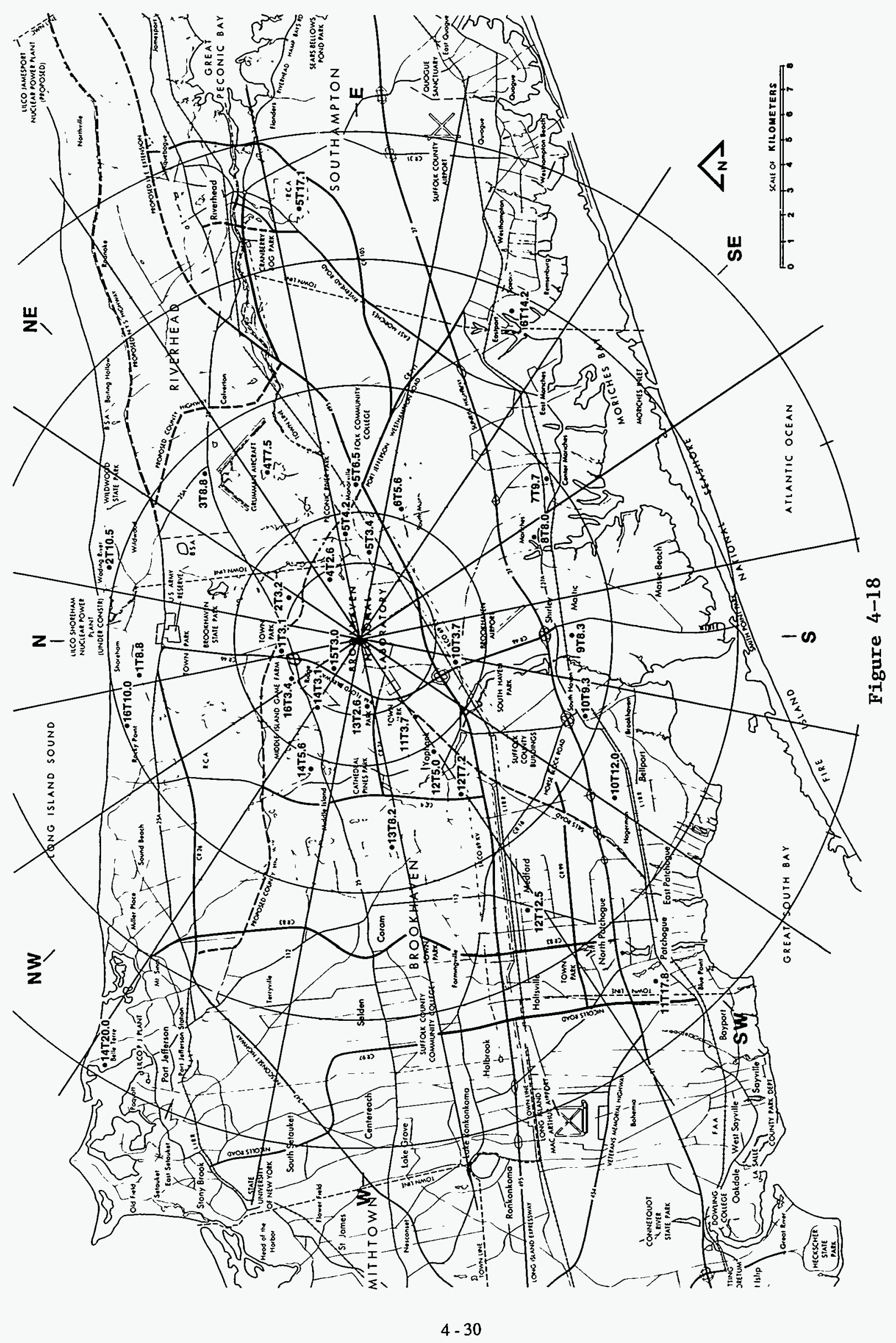


The airborne tritium concentrations measured outside Building 535 (Location 0901) was removed to make way for the trailers. Before that, it was moved for the parking lot.

For the present, site perimeter monitoring will continue to be used as a method to monitor for potential large releases and provide an upper boundary for both model verification and dose estimates. Compliance verification will be performed using CAP88 and measured source terms plus BNL meteorology. However, BNL has purchased a new site perimeter monitoring system that will use on-line neutron and gamma radiation detectors to monitor site boundary radiation levels in real time. These detectors will be placed at the same locations as the current air sampling stations and will relay exposure rate levels back to a central computer station via modem. This system will provide both a comprehensive record of site boundary radiation levels as well as instantaneous notification of any unplanned releases.

\subsubsection{Radioactive Particulates}

During 1994, positive displacement air pumps were operated at five on-site monitoring stations (0420, 0601, 0701, 1201, and 1601). The sampling media consisted of a 5-cm diameter air particulate filter followed by a $51.5 \mathrm{~cm}^{3}$ canister of triethylene diamine-impregnated charcoal for the collection of radiohalogens. Air particulate samples were collected on a weekly basis (except where the schedule was disrupted by the construction of the new environmental monitoring stations, i.e., at station 1601) and counted for gross alpha and beta activity using an anticoincidence proportional counter. The gross beta concentrations observed are comparable to EPA values for Yaphank, New York. ${ }^{5-8}$

In addition, analyses for gamma-emitting nuclides were performed on a weekly composite of the filter papers and on charcoal filter bed samples that had a sample period of one month. The analytical results for air particulate filters are shown in Table 4-10. Gamma-emitting radionuclides detected on charcoal filters are reported in Table $4-11$.

The presence of Chernobyl fallout, weapons test fallout from previous years, and cosmogenically produced radionuclides were detected by gamma spectroscopy at or near the systems minimum detectable activity levels.

\subsubsection{Terrestrial Ecological studies}

In response to a DOE Tiger Team finding (Weakness E/W-2: Lack of a Terrestrial Monitoring Program), the Laboratory in 1992, contracted IT Corporation to develop a site-wide soil and vegetation sampling plan for the BNI site. A fauna sampling program was implemented in 1992 and results were reported in the SER for 1992. This program will be repeated every five years, as such no collections were made in 1994. Similarly, a soil and vegetation collection program initiated in 1993 will be repeated every other year, as such no sampling was done in 1994. However, a routine annual sampling by sCDHS of soil, vegetation and fruits from farms in the vicinity of the laboratory was completed in June 1994. A deer sampling program, on-site and off-site, is expected to be implemented in 1995. The vegetation and soil samples were analyzed for radioactivity only.

\subsubsection{5(a) Radioactivity in Soil, Vegetation and Fruits}

The off-site soil and vegetation sampling program is a cooperative effort between BNL and the SCDHS. Local farms situated adjacent to BNL were sampled in June 1994. No radionuclides attributable to Laboratory operations were detected 
Table 4-10

BNL Site Environmental Report for Calendar Year 1994

Gross Alpha, Gross Beta and Gamma-Emitting Radionuclide Concentrations for Ambient Air Monitoring Stations

\begin{tabular}{|c|c|c|c|c|c|c|c|c|}
\hline Station & $\begin{array}{l}\text { Total Flow } \\
\left(m^{\wedge} 3\right)\end{array}$ & & $\begin{array}{c}\text { Alpha } \\
\text { (pCi/m3) }\end{array}$ & $\begin{array}{c}\text { Beta } \\
\text { (pCi/m3) }\end{array}$ & $\begin{array}{c}\mathrm{Be}-7 \\
(\mathrm{pCi} / \mathrm{m} 3)\end{array}$ & $\begin{array}{c}\mathrm{Co}-60 \\
(\mathrm{pCi} / \mathrm{m} 3)\end{array}$ & $\begin{array}{c}\text { Cs-137 } \\
\text { (pCi/m3) }\end{array}$ & $\begin{array}{c}\mathrm{K}-40 \\
(\mathrm{pCi} / \mathrm{m} 3)\end{array}$ \\
\hline \multirow[t]{4}{*}{0601} & 4449 & Min. & -0.0076 & -0.0060 & 0.1140 & ND & ND & 0.0945 \\
\hline & & Max. & 0.0040 & 0.0344 & 2.3300 & ND & ND & 0.4920 \\
\hline & & Avg. & 0.0000 & 0.0170 & 0.5236 & ND & ND & 0.2933 \\
\hline & & $N$ & 46 & 46 & 35 & 35 & 35 & 35 \\
\hline \multirow[t]{4}{*}{0701} & 5096 & Min. & -0.0038 & -0.0067 & 0.1200 & ND & 0.0168 & 0.2100 \\
\hline & & Max. & 0.0035 & 0.7220 & 0.7710 & ND & 0.0336 & 0.2620 \\
\hline & & Avg. & 0.0001 & 0.0290 & 0.3419 & ND & 0.0252 & 0.2360 \\
\hline & & $N$ & 52 & 52 & 40 & 40 & 40 & 40 \\
\hline \multirow[t]{4}{*}{0420} & 4531 & Min. & -0.0159 & -0.0571 & 0.1600 & 0.1150 & 0.0229 & 0.2530 \\
\hline & & Max. & 0.0047 & 0.4750 & 0.4860 & 0.1150 & 0.0229 & 0.2830 \\
\hline & & Avg. & -0.0003 & 0.0261 & 0.2563 & 0.1150 & 0.0229 & 0.2680 \\
\hline & & $N$ & 48 & 48 & 38 & 38 & 38 & 38 \\
\hline \multirow[t]{4}{*}{1201} & 5129 & Min. & -0.0040 & 0.0016 & 0.0777 & 0.2470 & 0.0214 & 1.1600 \\
\hline & & Max. & 0.0046 & 0.0677 & 0.5380 & 0.2470 & 0.0271 & 1.1600 \\
\hline & & Avg. & 0.0002 & 0.0190 & 0.2826 & 0.2470 & 0.0243 & 1.1600 \\
\hline & & $N$ & 52 & 52 & 39 & 39 & 39 & 39 \\
\hline \multirow[t]{4}{*}{1601} & 2954 & Min. & -0.0056 & 0.0041 & 0.1240 & ND & ND & 0.3500 \\
\hline & & Max. & 0.0027 & 0.0355 & 0.5990 & ND & ND & 0.3500 \\
\hline & & Avg. & 0.0000 & 0.0172 & 0.3270 & ND & ND & 0.3500 \\
\hline & & $\mathrm{N}$ & 31 & 31 & 19 & 19 & 19 & 19 \\
\hline DOE & $400.5 \mathrm{DAC}$ & & - & - & 50,000 & 400 & 400 & 900 \\
\hline
\end{tabular}

Note: Station 1601 was placed back in service in May following construction of new station.

$N=$ Number of samples collected.

ND $=$ Not Detected. 
Table 4 - 11

BNL Site Environmental Report for Calendar Year 1994

Air Station Charcoal Filter Gamma Analysis Results

\begin{tabular}{|c|c|c|c|c|}
\hline Station & $\begin{array}{l}\text { Total Flow } \\
\text { (m3) }\end{array}$ & & $\begin{array}{c}\mathrm{K}-40 \\
(\mathrm{pCi} / \mathrm{m} 3)\end{array}$ & $\begin{array}{c}\text { Cs-137 } \\
\text { (pCi/m3) }\end{array}$ \\
\hline \multirow[t]{4}{*}{0601} & 4449 & Minimum & 0.2640 & ND \\
\hline & & Maximum & 0.8540 & ND \\
\hline & & Average & 0.4656 & ND \\
\hline & & $N$ & 10 & 10 \\
\hline \multirow[t]{4}{*}{0701} & 5096 & Minimum & 0.0496 & 0.0073 \\
\hline & & Maximum & 1.7500 & 0.0082 \\
\hline & & Average & 0.5105 & 0.0078 \\
\hline & & $\mathbf{N}$ & 14 & 14 \\
\hline \multirow[t]{4}{*}{0420} & 4531 & Minimum & 0.0721 & 0.0095 \\
\hline & & Maximum & 1.0600 & 0.0095 \\
\hline & & Average & 0.3633 & 0.0095 \\
\hline & & $N$ & 11 & 11 \\
\hline \multirow[t]{4}{*}{1201} & 5129 & Minimum & 0.2620 & ND \\
\hline & & Maximum & 1.5200 & ND \\
\hline & & Average & 0.4928 & ND \\
\hline & & $\mathbf{N}$ & 12 & 12 \\
\hline \multirow[t]{4}{*}{1601} & 2954 & Minimum & 0.2730 & ND \\
\hline & & Maximum & 2.6100 & ND \\
\hline & & Average & 0.8604 & ND \\
\hline & & $N$ & 8 & 8 \\
\hline
\end{tabular}

$\mathrm{N}=$ Number of samples collected.

ND $=$ Not Detected.

Note: Station 1601 was placed back in service in May following construction of new station. 
in any of these samples (Table 4-12). The observed concentrations represent the contribution of primordial and cosmogenic sources, and weapons test fallout.

\subsubsection{Peconic River Aquatic Surveillance - Radiological Analyses}

Radionuclide measurements were performed on surface water samples collected from the Peconic River at six locations; HM, the location of the former site boundary, approximately 790 meters downstream of the STP discharge point; HQ, located approximately $2.1 \mathrm{~km}$ downstream from the discharge point; $H A$ and $H B$, located approximately $5 \mathrm{~km}$ downstream from the discharge point; HC, located approximately $7 \mathrm{~km}$ downstream of the discharge point; and HR, located $21 \mathrm{~km}$ downstream from the discharge point. A control location (Location HH) located on the Carmans River in North shirley, which is not influenced by BNL liquid effluent, was also sampled. The Peconic River sampling stations are identified in Figure 4-19. Routine grab sampling at Location HM and at Location $H Q$ were conducted three times per week. The locations are equipped with V-notched weirs to permit flow proportional sampling and volume measurements. Due to heavy vegetation growth down stream of these weirs, which causes no vertical drop across the weir, volume measurements could not be performed with the existing equipment. Figure 4-20 provides a twenty-four year review of liquid discharge volumes to the Peconic River and flow estimates for the Peconic River on-site. The data indicate that there was no measurable flow at the site boundary since 1983. Non-quantifiable flow, due to vegetation growth in the river bed downstream of the weir, has existed at Location HM since 1984. Between 1985 and 1994, water levels at Location HQ have been below the conduit which transports water from the BNI site to the weir at Location HQ. As stated earlier, vegetation growth below the weir is too dense to permit flow measurement using the currently installed equipment. Samples from Locations HA, HB, HC, HR, and HH were collected during the second, and fourth quarters of 1994.

The radiological data generated from the analysis of Peconic River surface water sampling are summarized in Table 4-13. The data indicate that gross beta, and cesium-137 are present above ambient levels at Locations $H M$ and $H Q$.

\subsubsection{Peconic River Aquatic Surveillance - Nonradiological Analyses}

The Peconic River was sampled at six locations during 1994; two on-site (Sampling Locations $H M$ and $H Q$ ) and four off-site (Sampling Locations $H A$, $H B$, $H C$, and HR). In addition, the Carmans River was also sampled (Location $H H$ ) as an off-site control location. These locations were sampled and analyzed for water quality parameters (i.e., pH, temperature, conductivity, and dissolved oxygen), anions (i.e., chlorides, sulfates, and nitrates), metals, and vocs routinely during 1994. Location $\mathrm{HQ}$, which is situated along the Peconic River at the $B N L$ site boundary, was not analyzed for metals and was only analyzed once for water quality parameters during 1994 due to the intermittent nature of this discharge.

A summary of water quality and metals analytical data for samples collected from these surface waters is contained in Tables 4-14 and 4-15, respectively. Review of these data indicate all water quality parameters to be consistent with the off-site control location and/or with historical data. The analytical data for metals showed all parameters to be consistent with historical data and the background Camans River station. All metals concentrations with the exception of iron are well below the existing sPDEs effluent limitations established by the NYSDEC for discharges to the Peconic River. Iron levels occur above the SPDES limits at several locations and is most probably due to the naturally high concentrations of iron in groundwater and native sediments. 
Table 4-12

BNL Site Environmental Report for Calendar Year 1994

Radionuclide Concentrations in Vegetation and Soil Around BNL

\begin{tabular}{lccccccc}
\hline \multicolumn{1}{c}{ Location } & Matrix & $\begin{array}{c}\text { Sample } \\
\text { Date }\end{array}$ & $\begin{array}{c}\text { Be-7 } \\
\text { pCi/Kg }\end{array}$ & $\begin{array}{c}\text { K-40 } \\
\text { pCi/Kg }\end{array}$ & $\begin{array}{c}\text { Cs-137 } \\
\text { pCi/Kg }\end{array}$ & $\begin{array}{l}\text { Ra-226 } \\
\text { pCi/Kg }\end{array}$ & $\begin{array}{c}\text { Th-22 } \\
\text { pCi/Kg }\end{array}$ \\
\hline Yaphank Honor Farm & Soil & $06 / 17 / 94$ & 944 & 7600 & 533 & 791 & 1400 \\
NYS Game Farm (Ridge) & Soil & $06 / 17 / 94$ & ND & 2945 & 430 & 494 & 202 \\
Berenzy's Orchard (Northville) & Soil & $06 / 17 / 94$ & ND & 5170 & 378 & 450 & 709 \\
Yaphank Honor Farm & Grass & $06 / 17 / 94$ & 4925 & 1050 & ND & ND & ND \\
NYS Game Farm (Ridge) & Grass & $06 / 17 / 94$ & 2254 & 2365 & 46 & ND & ND \\
Berenzy's Orchard (Northville) & Grass & $06 / 17 / 94$ & 2830 & 5525 & 124 & ND & ND \\
Berenzy's Orchard (Northville) & Strawberrys & $06 / 17 / 94$ & ND & ND & ND & ND & ND \\
Typical MDL & & & 0.07 & 0.18 & 0.01 & 0.03 & 0.23 \\
\hline
\end{tabular}

ND: Not Detected. Radionuclide Concentration less than the system MDL. MDL: Minimum Detection Limit. 
Table 4-13

Annual Gross Alpha, Gross Beta, Tritium, Gamma, and Sr-90 Activity

Concentrations in Peconic River and Carmans River

\begin{tabular}{|c|c|c|c|c|c|c|c|c|}
\hline Sampling Site & DS & $\begin{array}{l}\text { Gross } \\
\text { Alpha } \\
\text { pCirl }\end{array}$ & $\begin{array}{l}\text { Gross } \\
\text { Beta } \\
\text { pCill }\end{array}$ & $\begin{array}{l}\text { Tritium } \\
\text { pcin }\end{array}$ & $\begin{array}{l}K-40 \\
\text { pcir }\end{array}$ & $\begin{array}{l}\text { c0.60 } \\
\text { pcin }\end{array}$ & $\begin{array}{l}\text { Cs-137 } \\
\text { pCir }\end{array}$ & $\begin{array}{l}\text { Sr-90 } \\
\text { pCi/L. }\end{array}$ \\
\hline \multirow[t]{3}{*}{ HM : Peconic River / On-site } & $N$ & 150 & 150 & 150 & 12 & 12 & 12 & NA \\
\hline & Maximum & 4.35 & 30.4 & 7576 & 4.56 & ND & 3.75 & \\
\hline & Average & 1.22 & 6.55 & 2566 & 1.73 & & 155 & \\
\hline HQ: Peconic River & $N$ & 119 & 119 & 119 & 0 & 0 & 0 & NA \\
\hline \multirow[t]{2}{*}{ Boundary / On-site } & Maximum & 4.76 & 29.49 & 4797 & NA & NA & NA & \\
\hline & Average & 0.74 & 11.25 & 1795 & & & & \\
\hline \multirow[t]{3}{*}{ HA: Peconic River / Off-site } & $\mathbf{N}$ & 2 & 2 & 2 & 2 & 2 & 2 & 2 \\
\hline & Maximum & 0.62 & 1.42 & 193 & ND & ND & 0.46 & NA \\
\hline & Average & 0.38 & 1.02 & 39 & & & 0.23 & \\
\hline \multirow[t]{3}{*}{ HB: Peconic River/ Off-site } & $\mathbf{N}$ & 2 & 2 & 2 & 2 & 2 & 2 & 2 \\
\hline & Maximum & 0 & 1.94 & -19 & 3.24 & ND & 0.24 & NA \\
\hline & Average & -0.05 & 1.54 & -105 & 1.62 & & 0.12 & \\
\hline \multirow[t]{3}{*}{ HC: Peconic River/ Off-site } & $\mathbf{N}$ & 2 & 2 & 2 & 2 & 2 & 2 & 2 \\
\hline & Maximum & 0.57 & 1.42 & -80 & ND & ND & 0.26 & NA \\
\hline & Average & 0.49 & 1.39 & -114 & & & 0.13 & \\
\hline HR: Peconic River & $\mathbf{N}$ & 10 & 10 & 10 & 2 & 2 & 2 & 1 \\
\hline \multirow[t]{2}{*}{ Riverhead/Off-site } & Maximum & 0.7 & 7.3 & 216 & ND & ND & ND & NA \\
\hline & Average & 0.14 & 2.2 & -118 & & & & \\
\hline HH: Carmans River & $\mathbf{N}$ & 8 & 8 & 8 & 2 & 2 & 2 & 1 \\
\hline \multirow[t]{2}{*}{ Background } & Maximum & 0.76 & 4.37 & -16 & ND & ND & ND & NA \\
\hline & Average & 0.21 & 1.57 & -191 & & & & \\
\hline Typical MDL & & 0.46 & 1.2 & 300 & 3.9 & 0.23 & 0.2 & 0.1 \\
\hline $\begin{array}{l}\text { Typical MDL for ST. \# HM } \\
\text { and HQ only }\end{array}$ & & 2.3 & 6 & 1000 & & & & \\
\hline DOE Order 5400.5 Derived & & (a) & (a) & 80000 & 7000 & 200 & 120 & 40 \\
\hline \multicolumn{9}{|l|}{ Concentration Guide } \\
\hline Concentration Required to & & (a) & (a) & 20000 & 280 & (a) & (a) & 8 \\
\hline Produce SDWA Annual Dose & & & & & & & & \\
\hline
\end{tabular}

NA: Not Analyzed.

ND: Not Delected.

$\mathrm{N}$ : Number of Samples.

MDL: Minimum Detection Limit. 
Table 4-14

BNL Site Environmental Roport for Calendar Year 1994

Water Quality Data for Surface Water Samples

Collected Along the Peconic and Carmans Rivers

\begin{tabular}{|c|c|c|c|c|c|c|c|c|c|}
\hline RIver & $\begin{array}{c}\text { Sample } \\
\text { Location (a) }\end{array}$ & & $\begin{array}{l}\text { pH } \\
\text { SU }\end{array}$ & $\begin{array}{l}\text { Conductivity } \\
\text { umhos } / \mathrm{cm}\end{array}$ & $\begin{array}{c}\text { Temperature } \\
\text { C }\end{array}$ & $\begin{array}{c}\text { Dissolved Oxygen } \\
\text { mgl }\end{array}$ & $\begin{array}{l}\text { Chlorides } \\
\text { mgll }\end{array}$ & $\begin{array}{l}\text { Sulfates } \\
\text { mgll }\end{array}$ & $\begin{array}{c}\text { Nitrates as } \mathbf{N} \\
\text { mg/l }\end{array}$ \\
\hline \multirow[t]{6}{*}{ Peconic } & HM & $\begin{array}{c}\text { N } \\
\text { Minimum } \\
\text { Maximum } \\
\text { Average }\end{array}$ & $\begin{array}{l}151 \\
5.5 \\
9.9 \\
\text { NA }\end{array}$ & $\begin{array}{c}151 \\
103.3 \\
394.6 \\
205\end{array}$ & $\begin{array}{c}151 \\
0.5 \\
27.7 \\
14.3\end{array}$ & $\begin{array}{c}115 \\
4.1 \\
16.3 \\
7.7\end{array}$ & $\begin{array}{c}49 \\
21.5 \\
57.3 \\
30.3\end{array}$ & $\begin{array}{c}49 \\
12.5 \\
31.7 \\
15.3\end{array}$ & $\begin{array}{l}49 \\
1.7 \\
8.8 \\
4.1\end{array}$ \\
\hline & $\mathrm{HQ}$ & $\stackrel{\mathrm{N}}{\text { Concentration }}$ & $\begin{array}{c}0 \\
\text { NA }\end{array}$ & $\begin{array}{l}0 \\
\text { NA }\end{array}$ & $\begin{array}{c}0 \\
N A\end{array}$ & $\begin{array}{c}0 \\
\text { NA }\end{array}$ & $\begin{array}{c}1 \\
25.8\end{array}$ & $\stackrel{1}{12.7}$ & $\begin{array}{c}1 \\
2.5\end{array}$ \\
\hline & $H A$ & $\begin{array}{c}\mathrm{N} \\
\text { Minimum } \\
\text { Maximum } \\
\text { Average }\end{array}$ & $\begin{array}{l}2 \\
6.4 \\
6.6 \\
N A\end{array}$ & $\begin{array}{c}2 \\
52.2 \\
58.4 \\
55.3\end{array}$ & $\begin{array}{c}2 \\
11.5 \\
25.8 \\
18.7\end{array}$ & $\begin{array}{l}1 \\
5.1 \\
5.1 \\
5.1\end{array}$ & $\begin{array}{c}2 \\
6.3 \\
8.8 \\
7.6\end{array}$ & $\begin{array}{l}2 \\
<4.0 \\
6.2 \\
<4.0\end{array}$ & $\begin{array}{l}2 \\
<1.0 \\
<1.0 \\
<1.0\end{array}$ \\
\hline & $\mathrm{HB}$ & $\begin{array}{l}\mathrm{N} \\
\text { Minimum } \\
\text { Maximum } \\
\text { Average }\end{array}$ & $\begin{array}{c}2 \\
5.3 \\
6.9 \\
N A\end{array}$ & $\begin{array}{c}2 \\
60.8 \\
62.8 \\
61.8\end{array}$ & $\begin{array}{c}2 \\
2 \\
25 \\
13.5\end{array}$ & $\begin{array}{l}0 \\
\text { NA } \\
\text { NA } \\
\text { NA }\end{array}$ & $\begin{array}{l}2 \\
6.6 \\
8.5 \\
7.6\end{array}$ & $\begin{array}{l}2 \\
<4.0 \\
5.9 \\
<4.0\end{array}$ & $\begin{array}{l}2 \\
<1.0 \\
<1.0 \\
<1.0\end{array}$ \\
\hline & $\mathrm{HC}$ & $\begin{array}{c}\text { N } \\
\text { Minimum } \\
\text { Maximum } \\
\text { Average }\end{array}$ & $\begin{array}{c}2 \\
5.2 \\
7 \\
\mathrm{NA}\end{array}$ & $\begin{array}{c}2 \\
74.9 \\
80.1 \\
77.5\end{array}$ & $\begin{array}{c}2 \\
3 \\
29.4 \\
16.2\end{array}$ & $\begin{array}{l}0 \\
N A \\
N A \\
N A\end{array}$ & $\begin{array}{c}2 \\
9.5 \\
9.9 \\
9.7\end{array}$ & $\begin{array}{l}2 \\
<4.0 \\
7.6 \\
<4.0\end{array}$ & $\begin{array}{l}2 \\
<1.0 \\
<1.0 \\
<1.0\end{array}$ \\
\hline & HR & $\begin{array}{l}\stackrel{N}{N} \\
\text { Minimum } \\
\text { Maximum } \\
\text { Average }\end{array}$ & $\begin{array}{l}10 \\
5.7 \\
8.9 \\
\text { NA }\end{array}$ & $\begin{array}{c}11 \\
40.1 \\
122 \\
102.3\end{array}$ & $\begin{array}{c}11 \\
5.6 \\
29 \\
16.9\end{array}$ & $\begin{array}{c}8 \\
7.2 \\
12.7 \\
10.5\end{array}$ & $\begin{array}{c}2 \\
13.3 \\
15.1 \\
14.2\end{array}$ & $\begin{array}{c}2 \\
9.8 \\
10.9 \\
10.4\end{array}$ & $\begin{array}{l}2 \\
<1.0 \\
<1.0 \\
<1.0\end{array}$ \\
\hline Carmans & $\mathrm{HH}$ & $\begin{array}{c}\mathrm{N} \\
\text { Minimum } \\
\text { Maximum } \\
\text { Average }\end{array}$ & $\begin{array}{c}9 \\
6.2 \\
7.3 \\
\text { NA }\end{array}$ & $\begin{array}{c}9 \\
121.8 \\
147 \\
135.4\end{array}$ & $\begin{array}{c}9 \\
5.5 \\
27 \\
14.6\end{array}$ & $\begin{array}{c}6 \\
7.4 \\
12.4 \\
9.8\end{array}$ & $\begin{array}{c}2 \\
23.7 \\
25 \\
24.4\end{array}$ & $\begin{array}{c}2 \\
9.6 \\
10.3 \\
10\end{array}$ & $\begin{array}{l}2 \\
<1.0 \\
1.1 \\
<1.0\end{array}$ \\
\hline NYS AWOS (b) & & & $6.5-8.5$ & (c) & (c) & (c) & 250 & 250 & 10 \\
\hline Typlcal MDL & & & NA & 10 & NA & NA & 4 & 4 & 1 \\
\hline
\end{tabular}

N: No. of samples

NA: Not Applicable

MDL: Minimum Detection Limit

(a): The Peconic and Carmans Rivers sample locations are shown on Figure 27.

(b): AWaS: Since there are no Class C Surface Water Ambient Water Quality Standards (AWaS) for these compounds, the AWQS for Ground Water is pro (c): No AWOS specified.

The average concentration has been calculated by summing all detectable quantities then dividing the sum by the total number of samples collected. All non-detectable quantities have been evaluated as zero. If the average is less than the MDL, it is reported as less than MDL. 
Table 4-15

BNL Site Environmental Report for Calendar Year 1994

Metals Concentration Data for Surface Water Samples

Collected Along the Peconic and Carmans Rivers

\begin{tabular}{|c|c|c|c|c|c|c|c|c|c|c|c|c|}
\hline River & $\begin{array}{c}\text { Sample } \\
\text { Location (a) }\end{array}$ & & $\underset{\mathrm{mg} / \mathrm{L}}{\mathrm{Ag}}$ & $\begin{array}{c}\mathrm{Cd} \\
\mathrm{mg} / \mathrm{L}\end{array}$ & $\underset{\mathrm{mg} / \mathrm{L}}{\mathrm{Cr}}$ & $\begin{array}{c}\mathrm{Cu} \\
\mathrm{mg} / \mathrm{h}\end{array}$ & $\begin{array}{c}\mathrm{Fe} \\
\mathrm{mg} / \mathrm{L}\end{array}$ & $\begin{array}{l}\mathrm{Hg} \\
\mathrm{mg} / \mathrm{L}\end{array}$ & $\begin{array}{c}\mathrm{Mn} \\
\mathrm{mg} / \mathrm{L}\end{array}$ & $\begin{array}{c}\mathrm{Na} \\
\mathrm{mg} / \mathrm{L}\end{array}$ & $\begin{array}{c}\mathrm{Pb} \\
\mathrm{mg} / \mathrm{L}\end{array}$ & $\begin{array}{c}\mathrm{Zn} \\
\mathrm{mg} / \mathrm{L}\end{array}$ \\
\hline \multirow[t]{5}{*}{ Peconic } & $H M$ & $\begin{array}{c}\mathrm{N} \\
\text { Minimum } \\
\text { Maximum } \\
\text { Average }\end{array}$ & $\begin{array}{l}12 \\
<0.025 \\
<0.025 \\
<0.025\end{array}$ & $\begin{array}{c}12 \\
<0.0005 \\
<0.0005 \\
<0.0005\end{array}$ & $\begin{array}{c}12 \\
<0.005 \\
<0.005 \\
<0.005\end{array}$ & $\begin{array}{c}12 \\
<0.05 \\
0.058 \\
<0.05\end{array}$ & $\begin{array}{c}12 \\
0.104 \\
0.45 \\
0.24\end{array}$ & $\begin{array}{c}12 \\
<0.0002 \\
<0.0002 \\
<0.0002\end{array}$ & $\begin{array}{c}12 \\
<0.05 \\
0.1 \\
<0.05\end{array}$ & $\begin{array}{c}12 \\
20.09 \\
29.14 \\
24.32\end{array}$ & $\begin{array}{c}12 \\
<0.002 \\
0.0037 \\
<0.002\end{array}$ & $\begin{array}{c}12 \\
<0.02 \\
0.051 \\
0.034\end{array}$ \\
\hline & $\mathrm{HA}$ & $\begin{array}{c}\mathrm{N} \\
\text { Minimum } \\
\text { Maximum } \\
\text { Average }\end{array}$ & $\begin{array}{c}2 \\
<0.025 \\
<0.025 \\
<0.025\end{array}$ & $\begin{array}{c}2 \\
<0.0005 \\
<0.0005 \\
<0.0005\end{array}$ & $\begin{array}{c}2 \\
<0.005 \\
<0.005 \\
<0.005\end{array}$ & $\begin{array}{c}2 \\
<0.05 \\
<0.05 \\
<0.05\end{array}$ & $\begin{array}{c}2 \\
0.29 \\
1.48 \\
0.88\end{array}$ & $\begin{array}{c}2 \\
<0.0002 \\
<0.0002 \\
<0.0002\end{array}$ & $\begin{array}{c}2 \\
<0.05 \\
0.078 \\
<0.05\end{array}$ & $\begin{array}{c}2 \\
4.49 \\
6.55 \\
5.52\end{array}$ & $\begin{array}{c}2 \\
<0.002 \\
<0.002 \\
<0.002\end{array}$ & $\begin{array}{c}2 \\
<0.02 \\
0.024 \\
<0.02\end{array}$ \\
\hline & $\mathrm{HB}$ & $\begin{array}{c}\mathrm{N} \\
\text { Minimum } \\
\text { Maximum } \\
\text { Average }\end{array}$ & $\begin{array}{c}2 \\
<0.025 \\
<0.025 \\
<0.025\end{array}$ & $\begin{array}{c}2 \\
<0.0005 \\
<0.0005 \\
<0.0005\end{array}$ & $\begin{array}{c}2 \\
<0.005 \\
<0.005 \\
<0.005\end{array}$ & $\begin{array}{c}2 \\
<0.05 \\
<0.05 \\
<0.05\end{array}$ & $\begin{array}{c}2 \\
0.46 \\
0.79 \\
0.62\end{array}$ & $\begin{array}{c}2 \\
<0.0002 \\
<0.0002 \\
<0.0002\end{array}$ & $\begin{array}{c}2 \\
0.076 \\
0.089 \\
0.083\end{array}$ & $\begin{array}{c}2 \\
5.16 \\
6.02 \\
5.59\end{array}$ & $\begin{array}{c}2 \\
<0.002 \\
<0.002 \\
<0.002\end{array}$ & $\begin{array}{c}2 \\
<0.02 \\
0.021 \\
<0.02\end{array}$ \\
\hline & $\mathrm{HC}$ & $\begin{array}{c}\mathrm{N} \\
\text { Minimum } \\
\text { Maximum } \\
\text { Average }\end{array}$ & $\begin{array}{c}2 \\
<0.025 \\
<0.025 \\
<0.025\end{array}$ & $\begin{array}{c}2 \\
<0.0005 \\
<0.0005 \\
<0.0005\end{array}$ & $\begin{array}{c}2 \\
<0.005 \\
<0.005 \\
<0.005\end{array}$ & $\begin{array}{c}2 \\
<0.05 \\
<0.05 \\
<0.05\end{array}$ & $\begin{array}{c}2 \\
0.43 \\
1.18 \\
0.8\end{array}$ & $\begin{array}{c}2 \\
<0.0002 \\
0.00031 \\
<0.0002\end{array}$ & $\begin{array}{c}2 \\
0.06 \\
0.084 \\
0.072\end{array}$ & $\begin{array}{c}2 \\
6.88 \\
6.99 \\
6.94\end{array}$ & $\begin{array}{c}2 \\
<0.002 \\
<0.002 \\
<0.002\end{array}$ & $\begin{array}{c}2 \\
<0.02 \\
<0.02 \\
<0.02\end{array}$ \\
\hline & $H R$ & $\begin{array}{c}\mathrm{N} \\
\text { Minimum } \\
\text { Maximum } \\
\text { Average }\end{array}$ & $\begin{array}{c}2 \\
<0.025 \\
<0.025 \\
<0.025\end{array}$ & $\begin{array}{c}2 \\
<0.0005 \\
<0.0005 \\
<0.0005\end{array}$ & $\begin{array}{c}2 \\
<0.005 \\
<0.005 \\
<0.005\end{array}$ & $\begin{array}{c}2 \\
<0.05 \\
<0.05 \\
<0.05\end{array}$ & $\begin{array}{c}2 \\
0.55 \\
0.61 \\
0.58\end{array}$ & $\begin{array}{c}2 \\
<0.0002 \\
<0.0002 \\
<0.0002\end{array}$ & $\begin{array}{c}2 \\
0.099 \\
0.15 \\
0.12\end{array}$ & $\begin{array}{c}2 \\
9.27 \\
10.17 \\
9.72\end{array}$ & $\begin{array}{c}2 \\
<0.002 \\
<0.002 \\
<0.002\end{array}$ & $\begin{array}{l}2 \\
<0.02 \\
0.31 \\
<0.02\end{array}$ \\
\hline Carmans & $\mathrm{HH}$ & $\begin{array}{c}\mathbf{N} \\
\text { Minimum } \\
\text { Maximum } \\
\text { Average }\end{array}$ & $\begin{array}{c}2 \\
<0.025 \\
<0.025 \\
<0.025\end{array}$ & $\begin{array}{c}2 \\
<0.0005 \\
<0.0005 \\
<0.0005\end{array}$ & $\begin{array}{c}2 \\
<0.005 \\
<0.005 \\
<0.005\end{array}$ & $\begin{array}{l}2 \\
<0.05 \\
<0.05 \\
<0.05\end{array}$ & $\begin{array}{c}2 \\
0.23 \\
1.53 \\
0.88\end{array}$ & $\begin{array}{c}2 \\
<0.0002 \\
<0.0002 \\
<0.0002\end{array}$ & $\begin{array}{c}2 \\
0.057 \\
0.2 \\
0.13\end{array}$ & $\begin{array}{c}2 \\
14.9 \\
16.21 \\
15.56\end{array}$ & $\begin{array}{c}2 \\
<0.002 \\
<0.002 \\
<0.002\end{array}$ & $\begin{array}{c}2 \\
0.065 \\
0.075 \\
0.07\end{array}$ \\
\hline \multicolumn{3}{|c|}{$\begin{array}{l}\text { NYSDEC SPDES Limit } \\
\text { or AWQS }\end{array}$} & 0.05 & 0.001 & 0.09 & 0.4 & 0.6 & 0.0002 & (b) & (b) & 0.067 & 0.3 \\
\hline Typical MDL & & & 0.025 & 0.0005 & 0.005 & 0.05 & 0.075 & 0.0002 & 0.05 & 1 & 0.002 & 0.02 \\
\hline
\end{tabular}

N: $\quad$ No. of samples

AWQS: Ambient Water Quality Standard for Class C Surface Water

MDL: Minimum Detection Limit

(a): The Peconic and Carmans River sample locations are shown on Figure 27.

(b): There are no SPDES limits or AWQS specified for these compounds.

The average metals concentration has been calculated by summing all detectable concentrations then dividing the sum by the total number of samples collected. All non-detectable quantities have been evaluated as zero. If the average is less than the typical MDL, it is reported as less than the MDL. 
With regard to VOC analyses, during 1994 all surface waters were analyzed for VOC contamination by the S\&EP Division analytical laboratory. There were no VoCs detected above the laboratory detection limit of $2 \mu \mathrm{g} / \mathrm{I}$ in samples collected from the Peconic or Carmans River stations in 1994. Trace quantities (i.e., less than $2 \mu \mathrm{g} / \mathrm{L}$ ) of perchloroethylene were detected in one of the Carmans River samples and trace quantities of chloroform and toluene were detected in samples collected from station HQ.

\subsubsection{Aquatic Biological Surveillance}

The Laboratory, in collaboration with the NYSDEC Fisheries Division, has an ongoing program for the collection of fish from the Peconic River and surrounding fresh water bodies (Figure 4-19). In 1994, fish samples from the Peconic River were collected at Donahue's Pond, and Forge Pond. Control samples were collected from Carmans River and Swan Pond. Specific information regarding the sampling point, distance from the BNL effluent release point, species of fish collected and analytical results are presented in Table 4-16. In CY 1994, only gamma spectroscopy analysis was performed on these samples. The Peconic River fish contained cesium-137 concentrations which ranged from near background levels at Forge Pond $(37-328 \mathrm{pCi} / \mathrm{kg}$-wet $[1.40-33.42 \mathrm{~Bq} / \mathrm{kg}$-wet]) to $909 \mathrm{pCi} / \mathrm{kg}$-wet (34 Bq/kg-wet) at Donahue's Pond.

The Forge Pond and Donahue's Pond analytical data for cesium-137 indicate that this radionuclide is present in net concentration levels which range from $<1$ to 17 times control data. The presence of these levels may be indicative of a BNL contribution to the cesium-137 in the Peconic River ecosystem inventory. The maximum individual and collective dose from the aquatic biological pathway were calculated based on cesium-137 and strontium-90 concentrations. Since fishing for human consumption occurs downstream of the Laboratory's boundary, only samples collected off site were used for this assessment. Based on the methods and results just described, the maximum individual committed effective dose equivalent was estimated to be $0.58 \mathrm{mrem}(0.0058 \mathrm{mSv})$ and the collective committed effective dose equivalent was estimated to be 0.5 person-rem 10.005 person-Sv). The exposed population was estimated to be $625^{16}$ and comprised of individuals who frequently fish in the Forge Pond and the Donahue's Pond areas. Figure 4-21 shows a trend plot of cesium-137 in the Laboratory effluent at the STP outfall and cesium-137 concentrations of same species of fish (Brown Bullhead) caught at the STP outfall and in the Donahue's Pond $(10 \mathrm{~km}$ from the STP outfall). The relationship observed for cesium-137 concentration in water and fish at the STP outfall is similar, whereas, the pattern observed in fish at Donahue's Pond is similar but to a great extent flattened. This could be attributed to the fact that Donahue's Pond is a man made lake within the Peconic River, where dilution and the ability of fish to approach equilibrium with water constituents is enhanced.

\subsubsection{Biomonitoring of the STP Liquid Effluent}

Analysis of the STP effluent, which discharges to the Peconic River, for water quality and radioactivity is an integral part of the Laboratory's EM program. Biomonitoring, which monitors the impact of the BNL effluent on aquatic biota, was added to the base monitoring effort in 1987, and in 1994 a Chronic Toxicity Test program was added as per the requirements of the draft SPDES permit.

\subsubsection{9(a) Biomonitoring: Fish Species}

The species used in the 1994 biomonitoring effort ranged from sensitive species (brown or rainbow trout) to hardy species (bluegills, large mouth bass, golden shiner, etc.). The latter (hardy) species are endemic to Long Island freshwater bodies, and are considered as local game fish. The experimental set up consisted of a once-through flow system of the effluent through an aquarium 


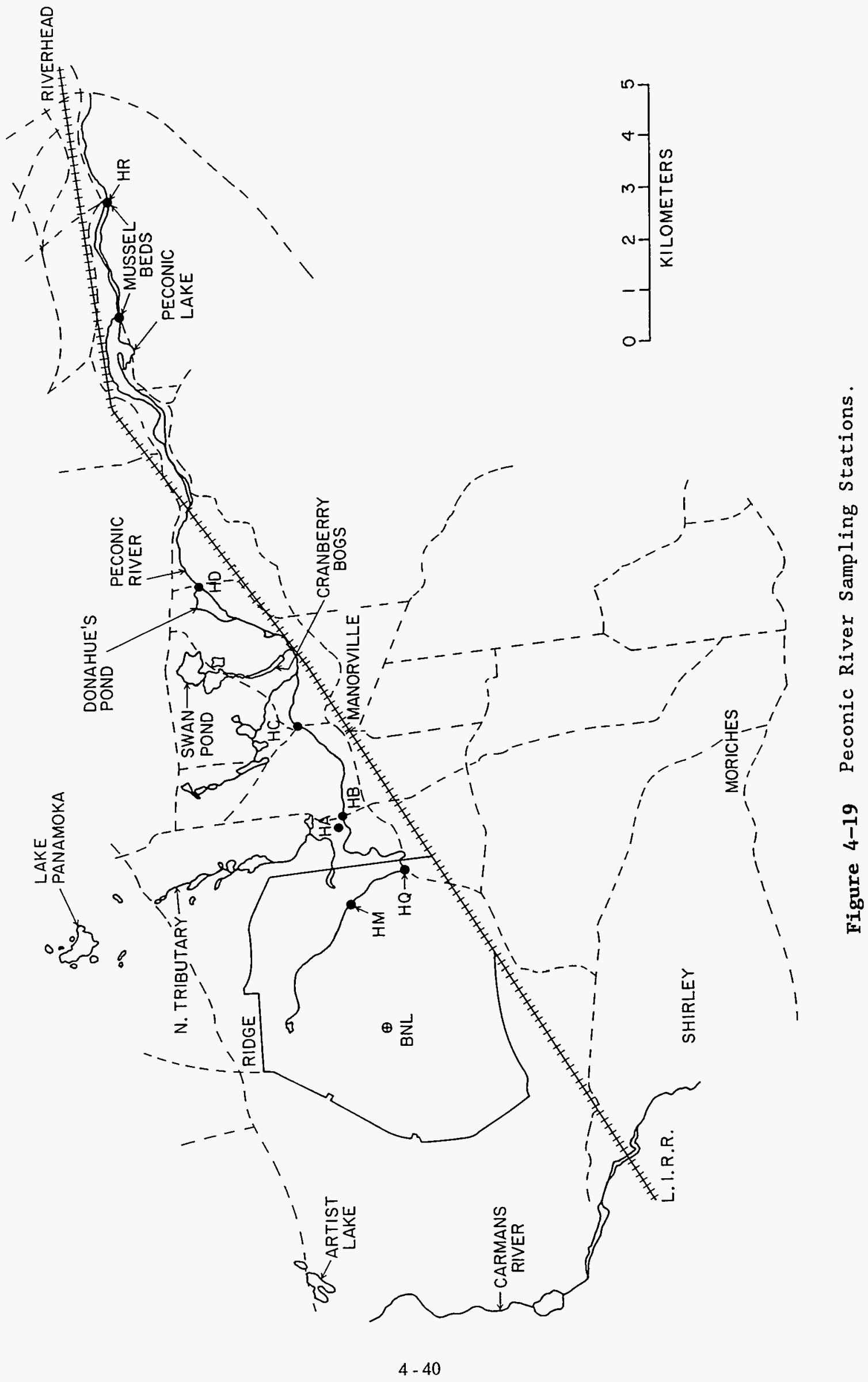




\section{Liquid Flow Data}

Sewage Plant and Peconic River

Figure 4-20

Flow, x 1 E9 Liters

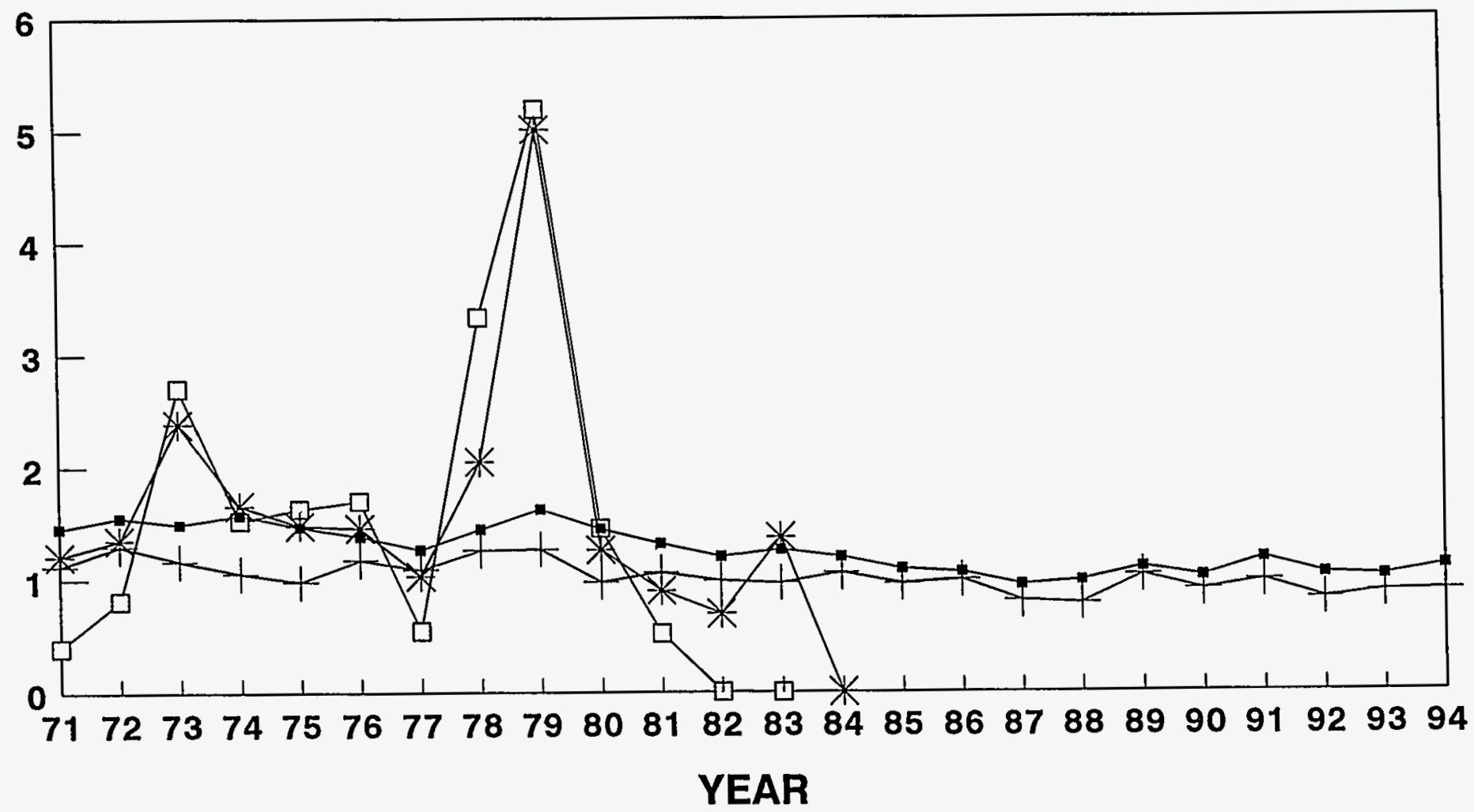

-DA + EA * HM - ${ }^{-} \mathrm{HQ}$

Liquid Flow Data - Sewage Plant and

Peconic River: 1971 to 1994 


\section{CESIUM - 137 DISTRIBUTION IN THE PECONIC RIVER AND FISH}

Figure 4-21

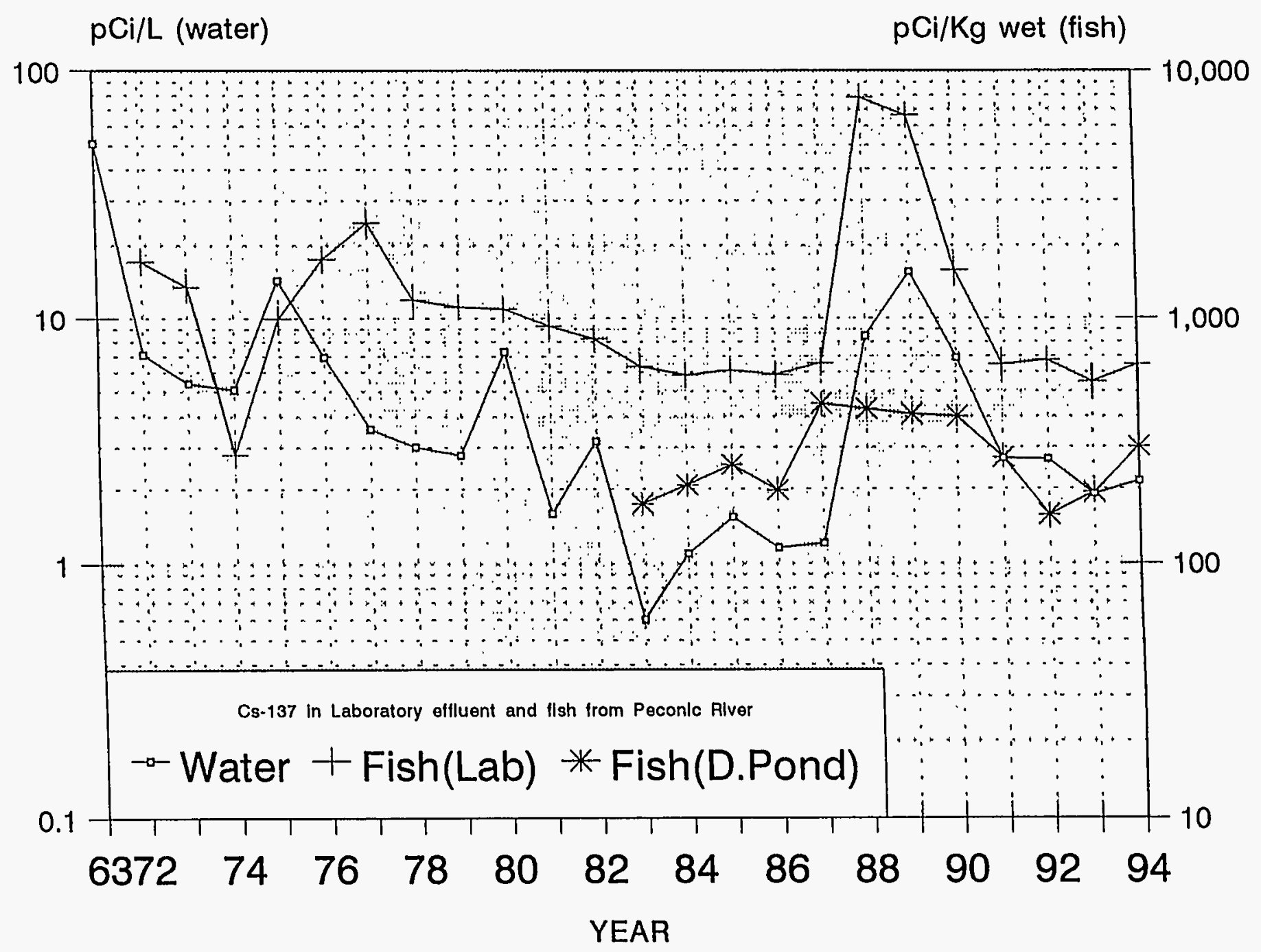


Table 4-16

BNL Site Environmental Report for Calendar Year 1994

Radlonuclide Concentrations In Fish

\begin{tabular}{|c|c|c|c|c|c|c|c|c|c|}
\hline Sample Location & $\begin{array}{l}\text { Distance } \\
\text { from BNL } \\
\text { Discharge }(\mathrm{Km})\end{array}$ & Remarks & $\begin{array}{l}\text { Sample } \\
\text { Date }\end{array}$ & Specles & $\begin{array}{c}\text { Cs-137 } \\
\text { Total } \\
\text { Concentration } \\
\text { pCi/Kg/ wet } \\
\end{array}$ & $\begin{array}{c}\text { Cs-137 } \\
\text { Net } \\
\text { Concentration } \\
\text { pCi/Kg/ wet } \\
\end{array}$ & pCi/Kg/ wet & $\begin{array}{c}\text { Sr-90 } \\
\text { Total } \\
\text { Concentration } \\
\text { pCiKg/ wet } \\
\end{array}$ & $\begin{array}{c}\text { Sr-90 } \\
\text { Net } \\
\text { Concentration } \\
\text { pCi/Kg/ wet }\end{array}$ \\
\hline Swan Pond & $\begin{array}{l}\text { Adjacent to } \\
\text { Donahue's Pond }\end{array}$ & $\begin{array}{l}\text { Control } \\
\text { Control } \\
\text { Control } \\
\text { Control } \\
\text { Control } \\
\text { Control } \\
\text { Control } \\
\text { Control } \\
\text { Control } \\
\text { Control } \\
\text { Control } \\
\text { Control } \\
\text { Control } \\
\text { Control } \\
\text { Control } \\
\text { Control } \\
\text { Control } \\
\text { Control } \\
\text { Control } \\
\text { Control } \\
\text { Control }\end{array}$ & $\begin{array}{l}04 / 27 / 94 \\
04 / 27 / 94 \\
04 / 27 / 94 \\
04 / 29 / 94 \\
09 / 01 / 94 \\
04 / 29 / 94 \\
04 / 29 / 94 \\
09 / 01 / 95 \\
09 / 01 / 95 \\
09 / 02 / 95 \\
04 / 25 / 94 \\
04 / 25 / 94 \\
04 / 25 / 94 \\
04 / 25 / 94 \\
04 / 25 / 94 \\
04 / 29 / 95 \\
04 / 29 / 95 \\
09 / 02 / 95 \\
09 / 02 / 95 \\
09 / 02 / 95 \\
09 / 02 / 95\end{array}$ & $\begin{array}{l}\text { Brown Bullhead } \\
\text { Brown Bullhead } \\
\text { Brown Bullhead } \\
\text { Brown Bullhead } \\
\text { Brown Bullhead } \\
\text { Bluegill } \\
\text { Bluegill } \\
\text { Bluegill } \\
\text { Bluegill } \\
\text { Bluegill } \\
\text { Yellow Perch } \\
\text { Yellow Perch } \\
\text { Yellow Perch } \\
\text { Yellow Perch } \\
\text { Yellow Perch } \\
\text { Pumpkin Seed } \\
\text { Pumpkin Seed } \\
\text { Pumpkin Seed } \\
\text { Golden Shiner } \\
\text { Golden Shiner } \\
\text { Chain Pickerel }\end{array}$ & $\begin{array}{c}44 \\
167 \\
523 \\
1687 \\
65 \\
57 \\
83 \\
27 \\
45 \\
\mathrm{ND} \\
450 \\
208 \\
337 \\
160 \\
240 \\
123 \\
160 \\
\mathrm{ND} \\
163 \\
56 \\
229\end{array}$ & $\begin{array}{l}\text { NA } \\
\text { NA } \\
\text { NA } \\
\text { NA } \\
\text { NA } \\
\text { NA } \\
\text { NA } \\
\text { NA } \\
\text { NA } \\
\text { NA } \\
\text { NA } \\
\text { NA } \\
\text { NA } \\
\text { NA } \\
\text { NA } \\
\text { NA } \\
\text { NA } \\
\text { NA } \\
\text { NA } \\
\text { NA } \\
\text { NA }\end{array}$ & $\begin{array}{c}1815 \\
5456 \\
3629 \\
N D \\
1856 \\
1648 \\
1009 \\
1706 \\
1682 \\
2407 \\
\text { ND } \\
1926 \\
2183 \\
1669 \\
1804 \\
1853 \\
2170 \\
\text { ND } \\
3815 \\
1792 \\
3865\end{array}$ & $\begin{array}{c}38 \\
253 \\
404 \\
544 \\
22 \\
16 \\
58 \\
\text { NA } \\
\text { NA } \\
35 \\
319 \\
168 \\
\text { NA } \\
\text { NA } \\
211 \\
\text { NA } \\
\text { NA } \\
\text { ND } \\
245 \\
\text { NA } \\
125\end{array}$ & $\begin{array}{l}\text { NA } \\
\text { NA } \\
\text { NA } \\
\text { NA } \\
\text { NA } \\
\text { NA } \\
\text { NA } \\
\text { NA } \\
\text { NA } \\
\text { NA } \\
\text { NA } \\
\text { NA } \\
\text { NA } \\
\text { NA } \\
\text { NA } \\
\text { NA } \\
\text { NA } \\
\text { NA } \\
\text { NA } \\
\text { NA } \\
\text { NA }\end{array}$ \\
\hline $\begin{array}{l}\text { Carmans River } \\
\text { Lower Lake }\end{array}$ & $\begin{array}{l}\text { Southwest of the } \\
\text { Laboratory }\end{array}$ & $\begin{array}{l}\text { Control } \\
\text { Control } \\
\text { Control } \\
\text { Control } \\
\text { Control } \\
\text { Control } \\
\text { Control } \\
\text { Control } \\
\text { Control } \\
\text { Control } \\
\text { Control } \\
\text { Control }\end{array}$ & $\begin{array}{l}04 / 26 / 94 \\
04 / 26 / 94 \\
04 / 26 / 94 \\
08 / 30 / 94 \\
04 / 26 / 94 \\
04 / 26 / 94 \\
08 / 30 / 94 \\
08 / 30 / 94 \\
04 / 26 / 94 \\
04 / 26 / 94 \\
08 / 30 / 95 \\
08 / 30 / 95\end{array}$ & $\begin{array}{l}\text { Brown Bullhead } \\
\text { Brown Bullhead } \\
\text { Brown Bullhead } \\
\text { Brown Bullhead } \\
\text { Bluegill } \\
\text { Bluegill } \\
\text { Bluegill } \\
\text { Bluegill } \\
\text { Large Mouth Bass } \\
\text { Large Mouth Bass } \\
\text { Pumpkin Seed } \\
\text { Eel }\end{array}$ & $\begin{array}{l}26 \\
46 \\
30 \\
18 \\
45 \\
\text { ND } \\
\text { ND } \\
79 \\
29 \\
35 \\
\text { ND } \\
160\end{array}$ & $\begin{array}{l}\text { NA } \\
\text { NA } \\
\text { NA } \\
\text { NA } \\
\text { NA } \\
\text { NA } \\
\text { NA } \\
\text { NA } \\
\text { NA } \\
\text { NA } \\
\text { NA } \\
\text { NA }\end{array}$ & $\begin{array}{c}2002 \\
2430 \\
2004 \\
2137 \\
2035 \\
2360 \\
3272 \\
\text { ND } \\
2102 \\
2007 \\
2662 \\
2488\end{array}$ & $\begin{array}{l}\text { NA } \\
44 \\
28 \\
\text { NA } \\
52 \\
22 \\
\text { NA } \\
\text { NA } \\
\text { NA } \\
47 \\
\text { NA } \\
110\end{array}$ & $\begin{array}{l}\text { NA } \\
\text { NA } \\
\text { NA } \\
\text { NA } \\
\text { NA } \\
\text { NA } \\
\text { NA } \\
\text { NA } \\
\text { NA } \\
\text { NA } \\
\text { NA } \\
\text { NA }\end{array}$ \\
\hline
\end{tabular}


Table 4-16 (Continued)

BNL Site Environmental Report for Calendar Year 1994 Radionuclide Concentrations in Fish

\begin{tabular}{|c|c|c|c|c|c|c|c|c|c|}
\hline Sample Location & $\begin{array}{l}\text { Distance } \\
\text { from BNL } \\
\text { Discharge }(\mathrm{Km})\end{array}$ & Remarks & $\begin{array}{l}\text { Sample } \\
\text { Date }\end{array}$ & Species & $\begin{array}{c}\text { Cs-137 } \\
\text { Total } \\
\text { Concentration } \\
\text { pCi/Kg/ wet } \\
\end{array}$ & $\begin{array}{c}\text { Cs-137 } \\
\text { Net } \\
\text { Concentration } \\
\text { pCi/Kg/ wet } \\
\end{array}$ & $\begin{array}{c}\mathrm{K}-40 \\
\mathrm{pci} / \mathrm{Kg} / \text { wet }\end{array}$ & $\begin{array}{c}\text { Sr-90 } \\
\text { Total } \\
\text { Concentration } \\
\text { pCi/kg/ wet }\end{array}$ & $\begin{array}{c}\text { Sr-90 } \\
\text { Net } \\
\text { Concentration } \\
\text { pCi/Kg/ wet } \\
\end{array}$ \\
\hline & & $\begin{array}{l}\text { Peconic } \\
\text { Peconic } \\
\text { Peconic } \\
\text { Peconic } \\
\text { Peconic } \\
\text { Peconic } \\
\text { Peconic } \\
\text { Peconic } \\
\text { Peconic } \\
\text { Peconic } \\
\text { Peconic } \\
\text { Peconic } \\
\text { Peconic } \\
\text { Peconic } \\
\text { Peconic } \\
\text { Peconic } \\
\text { Peconic } \\
\text { Peconic } \\
\text { Peconic }\end{array}$ & $\begin{array}{l}04 / 28 / 94 \\
04 / 28 / 94 \\
04 / 28 / 94 \\
04 / 28 / 94 \\
04 / 28 / 94 \\
04 / 28 / 94 \\
09 / 01 / 94 \\
09 / 01 / 94 \\
09 / 01 / 94 \\
04 / 28 / 94 \\
04 / 28 / 94 \\
04 / 28 / 94 \\
04 / 28 / 94 \\
04 / 28 / 94 \\
04 / 28 / 94 \\
04 / 28 / 94 \\
04 / 28 / 94 \\
04 / 28 / 94 \\
04 / 28 / 94\end{array}$ & $\begin{array}{l}\text { Chain Pickerel } \\
\text { Chain Pickerel } \\
\text { Chain Pickerel } \\
\text { Brown Bullhead } \\
\text { Brown Bullhead } \\
\text { Brown Bullhead } \\
\text { Brown Bullhead } \\
\text { Brown Bullhead } \\
\text { Brown Bullhead } \\
\text { Yellow Perch } \\
\text { Yellow Perch } \\
\text { Yellow Perch } \\
\text { Yellow Perch } \\
\text { Golden Shiner } \\
\text { Golden Shiner } \\
\text { Golden Shiner } \\
\text { Bluegills } \\
\text { Bluegills } \\
\text { Bluegills }\end{array}$ & $\begin{array}{l}665 \\
456 \\
561 \\
350 \\
510 \\
300 \\
450 \\
353 \\
238 \\
444 \\
377 \\
332 \\
900 \\
303 \\
285 \\
961 \\
370 \\
450 \\
647\end{array}$ & $\begin{array}{l}613 \\
404 \\
509 \\
298 \\
458 \\
248 \\
398 \\
301 \\
186 \\
392 \\
325 \\
280 \\
848 \\
251 \\
233 \\
909 \\
318 \\
398 \\
595\end{array}$ & $\begin{array}{l}2504 \\
2250 \\
2443 \\
1684 \\
2365 \\
1836 \\
2275 \\
1914 \\
2094 \\
2057 \\
1671 \\
1982 \\
2490 \\
2182 \\
1786 \\
2950 \\
2004 \\
2500 \\
2650\end{array}$ & $\begin{array}{r}556 \\
\text { ND } \\
310 \\
200 \\
367 \\
201 \\
236 \\
257 \\
201 \\
\text { NA } \\
246 \\
219 \\
445 \\
135 \\
119 \\
354 \\
\text { NA } \\
245 \\
334\end{array}$ & $\begin{array}{c}506 \\
\text { NA } \\
260 \\
150 \\
317 \\
151 \\
186 \\
207 \\
151 \\
\text { NA } \\
196 \\
169 \\
395 \\
85 \\
69 \\
304 \\
\text { NA } \\
195 \\
284\end{array}$ \\
\hline Forge Pond & $\begin{array}{l}20 \mathrm{Km} \\
20 \mathrm{Km} \\
20 \mathrm{Km} \\
20 \mathrm{Km} \\
20 \mathrm{Km} \\
20 \mathrm{Km} \\
20 \mathrm{Km} \\
20 \mathrm{Km}\end{array}$ & $\begin{array}{l}\text { Peconic } \\
\text { Peconic } \\
\text { Peconic } \\
\text { Peconic } \\
\text { Peconic } \\
\text { Peconic } \\
\text { Peconic } \\
\text { Peconic }\end{array}$ & $\begin{array}{l}04 / 28 / 94 \\
04 / 28 / 94 \\
04 / 28 / 94 \\
04 / 28 / 94 \\
08 / 31 / 94 \\
08 / 31 / 94 \\
08 / 31 / 94 \\
08 / 31 / 94\end{array}$ & $\begin{array}{l}\text { Eel } \\
\text { Eel } \\
\text { Eel } \\
\text { Bluegill } \\
\text { Bluegill } \\
\text { PS } \\
\text { Largemouth Bass } \\
\text { Mussels }\end{array}$ & $\begin{array}{c}224 \\
265 \\
380 \\
177 \\
89 \\
186 \\
378 \\
\text { ND }\end{array}$ & $\begin{array}{c}172 \\
213 \\
328 \\
125 \\
37 \\
134 \\
326 \\
\text { ND }\end{array}$ & $\begin{array}{c}1599 \\
2045 \\
\text { ND } \\
2344 \\
1990 \\
2573 \\
4611 \\
\text { ND }\end{array}$ & $\begin{array}{r}295 \\
245 \\
288 \\
145 \\
160 \\
\text { NA } \\
158 \\
\text { ND }\end{array}$ & $\begin{array}{c}245 \\
195 \\
238 \\
95 \\
110 \\
\text { NA } \\
108 \\
\text { NA }\end{array}$ \\
\hline
\end{tabular}


which contained the fish. Dissolved oxygen and temperature was monitored daily. Integrated water samples were collected in conjunction with fish sampling. Data collected in 1994 paralleled observations made in 1987 - 1993 in that there is a short term rapid intake of the principal radionuclide cesium-137. Data indicates that equilibrium is reached when the cesium-137 concentration in fish flesh is about 40 times the concentration found in the water. No significant differences were found between the trout species and the endemic species except that variations in dissolved oxygen and temperature were found to have a marked impact on uptake characteristics of the trout species (decreased uptake during summer months).

Effluent characteristics seemed to promote good growth rate, thus testifying to the viability of the effluent stream. In addition, TLDs which were implanted on mussels in 1992 to determine the feasibility of estimating doses to aquatic fauna, were analyzed in 1993. Because of the low levels of radionuclides in the water, it became clear that use of TLDs were impractical. To continue the assessment, it was decided to transplant mussels from non-contaminated areas to the STP outfall, where the highest radionuclide concentrations are to be expected, and study the uptake over a period of one year and use this uptake data and dose estimation computer models to calculate doses to these organisms. This experiment could not be completed in CY 1994 and will continue in CY 1995 .

\subsubsection{9(b) Biomonitoring: Chronic Toxicity Tests}

The Chronic Toxicity Testing program initiated in 1993 for the STP effluent was continued in 1994 with the collection and bioassay analysis of two effluent samples. This program consisted of performing seven day Tier II Chronic Toxicity Tests of the BNL STP Effluent. Two fresh water organisms, ceriodaphnia and fathead minnows, were utilized during testing. Testing consisted of subjecting these organisms in replicates of ten, to varying concentrations of the sTP effluent for a period of seven days. During the testing period size and or rate of reproduction was measured and compared to control organisms. Preliminary tests conducted in 1993 showed no adverse effects on the fathead minnow but reductions in the rate of reproduction was evident in the ceriodaphnia. Preliminary investigations revealed that low hardness of the BNL effluent as compared to the stock breeding solution may have contributed to this observation.

Again in 1994 there was no appreciable toxicity exhibited by the fathead minnow in the pure STP effluent. Testing conducted in May showed no chronic toxicity while the growth rate for these organisms was found to deviate from the control in the test conducted in september 1994. Review of the statistical analyses showed the NOEC for growth to be $<6.25 \%$. However, with the exception of the control group, a review of the raw test data showed the growth rates for all dilutions of the STP effluent to be consistent with previously conducted tests. Growth within the control was abnormally high. Testing conducted during 1994 attempted to discount the effects of low hardness on the ceriodaphnia. However due to the inability to produce a surviving control group in one of the two tests, these proved inconclusive.

The 1993 and 1994 test data was presented to the NYSDEC for evaluation and for further guidance for future testing. Mr. E. Kuzia of the NYSDEC Albany, concurred that low hardness could be a possible cause of reduced reproduction rates in the ceriodaphnia and approved using EPA Prescribed synthetic Fresh Water which had been adulterated to a hardness of $36 \mathrm{mg} / \mathrm{L}$ as a future dilution/control water source. Mr. Kuzia cautioned however, that the concentration of copper and other metallic constituents can cause similar effects and must be carefully monitored during testing to determine if the exhibited toxicity can be attributed to elevated levels of metallic elements. Quarterly chronic Toxicity Testing under the proposed SPDES permit is expected to begin during the second quarter of 1995. Test results will be reported, as part of the routine DMR, to the NYSDEC and SCDHS. This program will also include collection and analysis of water samples for metallic elements to further evaluate possible toxic effects. 


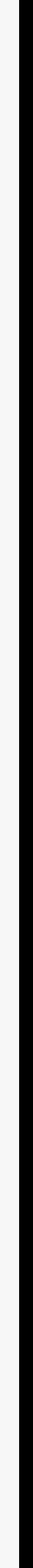




\subsection{GROUNDWATER PROTECTION - D. E. Paquette and J. R. Naidu}

The effort to protect groundwater quality at BNL is being implemented through programs designed to minimize future releases of environmental pollutants, and through site remediation activities being carried out under the IAG between the DOE, EPA, and NYSDEC. The IAG provides a framework for remediation of contaminated soils and groundwater at BNL.

The strategy for protecting groundwater at the BNL site is comprised of the following elements:

1. Engineering design reviews and environmental assessments for new and existing facilities to ensure that potential environmental impacts are fully evaluated and reduced to acceptable levels;

2. Upgrading existing facilities to reduce the risk of accidental release of contaminants to the environment (i.e., upgrading underground storage tanks, replacement of deteriorated sewer lines, construction of new waste management facilities utilizing best available technologies, etc.);

3. Rrompt response and remediation of spills to prevent migration of contaminants to surface waters and groundwater;

4. Conducting a groundwater and surface water monitoring program to provide for the early detection of contaminant releases;

5. Development of waste minimization practices to reduce the volume and toxicity of all wastes, and to utilize best management practices for the management and proper disposal of generated wastes;

6. Development of a Pollution Prevention Awareness Program to ensure that employees are cognizant of their responsibilities for the proper storage, use, and disposal of chemicals in the work place: and,

7. Conducting environmental restoration activities in areas where soils and groundwater have been contaminated by chemicals and radionuclides by past accidental spills, storage, and disposal activities.

\subsection{Groundwater Surveillance}

Groundwater quality at BNL is routinely monitored through a network of over 200 surveillance wells. The surveillance wells generally monitor specific site facilities where degradation of the groundwater is known or suspected, to fulfill permit requirements, and at BNL site boundary areas to assess the quality of groundwater entering or leaving the site. specific facilities include: the STP/Peconic River Area, Meadow Marsh-Upland Recharge Area, HWMF area, Current Landfill, Former Landfill, Ash Repository, CSF/MPF, AGS, WCF, and a number of smaller facilities. Wells located in specific areas of concern are shown in Figures 5-1 through 5-11. In addition to groundwater quality assessments, water level measurements are collected from approximately 400 wells to assess variations in groundwater flow directions and velocities.

\subsubsection{Potable Water and Process Supply Wells}

During 1994, approximately 16.0 MLD were pumped from the BNL potable and process water supply network. This network consists of six potable supply wells (Wells 4, 6, 7, 10, 11, and 12) and five secondary cooling/process water supply wells (Wells 5, 9, 101, 102, 103, 104, and 105). The six potable supply wells and five secondary cooling/process supply water wells are screened entirely 


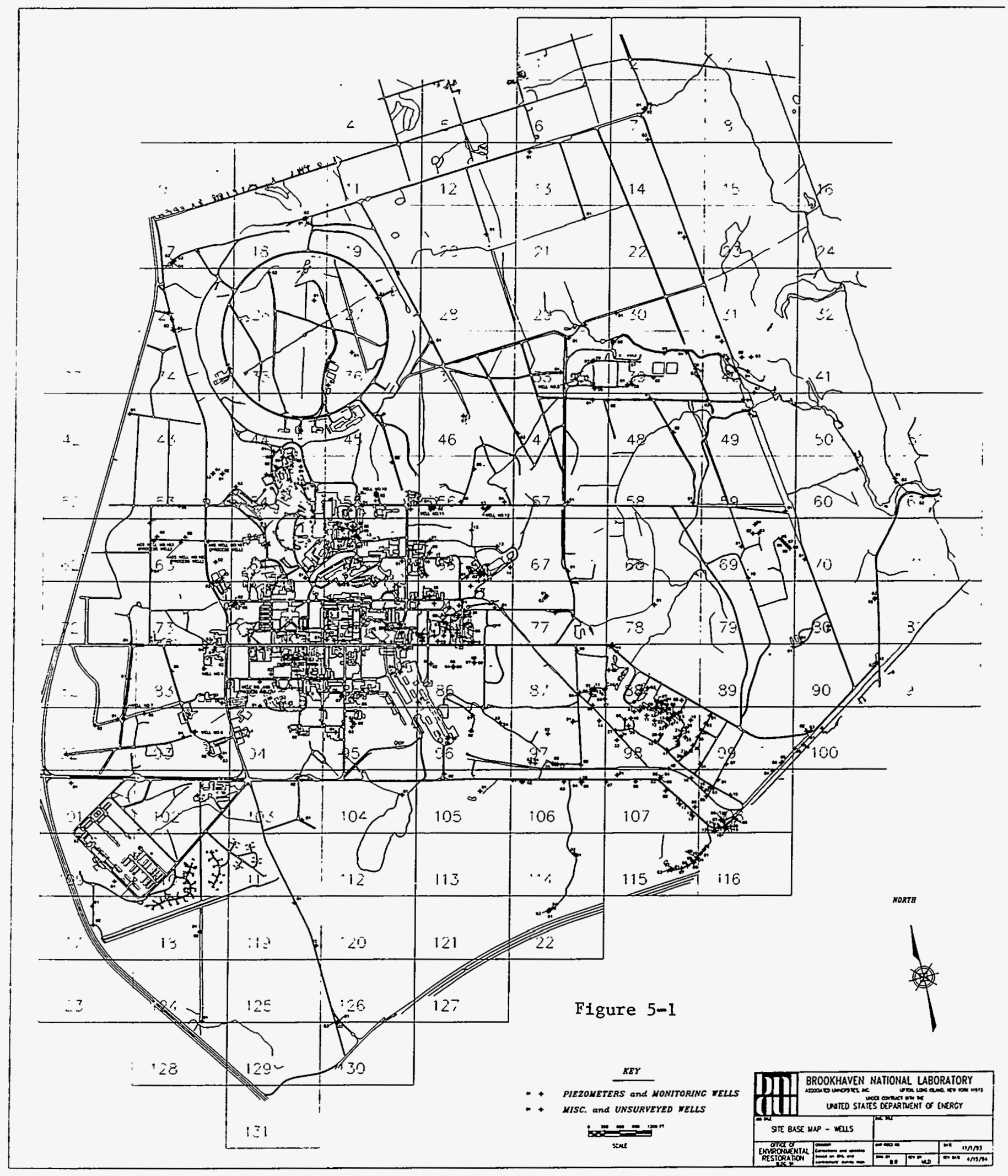




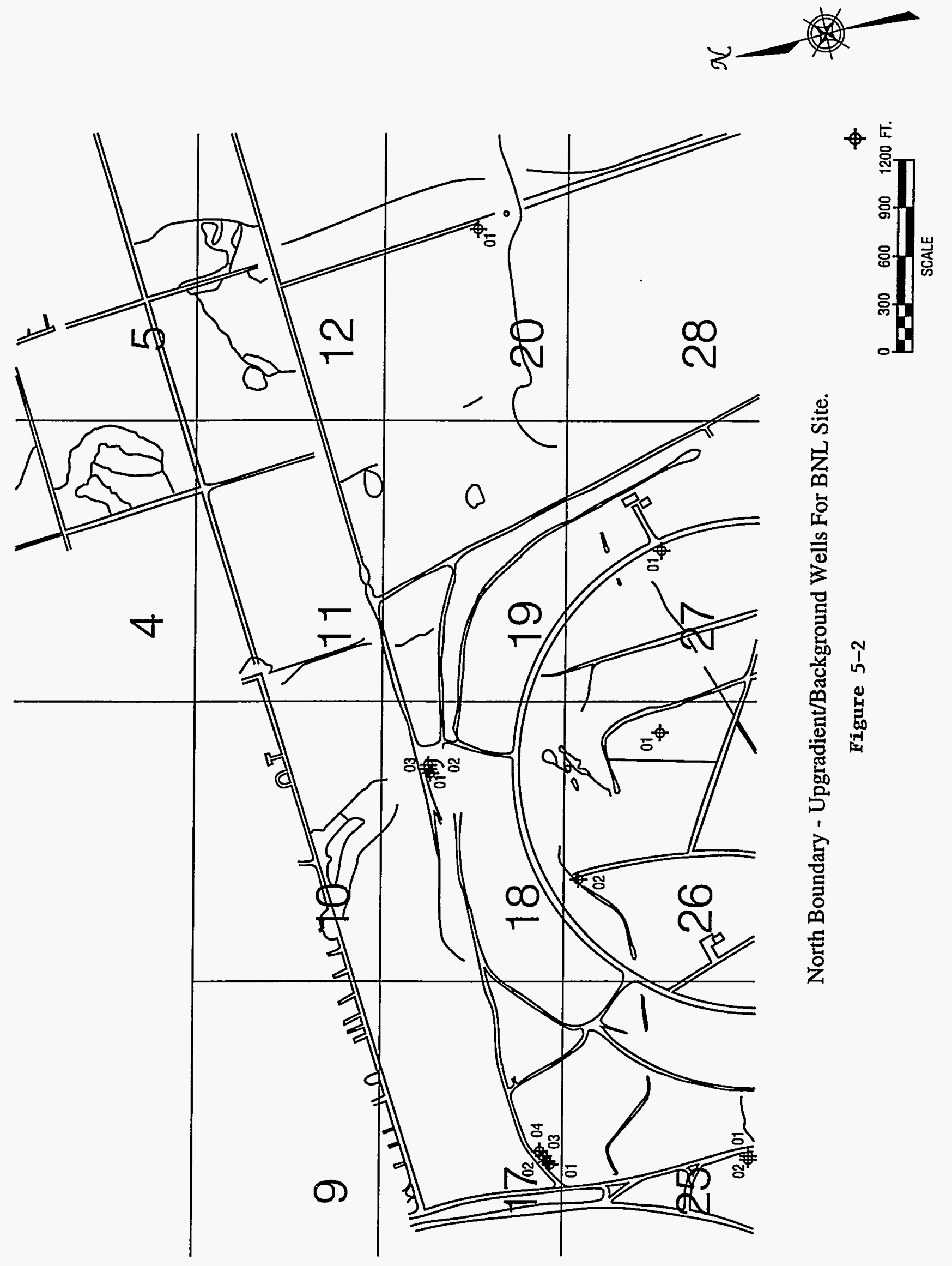




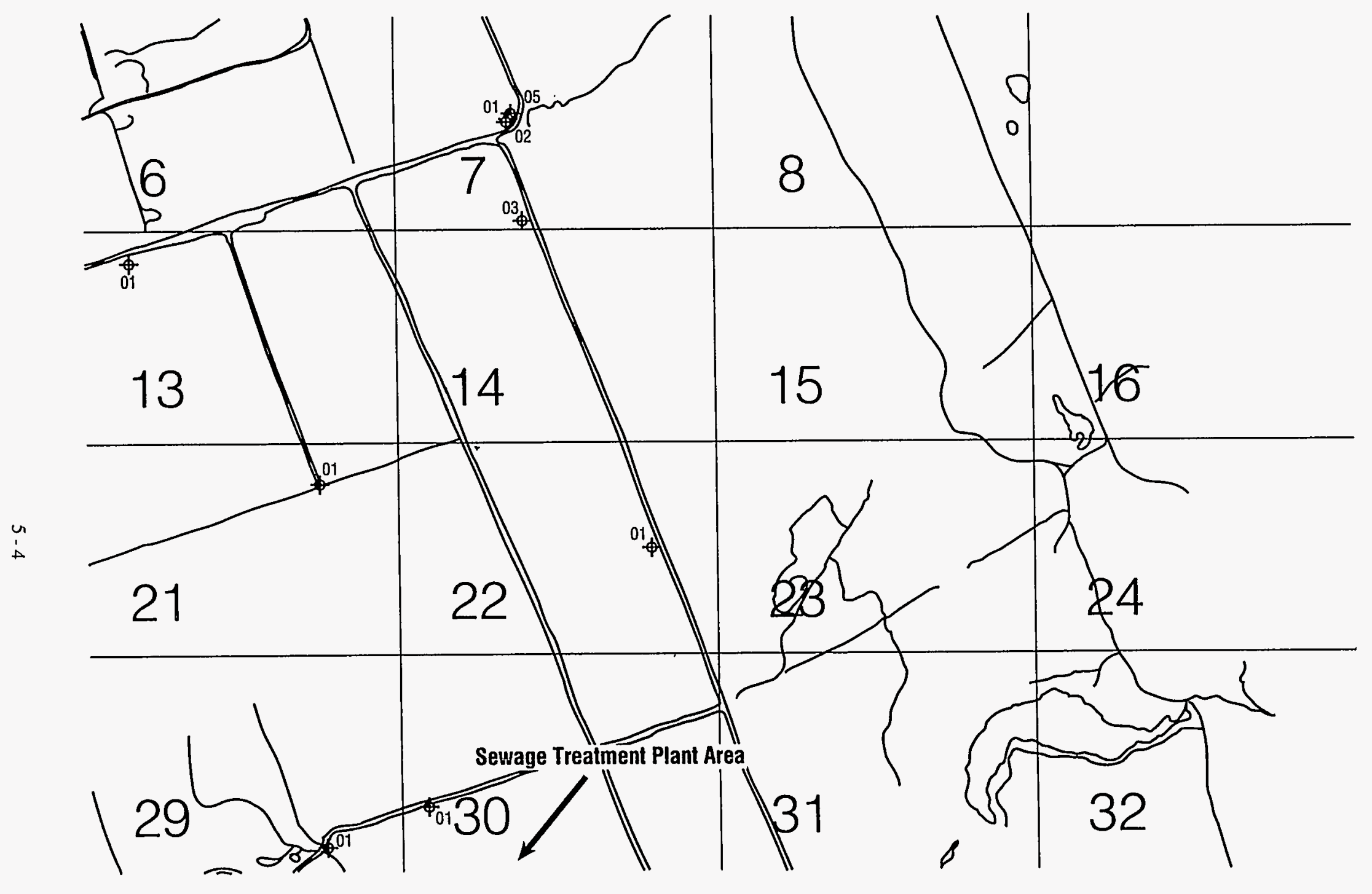

North Boundary - Upgradiant/background wells for BNL Site and Sewage Treatment Plant (northern portion).

Figure 5-3

$\overbrace{\text { SCALE }}^{300 \quad 600 \quad 900 \quad 1200 \mathrm{FT} .}$ 


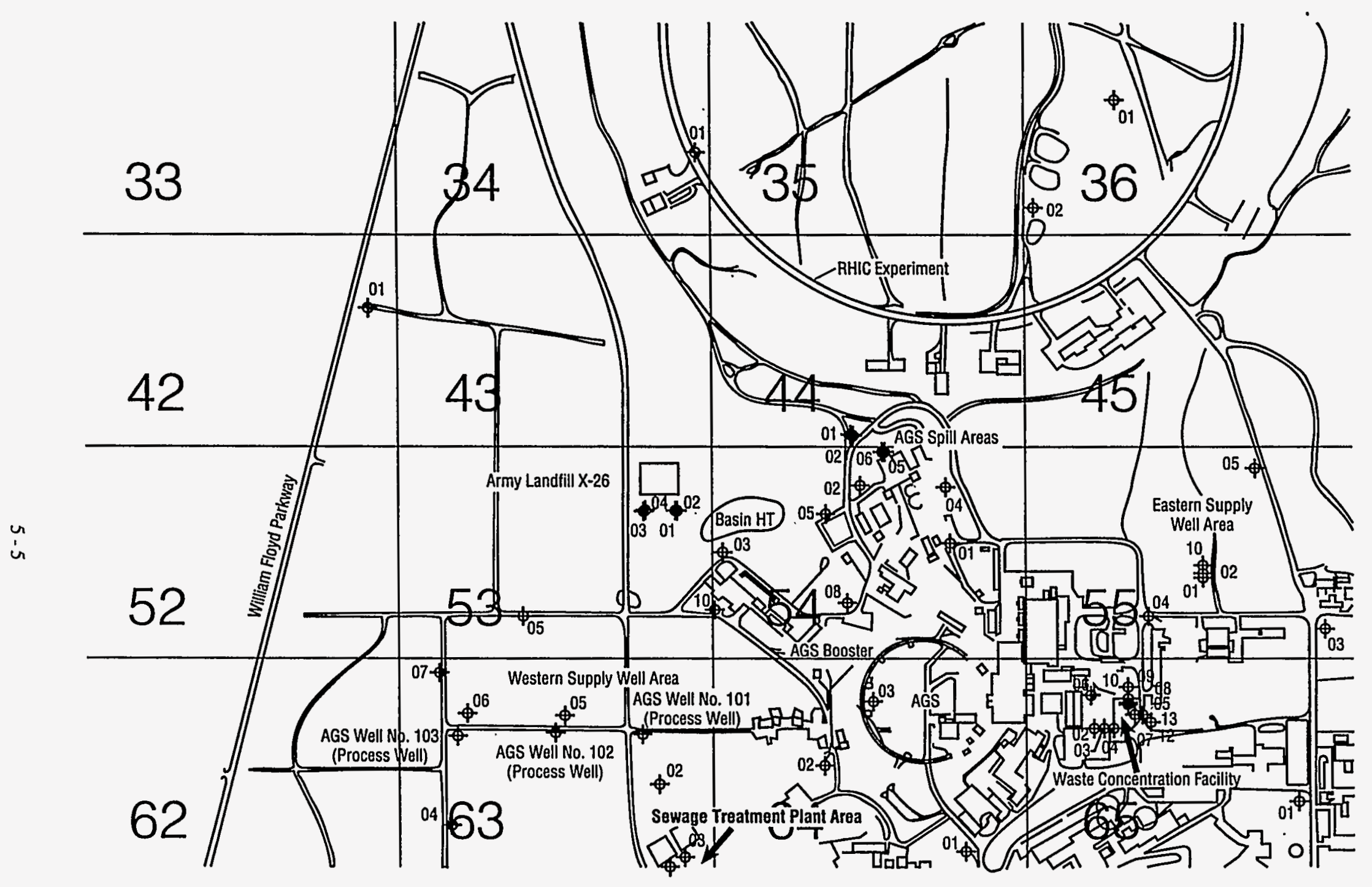

Western Supply Well Area (northern portion), AGS Experimental Areas, Waste Concentration Facility, Recharge Basin HT, Water Treatment Plant, Eastern Supply Well Area (western portion). 


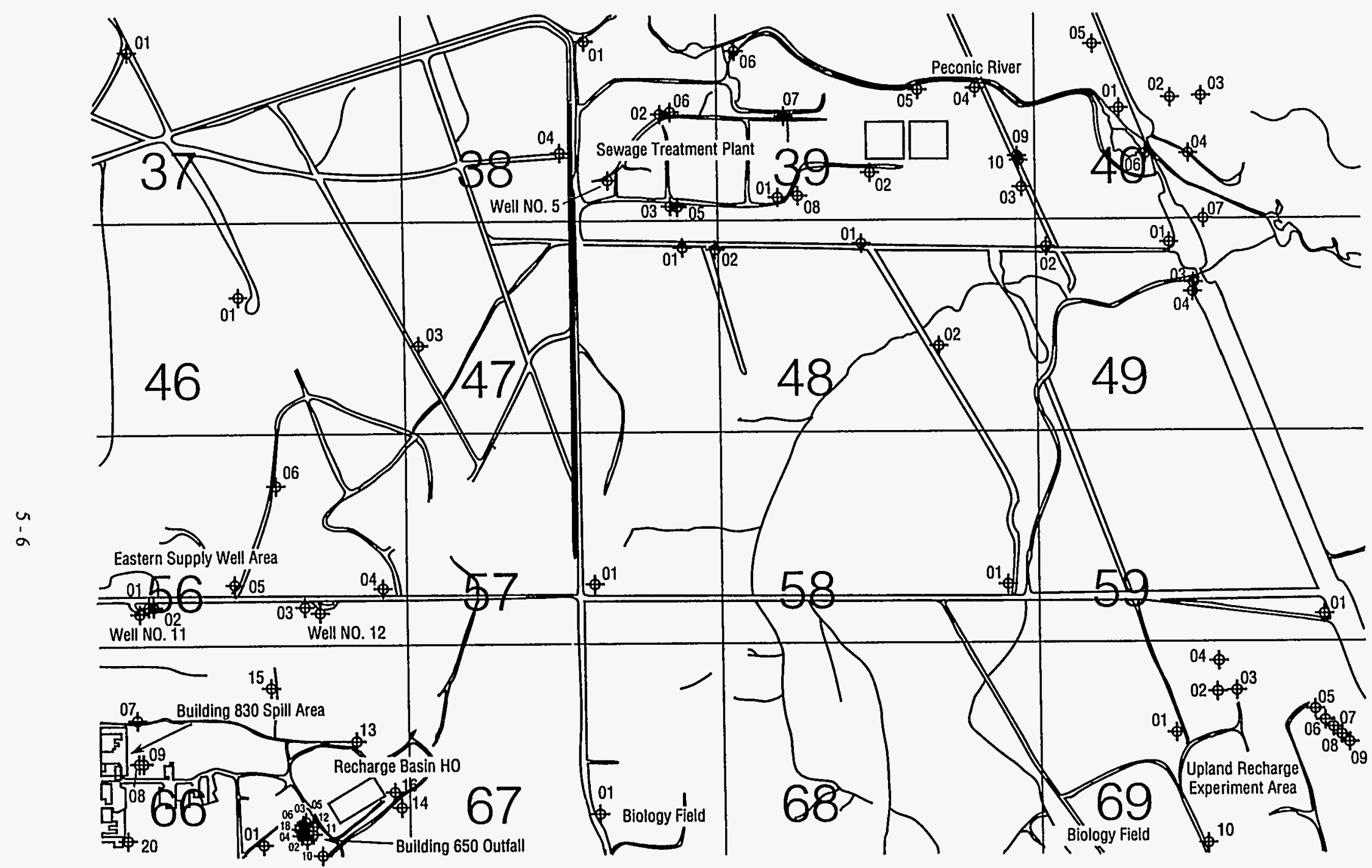

Sewage Treatment Plant and Peconic River Area, Eastern Supply Well Area, Building 830 Spill Site, Recharge Basin HO, Building 650 Outfall, Upland Recharge Experiment Area. 


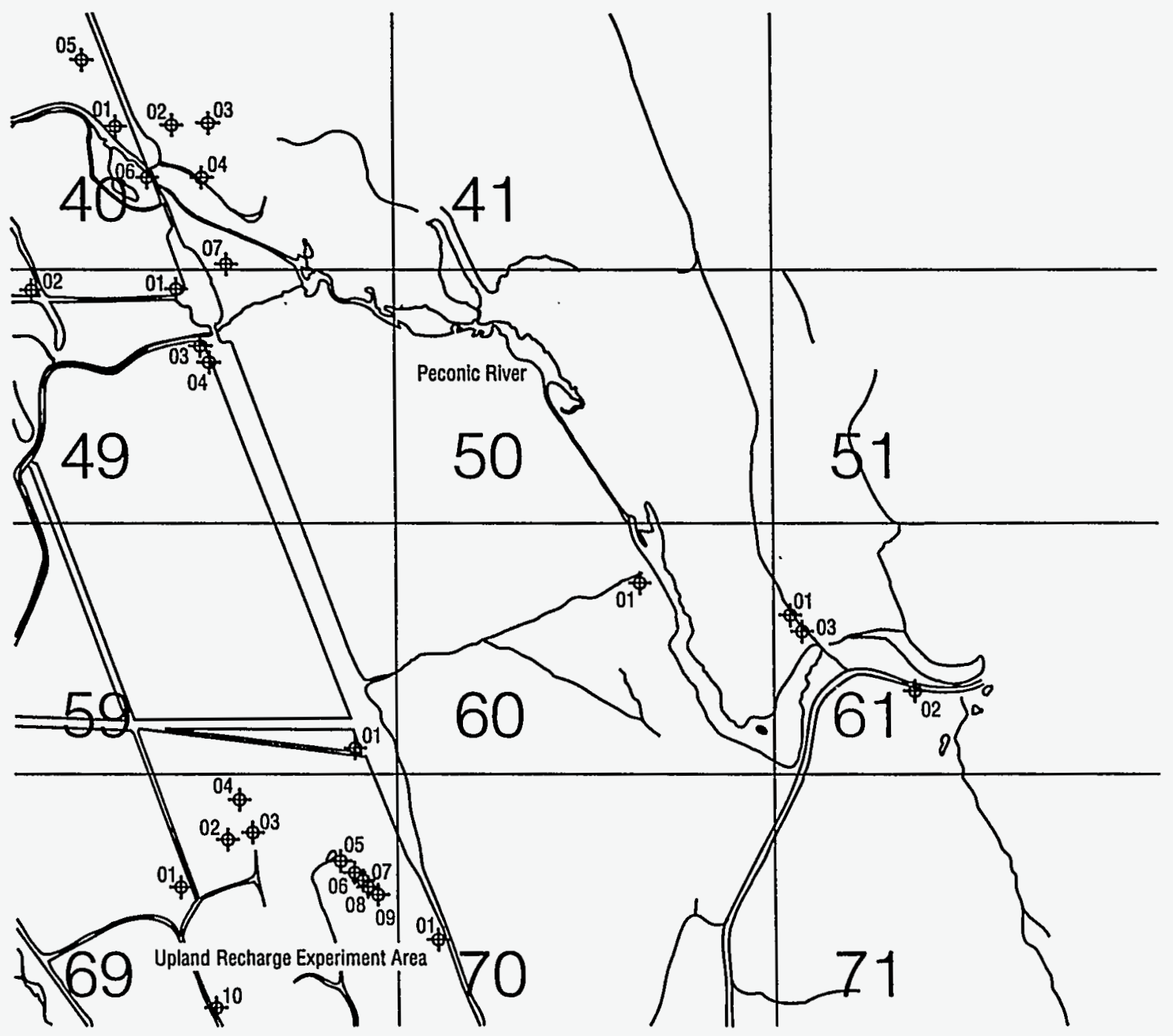

Peconic River, Upland Recharge Experiment Area.

Figure 5-6

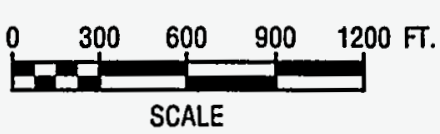




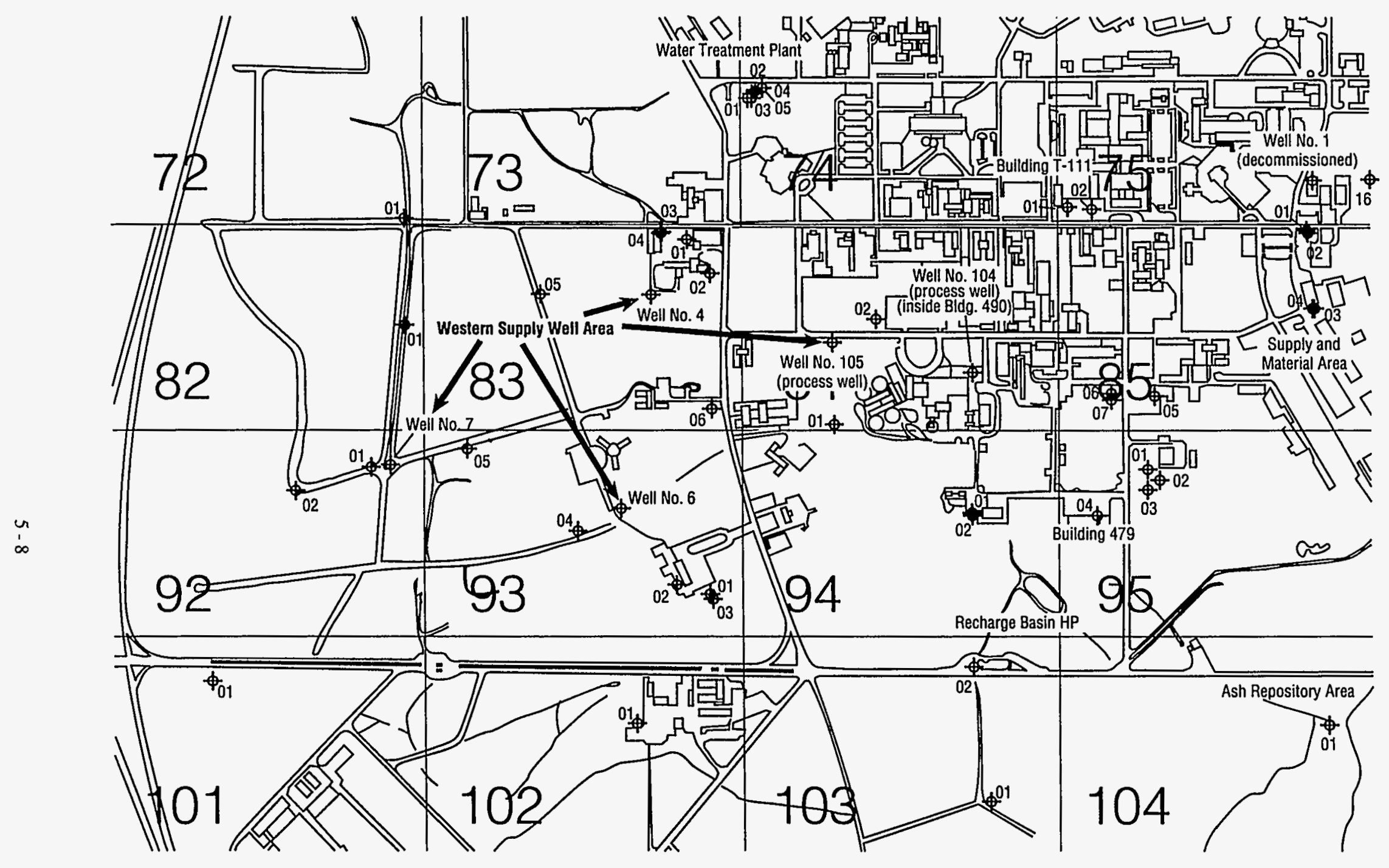

Western Supply Well Area (southern portion), Water Treatment Plant, Building T-111, Supply and Material Area (nothern portion), Building 479, Recharge Basin HP, Ash Repository Area.

Figure 5-7 


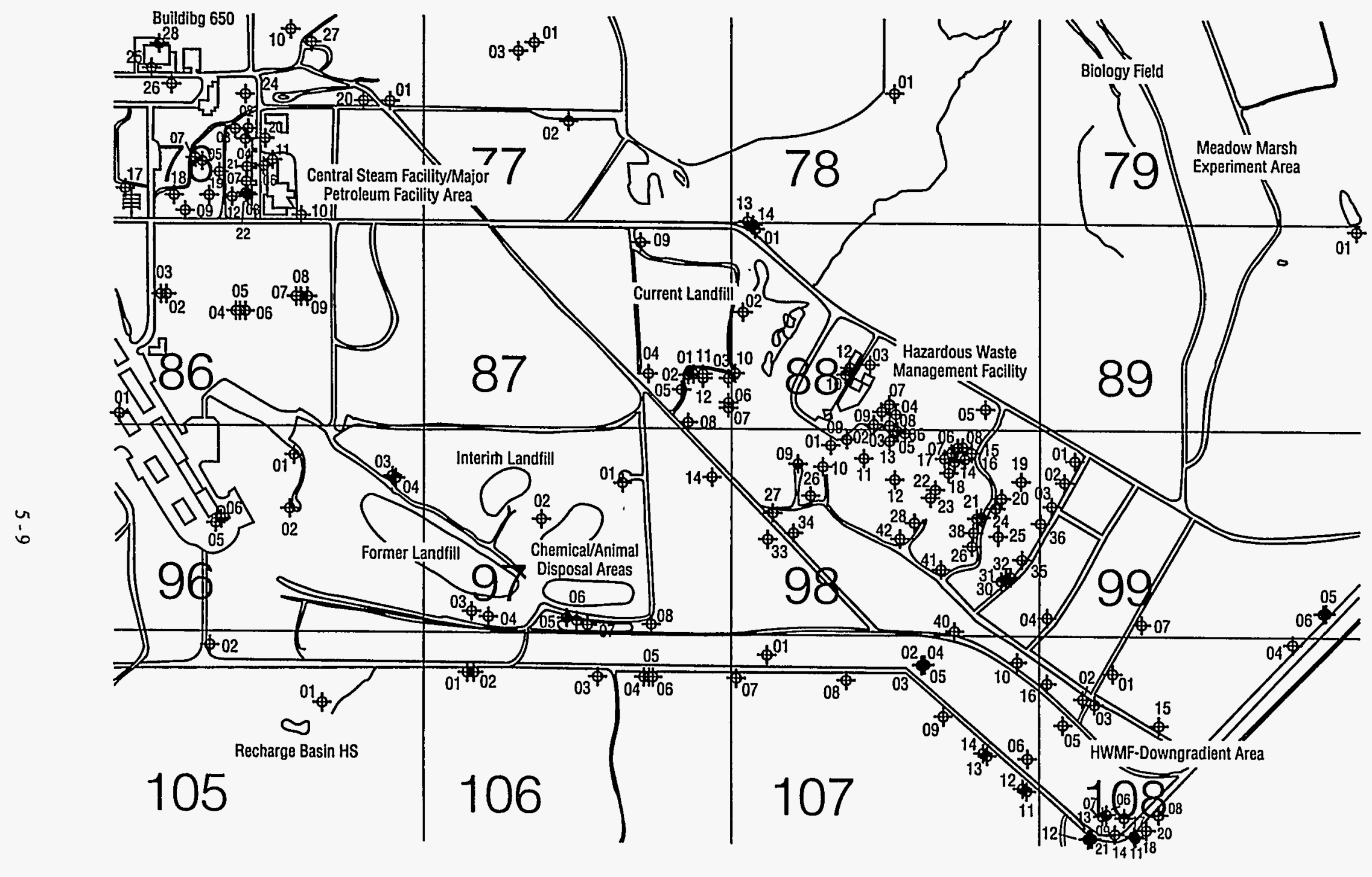

Building 650, Central Steam Facility/Major Petroleum Facility Area, Biology Experimental Fields, Meadow Marsh Experimental Area, Hazardous Waste Management Facility, Current Landfill, Former Landfill Area including Interim Landfill and Chemical/Animal Disposal Areas, Supply and Material Area (southern portion). 


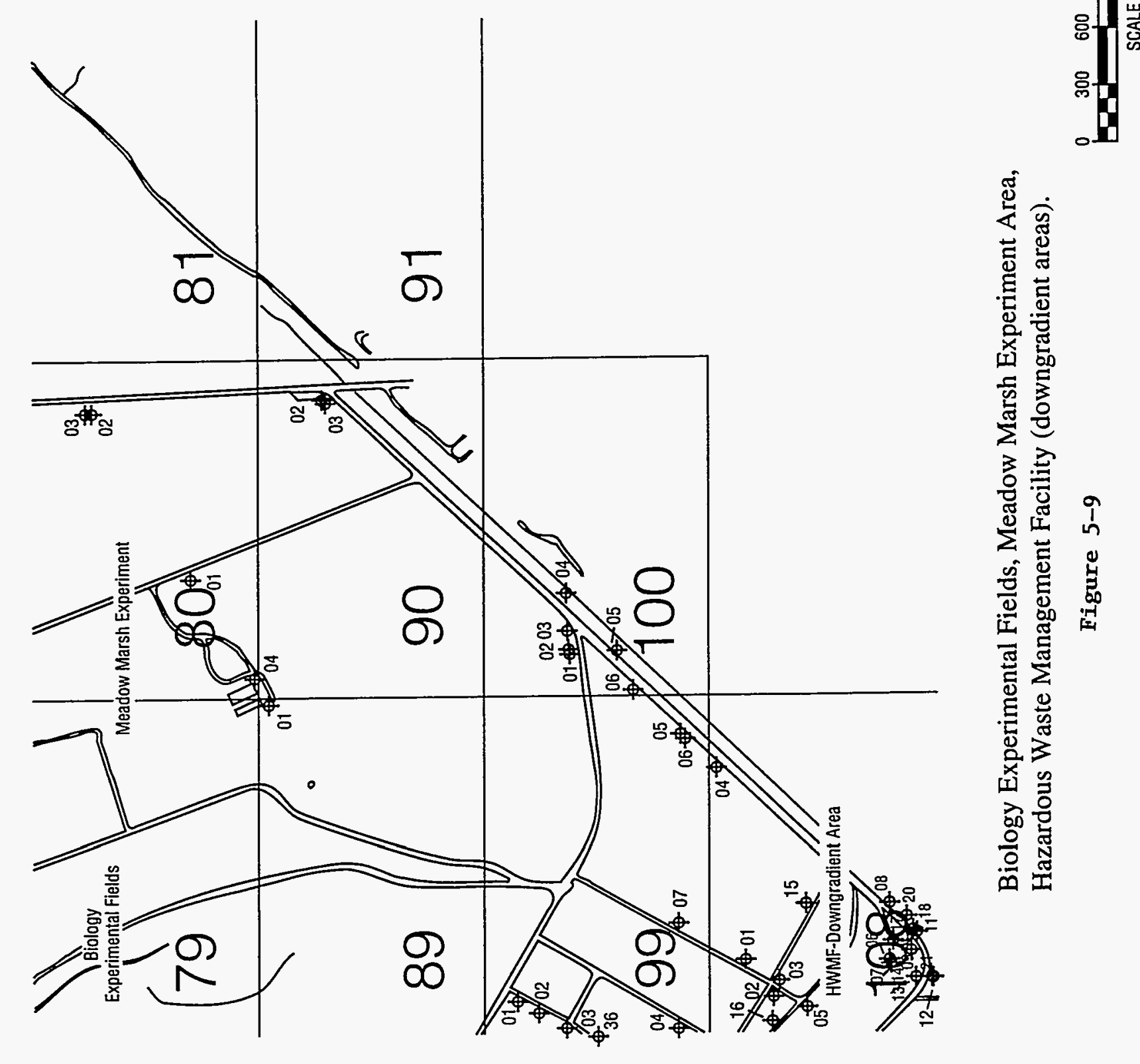




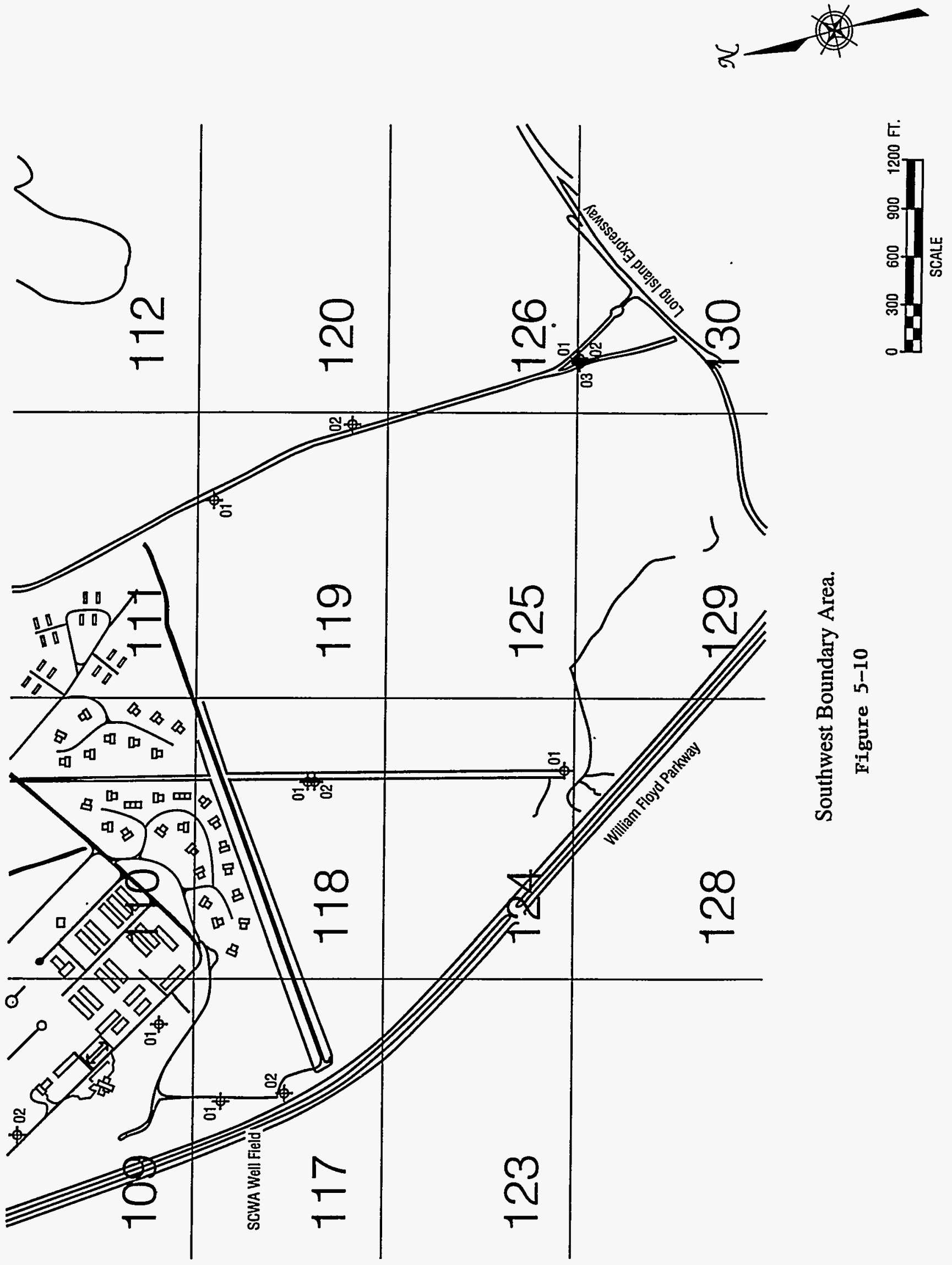




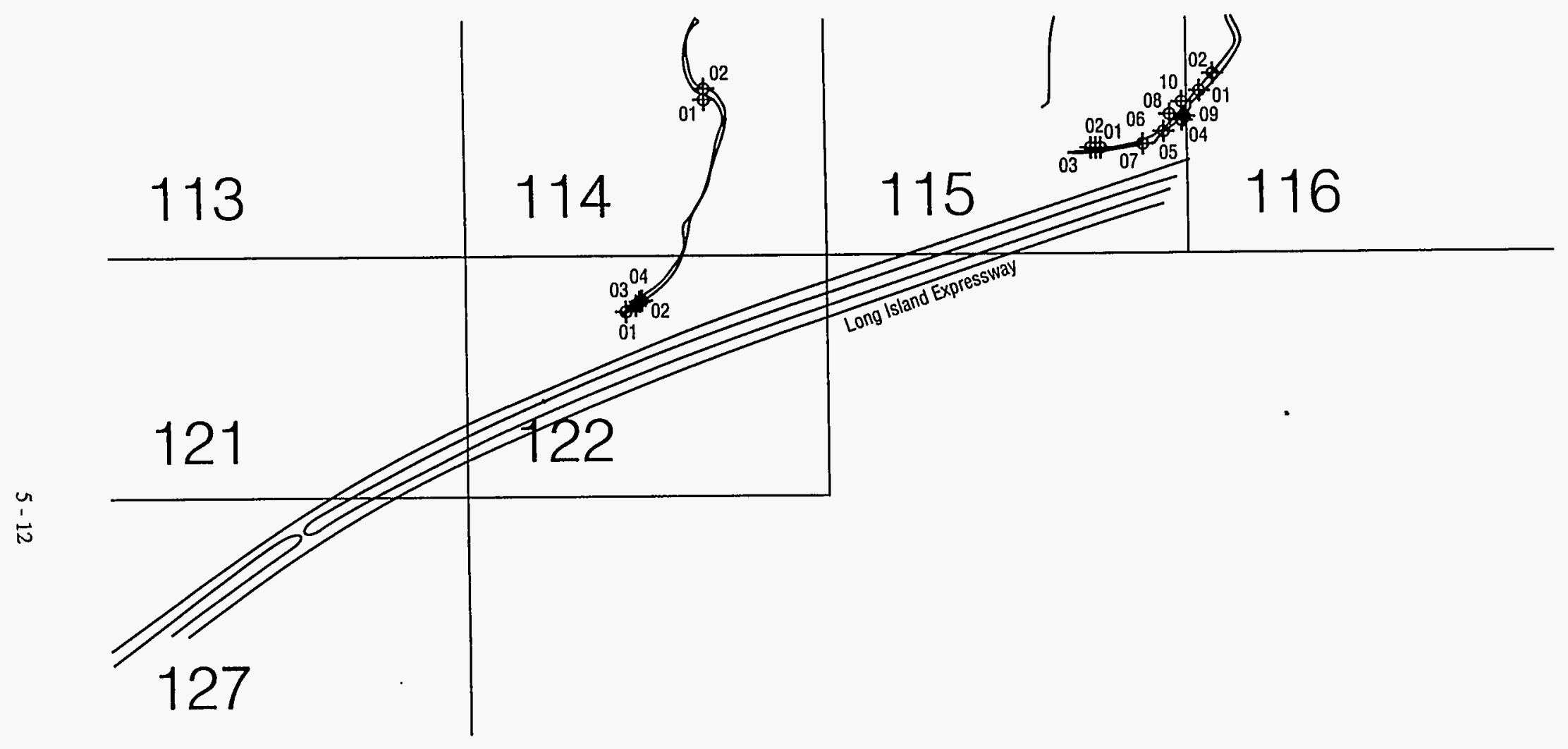

Southern Boundary - Downgradiant Areas of Former Landfill and Current Landfill.

Figure 5-11 
within the Upper Glacial aquifer. Wells 4, 6, 7, 10, 11, and 12 were used to supply drinking water, Wells 101, 102 and 103 were used to supply secondary cooling water to the AGS, and Wells 5 and 9 were used to supply process water to the STP and Biology Department fish house respectively. Well 105, which supplies secondary cooling water to the Medical Department Research Reactor was not operational during 1994 due to TCA concentrations above NYS groundwater effluent standards (i.e., $5 \mu \mathrm{g} / \mathrm{L}$ ). Following the shut down of well 105 (and decommissioned Well 104) in 1990, water from the Chilled Water Facility has been utilized for secondary cooling requirements of the MRR. In 1993 Well 105 was equipped with an activated carbon adsorption system for the mitigation of the volatile organic contaminants. Start-up of this well did not occur in CY 1994 due to operational problems with the control system. It is expected that well 105 will be returned to active service sometime during 1995 .

The data presented in the subsequent text and tables are compared to DCGs to determine compliance with operational limits and, because the Upper Glacial aquifer underlying Nassau and suffolk Counties has been designated as a "sole Source" aquifer, the data are also compared to the EPA and NYS DWS.

Grab samples were obtained from Potable Wells 4, 6, 7, 10, 11 and 12 on a quarterly basis and analyzed for radioactivity, water quality indices, metals, and Vocs. . Regulatory compliance samples were collected quarterly, the results of these analyses are discussed in Chapter 2 .

Process Supply Well Nos. 5, 9, 101, 102 and 103 were used periodically during 1994. These wells were sampled and analyzed for water quality, inorganic and organic contaminants routinely in 1994. Water chemistry analyses (i.e., pH and conductivity) were also performed for wells 101, 102 and 103 by the AGS facility operators as needed to meet the AGS operational requirements. As discussed above, Process Supply Well 105 which is used to provide secondary cooling water to the MRR remained out of service due to the presence of TCA in concentrations above NYS DWS, and was therefore not sampled in 1994.

\subsubsection{Radiological Analyses}

The average radionuclide concentrations in potable and process wells are reported in Table 5-1. The concentrations of radionuclides observed in potable water, were all small fractions of the applicable drinking water standards or guides and therefore do not pose a safety or health risk to individuals who drink or use the water on site. The annual dose resulting from consuming 100\% of the daily water intake from the highest concentration water sources would result in a committed effective dose equivalent of 0.01 mrem $(0.0001 \mathrm{mSv})$. Quality Control samples consisting of distilled and tap water from Building 535 are analyzed daily for gross alpha, gross beta, and tritium. These results are also presented in Table 5-1 and can be used for comparison with other groundwater sample results.

\subsubsection{Nonradiological Analyses}

Six wells were used to supply potable water at BNL during CY 1994 . The NYSDOH governs the quality of potable water supplies and requires that the water purveyor routinely monitor the supply for organic, bacteriological, and inorganic constituents. The NYSDOH requirements (under authority of the safe Drinking Water Act) are implemented by the sCDHs. Monitoring requirements for 1994 included quarterly analysis for pocs, monthly bacteriological analyses, annual analyses for lead and copper, radioactivity, asbestos, micro-extractables, socs and pesticides, and semi-annual inorganic analyses. Potable water samples were collected by BNL personnel and analyzed by a NYSDOH certified contractor laboratory using standard methods of analysis. All analytical data was submitted to the SCDHS as required by Chapter I, Part 5 of the NYS Sanitary Code. The bacteriological and inorganic analytical data and POC and SOC analytical data 
Table 5-1

BNL Site Environmental Report for Calendar Year 1994

On-Site Potable and Process Water

Annual Radionuclide Concentrations ( $p C i / L$ )

\begin{tabular}{|c|c|c|c|c|c|c|c|c|}
\hline Well \# & \multicolumn{2}{|c|}{$\begin{array}{l}\text { No. of } \\
\text { Samples }\end{array}$} & $\begin{array}{c}\text { Gross Alpha } \\
\text { pCill }\end{array}$ & $\begin{array}{c}\text { Gross Beta } \\
\text { pCilL }\end{array}$ & $\begin{array}{l}\text { Tritium } \\
\text { pCill }\end{array}$ & $\begin{array}{l}\mathrm{K}-40 \\
\mathrm{pCi} / \mathrm{L}\end{array}$ & $\begin{array}{l}\text { Co-60 } \\
\text { pCill }\end{array}$ & $\begin{array}{c}\text { Cs-137 } \\
\text { pCi/L }\end{array}$ \\
\hline WTP - In & 3 & Maximum & 2.08 & 1.47 & 110 & ND & ND & 0.13 \\
\hline (F 1) & & Average & 0.93 & 0.14 & -129 & & & 0.04 \\
\hline WTP - Eff & 3 & Maximum & 0.47 & 0.86 & -300 & ND & ND & ND \\
\hline$(F 2)$ & & Average & -0.23 & 0.56 & -140 & & & \\
\hline \multirow[t]{2}{*}{ FD - \#4 } & 4 & Maximum & 0.27 & 2.10 & 186 & 3.69 & 1.90 & ND \\
\hline & & Average & 0.09 & 1.09 & -14 & 1.23 & 0.70 & \\
\hline \multirow[t]{2}{*}{ FE - \#5 } & 2 & Maximum & 0.21 & 1.47 & -103 & ND & ND & ND \\
\hline & & Average & 0.02 & 1.06 & -103 & & & \\
\hline \multirow[t]{2}{*}{ FF - \#6 } & 4 & Maximum & 1.70 & 4.67 & -18 & ND & ND & ND \\
\hline & & Average & 0.44 & 1.48 & -120 & & & \\
\hline \multirow[t]{2}{*}{ FG - \#7 } & 4 & Maximum & 1.68 & 1.91 & -6 & 24.40 & ND & ND \\
\hline & & Average & 0.67 & 0.99 & -140 & 6.10 & & \\
\hline \multirow[t]{2}{*}{ FH - \# 101} & 2 & Maximum & 1.08 & 4.30 & -76 & ND & ND & ND \\
\hline & & Average & 0.54 & 3.11 & -119 & & & \\
\hline \multirow[t]{2}{*}{$\mathrm{FI}-\# 102$} & 1 & Maximum & 0.34 & -0.20 & -422 & ND & ND & 0.24 \\
\hline & & Average & 0.34 & -0.20 & -422 & & & 0.24 \\
\hline \multirow[t]{2}{*}{ FJ - \# 103} & 2 & Maximum & 0.00 & 2.24 & -73 & ND & ND & ND \\
\hline & & Average & -0.12 & 1.28 & -148 & & & \\
\hline \multirow[t]{2}{*}{ FM - \#9 Biology } & 4 & Maximum & 0.34 & 3.25 & 144 & 3.83 & ND & ND \\
\hline & & Average & 0.21 & 1.38 & -158 & 1.92 & & \\
\hline \multirow[t]{2}{*}{ FO - \# 10} & 4 & Maximum & 0.18 & 0.73 & 139 & 2.39 & ND & ND \\
\hline & & Average & -0.02 & 0.19 & -78 & & & \\
\hline \multirow[t]{2}{*}{ FP - \# 11} & 4 & Maximum & 1.74 & 1.87 & 55 & ND & 1.07 & ND \\
\hline & & Average & 0.83 & 0.35 & -32 & & 0.72 & \\
\hline \multirow[t]{2}{*}{$F Q-\# 12$} & 4 & Maximum & 0.27 & 0.86 & 167 & 3.77 & ND & ND \\
\hline & & Average & -0.03 & 0.56 & -62 & 1.29 & & \\
\hline \multicolumn{3}{|c|}{ NYS Drinking Water Standard } & 15 & 50 & 20000 & (a) & (a) & (a) \\
\hline \multicolumn{3}{|c|}{ DOE 5400.5 Drinking Water Guide } & (a) & (a) & 80000 & 280 & 200 & 120 \\
\hline \multicolumn{3}{|l|}{ Typical MDL } & 0.53 & 1.20 & 300 & 280 & 0.23 & 0.2 \\
\hline
\end{tabular}

ND: No Detected.

MDL: Minimum Detection Limit.

(a): No Standard Specified.

Note: DOE Order 5400.5 Drinking Water Guide concentrations derived by dividing DCGs by 25 . 
collected during CY 1994 has been summarized on Tables 2-5 and 2-6, respectively. With the exception of the lead and copper exceedance which is discussed in detail in section 2.6.2, review of the data contained in Tables 2-5 and 2-6 show the BNL potable supply to meet the NYS DWS in CY 1994.

In addition to the NYSDOH compliance monitoring requirements, the S\&EP Division maintains a comprehensive sampling and analysis program for the BNL potable water supply. During 1994, the S\&EP Division monitored the potable wells for metals, water quality parameters, and vocs. Statistical analysis of the data collected during 1994 for the potable wells is contained in Tables 5-2, 5-3, and $5-4$.

Review of the water quality data for the Laboratory potable supply wells shows the indices of water quality such as nitrates, sulfates, and chlorides to be well within the limits established in the NYS DWS. ${ }^{11,12}$ The pH values in these wells ranged from 5.1 - 7.1 and are typical of Long Island. Well Nos. 10, 11, and 12 are equipped with metering pumps which control the addition of sodium hydroxide in order to maintain the $\mathrm{pH}$ of the well pump effluent at approximately 7.3 and reduce the corrosivity of the groundwater.

The majority of metals including silver, cadmium, chromium, and mercury were not detected in the Laboratory supply system. Manganese, copper, lead, and zinc were detected at levels below their respective NYS DWS. Iron was not detected in water samples collected at the well head of Potable Well Nos. 10, 11, and 12 and was not detected in the treated effluent from the BNL WTP. Iron was detected at ambient levels in Potable Well Nos. 4, 6, and 7. The water from these latter wells is treated at the WTP which has an iron removal efficiency in excess of $90 \%$ and permits distribution of water (WTP-EFF) at concentrations below the $0.3 \mathrm{mg} / \mathrm{I}$ NYS DWS. Sodium was detected in all wells at ambient concentrations.

Samples were analyzed by the BNL S\&EP Analytical Laboratory and state approved contract laboratories. The data presented in subsequent text and tables are compared to DCGs to determine compliance with operational limits, and because the Upper Glacial aquifer underlying Nassau and Suffolk Counties has been designated as a "Sole source" aquifer," these data are also compared to New York state Drinking Water Standards (NYS DWS) and New York state Ambient Water Quality Standards (NYS AWQS).

During the second or third month of each quarter, BNL schedules the collection of potable water samples which are analyzed on site by S\&EP for ten organic compounds. The ten organic compounds consist of volatile halogenated aliphatic hydrocarbons and aromatic hydrocarbons. These samples serve both as a quality control on the contractor laboratory and as an additional source of organic data used in trend analysis of water quality. Water samples are collected from the well head and before treatment. Review of the organics data shows that only chloroform and TCA were detected in the potable wells. The concentration of TCA evidenced within Well 11 appears to exceed the NYS DWS; however, this well was fitted with a carbon adsorption treatment system during CY 1992 which effectively reduces the concentration of TCA to below the NYS DWS. All remaining eight organic compounds were not detected in water samples collected during CY 1994.

Process Wells 5, 9, 101, 102 and 103 were also sampled and analyzed during CY 1994. Wells 101, 102 and 103 are used solely for supplying cooling water to the AGS, Well 9 is used for supplying fresh water to the fish tanks housed in Building 463 and Well 5 was used as a supply of non-potable fresh water to the BNL STP. In CY 1994 a new water main was installed to the BNL STP in order to ensure an adequate water supply for this facility. Well 5 will, therefore, no longer be used as a water source. The analytical data contained in Tables 5-2 and 5-3 for these wells shows the concentrations of water quality and inorganic elements to be within ambient levels. Iron is present in all wells at concentrations which are consistent with native groundwater. With the exception of Well 9, all wells proved negative for vocs (Table 5-4). Well 9, which is 
Table 5-2

BNL Site Environmental Report for Calendar Year 1994

Potable Water and Process Supply Wells

Water Quality Data

\begin{tabular}{|c|c|c|c|c|c|c|}
\hline Well Id. (a) & & $\begin{array}{l}\mathrm{pH} \\
\text { SU }\end{array}$ & $\begin{array}{l}\text { Conductivity } \\
\text { umhos } / \mathrm{cm}\end{array}$ & $\begin{array}{c}\text { Chlorides } \\
\text { mg/L }\end{array}$ & $\begin{array}{c}\text { Sulfates } \\
\mathrm{mg} / \mathrm{L}\end{array}$ & $\begin{array}{c}\text { Nitrate as } N \\
\mathrm{mg} / \mathrm{L}\end{array}$ \\
\hline $\begin{array}{l}\text { WTP - In } \\
\quad(\mathrm{F} 1)\end{array}$ & $\begin{array}{c}\mathrm{N} \\
\text { Minimum } \\
\text { Maximum } \\
\text { Average }\end{array}$ & $\begin{array}{c}3 \\
5.1 \\
9.5 \\
\text { NA }\end{array}$ & $\begin{array}{c}3 \\
104 \\
149 \\
121.4\end{array}$ & $\begin{array}{c}3 \\
15.8 \\
17.7 \\
16.9\end{array}$ & $\begin{array}{c}3 \\
8.8 \\
11.3 \\
9.9\end{array}$ & $\begin{array}{l}3 \\
<1.0 \\
<1.0 \\
<1.0\end{array}$ \\
\hline $\begin{array}{l}\text { WTP - Eff } \\
\text { (F2) }\end{array}$ & $\begin{array}{c}\mathrm{N} \\
\text { Minimum } \\
\text { Maximum } \\
\text { Average }\end{array}$ & $\begin{array}{c}3 \\
5.8 \\
6.3 \\
\text { NA }\end{array}$ & $\begin{array}{c}3 \\
104.1 \\
127.1 \\
119.1\end{array}$ & $\begin{array}{c}3 \\
14.9 \\
18.9 \\
16.9\end{array}$ & $\begin{array}{c}3 \\
10.8 \\
12.9 \\
11.8\end{array}$ & $\begin{array}{l}3 \\
<1.0 \\
<1.0 \\
<1.0\end{array}$ \\
\hline 4 (FD) & $\begin{array}{c}\mathrm{N} \\
\text { Minimum } \\
\text { Maximum } \\
\text { Average }\end{array}$ & $\begin{array}{c}4 \\
5.1 \\
6.4 \\
\text { NA }\end{array}$ & $\begin{array}{c}4 \\
105.8 \\
114.5 \\
108.5\end{array}$ & $\begin{array}{c}3 \\
18.5 \\
19.1 \\
18.7\end{array}$ & $\begin{array}{c}3 \\
9.6 \\
9.9 \\
9.8\end{array}$ & $\begin{array}{l}3 \\
<1.0 \\
<1.0 \\
<1.0\end{array}$ \\
\hline$G(F F)$ & $\begin{array}{c}\mathrm{N} \\
\text { Minimum } \\
\text { Maximum } \\
\text { Average }\end{array}$ & $\begin{array}{c}4 \\
5.1 \\
6.5 \\
\text { NA }\end{array}$ & $\begin{array}{c}4 \\
91.6 \\
106.7 \\
99.9\end{array}$ & $\begin{array}{c}4 \\
11.9 \\
13.1 \\
12.4\end{array}$ & $\begin{array}{c}4 \\
9.8 \\
10.9 \\
10.3\end{array}$ & $\begin{array}{c}4 \\
<1.0 \\
<1.0 \\
<1.0\end{array}$ \\
\hline 7 (FG) & $\begin{array}{c}\mathrm{N} \\
\text { Minimum } \\
\text { Maximum } \\
\text { Average }\end{array}$ & $\begin{array}{c}4 \\
5.3 \\
6.6 \\
\text { NA }\end{array}$ & $\begin{array}{c}4 \\
98.7 \\
130.7 \\
112.9\end{array}$ & $\begin{array}{c}4 \\
16.6 \\
17.8 \\
17.1\end{array}$ & $\begin{array}{c}4 \\
9.6 \\
10.1 \\
9.9\end{array}$ & $\begin{array}{c}4 \\
<1.0 \\
<1.0 \\
<1.0\end{array}$ \\
\hline $10(\mathrm{FO})$ & $\begin{array}{c}\mathrm{N} \\
\text { Minimum } \\
\text { Maximum } \\
\text { Average }\end{array}$ & $\begin{array}{c}4 \\
5.4 \\
6.7 \\
N A\end{array}$ & $\begin{array}{c}4 \\
103.1 \\
150.5 \\
117.4\end{array}$ & $\begin{array}{c}4 \\
11.2 \\
15 \\
13.9\end{array}$ & $\begin{array}{c}4 \\
10.3 \\
12.5 \\
11.5\end{array}$ & $\begin{array}{c}4 \\
<1.0 \\
<1.0 \\
<1.0\end{array}$ \\
\hline 11 (FP) & $\begin{array}{c}\mathrm{N} \\
\text { Minimum } \\
\text { Maximum } \\
\text { Average }\end{array}$ & $\begin{array}{c}4 \\
5.2 \\
6.8 \\
\text { NA }\end{array}$ & $\begin{array}{c}4 \\
103.3 \\
110.4 \\
107.1\end{array}$ & $\begin{array}{c}4 \\
13.9 \\
15.5 \\
14.7\end{array}$ & $\begin{array}{c}4 \\
11 \\
12.6 \\
11.7\end{array}$ & $\begin{aligned} & 4 \\
&<1.0 \\
&<1.0 \\
&<1.0\end{aligned}$ \\
\hline 12 (FQ) & $\begin{array}{c}\mathrm{N} \\
\text { Minimum } \\
\text { Maximum } \\
\text { Average }\end{array}$ & $\begin{array}{c}4 \\
6.1 \\
7.1 \\
\text { NA }\end{array}$ & $\begin{array}{c}4 \\
111.6 \\
128.1 \\
116.8\end{array}$ & $\begin{array}{c}4 \\
14.8 \\
16.4 \\
15.8\end{array}$ & $\begin{array}{c}4 \\
10.8 \\
11.7 \\
11.1\end{array}$ & $\begin{array}{l}4 \\
<1.0 \\
<1.0 \\
<1.0\end{array}$ \\
\hline 5 (FE) & $\begin{array}{c}\mathrm{N} \\
\text { Minimum } \\
\text { Maximum } \\
\text { Average }\end{array}$ & $\begin{array}{c}2 \\
6 \\
6.24 \\
N A\end{array}$ & $\begin{array}{c}1 \\
48.7 \\
48.7 \\
48.7\end{array}$ & $\begin{array}{c}2 \\
3.6 \\
4.5 \\
4.1\end{array}$ & $\begin{array}{c}2 \\
8.6 \\
9.1 \\
8.9\end{array}$ & $\begin{array}{l}2 \\
<1.0 \\
<1.0 \\
<1.0\end{array}$ \\
\hline $101(\mathrm{FH})$ & $\begin{array}{c}\mathrm{N} \\
\text { Minimum } \\
\text { Maximum } \\
\text { Average }\end{array}$ & $\begin{array}{c}2 \\
6.2 \\
6.5 \\
N A\end{array}$ & $\begin{array}{c}2 \\
96.6 \\
110 \\
103.3\end{array}$ & $\begin{array}{c}2 \\
14.9 \\
15.5 \\
15.2\end{array}$ & $\begin{array}{c}2 \\
9.1 \\
9.5 \\
9.3\end{array}$ & $\begin{array}{l}3 \\
<1.0 \\
<1.0 \\
<1.0\end{array}$ \\
\hline $102(\mathrm{FI})$ & $\stackrel{\mathrm{N}}{\text { Concentration }}$ & $\begin{array}{c}1 \\
6.8\end{array}$ & $\stackrel{1}{118}$ & $\begin{array}{c}1 \\
18.3\end{array}$ & $\begin{array}{l}1 \\
8\end{array}$ & $\begin{array}{c}1 \\
<1.0\end{array}$ \\
\hline 103 (FJ) & $\begin{array}{c}\mathrm{N} \\
\text { Minimum } \\
\text { Maximum } \\
\text { Average }\end{array}$ & $\begin{array}{c}2 \\
5.8 \\
6.2 \\
\text { NA }\end{array}$ & $\begin{array}{c}2 \\
112.1 \\
126 \\
119.1\end{array}$ & $\begin{array}{c}2 \\
22.1 \\
23.1 \\
22.6\end{array}$ & $\begin{array}{c}2 \\
9.5 \\
9.7 \\
9.6\end{array}$ & $\begin{array}{c}2 \\
<1.0 \\
<1.0 \\
<1.0\end{array}$ \\
\hline NYSDWS & & (b) & (b) & 250 & 250 & 10 \\
\hline Typical MDL & & NA & 10 & 4 & 4 & 1 \\
\hline
\end{tabular}

N: No. of samples

NA: Not Applicable

WTP-In: Water Treatment Plant Influent

WTP-Eff: Water Treatment Plant Effluent

NYSDWS: Now York State Drinking Water Standard

MDL: Minimum Detection Limit

(a): The location of potable and process wells is shown on Figure 4-15

(b): No standard specified 
Table 5-3

BNL Site Environmental Report for Calendar Year 1994

Potable and Process Supply Wells

Metals Data

\begin{tabular}{|c|c|c|c|c|c|c|c|c|c|c|c|}
\hline Well ld. (a) & & $\begin{array}{c}\mathrm{Ag} \\
\mathrm{mg} / \mathrm{L}\end{array}$ & $\begin{array}{c}C d \\
m g h\end{array}$ & $\begin{array}{c}\mathrm{Cr} \\
\mathrm{mg} / \mathrm{L}\end{array}$ & $\begin{array}{c}\mathrm{Cu} \\
\mathrm{mg} \Omega\end{array}$ & $\begin{array}{c}\mathrm{Fe} \\
\mathrm{mg} / \mathrm{l}\end{array}$ & $\begin{array}{c}\mathrm{Hg} \\
\mathrm{mgl}\end{array}$ & $\begin{array}{c}M n \\
m g h l\end{array}$ & $\begin{array}{c}\mathrm{Na} \\
\mathrm{mg} \Omega\end{array}$ & $\begin{array}{c}\mathrm{Pb} \\
\mathrm{mg} / \mathrm{l}\end{array}$ & $\begin{array}{c}\mathrm{Zn} \\
\mathrm{mg} /\end{array}$ \\
\hline $\begin{array}{c}\text { WTP-In } \\
\text { (F1) }\end{array}$ & $\begin{array}{c}\mathrm{N} \\
\text { Minimum } \\
\text { Maximum } \\
\text { Average }\end{array}$ & $\begin{array}{c}3 \\
<0.025 \\
<0.025 \\
<0.025\end{array}$ & $\begin{array}{c}3 \\
<0.0005 \\
<0.0005 \\
<0.0005\end{array}$ & $\begin{array}{c}3 \\
<0.005 \\
<0.005 \\
<0.005\end{array}$ & $\begin{array}{c}3 \\
<0.05 \\
<0.05 \\
<0.05\end{array}$ & $\begin{array}{c}3 \\
<0.075 \\
2.9 \\
1.2\end{array}$ & $\begin{array}{c}3 \\
<0.0002 \\
<0.0002 \\
<0.0002\end{array}$ & $\begin{array}{c}3 \\
<0.05 \\
0.077 \\
<0.05\end{array}$ & $\begin{array}{c}3 \\
9.6 \\
11.4 \\
10.5\end{array}$ & $\begin{array}{c}3 \\
<0.002 \\
<0.002 \\
<0.002\end{array}$ & $\begin{array}{c}3 \\
<0.02 \\
0.21 \\
<0.02\end{array}$ \\
\hline $\begin{array}{l}\text { WTP-Eff } \\
\text { (F2) }\end{array}$ & $\begin{array}{c}\mathrm{N} \\
\text { Minimum } \\
\text { Maximum } \\
\text { Average }\end{array}$ & $\begin{array}{c}3 \\
<0.025 \\
<0.025 \\
<0.025\end{array}$ & $\begin{array}{c}3 \\
<0.0005 \\
<0.0005 \\
<0.0005\end{array}$ & $\begin{array}{c}3 \\
<0.005 \\
<0.005 \\
<0.005\end{array}$ & $\begin{array}{c}3 \\
<0.05 \\
0.074 \\
<0.05\end{array}$ & $\begin{array}{c}3 \\
<0.075 \\
<0.075 \\
<0.075\end{array}$ & $\begin{array}{c}3 \\
<0.0002 \\
<0.0002 \\
<0.0002\end{array}$ & $\begin{array}{c}3 \\
<0.05 \\
<0.05 \\
<0.05\end{array}$ & $\begin{array}{c}3 \\
9.9 \\
14.9 \\
12.4\end{array}$ & $\begin{array}{c}3 \\
<0.002 \\
<0.002 \\
<0.002\end{array}$ & $\begin{array}{c}3 \\
<0.02 \\
<0.02 \\
<0.02\end{array}$ \\
\hline $4(\mathrm{FD})$ & $\begin{array}{c}\mathrm{N} \\
\text { Minimum } \\
\text { Maximum } \\
\text { Average }\end{array}$ & $\begin{array}{c}4 \\
<0.025 \\
<0.025 \\
<0.025\end{array}$ & $\begin{array}{c}4 \\
<0.0005 \\
<0.0005 \\
<0.0005\end{array}$ & $\begin{array}{c}4 \\
<0.005 \\
<0.005 \\
<0.005\end{array}$ & $\begin{array}{c}4 \\
<0.05 \\
0.11 \\
0.05\end{array}$ & $\begin{array}{c}\quad 4 \\
<0.075 \\
1.94 \\
0.49\end{array}$ & $\begin{array}{c}4 \\
<0.0002 \\
<0.0002 \\
<0.0002\end{array}$ & $\begin{array}{c}4 \\
<0.05 \\
0.15 \\
0.08\end{array}$ & $\begin{array}{c}4 \\
8.6 \\
11.4 \\
10\end{array}$ & $\begin{array}{c}4 \\
<0.002 \\
0.0032 \\
0.002\end{array}$ & $\begin{array}{c}4 \\
0.024 \\
0.043 \\
0.03\end{array}$ \\
\hline $6(\mathrm{FF})$ & $\begin{array}{c}\mathrm{N} \\
\text { Minimum } \\
\text { Maximum } \\
\text { Average }\end{array}$ & $\begin{array}{c}4 \\
<0.025 \\
<0.025 \\
<0.025\end{array}$ & $\begin{array}{c}4 \\
<0.0005 \\
<0.0005 \\
<0.0005\end{array}$ & $\begin{array}{c}4 \\
<0.005 \\
<0.005 \\
<0.005\end{array}$ & $\begin{array}{c}4 \\
<0.05 \\
0.064 \\
<0.05\end{array}$ & $\begin{array}{l}4 \\
2.7 \\
4.1 \\
3.1\end{array}$ & $\begin{array}{c}4 \\
<0.0002 \\
<0.0002 \\
<0.0002\end{array}$ & $\begin{array}{c}4 \\
0.076 \\
0.12 \\
0.09\end{array}$ & $\begin{array}{c}4 \\
8 \\
9.1 \\
8.6\end{array}$ & $\begin{array}{c}4 \\
<0.002 \\
0.004 \\
<0.002\end{array}$ & $\begin{array}{c}4 \\
<0.02 \\
0.059 \\
0.04\end{array}$ \\
\hline 7 (FG) & $\begin{array}{c}\stackrel{N}{ } \\
\text { Maximum } \\
\text { Minimum } \\
\text { Average }\end{array}$ & $\begin{array}{c}4 \\
<0.025 \\
<0.025 \\
<0.025\end{array}$ & $\begin{array}{c}4 \\
<0.0005 \\
<0.0005 \\
<0.0005\end{array}$ & $\begin{array}{c}4 \\
<0.005 \\
<0.005 \\
<0.005\end{array}$ & $\begin{array}{c}4 \\
<0.05 \\
<0.05 \\
<0.05\end{array}$ & $\begin{array}{c}4 \\
1.48 \\
1.75 \\
1.62\end{array}$ & $\begin{array}{c}4 \\
<0.0002 \\
<0.0002 \\
<0.0002\end{array}$ & $\begin{array}{c}4 \\
0.07 \\
0.084 \\
0.076\end{array}$ & $\begin{array}{c}4 \\
10.32 \\
11.75 \\
11.1\end{array}$ & $\begin{array}{c}4 \\
<0.002 \\
<0.002 \\
<0.002\end{array}$ & $\begin{array}{c}4 \\
<0.02 \\
0.054 \\
<0.02\end{array}$ \\
\hline $10(\mathrm{FO})$ & $\begin{array}{c}\mathbf{N} \\
\text { Minimum } \\
\text { Maximum } \\
\text { Average }\end{array}$ & $\begin{array}{c}4 \\
<0.025 \\
<0.025 \\
<0.025\end{array}$ & $\begin{array}{c}4 \\
<0.0005 \\
0.0017 \\
<0.0005\end{array}$ & $\begin{array}{c}4 \\
<0.005 \\
<0.005 \\
<0.005\end{array}$ & $\begin{array}{c}4 \\
<0.05 \\
<0.05 \\
<0.05\end{array}$ & $\begin{array}{c}4 \\
<0.075 \\
<0.075 \\
<0.075\end{array}$ & $\begin{array}{c}4 \\
<0.0002 \\
<0.0002 \\
<0.0002\end{array}$ & $\begin{array}{c}4 \\
<0.05 \\
<0.05 \\
<0.05\end{array}$ & $\begin{array}{c}4 \\
9.11 \\
11.13 \\
9.85\end{array}$ & $\begin{array}{c}4 \\
<0.002 \\
<0.002 \\
<0.002\end{array}$ & $\begin{array}{c}4 \\
<0.02 \\
0.054 \\
0.025\end{array}$ \\
\hline $11(\mathrm{FP})$ & $\begin{array}{c}\mathrm{N} \\
\text { Minimum } \\
\text { Maximum } \\
\text { Average }\end{array}$ & $\begin{array}{c}4 \\
<0.025 \\
<0.025 \\
<0.025\end{array}$ & $\begin{array}{c}4 \\
<0.0005 \\
<0.0005 \\
<0.0005\end{array}$ & $\begin{array}{c}4 \\
<0.005 \\
<0.005 \\
<0.005\end{array}$ & $\begin{array}{c}4 \\
<0.05 \\
<0.05 \\
<0.05\end{array}$ & $\begin{array}{c}4 \\
<0.075 \\
<0.075 \\
<0.075\end{array}$ & $\begin{array}{c}4 \\
<0.0002 \\
<0.0002 \\
<0.0002\end{array}$ & $\begin{array}{c}4 \\
<0.05 \\
<0.05 \\
<0.05\end{array}$ & $\begin{array}{c}4 \\
10.34 \\
11.55 \\
10.97\end{array}$ & $\begin{array}{c}4 \\
<0.002 \\
0.0046 \\
<0.002\end{array}$ & $\begin{array}{c}4 \\
<0.02 \\
0.052 \\
0.025\end{array}$ \\
\hline 12 (FQ) & $\begin{array}{l}\mathrm{N} \\
\text { Minimum } \\
\text { Maximum } \\
\text { Average }\end{array}$ & $\begin{array}{c}4 \\
<0.025 \\
<0.025 \\
<0.025\end{array}$ & $\begin{array}{c}4 \\
<0.0005 \\
<0.0005 \\
<0.0005\end{array}$ & $\begin{array}{c}4 \\
<0.005 \\
<0.005 \\
<0.005\end{array}$ & $\begin{array}{c}4 \\
<0.05 \\
<0.05 \\
<0.05\end{array}$ & $\begin{array}{c}4 \\
<0.075 \\
<0.075 \\
<0.075\end{array}$ & $\begin{array}{c}4 \\
<0.0002 \\
<0.0002 \\
<0.0002\end{array}$ & $\begin{array}{c}4 \\
<0.05 \\
<0.05 \\
<0.05\end{array}$ & $\begin{array}{c}4 \\
12.62 \\
13.89 \\
13.18\end{array}$ & $\begin{array}{c}4 \\
<0.002 \\
<0.002 \\
<0.002\end{array}$ & $\begin{array}{c}4 \\
<0.02 \\
0.04 \\
<0.02\end{array}$ \\
\hline $5(\mathrm{FE})$ & $\begin{array}{c}\mathrm{N} \\
\text { Minimum } \\
\text { Maximum } \\
\text { Average }\end{array}$ & $\begin{array}{c}2 \\
<0.025 \\
<0.025 \\
<0.025\end{array}$ & $\begin{array}{c}2 \\
<0.0005 \\
<0.0005 \\
<0.0005\end{array}$ & $\begin{array}{c}2 \\
<0.005 \\
<0.005 \\
<0.005\end{array}$ & $\begin{array}{c}2 \\
<0.05 \\
<0.05 \\
<0.05\end{array}$ & $\begin{array}{c}2 \\
0.47 \\
0.51 \\
0.49\end{array}$ & $\begin{array}{c}2 \\
<0.0002 \\
<0.0002 \\
<0.0002\end{array}$ & $\begin{array}{l}2 \\
<0.05 \\
<0.05 \\
<0.05\end{array}$ & $\begin{array}{c}2 \\
3.78 \\
3.86 \\
3.82\end{array}$ & $\begin{array}{c}2 \\
<0.002 \\
0.0026 \\
<0.002\end{array}$ & $\begin{array}{c}2 \\
0.033 \\
0.057 \\
0.045\end{array}$ \\
\hline $9(F M)$ & $\begin{array}{c}\mathrm{N} \\
\text { Minimum } \\
\text { Maximum } \\
\text { Average }\end{array}$ & $\begin{array}{c}4 \\
<0.025 \\
<0.025 \\
<0.025\end{array}$ & $\begin{array}{c}4 \\
<0.0005 \\
<0.0005 \\
<0.0005\end{array}$ & $\begin{array}{c}4 \\
<0.005 \\
<0.005 \\
<0.005\end{array}$ & $\begin{array}{c}4 \\
<0.05 \\
<0.05 \\
<0.05\end{array}$ & $\begin{array}{c}4 \\
0.23 \\
1.22 \\
0.57\end{array}$ & $\begin{array}{c}4 \\
<0.0002 \\
<0.0002 \\
<0.0002\end{array}$ & $\begin{array}{c}4 \\
<0.05 \\
<0.05 \\
<0.05\end{array}$ & $\begin{array}{c}4 \\
11.18 \\
12.18 \\
11.52\end{array}$ & $\begin{array}{c}4 \\
<0.002 \\
<0.002 \\
<0.002\end{array}$ & $\begin{array}{l}\quad 4 \\
<0.02 \\
0.04 \\
<0.02\end{array}$ \\
\hline $101(\mathrm{FH})$ & $\begin{array}{c}\mathrm{N} \\
\text { Minimum } \\
\text { Maximum } \\
\text { Average }\end{array}$ & $\begin{array}{c}2 \\
<0.025 \\
<0.025 \\
<0.025\end{array}$ & $\begin{array}{c}2 \\
<0.0005 \\
<0.0005 \\
<0.0005\end{array}$ & $\begin{array}{c}2 \\
<0.005 \\
<0.005 \\
<0.005\end{array}$ & $\begin{array}{l}2 \\
<0.05 \\
<0.05 \\
<0.05\end{array}$ & $\begin{array}{c}2 \\
0.92 \\
0.95 \\
0.94\end{array}$ & $\begin{array}{c}2 \\
<0.0002 \\
<0.0002 \\
<0.0002\end{array}$ & $\begin{array}{c}2 \\
0.064 \\
0.065 \\
0.065\end{array}$ & $\begin{array}{c}2 \\
10.22 \\
11.13 \\
10.68\end{array}$ & $\begin{array}{c}2 \\
<0.002 \\
<0.002 \\
<0.002\end{array}$ & $\begin{array}{c}2 \\
<0.02 \\
0.043 \\
0.022\end{array}$ \\
\hline $102(F I)$ & $\stackrel{\mathrm{N}}{\text { Concentration }}$ & $\begin{array}{c}1 \\
<.025\end{array}$ & $<\frac{1}{<0.0005}$ & $\stackrel{1}{1}$ & $\stackrel{1}{0.05}$ & $\begin{array}{c}1 \\
3.37\end{array}$ & $\stackrel{1}{1} 0.0002$ & $\begin{array}{c}9 \\
0.37\end{array}$ & $\begin{array}{c}1 \\
12\end{array}$ & $\begin{array}{c}1 \\
0.0026\end{array}$ & $\begin{array}{c}1 \\
<0.02\end{array}$ \\
\hline $103(\mathrm{FJ})$ & $\begin{array}{c}\mathrm{N} \\
\text { Minimum } \\
\text { Maximum } \\
\text { Average }\end{array}$ & $\begin{array}{c}2 \\
<0.025 \\
<0.025 \\
<0.025\end{array}$ & $\begin{array}{c}2 \\
<0.0005 \\
<0.0005 \\
<0.0005\end{array}$ & $\begin{array}{c}2 \\
<0.005 \\
<0.005 \\
<0.005\end{array}$ & $\begin{array}{l}2 \\
<0.05 \\
<0.05 \\
<0.05\end{array}$ & $\begin{array}{c}2 \\
<0.075 \\
4.37 \\
2.19\end{array}$ & $\begin{array}{c}2 \\
<0.0002 \\
<0.0002 \\
<0.0002\end{array}$ & $\begin{array}{c}2 \\
0.64 \\
0.71 \\
0.68\end{array}$ & $\begin{array}{c}2 \\
13.72 \\
14.38 \\
14.05\end{array}$ & $\begin{array}{c}2 \\
<0.002 \\
<0.002 \\
<0.002\end{array}$ & $\begin{array}{c}2 \\
0.041 \\
0.044 \\
0.043\end{array}$ \\
\hline NYSDWS & & 0.05 & 0.01 & 0.05 & 1.3 & 0.3 & 0.002 & 0.3 & (b) & 0.015 & 5 \\
\hline Typical MDL & & 0.025 & 0.0005 & 0.005 & 0.05 & 0.075 & 0.0002 & 0.05 & 1 & 0.002 & 0.02 \\
\hline
\end{tabular}

N: No. of samples

WTP-In: Water Treatment Plant Influent

WTP-Eff: Water Treatment Plant Effiuent

NYSDWS: New York State Drinking Water Standard

MDL: Minimum Detection Limit

(a): The location of potable and process wells is shown on Figure 23.

(b): No standard specified.

The average metals concentration has been calculated by summing all detectable concentrations then dividing the sum by the total number of samples $c$ All non-detectable quantities have been evaluated as zero. If the average is less than the typical MDL, it is reported as less than the MDL. 
Table 5 -4

BNL Site Environmental Report for Calendar Year 1994

Potable Water and Process Supply Wells

Volatile Organic Compound Data

\begin{tabular}{|c|c|c|c|c|c|c|c|}
\hline Well Id. (a) & & $\begin{array}{l}\text { Chloroform } \\
\text { ug } /\end{array}$ & $\begin{array}{l}\text { 1,1 Dichloroethylene } \\
\text { ugh }\end{array}$ & $\begin{array}{c}\text { 1,1,1 - Trichloroethane } \\
\text { ug } / \text {. }\end{array}$ & $\begin{array}{l}\text { Toluene } \\
\text { ugh }\end{array}$ & $\begin{array}{l}\text { Xylene } \\
\text { ug } / \mathrm{L}\end{array}$ & $\begin{array}{c}\text { Ethylbenzene } \\
\text { ugh }\end{array}$ \\
\hline $\begin{array}{l}\text { WTP-In } \\
\text { (F1) }\end{array}$ & \begin{tabular}{l}
\multicolumn{1}{c}{$N$} \\
Minimum \\
Maximum \\
Average
\end{tabular} & $\begin{array}{l}3 \\
<2.0 \\
11 \\
4.5\end{array}$ & $\begin{array}{l}3 \\
<2.0 \\
<2.0 \\
<2.0\end{array}$ & $\begin{array}{l}3 \\
<2.0 \\
<2.0 \\
<2.0\end{array}$ & $\begin{array}{l}3 \\
<2.0 \\
<2.0 \\
<2.0\end{array}$ & $\begin{array}{l}3 \\
<2.0 \\
<2.0 \\
<2.0\end{array}$ & $\begin{array}{l}3 \\
<2.0 \\
<2.0 \\
<2.0\end{array}$ \\
\hline $\begin{array}{l}\text { WTP-Eff } \\
\text { (F2) }\end{array}$ & $\begin{array}{l}\mathrm{N} \\
\text { Minimum } \\
\text { Maximum } \\
\text { Average }\end{array}$ & $\begin{array}{c}3 \\
<2.0 \\
3 \\
<2.0\end{array}$ & $\begin{array}{l}3 \\
<2.0 \\
<2.0 \\
<2.0\end{array}$ & $\begin{array}{l}3 \\
<2.0 \\
<2.0 \\
<2.0\end{array}$ & $\begin{array}{l}3 \\
<2.0 \\
<2.0 \\
<2.0\end{array}$ & $\begin{array}{l}3 \\
<2.0 \\
<2.0 \\
<2.0\end{array}$ & $\begin{array}{l}3 \\
<2.0 \\
<2.0 \\
<2.0\end{array}$ \\
\hline $4(F D)$ & $\begin{array}{l}\text { N } \\
\text { Minimum } \\
\text { Maximum } \\
\text { Average }\end{array}$ & $\begin{array}{c}4 \\
6 \\
9 \\
2.3\end{array}$ & $\begin{array}{c}4 \\
<2.0 \\
<2.0 \\
<2.0\end{array}$ & $\begin{array}{c}4 \\
<2.0 \\
<2.0 \\
<2.0\end{array}$ & $\begin{array}{c}4 \\
<2.0 \\
<2.0 \\
<2.0\end{array}$ & $\begin{array}{l}4 \\
<2.0 \\
<2.0 \\
<2.0\end{array}$ & $\begin{array}{c}4 \\
<2.0 \\
<2.0 \\
<2.0\end{array}$ \\
\hline $6(\mathrm{FF})$ & $\begin{array}{c}\mathrm{N} \\
\text { Minimum } \\
\text { Maximum } \\
\text { Average }\end{array}$ & $\begin{array}{l}4 \\
<2.0 \\
<2.0 \\
<2.0\end{array}$ & $\begin{array}{l}4 \\
<2.0 \\
<2.0 \\
<2.0\end{array}$ & $\begin{array}{c}4 \\
<2.0 \\
<2.0 \\
<2.0\end{array}$ & $\begin{array}{l}4 \\
<2.0 \\
<2.0 \\
<2.0\end{array}$ & $\begin{array}{l}4 \\
<2.0 \\
<2.0 \\
<2.0\end{array}$ & $\begin{array}{l}4 \\
<2.0 \\
<2.0 \\
<2.0\end{array}$ \\
\hline 7 (FG) & $\begin{array}{c}\mathrm{N} \\
\text { Minimum } \\
\text { Maximum } \\
\text { Average }\end{array}$ & $\begin{array}{l}4 \\
<2.0 \\
<2.0 \\
<2.0\end{array}$ & $\begin{array}{l}4 \\
<2.0 \\
<2.0 \\
<2.0\end{array}$ & $\begin{array}{l}4 \\
<2.0 \\
<2.0 \\
<2.0\end{array}$ & $\begin{array}{l}4 \\
<2.0 \\
<2.0 \\
<2.0\end{array}$ & $\begin{array}{l}4 \\
<2.0 \\
<2.0 \\
<2.0\end{array}$ & $\begin{array}{l}4 \\
<2.0 \\
<2.0 \\
<2.0\end{array}$ \\
\hline 10 (FO) & $\begin{array}{c}\mathrm{N} \\
\text { Minimum } \\
\text { Maximum } \\
\text { Average }\end{array}$ & $\begin{array}{l}5 \\
<2.0 \\
<2.0 \\
<2.0\end{array}$ & $\begin{array}{l}5 \\
<2.0 \\
<2.0 \\
<2.0\end{array}$ & $\begin{array}{c}5 \\
<2.0 \\
3 \\
2\end{array}$ & $\begin{array}{l}5 \\
<2.0 \\
<2.0 \\
<2.0\end{array}$ & $\begin{array}{l}5 \\
<2.0 \\
<2.0 \\
<2.0\end{array}$ & $\begin{array}{l}5 \\
<2.0 \\
<2.0 \\
<2.0\end{array}$ \\
\hline $11(F P)$ & $\begin{array}{c}\mathrm{N} \\
\text { Minimum } \\
\text { Maximum } \\
\text { Average }\end{array}$ & $\begin{array}{l}4 \\
<2.0 \\
<2.0 \\
<2.0\end{array}$ & $\begin{array}{l}4 \\
<2.0 \\
<2.0 \\
<2.0\end{array}$ & $\begin{array}{c}4 \\
5 \\
8 \\
6.5\end{array}$ & $\begin{array}{l}4 \\
<2.0 \\
<2.0 \\
<2.0\end{array}$ & $\begin{array}{c}4 \\
<2.0 \\
<2.0 \\
<2.0\end{array}$ & $\begin{array}{l}4 \\
<2.0 \\
<2.0 \\
<2.0\end{array}$ \\
\hline 12 (FQ) & \begin{tabular}{l}
\multicolumn{1}{c}{$N$} \\
Minimum \\
Maximum \\
Average
\end{tabular} & $\begin{array}{l}4 \\
<2.0 \\
<2.0 \\
<2.0\end{array}$ & $\begin{array}{l}4 \\
<2.0 \\
<2.0 \\
<2.0\end{array}$ & $\begin{aligned} & 4 \\
< & 2.0 \\
< & 2.0 \\
< & 2.0\end{aligned}$ & $\begin{array}{l}4 \\
<2.0 \\
<2.0 \\
<2.0\end{array}$ & $\begin{array}{l}4 \\
<2.0 \\
<2.0 \\
<2.0\end{array}$ & $\begin{array}{c}4 \\
<2.0 \\
<2.0 \\
<2.0\end{array}$ \\
\hline $5(\mathrm{FE})$ & $\begin{array}{c}\mathrm{N} \\
\text { Minimum } \\
\text { Maximum } \\
\text { Average }\end{array}$ & $\begin{array}{l}2 \\
<2.0 \\
<2.0 \\
<2.0\end{array}$ & $\begin{array}{l}2 \\
<2.0 \\
<2.0 \\
<2.0\end{array}$ & $\begin{array}{l}2 \\
<2.0 \\
<2.0 \\
<2.0\end{array}$ & $\begin{array}{l}2 \\
<2.0 \\
<2.0 \\
<2.0\end{array}$ & $\begin{array}{l}2 \\
<2.0 \\
<2.0 \\
<2.0\end{array}$ & $\begin{array}{l}2 \\
<2.0 \\
<2.0 \\
<2.0\end{array}$ \\
\hline $9(\mathrm{FM})$ & $\begin{array}{c}\mathrm{N} \\
\text { Minimum } \\
\text { Maximum } \\
\text { Average }\end{array}$ & $\begin{aligned} & 4 \\
&< 2.0 \\
&<2.0 \\
&<2.0\end{aligned}$ & $\begin{array}{c}4 \\
<2.0 \\
3 \\
<2.0\end{array}$ & $\begin{array}{c}4 \\
5 \\
9 \\
7.3\end{array}$ & $\begin{array}{l}4 \\
<2.0 \\
11 \\
2.8\end{array}$ & $\begin{array}{c}4 \\
<2.0 \\
10 \\
2.5\end{array}$ & $\begin{array}{c}4 \\
<2.0 \\
5 \\
<2.0\end{array}$ \\
\hline $101(\mathrm{FH})$ & $\begin{array}{c}\mathrm{N} \\
\text { Minimum } \\
\text { Maximum } \\
\text { Average }\end{array}$ & $\begin{array}{l}2 \\
<2.0 \\
<2.0 \\
<2.0\end{array}$ & $\begin{array}{l}2 \\
<2.0 \\
<2.0 \\
<2.0\end{array}$ & $\begin{array}{l}2 \\
<2.0 \\
<2.0 \\
<2.0\end{array}$ & $\begin{array}{l}2 \\
<2.0 \\
<2.0 \\
<2.0\end{array}$ & $\begin{array}{l}2 \\
<2.0 \\
<2.0 \\
<2.0\end{array}$ & $\begin{array}{l}2 \\
<2.0 \\
<2.0 \\
<2.0\end{array}$ \\
\hline $102(F I)$ & $\stackrel{N}{\text { Concentration }}$ & $\begin{array}{c}1 \\
<2.0\end{array}$ & $\stackrel{1}{2} .0$ & $\begin{array}{c}1 \\
<2.0\end{array}$ & $\begin{array}{c}1 \\
<2.0\end{array}$ & $\begin{array}{c}1 \\
<2.0\end{array}$ & $\begin{array}{c}1 \\
<2.0\end{array}$ \\
\hline 103 (FJ) & $\begin{array}{c}\mathrm{N} \\
\text { Minimum } \\
\text { Maximum } \\
\text { Average }\end{array}$ & $\begin{array}{l}2 \\
<2.0 \\
<2.0 \\
<2.0\end{array}$ & $\begin{array}{l}2 \\
<2.0 \\
<2.0 \\
<2.0\end{array}$ & $\begin{array}{l}2 \\
<2.0 \\
<2.0 \\
<2.0\end{array}$ & $\begin{array}{l}2 \\
<2.0 \\
<2.0 \\
<2.0\end{array}$ & $\begin{array}{l}2 \\
<2.0 \\
<2.0 \\
<2.0\end{array}$ & $\begin{array}{l}2 \\
<2.0 \\
<2.0 \\
<2.0\end{array}$ \\
\hline NYSOWS & & 100 & 5 & 5 & 5 & 5 & 5 \\
\hline Typical MDL & & 2 & 2 & 2 & 2 & 2 & 2 \\
\hline
\end{tabular}

N: No. of samples

WTP-In: Water Treatment Plant Influent

WTP.Eff: Water Treatment Plant Effluent

NYSDWS: New York State Drinking Water Standard

MDL: Minimum Detection Limit

(a): The location of potable and process wells is shown on Figure 23

The average concentration has been calculated by summing all detectable quantities then dividing the sum by the total number of samples $c$ All non-delectable quantities have been evaluated as zero. If the average is less than the MDL, it is reported as less than MDL. 
located within a known Area of Concern, was found to contain concentrations of TCA, toluene, xylene and ethylbenzene which exceed the NYS DWS. This well is not used for potable purposes and the concentrations present do not interfere with the fish experimentation conducted within Building 463.

\subsubsection{Groundwater Monitoring}

Groundwater monitoring is being performed at BNL as an integral part of the BNL Environmental Monitoring Program (in fulfilment of DOE Orders and NYS permits) and the. BNL Environmental Restoration Program (to fulfil CERCLA monitoring requirements under the IAG). This program includes monitoring at active waste processing and temporary storage facilities to comply with RCRA, waste treatment facilities, operational monitoring around accelerators, and in areas of known or suspected soil and groundwater contamination.

Most groundwater monitoring wells on the site are $2 "$ to 4 " in diameter and constructed of PVC material and were installed using RCRA and CERCLA protocols. In the STP/Peconic River, HWMF, and Current Landfill areas, a number of old, small diameter (1.25") wells constructed of carbon steel casings and brass screens are still utilized for water quality and/or water level measurements. Following the planned RI/FS in each area, these older wells will either be abandoned or used exclusively for water level measurements. Groundwater samples are collected following documented sampling procedures based on EPA guidelines. ${ }^{41}$ Analytical techniques used are described in this report (see Appendix $C$ ), and in the BNL Site Environmental Monitoring Plan. ${ }^{33}$

\subsubsection{Nonradiological Analyses}

Sewage Treatment Plant/Peconic River Area: The Sewage Treatment Plant processes sanitary sewage for BNL facilities. The STP consists of a clarifier (for primary treatment) and sand filter beds (for secondary or effluent polishing). Approximately 15\% of the water released to the filter beds is either lost to evaporation or to direct groundwater recharge. The remaining water is discharged to the Peconic River. This discharge is regulated under a NYSDEC SPDES permit. Because of past radiological and chemical releases to the soils and groundwater in the BNL STP and the nearby Peconic River areas (both on-site and off-site), the STP and Peconic River areas are currently the subject of a RI/FS (Operable Unit V.), which is being conducted under the IAG between DOE, EPA, and NYSDEC. The surveillance well network at the STP and Peconic River areas consist of 18 shallow Upper Glacial aquifer wells (Figure 5-5). During 1994, groundwater samples from the 18 surveillance wells were analyzed for water quality, vocs, and metals (Tables 5-5 to 5-8). Water quality data from most wells located both upgradient and downgradient of the STP indicate that the $\mathrm{pH}$ was typically below the NYS AWQS of 6.5 - 8.5, with a median $\mathrm{pH}$ of 6.0. All other water quality parameters were within the applicable NYS AWQS. Five wells, however, exhibited elevated but below NYS AWQS nitrate-nitrogen levels (see Table 5-5). Results of metals analyses of groundwater samples indicate that iron concentrations exceeded above NYS DWS in five wells, with maximum observed iron concentrations ranging from $0.53-7.17 \mathrm{mg} / \mathrm{L}$. Cadmium was also detected in Well 38-03, at a maximum concentration of $1.10 \mathrm{mg} / \mathrm{L}$. Volatile Organic Compounds were not detected above NYS DWS in any samples.

Meadow Marsh-Upland Recharge Area: The Meadow Marsh-Upland Recharge area was used by BNL in the mid 1970 s as an experimental sewage treatment area. As a result of this experiment, the soils and groundwater in this area are suspected of being contaminated with a variety of radionuclides, metals, and vocs. Biological agricultural fields are also located in this area, and recent analysis of groundwater samples indicate that pesticides such as ethylene dibromide (EDB) 
Table 5-6

BNL Site Environmental Report for Calendar Year 1994

Peconic River/Sewage Treatment Plant and Meadow Marsh Ground Water Surveillance Wells, Water Quality Data

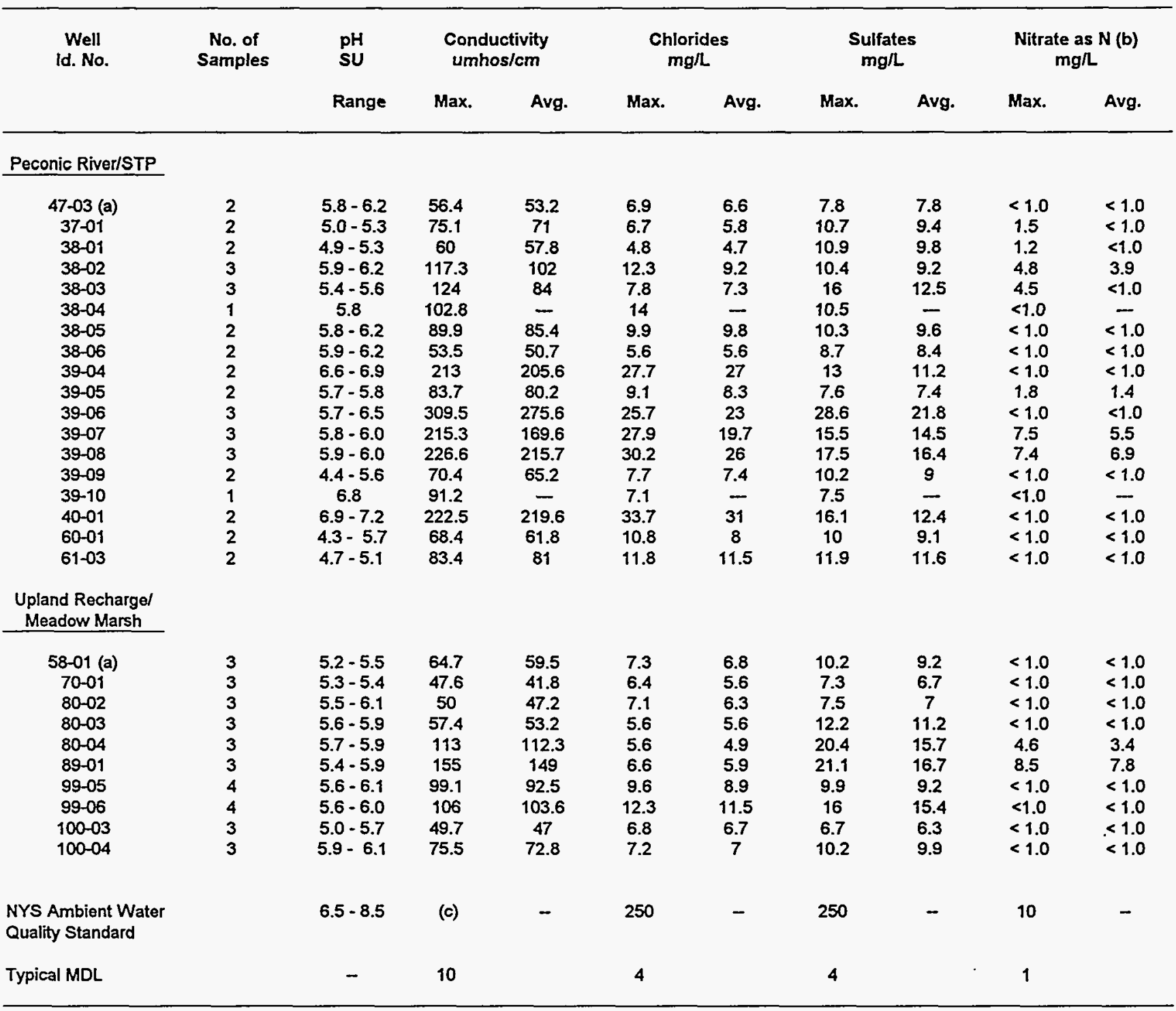

MDL: Minimum Detection Limit.
(a): Upgradient Well.
(b): Holding time expired for all samples.
(c): No standard specified. 
Table 5-6

BNL Site Environmental Report for Calendar Year 1994

Peconic River/Sewage Treatment Plant Area and Meadow Marsh Area Ground Water Surveillance Wells, Metals Data

\begin{tabular}{|c|c|c|c|c|c|c|c|c|c|c|c|}
\hline Location & $\begin{array}{l}\text { No. of } \\
\text { Samples }\end{array}$ & & $\underset{m g \Omega}{A g}$ & $\begin{array}{c}\mathrm{Cd} \\
\mathrm{mg} / \mathrm{L}\end{array}$ & $\underset{\mathrm{mg} \Omega}{\mathrm{Cr}}$ & $\underset{m g h}{C u}$ & $\begin{array}{l}\text { Fe } \\
\mathrm{mg} \Omega\end{array}$ & $\begin{array}{c}\mathrm{Hg} \\
\mathrm{mg} / \mathrm{h}\end{array}$ & $\underset{\mathrm{mgn}}{\mathrm{Na}}$ & $\begin{array}{l}\mathrm{Pb} \\
\mathrm{mg} /\end{array}$ & $\underset{m g n}{Z n}$ \\
\hline \multicolumn{12}{|l|}{ Peconic River/STP } \\
\hline 47-03(a) & 2 & $\begin{array}{l}\text { Maximum } \\
\text { Average }\end{array}$ & $\begin{array}{l}<0.025 \\
<0.025\end{array}$ & $\begin{array}{l}<0.0005 \\
<0.0005\end{array}$ & $\begin{array}{l}<0.005 \\
<0.005\end{array}$ & $\begin{array}{l}<0.05 \\
<0.05\end{array}$ & $\begin{array}{l}<0.075 \\
<0.075\end{array}$ & $\begin{array}{l}<0.0002 \\
<0.0002\end{array}$ & $\begin{array}{l}3.89 \\
3.68\end{array}$ & $\begin{array}{l}<0.002 \\
<0.002\end{array}$ & $\begin{array}{l}<0.02 \\
<0.02\end{array}$ \\
\hline $38-03$ & 3 & $\begin{array}{l}\text { Maximum } \\
\text { Average }\end{array}$ & $\begin{array}{l}<0.025 \\
<0.025\end{array}$ & $\begin{array}{l}0.0011 \\
0.0008\end{array}$ & $\begin{array}{l}<0.005 \\
<0.005\end{array}$ & $\begin{array}{l}<0.05 \\
<0.05\end{array}$ & $\begin{array}{c}0.19 \\
<0.075\end{array}$ & $\begin{array}{l}<0.0002 \\
<0.0002\end{array}$ & $\begin{array}{c}7 \\
5.08\end{array}$ & $\begin{array}{l}<0.002 \\
<0.002\end{array}$ & $\begin{array}{l}0.32 \\
0.26\end{array}$ \\
\hline 39.04 & 2 & $\begin{array}{l}\text { Maximum } \\
\text { Average }\end{array}$ & $\begin{array}{l}<0.025 \\
<0.025\end{array}$ & $\begin{array}{l}<0.0005 \\
<0.0005\end{array}$ & $\begin{array}{l}<0.005 \\
<0.005\end{array}$ & $\begin{array}{l}<0.05 \\
<0.05\end{array}$ & $\begin{array}{c}6.51 \\
4.988\end{array}$ & $\begin{array}{l}<0.0002 \\
<0.0002\end{array}$ & $\begin{array}{l}26.08 \\
25.86\end{array}$ & $\begin{array}{l}<0.002 \\
<0.002\end{array}$ & $\begin{array}{l}0.09 \\
0.02\end{array}$ \\
\hline $39-05$ & 2 & $\begin{array}{l}\text { Maximum } \\
\text { Average }\end{array}$ & $\begin{array}{l}<0.025 \\
<0.025\end{array}$ & $\begin{array}{l}<0.0005 \\
<0.0005\end{array}$ & $\begin{array}{l}<0.005 \\
<0.005\end{array}$ & $\begin{array}{l}<0.05 \\
<0.05\end{array}$ & $\begin{array}{c}0.53 \\
0.502\end{array}$ & $\begin{array}{l}<0.0002 \\
<0.0002\end{array}$ & $\begin{array}{l}7.52 \\
6.78\end{array}$ & $\begin{array}{l}<0.002 \\
<0.002\end{array}$ & $\begin{array}{l}0.03 \\
0.02\end{array}$ \\
\hline $39-06$ & 3 & $\begin{array}{l}\text { Maximum } \\
\text { Average }\end{array}$ & $\begin{array}{l}<0.025 \\
<0.025\end{array}$ & $\begin{array}{l}<0.0005 \\
<0.0005\end{array}$ & $\begin{array}{l}<0.005 \\
<0.005\end{array}$ & $\begin{array}{l}<0.05 \\
<0.05\end{array}$ & $\begin{array}{c}1.68 \\
1.252\end{array}$ & $\begin{array}{l}<0.0002 \\
<0.0002\end{array}$ & $\begin{array}{l}23.41 \\
15.60\end{array}$ & $\begin{array}{l}<0.002 \\
<0.002\end{array}$ & $\begin{array}{l}0.04 \\
0.03\end{array}$ \\
\hline $40-01$ & 2 & $\begin{array}{l}\text { Maximum } \\
\text { Average }\end{array}$ & $\begin{array}{l}<0.025 \\
<0.025\end{array}$ & $\begin{array}{l}<0.0005 \\
<0.0005\end{array}$ & $\begin{array}{l}<0.005 \\
<0.005\end{array}$ & $\begin{array}{l}<0.05 \\
<0.05\end{array}$ & $\begin{array}{l}7.17 \\
3.58\end{array}$ & $\begin{array}{l}<0.0002 \\
<0.0002\end{array}$ & $\begin{array}{l}27.61 \\
26.00\end{array}$ & $\begin{array}{l}<0.002 \\
<0.002\end{array}$ & $\begin{array}{l}0.61 \\
0.52\end{array}$ \\
\hline $60-01$ & 2 & $\begin{array}{c}\text { Maximum } \\
\text { Average }\end{array}$ & $\begin{array}{l}<0.025 \\
<0.025\end{array}$ & $\begin{array}{l}<0.0005 \\
<0.0005\end{array}$ & $\begin{array}{l}<0.005 \\
<0.005\end{array}$ & $\begin{array}{l}<0.05 \\
<0.05\end{array}$ & $\frac{2.15}{-}$ & $\begin{array}{l}<0.0002 \\
<0.0002\end{array}$ & $\begin{array}{l}7.83 \\
-\end{array}$ & $\stackrel{0.003}{-}$ & $\stackrel{0.03}{-}$ \\
\hline $\begin{array}{l}\text { All Other Wells } \\
\qquad(n=11)\end{array}$ & 23 & $\begin{array}{l}\text { Maximum } \\
\text { Average }\end{array}$ & $\begin{array}{l}<0.025 \\
<0.025\end{array}$ & $\begin{array}{l}<0.0005 \\
<0.0005\end{array}$ & $\begin{array}{l}<0.005 \\
<0.005\end{array}$ & $\begin{array}{l}<0.05 \\
<0.05\end{array}$ & $\begin{array}{l}0.096 \\
<0.075\end{array}$ & $\begin{array}{l}<0.0002 \\
<0.0002\end{array}$ & $\begin{array}{l}25.72 \\
10.05\end{array}$ & $\begin{array}{l}<0.002 \\
<0.002\end{array}$ & $\begin{array}{l}0.08 \\
<0.02\end{array}$ \\
\hline \multicolumn{12}{|c|}{ Recharge/Meadow Marsh } \\
\hline $58-01(a)$ & 3 & $\begin{array}{l}\text { Maximum } \\
\text { Average }\end{array}$ & $\begin{array}{l}<0.025 \\
<0.025\end{array}$ & $\begin{array}{l}<0.0005 \\
<0.0005\end{array}$ & $\begin{array}{l}<0.005 \\
<0.005\end{array}$ & $\begin{array}{l}<0.05 \\
<0.05\end{array}$ & $\begin{array}{l}<0.075 \\
<0.075\end{array}$ & $\begin{array}{l}<0.0002 \\
<0.0002\end{array}$ & $\begin{array}{l}5.41 \\
4.92\end{array}$ & $\begin{array}{l}<0.002 \\
<0.002\end{array}$ & $\begin{array}{l}0.59 \\
0.21\end{array}$ \\
\hline $89-01$ & 3 & $\begin{array}{l}\text { Maximum } \\
\text { Average }\end{array}$ & $\begin{array}{l}<0.025 \\
<0.025\end{array}$ & $\begin{array}{l}<0.0005 \\
<0.0005\end{array}$ & $\begin{array}{l}<0.005 \\
<0.005\end{array}$ & $\begin{array}{l}<0.05 \\
<0.05\end{array}$ & $\begin{array}{l}0.534 \\
0.178\end{array}$ & $\begin{array}{l}<0.0002 \\
<0.0002\end{array}$ & $\begin{array}{l}3.76 \\
3.39\end{array}$ & $\begin{array}{l}<0.002 \\
<0.002\end{array}$ & $\begin{array}{l}0.12 \\
0.05\end{array}$ \\
\hline $100-04$ & 3 & $\begin{array}{l}\text { Maximum } \\
\text { Average }\end{array}$ & $\begin{array}{l}<0.025 \\
<0.025\end{array}$ & $\begin{array}{l}0.0013 \\
<0.0005\end{array}$ & $\begin{array}{l}0.014 \\
<0.005\end{array}$ & $\begin{array}{l}<0.05 \\
<0.05\end{array}$ & $\begin{array}{l}5.61 \\
3.23\end{array}$ & $\begin{array}{l}<0.0002 \\
<0.0002\end{array}$ & $\begin{array}{l}5.78 \\
5.61\end{array}$ & $\begin{array}{c}0.04 \\
0.013\end{array}$ & $\begin{array}{l}1.43 \\
0.99\end{array}$ \\
\hline $\begin{array}{l}\text { All Other Wolis } \\
(n=7)\end{array}$ & 23 & $\begin{array}{l}\text { Maximum } \\
\text { Average }\end{array}$ & $\begin{array}{l}<0.025 \\
<0.025\end{array}$ & $\begin{array}{c}0.023 \\
<0.0005\end{array}$ & $\begin{array}{l}<0.005 \\
<0.005\end{array}$ & $\begin{array}{l}<0.05 \\
<0.05\end{array}$ & $\begin{array}{l}<0.075 \\
<0.075\end{array}$ & $\begin{array}{l}<0.0002 \\
<0.0002\end{array}$ & $\begin{array}{l}9.66 \\
5.25\end{array}$ & $\begin{array}{l}<0.002 \\
<0.002\end{array}$ & $\begin{array}{c}0.10 \\
<0.02\end{array}$ \\
\hline NYS DWS & & & 0.05 & 0.01 & 0.05 & 1.3 & 0.3 & 0.002 & (b) & 0.015 & 5.0 \\
\hline Typical MDL & & & 0.025 & 0.0005 & 0.005 & 0.5 & 0.075 & 0.0002 & 1.0 & 0.002 & 0.02 \\
\hline
\end{tabular}

MDL: Minimum Detection Limit.

(a): Upgradient Well.

(b): No Standard Specified. 
Table 5-7

BNL. Site Environmental Report for Calendar Year 1994

Peconic River/Sewage Treatment Plant Area and Upland RechargelMeadow Marsh Area

Ground Water Surveillance Wells, Chorocarbon Data

\begin{tabular}{|c|c|c|c|c|c|c|c|c|}
\hline Location & $\begin{array}{l}\text { No. of } \\
\text { Samples }\end{array}$ & & $\begin{array}{l}\text { TCA } \\
\text { ug/L }\end{array}$ & $\begin{array}{l}\text { TCE } \\
\text { ug/L }\end{array}$ & $\begin{array}{l}\text { PCE } \\
\text { ug/L }\end{array}$ & $\begin{array}{l}\text { DCA } \\
u g / L\end{array}$ & $\begin{array}{l}\text { DCE } \\
\text { ug/h }\end{array}$ & $\begin{array}{c}\text { Chloroform } \\
\text { ug/L }\end{array}$ \\
\hline \multicolumn{9}{|l|}{ Peconic River/STP } \\
\hline $\begin{array}{l}\text { All Wells } \\
(n=18)\end{array}$ & 39 & $\begin{array}{l}\text { Maximum } \\
\text { Average }\end{array}$ & $\begin{array}{l}3.0 \\
<2.0\end{array}$ & $\begin{array}{l}<2.0 \\
<2.0\end{array}$ & $\begin{array}{l}<2.0 \\
<2.0\end{array}$ & $\begin{array}{l}<2.0 \\
<2.0\end{array}$ & $\begin{array}{l}<2.0 \\
<2.0\end{array}$ & $\begin{array}{l}<2.0 \\
<2.0\end{array}$ \\
\hline \multicolumn{9}{|l|}{$\begin{array}{l}\text { Upland Recharge/ } \\
\text { Meadow Marsh }\end{array}$} \\
\hline $\begin{array}{l}\text { All Wells } \\
(n=10)\end{array}$ & 30 & $\begin{array}{l}\text { Maximum } \\
\text { Average }\end{array}$ & $\begin{array}{l}<2.0 \\
<2.0\end{array}$ & $\begin{array}{l}<2.0 \\
<2.0\end{array}$ & $\begin{array}{l}<2.0 \\
<2.0\end{array}$ & $\begin{array}{l}<2.0 \\
<2.0\end{array}$ & $\begin{array}{l}<2.0 \\
<2.0\end{array}$ & $\begin{array}{l}<2.0 \\
<2.0\end{array}$ \\
\hline NYS DWS & & & 5.0 & 5.0 & 5.0 & 5.0 & 5.0 & 100.0 \\
\hline Typical MDL & & & 2.0 & 2.0 & 2.0 & 2.0 & 2.0 & 2.0 \\
\hline
\end{tabular}

MDL: $\quad$ Minimum Detection Limit.

TCA: 1,1,1-trichloroethane.

TCE: Trichloroethylene.

PCE: Tetrachloroethylene.

DCA: Dichloroethane.

DCE: Dichloroethylene.

ND: $\quad$ Not detected. 
Table 5-8

BNL Site Environmental Report for Calendar Year 1994

Peconic River/Sewage Treatment Plant Area and Upland Recharge/Meadow Marsh Area

Ground Water Surveillance Wells, BETX Data

\begin{tabular}{|c|c|c|c|c|c|c|}
\hline Location & $\begin{array}{l}\text { No. of } \\
\text { Samples }\end{array}$ & & $\begin{array}{l}\text { Benzene } \\
\text { ug/L }\end{array}$ & $\begin{array}{c}\text { Ethylbenzene } \\
\text { ug } / \text {. }\end{array}$ & $\begin{array}{l}\text { Toluene } \\
\text { ugh }\end{array}$ & $\begin{array}{c}\text { Xylene } \\
\text { ugh/L }\end{array}$ \\
\hline \multicolumn{7}{|l|}{ Peconic River/STP } \\
\hline $\begin{array}{l}\text { All Wells } \\
(n=18)\end{array}$ & 39 & $\begin{array}{l}\text { Maximum } \\
\text { Average }\end{array}$ & $\begin{array}{l}<2.0 \\
<2.0\end{array}$ & $\begin{array}{l}<2.0 \\
<2.0\end{array}$ & $\begin{array}{l}<2.0 \\
<2.0\end{array}$ & $\begin{array}{l}<2.0 \\
<2.0\end{array}$ \\
\hline \multicolumn{7}{|l|}{$\begin{array}{l}\text { Upland Recharge/ } \\
\text { Meadow Marsh }\end{array}$} \\
\hline $\begin{array}{l}\text { All Wells } \\
(n=10)\end{array}$ & 30 & $\begin{array}{l}\text { Maximum } \\
\text { Average }\end{array}$ & $\begin{array}{l}<2.0 \\
<2.0\end{array}$ & $\begin{array}{l}<2.0 \\
<2.0\end{array}$ & $\begin{array}{l}<2.0 \\
<2.0\end{array}$ & $\begin{array}{l}<2.0 \\
<2.0\end{array}$ \\
\hline NYS DWS & & & 5.0 & 5.0 & 5.0 & 5.0 \\
\hline Typical MDL & & & 2.0 & 2.0 & 2.0 & 2.0 \\
\hline
\end{tabular}

MDL: Minimum Detection Limit. 
may have been applied to these agricultural fields. The surveillance well network at the Meadow Marsh-Upland Recharge area consists of 22 shallow to deep Upper Glacial aquifer wells and one upper Magothy aquifer well (Figures 5-6 and 5-8). Twelve of the monitoring wells were installed in 1994 as part of the ou VI RI/FS. During 1994, groundwater samples from the 10 older Upper Glacial aquifer surveillance wells were analyzed for water quality, vocs, and metals (Tables 5-5 to 5-8). Groundwater samples were also collected from the 10 existing and 12 new monitoring wells in December 1994 as part of the OU VI RI/FS. However, data from these samples are not presently available. Water quality data from wells located both upgradient and downgradient of the Meadow Marsh area indicate that the $\mathrm{pH}$ was typically below the lower limit of the NYS AWQS of 6.5 -8.5, with a median $\mathrm{pH}$ of 5.5. Two wells, 80-04 and 89-01, exhibited elevated but below NYS AWQS nitrate-nitrogen levels. All other water quality parameters were below the applicable NYS AWQS. Iron was detected above NYS DWS in shallow Upper Glacial aquifer Well 89-01 and in Magothy aquifer well 100-04, at maximum concentrations of 0.53 and $5.60 \mathrm{mg} / \mathrm{L}$, respectively. Lead was detected above NYS DWS in Well 100-04, with a maximum observed concentration of $0.040 \mathrm{mg} / \mathrm{L}$. No voCs were detected above typical detection limit of $2.0 \mu \mathrm{g} / \mathrm{L}$. Historically, the only VOC detected above NYS DWS in the Upland Recharge/Meadow Marsh area has been EDB at concentrations exceeding the $0.050 \mu \mathrm{g} / \mathrm{L}$ DWS (see BNL SER for CY 1993). Analysis for EDB, performed for groundwater samples collected during the December 1994 OU VI RI sample period, indicate that the EDB concentrations exceeded NYS DWS in four on-site wells. Well 89-14, located directly downgradient of the southern end of the Biological Agricultural field had a EDB concentration of $0.051 \mu \mathrm{g} / \mathrm{L}$. Whereas at the southeast site boundary, EDB was detected in wells 99-11 and 100-13 at concentrations ranging from $0.14 \mu \mathrm{g} / \mathrm{L}$ to $0.28 \mu \mathrm{g} / \mathrm{L}$.

Current Landfill Area: The Current Landfill was in operation from 1967 through 1990, when it was closed in accordance with the Long Island Landfill Law. The landfill was used for the disposal of putrescible garbage, sludge containing precipitated iron from the potable water Treatment Plant, and anaerobic digester sludge from the STP. The STP sludge contained low concentrations of radionuclides, and may have also contained organic compounds. The Laboratory also disposed of limited quantities of laboratory wastes which contained radioactive and chemical wastes. As a result of these disposal practices, the Current Landfill is a source of groundwater contamination. Permanent closure (i.e., capping) of this landfill is scheduled to start during the summer of 1995 . The full extent of groundwater contamination and assessment of remedial alternatives are currently being evaluated as part of the oU I Groundwater Removal Action. The surveillance well network at the Current Landfill consists of 41 shallow to deep Upper Glacial aquifer wells (Figure 5-8). During 1994, the 41 groundwater surveiliance wells were sampled for water quality, vocs, and metals (Tables 5-9 to 5-12). Water quality data from wells located at the Current Landfill indicate that the $\mathrm{pH}$ was typically slightly below the lower limit of the NYS AWQS of 6.5 - 8.5, with a median pH of 5.90. Although water quality parameters were within NYS AWQS, elevated conductivity levels were detected in downgradient wells (i.e., above background). Average conductivity for the upgradient Well 87-09 was $125.5 \mu$ mhos/cm, whereas the average conductivities for wells directly downgradient of the current Landfill ranged from 151 - $875 \mu$ mos/cm. Metals analyses indicate that 19 surveillance wells located downgradient of the current Landfill had average iron concentrations that exceeded the NYS DWS of $0.3 \mathrm{mg} / \mathrm{I}$. Upgradient Wells 87-09 and 87-21 typically had iron concentrations below the typical minimum detection limit of $0.075 \mathrm{mg} / \mathrm{L}$, however, iron levels in Well 87-09 exceeded DWS on one occasion, at a concentration of $0.858 \mathrm{mg} / \mathrm{L}$. In the downgradient wells where iron concentrations exceeded DWS, average iron concentrations ranged from 0.47 - 96.10 mg/L. Lead and zinc were detected in Well 87-05 at maximum concentrations of 0.343 and 5.21, respectively. Although there is no NYS DWS specified for sodium, sodium 
Table 5-9

BNL Site Environmental Report for Calendar Year 1994

Current Landfill, Former Landfill and Ash Repository

Cround Water Survelllanes Wells, Water Quality Data

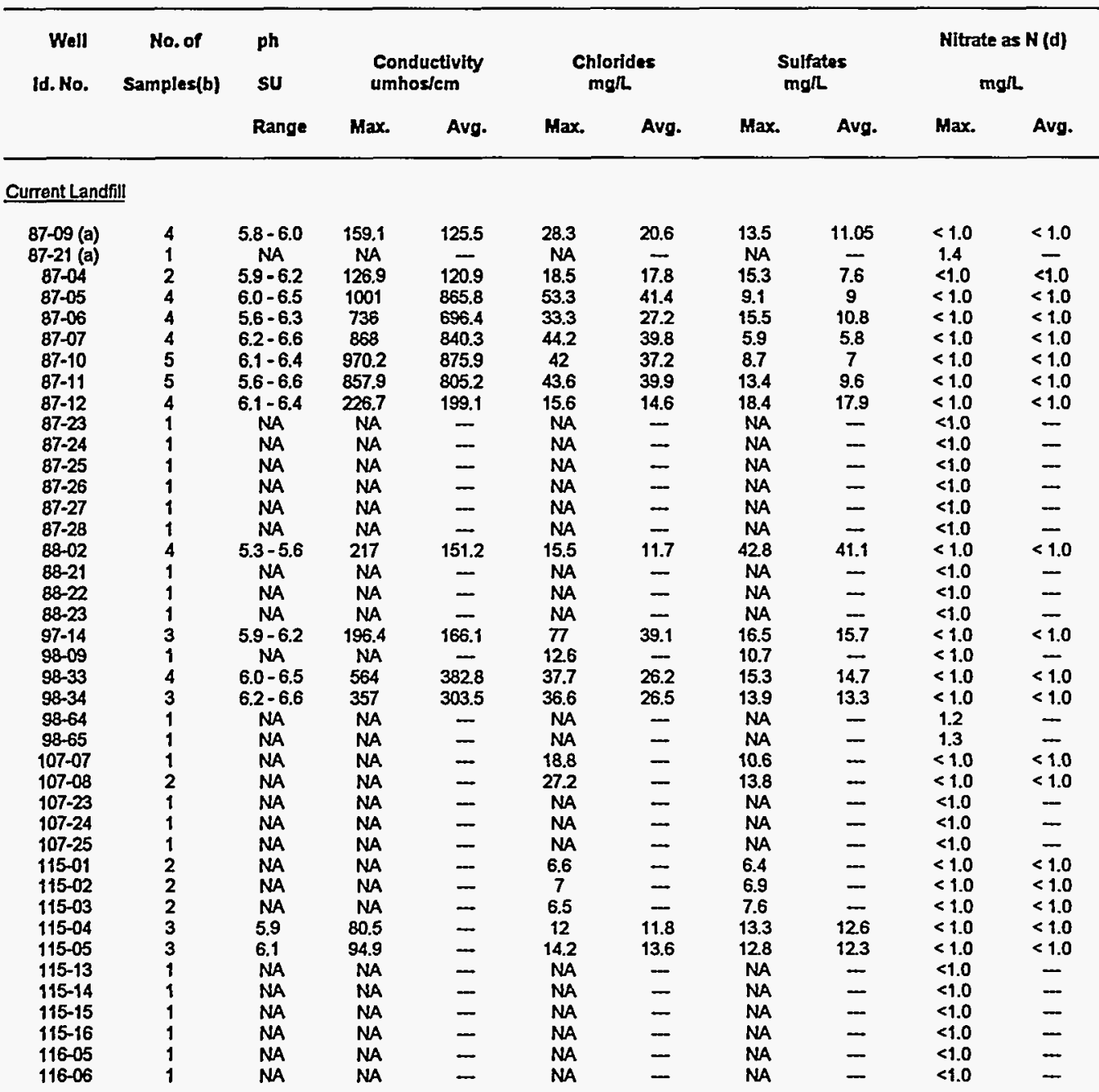

Former Landfill

$\begin{array}{ccccccccccc}86-42(a) & 1 & \text { NA } & \text { NA } & - & \text { NA } & - & \text { NA } & - & 1.5 \\ 86-43(a) & 1 & \text { NA } & \text { NA } & - & \text { NA } & - & \text { NA } & - & 1.8 \\ 87-22(a) & 1 & \text { NA } & \text { NA } & - & \text { NA } & - & \text { NA } & - & <1.0 \\ 96-03(a) & 2 & \text { NA } & \text { NA } & - & 5.2 & - & 18.4 & - & 1.1 & <1.0 \\ 96-04(a) & 3 & 5.3-5.6 & 113.7 & 111.0 & 9.8 & 8 & 12.4 & 9.6 & <1.0 & <1.0 \\ 96-02 & 1 & \text { NA } & \text { NA } & - & 5.7 & - & 11.2 & - & <1.0 & - \\ 97-01 & 1 & 5.64 & 57.4 & - & 7.8 & - & 8.1 & - & <1.0 \\ 97-02 & 2 & \text { NA } & \text { NA } & - & 4.7 & - & 5.8 & - & <1.0 & <1.0 \\ 97-03 & 2 & \text { NA } & \text { NA } & - & 7 & - & 51.6 & - & 3.6 & 2.8 \\ 97-05 & 2 & \text { NA } & \text { NA } & - & 5.3 & - & 18.3 & - & 2.8 & 2.3 \\ 97-08 & 2 & \text { NA } & \text { NA } & - & 5.6 & - & 8.8 & - & <1.0 & <1.0 \\ 97-17 & 1 & \text { NA } & \text { NA } & - & \text { NA } & - & \text { NA } & - & <1.0 & - \\ 97-18 & 1 & \text { NA } & \text { NA } & - & \text { NA } & - & \text { NA } & - & <1.0 & - \\ 106-02 & 2 & \text { NA } & \text { NA } & - & 8 & - & 24.2 & - & 1.4 & <1.0 \\ 106-04 & 2 & \text { NA } & \text { NA } & - & 4.5 & - & 9.9 & - & <1.0 & <1.0 \\ 106-13 & 1 & \text { NA } & \text { NA } & - & \text { NA } & - & \text { NA } & - & 3 \\ 106-14 & 1 & \text { NA } & \text { NA } & - & \text { NA } & - & \text { NA } & - & <1.0 & - \\ 106-15 & 1 & \text { NA } & \text { NA } & - & \text { NA } & - & \text { NA } & - & <1.0 & - \\ 106-16 & 1 & \text { NA } & \text { NA } & - & \text { NA } & - & \text { NA } & - & <1.0 & - \\ 106-17 & 1 & \text { NA } & \text { NA } & - & \text { NA } & - & \text { NA } & - & <1.0 & - \\ 106-18 & 1 & \text { NA } & \text { NA } & - & \text { NA } & - & \text { NA } & - & <1.0 & -\end{array}$

Ash Repository

\begin{tabular}{|c|c|c|c|c|c|c|c|c|c|}
\hline $104-01$ & $5.9-6.0$ & 138.2 & 134.6 & 17.3 & 17.2 & 10.1 & 9.7 & $<1.0$ & $<1.0$ \\
\hline $\begin{array}{l}\text { NYS Ambient Water } \\
\text { Quality Standard }\end{array}$ & $6.5-8.5$ & (c) & - & 250 & $\rightarrow$ & 250 & - & 10 & - \\
\hline Typical MDL & - & 10 & & 4 & & 4 & & 1 & \\
\hline
\end{tabular}

MDL: Minimum Detection Limit

(a): Upgradient Well

(b): Complete water quality analyses not conducted for all samples

(c): No standard specified.

(d): Holding time expired for all samples 
Table 5-10

BNL Site Environmental Report for Calendar Year 1994

Current Landfill, Former Landfill, and Ash Repository

Ground Water Surveillance Wells, Metals Data

\begin{tabular}{|c|c|c|c|c|c|c|c|c|c|c|c|}
\hline Location & $\begin{array}{l}\text { No. of } \\
\text { Samples }\end{array}$ & & $\underset{\mathrm{mg} / \mathrm{L}}{\mathrm{Ag}}$ & $\begin{array}{c}\mathrm{Cd} \\
\mathrm{mg} / \mathrm{L}\end{array}$ & $\underset{\mathrm{mg} / \mathrm{L}}{\mathrm{Cr}}$ & $\underset{\mathrm{mg} / \mathrm{Lu}}{\mathrm{Cu}}$ & $\underset{\mathrm{mg} / \mathrm{L}}{\mathrm{Fe}}$ & $\underset{\mathrm{mg} / \mathrm{L}}{\mathrm{Hg}}$ & $\underset{\mathrm{mg} / \mathrm{Na}}{\mathrm{Na}}$ & $\begin{array}{c}\mathrm{Pb} \\
\mathrm{mg} / \mathrm{L}\end{array}$ & $\underset{m g / L}{Z n}$ \\
\hline \multicolumn{12}{|c|}{ Current Landfill } \\
\hline $87-09(a)$ & $5(4)$ & $\begin{array}{c}\text { Maximum } \\
\text { Average }\end{array}$ & $\begin{array}{l}<0.025 \\
<0.025\end{array}$ & $\begin{array}{l}<0.005 \\
<0.005\end{array}$ & $\begin{array}{l}<0.005 \\
<0.005\end{array}$ & $\begin{array}{l}<0.05 \\
<0.05\end{array}$ & $\begin{array}{l}0.858 \\
0.172\end{array}$ & $\begin{array}{l}<0.0002 \\
<0.0002\end{array}$ & $\begin{array}{l}13.72 \\
11.00\end{array}$ & $\begin{array}{l}<0.002 \\
<0.002\end{array}$ & $\begin{array}{l}<0.02 \\
<0.02\end{array}$ \\
\hline $87-21(a)$ & 1 & $\begin{array}{c}\text { Maximum } \\
\text { Average }\end{array}$ & $\begin{array}{c}<0.025 \\
-\end{array}$ & $\begin{array}{c}<0.005 \\
-\end{array}$ & $<0.005$ & $<0.05$ & $<0.075$ & $\begin{array}{c}<0.0002 \\
-\end{array}$ & $\begin{array}{c}15.50 \\
-\end{array}$ & $\begin{array}{c}<0.002 \\
-\end{array}$ & $<0.02$ \\
\hline $87-04$ & $2(1)$ & $\begin{array}{c}\text { Maximum } \\
\text { Average }\end{array}$ & $\begin{array}{l}<0.025 \\
<0.025\end{array}$ & $\begin{array}{l}<0.0005 \\
<0.0005\end{array}$ & $\begin{array}{l}<0.005 \\
<0.005\end{array}$ & $\begin{array}{l}<0.05 \\
<0.05\end{array}$ & $\begin{array}{c}10.24 \\
9.84\end{array}$ & $\begin{array}{l}<0.0002 \\
<0.0002\end{array}$ & $\begin{array}{l}7.70 \\
7.19\end{array}$ & $\begin{array}{l}<0.002 \\
<0.002\end{array}$ & $\begin{array}{l}<0.02 \\
<0.02\end{array}$ \\
\hline $87-05$ & $4(3)$ & $\begin{array}{c}\text { Maximum } \\
\text { Average }\end{array}$ & $\begin{array}{l}<0.025 \\
<0.025\end{array}$ & $\begin{array}{l}<0.0005 \\
<0.0005\end{array}$ & $\begin{array}{l}<0.005 \\
<0.005\end{array}$ & $\begin{array}{l}<0.05 \\
<0.05\end{array}$ & $\begin{array}{c}88.3 \\
80.98\end{array}$ & $\begin{array}{l}<0.0002 \\
<0.0002\end{array}$ & $\begin{array}{l}45.66 \\
35.38\end{array}$ & $\begin{array}{l}0.343 \\
0.086\end{array}$ & $\begin{array}{l}5.21 \\
1.38\end{array}$ \\
\hline $87-06$ & $4(3)$ & $\begin{array}{c}\text { Maximum } \\
\text { Average }\end{array}$ & $\begin{array}{l}<0.025 \\
<0.025\end{array}$ & $\begin{array}{l}<0.0005 \\
<0.0005\end{array}$ & $\begin{array}{l}<0.005 \\
<0.005\end{array}$ & $\begin{array}{l}<0.05 \\
<0.05\end{array}$ & $\begin{array}{l}57.49 \\
51.42\end{array}$ & $\begin{array}{l}<0.0002 \\
<0.0002\end{array}$ & $\begin{array}{c}24.93 \\
21.3\end{array}$ & $\begin{array}{l}<0.002 \\
<0.002\end{array}$ & $\begin{array}{l}0.48 \\
0.23\end{array}$ \\
\hline $87-07$ & $4(3)$ & $\begin{array}{l}\text { Maximum } \\
\text { Average }\end{array}$ & $\begin{array}{l}<0.025 \\
<0.025\end{array}$ & $\begin{array}{l}<0.0005 \\
<0.0005\end{array}$ & $\begin{array}{l}<0.005 \\
<0.005\end{array}$ & $\begin{array}{l}<0.05 \\
<0.05\end{array}$ & $\begin{array}{c}50.2 \\
45.11\end{array}$ & $\begin{array}{l}<0.0002 \\
<0.0002\end{array}$ & $\begin{array}{l}31.93 \\
29.98\end{array}$ & $\begin{array}{l}<0.002 \\
<0.002\end{array}$ & $\begin{array}{l}0.03 \\
0.03\end{array}$ \\
\hline $87-10$ & $5(4)$ & $\begin{array}{c}\text { Maximum } \\
\text { Average }\end{array}$ & $\begin{array}{l}<0.025 \\
<0.025\end{array}$ & $\begin{array}{l}<0.005 \\
<0.005\end{array}$ & $\begin{array}{l}<0.005 \\
<0.005\end{array}$ & $\begin{array}{l}<0.45 \\
<0.09\end{array}$ & $\begin{array}{l}96.10 \\
84.12\end{array}$ & $\begin{array}{l}<0.0002 \\
<0.0002\end{array}$ & $\begin{array}{l}44.54 \\
37.41\end{array}$ & $\begin{array}{l}<0.002 \\
<0.002\end{array}$ & $\begin{array}{l}0.04 \\
<0.02\end{array}$ \\
\hline $87-11$ & $5(4)$ & $\begin{array}{l}\text { Maximum } \\
\text { Average }\end{array}$ & $\begin{array}{l}<0.025 \\
<0.025\end{array}$ & $\begin{array}{l}<0.005 \\
<0.005\end{array}$ & $\begin{array}{l}<0.005 \\
<0.005\end{array}$ & $\begin{array}{l}0.45 \\
0.09\end{array}$ & $\begin{array}{c}84.31 \\
68.7\end{array}$ & $\begin{array}{l}<0.0002 \\
<0.0002\end{array}$ & $\begin{array}{l}29.00 \\
27.40\end{array}$ & $\begin{array}{l}<0.002 \\
<0.002\end{array}$ & $\begin{array}{l}0.05 \\
<0.02\end{array}$ \\
\hline $87-12$ & $4(3)$ & $\begin{array}{l}\text { Maximum } \\
\text { Average }\end{array}$ & $\begin{array}{l}<0.025 \\
<0.025\end{array}$ & $\begin{array}{l}<0.005 \\
<0.005\end{array}$ & $\begin{array}{l}<0.005 \\
<0.005\end{array}$ & $\begin{array}{l}<0.05 \\
<0.05\end{array}$ & $\begin{array}{l}18.13 \\
15.55\end{array}$ & $\begin{array}{l}<0.0002 \\
<0.0002\end{array}$ & $\begin{array}{l}14.50 \\
13.14\end{array}$ & $\begin{array}{l}<0.002 \\
<0.002\end{array}$ & $\begin{array}{l}<0.02 \\
<0.02\end{array}$ \\
\hline $87-23$ & 1 & $\begin{array}{l}\text { Maximum } \\
\text { Average }\end{array}$ & $<0.025$ & $<0.005$ & $<0.005$ & $<0.05$ & 55.2 & $<0.0002$ & 20.40 & $<0.002$ & $<0.02$ \\
\hline $87-26$ & 1 & $\begin{array}{l}\text { Maximum } \\
\text { Average }\end{array}$ & $\begin{array}{c}<0.025 \\
-\end{array}$ & $\begin{array}{c}<0.005 \\
-\end{array}$ & $<0.005$ & $<0.05$ & $\stackrel{43.1}{-}$ & $<0.0002$ & $\begin{array}{c}10.60 \\
-\end{array}$ & $<\frac{0.002}{-}$ & $<0.02$ \\
\hline $87-27$ & 1 & $\begin{array}{l}\text { Maximum } \\
\text { Average }\end{array}$ & $<0.025$ & $<0.005$ & $<0.005$ & $<0.05$ & 18.9 & $<0.0002$ & 17.30 & $<0.002$ & $\begin{array}{c}<0.02 \\
-\end{array}$ \\
\hline $87-28$ & 1 & $\begin{array}{l}\text { Maximum } \\
\text { Average }\end{array}$ & $\begin{array}{c}<0.025 \\
-\end{array}$ & $\begin{array}{c}<0.005 \\
-\end{array}$ & $\begin{array}{c}<0.005 \\
-\end{array}$ & $<0.05$ & $\underline{0.61}$ & $\begin{array}{c}<0.0002 \\
-\end{array}$ & 12.40 & $<0.002$ & $<-0.02$ \\
\hline
\end{tabular}


Table 5-10 (continued)

BNL Site Environmental Report for Calendar Year 1994

Current Landfill, Former Landfill, and Ash Repository

Ground Water Survellance Wells, Metals Data

\begin{tabular}{|c|c|c|c|c|c|c|c|c|c|c|c|}
\hline Location & $\begin{array}{l}\text { No. of } \\
\text { Samples }\end{array}$ & & $\underset{\mathrm{mg} / \mathrm{Ag}}{\mathrm{Ag}}$ & $\underset{\mathrm{mg} / \mathrm{h}}{\mathrm{Cd}}$ & $\underset{\mathrm{mg} / \mathrm{L}}{\mathrm{Cr}}$ & $\begin{array}{c}\mathrm{Cu} \\
\mathrm{mgn}\end{array}$ & $\begin{array}{c}\mathrm{Fe} \\
\mathbf{m g h}\end{array}$ & $\begin{array}{l}\mathrm{Hg} \\
\mathrm{mg} /\end{array}$ & $\begin{array}{c}\mathrm{Na} \\
\mathrm{mg} / \mathrm{L}\end{array}$ & $\begin{array}{c}\mathrm{Pb} \\
\mathrm{mg} / \mathrm{L}\end{array}$ & $\underset{m g h}{Z n}$ \\
\hline $\begin{array}{c}\text { Current Landifill } \\
88-02\end{array}$ & $4(3)$ & $\begin{array}{l}\text { Maximum } \\
\text { Average }\end{array}$ & $<0.025$ & $<0.005$ & $<0.005$ & $<0.05$ & $\begin{array}{c}7.3 \\
5.381\end{array}$ & $\begin{array}{l}<0.0002 \\
<0.0002\end{array}$ & $\begin{array}{l}19.37 \\
16.02\end{array}$ & $\begin{array}{l}<0.002 \\
<0.002\end{array}$ & $\begin{array}{l}0.67 \\
0.50\end{array}$ \\
\hline $88-21$ & 1 & $\begin{array}{l}\text { Maximum } \\
\text { Average }\end{array}$ & $\begin{array}{c}<0.025 \\
-\end{array}$ & $<0.005$ & $<\frac{0.005}{-}$ & $<0.05$ & 5.57 & $<0.0002$ & $\begin{array}{c}34.20 \\
-\end{array}$ & $<\frac{0.002}{-}$ & $\stackrel{<0.02}{-}$ \\
\hline $88-22$ & 1 & $\begin{array}{l}\text { Maximum } \\
\text { Average }\end{array}$ & $<0.025$ & $<\underline{-0.005}$ & $<0.005$ & $<0.05$ & 24.9 & $<0.0002$ & 17.40 & $<0.002$ & $<0.02$ \\
\hline $88-23$ & 1 & $\begin{array}{l}\text { Maximum } \\
\text { Average }\end{array}$ & $<0.025$ & $<\frac{0.005}{-}$ & $\begin{array}{c}<0.005 \\
-\end{array}$ & $\stackrel{0.05}{-}$ & $\begin{array}{r}22.4 \\
-\end{array}$ & $\begin{array}{c}<0.0002 \\
-\end{array}$ & $\stackrel{14.70}{-}$ & $<-0.003$ & 0.03 \\
\hline $98-65$ & 3 & $\begin{array}{l}\text { Maximum } \\
\text { Average }\end{array}$ & $<0.025$ & $<0.005$ & $<0.005$ & $<0.05$ & $\stackrel{0.473}{-}$ & $\begin{array}{c}<0.0002 \\
-\end{array}$ & $\begin{array}{c}8.65 \\
-\end{array}$ & $\begin{array}{l}<0.002 \\
<0.002\end{array}$ & $\begin{array}{l}<0.02 \\
<0.02\end{array}$ \\
\hline $107-23$ & 1 & $\begin{array}{l}\text { Maximum } \\
\text { Average }\end{array}$ & $<0.025$ & $\stackrel{0.007}{-}$ & $<0.005$ & $<0.05$ & $\begin{array}{r}6.17 \\
-\end{array}$ & $\begin{array}{c}<0.0002 \\
-\end{array}$ & 24.30 & $<0.002$ & $\stackrel{<0.02}{-}$ \\
\hline $107-25$ & 1 & $\begin{array}{l}\text { Maximum } \\
\text { Average }\end{array}$ & $<0.025$ & $<0.005$ & $<0.005$ & $<0.05$ & $\begin{array}{c}3.26 \\
-\end{array}$ & $<0.0002$ & 13.00 & $<0.003$ & $<0.02$ \\
\hline $115-01$ & $2(1)$ & $\begin{array}{l}\text { Maximum } \\
\text { Average }\end{array}$ & $\begin{array}{l}<0.025 \\
<0.025\end{array}$ & $\begin{array}{l}<0.005 \\
<0.005\end{array}$ & $\begin{array}{l}<0.005 \\
<0.005\end{array}$ & $\begin{array}{l}<0.05 \\
<0.05\end{array}$ & $\begin{array}{l}0.474 \\
0.237\end{array}$ & $\begin{array}{l}<0.0002 \\
<0.0002\end{array}$ & $\begin{array}{l}5.49 \\
5.34\end{array}$ & $\begin{array}{l}<0.002 \\
<0.002\end{array}$ & $\begin{array}{l}<0.02 \\
<0.02\end{array}$ \\
\hline $115-14$ & 1 & $\begin{array}{l}\text { Maximum } \\
\text { Average }\end{array}$ & $<0.025$ & $<0.005$ & $<0.005$ & $<0.05$ & $\begin{array}{c}0.736 \\
-\end{array}$ & $<0.0002$ & 15.30 & $<0.002$ & $<0.02$ \\
\hline $\begin{array}{l}\text { All Other Wells } \\
\qquad(n=20)\end{array}$ & $33(27)$ & $\begin{array}{l}\text { Maximum } \\
\text { Average }\end{array}$ & $\begin{array}{l}<0.025 \\
<0.025\end{array}$ & $\begin{array}{l}<0.005 \\
<0.005\end{array}$ & $\begin{array}{c}0.011 \\
<0.005\end{array}$ & $\begin{array}{l}<0.05 \\
<0.05\end{array}$ & $\begin{array}{l}0.104 \\
<0.075\end{array}$ & $\begin{array}{l}<0.0002 \\
<0.0002\end{array}$ & $\begin{array}{l}24.80 \\
10.86\end{array}$ & $\begin{array}{l}<0.002 \\
<0.002\end{array}$ & $\begin{array}{l}<0.02 \\
<0.02\end{array}$ \\
\hline NYS DWS & & & 0.05 & 0.01 & 0.05 & 1.3 & 0.3 & 0.002 & (d) & 0.015 & 5 \\
\hline Typical MDL & & & 0.025 & $0.0005(c)$ & 0.005 & 0.5 & 0.075 & 0.0002 & 1 & 0.0002 & 0.02 \\
\hline $\begin{array}{ll}\text { MDL: } & \text { Minimum D } \\
\text { (b): } & \text { Number in } \\
\text { (c): } & \text { PACE Lab } \\
\text { (d): } & \text { No Standa }\end{array}$ & $\begin{array}{l}\text { tonthesis in } \\
\text { tories MDL } \\
\text { Specified. }\end{array}$ & ates san & $s$ analy & for $\mathrm{Hg}$ & & & & & & & \\
\hline
\end{tabular}


Table 5-10 (continued)

BNL Site Environmental Report for Calendar Year 1994

Current Landfill, Former Landfill, and Ash Repository Ground Water Survelllance Wells, Metals Data

\begin{tabular}{|c|c|c|c|c|c|c|c|c|c|c|c|}
\hline Location & $\begin{array}{l}\text { No. of } \\
\text { Samples }\end{array}$ & & $\begin{array}{c}\mathrm{Ag} \\
\mathrm{mg} / \mathrm{L}\end{array}$ & $\begin{array}{c}\mathrm{Cd} \\
\mathrm{mg} / \mathrm{L}\end{array}$ & $\underset{\mathrm{mg} / \mathrm{L}}{\mathrm{Cr}}$ & $\underset{\mathrm{mg} / \mathrm{Lu}}{\mathrm{Cu}}$ & $\begin{array}{c}\mathrm{Fe} \\
\mathrm{mg} / \mathrm{L}\end{array}$ & $\underset{m g / L}{\mathrm{Hg}}$ & $\begin{array}{c}\mathrm{Na} \\
\mathrm{mg} / \mathrm{L}\end{array}$ & $\begin{array}{c}\mathrm{Pb} \\
\mathrm{mg} / \mathrm{L}\end{array}$ & $\begin{array}{c}\mathrm{Zn} \\
\mathrm{mg} / \mathrm{L}\end{array}$ \\
\hline \multicolumn{12}{|l|}{ Formal Landfill } \\
\hline $86-42$ (a) & 1 & $\begin{array}{l}\text { Maximum } \\
\text { Average }\end{array}$ & $\begin{array}{c}<0.025 \\
\ldots\end{array}$ & $<0.005$ & $<0.005$ & $<0.05$ & $\begin{array}{c}0.156 \\
-\end{array}$ & $<0.0002$ & $\frac{13.4}{-}$ & $\begin{array}{c}<0.002 \\
-\end{array}$ & $<0.02$ \\
\hline $86-43$ (a) & 1 & $\begin{array}{l}\text { Maximum } \\
\text { Average }\end{array}$ & $<0.025$ & $<0.005$ & $<0.005$ & $<0.05$ & $\begin{array}{c}0.156 \\
-\end{array}$ & $<0.0002$ & $\stackrel{15.8}{-}$ & $\begin{array}{c}<0.002 \\
-\end{array}$ & $<0.02$ \\
\hline $87-22(a)$ & 1 & $\begin{array}{l}\text { Maximum } \\
\text { Average }\end{array}$ & $\begin{array}{c}<0.025 \\
-\end{array}$ & $\begin{array}{c}<0.005 \\
-\end{array}$ & $\begin{array}{c}<0.005 \\
-\end{array}$ & $<0.05$ & $\frac{0.156}{-}$ & $<0.0002$ & 4.5 & $\begin{array}{c}<0.002 \\
-\end{array}$ & $\stackrel{0.02}{-}$ \\
\hline $96-03(a)$ & $2(1)$ & $\begin{array}{l}\text { Maximum } \\
\text { Average }\end{array}$ & $\begin{array}{c}<0.025 \\
-\end{array}$ & $\begin{array}{c}<0.005 \\
-\end{array}$ & $\begin{array}{l}<0.005 \\
<0.005\end{array}$ & $<0.05$ & $\begin{array}{c}<0.075 \\
-\end{array}$ & $<0.0002$ & 9.04 & $\underline{0.004}$ & $<0.02$ \\
\hline $96-04(a)$ & $3(2)$ & $\begin{array}{l}\text { Maximum } \\
\text { Average }\end{array}$ & $\begin{array}{l}<0.025 \\
<0.025\end{array}$ & $\begin{array}{l}<0.005 \\
<0.005\end{array}$ & $\begin{array}{l}<0.005 \\
<0.005\end{array}$ & $\begin{array}{l}<0.05 \\
<0.05\end{array}$ & $\begin{array}{l}<0.075 \\
<0.075\end{array}$ & $\begin{array}{l}<0.0002 \\
<0.0002\end{array}$ & $\begin{array}{l}6.27 \\
5.14\end{array}$ & $\begin{array}{l}<0.002 \\
<0.002\end{array}$ & $\begin{array}{l}0.12 \\
0.06\end{array}$ \\
\hline $97-08$ & $2(1)$ & $\begin{array}{l}\text { Maximum } \\
\text { Average }\end{array}$ & $\begin{array}{l}<0.025 \\
<0.025\end{array}$ & $\begin{array}{l}<0.005 \\
<0.005\end{array}$ & $\begin{array}{l}<0.005 \\
<0.005\end{array}$ & $\begin{array}{l}<0.05 \\
<0.05\end{array}$ & $\begin{array}{l}11.900 \\
6.040\end{array}$ & $<0.0002$ & $\stackrel{4.09}{-}$ & $\begin{array}{l}<0.003 \\
<0.003\end{array}$ & $\begin{array}{l}<0.02 \\
<0.02\end{array}$ \\
\hline $97-18$ & 1 & $\begin{array}{l}\text { Maximum } \\
\text { Average }\end{array}$ & $<0.025$ & $<0.005$ & $\begin{array}{c}<0.005 \\
-\end{array}$ & $<0.05$ & 20.200 & $<0.0002$ & $\begin{array}{c}5.24 \\
--\end{array}$ & $\begin{array}{c}<0.002 \\
-\end{array}$ & $<0.02$ \\
\hline $\begin{array}{l}\text { All Other Wells } \\
\quad(n=14)\end{array}$ & 19 & $\begin{array}{l}\text { Maximum } \\
\text { Average }\end{array}$ & $\begin{array}{l}<0.025 \\
<0.025\end{array}$ & $\begin{array}{l}<0.005 \\
<0.005\end{array}$ & $\begin{array}{l}0.011 \\
<0.005\end{array}$ & $\begin{array}{l}<0.05 \\
<0.05\end{array}$ & $\begin{array}{l}<0.075 \\
<0.075\end{array}$ & $\begin{array}{c}0.001 \\
<0.0002\end{array}$ & $\begin{array}{c}10.70 \\
5.23\end{array}$ & $\begin{array}{l}<0.002 \\
<0.002\end{array}$ & $\begin{array}{l}0.42 \\
0.03\end{array}$ \\
\hline$\frac{\text { Ash Repository }}{104-01}$ & $3(2)$ & $\begin{array}{l}\text { Maximum } \\
\text { Average }\end{array}$ & $\begin{array}{l}<0.025 \\
<0.025\end{array}$ & $\begin{array}{l}<0.005 \\
<0.005\end{array}$ & $\begin{array}{l}<0.005 \\
<0.005\end{array}$ & $\begin{array}{l}<0.05 \\
<0.05\end{array}$ & $\begin{array}{l}<0.075 \\
<0.075\end{array}$ & $\begin{array}{l}<0.0002 \\
<0.0002\end{array}$ & $\begin{array}{l}10.80 \\
10.21\end{array}$ & $\begin{array}{l}<0.002 \\
<0.002\end{array}$ & $\begin{array}{l}<0.02 \\
<0.02\end{array}$ \\
\hline NYS DWS & & & 0.05 & 0.01 & 0.05 & 1.3 & 0.3 & 0.002 & (d) & 0.015 & 5 \\
\hline Typical MDL & & & 0.025 & $0.0005(c)$ & 0.005 & 0.5 & 0.075 & 0.0002 & 1 & 0.0002 & 0.02 \\
\hline $\begin{array}{ll}\text { MDL: } & \text { Minimum D } \\
\text { (a): } & \text { Upgradien } \\
\text { (b): } & \text { Number in } \\
\text { (c): } & \text { PACE Lab } \\
\text { (d): } & \text { No Standa }\end{array}$ & $\begin{array}{l}\text { ection Limi } \\
\text { Vell. } \\
\text { arenthesis i } \\
\text { atories MD } \\
\text { Specified. }\end{array}$ & $\begin{array}{l}\text { dicates sam } \\
\text { for Cadmiu }\end{array}$ & $\begin{array}{l}\text { s analy } \\
=0.005\end{array}$ & for $\mathrm{Hg}$ & & & & & & & \\
\hline
\end{tabular}


Tablo 5-11

BNL Site Environmental Report for Calendar Year 199

Curront Landfill and Former Landfill Areas

Ground Water Survelllance Wolle, Chlorocarbon Data

\begin{tabular}{|c|c|c|c|c|c|c|c|c|}
\hline Location & $\begin{array}{l}\text { No. of } \\
\text { Samples }\end{array}$ & & $\begin{array}{l}\text { TCA } \\
\text { ugh }\end{array}$ & $\begin{array}{l}\text { TCE } \\
\text { ugl }\end{array}$ & $\begin{array}{l}\text { PCE } \\
\text { ugh }\end{array}$ & $\begin{array}{l}\text { DCA } \\
\text { ugh }\end{array}$ & $\begin{array}{l}\text { DCE } \\
\text { uph }\end{array}$ & $\begin{array}{c}\text { Chloroform } \\
\text { ugh }\end{array}$ \\
\hline \multicolumn{9}{|l|}{ Current Lanofil } \\
\hline $87-09(a)$ & 5 & $\begin{array}{l}\text { Maximum } \\
\text { Average }\end{array}$ & $\begin{array}{l}<2.0 \\
<2.0\end{array}$ & $\begin{array}{l}<2.0 \\
<2.0\end{array}$ & $\begin{array}{l}<2.0 \\
<20\end{array}$ & $\begin{array}{l}<2.0 \\
<2.0\end{array}$ & $\begin{array}{l}<20 \\
<20\end{array}$ & $\begin{array}{l}<20 \\
<20\end{array}$ \\
\hline $87-21(a)$ & 1 & $\begin{array}{l}\text { Meximum } \\
\text { Averago }\end{array}$ & $<20$ & $<2.0$ & $<2.0$ & $<2.0$ & $<20$ & $<2.0$ \\
\hline $87-06$ & 4 & $\begin{array}{c}\text { Maximum } \\
\text { Average }\end{array}$ & $\begin{array}{l}<2.0 \\
<2.0\end{array}$ & $\begin{array}{l}<2.0 \\
<2.0\end{array}$ & $\begin{array}{l}<2.0 \\
<2.0\end{array}$ & $\begin{array}{l}7.0 \\
3.5\end{array}$ & $\begin{array}{l}<2.0 \\
<2.0\end{array}$ & $\begin{array}{l}<2.0 \\
<2.0\end{array}$ \\
\hline 87-07 & 4 & $\begin{array}{l}\text { Maximum } \\
\text { Average }\end{array}$ & $\begin{array}{l}<2.0 \\
<2.0\end{array}$ & $\begin{array}{l}<2.0 \\
<2.0\end{array}$ & $\begin{array}{l}<2.0 \\
<2.0\end{array}$ & $\begin{array}{l}7.0 \\
5.2\end{array}$ & $\begin{array}{l}<20 \\
<20\end{array}$ & $\begin{array}{l}<20 \\
<20\end{array}$ \\
\hline $87-10$ & 5 & $\underset{\text { Average }}{\text { Maximum }}$ & $\begin{array}{l}<2.0 \\
<2.0\end{array}$ & $\begin{array}{l}<2.0 \\
<2.0\end{array}$ & $\begin{array}{l}<2.0 \\
<2.0\end{array}$ & $\begin{array}{l}6.0 \\
5.2\end{array}$ & $\begin{array}{l}<2.0 \\
<2.0\end{array}$ & $\begin{array}{l}<2.0 \\
<2.0\end{array}$ \\
\hline $88-22$ & 1 & $\begin{array}{c}\text { Maximum } \\
\text { Averago }\end{array}$ & $<2.0$ & $<2.0$ & $\begin{array}{c}<2.0 \\
-\end{array}$ & $\stackrel{11.0}{-}$ & $<20$ & $<2$. \\
\hline $107-08$ & 2 & $\begin{array}{l}\text { Maximum } \\
\text { Averago }\end{array}$ & $\begin{array}{l}<2.0 \\
<20\end{array}$ & $\begin{array}{l}<2.0 \\
<2.0\end{array}$ & $\begin{array}{l}<2.0 \\
<20\end{array}$ & $\begin{array}{l}6.0 \\
5.4\end{array}$ & $\begin{array}{l}<2.0 \\
<2.0\end{array}$ & $\begin{array}{l}<2.0 \\
<20\end{array}$ \\
\hline $107-23$ & 1 & $\begin{array}{l}\text { Maximum } \\
\text { Average }\end{array}$ & 13.0 & $<2.0$ & $<2.0$ & 67.0 & $<2.0$ & $<2.0$ \\
\hline $107-24$ & 1 & $\begin{array}{l}\text { Maximum } \\
\text { Average }\end{array}$ & $<1.0$ & $<1.0$ & $<1.0$ & $\begin{array}{c}17.0 \\
-\end{array}$ & $<1.0$ & $<1.0$ \\
\hline $107-25$ & 1 & $\begin{array}{c}\text { Maximum } \\
\text { Average }\end{array}$ & 6.0 & 1.0 & $<1.0$ & 38.0 & 2.0 & $<1.0$ \\
\hline $115-04$ & 3 & $\begin{array}{l}\text { Maximum } \\
\text { Average }\end{array}$ & $\begin{array}{l}29.0 \\
17.3\end{array}$ & $\begin{array}{l}6.4 \\
4.8\end{array}$ & $\begin{array}{l}5.6 \\
4.5\end{array}$ & $\begin{array}{l}<2.0 \\
<2.0\end{array}$ & $\begin{array}{l}3.8 \\
<2.0\end{array}$ & $\begin{array}{l}3.2 \\
<20\end{array}$ \\
\hline $115-05$ & 3 & $\begin{array}{c}\text { Maximum } \\
\text { Average }\end{array}$ & $\begin{array}{l}15.0 \\
9.7\end{array}$ & $\begin{array}{l}2.0 \\
<2.0\end{array}$ & $\begin{array}{l}2.0 \\
<2.0\end{array}$ & $\begin{array}{l}29.0 \\
14.3\end{array}$ & $\begin{array}{l}<2.0 \\
<2.0\end{array}$ & $\begin{array}{r}2.0 \\
<2.0\end{array}$ \\
\hline $115-13$ & 1 & $\begin{array}{c}\text { Maximum } \\
\text { Averago }\end{array}$ & $\frac{62.0}{-}$ & $\stackrel{10.0}{-}$ & $<1.0$ & $\begin{array}{c}360.0 \\
-\end{array}$ & 34.0 & $<1.0$ \\
\hline $115-14$ & 1 & $\begin{array}{l}\text { Maximum } \\
\text { Averago }\end{array}$ & $\frac{2.0}{-}$ & $<1.0$ & $\stackrel{<1.0}{-}$ & $\stackrel{52}{-}$ & $<1.0$ & $<1.0$ \\
\hline $116-05$ & 1 & $\begin{array}{l}\text { Maximum } \\
\text { Average }\end{array}$ & 18.0 & $\frac{4}{-}$ & $\frac{3}{-}$ & $<1.0$ & 2.0 & $<20$ \\
\hline $116-06$ & 1 & $\begin{array}{l}\text { Maximum } \\
\text { Average }\end{array}$ & 5.0 & $<1.0$ & $<1.0$ & 33 & 20 & $<2.0$ \\
\hline $\begin{array}{l}\text { All Other Wets } \\
(n=25) \\
\text { Former Landisl }\end{array}$ & 49 & $\begin{array}{c}\text { Maximum } \\
\text { Average }\end{array}$ & $\begin{array}{l}2.0 \\
<2.0\end{array}$ & $\begin{array}{l}<2.0 \\
<2.0\end{array}$ & $\begin{array}{l}<2.0 \\
<2.0\end{array}$ & $\begin{array}{l}3.0 \\
<2.0\end{array}$ & $\begin{array}{l}<2.0 \\
<2.0\end{array}$ & $\begin{array}{l}5.4 \\
<2.0\end{array}$ \\
\hline $86-42(a)$ & 1 & $\begin{array}{l}\text { Moximum } \\
\text { Average }\end{array}$ & $\stackrel{1.0}{-}$ & $<2.0$ & $\frac{4.0}{-}$ & $<1.0$ & $<1.0$ & $<20$ \\
\hline $86-43(a)$ & 1 & $\begin{array}{l}\text { Maximum } \\
\text { Average }\end{array}$ & $\stackrel{1.0}{\rightarrow}$ & $<1.0$ & $<1.0$ & $<1.0$ & $<1.0$ & $<20$ \\
\hline $87-22(a)$ & 1 & $\begin{array}{l}\text { Maximem } \\
\text { Average }\end{array}$ & $<1.0$ & $<1.0$ & $<1.0$ & $<1.0$ & $<1.0$ & $<1.0$ \\
\hline $96-03(a)$ & 2 & $\begin{array}{l}\text { Maximum } \\
\text { Averago }\end{array}$ & $\begin{array}{l}<1.0 \\
<1.0\end{array}$ & $\begin{array}{l}<1.0 \\
<1.0\end{array}$ & $\begin{array}{l}<1.0 \\
<1.0\end{array}$ & $\begin{array}{l}<1.0 \\
<1.0\end{array}$ & $\begin{array}{l}<1.0 \\
<1.0\end{array}$ & $\begin{array}{l}<1.0 \\
<1.0\end{array}$ \\
\hline $96-04(a)$ & 3 & $\underset{\text { Average }}{\text { Madmum }}$ & $\begin{array}{l}<2.0 \\
<2.0\end{array}$ & $\begin{array}{l}<2.0 \\
<2.0\end{array}$ & $\begin{array}{l}<2.0 \\
<2.0\end{array}$ & $\begin{array}{l}<2.0 \\
<2.0\end{array}$ & $\begin{array}{l}<2.0 \\
<2.0\end{array}$ & $\begin{array}{l}<2.0 \\
<2.0\end{array}$ \\
\hline $106-13$ & 1 & $\begin{array}{l}\text { Maximum } \\
\text { Average }\end{array}$ & $\frac{7.0}{-}$ & $<1.0$ & $<1.0$ & $\frac{2.0}{-}$ & $<1.0$ & 20 \\
\hline $106-14$ & 1 & $\underset{\text { Average }}{\text { Maximum }}$ & $<1.0$ & 6.0 & $<1.0$ & $<1.0$ & $<1.0$ & $<2.0$ \\
\hline $\begin{array}{l}\text { Al Other Wels } \\
(n=12)\end{array}$ & 20 & $\begin{array}{l}\text { Maximum } \\
\text { Average }\end{array}$ & $\begin{array}{l}<2.0 \\
<20\end{array}$ & $\begin{array}{l}2.0 \\
<2.0\end{array}$ & $\begin{array}{l}3.0 \\
<2.0\end{array}$ & $\begin{array}{l}<2.0 \\
<2.0\end{array}$ & $\begin{array}{l}<2.0 \\
<2.0\end{array}$ & $\begin{array}{l}6.0 \\
<20\end{array}$ \\
\hline \multicolumn{9}{|l|}{ Ash Repository } \\
\hline $104-01$ & 3 & $\begin{array}{l}\text { Maximum } \\
\text { Average }\end{array}$ & $\begin{array}{l}<2.0 \\
<2.0\end{array}$ & $\begin{array}{l}<2.0 \\
<20\end{array}$ & $\begin{array}{l}<2.0 \\
<2.0\end{array}$ & $\begin{array}{l}<2.0 \\
<2.0\end{array}$ & $\begin{array}{l}<2.0 \\
<2.0\end{array}$ & $\begin{array}{l}<20 \\
<20\end{array}$ \\
\hline NYS DWS & & & 5.0 & 5.0 & 5.0 & 5.0 & 5.0 & 100.0 \\
\hline Typlcal MOL (b) & & & 20 & 20 & 20 & 20 & 2.0 & 2.0 \\
\hline
\end{tabular}

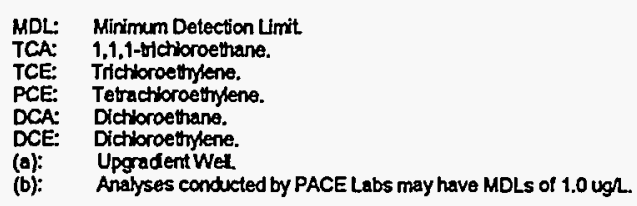


Table 5-12

BNL Site Environmental Report for Calendar Year 1994

Current Landfill, Former Landfill, and Ash Repository

Ground Water Surveillance Wells, BETX Data

\begin{tabular}{|c|c|c|c|c|c|c|}
\hline Location & $\begin{array}{l}\text { No. of } \\
\text { Samples }\end{array}$ & & $\begin{array}{c}\text { Benzine } \\
\text { ug/L }\end{array}$ & $\begin{array}{c}\text { Ethylbenzene } \\
\text { ug/L }\end{array}$ & $\begin{array}{l}\text { Toluene } \\
\text { ug/L }\end{array}$ & $\begin{array}{c}\text { Xylene } \\
\text { ug/L }\end{array}$ \\
\hline \multicolumn{7}{|l|}{ Current Landfill } \\
\hline $87-09$ (a) & 5 & $\begin{array}{l}\text { Maximum } \\
\text { Average }\end{array}$ & $\begin{array}{l}<2.0 \\
<2.0\end{array}$ & $\begin{array}{l}<2.0 \\
<2.0\end{array}$ & $\begin{array}{l}<2.0 \\
<2.0\end{array}$ & $\begin{array}{l}<2.0 \\
<2.0\end{array}$ \\
\hline $87-21(a)$ & 1 & $\begin{array}{c}\text { Maximum } \\
\text { Average }\end{array}$ & $\begin{array}{l}<1.0 \\
<1.0\end{array}$ & $\begin{array}{l}<1.0 \\
<1.0\end{array}$ & $\begin{array}{l}<1.0 \\
<1.0\end{array}$ & $\begin{array}{l}<1.0 \\
<1.0\end{array}$ \\
\hline $87-04$ & 2 & $\begin{array}{l}\text { Maximum } \\
\text { Average }\end{array}$ & $\begin{array}{l}<2.0 \\
<2.0\end{array}$ & $\begin{array}{l}<2.0 \\
<2.0\end{array}$ & $\begin{array}{l}<2.0 \\
<2.0\end{array}$ & $\begin{array}{l}<2.0 \\
<2.0\end{array}$ \\
\hline $87-05$ & 4 & $\begin{array}{l}\text { Maximum } \\
\text { Average }\end{array}$ & $\begin{array}{l}6.0 \\
4.1\end{array}$ & $\begin{array}{l}3.0 \\
<2.0\end{array}$ & $\begin{array}{l}<2.0 \\
<2.0\end{array}$ & $\begin{array}{l}<2.0 \\
<2.0\end{array}$ \\
\hline $87-06$ & 4 & $\begin{array}{c}\text { Maximum } \\
\text { Average }\end{array}$ & $\begin{array}{l}5.0 \\
4.0\end{array}$ & $\begin{array}{l}<2.0 \\
<2.0\end{array}$ & $\begin{array}{l}<2.0 \\
<2.0\end{array}$ & $\begin{array}{l}<2.0 \\
<2.0\end{array}$ \\
\hline $87-07$ & 4 & $\begin{array}{l}\text { Maximum } \\
\text { Average }\end{array}$ & $\begin{array}{l}6.0 \\
4.0\end{array}$ & $\begin{array}{l}<2.0 \\
<2.0\end{array}$ & $\begin{array}{l}<2.0 \\
<2.0\end{array}$ & $\begin{array}{l}<2.0 \\
<2.0\end{array}$ \\
\hline $87-10$ & 5 & $\begin{array}{l}\text { Maximum } \\
\text { Average }\end{array}$ & $\begin{array}{l}3.0 \\
2.5\end{array}$ & $\begin{array}{l}4.0 \\
<2.0\end{array}$ & $\begin{array}{l}<2.0 \\
<2.0\end{array}$ & $\begin{array}{l}<2.0 \\
<2.0\end{array}$ \\
\hline $87-11$ & 5 & $\begin{array}{l}\text { Maximum } \\
\text { Average }\end{array}$ & $\begin{array}{l}6.0 \\
4.6\end{array}$ & $\begin{array}{l}<2.0 \\
<2.0\end{array}$ & $\begin{array}{l}3.0 \\
<2.0\end{array}$ & $\begin{array}{l}<2.0 \\
<2.0\end{array}$ \\
\hline $\begin{array}{l}\text { All Other Wells } \\
\qquad(n=33)\end{array}$ & 54 & $\begin{array}{l}\text { Maximum } \\
\text { Average }\end{array}$ & $\begin{array}{l}3.0 \\
<2.0\end{array}$ & $\begin{array}{l}<2.0 \\
<2.0\end{array}$ & $\begin{array}{l}<2.0 \\
<2.0\end{array}$ & $\begin{array}{l}<2.0 \\
<2.0\end{array}$ \\
\hline \multicolumn{7}{|l|}{ Former Landfill } \\
\hline $\begin{array}{l}\text { All Wells } \\
(n=21)\end{array}$ & 30 & $\begin{array}{l}\text { Maximum } \\
\text { Average }\end{array}$ & $\begin{array}{l}<2.0 \\
<2.0\end{array}$ & $\begin{array}{l}<2.0 \\
<2.0\end{array}$ & $\begin{array}{l}<2.0 \\
<2.0\end{array}$ & $\begin{array}{l}<2.0 \\
<2.0\end{array}$ \\
\hline Ash Repository & & & & & & \\
\hline $104-01$ & 3 & $\begin{array}{l}\text { Maximum } \\
\text { Average }\end{array}$ & $\begin{array}{l}<2.0 \\
<2.0\end{array}$ & $\begin{array}{l}<2.0 \\
<2.0\end{array}$ & $\begin{array}{l}<2.0 \\
<2.0\end{array}$ & $\begin{array}{l}<2.0 \\
<2.0\end{array}$ \\
\hline
\end{tabular}

MDL: Minimum Detection Limit.

(a): Upgradient Well. 
concentrations were elevated in downgradient wells. Upgradient Wells 87-09 and 87-21 had an average sodium concentration of 11.0 and $15.5 \mathrm{mg} / \mathrm{L}$, respectively, whereas sodium concentrations in the wells located downgradient of the current Irandfill ranged from $8.5-45.6 \mathrm{mg} / \mathrm{L}$. Groundwater analyses for vocs indicate that 12 downgradient wells had concentrations of organic contaminants above NYS DWS during 1994. Organic contaminants were not detected in upgradient Wells 8709 and 87-21. Of the downgradient wells where NYS DWS were exceeded: TCA was detected at maximum concentrations of $13 \mu \mathrm{g} / \mathrm{L}$ in Well $107-23,29 \mu \mathrm{g} / \mathrm{L}$ in Well 115-04, $15 \mu \mathrm{g} / \mathrm{L}$ in Well 115-05, $62 \mu \mathrm{g} / \mathrm{L}$ in Well 115-13, $18 \mu \mathrm{g} / \mathrm{L}$ in Well 116-05, and $5.0 \mu \mathrm{g} / \mathrm{L}$ in Well 116-06; DCA was detected at maximum concentrations of $7 \mu \mathrm{g} / \mathrm{L}$ in Well 87-06 and Well 87-07, $6 \mu \mathrm{g} / \mathrm{L}$ in Well 87-10, $11 \mu \mathrm{g} / \mathrm{I}$ in Well 88-22, 6.0 $\mu \mathrm{g} / \mathrm{L}$ in Well 107-08, $67 \mu \mathrm{g} / \mathrm{I}$ in Well 107-23, $17 \mu \mathrm{g} / \mathrm{L}$ in Well 107-24, 38 $\mu \mathrm{g} / \mathrm{L}$ in Well 107-25, $28 \mu \mathrm{g} / \mathrm{L}$ in Well 115-05, $360 \mu \mathrm{g} / \mathrm{L}$ in Well 115-13, 52 $\mathrm{gg} / \mathrm{L}$ in Well 115-14 and $33 \mu \mathrm{g} / \mathrm{L}$ in Well 116-06; benzene was detected in Wells 87-05, 87-06, 87-07, and 87-11 at maximum concentrations of $6 \mu \mathrm{g} / \mathrm{I}, 5 \mu \mathrm{g} / \mathrm{L}, 6 \mu \mathrm{g} / \mathrm{I}$, and $6 \mu \mathrm{g} / \mathrm{L}$, respectively; and chloroethane was detected at maximum concentrations of $94 \mu \mathrm{g} / \mathrm{I}$ in Well 87-10, $18 \mu \mathrm{g} / \mathrm{L}$ in Well $87-11,28 \mu \mathrm{g} / \mathrm{L}$ in Well 87-23, $18 \mu \mathrm{g} / \mathrm{L}$ in Well $88-$ $22,13 \mu \mathrm{g} / \mathrm{L}$ in Well 107-23, $23 \mu \mathrm{g} / \mathrm{I}$ in Well 107-24, $22 \mu \mathrm{g} / \mathrm{L}$ in Well 107-25, 130 $\mu \mathrm{g} / \mathrm{L}$ in Well 115-13, and $29 \mu \mathrm{g} / \mathrm{L}$ in Well 115-14. Trend plots for DCA based on data from representative monitoring wells downgradient of the Current Landfill are presented in Figure 5-12. Iron and manganese trend data are presented in Figures 5-13 and 5-14, respectively.

Eormer Landfill: The Former Landfill area was initially used by the United States Army during World Wars I and II, and then by BNL from 1947 through 1966. The Laboratory used the southeast corner of the landfill for the disposal of construction and demolition debris, sewage sludge, chemical and low-level radioactive waste, used equipment, and animal carcasses. From 1960 through 1966, laboratory waste, glassware containing chemical and radioactive waste, and animal carcasses containing radioactive tracers were disposed of in shallow pits in an area directly east of the Former Iandfill. The Former Landfill and chemical disposal areas have been identified as areas that are contributing to soil and groundwater contamination. Remedial alternatives for capping, source removal, and groundwater remediation in the Former landfill area are currently being assessed as part of the OU I RI/ES. The surveillance well network monitoring the Former Landfill area consist of a total of 21 shallow Upper Glacial aquifer wells (Figure 5-8). Eleven of these wells were installed during 1994 as part of the OU I RI/FS. During the OU I RI, 14 temporary groundwater screening wells were also installed in and downgradient of the Former Landfill area during the ou $I$ RI to assess the vertical and horizontal extent of groundwater contamination. During 1994, groundwater samples were collected from the 21 surveillance wells, and were analyzed for primarily vocs and metals (Tables 5-9 to 5-12). A limited number of samples were analyzed for water quality parameters. As with previous years, the $\mathrm{pH}$ was typically below the lower limit of the NYS AWQS of 6.5 - 8.5, with a median $\mathrm{pH}$ of 5.4. Metals analyses indicate that only two wells, Wells $97-$ 08 and 97-18 exceeded NYS DWS with maximum observed iron concentrations of 11.9 and $20.2 \mathrm{mg} / \mathrm{L}$, respectively. Analyses of groundwater samples for vocs indicate that two wells had concentrations of organic contaminants above NYS DWS. TCA Was detected in Well 106-13 at a maximum concentration of $7 \mu \mathrm{g} / \mathrm{L}$, and TCE was detected in Well 106-14 at a maximum concentration of $6 \mu \mathrm{g} / \mathrm{L}$. Above DWS concentrations of Vocs were also detected in four temporary profile wells installed along the site boundary downgradient of the Former Landfill. During the groundwater screening survey, a maximum of $9.5 \mu \mathrm{g} / \mathrm{I}$ of TCA was detected in temporary Well $\mathrm{HP}-114-03 ; 17.4 \mu \mathrm{g} / \mathrm{L}$ of $\mathrm{TCA}$ and $6.2 \mu \mathrm{g} / \mathrm{L}$ of TCE were detected in Well HP-115-08; and $11.6 \mu \mathrm{g} / \mathrm{L}$ of TCA in Well HP-115-09. Contaminants that may have originated from the Former Landfill area were also detected in off-site temporary well HP-OS-13, in a zone located in the deep portion of the Upper Glacial aquifer. Maximum values of VoCs that were detected above NYS DWS in Well HP-OS-13 were TCA at $5.9 \mu \mathrm{g} / \mathrm{L}, 1,2-\mathrm{DCA}$ at $8 \mu \mathrm{g} / \mathrm{L}$, and TCE at $37.9 \mu \mathrm{g} / \mathrm{L}$. 


\section{CURRENT LANDFILL}
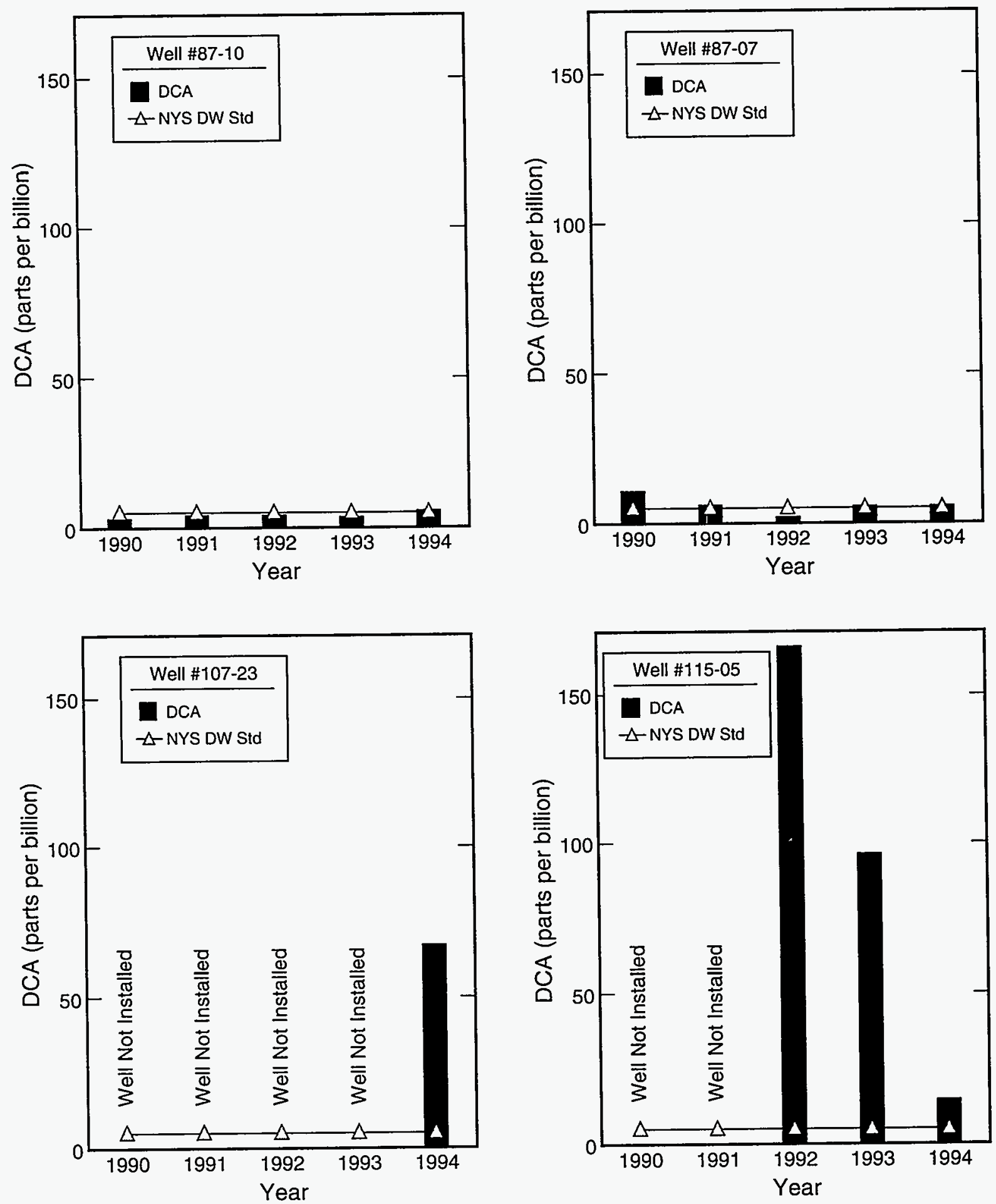

Figure 5-12 1,1-Dichloroethane (DCA) concentration trends in wells downgradient of the Current Landfill: Well 87-10 located at downgradient margin of landfill; Well $87-07$ located $75 \mathrm{~m}$ downgradient of landfill; Well 107-23 located $675 \mathrm{~m}$ downgradient of landfill; and Well 115-05 located at the site boundary $1,225 \mathrm{~m}$ downgradient of the landfill. 


\section{CURRENT LANDFILL}
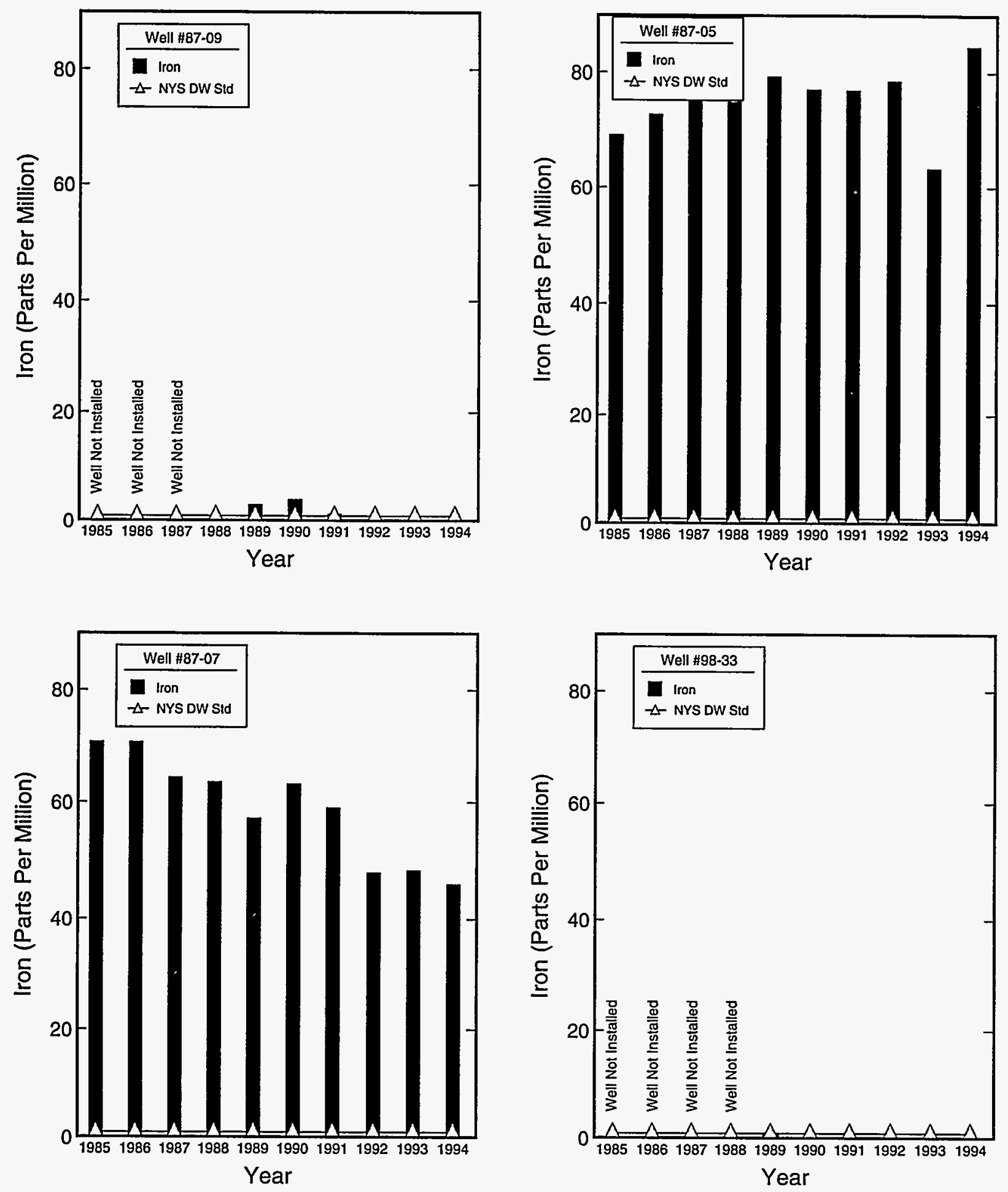

Figure 5-13 Iron Concentration trends in wells upgradient and downgradient of the Current Landfill: Well 87-09 located at upgradient margin of landfill; Well 87-05 located at downgradient margin of landfill; Well 87-07 located 75m downgradient of landfill; and Well $98-33$ located $310 \mathrm{~m}$ downgradient of landfill. 


\section{CURRENT LANDFILL}
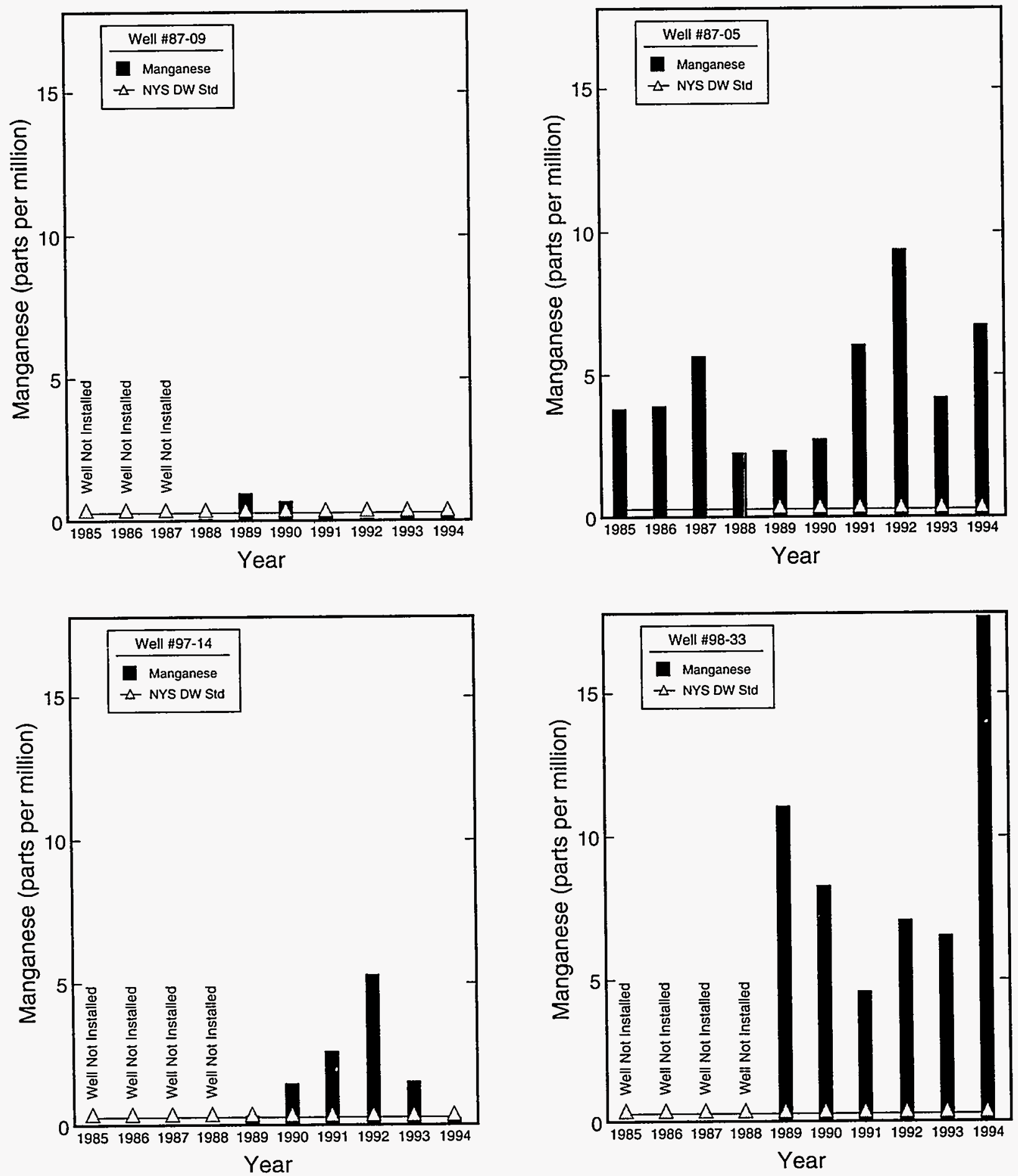

Figure 5-14 Manganese concentration trends in wells upgradient and downgradient of the Current Landfill: Well 87-09 located at upgradient margin of landfill; Well 87-05 located at downgradient margin of landfill; Well 97-14 located 150m downgradient of landfill; and Well 98-33 located 310m downgradient of landfill. 
Ash Repository Area: The Ash Repository area was used from 1943 through 1963 for the disposal of ash from a former on-site solid waste incinerator. The Ash Repository area has been identified as an area potentially contributing to soil and groundwater contamination, and was investigated during the OU I RI/ES conducted during 1994. The Ash Repository area is monitored by a single downgradient shallow Upper Glacial aquifer well (Figure 5-7). During 1994, groundwater samples collected from the Ash Repository surveillance wells were analyzed for water quality, vocs, and metals (Tables 5-9 to 5-12). Water quality data from Well 104-01 indicate that the pH was typically below the lower limit of the NYS AWQS of 6.5 -8.5, with a median pH of 6.0. The remaining water quality parameters, metals, and VOC concentrations were below the applicable NYS AWQS and DWS.

Hazardous Waste Management Facility Area: The HWMF is the central (RCRA) receiving facility for the processing, limited treatment (neutralization), and storage of hazardous and radioactive wastes prior to permanent off-site disposal. As the result of past handling, storage and disposal practices, soil and groundwater contamination has occurred within the HWMF. Recent investigations have indicated that groundwater contamination extends from this facility downgradient to an area south of the Iong Island Expressway. The full extent of groundwater contamination and assessment of remedial alternatives are currently being evaluated as part of the oU I Groundwater Removal Action. The groundwater survejllance well network at and downgradient of the HWMF consists of 45 shallow to deep Upper Glacial aquifer wells (Figures 5-8 and 5-11). During 1994, the 45 HWMF surveillance wells were monitored primarily for metals and VoCs (Tables 5-13 to 5-16). Water quality analyses were also performed on a limited number of samples. As with previous years, the $\mathrm{pH}$ of groundwater in the HWM area was typically slightly below the lower limit of the NYS AWQS of $6.5-8.5$, with a median $\mathrm{pH}$ of 6.0. All other water quality parameters were below the applicable NYS AWQS. Iron was detected at concentrations above NYS DWS in all three upgradient wells at maximum concentrations ranging from $0.73 \mathrm{mg} / \mathrm{L}$ to $0.9 \mathrm{mg} / \mathrm{L}$, and seven downgradient wells at maximum observed concentrations ranging from 0.38 to $3.56 \mathrm{mg} / \mathrm{L}$. Zinc was also detected above NYS DWS in Well 99-02 at $6.3 \mathrm{mg} / \mathrm{I}$. of the 45 HWMF surveillance wells, 11 wells had VOC concentrations above NYS DWS at least once during 1994. No vOCs were detected in the upgradient Wells 88-13, 88-14, or 88-20. Of the surveillance wells within and downgradient of the HWMF in which NYS DWS were exceeded TCA was detected (maximum values observed) in Well

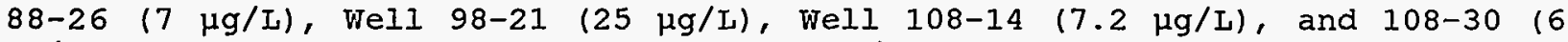
$\mu \mathrm{g} / \mathrm{L})$; TCE was detected in Well 108-30 (7 $\mu \mathrm{g} / \mathrm{I})$; PCE was detected in Well 88-04

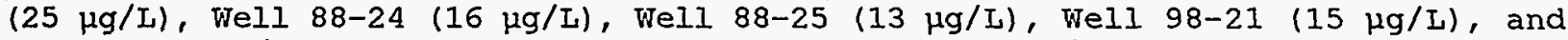
108-30 (17 $\mu \mathrm{g} / \mathrm{I})$; DCA was detected in Well 98-57 (14 $\mu \mathrm{g} / \mathrm{L})$, Well 98-58 (56 $\mu \mathrm{g} / \mathrm{L})$,

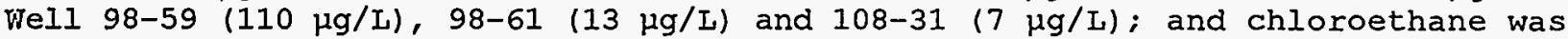

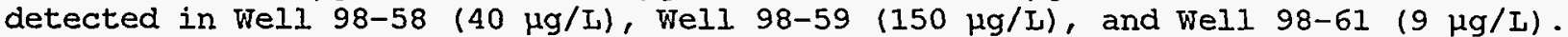
Trend plots for PCE based on data from representative monitoring wells within and downgradient of the HWMF are presented in Figure 5-15.

Central steam Facility/Major Petroleum Eacility Area: The CSF supplies steam for heating to all major facilities of the Laboratory through an underground distribution system. The MPF is the holding area for most fuels used at the CSE. Five shallow wells monitoring the MPF were installed as part of the licensing requirements for this facility, and are screened across the water table to allow for the detection of free product (i.e., oil floating on top of the groundwater). The surveillance wells at the CSF were installed primarily to monitor groundwater contamination resulting from a 1977 leak of approximately 23, 000 gallons of Alternative Liquid Fuel (a fuel oil/spent solvent mixture) at this facility. The CSF/MPE area is the subject of an on going RI/FS (OU IV) which started in the Fall of 1992. The surveillance well networks at the CSF and MPF consist of a total of 30 shallow to deep Upper Glacial aquifer wells (Figures 5-5 and 5-8). During 1994, the 30 surveillance wells were monitored for water quality, metals, and Vocs (Tables 5-17 to 5-20). The five MPF wells were also sampled for floating petroleum products. Water quality data indicate that pH was typically 
Table 5-13

BNL Site Environmental Report for Calendar Year 1994

Hazardous Waste Management Facility

Ground Water Surveillance Wells, Water Quality Data

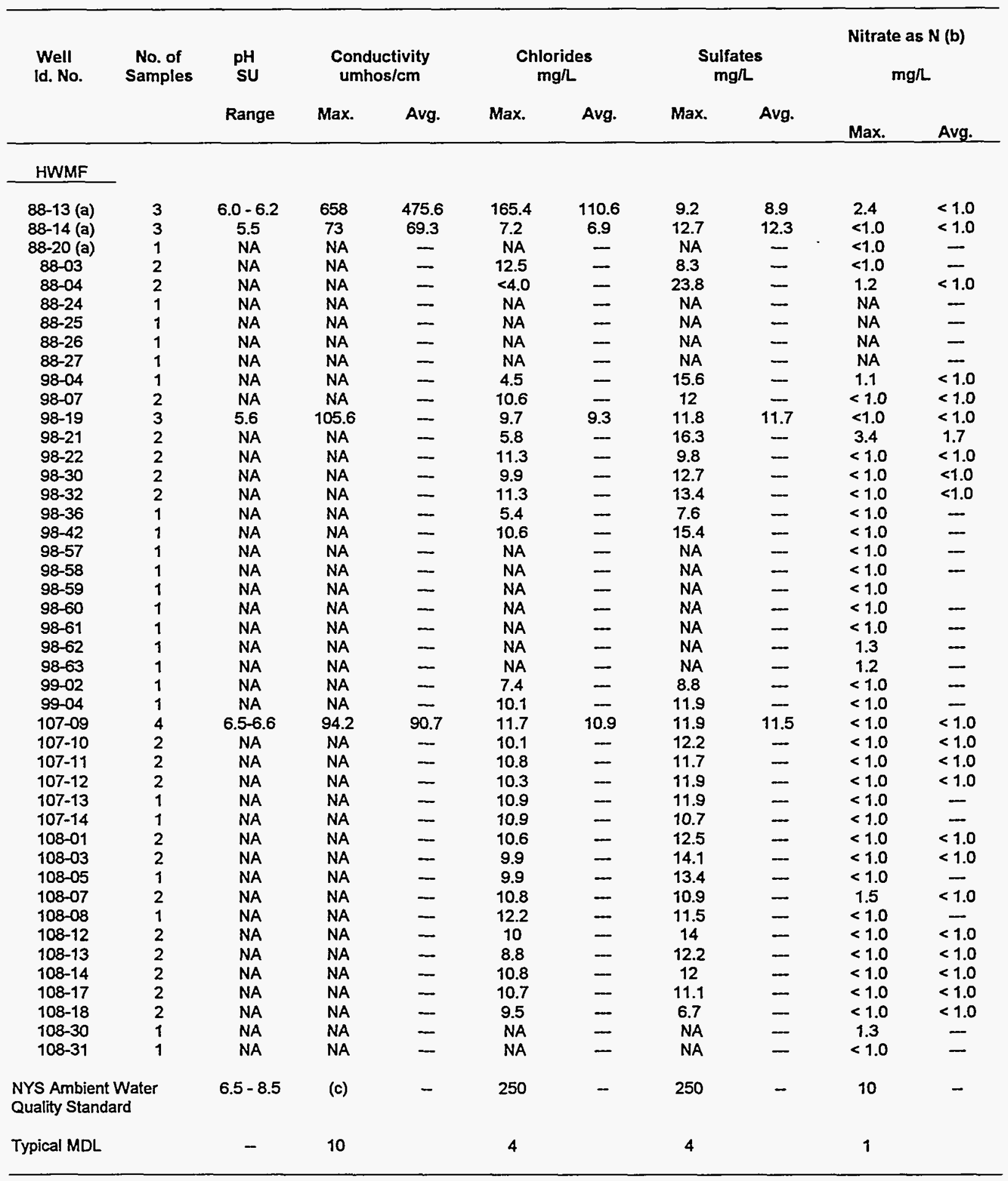

MDL: Minimum Detection Limit.

(a): Upgradient Well.

(b): Holding time expired for all samples.

(c): No standard specified. 
Table 5-14

BNL Site Environmental Report for Calendar Year 199

Hazardous Waste Management Facility Area

Ground Water Survalllance Wells, Chlorocarbon Data

\begin{tabular}{|c|c|c|c|c|c|c|c|c|}
\hline Location & $\begin{array}{l}\text { No, of } \\
\text { Samples }\end{array}$ & & $\begin{array}{l}\text { TCA } \\
\text { vol }\end{array}$ & $\begin{array}{l}\text { TCE } \\
\text { ugl }\end{array}$ & $\begin{array}{l}\text { PCE } \\
\text { ugh }\end{array}$ & $\begin{array}{l}\text { DCA } \\
\text { cos }\end{array}$ & $\begin{array}{l}\text { DCE } \\
\text { ugh }\end{array}$ & $\begin{array}{c}\text { Chloroform } \\
\text { ugh }\end{array}$ \\
\hline \multicolumn{9}{|l|}{ HWMF } \\
\hline $88-13$ (a) & 3 & $\begin{array}{c}\text { Maximum } \\
\text { Average }\end{array}$ & $\begin{array}{l}<1.0 \\
<2.0\end{array}$ & $\begin{array}{l}<2.0 \\
<2.0\end{array}$ & $\begin{array}{l}<2.0 \\
<2.0\end{array}$ & $\begin{array}{l}<2.0 \\
<2.0\end{array}$ & $\begin{array}{l}<2.0 \\
<2.0\end{array}$ & $\begin{array}{l}<2.0 \\
<2.0\end{array}$ \\
\hline $88-14(a)$ & 3 & $\begin{array}{l}\text { Maximum } \\
\text { Average }\end{array}$ & $\begin{array}{l}<2.0 \\
<20\end{array}$ & $\begin{array}{l}<2.0 \\
<20\end{array}$ & $\begin{array}{l}<2.0 \\
<2.0\end{array}$ & $\begin{array}{l}<2.0 \\
<2.0\end{array}$ & $\begin{array}{l}<2.0 \\
<2.0\end{array}$ & $\begin{array}{l}<2.0 \\
<2.0\end{array}$ \\
\hline $88-20$ (a) & 1 & $\begin{array}{c}\text { Maximum } \\
\text { Average }\end{array}$ & $<1.0$ & $<1.0$ & $\stackrel{<1.0}{-}$ & $<1.0$ & $<1.0$ & $<20$ \\
\hline $88-04$ & 2 & $\begin{array}{l}\text { Maximum } \\
\text { Average }\end{array}$ & $\begin{array}{l}4.0 \\
3.8\end{array}$ & $\begin{array}{l}<1.0 \\
<1.0\end{array}$ & $\begin{array}{c}25 \\
25.0\end{array}$ & $\begin{array}{l}<1.0 \\
<1.0\end{array}$ & $\begin{array}{l}<1.0 \\
<1.0\end{array}$ & $\begin{array}{l}<1.0 \\
<1.0\end{array}$ \\
\hline $88-24$ & 1 & $\begin{array}{l}\text { Maximum } \\
\text { Average }\end{array}$ & $<1.0$ & $<1.0$ & $\begin{array}{c}16.0 \\
-\end{array}$ & $\begin{array}{l}<1.0 \\
-\end{array}$ & $<1.0$ & $<1.0$ \\
\hline $88-26$ & 1 & $\begin{array}{l}\text { Maximum } \\
\text { Average }\end{array}$ & $\begin{array}{l}7.0 \\
-\end{array}$ & $\stackrel{<1.0}{-}$ & $\begin{array}{c}13.0 \\
-\end{array}$ & $\stackrel{<1.0}{--}$ & $\stackrel{<1.0}{-}$ & $<1.0$ \\
\hline $98-21$ & 2 & $\begin{array}{c}\text { Maximum } \\
\text { Average }\end{array}$ & $\begin{array}{l}25.0 \\
11.0\end{array}$ & $\begin{array}{l}<1.0 \\
<1.0\end{array}$ & $\begin{array}{c}15.0 \\
8.1\end{array}$ & $\begin{array}{l}<1.0 \\
<1.0\end{array}$ & $\begin{array}{l}<1.0 \\
<1.0\end{array}$ & $\begin{array}{l}1.0 \\
<1.0\end{array}$ \\
\hline $88-57$ & 1 & $\begin{array}{c}\text { Maximum } \\
\text { Average }\end{array}$ & $<1.0$ & $<1.0$ & $<1.0$ & $\stackrel{14.0}{-}$ & $<1.0$ & $<1.0$ \\
\hline $98-58$ & 1 & $\begin{array}{c}\text { Maximum } \\
\text { Average }\end{array}$ & $<1.0$ & $<1.0$ & $<1.0$ & $\begin{array}{c}56.0 \\
-\end{array}$ & 1.0 & $<1.0$ \\
\hline 88.59 & 1 & $\begin{array}{l}\text { Maximum } \\
\text { Average }\end{array}$ & $\frac{1.0}{-}$ & $\frac{1.0}{-}$ & $<1.0$ & $\begin{array}{c}110.0 \\
-\end{array}$ & $\begin{array}{l}3.0 \\
-\end{array}$ & $<1.0$ \\
\hline $98-61$ & 1 & $\begin{array}{c}\text { Maximum } \\
\text { Average }\end{array}$ & $\begin{array}{c}<1.0 \\
-\end{array}$ & $\begin{array}{c}<1.0 \\
-\end{array}$ & $<1.0$ & $\begin{array}{c}13.0 \\
-\end{array}$ & $<1.0$ & $\begin{array}{c}<1.0 \\
--\end{array}$ \\
\hline $108-14$ & 2 & $\begin{array}{c}\text { Maximum } \\
\text { Average }\end{array}$ & $\begin{array}{l}7.2 \\
6.6\end{array}$ & $\begin{array}{l}2.0 \\
1.7\end{array}$ & $\begin{array}{l}2.0 \\
1.7\end{array}$ & $\begin{array}{l}<1.0 \\
<1.0\end{array}$ & $\begin{array}{l}<1.0 \\
<1.0\end{array}$ & $\begin{array}{c}2.6 \\
<2.0\end{array}$ \\
\hline $108-30$ & 1 & $\begin{array}{c}\text { Maximum } \\
\text { Average }\end{array}$ & 6.0 & $\begin{array}{r}7.0 \\
-\end{array}$ & $\begin{array}{c}17.0 \\
-\end{array}$ & $<1.0$ & $<1.0$ & - \\
\hline $108-31$ & 1 & $\begin{array}{l}\text { Maximum } \\
\text { Average }\end{array}$ & 20 & $<1.0$ & $\stackrel{<1.0}{-}$ & $\begin{array}{l}7.0 \\
-\end{array}$ & $<1.0$ & $<1.0$ \\
\hline $\begin{array}{l}\text { All Other Wells } \\
(n=39)\end{array}$ & 49 & $\begin{array}{l}\text { Maximum } \\
\text { Average }\end{array}$ & $\begin{array}{l}4.8 \\
<2.0\end{array}$ & $\begin{array}{l}2.0 \\
2.0\end{array}$ & $\begin{array}{l}4.8 \\
2.0\end{array}$ & $\begin{array}{l}20 \\
<2.0\end{array}$ & $\begin{array}{l}<2.0 \\
<2.0\end{array}$ & $\begin{array}{l}<2.0 \\
<2.0\end{array}$ \\
\hline NYSDWS & & & 5.0 & 5.0 & 5.0 & 5.0 & 5.0 & 5.0 \\
\hline Typical MDL (b) & & & 2.0 & 2.0 & 2.0 & 2.0 & 20 & 20 \\
\hline
\end{tabular}

MDL: Minimum Detection Limit.

TCA: 1,1,1-trichloroethane.

TCE: Trichloroethylene.

PCE: Trichloroethylene.

PCE: Tetrachloroethylen

DCA: Dichloroethane.

(a): Upgradient well.

(b): Analyses conducted by PACE Labs may have MDLs of $1.0 \mathrm{ug} /$. 
Table 6-15

BNL Site Environmental Report for Calendar Year 1994

Hazardous Waste Management Area

Ground Water Survellance Wells, Metals Data

\begin{tabular}{|c|c|c|c|c|c|c|c|c|c|c|c|}
\hline Location (a) & $\begin{array}{l}\text { No. of } \\
\text { Samples(b) }\end{array}$ & & $\underset{\mathrm{mg} / \mathrm{Ag}}{\mathrm{Ag}}$ & $\begin{array}{c}C d \\
\text { mght }\end{array}$ & $\underset{\mathrm{mg} / \mathrm{L}}{\mathrm{Cr}}$ & $\begin{array}{c}\mathrm{Cu} \\
\mathrm{mg} / \mathrm{L}\end{array}$ & $\begin{array}{c}\mathrm{Fe} \\
\mathrm{mg} / \mathrm{L}\end{array}$ & $\begin{array}{l}\mathrm{Hg} \\
\mathrm{mg} / \mathrm{L}\end{array}$ & $\begin{array}{c}\mathrm{Na} \\
\mathrm{mgll}\end{array}$ & $\begin{array}{l}\mathrm{Pb} \\
\mathrm{mg} / \mathrm{L}\end{array}$ & $\underset{\mathrm{mgll}}{\mathrm{Zn}}$ \\
\hline $88-13$ (a) & 3 & $\begin{array}{l}\text { Maximum } \\
\text { Average }\end{array}$ & $\begin{array}{l}<0.025 \\
<0.025\end{array}$ & $\begin{array}{l}<0.005 \\
<0.005\end{array}$ & $\begin{array}{l}<0.005 \\
<0.005\end{array}$ & $\begin{array}{l}<0.05 \\
<0.05\end{array}$ & $\begin{array}{l}0.734 \\
0.245\end{array}$ & $\begin{array}{l}<0.0002 \\
<0.0002\end{array}$ & $\begin{array}{l}59.62 \\
34.47\end{array}$ & $\begin{array}{l}<0.002 \\
<0.002\end{array}$ & $\begin{array}{l}0.03 \\
<0.02\end{array}$ \\
\hline $88-14$ (a) & 3 & $\begin{array}{l}\text { Maximum } \\
\text { Average }\end{array}$ & $\begin{array}{l}<0.025 \\
<0.025\end{array}$ & $\begin{array}{l}<0.005 \\
<0.005\end{array}$ & $\begin{array}{l}<0.005 \\
<0.005\end{array}$ & $\begin{array}{l}<0.05 \\
<0.05\end{array}$ & $\begin{array}{l}0.858 \\
0.286\end{array}$ & $\begin{array}{l}<0.0002 \\
<0.0002\end{array}$ & $\begin{array}{l}5.03 \\
4.87\end{array}$ & $\begin{array}{l}<0.002 \\
<0.002\end{array}$ & $\begin{array}{l}<0.02 \\
<0.02\end{array}$ \\
\hline $88-20$ (a) & 1 & $\begin{array}{l}\text { Maximum } \\
\text { Average }\end{array}$ & $<0.025$ & $<0.005$ & $\underline{0.007}$ & $<0.05$ & $\frac{0.904}{-}$ & $<0.0002$ & $\frac{13.3}{-}$ & $\begin{array}{c}<0.002 \\
-\end{array}$ & $<0.02$ \\
\hline $88-25$ & 1 & $\begin{array}{c}\text { Maximum } \\
\text { Average }\end{array}$ & $\begin{array}{c}<0.025 \\
-\end{array}$ & $\begin{array}{c}<.005 \\
-\end{array}$ & $\begin{array}{c}<0.005 \\
-\end{array}$ & $<0.05$ & $\begin{array}{c}3.56 \\
-\end{array}$ & $\begin{array}{c}<0.0002 \\
-\end{array}$ & 9.09 & $\stackrel{0.002}{-}$ & $\begin{array}{c}<0.02 \\
-\end{array}$ \\
\hline $88-27$ & 1 & $\begin{array}{l}\text { Maximum } \\
\text { Average }\end{array}$ & $\begin{array}{c}<0.025 \\
-\end{array}$ & $<0.005$ & $\begin{array}{c}<0.005 \\
-\end{array}$ & $<0.05$ & $\frac{0.687}{-}$ & $<0.0002$ & $\frac{6.82}{-}$ & $\begin{array}{c}0.003 \\
-\end{array}$ & $<0.02$ \\
\hline $98-04$ & $1(0)$ & $\begin{array}{l}\text { Maximum } \\
\text { Average }\end{array}$ & $\begin{array}{c}<0.025 \\
-\end{array}$ & $\begin{array}{c}<0.005 \\
-\end{array}$ & $\underline{0.011}$ & $<0.05$ & $\underline{0.71}$ & NA & $\frac{3.60}{-}$ & $\begin{array}{c}<.003 \\
-\end{array}$ & $\frac{1.06}{-}$ \\
\hline $98-58$ & 1 & $\begin{array}{l}\text { Maximum } \\
\text { Average }\end{array}$ & $\begin{array}{c}<0.025 \\
-\end{array}$ & $<0.005$ & $<0.005$ & $<0.05$ & $\begin{array}{c}0.592 \\
\ldots\end{array}$ & $<0.0002$ & $\begin{array}{c}20.30 \\
-\end{array}$ & $<0.002$ & $<0.02$ \\
\hline $98-59$ & 1 & $\begin{array}{l}\text { Maximum } \\
\text { Average }\end{array}$ & $\begin{array}{c}<0.025 \\
-\end{array}$ & $<0.005$ & $\begin{array}{c}<0.005 \\
-\end{array}$ & $<0.05$ & $\begin{array}{c}0.389 \\
-\end{array}$ & $<0.0002$ & $\frac{23.30}{-}$ & $\begin{array}{c}<0.002 \\
-\end{array}$ & $<0.02$ \\
\hline $98-63$ & 1 & $\begin{array}{l}\text { Maximum } \\
\text { Average }\end{array}$ & $\begin{array}{c}<0.025 \\
-\end{array}$ & $<0.005$ & $\begin{array}{c}<0.005 \\
-\end{array}$ & $<0.05$ & $\stackrel{1.36}{-}$ & $\begin{array}{c}<0.0002 \\
-\end{array}$ & $\stackrel{7.07}{-}$ & $\begin{array}{c}<0.002 \\
-\end{array}$ & $<0.02$ \\
\hline $99-02$ & $1(0)$ & $\begin{array}{l}\text { Maximum } \\
\text { Average }\end{array}$ & $<0.025$ & $\begin{array}{c}<0.005 \\
-\end{array}$ & $\begin{array}{c}<0.009 \\
\ldots\end{array}$ & $<0.05$ & $\stackrel{1.64}{-}$ & NA & $\frac{4.1}{-}$ & $\underline{0.05}$ & 6.3 \\
\hline $\begin{array}{l}\text { All Other Wolls } \\
\quad(n=35)\end{array}$ & 59 & $\begin{array}{l}\text { Maximum } \\
\text { Average }\end{array}$ & $\begin{array}{l}<0.025 \\
<0.025\end{array}$ & $\begin{array}{l}<0.005 \\
<0.005\end{array}$ & $\begin{array}{l}0.011 \\
<0.005\end{array}$ & $\begin{array}{l}<0.05 \\
<0.05\end{array}$ & $\begin{array}{l}0.080 \\
<0.075\end{array}$ & $\begin{array}{l}<0.0002 \\
<0.0002\end{array}$ & $\begin{array}{l}13.4 \\
6.60\end{array}$ & $\begin{array}{l}0.005 \\
<0.003\end{array}$ & $\begin{array}{l}4.40 \\
0.07\end{array}$ \\
\hline NYS DWS & & & 0.05 & 0.01 & 0.05 & 1.3 & 0.3 & 0.002 & (d) & 0.015 & 5.0 \\
\hline Typical MDL & & & 0.025 & 0.0005 (c) & 0.005 & 0.05 & 0.075 & 0.0002 & 1.0 & 0.002 & 0.02 \\
\hline
\end{tabular}

MDL: Minimum Detection Limit.

(a): Upgradient Well.

(b): Number in parenthesis indicates samples analyzed for $\mathrm{Hg}$

(c): PACE Laboratorios'MOL for Cadmium $=0.005 \mathrm{mg} / \mathrm{L}$. NYTEST $=0.009 \mathrm{mg} / \mathrm{L}$

(d): No Standard Spocified. 
Table 5-16

BNL Site Environmental Report for Calendar Year 1994

Hazardous Waste Management Area

Ground Water Surveillance Wells, BETX Data

\begin{tabular}{|c|c|c|c|c|c|c|}
\hline Location & $\begin{array}{l}\text { No. of } \\
\text { Samples }\end{array}$ & & $\begin{array}{c}\text { Benzene } \\
\text { ug } / \text {. }\end{array}$ & $\begin{array}{c}\text { Ethylbenzene } \\
\text { ug/L }\end{array}$ & $\begin{array}{c}\text { Toluene } \\
\text { ugh }\end{array}$ & $\begin{array}{l}\text { Xylene } \\
\text { ugh }\end{array}$ \\
\hline $\begin{array}{l}\text { All Wells } \\
(n=45)\end{array}$ & 72 & $\begin{array}{l}\text { Maximum } \\
\text { Average }\end{array}$ & $\begin{array}{l}2.1 \\
<2.0\end{array}$ & $\begin{array}{l}<2.0 \\
<2.0\end{array}$ & $\begin{array}{l}<2.0 \\
<2.0\end{array}$ & $\begin{array}{l}<2.0 \\
<2.0\end{array}$ \\
\hline NYS DWS & & & 5.0 & 5.0 & 5.0 & 5.0 \\
\hline Typical MDL & & & 2.0 & 2.0 & 2.0 & 2.0 \\
\hline
\end{tabular}

MDL: $\quad$ Minimum Detection Limit. 


\section{HAZARDOUS WASTE MANAGEMENT AREA}
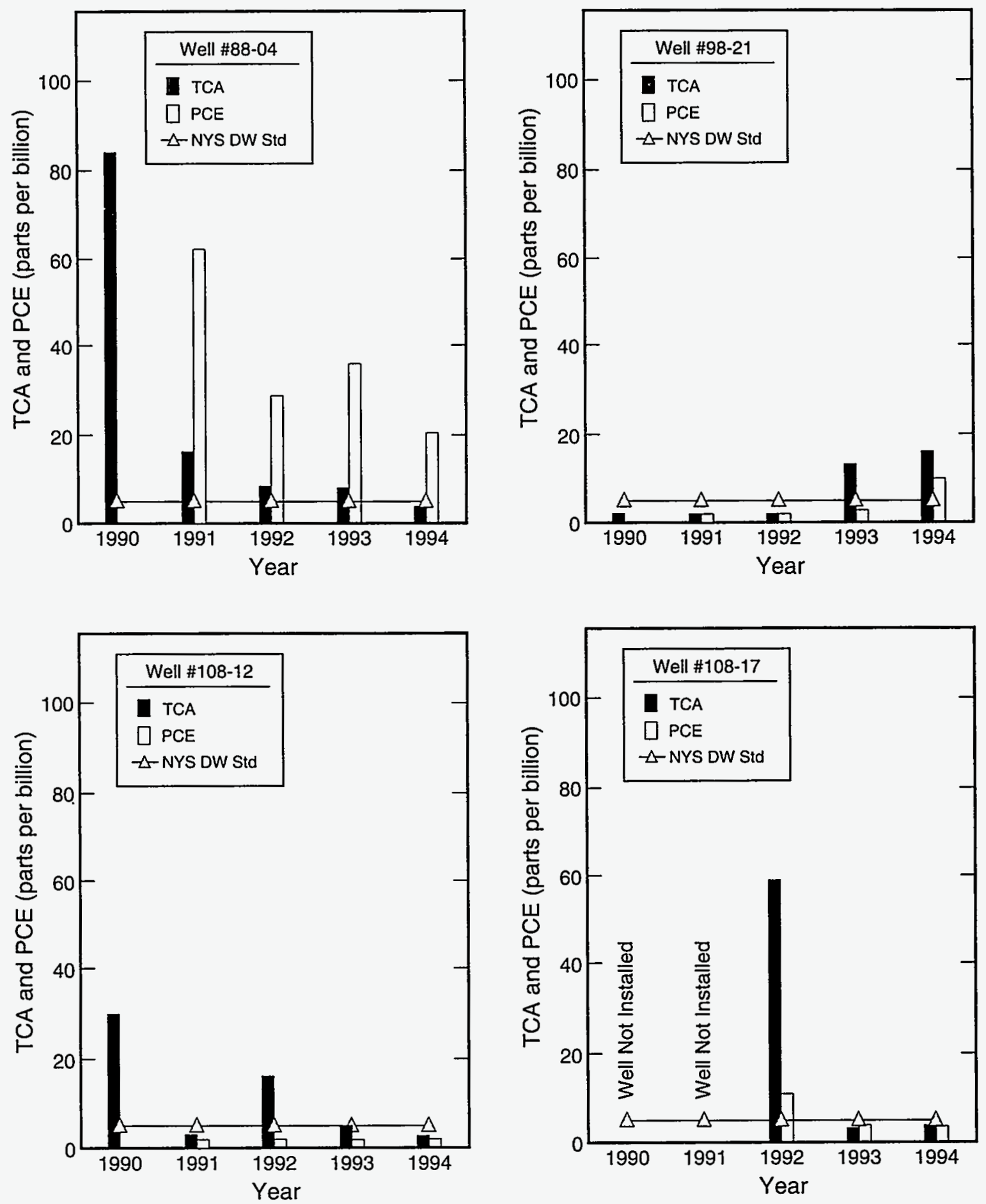

Figure 5-15 Tetrachloroethylene (PCE) concentration trends in wells located within and downgradient of the Hazardous Waste Management Facility (HWMF): Well 88-04 located within the HWMF; Well 98-21 located 110m downgradient of HWMF; Well 108-12 located at site boundary 675m downgradient of HWMF; and Well 108-17 located at site boundary $680 \mathrm{~m}$ downgradient of HWMF. 
Table 5-17

BNL Site Environmental Report for Calendar Year 1994

Major Petroleum Facility/Central Steam Facility

Building 650 and Building 650 Outfall

Ground Water Surveillance Wells, Water Quality Data

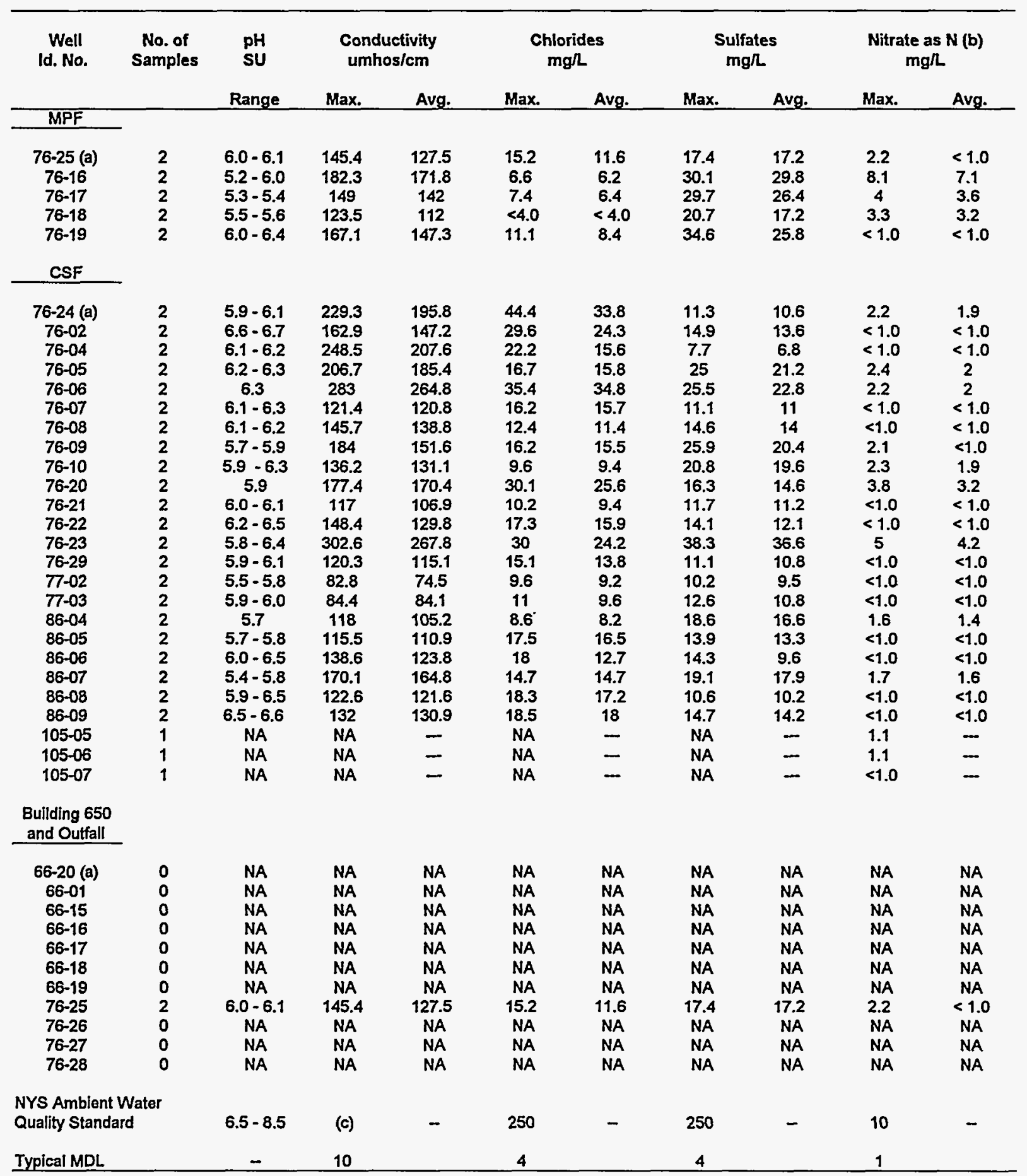

NA: Not Analyzed or Data Not Avallable

MDL: Minimum Detection Limit.

(a): Upgradient Well.

(b): Holding time expired for all samples.

(c): No standard specified. 
Table 5-18

BNL Site Environmental Report for Calendar Year 1994

Major Petroleum Facility, Central Steam Facility, and Bldg. 650

Ground Water Surveillance Wells, Metals Data

\begin{tabular}{|c|c|c|c|c|c|c|c|c|c|c|c|}
\hline Location & $\begin{array}{l}\text { No. of } \\
\text { Samples }\end{array}$ & & $\underset{\mathrm{mg} / \mathrm{L}}{\mathrm{Ag}}$ & $\begin{array}{c}\mathrm{Cd} \\
\mathrm{mg} / \mathrm{L}\end{array}$ & $\begin{array}{c}\mathrm{Cr} \\
\mathrm{mg} / \mathrm{L}\end{array}$ & $\begin{array}{c}\mathrm{Cu} \\
\mathrm{mg} / \mathrm{L}\end{array}$ & $\begin{array}{c}\mathrm{Fe} \\
\mathrm{mg} / \mathrm{L}\end{array}$ & $\begin{array}{c}\mathrm{Hg} \\
\mathrm{mg} / \mathrm{L}\end{array}$ & $\begin{array}{c}\mathrm{Na} \\
\mathrm{mg} / \mathrm{L}\end{array}$ & $\begin{array}{c}\mathrm{Pb} \\
\mathrm{mg} / \mathrm{L}\end{array}$ & $\begin{array}{c}\mathrm{Zn} \\
\mathrm{mg} / \mathrm{L}\end{array}$ \\
\hline \multicolumn{12}{|c|}{ Major Petroleum Facility } \\
\hline $\begin{array}{l}\text { All Wells } \\
(n=5)\end{array}$ & 10 & $\begin{array}{c}\text { Maximum } \\
\text { Average }\end{array}$ & $\begin{array}{l}<0.025 \\
<0.025\end{array}$ & $\begin{array}{l}<0.0005 \\
<0.0005\end{array}$ & $\begin{array}{l}<0.005 \\
<0.005\end{array}$ & $\begin{array}{l}<0.05 \\
<0.05\end{array}$ & $\begin{array}{l}<0.075 \\
<0.075\end{array}$ & $\begin{array}{l}<0.0002 \\
<0.0002\end{array}$ & $\begin{array}{l}17.67 \\
10.36\end{array}$ & $\begin{array}{l}<0.002 \\
<0.002\end{array}$ & $\begin{array}{l}<0.02 \\
<0.02\end{array}$ \\
\hline \multicolumn{12}{|c|}{ Central Steam Facility } \\
\hline $76-24(a)$ & 2 & $\begin{array}{l}\text { Maximum } \\
\text { Average }\end{array}$ & $\begin{array}{l}<0.025 \\
<0.025\end{array}$ & $\begin{array}{l}<0.0005 \\
<0.0005\end{array}$ & $\begin{array}{l}<0.005 \\
<0.005\end{array}$ & $\begin{array}{l}<0.05 \\
<0.05\end{array}$ & $\begin{array}{l}<0.075 \\
<0.075\end{array}$ & $\begin{array}{l}<0.0002 \\
<0.0002\end{array}$ & $\begin{array}{l}18.00 \\
16.28\end{array}$ & $\begin{array}{l}<0.002 \\
<0.002\end{array}$ & $\begin{array}{c}0.03 \\
<0.02\end{array}$ \\
\hline $76-04$ & 2 & $\begin{array}{l}\text { Maximum } \\
\text { Average }\end{array}$ & $\begin{array}{l}<0.025 \\
<0.025\end{array}$ & $\begin{array}{l}<0.0005 \\
<0.0005\end{array}$ & $\begin{array}{l}<0.005 \\
<0.005\end{array}$ & $\begin{array}{l}<0.05 \\
<0.05\end{array}$ & $\begin{array}{l}45.30 \\
30.19\end{array}$ & $\begin{array}{l}<0.0002 \\
<0.0002\end{array}$ & $\begin{array}{l}15.44 \\
12.96\end{array}$ & $\begin{array}{l}<0.002 \\
<0.002\end{array}$ & $\begin{array}{l}0.07 \\
0.06\end{array}$ \\
\hline $76-06$ & 2 & $\begin{array}{l}\text { Maximum } \\
\text { Average }\end{array}$ & $\begin{array}{l}<0.025 \\
<0.025\end{array}$ & $\begin{array}{l}<0.0005 \\
<0.0005\end{array}$ & $\begin{array}{l}<0.005 \\
<0.005\end{array}$ & $\begin{array}{l}<0.05 \\
<0.05\end{array}$ & $\begin{array}{l}1.781 \\
0.891\end{array}$ & $\begin{array}{l}<0.0002 \\
<0.0002\end{array}$ & $\begin{array}{l}21.06 \\
17.44\end{array}$ & $\begin{array}{l}<0.002 \\
<0.002\end{array}$ & $\begin{array}{l}0.04 \\
0.02\end{array}$ \\
\hline $76-21$ & 2 & $\begin{array}{c}\text { Maximum } \\
\text { Average }\end{array}$ & $\begin{array}{l}<0.025 \\
<0.025\end{array}$ & $\begin{array}{l}<0.0005 \\
<0.0005\end{array}$ & $\begin{array}{l}<0.005 \\
<0.005\end{array}$ & $\begin{array}{l}<0.05 \\
<0.05\end{array}$ & $\begin{array}{l}2.84 \\
2.81\end{array}$ & $\begin{array}{l}<0.0002 \\
<0.0002\end{array}$ & $\begin{array}{l}5.65 \\
5.41\end{array}$ & $\begin{array}{l}<0.002 \\
<0.002\end{array}$ & $\begin{array}{l}<0.02 \\
<0.02\end{array}$ \\
\hline $\begin{array}{l}\text { All Other Wells } \\
(n=21)\end{array}$ & 39 & $\begin{array}{l}\text { Maximum } \\
\text { Average }\end{array}$ & $\begin{array}{l}<0.025 \\
<0.025\end{array}$ & $\begin{array}{l}<0.0005 \\
<0.0005\end{array}$ & $\begin{array}{l}<0.005 \\
<0.005\end{array}$ & $\begin{array}{l}<0.05 \\
<0.05\end{array}$ & $\begin{array}{l}<0.075 \\
<0.075\end{array}$ & $\begin{array}{l}<0.0002 \\
<0.0002\end{array}$ & $\begin{array}{l}28.24 \\
12.03\end{array}$ & $\begin{array}{l}<0.002 \\
<0.002\end{array}$ & $\begin{array}{l}<0.02 \\
<0.02\end{array}$ \\
\hline NYS DWS & & & 0.05 & 0.01 & 0.05 & 1.3 & 0.3 & 0.002 & (b) & 0.015 & 5.0 \\
\hline Typical MDL & & & 0.025 & 0.0005 & 0.005 & 0.05 & 0.075 & 0.0002 & 1.0 & 0.002 & 0.02 \\
\hline
\end{tabular}

MDL: Minimum Detection Limit.

$\begin{array}{ll}\text { (a): } & \text { Upgradient Well. } \\ \text { (b): } & \text { No Standard Specified. }\end{array}$ 
Table 5-19

BNL Site Environmental Report for Calendar Year 1994

Major Petroleum Facility and Central Steam Facility

Ground Water Surveillance Wells, Chlorocarbon Data

\begin{tabular}{|c|c|c|c|c|c|c|c|c|}
\hline Location & $\begin{array}{l}\text { No. of } \\
\text { Samples }\end{array}$ & & $\begin{array}{l}\text { TCA } \\
\text { uglt }\end{array}$ & $\begin{array}{l}\text { TCE } \\
\text { ugh }\end{array}$ & $\begin{array}{l}\text { PCE } \\
\text { ugll }\end{array}$ & $\begin{array}{l}\text { DCA } \\
\text { ugl }\end{array}$ & $\begin{array}{l}\text { DCE } \\
\text { ugh }\end{array}$ & $\begin{array}{c}\text { Chloroform } \\
\text { ug } \Omega\end{array}$ \\
\hline \multicolumn{9}{|c|}{ Major Petroleum Facility } \\
\hline $76-25$ (a)(b) & 2 & $\begin{array}{l}\text { Maximum } \\
\text { Average }\end{array}$ & $\begin{array}{c}7 \\
4.2\end{array}$ & $\begin{array}{l}<2.0 \\
<20\end{array}$ & $\begin{array}{l}<2.0 \\
<2.0\end{array}$ & $\begin{array}{l}<2.0 \\
<2.0\end{array}$ & $\begin{array}{l}<20 \\
<20\end{array}$ & $\begin{array}{l}<2.0 \\
<2.0\end{array}$ \\
\hline $76-19$ & 2 & $\begin{array}{l}\text { Maximum } \\
\text { Average }\end{array}$ & $\begin{array}{l}<2.0 \\
<2.0\end{array}$ & $\begin{array}{l}<2.0 \\
<2.0\end{array}$ & $\begin{array}{c}5 \\
28\end{array}$ & $\begin{array}{l}<2.0 \\
<2,0\end{array}$ & $\begin{array}{l}<2.0 \\
<20\end{array}$ & $\begin{array}{l}<2.0 \\
<2.0\end{array}$ \\
\hline $\begin{array}{l}\text { Al Other Wells } \\
(n=3)\end{array}$ & 6 & $\begin{array}{c}\text { Maximum } \\
\text { Average }\end{array}$ & $\begin{array}{l}<2.0 \\
<2.0\end{array}$ & $\begin{array}{l}<2.0 \\
<2.0\end{array}$ & $\begin{array}{l}<20 \\
<20\end{array}$ & $\begin{array}{l}<2.0 \\
<2.0\end{array}$ & $\begin{array}{l}<20 \\
<2.0\end{array}$ & $\begin{array}{l}<2.0 \\
<2.0\end{array}$ \\
\hline \multicolumn{9}{|c|}{ Central Steam Facility } \\
\hline $76-24$ (a)(b) & 2 & $\begin{array}{l}\text { Maximum } \\
\text { Average }\end{array}$ & $\begin{array}{l}<2.0 \\
<2.0\end{array}$ & $\begin{array}{l}<2.0 \\
<2.0\end{array}$ & $\begin{array}{l}<2.0 \\
<2.0\end{array}$ & $\begin{array}{l}<2.0 \\
<2.0\end{array}$ & $\begin{array}{l}<20 \\
<2.0\end{array}$ & $\begin{array}{l}<2.0 \\
<2.0\end{array}$ \\
\hline $76-04$ & $1(c)$ & $\begin{array}{l}\text { Maximum } \\
\text { Average }\end{array}$ & $\begin{array}{c}<50.0 \\
-\end{array}$ & 13 & $\frac{36}{-}$ & $<50$. & $<50$. & $<50$ \\
\hline $76-05$ & 2 & $\begin{array}{l}\text { Maximum } \\
\text { Average }\end{array}$ & $\begin{array}{l}<2.0 \\
<2.0\end{array}$ & $\begin{array}{l}<2.0 \\
<20\end{array}$ & $\begin{array}{c}26 \\
20.5\end{array}$ & $\begin{array}{l}<2.0 \\
<2.0\end{array}$ & $\begin{array}{l}<20 \\
<20\end{array}$ & $\begin{array}{l}<2.0 \\
<2.0\end{array}$ \\
\hline $76-08$ & 2 & $\begin{array}{c}\text { Maximum } \\
\text { Average }\end{array}$ & $\begin{array}{l}<2.0 \\
<20\end{array}$ & $\begin{array}{c}3 \\
2.4\end{array}$ & $\begin{array}{l}43 \\
35\end{array}$ & $\begin{array}{l}<2.0 \\
<2.0\end{array}$ & $\begin{array}{l}<20 \\
<2.0\end{array}$ & $\begin{array}{l}<2.0 \\
<2.0\end{array}$ \\
\hline $76-09$ & 2 & $\begin{array}{l}\text { Maximum } \\
\text { Average }\end{array}$ & $\begin{array}{l}<2.0 \\
<2.0\end{array}$ & $\begin{array}{l}<2.0 \\
<2.0\end{array}$ & $\begin{array}{c}23 \\
13.5\end{array}$ & $\begin{array}{l}<2.0 \\
<2.0\end{array}$ & $\begin{array}{l}<20 \\
<20\end{array}$ & $\begin{array}{l}<2.0 \\
<2.0\end{array}$ \\
\hline $76-21$ & 2 & $\begin{array}{l}\text { Maximum } \\
\text { Average }\end{array}$ & $\begin{array}{l}<2.0 \\
<2.0\end{array}$ & $\begin{array}{l}<2.0 \\
<2.0\end{array}$ & $\begin{array}{l}51 \\
32\end{array}$ & $\begin{array}{l}<2.0 \\
<2.0\end{array}$ & $\begin{array}{l}<20 \\
<20\end{array}$ & $\begin{array}{l}<2 \\
<2\end{array}$ \\
\hline $76-23$ & 2 & $\begin{array}{c}\text { Maximum } \\
\text { Average }\end{array}$ & $\begin{array}{l}<2.0 \\
<2.0\end{array}$ & $\begin{array}{l}<2.0 \\
<2.0\end{array}$ & $\begin{array}{c}11 \\
10.5\end{array}$ & $\begin{array}{l}<2.0 \\
<2.0\end{array}$ & $\begin{array}{l}<2.0 \\
<20\end{array}$ & $\begin{array}{l}<2.0 \\
<2.0\end{array}$ \\
\hline $86-04$ & 2 & $\begin{array}{l}\text { Maximum } \\
\text { Average }\end{array}$ & $\begin{array}{l}<2.0 \\
<2.0\end{array}$ & $\begin{array}{l}<2.0 \\
<2.0\end{array}$ & $\begin{array}{c}3 \\
2.3\end{array}$ & $\begin{array}{l}<2.0 \\
<2.0\end{array}$ & $\begin{array}{l}<2.0 \\
<2.0\end{array}$ & $\begin{array}{l}<2.0 \\
<2.0\end{array}$ \\
\hline $105-06$ & 1 & $\begin{array}{l}\text { Maximum } \\
\text { Average }\end{array}$ & 18 & 39 & 65 & $\stackrel{3}{-}$ & - & 2 \\
\hline $105-07$ & 1 & $\begin{array}{l}\text { Maximum } \\
\text { Average }\end{array}$ & 4 & 7 & 4 & $\frac{2}{-}$ & $\frac{1}{-}$ & $<2.0$ \\
\hline $\begin{array}{l}\text { All Other Wells } \\
(n=15) \text {. }\end{array}$ & 29 & $\begin{array}{l}\text { Maximum } \\
\text { Average }\end{array}$ & $\begin{array}{l}<2.0 \\
<2.0\end{array}$ & $\begin{array}{l}<2.0 \\
<2.0\end{array}$ & $\begin{array}{c}3 \\
<20\end{array}$ & $\begin{array}{l}<2.0 \\
<2.0\end{array}$ & $\begin{array}{l}<2.0 \\
<2.0\end{array}$ & $\begin{array}{l}<2.0 \\
<2.0\end{array}$ \\
\hline NYS DWS & & & 5.0 & 5.0 & 5.0 & 5.0 & 5.0 & 100.0 \\
\hline Trpical MDL & & & 2.0 & 2.0 & 2.0 & 2.0 & 2.0 & 2.0 \\
\hline
\end{tabular}

MDL: Minimum Detection Limit.

TCA: 1,1,1-trichloroethane.

TCE: Trichloroethylene.

PCE: Tetrachloroethylene.

DCA: Dichloroethane.

DCE: Dichloroethylene.

(a): Upgradient Well.

(b): Well 76-25 is also a downgradient Well for Building 650

(c): Sample analyzed at a 1:50 dilution 
Table 5-20

BNL SIte Environmental Report for Calendar Year 1994

Major Petroleum Facillity and Central Steam Facility

Ground Water Survelllance Wells, BETX Data

\begin{tabular}{|c|c|c|c|c|c|c|}
\hline Location & $\begin{array}{l}\text { No. of } \\
\text { Samples }\end{array}$ & & $\begin{array}{c}\text { Benzene } \\
\text { ugl } \text {. }\end{array}$ & $\begin{array}{c}\text { Ethylbenzene } \\
\text { ugh }\end{array}$ & $\begin{array}{c}\text { Toluene } \\
\text { ugh }\end{array}$ & $\begin{array}{l}\text { Xylene } \\
\text { ugh }\end{array}$ \\
\hline \multicolumn{7}{|c|}{ Major Petroleum Facility } \\
\hline $\begin{array}{l}\text { Al Wells } \\
(n=5)\end{array}$ & 10 & $\begin{array}{l}\text { Maximum } \\
\text { Average }\end{array}$ & $\begin{array}{l}<2.0 \\
<2.0\end{array}$ & $\begin{array}{l}<2.0 \\
<2.0\end{array}$ & $\begin{array}{l}<2.0 \\
<2.0\end{array}$ & $\begin{array}{l}<2.0 \\
<2.0\end{array}$ \\
\hline \multicolumn{7}{|c|}{ Central Steam Facility } \\
\hline $76-24(a)$ & 2 & $\begin{array}{l}\text { Maximum } \\
\text { Average }\end{array}$ & $\begin{array}{l}<2.0 \\
<2.0\end{array}$ & $\begin{array}{l}<2.0 \\
<2.0\end{array}$ & $\begin{array}{l}<2.0 \\
<2.0\end{array}$ & $\begin{array}{l}<2.0 \\
<2.0\end{array}$ \\
\hline $76-04$ & $1(b)$ & $\begin{array}{l}\text { Maximum } \\
\text { Average }\end{array}$ & $\begin{array}{c}<5.0 \\
-\end{array}$ & $\begin{array}{c}660.0 \\
-\end{array}$ & $\begin{array}{c}1300.0 \\
-\end{array}$ & $\begin{array}{c}2140.0 \\
-\end{array}$ \\
\hline $76-08$ & 2 & $\begin{array}{c}\text { Maximum } \\
\text { Average }\end{array}$ & $\begin{array}{l}<2.0 \\
<2.0\end{array}$ & $\begin{array}{l}<2.0 \\
<2.0\end{array}$ & $\begin{array}{l}<2.0 \\
<2.0\end{array}$ & $\begin{array}{l}30.0 \\
15.0\end{array}$ \\
\hline $76-21$ & 2 & $\begin{array}{l}\text { Maximum } \\
\text { Average }\end{array}$ & $\begin{array}{l}<2.0 \\
<2.0\end{array}$ & $\begin{array}{l}25.0 \\
12.5\end{array}$ & $\begin{array}{l}<2.0 \\
<2.0\end{array}$ & $\begin{array}{l}14.0 \\
7.0\end{array}$ \\
\hline $\begin{array}{l}\text { All Other Wells } \\
(n=21)\end{array}$ & 39 & $\begin{array}{c}\text { Maximum } \\
\text { Average }\end{array}$ & $\begin{array}{l}<2.0 \\
<2.0\end{array}$ & $\begin{array}{l}<2.0 \\
<2.0\end{array}$ & $\begin{array}{l}<2.0 \\
<2.0\end{array}$ & $\begin{array}{l}<2.0 \\
<2.0\end{array}$ \\
\hline NYS DWS & & & 5.0 & 5.0 & 5.0 & 5.0 \\
\hline Typical MDL & & & 2.0 & 2.0 & 2.0 & 2.0 \\
\hline
\end{tabular}

MDL: Minimum Detection Limit.

(a): Upgradient Well.

(b): Sample was analyzed at a 1:50 dilution 
below the lower limit of the NYS AWQS of $6.5-8.5$, with a median pH of 5.9 . other water quality parameters were below the applicable NYS AwQS. Results from metals analyses of groundwater samples indicate that most metals concentrations were below the applicable NYS DWS, except for elevated iron concentrations detected in samples from Wells 76-04 (45.3 mg/L), 76-06 (1.78 mg/L), and 76-21 $(2.84 \mathrm{mg} / \mathrm{I})$. Analyses for Vocs in groundwater samples from the five wells monitoring the MPE indicated that voCs were present at concentrations at or above NYS DWS in two wells, upgradient Well 76-25 with TCA at a maximum concentration of $7 \mu \mathrm{g} / \mathrm{L}$ and Well 76-19 with PCE at a maximum observed concentration of $5 \mu \mathrm{g} / \mathrm{L}$. In both cases, the Vocs detected are not the result of spills or leaks associated with MPE operations. In the case of upgradient Well 76-25, the TCA is likely to have originated from releases in the Building 650 area, whereas the PCE detected in Well 76-19 is likely to have originated from a spill site located near Building 610. No BETX compounds were detected in the MPF wells. The five surveillance wells at the MPF were examined for floating petroleum products on a monthly basis. As with previous years, no floating petroleum products were observed during 1994. Of the twenty-five CSF surveillance wells sampled during 1994, eight wells had VOCs at concentrations above NYS DWS: TCA was detected in Well 105-05 at maximum concentration of $18 \mu \mathrm{g} / \mathrm{L}$; TCE was detected in Wells 76-04, 105-06, and 105-07 at maximum concentrations of $13 \mu \mathrm{g} / \mathrm{L}, 39 \mu \mathrm{g} / \mathrm{L}, \mathrm{and} 7 \mathrm{\mu g} / \mathrm{L}$, respectively; PCE was detected in Wells 76-04, 76-05, 76-08, 76-09, 76-21, 76-23, and 105-06 at maximum concentrations of $36 \mu \mathrm{g} / \mathrm{L}, 26 \mu \mathrm{g} / \mathrm{L}, 43 \mu \mathrm{g} / \mathrm{L}, 23 \mu \mathrm{g} / \mathrm{L}, 51$ $\mu \mathrm{g} / \mathrm{I}, 11 \mu \mathrm{g} / \mathrm{L}$, and $65 \mu \mathrm{g} / \mathrm{I}$, respectively; ethylbenzene was detected in Wells 7604 and 76-21 at maximum concentrations of $660 \mu \mathrm{g} / \mathrm{L}$ and $25 \mu \mathrm{g} / \mathrm{L}$, respectively; Toluene was detected in Well 76-04 at a maximum concentration of $21,300 \mu \mathrm{g} / \mathrm{L}$; and xylene (total) was detected in Wells 76-04, 76-08, and 76-21 at concentrations of $2,140 \mu \mathrm{g} / \mathrm{L}, 30 \mu \mathrm{g} / \mathrm{L}$, and $14 \mu \mathrm{g} / \mathrm{L}$, respectively. Trend plots for TCA, PCE, ethylbenzene, toluene, and xylene (total) based on data from representative monitoring wells downgradient of the 1977 fuel oil/solvent spill area are presented in Figure 5-16.

Building 650: Building 650 was utilized as a decontamination facility for the removal of radioactivity from clothing and heavy equipment. Drainage from an exterior heavy equipment decontamination pad led to a natural depression approximately 800 feet to the northeast of Building 650 (known as the Building 650 sump outfall), near AGS Recharge Basin Ho. The surveillance well network at Building 650 and the 650 Outfall area consists of 11 shallow Upper Glacial aquifer wells (Eigure 5-5). Ten of these wells were installed in 1993 as part of the OU IV RI/ES. The full extent of soil and groundwater contamination resulting from operations at Building 650 is presently being evaluated as part of the OU IV RI/ES. During 1994, groundwater samples were collected only from Well 76-25, which is located directly downgradient of Building 650 and which is also utilized as the upgradient well for the MPF (see above). As noted previously, TCA was detected in Well 76-25 at a maximum concentration of $7 \mu \mathrm{g} / \mathrm{L}$ (Table 5-20).

Alternating Gradient Synchrotron Area: In the AGS experimental areas, surface spills and discharges to cesspools and recharge basins have resulted in Voc contamination of soils and groundwater. Several documented spills have occurred in the AGS Bubble Chamber area, which was used as a storage area for drums and liquid filled scintillation counters. Iow level radionuclides have also been detected in groundwater, which may be the result of the outside storage of activated scrap metal or soil/soil moisture activation due to beam target interaction. The AGS experimental areas will be the subject of the OU III RI/FS which is scheduled to begin in 1995. The surveillance well network for the AGS area consists of 11 shallow Upper Glacial aquifer wells which primarily monitor groundwater near and downgradient of the AGS Bubble Chamber spill areas and the AGS Booster facility (Figure 5-4). During 1994, groundwater samples were 


\section{CENTRAL STEAM FACILITY/MAJOR PETROLEUM FACILITY}
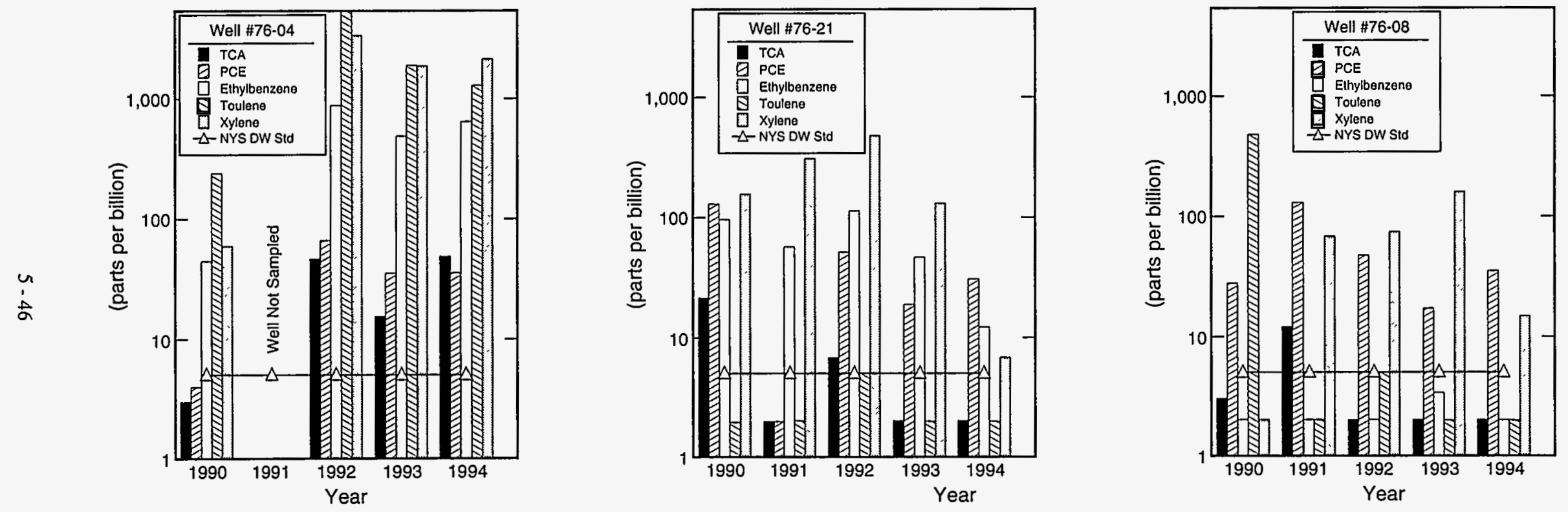

Figure 5-16 1,1,1-trichloroethane (TCA), tetrachloroethylene (PCE), ethylbenzene, toluene and xylene (total) concentration trends in wells located within and downgradient of the1977 fuel oil/solvent spill area: Well 76-04 located within the spill area; Well 76-21 located 60m downgradient of spill site; and Well 76-08 located $90 \mathrm{~m}$ downgradient of spill site. 
collected from the 11 AGs area surveillance wells, and were analyzed for water quality, Vocs, and metals (Tables 5-21 to 5-24). Water quality analyses indicate that the $\mathrm{pH}$ of the groundwater samples collected was typically below the lower limit of the NYS AWQS of 6.5 - 8.5, with a median pH of 6.0. Other water quality parameters were below the applicable NYS AWQS. Results for metals analyses indicated that except for elevated iron and zinc concentrations in samples collected from Wells 54-01 and 54-02, all metals were at concentrations below the applicable NYS DWS. Metals analyses from Wells 54-01 and 54-02 (both older wells constructed of carbon steel casings) indicate above NYS DWS for iron $(7.71 \mathrm{mg} / \mathrm{L}$ and $1.04 \mathrm{mg} / \mathrm{L}$, respectively), and zinc in Well 54-01 (5.26 mg/L). Analyses for VOCs in groundwater samples collected from this area indicate that TCA was detected at concentrations that exceeded NYS DWS in Well 64-03, at a maximum concentration of $15 \mathrm{\mu g} / \mathrm{I}$. TCA detected in Well 64-03 may have originated from cesspools associated with Buildings 914 and 919, which are located directly upgradient of this well. The contents of these cesspools have been investigated under the IAG (Cesspools EE/CA) and have been shown to contain VOCs at levels in exceedance of NYS Soil Cleanup Guidelines. The full extent of groundwater contamination will be examined during the OU III RI/FS.

Waste Concentration Facility Area: At the WCF, due to a number of minor leaks, soil and groundwater contamination at the WCE area has occurred. The extent of soil contamination within the WCF area will be examined during the OU II RI/ES, whereas groundwater contamination will be examined during the OU III RI/ES. The surveillance well network monitoring the WCF consists of six shallow Upper Glacial aquifer wells (Figure 5-4). At the WCF (D-Tanks area), one upgradient and five downgradient surveillance wells were sampled during 1994 (Tables 5-25 to 5-28). Water quality analyses indicate that the pH of the groundwater samples collected was typically below the lower limit of the NYS AWQS of $6.5-8.5$, with a median $\mathrm{pH}$ of 6.3. Although elevated nitrate concentrations were detected in all six wells, all water quality parameters were below the applicable NYS AWQS. Results from metals analyses of groundwater from this area indicated that all metals were below the applicable NYS DWS. Analysis for vocs in groundwater samples indicate TCA at concentrations exceeding NYS DWS in four wells. TCA was detected in upgradient Well 65-06 at $7 \mu \mathrm{g} / \mathrm{L}$, and in downgradient wells 65-02, 6503 , and $65-05$ at $19 \mu \mathrm{g} / \mathrm{L}, 13 \mu \mathrm{g} / \mathrm{L}$ and $14 \mu \mathrm{g} / \mathrm{L}$, respectively. Since TCA was detected in upgradient Well 65-06, it is possible that the TCA detected in the downgradient wells did not originated from the WCE. Trend plots for TCA based on data from representative monitoring wells within the WCF Area are presented in Figure 5-17.

Building 830 Area: In 1986, a transfer pipe leak in the Building 830 liquid waste handling system resulted in the release of approximately 900 gallons of low-level radioactive waste. Remedial actions included the removal of contaminated soils and the installation of three shallow Upper Glacial aquifer wells to assess potential impacts to groundwater quality. Past monitoring has revealed low-level (i.e., below NYS DWS) radionuclide contamination. The full extent of and residual soil and groundwater contamination in this area will be assessed during the OU III RI/FS. During 1994, groundwater samples were collected from the three Building 830 area surveillance wells (Eigure 5-5), and were analyzed for water quality, vocs, and metals (Tables 5-25 to 5-28). Water quality analyses indicate that the $\mathrm{pH}$ of the groundwater samples collected was typically slightly below the lower limit of the NYS AWOS of $6.5-8.5$, with a median $\mathrm{pH}$ of 6.20. Other water quality parameters were below the applicable NYS AWQS. Results from metals and VOC analyses of groundwater samples indicate that all metals and VOC concentrations were below the applicable NYS DWS.

Former Building T-111 Area: Historical accounts suggest that between 1951 and 1953 approximately five gallons of TCE was discharged to the ground every other 
Table 5-21

BNL Site Environmental Report for Calendar Year 1994

AGS and Linac

Ground Water Survellance Wells, Water Quality Data

\begin{tabular}{|c|c|c|c|c|c|c|c|c|c|c|}
\hline \multirow[t]{2}{*}{$\begin{array}{l}\text { Well } \\
\text { Id. No. }\end{array}$} & \multirow[t]{2}{*}{$\begin{array}{l}\text { No. of } \\
\text { Samples }\end{array}$} & \multirow{2}{*}{$\begin{array}{c}\text { pH } \\
\text { su } \\
\text { Range }\end{array}$} & \multicolumn{2}{|c|}{$\begin{array}{l}\text { Conductivity } \\
\text { umhos } / \mathrm{cm}\end{array}$} & \multicolumn{2}{|c|}{$\begin{array}{c}\text { Chlorides } \\
\mathrm{mg} / \mathrm{L}\end{array}$} & \multicolumn{2}{|c|}{$\begin{array}{l}\text { Sulfates } \\
\text { mg/L }\end{array}$} & \multicolumn{2}{|c|}{$\begin{array}{c}\text { Nitrate as } N(b) \\
\text { mg/l }\end{array}$} \\
\hline & & & Max & Avg. & Max. & Avg. & Max. & Avg. & Max. & Avg. \\
\hline \multicolumn{11}{|l|}{ AGS } \\
\hline $\begin{array}{c}44-01(a) \\
44-02(a) \\
54-01 \\
54-02 \\
54-05 \\
54-06 \\
54-07 \\
54-08 \\
64-01 \\
64-02 \\
64-03\end{array}$ & $\begin{array}{l}3 \\
3 \\
2 \\
3 \\
3 \\
3 \\
3 \\
3 \\
3 \\
3 \\
3\end{array}$ & $\begin{array}{l}5.2-5.5 \\
5.6-5.7 \\
6.1-7.1 \\
5.6-6.4 \\
5.4-6.2 \\
5.9-6.3 \\
6.7-6.8 \\
6.3-6.4 \\
5.7-6.1 \\
6.1-6.2 \\
5.9-6.2\end{array}$ & $\begin{array}{c}87.6 \\
58.7 \\
175.5 \\
315 \\
98.1 \\
427 \\
235 \\
198.5 \\
335 \\
338.4 \\
346.8\end{array}$ & $\begin{array}{c}78.5 \\
55.9 \\
147 \\
165.3 \\
76.2 \\
341.5 \\
210.8 \\
167.4 \\
249.8 \\
250.8 \\
268.9\end{array}$ & $\begin{array}{c}8.1 \\
<4.0 \\
12.6 \\
82.3 \\
5 \\
75 \\
21.4 \\
31 \\
67.3 \\
39.7 \\
74.2\end{array}$ & $\begin{array}{c}6.5 \\
<4.0 \\
9.4 \\
35.5 \\
<4.0 \\
44.9 \\
14.6 \\
24.3 \\
44.5 \\
25.3 \\
44.9\end{array}$ & $\begin{array}{c}15.8 \\
10 \\
18.3 \\
12.5 \\
14.7 \\
34.3 \\
22 \\
10 \\
21.8 \\
28 \\
21.8\end{array}$ & $\begin{array}{c}13.1 \\
9.1 \\
16.9 \\
7.7 \\
13.7 \\
27.7 \\
18.8 \\
9.1 \\
18.7 \\
23.9 \\
20.3\end{array}$ & $\begin{array}{l}1.5 \\
<1.0 \\
<1.0 \\
<1.0 \\
<1.0 \\
2.1 \\
3.6 \\
1.3 \\
5.1 \\
3.5 \\
5.2\end{array}$ & $\begin{array}{l}<1.0 \\
<1.0 \\
<1.0 \\
<1.0 \\
<1.0 \\
1.7 \\
3.3 \\
<1.0 \\
3.3 \\
2.9 \\
4.5\end{array}$ \\
\hline \multicolumn{11}{|l|}{ LINAC } \\
\hline $\begin{array}{c}53-01(a) \\
53-02(a) \\
54-03\end{array}$ & $\begin{array}{l}3 \\
2 \\
3\end{array}$ & $\begin{array}{c}5.3-5.8 \\
5.2 \\
6.1-6.5\end{array}$ & $\begin{array}{l}52.9 \\
66.9 \\
279\end{array}$ & $\begin{array}{l}49.4 \\
62.2 \\
191\end{array}$ & $\begin{array}{c}5 \\
8.2 \\
37.8\end{array}$ & $\begin{array}{l}<4.0 \\
8.1 \\
24.8\end{array}$ & $\begin{array}{l}7.2 \\
9.2 \\
58\end{array}$ & $\begin{array}{c}4.7 \\
9 \\
30.2\end{array}$ & $\begin{array}{l}<1.0 \\
<1.0 \\
<1.0\end{array}$ & $\begin{array}{l}<1.0 \\
<1.0 \\
<1.0\end{array}$ \\
\hline \multicolumn{2}{|c|}{$\begin{array}{l}\text { NYS Ambient Water } \\
\text { Quality Standard }\end{array}$} & $6.5-8.5$ & (c) & - & 250 & - & 250 & - & 10 & - \\
\hline Typical MDL & & - & 10 & & 4 & & 4 & & 1 & \\
\hline
\end{tabular}

NA: $\quad$ Analysis Not Available.

MDL: $\quad$ Minimum Detection Limit.

(a): Upgradient Well.

(b): Holding time expired for all samples.

(c): No standard specified. 
Table 5-22

BNL Site Environmental Report for Calendar Year 1994

AGS and Linac

Ground Water Surveillance Wells, Metals Data

\begin{tabular}{|c|c|c|c|c|c|c|c|c|c|c|c|}
\hline Location & $\begin{array}{l}\text { No. of } \\
\text { Samples }\end{array}$ & & $\underset{\mathrm{mg} / \mathrm{L}}{\mathrm{Ag}}$ & $\begin{array}{c}\mathrm{Cd} \\
\mathrm{mg} / \mathrm{L}\end{array}$ & $\begin{array}{c}\mathrm{Cr} \\
\mathrm{mg} / \mathrm{L}\end{array}$ & $\begin{array}{c}\mathrm{Cu} \\
\mathrm{mg} / \mathrm{L}\end{array}$ & $\begin{array}{c}\mathrm{Fe} \\
\mathrm{mg} / \mathrm{L}\end{array}$ & $\begin{array}{c}\mathrm{Hg} \\
\mathrm{mgh}\end{array}$ & $\begin{array}{c}\mathrm{Na} \\
\mathrm{mg} / \mathrm{L}\end{array}$ & $\begin{array}{l}\mathrm{Pb} \\
\mathrm{mg} / \mathrm{L}\end{array}$ & $\underset{\mathrm{mg} / \mathrm{Ln}}{\mathrm{Zn}}$ \\
\hline \multicolumn{12}{|l|}{ AGS } \\
\hline $44-01(a)$ & 3 & $\begin{array}{l}\text { Maximum } \\
\text { Average }\end{array}$ & $\begin{array}{l}<0.025 \\
<0.025\end{array}$ & $\begin{array}{l}<0.0005 \\
<0.0005\end{array}$ & $\begin{array}{l}<0.005 \\
<0.005\end{array}$ & $\begin{array}{l}<0.05 \\
<0.05\end{array}$ & $\begin{array}{l}<0.075 \\
<0.075\end{array}$ & $\begin{array}{l}<0.0002 \\
<0.0002\end{array}$ & $\begin{array}{l}4.58 \\
4.39\end{array}$ & $\begin{array}{l}<0.002 \\
<0.002\end{array}$ & $\begin{array}{l}<0.02 \\
<0.02\end{array}$ \\
\hline $44-02(a)$ & 3 & $\begin{array}{l}\text { Maximum } \\
\text { Average }\end{array}$ & $\begin{array}{l}<0.025 \\
<0.025\end{array}$ & $\begin{array}{l}<0.0005 \\
<0.0005\end{array}$ & $\begin{array}{l}<0.005 \\
<0.005\end{array}$ & $\begin{array}{l}<0.05 \\
<0.05\end{array}$ & $\begin{array}{c}0.081 \\
<0.075\end{array}$ & $\begin{array}{l}<0.0002 \\
<0.0002\end{array}$ & $\begin{array}{l}2.70 \\
2.61\end{array}$ & $\begin{array}{c}0.006 \\
<0.005\end{array}$ & $\begin{array}{l}<0.02 \\
<0.02\end{array}$ \\
\hline $54 \cdot 01$ & 2 & $\begin{array}{l}\text { Maximum } \\
\text { Average }\end{array}$ & $\begin{array}{l}<0.025 \\
<0.025\end{array}$ & $\begin{array}{l}0.0054 \\
0.0034\end{array}$ & $\begin{array}{l}<0.005 \\
<0.005\end{array}$ & $\begin{array}{l}<0.05 \\
<0.05\end{array}$ & $\begin{array}{l}7.71 \\
3.20\end{array}$ & $\begin{array}{l}<0.0002 \\
<0.0002\end{array}$ & $\begin{array}{l}11.66 \\
10.68\end{array}$ & $\begin{array}{c}0.004 \\
<0.002\end{array}$ & $\begin{array}{l}5.26 \\
2.63\end{array}$ \\
\hline $54-02$ & 2 & $\begin{array}{l}\text { Maximum } \\
\text { Average }\end{array}$ & $\begin{array}{l}<0.025 \\
<0.025\end{array}$ & $\begin{array}{l}<0.0005 \\
<0.0005\end{array}$ & $\begin{array}{l}<0.005 \\
<0.005\end{array}$ & $\begin{array}{l}<0.05 \\
<0.05\end{array}$ & $\begin{array}{r}1.040 \\
0.75\end{array}$ & $\begin{array}{l}<0.0002 \\
<0.0002\end{array}$ & $\begin{array}{l}32.12 \\
22.14\end{array}$ & $\begin{array}{l}<0.002 \\
<0.002\end{array}$ & $\begin{array}{l}0.04 \\
0.02\end{array}$ \\
\hline $\begin{array}{l}\text { All Other Wells } \\
(n=7)\end{array}$ & 21 & $\begin{array}{l}\text { Maximum } \\
\text { Average }\end{array}$ & $\begin{array}{l}<0.025 \\
<0.025\end{array}$ & $\begin{array}{l}<0.0005 \\
<0.0005\end{array}$ & $\begin{array}{l}<0.005 \\
<0.005\end{array}$ & $\begin{array}{l}<0.05 \\
<0.05\end{array}$ & $\begin{array}{l}<0.075 \\
<0.075\end{array}$ & $\begin{array}{l}<0.0002 \\
<0.0002\end{array}$ & $\begin{array}{l}39.35 \\
16.16\end{array}$ & $\begin{array}{l}<0.002 \\
<0.002\end{array}$ & $\begin{array}{l}0.06 \\
<0.02\end{array}$ \\
\hline \multicolumn{12}{|l|}{ Linac } \\
\hline $\begin{array}{l}\text { All Wells } \\
(n=3)\end{array}$ & 8 & $\begin{array}{l}\text { Maximum } \\
\text { Average }\end{array}$ & $\begin{array}{l}<0.025 \\
<0.025\end{array}$ & $\begin{array}{l}<0.0005 \\
<0.0005\end{array}$ & $\begin{array}{l}<0.005 \\
<0.005\end{array}$ & $\begin{array}{l}<0.05 \\
<0.05\end{array}$ & $\begin{array}{l}<0.075 \\
<0.075\end{array}$ & $\begin{array}{l}<0.0002 \\
<0.0002\end{array}$ & $\begin{array}{c}24.74 \\
9.96\end{array}$ & $\begin{array}{l}<0.002 \\
<0.002\end{array}$ & $\begin{array}{l}0.05 \\
<0.02\end{array}$ \\
\hline NYS DWS & & & 0.05 & 0.01 & 0.05 & 1.3 & 0.3 & 0.002 & (b) & 0.015 & 5.0 \\
\hline Typical MDL & & & 0.025 & 0.0005 & 0.005 & 0.05 & 0.075 & 0.0002 & 1.0 & 0.002 & 0.02 \\
\hline
\end{tabular}

MDL: Minimum Detection Limit.

(a): Upgradient Well.

(b): No Standard Specified. 
Table 5-23

BNL Site Environmental Report for Calendar Year 1994

$$
\text { AGS and Linac }
$$

Ground Water Surveillance Wells, Chlorocarbon Data

\begin{tabular}{|c|c|c|c|c|c|c|c|c|}
\hline Location & $\begin{array}{l}\text { No. of } \\
\text { Samples }\end{array}$ & & $\begin{array}{l}\text { TCA } \\
\text { ug/L }\end{array}$ & $\begin{array}{l}\text { TCE } \\
\text { ug/L }\end{array}$ & $\begin{array}{l}P C E \\
\text { ug/L }\end{array}$ & $\begin{array}{l}D C A \\
u g / L\end{array}$ & $\begin{array}{l}\text { DCE } \\
\text { ug/L }\end{array}$ & $\begin{array}{c}\text { Chloroform } \\
\text { ug/L }\end{array}$ \\
\hline \multicolumn{9}{|l|}{ AGS } \\
\hline $44-01(a)$ & 3 & $\begin{array}{l}\text { Maximum } \\
\text { Average }\end{array}$ & $\begin{array}{l}<2.0 \\
<2.0\end{array}$ & $\begin{array}{l}<2.0 \\
<2.0\end{array}$ & $\begin{array}{l}<2.0 \\
<2.0\end{array}$ & $\begin{array}{l}<2.0 \\
<2.0\end{array}$ & $\begin{array}{l}<2.0 \\
<2.0\end{array}$ & $\begin{array}{l}<2.0 \\
<2.0\end{array}$ \\
\hline $44-02(a)$ & 3 & $\begin{array}{l}\text { Maximum } \\
\text { Average }\end{array}$ & $\begin{array}{l}<2.0 \\
<2.0\end{array}$ & $\begin{array}{l}<2.0 \\
<2.0\end{array}$ & $\begin{array}{l}<2.0 \\
<2.0\end{array}$ & $\begin{array}{l}<2.0 \\
<2.0\end{array}$ & $\begin{array}{l}<2.0 \\
<2.0\end{array}$ & $\begin{array}{l}<2.0 \\
<2.0\end{array}$ \\
\hline $64-03$ & 3 & $\begin{array}{l}\text { Maximum } \\
\text { Average }\end{array}$ & $\begin{array}{l}15.0 \\
10.0\end{array}$ & $\begin{array}{l}<2.0 \\
<2.0\end{array}$ & $\begin{array}{l}<2.0 \\
<2.0\end{array}$ & $\begin{array}{l}3.0 \\
<2.0\end{array}$ & $\begin{array}{l}<2.0 \\
<2.0\end{array}$ & $\begin{array}{l}<2.0 \\
<2.0\end{array}$ \\
\hline $\begin{array}{l}\text { All Other Wells } \\
(n=8)\end{array}$ & 22 & $\begin{array}{l}\text { Maximum } \\
\text { Average }\end{array}$ & $\begin{array}{l}4.7 \\
<2.0\end{array}$ & $\begin{array}{l}<2.0 \\
<2.0\end{array}$ & $\begin{array}{l}<2.0 \\
<2.0\end{array}$ & $\begin{array}{l}<2.0 \\
<2.0\end{array}$ & $\begin{array}{l}<2.0 \\
<2.0\end{array}$ & $\begin{array}{l}3.0 \\
<2.0\end{array}$ \\
\hline \multicolumn{9}{|l|}{ Linac } \\
\hline $\begin{array}{l}\text { All Wells } \\
(n=3)\end{array}$ & 8 & $\begin{array}{l}\text { Maximum } \\
\text { Average }\end{array}$ & $\begin{array}{l}<2.0 \\
<2.0\end{array}$ & $\begin{array}{l}<2.0 \\
<2.0\end{array}$ & $\begin{array}{l}<2.0 \\
<2.0\end{array}$ & $\begin{array}{l}<2.0 \\
<2.0\end{array}$ & $\begin{array}{l}<2.0 \\
<2.0\end{array}$ & $\begin{array}{l}<2.0 \\
<2.0\end{array}$ \\
\hline NYS DWS & & & 5.0 & 5.0 & 5.0 & 5.0 & 5.0 & 100.0 \\
\hline Typical MDL & & & 2.0 & 2.0 & 2.0 & 2.0 & 2.0 & 2.0 \\
\hline
\end{tabular}

MDL: Minimum Detection Limit.

TCA: 1,1,1-trichloroethane.

TCE: Trichloroethylene.

PCE: Tetrachloroethylene.

DCA: Dichloroethane.

DCE: Dichloroethylene.

(a): Upgradient Well. 
Table 5-24

BNL Site Environmental Report for Calendar Year 1994 AGS and Linac

Ground Water Surveillance Wells, BETX Data *

\begin{tabular}{|c|c|c|c|c|c|c|}
\hline Location & $\begin{array}{r}\text { No. o } \\
\text { Sampl }\end{array}$ & & $\begin{array}{c}\text { Benzene } \\
\text { ugl }\end{array}$ & $\begin{array}{c}\text { Ethylbenzene } \\
\text { ugrL }\end{array}$ & $\begin{array}{c}\text { Toluene } \\
\text { ugn }\end{array}$ & $\begin{array}{l}\text { Xylene } \\
\text { ugh }\end{array}$ \\
\hline \multicolumn{7}{|l|}{ AGS } \\
\hline $\begin{array}{l}\text { All Wells } \\
(n=11)\end{array}$ & 31 & $\begin{array}{l}\text { Maximum } \\
\text { Average }\end{array}$ & $\begin{array}{l}<2.0 \\
<2.0\end{array}$ & $\begin{array}{l}<2.0 \\
<2.0\end{array}$ & $\begin{array}{l}<2.0 \\
<2.0\end{array}$ & $\begin{array}{l}<2.0 \\
<2.0\end{array}$ \\
\hline \multicolumn{7}{|l|}{ Linac } \\
\hline $\begin{array}{l}\text { All Wells } \\
(n=3)\end{array}$ & 8 & $\begin{array}{l}\text { Maximum } \\
\text { Average }\end{array}$ & $\begin{array}{l}<2.0 \\
<2.0\end{array}$ & $\begin{array}{l}<2.0 \\
<2.0\end{array}$ & $\begin{array}{l}<2.0 \\
<2.0\end{array}$ & $\begin{array}{l}<2.0 \\
<2.0\end{array}$ \\
\hline NYS DWS & & & 5.0 & 5.0 & 5.0 & 5.0 \\
\hline Typical MDL & & & 2.0 & 2.0 & 2.0 & 2.0 \\
\hline
\end{tabular}

MDL: Minimum Detection Limit. 
Table 5-27

BNL Site Environmental Report for Calendar Year 1994

Miscellaneous Areas

Ground Water Survelliance Wells, Chlorocarbon Data

\begin{tabular}{|c|c|c|c|c|c|c|c|c|}
\hline Location & $\begin{array}{l}\text { No. of } \\
\text { Samples }\end{array}$ & & $\begin{array}{l}\text { TCA } \\
\text { ugn }\end{array}$ & $\begin{array}{l}\text { TCE } \\
\text { ugh }\end{array}$ & $\begin{array}{l}\text { PCE } \\
\text { ugr }\end{array}$ & $\begin{array}{l}\text { DCA } \\
\text { ug } \Omega\end{array}$ & $\begin{array}{l}\text { DCE } \\
\text { ugn }\end{array}$ & $\begin{array}{c}\text { Chloroform } \\
\text { ugn }\end{array}$ \\
\hline \multicolumn{9}{|l|}{ WCF } \\
\hline $65-06(a)$ & 1 & $\begin{array}{l}\text { Maximum } \\
\text { Average }\end{array}$ & $\begin{array}{c}7.0 \\
-\end{array}$ & $<2.0$ & $\begin{array}{c}<2.0 \\
-\end{array}$ & $\begin{array}{c}<2.0 \\
-\end{array}$ & $<2.0$ & $\begin{array}{c}<2.0 \\
-\end{array}$ \\
\hline $65-01$ & 3 & $\begin{array}{c}\text { Maximum } \\
\text { Average }\end{array}$ & $\begin{array}{l}<2.0 \\
<2.0\end{array}$ & $\begin{array}{l}<2.0 \\
<2.0\end{array}$ & $\begin{array}{l}<2.0 \\
<2.0\end{array}$ & $\begin{array}{l}<2.0 \\
<2.0\end{array}$ & $\begin{array}{l}<2.0 \\
<2.0\end{array}$ & $\begin{array}{l}<2.0 \\
<2.0\end{array}$ \\
\hline $65-02$ & 2 & $\begin{array}{l}\text { Maximum } \\
\text { Average }\end{array}$ & $\begin{array}{l}19.0 \\
16.0\end{array}$ & $\begin{array}{l}<2.0 \\
<2.0\end{array}$ & $\begin{array}{l}<2.0 \\
<2.0\end{array}$ & $\begin{array}{l}<2.0 \\
<2.0\end{array}$ & $\begin{array}{l}<2.0 \\
<2.0\end{array}$ & $\begin{array}{l}<2.0 \\
<2.0\end{array}$ \\
\hline $65-03$ & 2 & $\begin{array}{l}\text { Maximum } \\
\text { Average }\end{array}$ & $\begin{array}{l}13.0 \\
10.5\end{array}$ & $\begin{array}{l}<2.0 \\
<2.0\end{array}$ & $\begin{array}{l}<2.0 \\
<2.0\end{array}$ & $\begin{array}{l}<2.0 \\
<2.0\end{array}$ & $\begin{array}{l}<2.0 \\
<2.0\end{array}$ & $\begin{array}{l}<2.0 \\
<2.0\end{array}$ \\
\hline $65-04$ & 2 & $\begin{array}{l}\text { Maximum } \\
\text { Average }\end{array}$ & $\begin{array}{l}<2.0 \\
<2.0\end{array}$ & $\begin{array}{l}<2.0 \\
<2.0\end{array}$ & $\begin{array}{l}<2.0 \\
<2.0\end{array}$ & $\begin{array}{l}<2.0 \\
<2.0\end{array}$ & $\begin{array}{l}<2.0 \\
<2.0\end{array}$ & $\begin{array}{l}<2.0 \\
<2.0\end{array}$ \\
\hline $65-05$ & 2 & $\begin{array}{l}\text { Maximum } \\
\text { Average }\end{array}$ & $\begin{array}{l}14.0 \\
11.0\end{array}$ & $\begin{array}{l}<2.0 \\
<2.0\end{array}$ & $\begin{array}{l}<2.0 \\
<2.0\end{array}$ & $\begin{array}{l}<2.0 \\
<2.0\end{array}$ & $\begin{array}{l}<2.0 \\
<2.0\end{array}$ & $\begin{array}{l}<2.0 \\
<2.0\end{array}$ \\
\hline \multicolumn{9}{|l|}{ Bldg. 830} \\
\hline $\begin{array}{l}\text { All Wells } \\
(n=3)\end{array}$ & 6 & $\begin{array}{c}\text { Maximum } \\
\text { Average }\end{array}$ & $\begin{array}{l}<2.0 \\
<2.0\end{array}$ & $\begin{array}{l}<2.0 \\
<2.0\end{array}$ & $\begin{array}{l}<2.0 \\
<2.0\end{array}$ & $\begin{array}{l}<2.0 \\
<2.0\end{array}$ & $\begin{array}{l}<2.0 \\
<2.0\end{array}$ & $\begin{array}{l}<2.0 \\
<2.0\end{array}$ \\
\hline \multicolumn{9}{|l|}{ P\&GA $(T-111)$} \\
\hline $85-07$ & 3 & $\begin{array}{c}\text { Maximum } \\
\text { Average }\end{array}$ & $\begin{array}{r}11.0 \\
9.7\end{array}$ & $\begin{array}{l}<2.0 \\
<2.0\end{array}$ & $\begin{array}{l}<2.0 \\
<2.0\end{array}$ & $\begin{array}{l}4.0 \\
3.7\end{array}$ & $\begin{array}{l}5.0 \\
3.7\end{array}$ & $\begin{array}{l}<2.0 \\
<2.0\end{array}$ \\
\hline $\begin{array}{l}\text { All Other Wells } \\
(n=3)\end{array}$ & 9 & $\begin{array}{l}\text { Maximum } \\
\text { Average }\end{array}$ & $\begin{array}{l}<2.0 \\
<2.0\end{array}$ & $\begin{array}{l}<2.0 \\
<2.0\end{array}$ & $\begin{array}{l}<2.0 \\
<2.0\end{array}$ & $\begin{array}{l}<2.0 \\
<2.0\end{array}$ & $\begin{array}{l}<2.0 \\
<2.0\end{array}$ & $\begin{array}{c}4 \\
<2.0\end{array}$ \\
\hline WTP & & & & & & & & \\
\hline $\begin{array}{l}\text { All Wells } \\
(n=5)\end{array}$ & 8 & $\begin{array}{l}\text { Maximum } \\
\text { Average }\end{array}$ & $\begin{array}{l}<2.0 \\
<2.0\end{array}$ & $\begin{array}{l}<2.0 \\
<2.0\end{array}$ & $\begin{array}{l}<2.0 \\
<2.0\end{array}$ & $\begin{array}{l}<2.0 \\
<2.0\end{array}$ & $\begin{array}{l}<2.0 \\
<2.0\end{array}$ & $\begin{array}{l}9.0 \\
6.8\end{array}$ \\
\hline NYS DWS & & & 5.0 & 5.0 & 5.0 & 5.0 & 5.0 & 100.0 \\
\hline Typical MDL & & & 2.0 & 2.0 & 2.0 & 2.0 & 2.0 & 2.0 \\
\hline
\end{tabular}

MDL: Minimum Detection Limit.

TCA: 1,1,1-trichloroethane.

TCE: Trichloroethylene.

PCE: Tetrachloroethylene.

DCA: Dichloroethane.

DCE: Dichloroethylene.

(a): Upgradient Well. 
Table 5-28

8NL Site Environmental Report for Calendar Year 1994

Miscellaneous Area

Ground Water Surveillance Wells, BETX Data

\begin{tabular}{|c|c|c|c|c|c|}
\hline Location & $\begin{array}{l}\text { No. of } \\
\text { Samples }\end{array}$ & $\begin{array}{c}\text { Benzene } \\
\text { ug } h\end{array}$ & $\begin{array}{c}\text { Ethylbenzene } \\
\text { ug/L }\end{array}$ & $\begin{array}{c}\text { Toluene } \\
\text { ughl }\end{array}$ & $\begin{array}{c}\text { Xylene } \\
\text { ugh }\end{array}$ \\
\hline \multicolumn{6}{|l|}{ WCF } \\
\hline $\begin{array}{l}\text { All Wells } \\
(n=6)\end{array}$ & 12 & $\begin{array}{l}<2.0 \\
<2.0\end{array}$ & $\begin{array}{l}<2.0 \\
<2.0\end{array}$ & $\begin{array}{l}<2.0 \\
<2.0\end{array}$ & $\begin{array}{l}<2.0 \\
<2.0\end{array}$ \\
\hline \multicolumn{6}{|l|}{ Bldg. 850} \\
\hline $\begin{array}{l}\text { All Wells } \\
(n=3)\end{array}$ & 7 & $\begin{array}{l}<2.0 \\
<2.0\end{array}$ & $\begin{array}{l}<2.0 \\
<2.0\end{array}$ & $\begin{array}{l}<2.0 \\
<2.0\end{array}$ & $\begin{array}{l}<2.0 \\
<2.0\end{array}$ \\
\hline \multicolumn{6}{|l|}{ P\&GA (T-111) } \\
\hline $\begin{array}{l}\text { All Wells } \\
(n=4)\end{array}$ & 12 & $\begin{array}{l}<2.0 \\
<2.0\end{array}$ & $\begin{array}{l}<2.0 \\
<2.0\end{array}$ & $\begin{array}{l}<2.0 \\
<2.0\end{array}$ & $\begin{array}{l}<2.0 \\
<2.0\end{array}$ \\
\hline \multicolumn{6}{|l|}{ WTP } \\
\hline $\begin{array}{l}\text { All Wells } \\
(n=5)\end{array}$ & 9 & $\begin{array}{l}<2.0 \\
<2.0\end{array}$ & $\begin{array}{l}<2.0 \\
<2.0\end{array}$ & $\begin{array}{l}<2.0 \\
<2.0\end{array}$ & $\begin{array}{l}<2.0 \\
<2.0\end{array}$ \\
\hline NYS DWS & & 5.0 & 5.0 & 5.0 & 5.0 \\
\hline Typical MDL & & 2.0 & 2.0 & 2.0 & 2.0 \\
\hline
\end{tabular}

MDL: Minimum Detection Limit. 


\section{WASTE CONCENTRATION FACILITY}
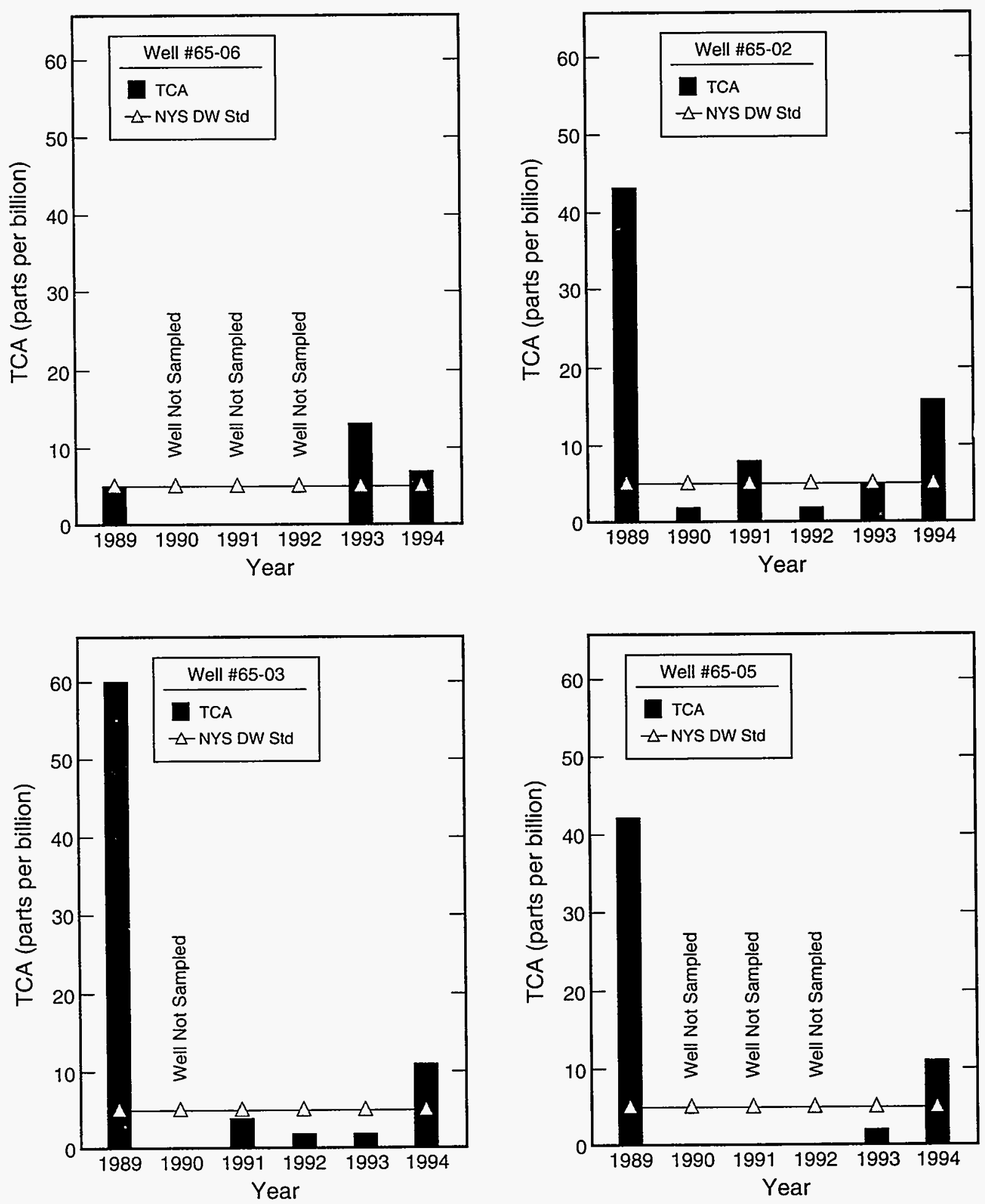

Figure 5-17 1,1,1-trichloroethane (TCA) concentration trends in wells located upgradient and downgradient of the Waste Concentration Facility (WCF): Well 65-06 located directly upgradient of the WCF; Wells 65-02, and 65-03 and 65-05 located directly downgradient of the WCF. 
day near former Building $\mathrm{T}-111$ (presently the Building 515 complex). Groundwater monitoring conducted downgradient of the Former Building T-111 area since 1990 has, however, revealed TCA contamination at concentrations slightly above the NYS DWS. An evaluation of the extent of soil and groundwater contamination in the Former Building T-111 area will be conducted as part of the OU III RI/FS. The surveillance well network near and downgradient of the Building $\mathrm{T}-11 \mathrm{ll}$ area presently consists of three shallow and one middle upper Glacial aquifer wells (Figure 5-7). During 1994, groundwater samples were collected from the four surveillance wells, and were analyzed for water quality., vocs, and metals (Tables 5-25 to 5-28). Water quality analyses indicate that the $\mathrm{pH}$ of groundwater samples collected from shallow Upper Glacial aquifer wells was typically slightly below the lower limit of the NYS AWQS of 6.5 - 8.5, with a median pH of 6.00, whereas the median $\mathrm{pH}$ of samples collected from middle Upper Glacial well 85-07 was 7.75. Other water quality parameters were below the applicable NYS AWQS. Results from metals analyses of groundwater samples from this area indicate that all metals concentrations were below the applicable NYS DWS. Analyses for vocs however, indicate that TCA and DCE were detected at or above NYS DWS in middle Upper Glacial aquifer well 85-07, with maximum concentrations of TCA at $11 \mu \mathrm{g} / \mathrm{L}$ and DCE at $5 \mu \mathrm{g} / \mathrm{L}$.

Water Treatment Plant Area: At the direction of the NYSDEC, five groundwater surveillance wells were installed at the Water Treatment Plant in 1993 to assess potential leaching of suspended iron from the plant's recharge basins into the groundwater. Naturally high levels of iron in groundwater are removed at the WTP, and the sequestered iron is discharged to the recharge basins. During 1994, groundwater samples were collected from the five WTP surveillance wells (Figures 5-4 and 5-7), and the samples were analyzed for water quality, vocs, and metals (Tables 5-25 to 5-28). Water quality analyses indicate that the $\mathrm{pH}$ of the groundwater samples collected from upgradient wells was typically slightly below the lower limit of the NYS AWQS of 6.5 - 8.5, with a median $\mathrm{pH}$ of 6.05 , whereas the $\mathrm{pH}$ was within limits in wells directly downgradient of the basins. Other water quality parameters were below the applicable NYS AWQS. Results from metals and VOC analyses of groundwater samples from this area indicate that all metals and VOC concentrations were below the applicable NYS DWS.

Supply and Materiel Area: The Supply and Materiel area is the central shipping and receiving facility for the $\mathrm{BNL}$ site, and is also the location of several small machine shops and storage areas. There have been several documented spill events within the supply and Materiel area, including a TCA release to the sanitary system and soils in the vicinity of a vapor degreaser located in Building 208, and a leaking underground fuel oil tank near Building 457. The full extent of soil and groundwater contamination in the supply and Materiel area will be examined during the OU III RI/FS. The surveillance well network near the Supply and Materiel area consists of eight shallow and two middle Upper Glacial aquifer wells (Figures 5-7 and 5-8). During 1994, the wells were sampled for water quality, VoCs, and metals (Tables 5-29 to 5-32). Water quality analyses indicate that the $\mathrm{pH}$ of the groundwater samples collected was typically below the lower limit of the NYS AWQS of 6.5 - 8.5, with a median pH of 6.10. Other water quality parameters were below the applicable NYS AWQS. Results from metals analyses of groundwater from this area indicated that iron concentrations were above NYS DWS in upgradient Well 85-02 with a maximum observed concentration of $0.314 \mathrm{mg} / \mathrm{L}$, and in downgradient well 105-02 (an older well constructed of carbon steel casings) at a concentration of $1.34 \mathrm{mg} / \mathrm{I}$. Analyses of groundwater samples for VOCs indicated that TCA was detected above NYS DWS in Well 85-03 at $9 \mu \mathrm{g} / \mathrm{L}$, Well 96-06 at $110 \mathrm{\mu g} / \mathrm{L}$, and Well 96-07 (formerly ICF-3) at 470 $\mathrm{gg} / \mathrm{L}$. DCE was also detected on Wells 96-06 and 96-07 at maximum observed concentrations of 8 $\mu \mathrm{g} / \mathrm{L}$ and $12 \mu \mathrm{g} / \mathrm{L}$, respectively. Trend plots for TCA based on data from representative monitoring wells within and downgradient of the $S \& M$ Area are presented in Figure 5-18. 
Table 5-29

BNL Site Envlronmental Report for Calendar Year 1994

Supply and Materiel Area

Ground Water Surveillance Wells, Water Quality Data

\begin{tabular}{|c|c|c|c|c|c|c|c|c|c|c|}
\hline \multirow[t]{2}{*}{$\begin{array}{l}\text { Well } \\
\text { Id. No. }\end{array}$} & \multirow[t]{2}{*}{$\begin{array}{c}\text { No. of } \\
\text { Samples }\end{array}$} & \multirow{2}{*}{$\begin{array}{c}\text { pH } \\
\text { SU } \\
\text { Range }\end{array}$} & \multicolumn{2}{|c|}{$\begin{array}{l}\text { Conductivity } \\
\text { umhos } / \mathrm{cm}\end{array}$} & \multicolumn{2}{|c|}{$\begin{array}{c}\text { Chlorides } \\
\text { mgll }\end{array}$} & \multicolumn{2}{|c|}{$\begin{array}{l}\text { Sulfates } \\
\text { mg/L }\end{array}$} & \multicolumn{2}{|c|}{$\begin{array}{c}\text { Nitrate as } N(b) \\
\text { mg/L }\end{array}$} \\
\hline & & & Max. & Avg. & Max. & Avg. & Max. & Avg. & Max. & Avg. \\
\hline \multicolumn{11}{|l|}{ S\&M } \\
\hline $\begin{array}{c}85-01(a) \\
85-02(a) \\
85-03 \\
86-01 \\
86-20 \\
86-21 \\
96-06 \\
96-07 \\
105-01 \\
105-02\end{array}$ & $\begin{array}{l}3 \\
3 \\
3 \\
1 \\
3 \\
3 \\
3 \\
2 \\
1 \\
2\end{array}$ & $\begin{array}{c}5.7-6.1 \\
5.8-6.5 \\
6.0-6.5 \\
5.9 \\
6.1-6.2 \\
5.9-6.0 \\
5.9-6.2 \\
6.0 \\
5.5 \\
5.8-6.1\end{array}$ & $\begin{array}{c}318.4 \\
120.2 \\
203.5 \\
380 \\
274 \\
205.1 \\
195.3 \\
185.4 \\
67.6 \\
395.2\end{array}$ & $\begin{array}{c}286.7 \\
114.6 \\
194.2 \\
- \\
213.7 \\
176.8 \\
184.3 \\
185.4 \\
- \\
282.8\end{array}$ & $\begin{array}{c}55.9 \\
17.8 \\
19.1 \\
67.8 \\
48.4 \\
22.8 \\
32.6 \\
20.1 \\
5.7 \\
102.2\end{array}$ & $\begin{array}{c}46.1 \\
16.9 \\
15.1 \\
- \\
29.9 \\
14.2 \\
26.8 \\
18.8 \\
\overline{70.9}\end{array}$ & $\begin{array}{c}24.3 \\
8.9 \\
17.6 \\
21.8 \\
17.9 \\
23.7 \\
19.2 \\
25 \\
8.6 \\
11.3\end{array}$ & $\begin{array}{c}23.6 \\
8.3 \\
16.4 \\
-\overline{15.8} \\
19.1 \\
18.1 \\
24 \\
\overline{10.8}\end{array}$ & $\begin{array}{c}2.4 \\
<1.0 \\
3 \\
4.9 \\
3 \\
3.1 \\
2.2 \\
3.4 \\
<1.0 \\
<1.0\end{array}$ & $\begin{array}{l}2.3 \\
<1.0 \\
2.5 \\
- \\
2.6 \\
2.9 \\
1.8 \\
3.2 \\
-\overline{<1.0}\end{array}$ \\
\hline \multicolumn{2}{|c|}{$\begin{array}{l}\text { NYS Ambient Water } \\
\text { Quality Standard }\end{array}$} & $6.5-8.5$ & (c) & - & 250 & - & 250 & - & 10 & - \\
\hline \multicolumn{2}{|l|}{ Typical MDL } & - & 10 & & 4 & & 4 & & 1 & \\
\hline
\end{tabular}

NA: Analysis Not Available.

MDL: Minimum Detection Limit.

(a): Upgradient Well.

(b): Holding time expired for all samples.

(c): No standard specified. 
Table 5-30

BNL Site Environmental Report for Calendar Year 1994

Supply and Materiel Area

Ground Water Surveillance Wells, Metals Data

\begin{tabular}{|c|c|c|c|c|c|c|c|c|c|c|c|}
\hline Location & $\begin{array}{l}\text { No. of } \\
\text { Samples }\end{array}$ & & $\begin{array}{c}\mathrm{Ag} \\
\mathrm{mg} / \mathrm{L}\end{array}$ & $\begin{array}{c}\mathrm{Cd} \\
\mathrm{mgh}\end{array}$ & $\begin{array}{c}\mathrm{Cr} \\
\mathrm{mg} / \mathrm{L}\end{array}$ & $\begin{array}{c}\mathrm{Cu} \\
\mathrm{mgn}\end{array}$ & $\begin{array}{c}\mathrm{Fe} \\
\mathrm{mgh}\end{array}$ & $\underset{m g h}{\mathrm{Hg}}$ & $\underset{\mathrm{mgh}}{\mathrm{Na}}$ & $\begin{array}{c}\mathrm{Pb} \\
\mathrm{mg} / \mathrm{L}\end{array}$ & $\underset{\mathrm{mg} / \mathrm{L}}{\mathrm{Zn}}$ \\
\hline $85-01$ (a) & 3 & $\begin{array}{l}\text { Maximum } \\
\text { Average }\end{array}$ & $\begin{array}{l}<0.025 \\
<0.025\end{array}$ & $\begin{array}{l}<0.0005 \\
<0.0005\end{array}$ & $\begin{array}{l}<0.005 \\
<0.005\end{array}$ & $\begin{array}{l}<0.05 \\
<0.05\end{array}$ & $\begin{array}{l}0.111 \\
<0.075\end{array}$ & $\begin{array}{l}<0.0002 \\
<0.0002\end{array}$ & $\begin{array}{l}30.07 \\
28.94\end{array}$ & $\begin{array}{l}<0.005 \\
<0.005\end{array}$ & $\begin{array}{l}0.07 \\
0.02\end{array}$ \\
\hline $85-02(a)$ & 3 & $\begin{array}{l}\text { Maximum } \\
\text { Average }\end{array}$ & $\begin{array}{l}<0.025 \\
<0.025\end{array}$ & $\begin{array}{l}<0.0005 \\
<0.0005\end{array}$ & $\begin{array}{l}0.034 \\
0.011\end{array}$ & $\begin{array}{l}<0.05 \\
<0.05\end{array}$ & $\begin{array}{l}0.314 \\
0.105\end{array}$ & $\begin{array}{l}<0.0002 \\
<0.0002\end{array}$ & $\begin{array}{l}8.59 \\
8.03\end{array}$ & $\begin{array}{l}<0.005 \\
<0.005\end{array}$ & $\begin{array}{l}<0.02 \\
<0.02\end{array}$ \\
\hline 105.02 & 2 & $\begin{array}{l}\text { Maximum } \\
\text { Average }\end{array}$ & $\begin{array}{l}<0.025 \\
<0.025\end{array}$ & $\begin{array}{l}<0.0005 \\
<0.0005\end{array}$ & $\begin{array}{l}<0.005 \\
<0.005\end{array}$ & $\begin{array}{l}<0.05 \\
<0.05\end{array}$ & $\begin{array}{l}1.00 \\
0.896\end{array}$ & $\begin{array}{l}<0.0002 \\
<0.0002\end{array}$ & $\begin{array}{l}48.23 \\
35.14\end{array}$ & $\begin{array}{l}<0.002 \\
<0.002\end{array}$ & $\begin{array}{l}0.02 \\
<0.02\end{array}$ \\
\hline $\begin{array}{l}\text { All Other Wells } \\
(n=7)\end{array}$ & 16 & $\begin{array}{l}\text { Maximum } \\
\text { Average }\end{array}$ & $\begin{array}{l}<0.025 \\
<0.025\end{array}$ & $\begin{array}{l}<0.0005 \\
<0.0005\end{array}$ & $\begin{array}{l}<0.005 \\
<0.005\end{array}$ & $\begin{array}{l}<0.05 \\
<0.05\end{array}$ & $\begin{array}{l}<0.075 \\
<0.075\end{array}$ & $\begin{array}{l}<0.0002 \\
<0.0002\end{array}$ & $\begin{array}{l}20.12 \\
14.96\end{array}$ & $\begin{array}{l}<0.002 \\
<0.002\end{array}$ & $\begin{array}{l}0.12 \\
0.04\end{array}$ \\
\hline NYS DWS & & & 0.05 & 0.01 & 0.05 & 1.3 & 0.3 & 0.002 & (b) & 0.015 & 5.0 \\
\hline Typical MDL & & & 0.025 & 0.0005 & 0.005 & 0.05 & 0.075 & 0.0002 & 1.0 & 0.002 & 0.02 \\
\hline
\end{tabular}

MDL: Minimum Detection Limit.

(a): Upgradient Well.

(b): No Standard Specified. 
Table 5-31

BNL Site Environmental Report For Calendar Year 1994

Supply and Materiel Area

Ground Water Surveillance Wells, Chlorocarbon Data

\begin{tabular}{|c|c|c|c|c|c|c|c|c|}
\hline Location & $\begin{array}{l}\text { No. of } \\
\text { Samples }\end{array}$ & & $\begin{array}{l}\text { TCA } \\
\text { ug } / L\end{array}$ & $\begin{array}{l}\text { TCE } \\
\text { ug/L }\end{array}$ & $\begin{array}{l}\text { PCE } \\
\text { ug/L }\end{array}$ & $\begin{array}{l}\text { DCA } \\
\text { ug } / L\end{array}$ & $\begin{array}{l}\text { DCE } \\
\text { ugll }\end{array}$ & $\begin{array}{c}\text { Chloroform } \\
\text { ugh }\end{array}$ \\
\hline $85-01(a)$ & 3 & $\begin{array}{l}\text { Maximum } \\
\text { Average }\end{array}$ & $\begin{array}{l}<2.0 \\
<2.0\end{array}$ & $\begin{array}{l}<2.0 \\
<2.0\end{array}$ & $\begin{array}{l}<2.0 \\
<2.0\end{array}$ & $\begin{array}{l}<2.0 \\
<2.0\end{array}$ & $\begin{array}{l}<2.0 \\
<2.0\end{array}$ & $\begin{array}{l}<2.0 \\
<2.0\end{array}$ \\
\hline $85-02(a)$ & 3 & $\begin{array}{l}\text { Maximum } \\
\text { Average }\end{array}$ & $\begin{array}{l}<2.0 \\
<2.0\end{array}$ & $\begin{array}{l}<2.0 \\
<2.0\end{array}$ & $\begin{array}{l}<2.0 \\
<2.0\end{array}$ & $\begin{array}{l}<2.0 \\
<2.0\end{array}$ & $\begin{array}{l}<2.0 \\
<2.0\end{array}$ & $\begin{array}{l}<2.0 \\
<2.0\end{array}$ \\
\hline $85-03$ & 3 & $\begin{array}{l}\text { Maximum } \\
\text { Average }\end{array}$ & $\begin{array}{l}9.0 \\
4.7\end{array}$ & $\begin{array}{l}<2.0 \\
<2.0\end{array}$ & $\begin{array}{l}<2.0 \\
<2.0\end{array}$ & $\begin{array}{l}<2.0 \\
<2.0\end{array}$ & $\begin{array}{l}<2.0 \\
<2.0\end{array}$ & $\begin{array}{l}<2.0 \\
<2.0\end{array}$ \\
\hline $96-06$ & 3 & $\begin{array}{l}\text { Maximum } \\
\text { Average }\end{array}$ & $\begin{array}{c}110.0 \\
41.7\end{array}$ & $\begin{array}{l}<2.0 \\
<2.0\end{array}$ & $\begin{array}{l}<2.0 \\
<2.0\end{array}$ & $\begin{array}{l}<2.0 \\
<2.0\end{array}$ & $\begin{array}{l}8.0 \\
2.7\end{array}$ & $\begin{array}{l}<2.0 \\
<2.0\end{array}$ \\
\hline $96-07$ & 2 & $\begin{array}{c}\text { Maximum } \\
\text { Average }\end{array}$ & $\begin{array}{l}470.0 \\
305.0\end{array}$ & $\begin{array}{l}4.0 \\
3.5\end{array}$ & $\begin{array}{l}<2.0 \\
<2.0\end{array}$ & $\begin{array}{l}<2.0 \\
<2.0\end{array}$ & $\begin{array}{c}12.0 \\
8.0\end{array}$ & $\begin{array}{l}<2.0 \\
<2.0\end{array}$ \\
\hline $\begin{array}{l}\text { All Other Wells } \\
(n=5)\end{array}$ & 10 & $\begin{array}{l}\text { Maximum } \\
\text { Average }\end{array}$ & $\begin{array}{l}3.0 \\
<2.0\end{array}$ & $\begin{array}{l}<2.0 \\
<2.0\end{array}$ & $\begin{array}{l}<2.0 \\
<2.0\end{array}$ & $\begin{array}{l}<2.0 \\
<2.0\end{array}$ & $\begin{array}{l}<2.0 \\
<2.0\end{array}$ & $\begin{array}{l}<2.0 \\
<2.0\end{array}$ \\
\hline NYS DWS & & & 5.0 & 5.0 & 5.0 & 5.0 & 5.0 & 100.0 \\
\hline Typical MDL & & & 2.0 & 2.0 & 2.0 & 2.0 & 2.0 & 2.0 \\
\hline
\end{tabular}

MDL: $\quad$ Minimum Detection Limit

TCA: 1,1,1-trichloroethane.

TCE: Trichloroethylene.

PCE: Tetrachloroethylene.

DCA: Dichloroethane.

DCE: Dichloroethylene.

(a): Upgradient Well. 
Table 5-32

BNL Site Environmental Report for Calendar Year 1994

Supply and Materiel Area

Ground Water Surveillance Wells, BETX Data

\begin{tabular}{lccccc}
\hline Location & $\begin{array}{c}\text { No. of } \\
\text { Samples }\end{array}$ & $\begin{array}{c}\text { Benzene } \\
\text { ugh }\end{array}$ & $\begin{array}{c}\text { Ethylbenzene } \\
\text { ugh }\end{array}$ & $\begin{array}{c}\text { Toluene } \\
\text { ugh }\end{array}$ & $\begin{array}{c}\text { Xylene } \\
\text { ugh }\end{array}$ \\
\hline $\begin{array}{l}\text { All Wells } \\
(n=10)\end{array}$ & 24 & $\begin{array}{c}\text { Maximum } \\
\text { Average }\end{array}$ & $<2.0$ & $<2.0$ & $<2.0$ \\
NYS DWS & & 5.0 & $<2.0$ & $<2.0$ & $<2.0$ \\
Typical MDL & & 2.0 & 5.0 & 5.0 & 5.0 \\
\hline
\end{tabular}

MDL: Minimum Detection Limit. 


\section{SUPPLY \& MATERIEL}
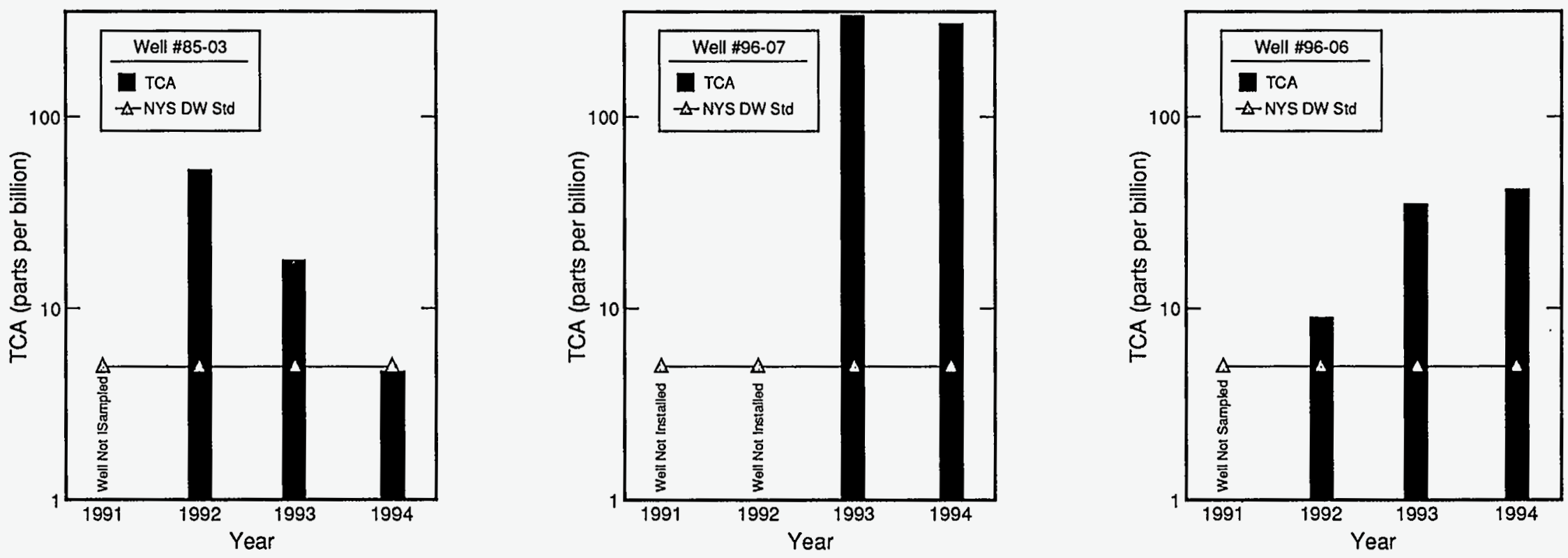

Figure 5-18 1,1,1-trichloroethane concentration trends in wells located within and downgradient of the Supply and Materiel Area (S\&M): Well 85-03 located in northern portion of the S\&M Area and downgradient of Building T-86; Well 96-07 located 60m downgradient of Building 208; and Well 96-06 located 225m downgradient of Building 208. 
Building 479 Area: In 1992, a single shallow Upper Glacial aquifer well (95-04) was installed to investigate a lubricating oil spill in the heavy machine shop located in Building 479. During 1994, Well 95-04 (Figure 5-7) was sampled for water quality, vocs, metals, and floating product. Water quality analysis indicated that the $\mathrm{pH}$ of the groundwater is below the lower limit of the NYS AWQS of 6.5 - 8.5, with a median $\mathrm{pH}$ of 5.85. Other water quality parameters were below the applicable NYS AWQS. No floating product was observed, and the results from VOC and metals analyses of the groundwater sample indicated that all VoC and metals concentrations were below the applicable NYS DWS. Additionally, as the result of an extensive PCB/hydrocarbon contaminated soil removal action in another portion of the Building 479 complex, groundwater quality in the Building 479 area will be assessed in greater detail during the OU III RI/FS.

North Boundary Area: Along the north boundary of BNL, eleven surveillance wells monitor background (ambient) water conditions. These wells consist of shallow, intermediate, and deep Upper Glacial aquifer wells, and one upper Magothy aquifer well (Figures 5-2 and 5-3). During 1994, these wells were sampled for water quality, Vocs, and metals (Tables 5-33 to 5-36). Water quality analyses indicate that the $\mathrm{pH}$ of the groundwater samples collected from the shallow to middle Upper Glacial aquifer welis were typically below the lower limit of the NYS AwQS of 6.5 - 8.5, with a median $\mathrm{pH}$ of 6.00, whereas the $\mathrm{pH}$ measurements for samples form deep Glacial and Magothy wells were typically within the NYS AWQS with a median pH of 7.20. Nitrate concentrations exceeded NYS AWQS in deep Upper Glacial Well 17-03 at $10.8 \mathrm{mg} / \mathrm{L}$. Results for metals analyses indicated that iron concentrations were above the NYS DWS in two wells. Analysis of groundwater samples for VOCs indicate that TCA and DCA were detected in deep Upper Glacial Well 18-03 at maximum concentrations of $6 \mu \mathrm{g} / \mathrm{I}$ and $6 \mu \mathrm{g} / \mathrm{L}$, respectively. The nitrates detected in Well 17-03 and vocs detected in well 18-03 signify the migration of contaminants from off-site areas onto the BNI site.

Fest Sector Area: Potable and process supply wells located in the west sector of the developed area of the BNL site have been impacted by low level voc contamination (principally TCA). Groundwater contamination in this area has originated from source areas located in the upgradient AGs experimental areas, operations at the Paint Shop, and possibly from sewer line leaks. Moreover, the combined pumpage from the supply wells have resulted in considerable deviations in groundwater flow directions (horizontally and vertically) and the commingling of contaminant plumes. Source area characterization and groundwater contamination will be assessed in the west sector area, specifically in the vicinity of the Paint Shop, Potable Well 4, decommissioned Potable Well 2, and Process Supply Wells 9, 104, and 105, during the OU III RI/FS which is scheduled to begin in 1995. The west sector of BNL is currently monitored by ten shallow to middle Upper Glacial aquifer surveillance wells (Figures 5-4 and 5-7). During 1994, nine wells were sampled for water quality, metals, and vocs (Tables 5-33 to 5-36). Water quality analyses indicate that the $\mathrm{pH}$ of the groundwater samples collected was typically below the lower limit of the NYS AWQS of $6.5-8.5$, with a median $\mathrm{pH}$ of 6.3. All other water quality parameters were below applicable NYS AWQS. Metals analyses indicate that all metals concentrations were below the applicable NYS DWS. Groundwater samples from Well 83-02 exceeded the NYS DWS for TCA, with a maximum observed concentration of $11 \mu \mathrm{g} / \mathrm{I}$. Trend plots for TCA based on data for Well 83-02 is presented in Figure 5-19.

South Boundary Area:' Due to the direction of groundwater flow, groundwater contamination resulting from chemical releases in the central developed area of the site (e.g., the AGS experimental areas, Waste Concentration Facility, Former Building T-111, Paint Shop, and the Supply and Materiel Warehouse area) would ultimately migrate to BNL's south/southwestern boundary prior to migrating offsite. Groundwater surveillance using a limited number of permanent on-site 
Table 5-33

BNL Site Environmental Report for Calendar Year 1994

North, West and South Sectors

Ground Water Surveillance Wells, Water Quality Data

\begin{tabular}{|c|c|c|c|c|c|c|c|c|c|c|}
\hline \multirow[t]{2}{*}{$\begin{array}{l}\text { Well } \\
\text { Id. No. }\end{array}$} & \multirow[t]{2}{*}{$\begin{array}{l}\text { No. of } \\
\text { Samples }\end{array}$} & \multirow{2}{*}{$\begin{array}{c}\text { pH } \\
\text { sU }\end{array}$} & \multicolumn{2}{|c|}{$\begin{array}{l}\text { Conductivity } \\
\text { umhos } / \mathrm{cm}\end{array}$} & \multicolumn{2}{|c|}{$\begin{array}{l}\text { Chlorides } \\
\text { mg/L }\end{array}$} & \multicolumn{2}{|c|}{$\begin{array}{l}\text { Sulfates } \\
\text { mg/l }\end{array}$} & \multicolumn{2}{|c|}{$\begin{array}{c}\text { Nitrate as } N(b) \\
\text { mg/L }\end{array}$} \\
\hline & & & Max. & Avg. & Max. & Avg. & Max. & Avg. & Max. & Avg. \\
\hline \multicolumn{11}{|l|}{ North Sector } \\
\hline $\begin{array}{l}07-03 \\
13-01 \\
17-01 \\
17-02 \\
17-03 \\
17-04 \\
18-01 \\
18-02 \\
18-03 \\
25-01 \\
25-02\end{array}$ & $\begin{array}{l}2 \\
2 \\
3 \\
3 \\
3 \\
3 \\
3 \\
3 \\
3 \\
2 \\
2\end{array}$ & $\begin{array}{l}6.0-6.1 \\
5.6-5.7 \\
5.1-5.8 \\
5.4-5.8 \\
5.6-6.0 \\
6.8-7.6 \\
5.4-5.5 \\
5.5-5.8 \\
5.5-6.9 \\
5.4-5.5 \\
5.2-5.4\end{array}$ & $\begin{array}{c}51.2 \\
45.5 \\
105.3 \\
248.6 \\
328.2 \\
136.8 \\
46.3 \\
71 \\
223 \\
57 \\
225\end{array}$ & $\begin{array}{c}46 \\
42.9 \\
86 \\
227 \\
305.9 \\
121 \\
45.6 \\
62.2 \\
170.7 \\
56.8 \\
201\end{array}$ & $\begin{array}{c}5.3 \\
5.2 \\
8.4 \\
40 \\
40 \\
5.7 \\
5.8 \\
9.5 \\
16.5 \\
7.4 \\
62.3\end{array}$ & $\begin{array}{c}4.8 \\
4.6 \\
7.8 \\
39.1 \\
38.5 \\
5.5 \\
<4.0 \\
8.2 \\
13.7 \\
7.2 \\
56.4\end{array}$ & $\begin{array}{l}<4.0 \\
6.4 \\
24.1 \\
19.4 \\
30.9 \\
<4.0 \\
6.6 \\
7.7 \\
13.7 \\
7.5 \\
12.2\end{array}$ & $\begin{array}{c}<4.0 \\
6.1 \\
15 \\
18.9 \\
30.5 \\
<4.0 \\
6.3 \\
7.2 \\
12.4 \\
7.4 \\
10.9\end{array}$ & $\begin{array}{l}<1.0 \\
<1.0 \\
<1.0 \\
6.5 \\
10.8 \\
<1.0 \\
<1.0 \\
<1.0 \\
4.7 \\
<1.0 \\
<1.0\end{array}$ & $\begin{array}{l}<1.0 \\
<1.0 \\
<1.0 \\
5.9 \\
10.7 \\
<1.0 \\
<1.0 \\
<1.0 \\
2.3 \\
<1.0 \\
<1.0\end{array}$ \\
\hline \multicolumn{11}{|l|}{ West Sector } \\
\hline $\begin{array}{c}72-01 \\
83-01 \\
83-02 \\
84-01 \\
94-01 \\
101-01 \\
102-01 \\
103-01 \\
103-02\end{array}$ & $\begin{array}{l}3 \\
3 \\
3 \\
2 \\
2 \\
3 \\
2 \\
3 \\
3\end{array}$ & $\begin{array}{c}5.3-5.6 \\
6.0-6.3 \\
6.0-6.2 \\
5.9-6.0 \\
6.0 \\
5.8-6.4 \\
5.1-5.7 \\
6.5-7.0 \\
6.8-7.3\end{array}$ & $\begin{array}{c}60.6 \\
125 \\
125.5 \\
163.2 \\
145.1 \\
144.7 \\
139.2 \\
129 \\
98.82\end{array}$ & $\begin{array}{c}59 \\
122.7 \\
120.3 \\
73.8 \\
136.8 \\
105.7 \\
129.2 \\
124.9 \\
96.5\end{array}$ & $\begin{array}{c}8.1 \\
20.1 \\
16.6 \\
28.9 \\
10 \\
41.3 \\
27.3 \\
19 \\
6.2\end{array}$ & $\begin{array}{c}7.7 \\
19.2 \\
16.2 \\
26.2 \\
9.7 \\
32.1 \\
22.4 \\
16.5 \\
6.2\end{array}$ & $\begin{array}{c}10 \\
10.3 \\
10.6 \\
11.8 \\
21.6 \\
9.5 \\
15.5 \\
11.1 \\
12.6\end{array}$ & $\begin{array}{c}9.3 \\
10.1 \\
9.9 \\
11.6 \\
17.7 \\
7.7 \\
14.3 \\
10.9 \\
10.5\end{array}$ & $\begin{array}{l}<1.0 \\
<1.0 \\
<1.0 \\
<1.0 \\
2.6 \\
1.5 \\
<1.0 \\
<1.0 \\
<1.0\end{array}$ & $\begin{array}{l}<1.0 \\
<1.0 \\
<1.0 \\
<1.0 \\
2.3 \\
<1.0 \\
<1.0 \\
<1.0 \\
<1.0\end{array}$ \\
\hline \multicolumn{11}{|l|}{ South Sector } \\
\hline $\begin{array}{l}118-01 \\
118-02 \\
122-01 \\
122-02 \\
126-01 \\
130-02 \\
130-03\end{array}$ & $\begin{array}{l}3 \\
3 \\
3 \\
3 \\
3 \\
3 \\
2\end{array}$ & $\begin{array}{l}5.4-6.0 \\
5.6-6.1 \\
5.6-5.8 \\
5.7-5.9 \\
5.0-5.7 \\
5.3-5.9 \\
5.9-6.5\end{array}$ & $\begin{array}{c}88.7 \\
132 \\
43.6 \\
127.8 \\
59.6 \\
161.4 \\
161.4\end{array}$ & $\begin{array}{c}81.8 \\
128.3 \\
43.5 \\
122.7 \\
53.3 \\
149.2 \\
159.5\end{array}$ & $\begin{array}{c}14.1 \\
27.7 \\
6 \\
19.7 \\
5.2 \\
25.6 \\
23.8\end{array}$ & \begin{tabular}{c|}
11.6 \\
27.4 \\
5.9 \\
16.6 \\
4.8 \\
24.3 \\
23.6
\end{tabular} & $\begin{array}{c}8.8 \\
9 \\
6.4 \\
16.4 \\
10 \\
19.2 \\
13.9\end{array}$ & $\begin{array}{c}7.5 \\
8.8 \\
5.8 \\
12 \\
9.8 \\
19 \\
13.4\end{array}$ & $\begin{array}{l}<1.0 \\
<1.0 \\
<1.0 \\
<1.0 \\
<1.0 \\
1.3 \\
1.4\end{array}$ & $\begin{array}{l}<1.0 \\
<1.0 \\
<1.0 \\
<1.0 \\
<1.0 \\
1.2 \\
1.4\end{array}$ \\
\hline $\begin{array}{l}\text { NYS Ambient Water } \\
\text { Quality Standard }\end{array}$ & & $6.5-8.5$ & (c) & - & 250 & - & 250 & - & 10 & - \\
\hline Typical MDL & & - & 10 & & 4 & & 4 & & 1 & \\
\hline
\end{tabular}

MDL: Minimum Detection Limit.
(a): Upgradient Well.
(b): Holding time expired for all samples.
(c): No standard specified. 
Table 5-34

BNL Site Environmental Report for Calendar Year 1994

North Boundary, West Sector, Southern Boundary

Ground Water Surveillance Wells, Metals Data

\begin{tabular}{|c|c|c|c|c|c|c|c|c|c|c|c|}
\hline Location & $\begin{array}{l}\text { No. of } \\
\text { Samples }\end{array}$ & & $\underset{\mathrm{mg} / \mathrm{L}}{\mathrm{Ag}}$ & $\begin{array}{c}\text { Cd } \\
\text { mg/L }\end{array}$ & $\begin{array}{c}\mathrm{Cr} \\
\mathrm{mg} / \mathrm{L}\end{array}$ & $\underset{m g / L}{C u}$ & $\begin{array}{c}\mathrm{Fe} \\
\mathrm{mg} / \mathrm{h}\end{array}$ & $\underset{\mathrm{mg} / \mathrm{L}}{\mathrm{Hg}}$ & $\underset{\mathrm{mg} / \mathrm{L}}{\mathrm{Na}}$ & $\begin{array}{c}\mathrm{Pb} \\
\mathrm{mg} / \mathrm{L}\end{array}$ & $\begin{array}{l}\mathrm{Zn} \\
\mathrm{mglh}\end{array}$ \\
\hline \multicolumn{12}{|c|}{ North Boundary(a) } \\
\hline $07-03$ & 2 & $\begin{array}{l}\text { Maximum } \\
\text { Average }\end{array}$ & $\begin{array}{l}<0.025 \\
<0.025\end{array}$ & $\begin{array}{l}0.0005 \\
<0.0005\end{array}$ & $\begin{array}{l}<0.005 \\
<0.005\end{array}$ & $\begin{array}{l}<0.05 \\
<0.05\end{array}$ & $\begin{array}{l}3.43 \\
3.04\end{array}$ & $\begin{array}{l}<0.0002 \\
<0.0002\end{array}$ & $\begin{array}{l}2.48 \\
1.39\end{array}$ & $\begin{array}{l}<0.002 \\
<0.002\end{array}$ & $\begin{array}{l}3.6 \\
1.8\end{array}$ \\
\hline $17-01$ & 3 & $\begin{array}{l}\text { Maximum } \\
\text { Average }\end{array}$ & $\begin{array}{l}<0.025 \\
<0.025\end{array}$ & $\begin{array}{l}<0.0005 \\
<0.0005\end{array}$ & $\begin{array}{l}<0.005 \\
<0.005\end{array}$ & $\begin{array}{l}<0.05 \\
<0.05\end{array}$ & $\begin{array}{l}0.34 \\
0.11\end{array}$ & $\begin{array}{l}<0.0002 \\
<0.0002\end{array}$ & $\begin{array}{l}7.75 \\
6.57\end{array}$ & $\begin{array}{l}<0.002 \\
<0.002\end{array}$ & $\begin{array}{l}0.05 \\
<0.02\end{array}$ \\
\hline $\begin{array}{l}\text { All Other Wells } \\
(n=9)\end{array}$ & 24 & $\begin{array}{l}\text { Maximum } \\
\text { Average }\end{array}$ & $\begin{array}{l}<0.025 \\
<0.025\end{array}$ & $\begin{array}{l}<0.0005 \\
<0.0005\end{array}$ & $\begin{array}{l}0.009 \\
<0.005\end{array}$ & $\begin{array}{l}<0.05 \\
<0.05\end{array}$ & $\begin{array}{l}0.247 \\
<0.075\end{array}$ & $\begin{array}{l}<0.0002 \\
<0.0002\end{array}$ & $\begin{array}{l}40.47 \\
12.35\end{array}$ & $\begin{array}{l}<0.002 \\
<0.002\end{array}$ & $\begin{array}{c}0.05 \\
<0.020\end{array}$ \\
\hline \multicolumn{12}{|l|}{ West Sector } \\
\hline $83-02$ & 3 & $\begin{array}{l}\text { Maximum } \\
\text { Average }\end{array}$ & $\begin{array}{l}<0.025 \\
<0.025\end{array}$ & $\begin{array}{l}<0.0005 \\
<0.0005\end{array}$ & $\begin{array}{l}<0.005 \\
<0.005\end{array}$ & $\begin{array}{l}<0.05 \\
<0.05\end{array}$ & $\begin{array}{l}0.337 \\
0.223\end{array}$ & $\begin{array}{l}<0.0002 \\
<0.0002\end{array}$ & $\begin{array}{l}11.22 \\
11.77\end{array}$ & $\begin{array}{l}<0.002 \\
<0.002\end{array}$ & $\begin{array}{l}<0.02 \\
<0.02\end{array}$ \\
\hline $\begin{array}{l}\text { All Other Wells } \\
(n=8)\end{array}$ & 21 & $\begin{array}{l}\text { Maximum } \\
\text { Average }\end{array}$ & $\begin{array}{l}<0.025 \\
<0.025\end{array}$ & $\begin{array}{l}<0.0005 \\
<0.0005\end{array}$ & $\begin{array}{l}<0.005 \\
<0.005\end{array}$ & $\begin{array}{l}<0.05 \\
<0.05\end{array}$ & $\begin{array}{l}0.156 \\
<0.075\end{array}$ & $\begin{array}{l}<0.0002 \\
<0.0002\end{array}$ & $\begin{array}{l}23.52 \\
11.32\end{array}$ & $\begin{array}{l}<0.002 \\
<0.002\end{array}$ & $\begin{array}{l}0.11 \\
0.03\end{array}$ \\
\hline \multicolumn{12}{|c|}{ Southern Boundary(b) } \\
\hline $\begin{array}{l}\text { All Wells } \\
(n=7)\end{array}$ & 21 & $\begin{array}{l}\text { Maximum } \\
\text { Average }\end{array}$ & $\begin{array}{l}<0.025 \\
<0.025\end{array}$ & $\begin{array}{l}<0.0005 \\
<0.0005\end{array}$ & $\begin{array}{c}0.008 \\
<0.005\end{array}$ & $\begin{array}{l}<0.05 \\
<0.05\end{array}$ & $\begin{array}{l}0.228 \\
<0.075\end{array}$ & $\begin{array}{l}<0.0002 \\
<0.0002\end{array}$ & $\begin{array}{l}17.74 \\
9.72\end{array}$ & $\begin{array}{l}0.003 \\
<0.002\end{array}$ & $\begin{array}{l}0.08 \\
<0.02\end{array}$ \\
\hline NYS DWS & & & 0.05 & 0.01 & 0.05 & 1.3 & 0.3 & 0.002 & (c) & 0.015 & 5.0 \\
\hline Typical MDL & & & 0.025 & 0.0005 & 0.005 & 0.5 & 0.075 & 0.0002 & 1.0 & 0.002 & 0.02 \\
\hline
\end{tabular}

MDL: Minimum Detection Limit.

(a): North Boundary Wells monitor background water quality for site.

(b): South Boundary Wells monitoring Hazardous Waste Management Facility and Current Landfill not included.

(c): No Standard Specified. 
Table 5-35

BNL Site Environmental Report for Calendar Year 1994

North Boundary, West Sector, and South Boundary

Ground Water Surveillance Wells, Chlorocarbon Data

\begin{tabular}{|c|c|c|c|c|c|c|c|c|}
\hline Location & $\begin{array}{l}\text { No. of } \\
\text { Samples }\end{array}$ & & $\begin{array}{l}\text { TCA } \\
\text { ugn }\end{array}$ & $\begin{array}{l}\text { TCE } \\
\text { ug/L }\end{array}$ & $\begin{array}{l}\text { PCE } \\
\text { ughl }\end{array}$ & $\begin{array}{l}\text { DCA } \\
\text { ugh }\end{array}$ & $\begin{array}{l}\text { DCE } \\
\text { ugh }\end{array}$ & $\begin{array}{c}\text { Chloroform } \\
\text { ugh }\end{array}$ \\
\hline \multicolumn{9}{|c|}{ North Boundary $\langle a\rangle$} \\
\hline $18-03$ & 3 & $\begin{array}{l}\text { Maximum } \\
\text { Average }\end{array}$ & $\begin{array}{l}6.0 \\
3.9\end{array}$ & $\begin{array}{l}<2.0 \\
<2.0\end{array}$ & $\begin{array}{l}<2.0 \\
<2.0\end{array}$ & $\begin{array}{l}6.0 \\
3.3\end{array}$ & $\begin{array}{l}<2.0 \\
<2.0\end{array}$ & $\begin{array}{l}<2.0 \\
<2.0\end{array}$ \\
\hline $\begin{array}{l}\text { All Other Wells } \\
(n=10)\end{array}$ & 26 & $\begin{array}{l}\text { Maximum } \\
\text { Average }\end{array}$ & $\begin{array}{l}<2.0 \\
<2.0\end{array}$ & $\begin{array}{l}<2.0 \\
<2.0\end{array}$ & $\begin{array}{l}<2.0 \\
<2.0\end{array}$ & $\begin{array}{l}<2.0 \\
<2.0\end{array}$ & $\begin{array}{l}<2.0 \\
<2.0\end{array}$ & $\begin{array}{l}<2.0 \\
<2.0\end{array}$ \\
\hline \multicolumn{9}{|l|}{ West Sector } \\
\hline $83-02$ & 3 & $\begin{array}{l}\text { Maximum } \\
\text { Average }\end{array}$ & $\begin{array}{l}11.0 \\
11.0\end{array}$ & $\begin{array}{l}<2.0 \\
<2.0\end{array}$ & $\begin{array}{l}<2.0 \\
<2.0\end{array}$ & $\begin{array}{l}<2.0 \\
<2.0\end{array}$ & $\begin{array}{l}<2.0 \\
<2.0\end{array}$ & $\begin{array}{l}10 \\
8.7\end{array}$ \\
\hline $\begin{array}{l}\text { All Other Wells } \\
(n=8)\end{array}$ & 21 & $\begin{array}{l}\text { Maximum } \\
\text { Average }\end{array}$ & $\begin{array}{l}<2.0 \\
<2.0\end{array}$ & $\begin{array}{l}<2.0 \\
<2.0\end{array}$ & $\begin{array}{l}<2.0 \\
<2.0\end{array}$ & $\begin{array}{l}<2.0 \\
<2.0\end{array}$ & $\begin{array}{l}<2.0 \\
<2.0\end{array}$ & $\begin{array}{l}25 \\
3.4\end{array}$ \\
\hline \multicolumn{9}{|c|}{ South Boundary (a) } \\
\hline $103-02$ & 3 & $\begin{array}{l}\text { Maximum } \\
\text { Average }\end{array}$ & $\begin{array}{c}10.0 \\
9.3\end{array}$ & $\begin{array}{l}6.0 \\
4.7\end{array}$ & $\begin{array}{l}<2.0 \\
<2.0\end{array}$ & $\begin{array}{l}<2.0 \\
<2.0\end{array}$ & $\begin{array}{l}3.0 \\
2.6\end{array}$ & $\begin{array}{l}3.0 \\
3.0\end{array}$ \\
\hline $130-03$ & 2 & $\begin{array}{l}\text { Maximum } \\
\text { Average }\end{array}$ & $\begin{array}{l}7.0 \\
6.5\end{array}$ & $\begin{array}{l}12.0 \\
11.5\end{array}$ & $\begin{array}{l}<2.0 \\
<2.0\end{array}$ & $\begin{array}{l}<2.0 \\
<2.0\end{array}$ & $\begin{array}{l}3.0 \\
2.5\end{array}$ & $\begin{array}{l}7.0 \\
6.5\end{array}$ \\
\hline $\begin{array}{l}\text { All Other Wells } \\
(n=5)\end{array}$ & 15 & $\begin{array}{l}\text { Maximum } \\
\text { Average }\end{array}$ & $\begin{array}{l}<2.0 \\
<2.0\end{array}$ & $\begin{array}{l}<2.0 \\
<2.0\end{array}$ & $\begin{array}{l}<2.0 \\
<2.0\end{array}$ & $\begin{array}{l}<2.0 \\
<2.0\end{array}$ & $\begin{array}{l}<2.0 \\
<2.0\end{array}$ & $\begin{array}{l}<2.0 \\
<2.0\end{array}$ \\
\hline NYS DWS & & & 5.0 & 5.0 & 5.0 & 5.0 & 5.0 & 5.0 \\
\hline Typical MDL & & & 2.0 & 2.0 & 2.0 & 2.0 & 2.0 & 2.0 \\
\hline
\end{tabular}

MDL: Minimum Detection Limit.

TCA: 1,1,1-trichloroethane.

TCE: Trichloroethylene.

PCE: Tetrachloroethylene.

DCA: Dichloroethane.

DCE: Dichloroethylene.

(a): North Boundary Wells monitor background water quality for site.

(b): South Boundary Wells monitoring Hazardous Waste Management Facility and Current Landfill not included. 
Table 5-36

BNL Site Environmental Report for Calendar Year 1994

North Boundary, West Sector, and South Boundary

Ground Water Surveillance Wells, BETX Data

\begin{tabular}{|c|c|c|c|c|c|c|}
\hline Location & $\begin{array}{l}\text { No. of } \\
\text { Sample }\end{array}$ & & $\begin{array}{c}\text { Benzene } \\
\text { ugh }\end{array}$ & $\begin{array}{c}\text { Ethylbenzene } \\
\text { ug/L }\end{array}$ & $\begin{array}{c}\text { Toluene } \\
\text { ug/. }\end{array}$ & $\begin{array}{l}\text { Xylene } \\
\text { ugh }\end{array}$ \\
\hline \multicolumn{7}{|l|}{ North Boundary (a) } \\
\hline $\begin{array}{l}\text { All Wells } \\
(n=11)\end{array}$ & 29 & $\begin{array}{l}\text { Maximum } \\
\text { Average }\end{array}$ & $\begin{array}{l}<2.0 \\
<2.0\end{array}$ & $\begin{array}{l}<2.0 \\
<2.0\end{array}$ & $\begin{array}{l}<2.0 \\
<2.0\end{array}$ & $\begin{array}{l}<2 \\
<2\end{array}$ \\
\hline \multicolumn{7}{|l|}{ West Sector } \\
\hline $\begin{array}{l}\text { All Wells } \\
(n=9)\end{array}$ & 24 & $\begin{array}{l}\text { Maximum } \\
\text { Average }\end{array}$ & $\begin{array}{l}<2.0 \\
<2.0\end{array}$ & $\begin{array}{l}<2.0 \\
<2.0\end{array}$ & $\begin{array}{l}<2.0 \\
<2.0\end{array}$ & $\begin{array}{l}<2 \\
<2\end{array}$ \\
\hline \multicolumn{7}{|l|}{ South Boundary (b) } \\
\hline $\begin{array}{l}\text { All Wells } \\
(n=7)\end{array}$ & 20 & $\begin{array}{l}\text { Maximum } \\
\text { Average }\end{array}$ & $\begin{array}{l}<2.0 \\
<2.0\end{array}$ & $\begin{array}{l}<2.0 \\
<2.0\end{array}$ & $\begin{array}{l}<2.0 \\
<2.0\end{array}$ & $\begin{array}{l}<2 \\
<2\end{array}$ \\
\hline NYS DWS & & & 5.0 & 5.0 & 5.0 & 5.0 \\
\hline Typical MDL & & & 2.0 & 2.0 & 2.0 & 2.0 \\
\hline
\end{tabular}

MDL: Minimum Detection Limit.

(a): North Boundary Wells monitor background water quality for site.

(b): South Boundary Wells monitoring Hazardous Waste Management Facility and Current Landfill not included. 


\section{SOUTH BOUNDARY}
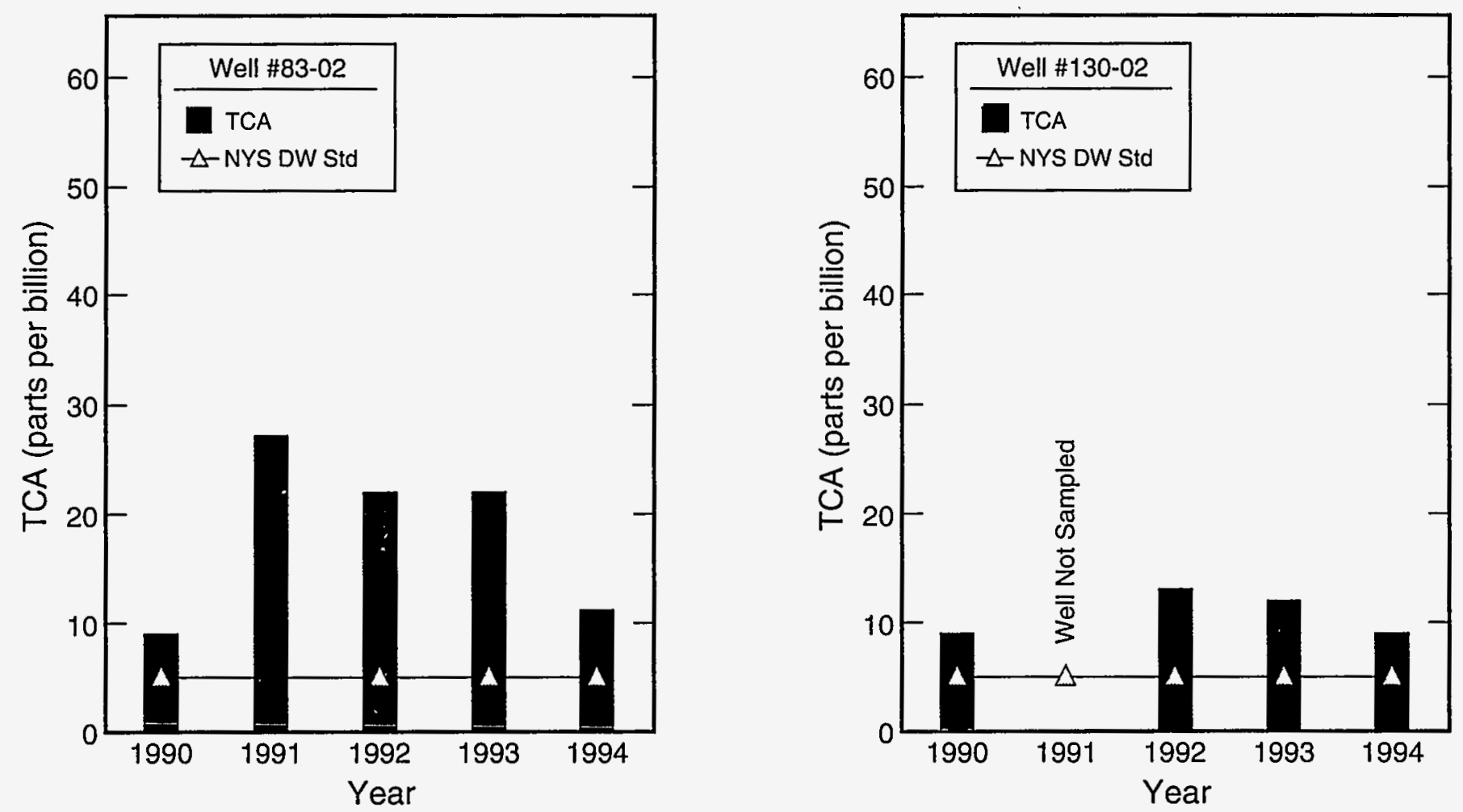

Figure 5-19 1,1,1-trichloroethane (TCA) concentration trends in wells located within the West Sector and southwestern boundary of the BNL site: Well 83-02 located in the Paint Shop and Potable Well 4 area; and Well 130-02 located near the BNL South Gate area. 
wells; and temporary off-site wells, indicates that low level vocs have migrated beyond the BNL boundary. The surveillance well network along BNL's southern (downgradient) boundary, currently consists of seven wells which monitor the shallow, intermediate, and deep portions of the Upper Glacial aquifer. (South Boundary surveillance wells monitoring the current Landfill and HWMF are not included in this summary). During 1994, the seven wells were sampled for water quality, metals, and vocs. (Tables 5-33 to 5-36). Water quality analyses indicate that the $\mathrm{pH}$ of the groundwater samples collected was typically below the lower limit of the NYS AWQS of 6.5 - 8.5, with a median pH of 5.75. All other water quality parameters were below applicable NYS AWQS. All metals concentrations were below NYS DWS. Both TCA and TCE were detected in Wells 130-02 and 130-03 at concentrations that exceed the NYS DWS. In Well 130-02, maximum observed concentrations of $10 \mu \mathrm{g} / \mathrm{L}$ and $6 \mu \mathrm{g} / \mathrm{L}$, respectively. TCA and TCE were detected in Vell 130-03, at maximum observed concentrations of $7 \mu \mathrm{g} / \mathrm{L}$ and $12 \mu \mathrm{g} / \mathrm{L}$, respectively. Examination of the extent of groundwater contamination detected in Wells 130-02 and 130-03, and off-site contamination detected in wells downgradient of the BNL boundary, will be conducted during the OU III RI/FS which is scheduled to begin in 1995. Trend plots for TCA based on data for Well 130-02 are presented in Figure 5-19.

\subsubsection{Radiological Analyses}

In 1994, the cooperative program between BNL and the SCDHS continued for the collection and analysis of samples from wells serving private homes. As part of this program, samples were collected quarterly from 26 private drinking water wells in suffolk County and one from the Peconic River. Twelve of these sampling stations were from homes near the Laboratory, with the remainder from locations randomly selected by SCDHS. Samples were analyzed for gross alpha, gross beta, and tritium on a quarterly basis, while analyses for gamma spectroscopy were performed annually. Results from this program are presented in Table 5-37 and indicate that tritium was detected in samples collected from five locations adjacent to the Laboratory. (One location was a sampling point along the Peconic River and four locations were private potable wells.) The private wells, sampled in the this program, are screened at depths ranging from 50 to 200 feet and had annual average tritium concentrations that ranged from below detection limits to $1703 \mathrm{pCi} / \mathrm{L}(\mathrm{Bq} / \mathrm{L})$. Although above background, these data were consistent with data collected since 1979, and were less than 9\% of concentration limits and 3\% of the dose limit specified by the NYS DWS for community water supplies. Gamma spectro-scopy results from these private wells in 1994 indicated the presence of trace quantities of world-wide fallout radionuclides cesium-137, and of naturally occurring K-40. In most of the samples, the observed concentrations were below the detection limit but above the two sigma counting error. They are reported as trace for trending purposes. The Peconic River sampling location was observed to contain cesium-137.

The data for the samples collected from control wells, wells in the North Boundary and West Sectors, South Boundary, central part of the BNL site, RHIC, the Current and Former Landfills, Former Army Landfill, Ash Repository, MPF, CSF, Peconic River on site/off site, Meadow Marsh-Upland Recharge, and the HWM areas are shown in Tables 5-38, 5-39, 5-40, 5-41, 5-42 and 5-43.

Sewage Treatment Plant/Reconic River/Meadow Marsh - Upland Recharge Areas: The yearly average concentrations of radionuclides in samples from the wells adjacent to the sand filter beds at the STP, downstream of the Peconic River, and adjacent to the Meadow Marsh-Upland Recharge Area are summarized in Table 5-38. The location of these wells are presented in Figures 5-5, 5-6 and 5-9. Elevated gross beta, tritium, and cesium-137 concentrations have been found in on-site wells adjacent to the sand filter beds and the Peconic River. The observed levels are probably attributable to losses from the tile collection field 
Table 5-37

BNL Site Environmental Report for Calendar Year 1994

Radionuclide Concentrations in Off-Site Potable wells

\begin{tabular}{|c|c|c|c|c|c|c|c|}
\hline $\begin{array}{l}\text { Sample } \\
\text { Location }\end{array}$ & $\begin{array}{c}\text { No. of } \\
\text { Samples }\end{array}$ & $\begin{array}{c}\text { Gross Alpha } \\
\text { Average }\end{array}$ & Maximum & $\begin{array}{c}\text { Gross Beta } \\
\text { Average }\end{array}$ & Maximum & $\begin{array}{l}\text { Tritium } \\
\text { Average }\end{array}$ & Maximum \\
\hline 1 & 3 & 0.22 & 0.27 & 13.44 & 24.5 & 1408 & 1780 \\
\hline 2 & 4 & 0.64 & 0.96 & 0.84 & 2.02 & 1703 & 2224 \\
\hline 3 & 4 & 0.01 & 0.23 & 1.19 & 1.7 & 1696 & 2193 \\
\hline 4 & 4 & 0.36 & 0.71 & 1.97 & 2.36 & 1442 & 1970 \\
\hline 5 & 3 & 0.26 & 1.28 & 1.47 & 1.9 & 200 & 382 \\
\hline 6 & 3 & -0.05 & 0.15 & 3.47 & 3.83 & -13 & 245 \\
\hline 7 & 1 & 0 & 0 & 5.4 & 5.4 & 148 & 148 \\
\hline 8 & 3 & 0.06 & 0.12 & 0.88 & 0.91 & 70 & 153 \\
\hline 9 & 3 & -0.38 & 0 & 1.2 & 2.4 & 32 & 107 \\
\hline 10 & 2 & 0 & 0 & 1.05 & 1.45 & -65 & 411 \\
\hline 11 & 2 & -0.11 & 0.11 & 1.26 & 2.22 & -130 & 267 \\
\hline 12 & 2 & -0.24 & 0.45 & 1.11 & 1.84 & -25 & 60 \\
\hline 13 & 2 & -0.41 & 0 & 0.18 & 0.61 & -46 & 116 \\
\hline 14 & 4 & 0.2 & 0.51 & 1.68 & 2.61 & -74 & 186 \\
\hline 15 & 4 & 0.12 & 0.55 & 1.8 & 3.29 & -65 & 233 \\
\hline 16 & 3 & 0.22 & 0.58 & 8.05 & 22.8 & 21 & 150 \\
\hline 17 & 2 & 0.41 & 0.71 & 1.19 & 1.78 & -205 & 106 \\
\hline 18 & 2 & -0.09 & 0 & 1.19 & 1.23 & -248 & 55 \\
\hline 19 & 2 & 0.1 & 0.29 & 1.96 & 2.81 & -315 & -90 \\
\hline 20 & 2 & 0.63 & 1.08 & 0.52 & 0.55 & -332 & -148 \\
\hline 21 & 2 & -0.09 & 0.29 & 0.6 & 0.71 & -77 & -25 \\
\hline 22 & 3 & -0.07 & 0 & 0.88 & 1.18 & -174 & 6 \\
\hline 23 & 1 & 0.31 & 0.31 & 3.28 & 3.28 & -112 & -112 \\
\hline 24 & 2 & 0.37 & 1.51 & -0.74 & 2.19 & 1180 & 1191 \\
\hline 25 & 2 & 0.06 & 0.28 & 0.02 & 0.65 & -308 & -122 \\
\hline 26 & 1 & 0 & 0 & 0.69 & 0.69 & -604 & -604 \\
\hline 27 & 1 & -0.39 & -0.39 & 0.16 & 0.16 & -582 & -582 \\
\hline \multirow{2}{*}{\multicolumn{2}{|c|}{$\begin{array}{l}\text { NYS Drinking Water } \\
\text { Standard } \\
\text { Typical MDL }\end{array}$}} & 15 & & 50 & & 20,000 & \\
\hline & & 0.53 & & 1.2 & & 300 & \\
\hline
\end{tabular}

PR : Peconic River sampling point.

MDL: Minimum Detection Limit 
Table $5-38$

BNL stte Environmental Report for Calendar Year 199

Peconic River On-site/Ori-site, Meadow Marsh/Upland Recharge Area

Oround Water Surveillance Wells, Radloactivity Data

\begin{tabular}{|c|c|c|c|c|c|c|c|c|c|}
\hline Area & sample & $\begin{array}{l}\text { No. of } \\
\text { samples }\end{array}$ & DS & $\begin{array}{l}\text { Gross Alpha } \\
\text { pCîl }\end{array}$ & $\begin{array}{c}\text { Oross Beta } \\
\text { pCil }\end{array}$ & $\underset{\text { pCin }}{\text { Tritium }}$ & $\underset{p C i n}{K-10}$ & $\begin{array}{l}\text { Css-137 } \\
\text { pCln }\end{array}$ & $\begin{array}{l}\text { sron } \\
\text { pein }\end{array}$ \\
\hline \multirow{32}{*}{$\begin{array}{l}\text { Peconic River } \\
\text { On-Site }\end{array}$} & $22-01$ & 2 & \multirow{39}{*}{$\begin{array}{l}\text { Maximum } \\
\text { Average } \\
\text { Maximum } \\
\text { Average } \\
\text { Maximum } \\
\text { Average } \\
\text { Maximum } \\
\text { Average } \\
\text { Maximum } \\
\text { Average } \\
\text { Maximum } \\
\text { Average } \\
\text { Maximum } \\
\text { Average } \\
\text { Maximum } \\
\text { Average } \\
\text { Maximum } \\
\text { Average } \\
\text { Maximum } \\
\text { Average } \\
\text { Maximum } \\
\text { Average } \\
\text { Maximum } \\
\text { Average } \\
\text { Maximum } \\
\text { Average } \\
\text { Maximum } \\
\text { Average } \\
\text { Maximum } \\
\text { Average } \\
\text { Maximum } \\
\text { Average } \\
\text { Maximum } \\
\text { Average } \\
\text { Maximum } \\
\text { Average } \\
\text { Maximum } \\
\text { Average } \\
\text { Maximum } \\
\text { Average } \\
\text { Maximum } \\
\text { Average } \\
\text { Maximum } \\
\text { Average } \\
\text { Maximum } \\
\text { Average } \\
\text { Maximum } \\
\text { Average } \\
\text { Maximum } \\
\text { Average } \\
\text { Maximum } \\
\text { Average } \\
\text { Maximum } \\
\text { Average } \\
\text { Maximum } \\
\text { Average } \\
\text { Meximum } \\
\text { Average } \\
\text { Maximum } \\
\text { Average } \\
\text { Maximum } \\
\text { Average } \\
\text { Maximum } \\
\text { Average } \\
\text { Meximum } \\
\text { Average } \\
\text { Maximum } \\
\text { Average } \\
\text { Maximum } \\
\text { Averagee } \\
\text { Maxximum } \\
\text { Average } \\
\text { Maximum } \\
\text { Average } \\
\text { Alaximutm } \\
\text { Average } \\
\text { Maximum } \\
\text { Average }\end{array}$} & \multirow{39}{*}{ 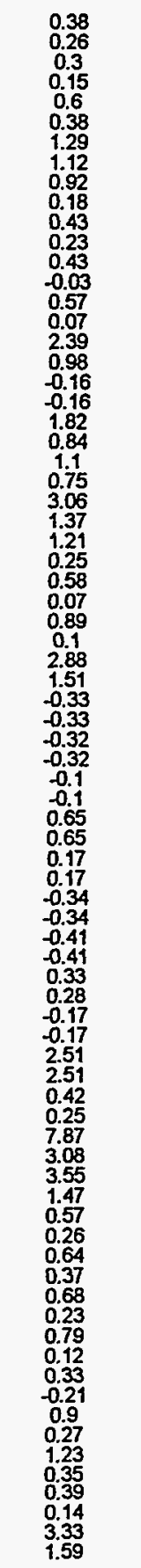 } & \multirow{39}{*}{ 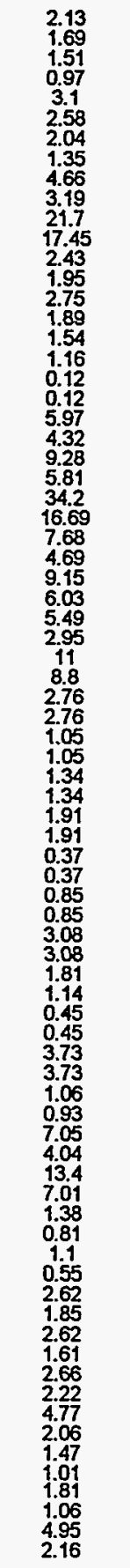 } & \multirow{39}{*}{$\begin{array}{c}61 \\
-146 \\
92 \\
-18 \\
88 \\
15 \\
-136 \\
-317 \\
1280 \\
783 \\
608 \\
116 \\
-60 \\
-76 \\
58 \\
-24 \\
11 \\
-72 \\
-83 \\
-83 \\
1490 \\
864 \\
574 \\
525 \\
3400 \\
1363 \\
1780 \\
932 \\
2630 \\
1592 \\
340 \\
54 \\
1830 \\
1025 \\
-130 \\
-130 \\
-11 \\
-11 \\
-43 \\
-43 \\
-100 \\
-100 \\
-122 \\
-122 \\
-110 \\
-110 \\
11 \\
11 \\
174 \\
15 \\
-66 \\
-66 \\
-153 \\
-153 \\
88 \\
-152 \\
655 \\
224 \\
-134 \\
-180 \\
238 \\
17 \\
70 \\
-2 \\
231 \\
-101 \\
-121 \\
-190 \\
416 \\
43 \\
-44 \\
-205 \\
137 \\
25 \\
389 \\
-72 \\
164 \\
-89\end{array}$} & \multirow{3}{*}{$\begin{array}{c}\text { ND } \\
17.8 \\
1.91 \\
\text { ND }\end{array}$} & \multirow{3}{*}{$\begin{array}{l}\text { ND } \\
8.21 \\
4.11 \\
\text { ND }\end{array}$} & $N A$ \\
\hline & $30-01$ & 2 & & & & & & & $N A$ \\
\hline & $37-01$ & 2 & & & & & & & $\mathrm{NA}$ \\
\hline & $38-01$ & 2 & & & & & ND & ND & $N A$ \\
\hline & $38-02$ & 4 & & & & & ND & ND & NA \\
\hline & $38-03$ & 4 & & & & & ND & 0.27 & NA \\
\hline & $38-04$ & 2 & & & & & ND & ND & NA \\
\hline & $38-05$ & 3 & & & & & 5.3 & ND & $N A$ \\
\hline & $38-06$ & 3 & & & & & 1.81 & ND & NA \\
\hline & $39-03$ & 1 & & & & & ND & ND & NA \\
\hline & $39-04$ & 2 & & & & & 7.2 & $\begin{array}{l}0.28 \\
0.14\end{array}$ & NA \\
\hline & $39-05$ & 2 & & & & & NO & No & NA \\
\hline & $39-06$ & 3 & & & & & $\begin{array}{r}7.35 \\
.3\end{array}$ & ND & NA \\
\hline & $39-07$ & 4 & & & & & 3.28 & ND & $N A$ \\
\hline & $39-08$ & 4 & & & & & 3.66 & ND & $N A$ \\
\hline & $39-10$ & 2 & & & & & $\begin{array}{l}4.38 \\
2.19\end{array}$ & ND & NA \\
\hline & $40-01$ & 2 & & & & & ND & ND & NA \\
\hline & $40-02$ & 1 & & & & & ND & ND & NA \\
\hline & $40-03$ & 1 & & & & & ND & NO & NA \\
\hline & $40-04$ & 1 & & & & & 4.27 & ND & NA \\
\hline & $40-05$ & 1 & & & & & ND & ND & NA \\
\hline & $40-07$ & 1 & & & & & ND & ND & NA \\
\hline & 47-01 & 1 & & & & & $\begin{array}{l}10.8 \\
10.8\end{array}$ & ND & $N A$ \\
\hline & $47-02$ & 1 & & & & & 4.2 & $\begin{array}{l}0.28 \\
0.28\end{array}$ & NA \\
\hline & $47-03$ & 2 & & & & & $\begin{array}{l}4.2 \\
3.39\end{array}$ & ND & $N A$ \\
\hline & $48-01$ & 1 & & & & & ND & ND & $N A$ \\
\hline & $49-02$ & 2 & & & & & 4.51 & ND & NA \\
\hline & $58-01$ & 3 & & & & & 9.03 & ND & NA \\
\hline & $60-01$ & 3 & & & & & 9.49 & 0.28 & $N A$ \\
\hline & $61-03$ & 3 & & & & & $\begin{array}{l}0.14 \\
2.49\end{array}$ & ND & NA \\
\hline & $80-02$ & 3 & & & & & $\begin{array}{l}1.65 \\
5.07\end{array}$ & ND & NA \\
\hline & $80-03$ & 3 & & & & & $\begin{array}{l}1.69 \\
6.51\end{array}$ & ND & NA \\
\hline Meadow Marsh & $70-01$ & 3 & & & & & 2.17 & ND & NA \\
\hline & $80-04$ & 3 & & & & & 5.08 & 0.2 & $N A$ \\
\hline & $89-01$ & 3 & & & & & $\begin{array}{l}2.62 \\
4.75 \\
1.58\end{array}$ & 0.12 & NA \\
\hline & $99-05$ & 4 & & & & & 4.93 & ND & $N A$ \\
\hline & $99-06$ & 4 & & & & & $\begin{array}{l}4.04 \\
2.5\end{array}$ & ND & $N A$ \\
\hline & $100-03$ & 3 & & & & & 3.65 & ND & NA \\
\hline & $100-04$ & 3 & & & & & $\begin{array}{l}7.85 \\
9.5 \\
6.27\end{array}$ & ND & NA \\
\hline NYS Drinking Wa & & & & 15 & 50 & 20000 & (a) & (a) & 8 \\
\hline $\begin{array}{l}\text { DOE Order } 5400 \\
\text { Concentration Gu } \\
\text { Drinking Water }\end{array}$ & $\begin{array}{l}\text { Derived } \\
\text { ide for }\end{array}$ & & & (a) & (a) & 80000 & 120 & 280 & 40 \\
\hline Typical MDL & & & & 0.53 & 1.2 & 300 & 0.2 & 3.9 & 0.1 \\
\hline
\end{tabular}

ND: Not Analyzed.

MDL: Minimum Detection Limit $\quad$ NOIl 47-01: Th-22811.65 pCin; Well 89-01:Co-60/0.15 pCin: Well 39-07: C0-60/1.09

(a): No Standard Specified. Well 39-06: Be-7/2.24 pCin: Well 60-01: Th-22812.40 pCin: 
Table 5-39

BNL. Site Environmental Report for Calendar Year 1994

North Boundary, West Sector, South Miscellaneous Areas of the BNL Site

Ground Water Survelllance Wells, Radioactivity Data

\begin{tabular}{|c|c|c|c|c|c|c|c|c|c|c|}
\hline Area & $\begin{array}{c}\text { Sample } \\
\text { ID }\end{array}$ & $\begin{array}{l}\text { No. of } \\
\text { Samples }\end{array}$ & DS & $\begin{array}{c}\text { Gross Alpha } \\
\text { pCilL }\end{array}$ & $\begin{array}{c}\text { Gross Beta } \\
\text { pCI/L }\end{array}$ & $\begin{array}{l}\text { Trittum } \\
\text { pCl/L }\end{array}$ & $\begin{array}{l}\mathrm{K}-40 \\
\mathrm{pCI} / \mathrm{L}\end{array}$ & $\begin{array}{l}\text { Co-60 } \\
\text { pCIIL }\end{array}$ & $\begin{array}{c}\text { Cs-137 } \\
\text { pCI/L }\end{array}$ & $\begin{array}{l}\text { Sr-90 } \\
\text { pCl/L. }\end{array}$ \\
\hline \multirow[t]{20}{*}{ North Boundary } & $07-03$ & 2 & Maximum & 0.83 & 4.14 & -38 & ND & 2.55 & 5.91 & $N A$ \\
\hline & & & Average & 0.51 & 3.87 & -418 & & 1.28 & 2.91 & \\
\hline & $13-01$ & 2 & Maximum & 0.16 & 0.5 & 155 & 2.85 & ND & ND & NA \\
\hline & & & Average & -0.02 & 0.33 & 68 & 1.42 & & & \\
\hline & $17-01$ & 3 & Maximum & 1.27 & 1.24 & 39 & ND & ND & ND & NA \\
\hline & & & Average & 0.47 & -0.32 & -56 & & & & \\
\hline & $17-02$ & 3 & Maximum & 1.44 & 3.89 & 133 & ND & ND & ND & NA \\
\hline & & & Average & 1.05 & 2.43 & -33 & & & & \\
\hline & $17-03$ & 3 & Maximum & 1.12 & 0.77 & 11 & ND & ND & ND & NA \\
\hline & & & Average & 0.18 & -0.4 & -82 & & & & \\
\hline & $18-01$ & 3 & Maximum & 0.96 & 5.05 & -94.00 & 2.72 & ND & ND & NA \\
\hline & & & Average & -0.42 & 0.67 & -403.00 & 0.91 & & & \\
\hline & $18-02$ & 3 & Maximum & 0.66 & -1.01 & -106.00 & 2.96 & ND & ND & NA \\
\hline & & & Average & 0.12 & -2.19 & -238.00 & 0.99 & & & \\
\hline & $18-03$ & 3 & Maximum & 1.43 & 16.40 & -116.00 & 2.10 & ND & ND & NA \\
\hline & & & Average & 0.90 & 5.80 & -247.00 & 0.70 & & & \\
\hline & $25-01$ & 2 & Maximum & 0.14 & 2.97 & -79.00 & ND & 0.63 & ND & NA \\
\hline & & & Average & 0.03 & 1.92 & -86.00 & & & & \\
\hline & $25-02$ & 2 & Maximum & 0.14 & 2.13 & 1090.00 & ND & ND & ND & NA \\
\hline & & & Average & -0.02 & 1.64 & 566.00 & & & & \\
\hline \multirow[t]{8}{*}{ West Sector } & $72-01$ & 2 & Maximum & 0.08 & -0.15 & -155.00 & ND & 3.75 & ND & NA \\
\hline & & & Average & -0.05 & -0.27 & -160.00 & & 1.88 & & \\
\hline & $83-01$ & 3 & Maximum & 0.12 & 0.40 & 17.00 & 4.18 & 0.17 & ND & NA \\
\hline & & & Average & -0.14 & -0.01 & -256.00 & 1.40 & 0.06 & & \\
\hline & $83-02$ & 3 & Maximum & 1.11 & 1.78 & 142.00 & ND & ND & ND & NA \\
\hline & & & Average & 0.37 & 1.02 & 63.00 & & & & \\
\hline & $84-01$ & 2 & Maximum & 2.35 & 2.91 & 143.00 & ND & ND & ND & NA \\
\hline & & & Average & 1.39 & 2.23 & 36.00 & & & & \\
\hline
\end{tabular}


Table 5-39 (Continued)

BNL SIte Environmental Report for Calendar Year 1994

North Boundary, West Sector, South Miscellaneous Areas of the BNL Site

Ground Water Survellance Wells, Radloactivity Data

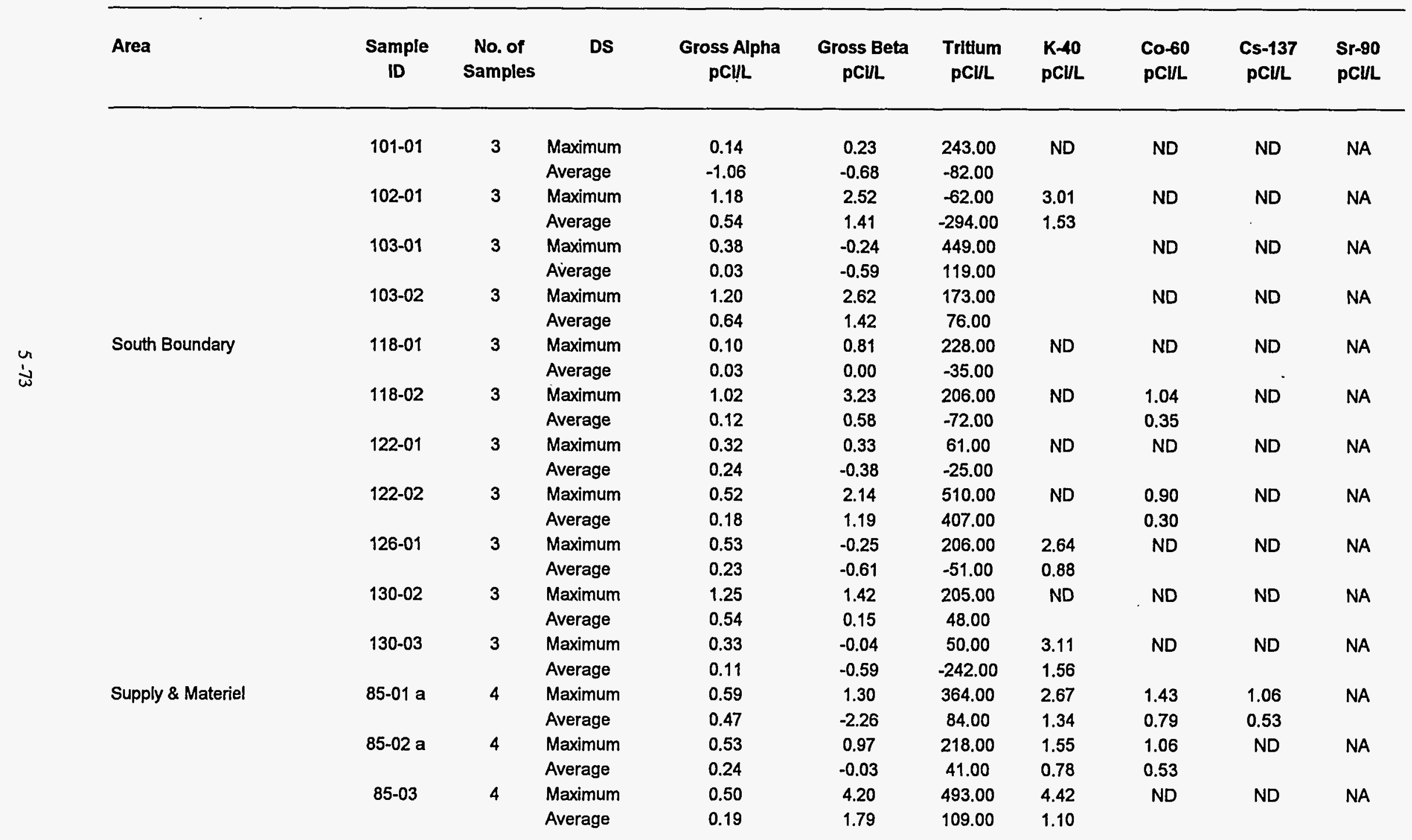


Table 5-39 (Continued)

BNL Site Environmental Report for Calendar Year 1994

North Boundary, West Sector, South Miscellaneous Areas of the BNL Site

Ground Water Survelllance Wells, Radioactlvity Data

\begin{tabular}{|c|c|c|c|c|c|c|c|c|c|c|}
\hline Area & $\begin{array}{c}\text { Sample } \\
\text { ID }\end{array}$ & $\begin{array}{c}\text { No, of } \\
\text { Samples }\end{array}$ & DS & $\begin{array}{c}\text { Gross Alpha } \\
\text { pCllL }\end{array}$ & $\begin{array}{c}\text { Gross Beta } \\
\text { pCill. }\end{array}$ & $\begin{array}{l}\text { Tritium } \\
\text { pCILL }\end{array}$ & $\begin{array}{l}\text { K-40 } \\
\text { pCVLL. }\end{array}$ & $\begin{array}{l}\text { Co-60 } \\
\text { pCi/L. }\end{array}$ & $\begin{array}{c}\text { Cs-137 } \\
\text { pCl/L }\end{array}$ & $\begin{array}{l}\text { Sr-90 } \\
\text { pCill. }\end{array}$ \\
\hline & $86-01$ & 2 & Maximum & 1.82 & 3.34 & 0.00 & ND & ND & ND & NA \\
\hline & & & Average & 0.44 & 1.92 & -146.00 & & & & \\
\hline & $86-20$ & 3 & Maximum & 2.15 & 1.89 & 150.00 & ND & ND & ND & NA \\
\hline & & & Average & 0.41 & 1.61 & 131.00 & & & & \\
\hline & $86-21$ & 3 & Maximum & 0.76 & 2.41 & 130.00 & 3.87 & ND & ND & NA \\
\hline & & & Average & -0.03 & 0.68 & -49.00 & 1.94 & & & \\
\hline & $96-06$ & 3 & Maximum & 0.13 & 1.61 & 286.00 & ND & ND & 0.17 & NA \\
\hline & & & Average & 0.04 & 1.34 & 63.00 & & & 0.06 & \\
\hline & $96-07$ & 2 & Maximum & 0.77 & 2.66 & 122.00 & 2.79 & ND & ND & NA \\
\hline & & & Average & 0.47 & 2.24 & 118.00 & 1.40 & & & \\
\hline & $105-01$ & 1 & Maximum & -0.26 & 0.73 & 103.00 & ND & ND & ND & NA \\
\hline & & & Average & -0.26 & 0.73 & 103.00 & & & & \\
\hline & $105-02$ & 3 & Maximum & 0.68 & 1.42 & 396.00 & ND & ND & ND & NA \\
\hline & & & Average & 0.55 & -0.56 & 314.00 & & & & \\
\hline Typical MDL & & & & 0.53 & 1.20 & 300.00 & 3.90 & 0.23 & 0.20 & 0.10 \\
\hline NYS Drinking Water Standard & & & & 15 & 50 & 20000 & (a) & (a) & (a) & 8 \\
\hline DOE Order 5400.5 Derived & & & & (a) & (a) & 80000 & 280 & 200 & 120 & 40 \\
\hline Concentration Guide for & & & & & & & & & & \\
\hline Drinking Water & & & & & & & & & & \\
\hline
\end{tabular}

NA: Not Analyzed.

ND: Not Detected.

MDL: Minimum Detection Limit.

(a): No Standard Specified. 
Table 5-40

BNL Site Environmental Report for Calendar Year 1994

Miscellaneous Areas of the BNL Site

Ground Water Surveillance Wells, Radioactivity Data

\begin{tabular}{|c|c|c|c|c|c|c|c|c|c|c|c|}
\hline Area & $\underset{\text { ID }}{\text { Sample }}$ & $\begin{array}{c}\text { No. of } \\
\text { Samples }\end{array}$ & DS & $\begin{array}{l}\text { Gross Alpha } \\
\text { pCill }\end{array}$ & $\begin{array}{l}\text { Gross Beta } \\
\text { pCill }\end{array}$ & $\begin{array}{c}\text { Tritium } \\
\text { pCill }\end{array}$ & $\begin{array}{l}\mathrm{Na}-22 \\
\mathrm{pCi} / \mathrm{L}\end{array}$ & $\begin{array}{l}\text { K-40 } \\
\text { pCi/L }\end{array}$ & $\begin{array}{l}\text { Co-60 } \\
\text { pCi/L }\end{array}$ & $\begin{array}{l}\text { Cs-137 } \\
\text { pCi/L }\end{array}$ & $\begin{array}{l}\text { Sr-90 } \\
\text { pCill }\end{array}$ \\
\hline \multirow[t]{4}{*}{ Army Landfill $(X-26)$} & $53-01$ & 3 & $\begin{array}{l}\text { Maximu } \\
\text { Average }\end{array}$ & $\begin{array}{l}1.08 \\
0.5\end{array}$ & $\begin{array}{l}1.01 \\
0.35\end{array}$ & $\begin{array}{l}-38 \\
-81\end{array}$ & ND & ND & ND & $\begin{array}{l}0.71 \\
0.24\end{array}$ & NA \\
\hline & $53-02$ & 2 & $\begin{array}{l}\text { Maximu } \\
\text { Average }\end{array}$ & $\begin{array}{c}0.22 \\
0.2\end{array}$ & $\begin{array}{l}1.97 \\
1.54\end{array}$ & $\begin{array}{c}118 \\
12\end{array}$ & ND & ND & ND & ND & NA \\
\hline & $53-03$ & 2 & $\begin{array}{l}\text { Maximu } \\
\text { Average }\end{array}$ & $\begin{array}{l}0.23 \\
0.22\end{array}$ & $\begin{array}{l}1.4 \\
0.97\end{array}$ & $\begin{array}{l}-77 \\
-102\end{array}$ & ND & ND & ND & ND & NA \\
\hline & $53-04$ & 2 & $\begin{array}{l}\text { Maximu } \\
\text { Average }\end{array}$ & $\begin{array}{l}1.1 \\
0.6\end{array}$ & $\begin{array}{c}0.13 \\
0.1\end{array}$ & $\begin{array}{l}-72 \\
-148\end{array}$ & ND & ND & ND & ND & NA \\
\hline \multirow[t]{11}{*}{ AGS } & 44-01 & 3 & $\begin{array}{l}\text { Maximu } \\
\text { Average }\end{array}$ & $\begin{array}{l}0.97 \\
0.77\end{array}$ & $\begin{array}{l}2.91 \\
2.02\end{array}$ & $\begin{array}{c}213 \\
17\end{array}$ & ND & ND & $\begin{array}{l}0.98 \\
0.33\end{array}$ & ND & NA \\
\hline & $44-02$ & 3 & $\begin{array}{l}\text { Maximu } \\
\text { Average }\end{array}$ & $\begin{array}{l}0.61 \\
0.58\end{array}$ & $\begin{array}{l}1.86 \\
1.19\end{array}$ & $\begin{array}{c}10 \\
-30\end{array}$ & ND & ND & $\begin{array}{l}0.19 \\
0.06\end{array}$ & ND & NA \\
\hline & $54-01$ & 3 & $\begin{array}{l}\text { Maximu } \\
\text { Average }\end{array}$ & $\begin{array}{c}0.56 \\
-0.02\end{array}$ & $\begin{array}{l}3.08 \\
2.29\end{array}$ & $\begin{array}{l}-47 \\
-191\end{array}$ & ND & ND & ND & ND & NA \\
\hline & $54-02$ & 3 & Maximu & 1.25 & 3.34 & 140 & ND & 3.01 & ND & ND & NA \\
\hline & $54-05$ & 3 & $\begin{array}{l}\text { Average } \\
\text { Maximu }\end{array}$ & $\begin{array}{l}0.79 \\
0.56\end{array}$ & $\begin{array}{l}1.09 \\
1.13\end{array}$ & $\begin{array}{c}22 \\
160\end{array}$ & ND & $\begin{array}{l}1.57 \\
2.45\end{array}$ & 0.24 & ND & NA \\
\hline & $54-06$ & 3 & Average & $\begin{array}{l}0.38 \\
1.79 \\
0.38\end{array}$ & $\begin{array}{l}0.67 \\
3.73 \\
1.45\end{array}$ & $\begin{array}{l}65 \\
167 \\
-2\end{array}$ & $\begin{array}{l}1.75 \\
0.58\end{array}$ & $\begin{array}{l}0.82 \\
2.16\end{array}$ & $\begin{array}{c}0.08 \\
\text { ND }\end{array}$ & ND & NA \\
\hline & $54-07$ & 4 & Maximu & 1.99 & 6.96 & 594 & 2.6 & 7.58 & ND & 0.33 & NA \\
\hline & $54-08$ & 4 & Maximu & 0.88 & 2.89 & 126 & ND & $\begin{array}{l}4.47 \\
2.89\end{array}$ & ND & ND & NA \\
\hline & $64-01$ & 3 & Maximu & $\begin{array}{l}1.46 \\
0.38\end{array}$ & 11.5 & 313 & ND & 7.78 & ND & ND & NA \\
\hline & $64-02$ & 3 & Maximu & 0.4 & $\begin{array}{l}0.12 \\
16.8\end{array}$ & 1410 & 5.79 & 2.45 & ND & 1.42 & NA \\
\hline & $64-03$ & 3 & Mverage & $\begin{array}{l}1.4 \\
0.54\end{array}$ & $\begin{array}{l}6.60 \\
6.64 \\
3.9\end{array}$ & $\begin{array}{l}023 \\
189 \\
-56\end{array}$ & $\begin{array}{l}4.33 \\
0.73 \\
0.42\end{array}$ & $\begin{array}{l}2.20 \\
3.64 \\
2.33\end{array}$ & ND & ND & NA \\
\hline
\end{tabular}


Table 5-40 (Continued)

BNL Site Environmental Report for Calendar Year 1994

Miscellaneous Areas of the BNL Site

Ground Water Surveillance Wells, Radioactivity Data

\begin{tabular}{|c|c|c|c|c|c|c|c|c|c|c|c|}
\hline Area & $\underset{\text { ID }}{\text { Sample }}$ & $\begin{array}{c}\text { No. of } \\
\text { Samples }\end{array}$ & DS & $\begin{array}{c}\text { Gross Alpha } \\
\text { pCilL }\end{array}$ & $\begin{array}{l}\text { Gross Beta } \\
\text { pCi/L }\end{array}$ & $\underset{\text { pCill }}{\text { Tritium }}$ & $\begin{array}{c}\mathrm{Na-22} \\
\text { pCill }\end{array}$ & $\begin{array}{l}\text { K-40 } \\
\text { pCi/L }\end{array}$ & $\begin{array}{l}\text { Co-60 } \\
\text { pCill }\end{array}$ & $\begin{array}{c}\text { Cs-137 } \\
\text { pCi/L }\end{array}$ & $\begin{array}{l}\text { Sr-90 } \\
\text { pCill }\end{array}$ \\
\hline \multirow[t]{7}{*}{ WCF } & $65-06 a$ & 2 & $\begin{array}{l}\text { Maximu } \\
\text { Average }\end{array}$ & $\begin{array}{l}1.35 \\
0.34\end{array}$ & $\begin{array}{c}16.8 \\
11.32\end{array}$ & $\begin{array}{l}3530 \\
3400\end{array}$ & $\begin{array}{l}5.84 \\
5.53\end{array}$ & $\begin{array}{l}2.9 \\
1.51\end{array}$ & ND & ND & NA \\
\hline & $65-01$ & 3 & $\begin{array}{l}\text { Maximu } \\
\text { Average }\end{array}$ & $\begin{array}{r}0.34 \\
-0.04\end{array}$ & $\begin{array}{l}1.96 \\
1.16\end{array}$ & $\begin{array}{c}275 \\
83\end{array}$ & ND & $\begin{array}{l}2.79 \\
0.93\end{array}$ & ND & ND & NA \\
\hline & $65-02$ & 2 & $\begin{array}{l}\text { Maximu } \\
\text { Average }\end{array}$ & $\begin{array}{l}1.78 \\
1.17\end{array}$ & $\begin{array}{c}16.1 \\
12.14\end{array}$ & $\begin{array}{l}5610 \\
5505\end{array}$ & $\begin{array}{l}9.75 \\
8.03\end{array}$ & $\begin{array}{l}5.2 \\
2.6\end{array}$ & ND & ND & NA \\
\hline & $65-03$ & 2 & Maximu & 0.78 & 7.48 & 5890 & 4.65 & 4.28 & ND & ND & NA \\
\hline & & & Average & 0.77 & 7.16 & 5360 & 4.59 & 2.14 & & & \\
\hline & $65-04$ & 2 & $\begin{array}{l}\text { Maximu } \\
\text { Average }\end{array}$ & $\begin{array}{l}0.91 \\
0.38\end{array}$ & $\begin{array}{l}4.27 \\
4.26\end{array}$ & $\begin{array}{l}3790 \\
2710\end{array}$ & $\begin{array}{l}0.76 \\
0.74\end{array}$ & $\begin{array}{l}2.78 \\
1.39\end{array}$ & ND & ND & NA \\
\hline & $65-05$ & 3 & $\begin{array}{l}\text { Maximu } \\
\text { Average }\end{array}$ & $\begin{array}{l}1.63 \\
0.49\end{array}$ & $\begin{array}{l}4.32 \\
2.65\end{array}$ & $\begin{array}{l}2760 \\
1187\end{array}$ & $\begin{array}{l}0.57 \\
0.38\end{array}$ & $\begin{array}{c}2.6 \\
1.35\end{array}$ & ND & ND & NA \\
\hline \multirow[t]{4}{*}{ PG\&A } & $75-01$ & 3 & $\begin{array}{l}\text { Maximu } \\
\text { Average }\end{array}$ & $\begin{array}{l}2.75 \\
0.92\end{array}$ & $\begin{array}{r}1.99 \\
-1.37\end{array}$ & $\begin{array}{l}411 \\
231\end{array}$ & $\begin{array}{l}0.26 \\
0.09\end{array}$ & ND & ND & ND & NA \\
\hline & $75-02$ & 3 & $\begin{array}{l}\text { Maximu } \\
\text { Average }\end{array}$ & $\begin{array}{c}0.69 \\
-0.03\end{array}$ & $\begin{array}{l}1.99 \\
1.58\end{array}$ & $\begin{array}{l}307 \\
187\end{array}$ & ND & $\begin{array}{c}18.3 \\
6.1\end{array}$ & ND & ND & NA \\
\hline & 85-06 & 3 & $\begin{array}{l}\text { Maximu } \\
\text { Average }\end{array}$ & $\begin{array}{l}0.43 \\
0.27\end{array}$ & $\begin{array}{l}2.45 \\
1.03\end{array}$ & $\begin{array}{c}115 \\
60\end{array}$ & ND & $\begin{array}{l}4.11 \\
1.37\end{array}$ & ND & ND & NA \\
\hline & $85-07$ & 3 & $\begin{array}{l}\text { Maximu } \\
\text { Average }\end{array}$ & $\begin{array}{l}0.71 \\
0.45\end{array}$ & $\begin{array}{l}3.16 \\
0.89\end{array}$ & $\begin{array}{l}-18 \\
-76\end{array}$ & ND & $\begin{array}{l}3.39 \\
1.69\end{array}$ & ND & $\begin{array}{c}1.1 \\
0.55\end{array}$ & NA \\
\hline \multirow[t]{3}{*}{ NSLS } & 85-01 & 4 & Maximu & 0.59 & 1.3 & 364 & ND & 2.69 & 1.43 & 1.06 & NA \\
\hline & & & Average & 0.46 & -3.02 & 112 & & 0.67 & 0.39 & 0.27 & \\
\hline & $85-02$ & 4 & $\begin{array}{l}\text { Maximu } \\
\text { Average }\end{array}$ & $\begin{array}{l}0.53 \\
0.24\end{array}$ & $\begin{array}{c}0.97 \\
-0.02\end{array}$ & $\begin{array}{c}218 \\
42\end{array}$ & ND & $\begin{array}{l}15.5 \\
3.87\end{array}$ & $\begin{array}{l}1.06 \\
0.27\end{array}$ & ND & NA \\
\hline \multirow[t]{3}{*}{ Bldg. \# 830} & $66-07$ & 2 & $\begin{array}{l}\text { Maximu } \\
\text { Average }\end{array}$ & $\begin{array}{l}-0.21 \\
-0.21\end{array}$ & $\begin{array}{l}1.92 \\
1.17\end{array}$ & $\begin{array}{l}214 \\
178\end{array}$ & ND & ND & ND & ND & NA \\
\hline & $66-08$ & 2 & $\begin{array}{l}\text { Maximu } \\
\text { Average }\end{array}$ & $\begin{array}{l}0.41 \\
0.28\end{array}$ & $\begin{array}{c}2.34 \\
2.2\end{array}$ & $\begin{array}{l}-125 \\
-208\end{array}$ & ND & ND & ND & ND & NA \\
\hline & $66-09$ & 2 & $\begin{array}{l}\text { Maximu } \\
\text { Average }\end{array}$ & $\begin{array}{l}0.73 \\
0.37\end{array}$ & $\begin{array}{c}1.54 \\
1.3\end{array}$ & $\begin{array}{l}-35 \\
-106\end{array}$ & ND & $\begin{array}{l}3.06 \\
1.53\end{array}$ & ND & ND & NA \\
\hline
\end{tabular}


Table 5-40 (Continued)

BNL Site Environmental Report for Calendar Year 1994

Miscellaneous Areas of the BNL Site

Ground Water Surveillance Wells, Radioactivity Data

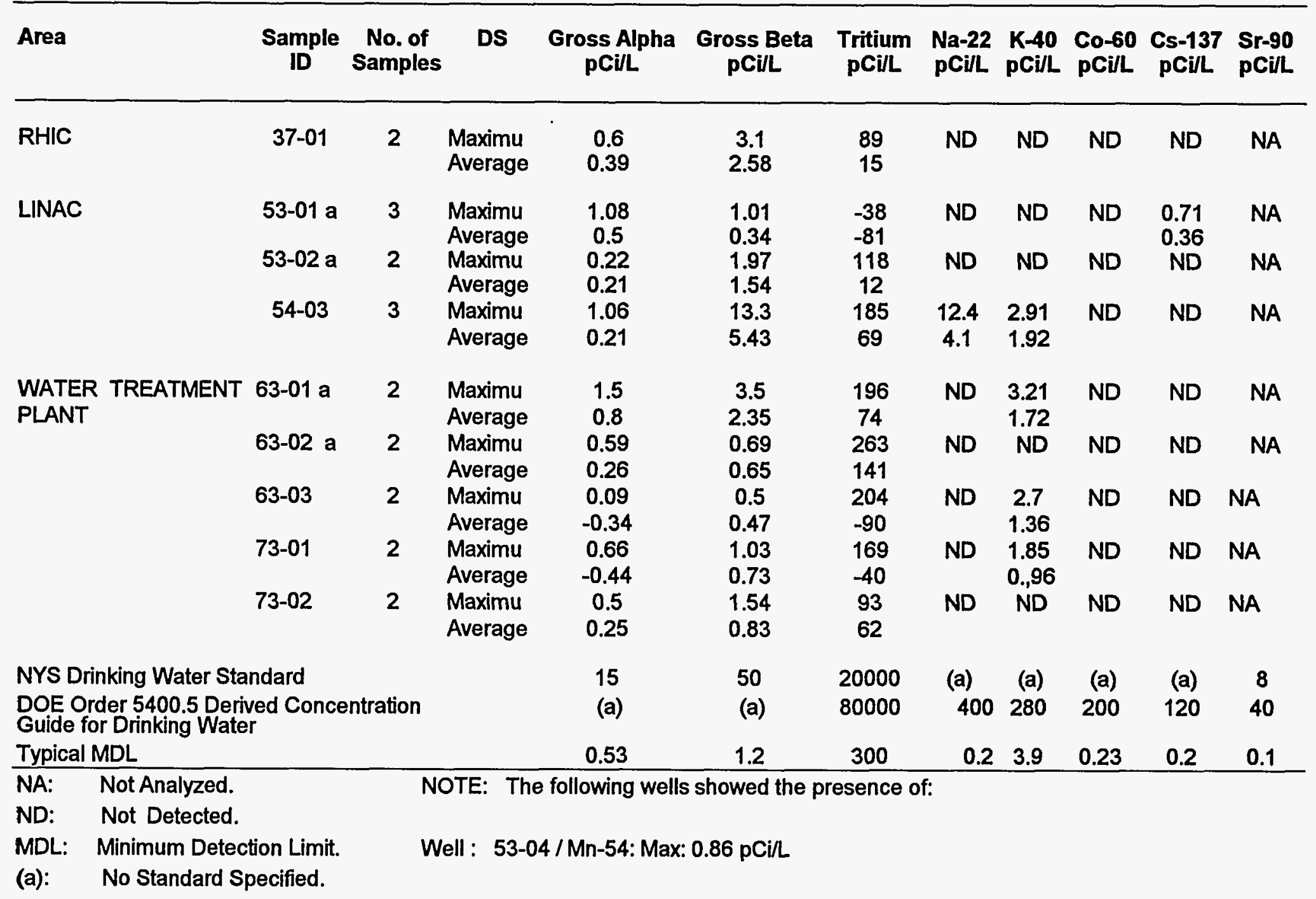


Table 5-41

BNL Site Environmental report for Calendar Year 1994

Current Landfill, Former Landfill, and Ash Repository Areas

Oroundwater Survelliance Wells, Radlosctivity Data

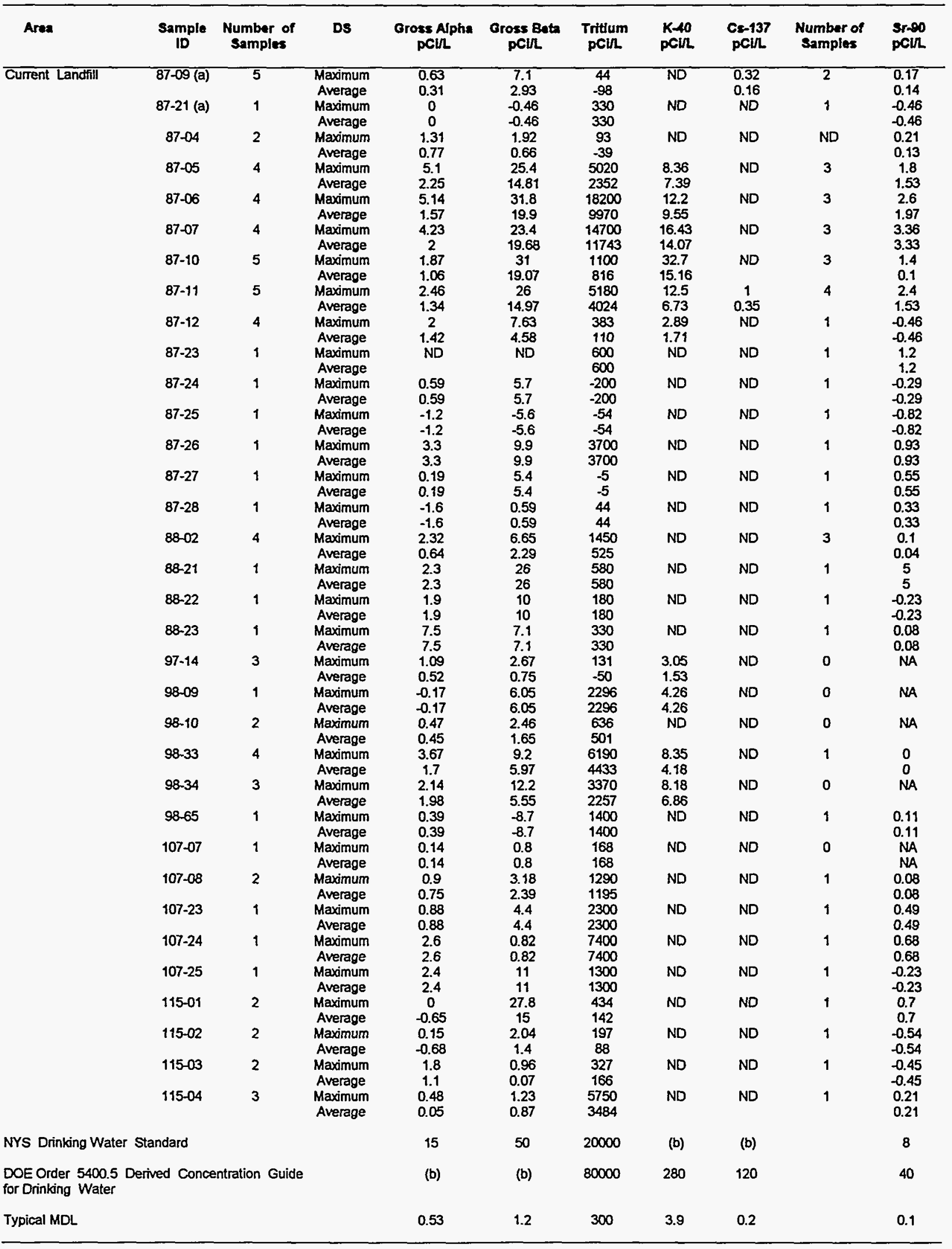

NA: Not Analyzed

ND: Not Detected

MDL: Minimum Detection Limit

(a): Upgradient Well

(b): No Standard Specified
NOTE: The following wells showed the presence of:

C0-60: Well \#97-14: Max: 0.29/ Avg: 0.15 pCil

Na-22: Well \#87-07: Max: 0.46/ Avg: 0.34; Well \#87-10 :Max: 0.32/ Avg: 08 pCin

Ra-226: Well \#87-07: Max: 0.51/Avg: 0.17 pCin

Th-228: Well \#87-05: Max: 4.51/ Avg: 1.5; Well \#87-07: Max: 0.89/ Avg: 0.30 pCi 
Tabie 6-41 (Continued)

BNL Site Environmental report for Calendar Year 19s4

Current Landfill, Former Landrill, and Ash Repository Areas

Groundwater Surveillance Wells, Radioactivity Data

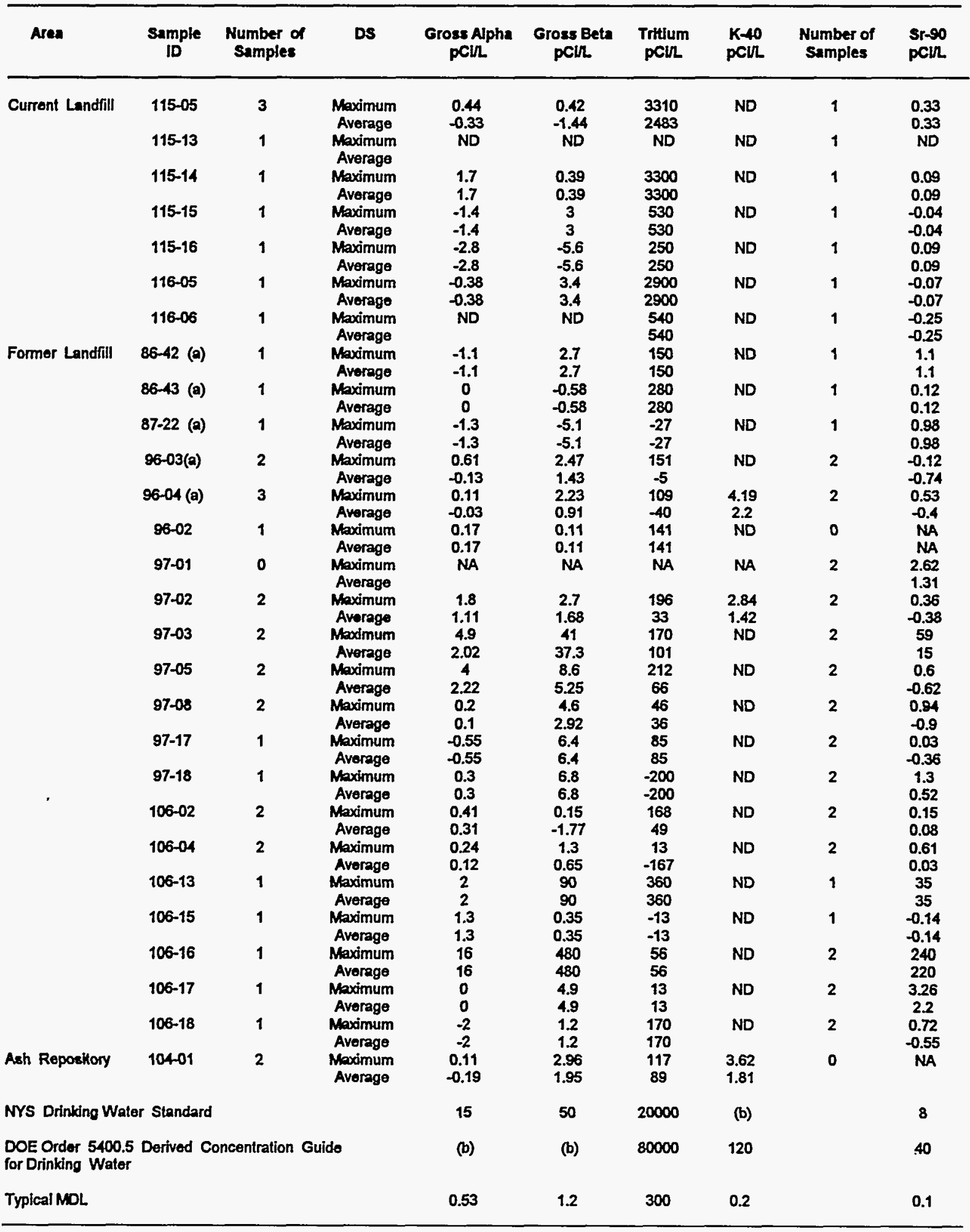

NA: Not Analyzed

ND: Not Detected

MDL: Minimum Delection Limit

(a): Upgradient Woll

(b): No Standard Spocified
NOTE: The following wells showed the presence of:

Cs-137: Well *96-03 (a): Max: 0.73/ Avg: 0.37;

Co-60: Well *97-01: Max: 0.15/ Avg: 0.08; Well *106-02 Max: 0.18/ Avg: 08 
Table 5-42

BNL Site Environmental Report for Calendar Year 1994

Major Petroleum Facllity and Central Steam Facillty

Cround Water Survelliance Wells, Radloactivity Data

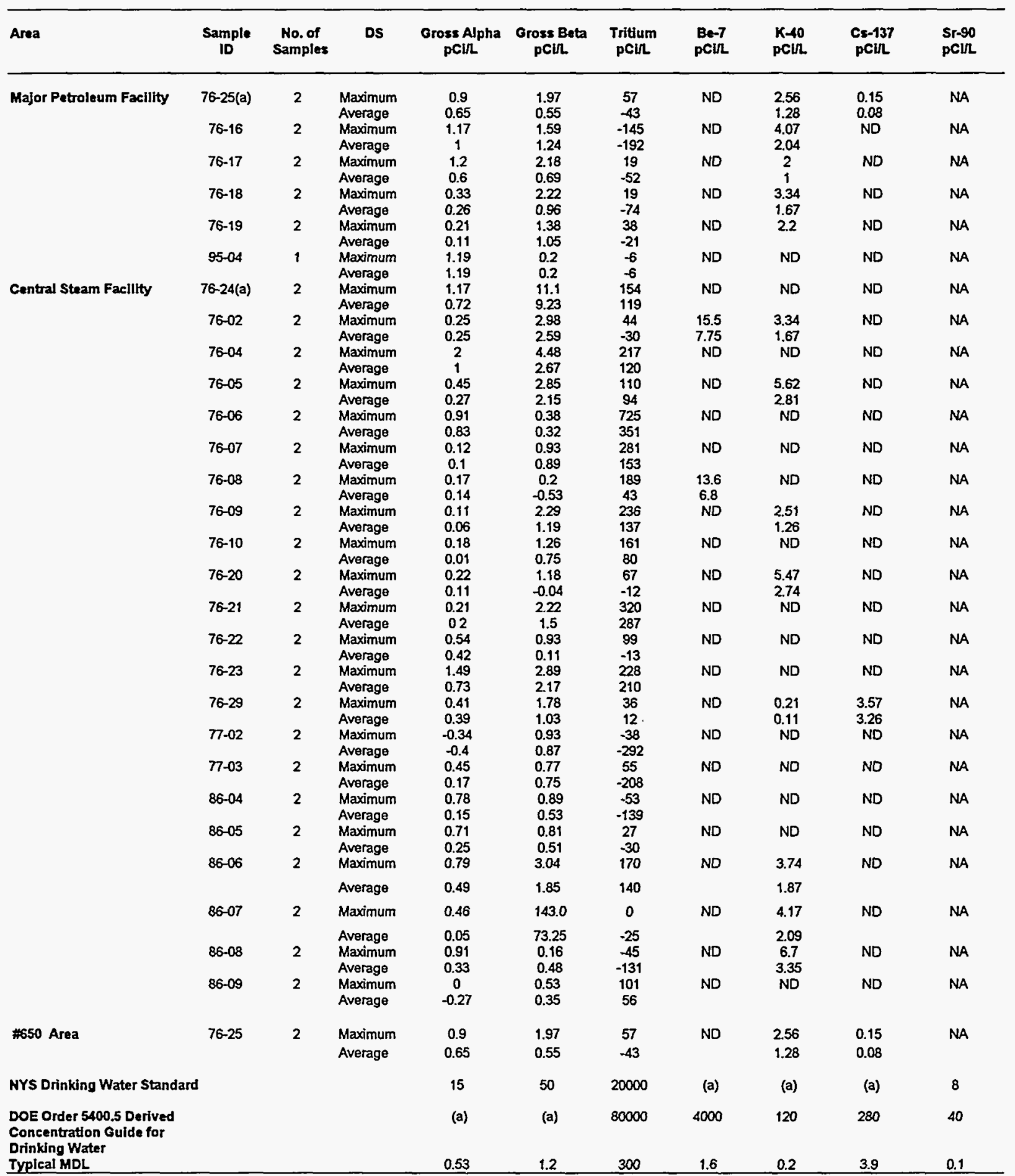

NA: Not Analyzed.

ND: Not Detected.

MDL: Minimum Detection Limlt.

(a): No Standard Specified.
NOTE: The following wells showed the presence of $\mathrm{Co-60}$

Well 77-02/ 1.34 pCin: Well 86-05/1.19 pCil; Well 86-09/ 0.20 pCil Well 76-16/ Co-60: 0.88 pCin:

Wells $105-05 ; 105-06 ; 105-07$ from CSF Area were not sampled

NOTE: The following wells from \#550 area were not sampled in 1994:66-20, 66-01, 66-15, 66-16 $66-17,66-18,66-19,76-26,76-27,76-28$ 
underlying the sand filter beds and periodic recharge to groundwater from the Peconic River in this area. In 1994, on-site average gross beta groundwater concentrations in this area ranged from <0.01\% to 17.68 of the NYS DWS. Average tritium concentrations ranged from non-detectable to $5.1 \%$ of the NYS DWS. Gamma emitting radionuclides, $\mathrm{K}-40$, cobalt-60, and cesium-137, were the only radionuclides detected in the Peconic River on-site/off-site areas and the Meadow Marsh-Upland Recharge Area monitoring wells. Tritium trend data from representative monitoring wells located within the STP Area (filter beds area) are presented in Figure 5-20. Trend data for tritium from representative monitoring wells located along the Peconic River are presented in Figure 5-21.

North Boundary, Former Army Landfill, AGS, WCF, T-111, NSLS, RHIC, Building 830, South Boundary, Supply and rateriel, and Wost Soctor (Figures 5-2, 5-3, 5-4, 5-5, 5-7, 5-10, and 5-11 and Tables 5-39 and 5-40): Most results from wells in these areas were either below the system detection limits or typical of groundwater not impacted by laboratory operations. The highest gross beta levels observed were in the vicinity of WCE area (Well 65-02) and the North Boundary (18-03). Down gradient of the AGS and at Building 811 , Na-22 was routinely detected at concentrations less than $3 \%$ of NYS DWS, and trace concentrations of Na-22 were also detected in monitoring wells located in the former building T-111 area.

Building 830 Area: In the vicinity of Building 830 (Table 5-40), radiological results for groundwater monitoring samples indicated elevated levels of gross beta indicating the impact of past activity in this area (Figure 5-5). The observed concentrations are less than 5\% of the NYS DWS.

Current Landfill: Radionuclide results for samples collected at the current Landfill (Eigure 5-8) are presented in Table 5-41. At the Current Landfill, 26 down-gradient wells consistently show elevated gross beta concentrations; 28 wells exhibit above background concentrations of tritium; Co-60 and Na-22 were detected in three wells; and cesium-137 was detected in three wells. Strontium90 was detected in five wells. The highest annual average gross beta, tritium and Sr-90 concentrations were 52\%, $59 \%$ and $62 \%$, respectively of the NYS DWS. In general, radionuclide concentrations in the wells are consistent with inorganic contaminants, specifically iron, observed at the same locations. The presence of radionuclides in groundwater samples, collected from the current Landfill area, is the result of BNL's past practice of disposing of low specific activity material in that location. This practice was terminated in 1978. Gross beta, strontium-90, and tritium trend data from representative wells downgradient of the Current Landfill are presented in Figures 5-22, 5-23, and 5-24, respectively.

Formor Landfill Area: The highest annual average gross beta concentration was $75 \%$ of the NYS DWS and was observed in Well 97-03. Tritium and gamma activity concentrations were at or below the MDL of the detection system and well below the NYS DWS. This has been observed consistently over the past few years. The presence of radionuclides in groundwater samples from the Former Landfill and Chemical Hole Area (Figures 5-7 and 5-8) is the result of BNL's past practice of disposing of low specific activity material in that location. Trend plots for strontium-90 based on data from Well $97-03$ is given in Figure 5-23.

Contral Steam Facility/Major Petroleum Facility Area: Table 5-42 shows the radionuclide concentrations in the MPF and CSF. Areas (Figure 5-8). Data indicates that the radionuclides were all at or below the MDL of the detecting system, except for the presence of tritium and Be-7 in Wells 76-06 and 76-08 respectively, at the CSF. Well 66-08 which is used as an upgradient well for the CSF (but down gradient of Building 830) did not show any gamma activity this year indicating that either dilution and/or migration have lowered the levels of 


\section{SEWAGE TREATMENT PLANT - FILTER BEDS}
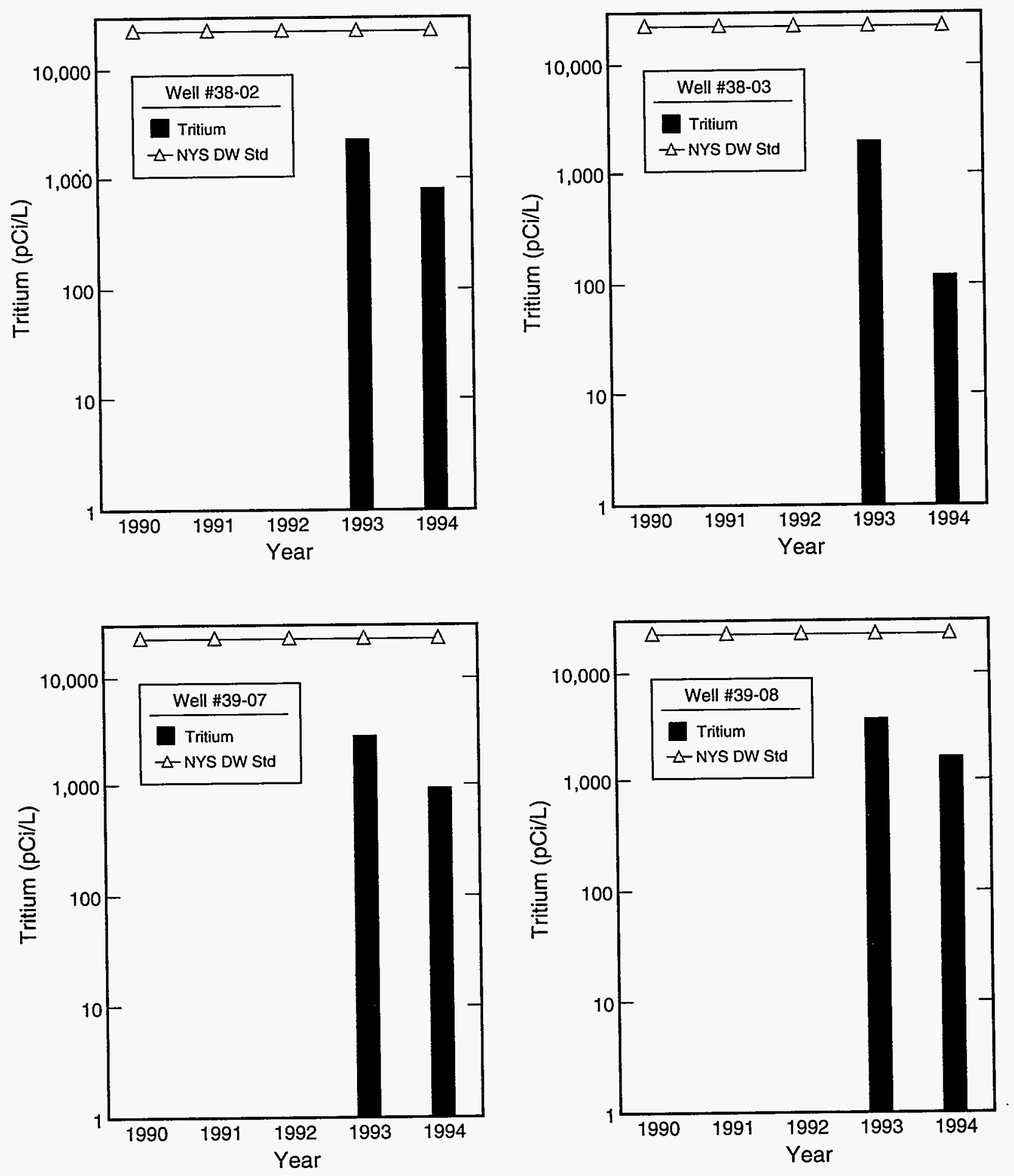

Figure 5-20 Tritium concentration trends in wells located in the Sewage Treatment Plant (STP)Area: Wells 38-02, 38-03, 39-07 and 39-08 located in the STP filter bed areas. 


\section{ALONG PECONIC RIVER}
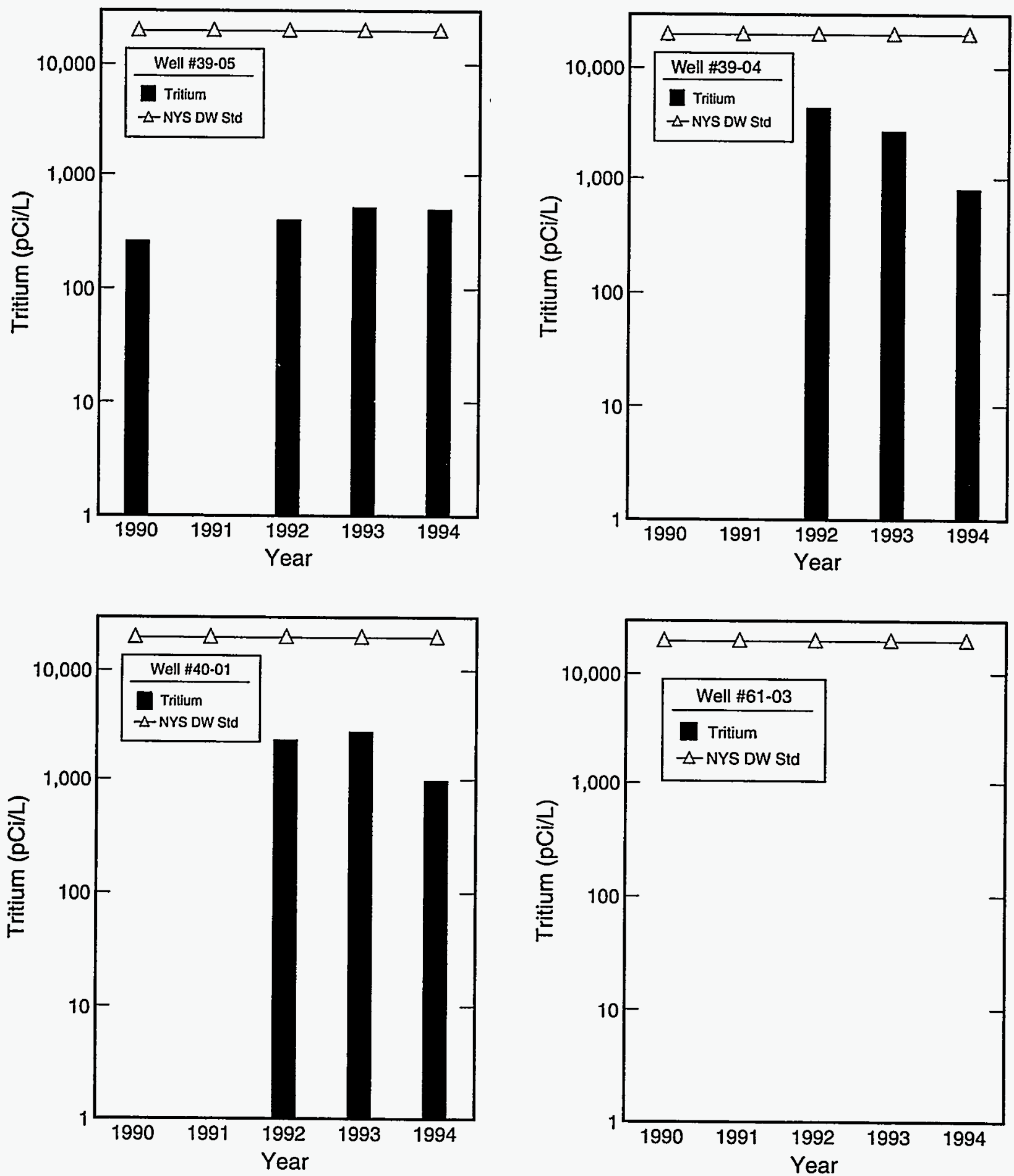

Figure 5-21 Tritium concentration trends in wells located along the Peconic River on site, downstream of the Sewage Treatment Plant discharge point (EA): Well 39-05 located 310m downstream of EA;

Well 39-04 located 440m downstream of EA; Well 40-01 located 670m downstream of EA; and Well 61-03 located 1,200m downstream of Ea. 


\section{CURRENT LANDFILL .}
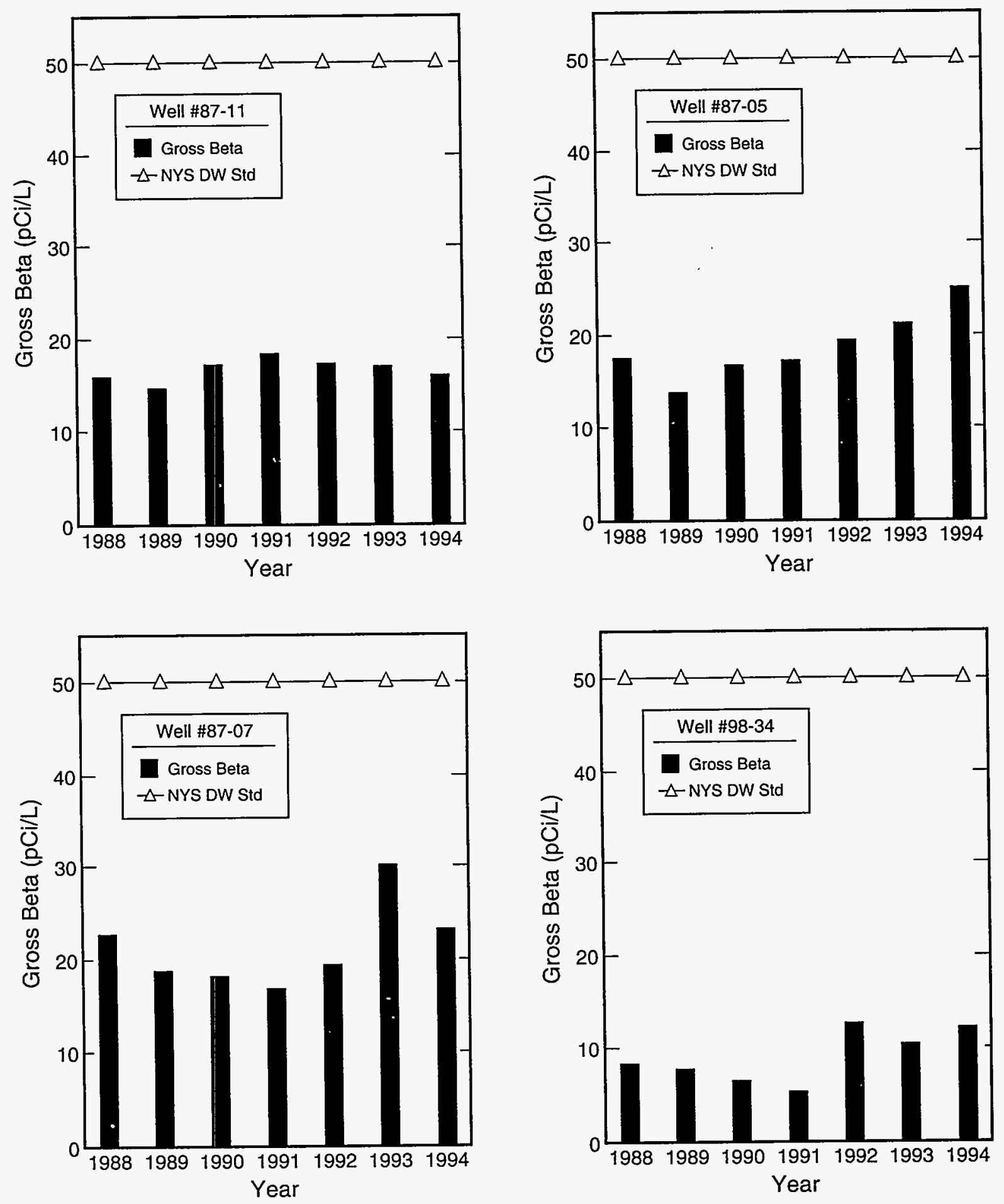

Figure 5-22

Gross beta concentration trends in wells located downgradient of the Current Landfill: Well 87-11 located at downgradient margin of landfill; Well 87-05 located at downgradient margin of landfill; Well 87-07 located 75m downgradient of landfill; and Well 98-34 located 310m downgradient of landfill. 


\section{CURRENT LANDFILL/FORMER LANDFILL}
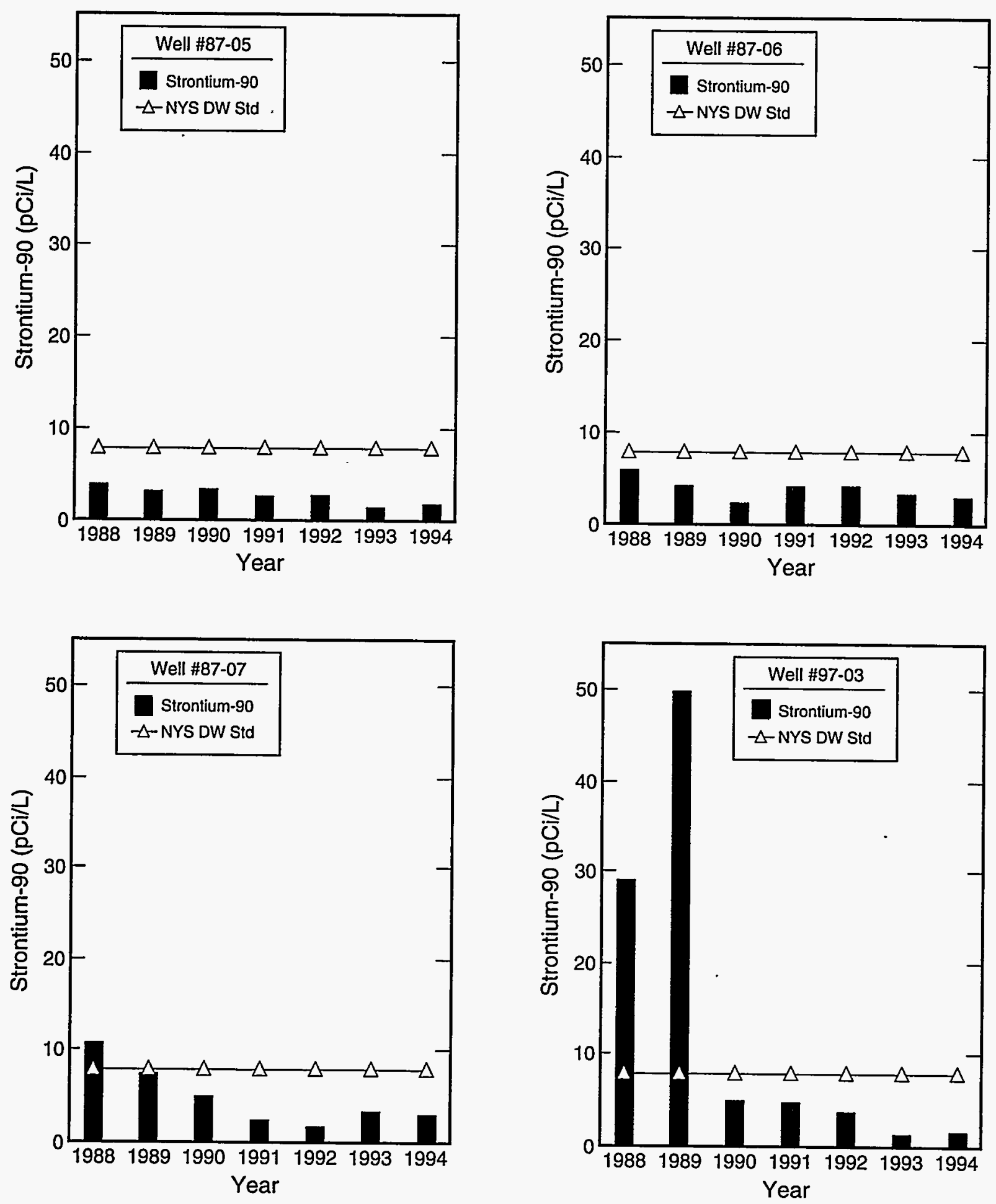

Figure 5-23 Strontium-90 concentration trends in wells located downgradient of the Current Landfill and Former Landfill: Well 87-05 located at downgradient margin of Current Landfill; Wells 87-06 and 87-07 located 75m downgradient of Current Landfill; and Well 97-03 located at the downgradient margin of Former Landfill. 


\section{CURRENT LANDFILL}
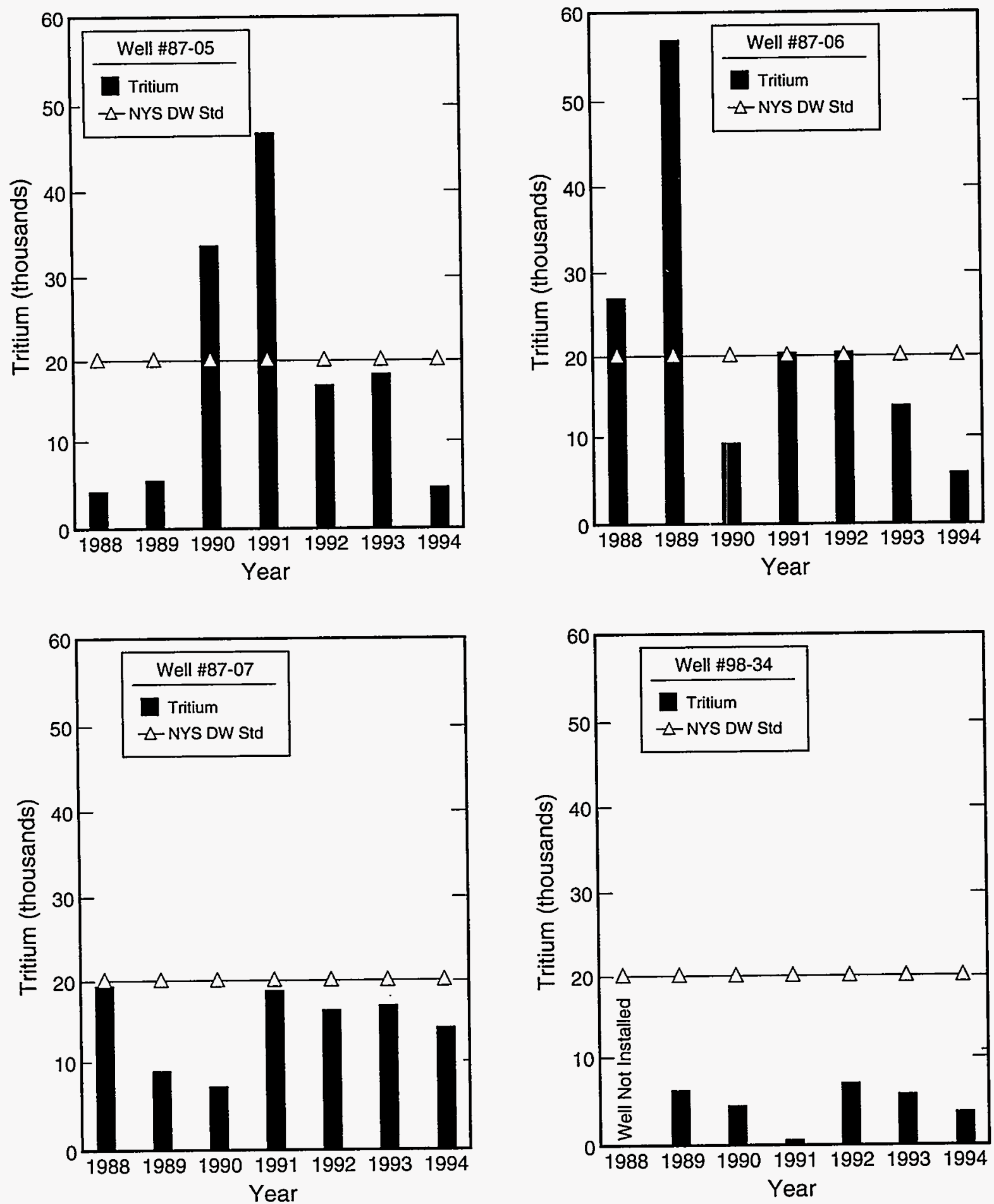

Figure 5-24

Tritium concentration trends in wells located downgradient of the Current Landfill: Well 87-05 located at downgradient margin of landfill; Wells $87-06$ and $87-07$ located $75 \mathrm{~m}$ downgradient of landfill; and Well 98-34 located 310m downgradient of landfill. 
radioactivity seen in these wells in the past. Well 76-25, also considered as an upgradient well to the CSF/MPE Area, did not show any radioactivity above background.

Hazardous Faste Managoment Facility (HIME) Area: The groundwater monitoring well network at the HWMF consists of a shallow well network located near the facility and a set of deeper wells that extends out from the facility in the direction of groundwater flow. The radiological results for the samples collected from these wells are presented in Table 5-43. Elevated annual average gross beta concentration was observed in Well 88-04, with an observed concentration of $198 \%$ of the gross beta NYS DWS. Corresponding elevations in Sr-90 was also noted in this well (612\% of the NYS DWS). Thirty well locations exhibit tritium concentrations in excess of ambient levels. The maximum annual average concentration observed in this area was 1858 of the NYS DWS (Well 88-26). Cobalt-60 was detected periodically in samples from this area at concentrations substantially less than 18 of the NYS DWS. The locations where these concentrations were observed were well within the site boundary. Groundwater concentrations at all site boundary stations were well within regulatory guidelines. Gross beta, strontium-90, and tritium trend data from representative monitoring wells within and downgradient of the HWMF are presented in Figures 5-25, 5-26, and 5-27, respectively. 
Table $5-43$

BNL Site Environmental Report for Calendar Year 1994

Hazardous Waste Management Area

Groundwater Surveillance Wells, Radioactivity Data

\begin{tabular}{|c|c|c|c|c|c|c|c|c|c|}
\hline Area & $\begin{array}{l}\text { Sample } \\
\text { ID }\end{array}$ & $\begin{array}{l}\text { No. of } \\
\text { Samples }\end{array}$ & DS & $\begin{array}{l}\text { Gross Alpha } \\
\text { pCill }\end{array}$ & $\begin{array}{c}\text { Gross Beta } \\
\text { pCirl }\end{array}$ & $\begin{array}{l}\text { Tritium } \\
\text { pCinL }\end{array}$ & $\begin{array}{l}\text { K-40 } \\
\text { pCill }\end{array}$ & DS & $\begin{array}{l}\text { Sr-80 } \\
\text { pCirl }\end{array}$ \\
\hline \multirow[t]{21}{*}{$\begin{array}{l}\text { Hazardous Waste } \\
\text { Management Area }\end{array}$} & $88-13$ (a) & 3 & $\begin{array}{l}\text { Maximum } \\
\text { Average }\end{array}$ & $\begin{array}{l}1.58 \\
0.24\end{array}$ & $\begin{array}{l}5.41 \\
3.75\end{array}$ & $\begin{array}{c}184 \\
62\end{array}$ & ND & 1 & $\begin{array}{l}0.08 \\
0.08\end{array}$ \\
\hline & $88-14$ (a) & 3 & $\begin{array}{l}\text { Maximum } \\
\text { Average }\end{array}$ & $\begin{array}{l}1.54 \\
0.94\end{array}$ & $\begin{array}{l}4.87 \\
2.2\end{array}$ & $\begin{array}{c}195 \\
24\end{array}$ & $\begin{array}{l}4.75 \\
2.38\end{array}$ & 1 & $\begin{array}{l}-0.83 \\
-0.83\end{array}$ \\
\hline & $88-03$ & 2 & $\begin{array}{l}\text { Maximum } \\
\text { Average }\end{array}$ & $\begin{array}{l}0.25 \\
0.03\end{array}$ & $\begin{array}{c}6.39 \\
6.1\end{array}$ & $\begin{array}{l}1410 \\
1085\end{array}$ & $\begin{array}{l}4.88 \\
2.44\end{array}$ & 1 & $\begin{array}{l}1.4 \\
1.4\end{array}$ \\
\hline & $88-04$ & 2 & $\begin{array}{l}\text { Maximum } \\
\text { Average }\end{array}$ & $\begin{array}{l}0.36 \\
0.18\end{array}$ & $\begin{array}{l}120 \\
99.25\end{array}$ & $\begin{array}{l}3900 \\
3255\end{array}$ & $\begin{array}{l}1.98 \\
0.99\end{array}$ & 1 & $\begin{array}{l}49 \\
49\end{array}$ \\
\hline & $88-24$ & 1 & $\begin{array}{l}\text { Maximum } \\
\text { Average }\end{array}$ & $\begin{array}{l}0 \\
0\end{array}$ & $\begin{array}{l}14 \\
14\end{array}$ & $\begin{array}{l}3400 \\
3400\end{array}$ & ND & 1 & $\begin{array}{l}0.27 \\
0.27\end{array}$ \\
\hline & $88-25$ & 1 & $\begin{array}{l}\text { Maximum } \\
\text { Average }\end{array}$ & $\begin{array}{l}2.8 \\
2.8\end{array}$ & $\begin{array}{l}10 \\
10\end{array}$ & $\begin{array}{l}200 \\
200\end{array}$ & ND & 1 & $\begin{array}{l}-1.8 \\
-1.8\end{array}$ \\
\hline & $88-26$ & 1 & $\begin{array}{l}\text { Maximum } \\
\text { Average }\end{array}$ & $\begin{array}{l}3.52 \\
3.52\end{array}$ & $\begin{array}{l}26 \\
26\end{array}$ & $\begin{array}{l}37000 \\
37000\end{array}$ & ND & 1 & $\begin{array}{l}3.8 \\
3.8\end{array}$ \\
\hline & $88-27$ & 1 & $\begin{array}{l}\text { Maximum } \\
\text { Average }\end{array}$ & $\begin{array}{l}-0.53 \\
-0.53\end{array}$ & $\begin{array}{l}-0.91 \\
-0.91\end{array}$ & $\begin{array}{l}15 \\
15\end{array}$ & ND & 1 & $\begin{array}{l}-2.1 \\
-2.1\end{array}$ \\
\hline & $98-04$ & 1 & $\begin{array}{l}\text { Maximum } \\
\text { Average }\end{array}$ & $\begin{array}{l}-0.08 \\
-0.08\end{array}$ & $\begin{array}{l}30.4 \\
30.4\end{array}$ & $\begin{array}{l}817 \\
817\end{array}$ & $\begin{array}{l}3.06 \\
3.06\end{array}$ & 0 & NA \\
\hline & $98-07$ & 2 & $\begin{array}{l}\text { Maximum } \\
\text { Average }\end{array}$ & $\begin{array}{l}0.25 \\
0.12\end{array}$ & $\begin{array}{c}1.6 \\
1.24\end{array}$ & $\begin{array}{l}269 \\
180\end{array}$ & ND & 2 & $\begin{array}{l}3.1 \\
0.1\end{array}$ \\
\hline & $98-19$ & 3 & $\begin{array}{l}\text { Maximum } \\
\text { Average }\end{array}$ & $\begin{array}{r}0.47 \\
-0.17\end{array}$ & $\begin{array}{r}2.46 \\
-0.73\end{array}$ & $\begin{array}{l}636 \\
400\end{array}$ & ND & 1 & $\begin{array}{l}0.64 \\
0.64\end{array}$ \\
\hline & $98-21$ & 2 & $\begin{array}{l}\text { Maximum } \\
\text { Average }\end{array}$ & $\begin{array}{r}0.75 \\
-0.43\end{array}$ & $\begin{array}{c}6.99 \\
5.2\end{array}$ & $\begin{array}{l}4140 \\
3220\end{array}$ & ND & 1 & $\begin{array}{l}3.7 \\
3.7\end{array}$ \\
\hline & $98-22$ & 2 & $\begin{array}{l}\text { Maximum } \\
\text { Average }\end{array}$ & $\begin{array}{l}0.57 \\
0.24\end{array}$ & $\begin{array}{c}17 \\
11.64\end{array}$ & $\begin{array}{l}300 \\
289\end{array}$ & $\begin{array}{l}2.65 \\
1.33\end{array}$ & 1 & $\begin{array}{l}3.5 \\
3.5\end{array}$ \\
\hline & $98-30$ & 2 & $\begin{array}{l}\text { Maximum } \\
\text { Average }\end{array}$ & $\begin{array}{l}2.4 \\
1.28\end{array}$ & $\begin{array}{c}26 \\
14.08\end{array}$ & $\begin{array}{l}1240 \\
1040\end{array}$ & ND & 1 & $\begin{array}{l}10 \\
10\end{array}$ \\
\hline & $98-32$ & 2 & $\begin{array}{l}\text { Maximum } \\
\text { Average }\end{array}$ & $\begin{array}{r}0.54 \\
-0.23\end{array}$ & $\begin{array}{l}29.3 \\
15.5\end{array}$ & $\begin{array}{l}1096 \\
945\end{array}$ & $\begin{array}{l}2.23 \\
1.43\end{array}$ & 1 & $\begin{array}{l}-0.81 \\
-0.81\end{array}$ \\
\hline & $98-36$ & 1 & $\begin{array}{l}\text { Maximum } \\
\text { Average }\end{array}$ & $\begin{array}{l}-0.42 \\
-0.42\end{array}$ & $\begin{array}{l}1.23 \\
1.23\end{array}$ & $\begin{array}{l}55 \\
55\end{array}$ & ND & 0 & NA \\
\hline & $98-42$ & 1 & $\begin{array}{l}\text { Maximum } \\
\text { Average }\end{array}$ & $\begin{array}{l}-0.09 \\
-0.09\end{array}$ & $\begin{array}{l}3.46 \\
3.46\end{array}$ & $\begin{array}{l}427 \\
427\end{array}$ & ND & ND & NA \\
\hline & $98-59$ & 1 & $\begin{array}{l}\text { Maximum } \\
\text { Average }\end{array}$ & $\begin{array}{l}-1.32 \\
-1.32\end{array}$ & $\begin{array}{l}1.13 \\
1.13\end{array}$ & $\begin{array}{l}1800 \\
1800\end{array}$ & ND & 1 & $\begin{array}{l}0.3 \\
0.3\end{array}$ \\
\hline & $98-60$ & 1 & $\begin{array}{l}\text { Maximum } \\
\text { Average }\end{array}$ & $\begin{array}{l}-0.58 \\
-0.58\end{array}$ & $\begin{array}{l}-5.8 \\
-5.8\end{array}$ & $\begin{array}{l}11 \\
11\end{array}$ & ND & 1 & $\begin{array}{l}-0.32 \\
-0.32\end{array}$ \\
\hline & $98-61$ & 1 & $\begin{array}{l}\text { Maximum } \\
\text { Average }\end{array}$ & $\begin{array}{l}-0.82 \\
-0.82\end{array}$ & $\begin{array}{l}-3.5 \\
-3.5\end{array}$ & $\begin{array}{l}140 \\
140\end{array}$ & ND & 1 & $\begin{array}{l}0.29 \\
0.29\end{array}$ \\
\hline & $98-62$ & 1 & $\begin{array}{l}\text { Maximum } \\
\text { Average }\end{array}$ & $\begin{array}{l}-1.2 \\
-1.2\end{array}$ & $\begin{array}{l}-2.7 \\
-2.7\end{array}$ & $\begin{array}{l}-13 \\
-13\end{array}$ & ND & 1 & $\begin{array}{l}0.04 \\
0.04\end{array}$ \\
\hline \multicolumn{4}{|c|}{ NYS Drinking Water Standard } & 15 & 50 & 20000 & (b) & & 8 \\
\hline \multicolumn{4}{|c|}{$\begin{array}{l}\text { DOE Order } 5400.5 \text { Derived Concentration } \\
\text { Guide for Drinking Water }\end{array}$} & (b) & (b) & 80000 & 120 & & 40 \\
\hline \multicolumn{4}{|l|}{ Typical MDL } & 0.53 & 1.2 & 300 & 0.2 & & 0.23 \\
\hline
\end{tabular}

NA: Not Analyzed

ND: Not Detected

MDL: Minimum Detection Limit

(a): Upgradient Well

(b): No Standard Specified
Note: The following wells showed the presence of:

Well 88-03/C0-60: Max: 0.17; Avg: 0.08 pCill

Well 88-04/Na-22: Max: 3.49; Avg: 1,75 pCi/L 
Table 5-43 (Continued)

BNL Site Environmental Report for Calendar Year 1994

Hazardous Waste Management Area

Groundwater Surveillance Wells, Radioactivity Data

\begin{tabular}{|c|c|c|c|c|c|c|c|c|c|}
\hline Area & $\underset{\text { ID }}{\text { Sample }}$ & $\begin{array}{l}\text { No. of } \\
\text { Samples }\end{array}$ & DS & $\begin{array}{l}\text { Gross Alpha } \\
\text { pCill }\end{array}$ & $\begin{array}{l}\text { Gross Beta } \\
\text { pCill }\end{array}$ & $\begin{array}{l}\text { Tritium } \\
\text { pCill }\end{array}$ & $\begin{array}{l}\mathrm{K}-40 \\
\mathrm{pCilL}\end{array}$ & DS & $\begin{array}{l}\text { Sr-90 } \\
\text { pCill }\end{array}$ \\
\hline Hazardous Waste & $98-63$ & 1 & Maximum & 1.1 & -6.1 & 24 & ND & 1 & -0.77 \\
\hline \multirow[t]{29}{*}{ Management Area } & & & Average & 1.1 & -6.1 & 24 & & & -0.77 \\
\hline & $99-02$ & 1 & Maximum & -0.29 & 2.07 & 17 & ND & 0 & NA \\
\hline & & & Average & -0.29 & 2.07 & 17 & & & \\
\hline & $99-04$ & 2 & Maximum & 0.57 & 49.8 & 1580 & 6.69 & 1 & -1.3 \\
\hline & & & Average & 0.41 & 24.54 & 1293 & 3.35 & & -1.3 \\
\hline & $107-09$ & 4 & Maximum & 0.86 & 0.88 & 2280 & ND & 0 & NA \\
\hline & & & Average & 0.46 & -0.07 & 1635 & & & \\
\hline & $107-10$ & 2 & Maximum & 0.57 & 3 & 1170 & ND & 1 & -0.1 \\
\hline & & & Average & 0.45 & 2.25 & 1000 & & & -0.1 \\
\hline & $107-11$ & 2 & Maximum & 0.75 & 1.5 & 1730 & ND & 1 & -1.4 \\
\hline & & & Average & 0.54 & 1.21 & 1350 & & & -1.4 \\
\hline & $107-12$ & 2 & Maximum & 0.57 & 4.38 & 1150 & 4.3 & 1 & 0.18 \\
\hline & & & Average & 0.28 & 2.19 & 1075 & 2.15 & & 0.18 \\
\hline & $107-13$ & 1 & Maximum & 0.18 & 0.61 & 1770 & ND & 0 & NA \\
\hline & & & Average & 0.18 & 0.61 & 1770 & & & \\
\hline & $107-14$ & 1 & Maximum & 0.08 & 1.23 & 1450 & 4.33 & 0 & NA \\
\hline & & & Average & 0.08 & 1.23 & 1450 & 4.33 & & \\
\hline & $108-01$ & 2 & Maximum & 0.25 & 2.42 & 1200 & 2.81 & 1 & -0.71 \\
\hline & & & Average & 0.22 & 1.81 & 1180 & 1.4 & & -0.71 \\
\hline & $108-03$ & 2 & Maximum & 3 & 8.2 & 1130 & 4.34 & 1 & -0.82 \\
\hline & & & Average & 1.9 & 6.14 & 985 & 2.17 & & -0.82 \\
\hline & $108-05$ & 1 & Maximum & 0.56 & 3.3 & 1160 & ND & 0 & NA \\
\hline & & & Average & 0.56 & 3.3 & 1160 & & & \\
\hline & $108-07$ & 2 & Maximum & 0.39 & 3.38 & 1350 & ND & 1 & -0.44 \\
\hline & & & Average & -0.2 & -0.96 & 1055 & & & -0.44 \\
\hline & $108-08$ & 2 & Maximum & 0.16 & -4.34 & 1400 & ND & 1 & 0.62 \\
\hline & & & Average & 0.08 & -4.34 & 1345 & & & 0.62 \\
\hline & $108-12$ & 2 & Maximum & -0.16 & 4.6 & 1910 & 2.85 & 1 & -0.17 \\
\hline & & & Average & -0.83 & 3.45 & 1455 & 1.43 & & -0.17 \\
\hline \multicolumn{4}{|c|}{ NYS Drinking Water Standard } & 15 & 50 & 20000 & (b) & & 8 \\
\hline \multicolumn{4}{|c|}{$\begin{array}{l}\text { DOE Order } 5400.5 \text { Derived Concentration } \\
\text { Gulde for Drinking Water }\end{array}$} & (b) & (b) & 80000 & 120 & & 40 \\
\hline \multicolumn{4}{|l|}{ Typical MDL } & 0.53 & 1.2 & 300 & 0.2 & & 0.23 \\
\hline
\end{tabular}

NA: Not Analyzed

ND: Not Detected

MDL: Minimum Detection Limit

(a): Upgradient Well

(b): No Standard Specified 
Table 5-43 (Continued)

BNL Site Environmental Report for Calendar Year 1994

Hazardous Waste Management Area

Groundwater Surveillance Wells, Radioactivity Data

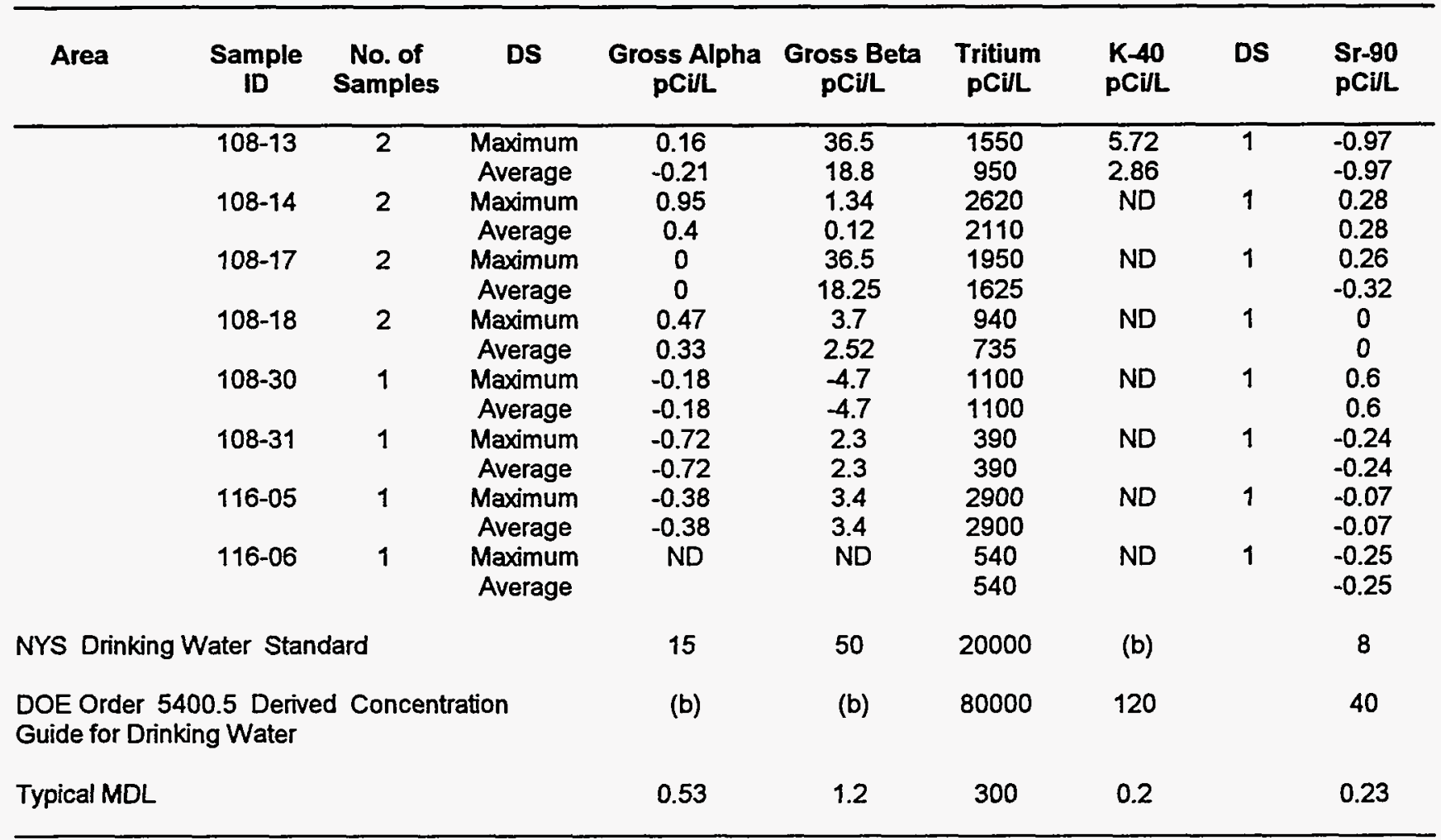

NA: Not Analyzed

ND: Not Detected

MDL: Minimum Detection Limit

(a): Upgradient Well

(b): No Standard Specified 


\section{HAZARDOUS WASTE MANAGEMENT AREA}
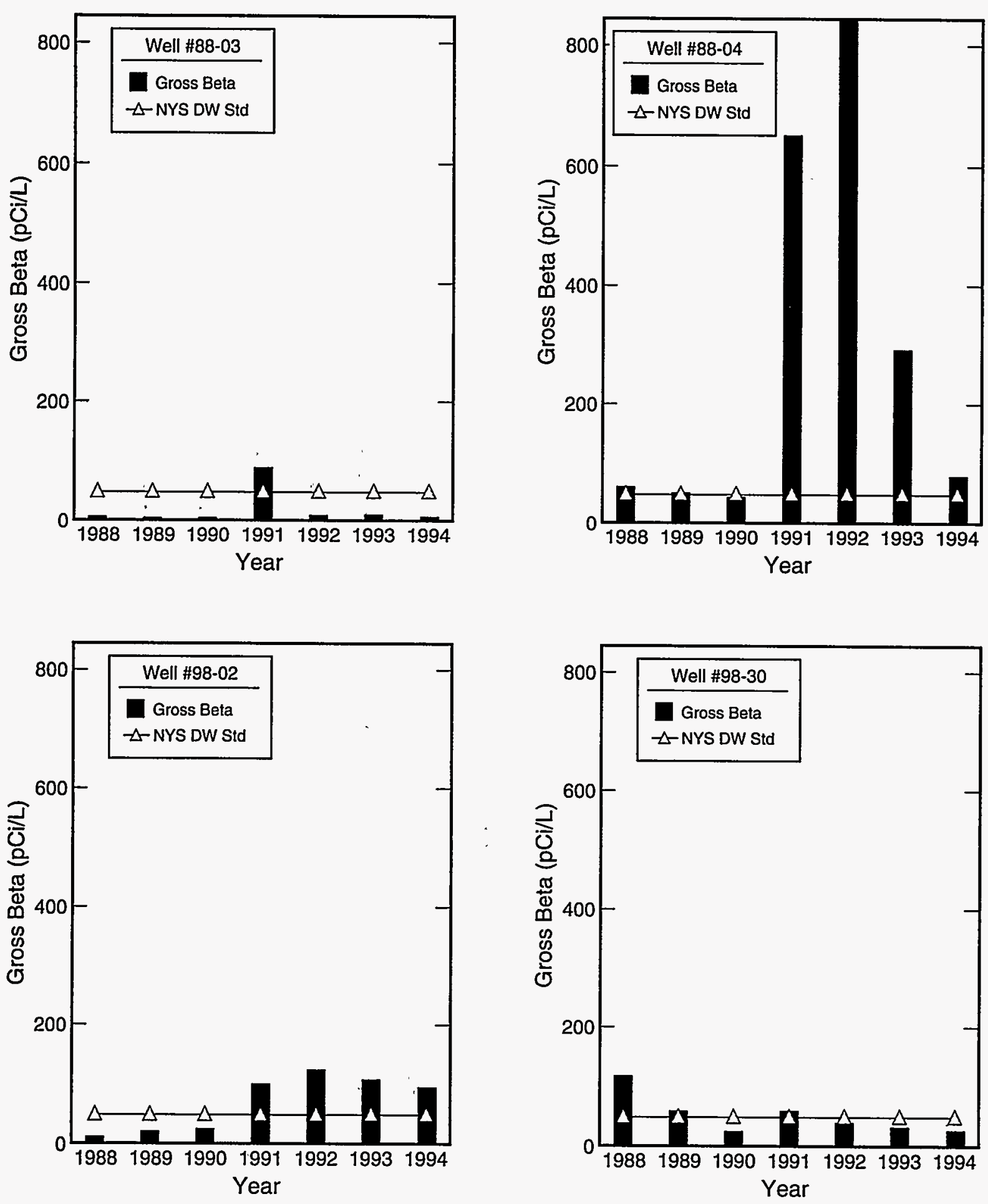

Figure 5-25 Gross beta concentration trends in wells located within and downgradient of the Hazardous Waste Management Facility (HWMF): Wells 88-03, 88-04 and 98-02 located within HWMF; and Well 98-30 located 200m downgradient of HWMF. 
HAZARDOUS WASTE MANAGEMENT AREA
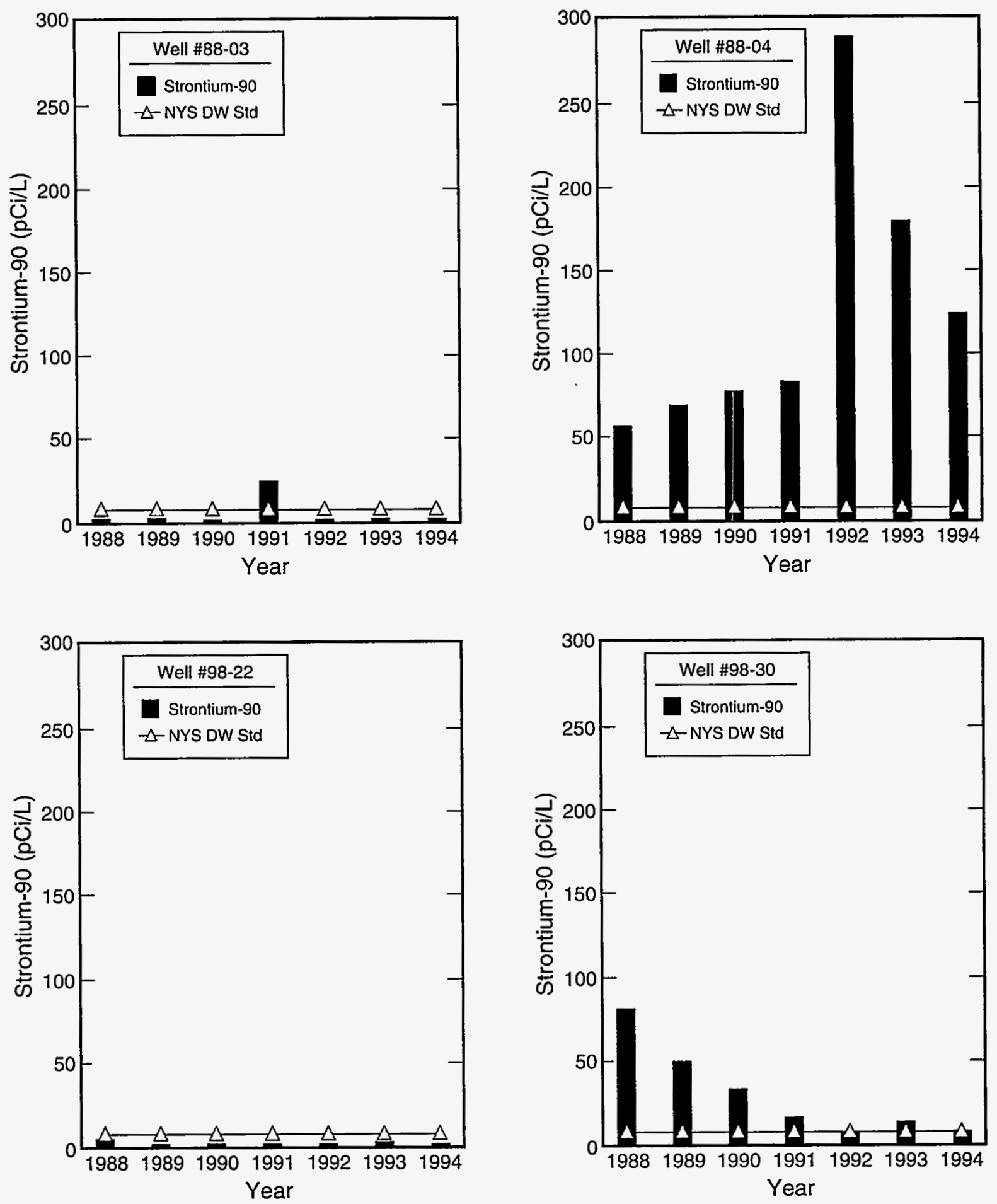

Figure 5-26 Strontium-90 concentration trends in wells located within and downgradient of the Hazardous Waste Management Facility (HWMF): Wells 88-03 and 88-04 located within the HWMF; Well located at downgradient margin of HWMF; and Well 98-30 located 200m downgradient of HWMF. 


\section{HAZARDOUS WASTE MANAGEMENT AREA}
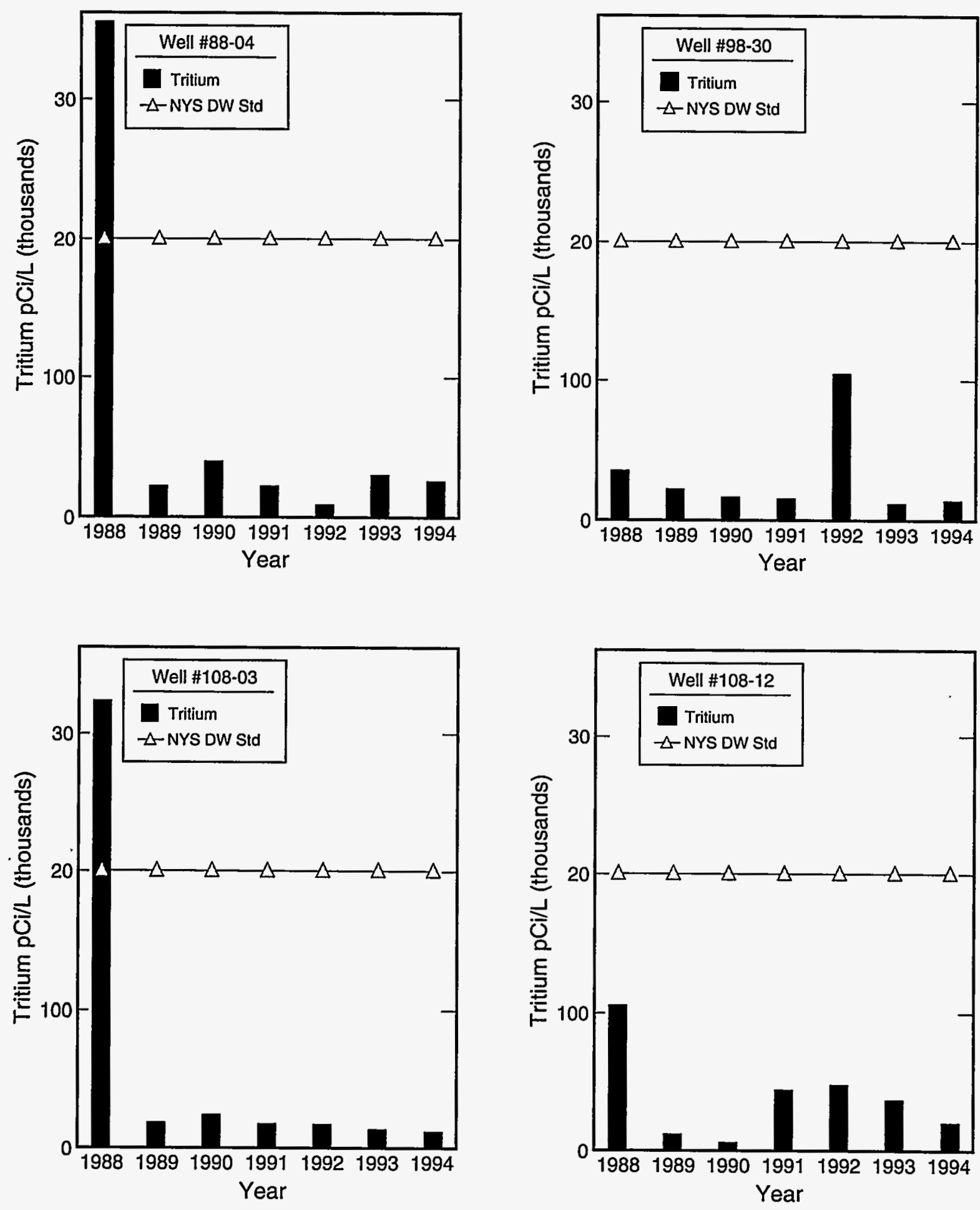

Figure 5-27 Tritium concentration trends in wells located within and downgradient of the Hazardous Waste Management Facility (HWMF): Well 88-04 located within the HWMF; Well 98-30 located 200m downgradient of the HWMF; Well 108-03 located 420m downgradient of the HWMF; and Well 108-12 located at the site boundary, 675m downgradient of the HWMF. 


\subsection{OEF-SITE DOSE ESTIMATES - G. I. Schroeder and J. R. Naidu \\ 6.1 Dose Equivalents due to Airborne Effluents}

The major radionuclides released from BNL airborne effluent discharge points were tritium and argon-41. The measured tritium concentrations and dose equivalents at the site boundary are shown in Table 6-1. The highest annual average site boundary concentration of tritium vapor was $4.5 \mathrm{pCi} / \mathrm{m}^{3}(0.17 \mathrm{~Bq} / \mathrm{L})$ at Monitoring Locations 0201 (NE) and the committed effective dose equivalent (inhalation and skin absorption) was 0.004 mrem (4E-5 msv) for the hypothetical individual residing at that location. The exposure rate due to argon-41 was not measured at the site boundary. The dose-equivalent rates for these radionuclides, calculated using CAP88, are presented in Table 6-2. The maximum site-boundary dose-equivalent from argon-41 and oxygen-15 was calculated to be $(0.115 \mathrm{mrem} / \mathrm{yr}(0.001 \mathrm{msv} / \mathrm{yr})$. The maximum site boundary dose from all three radionuclides was $0.119 \mathrm{mrem} / \mathrm{yr}(0.0012 \mathrm{mSv} / \mathrm{yr})$.

The collective (population) dose equivalent was estimated for radionuclides released to the airborne environment using measured effluent release data and recorded BNL meteorological parameters. Using actual source terms and meteorological data at the given release point should yield the best projection of airborne concentrations, and thus dose to the general population. This approach also minimizes the effects of local micrometeorological conditions which may exist, resulting in differences between the measured and expected tritium concentrations at the perimeter monitoring stations.

Collective whole body doses resulting from the radionuclides released from each facility are presented in Table 6-3. Argon-41 contributed a collective dose equivalent of 3.45 person-rem ( 0.035 person-sv) which is essentially the entire collective dose equivalent for the site. The dose equivalent contributions from tritium and carbon-11 were 0.027 and $4.56 \mathrm{E}-3$ person-rem $(2.7 \mathrm{E}-4$ and $4.56 \mathrm{E}-5$ person-Sv), respectively. This is depicted graphically in Figure 6-1. The fraction of collective dose as a function of facility is presented graphically in Figure 6-2. The 1994 population collective dose equivalent resulting from the release of airborne radionuclides by the Iaboratory was 3.49 person-rem 10.035 person-SV). This can be compared to the population collective dose-equivalent due to cosmic and terrestrial natural background of 291,000 person-rem (2,910 person-Sv). The Laboratory airborne releases comprised $0.0007 \%$ of the total dose due to natural background.

\subsection{Dose Equivalents due to Liquid Effluents}

Since the Peconic River is not used as a drinking water supply, ${ }^{2}$ nor for irrigation, its waters do not constitute a direct pathway for the ingestion of radioactivity. However, the Peconic River does recharge the aquifer and acts as a limited source for sport fishing. In 1994, the collective dose equivalent resulting from the ingestion of drinking water was computed by evaluating the radioactive content by private potable water.

For the drinking water pathway, only tritium was detected in off-site potable wells. The highest annual average concentration for a single residence was $2,224 \mathrm{pCi} / \mathrm{I}(82.3 \mathrm{~Bq} / \mathrm{I})$. The average concentration for the group of positive tritium concentrations at private potable wells was $600 \mathrm{pCi} / \mathrm{L}(22.2 \mathrm{~Bq} / \mathrm{L})$. (The NYS DWS for tritium is $20,000 \mathrm{pCi} / \mathrm{L}$.$) This corresponds to a committed effective$ dose equivalent to the maximum individual of $0.103 \mathrm{mrem}(0.002 \mathrm{mSv}) \mathrm{and}$ a collective dose equivalent to the population at risk (assumed to be not more than 500 persons) of 0.052 person-rem (0.0005 person-Sv). This data is summarized in Table 6-4. 
Table 6-1

BNL Site Environmental Report for Calendar Year 1994

Committed Effective Dose Equivalent at Site Boundary

Due to Tritium

\begin{tabular}{|c|c|c|c|}
\hline Location & Sector ID & $\begin{array}{l}\text { Flow Wt'd. } \\
\text { Avg. } \\
\text { (pCi/m3) }\end{array}$ & $\begin{array}{l}\text { CEDE* } \\
\text { (mrem) }\end{array}$ \\
\hline 0101 & $N$ & 1.60 & 0.0013 \\
\hline 0201 & NNE & 4.51 & 0.0035 \\
\hline 0302 & NE & 2.44 & 0.0019 \\
\hline 0401 & ENE & 1.90 & 0.0015 \\
\hline 0501 & $E$ & 2.01 & 0.0016 \\
\hline 0602 & ESE & 1.45 & 0.0011 \\
\hline 0702 & SE & 3.52 & 0.0028 \\
\hline 0803 & SSE & 1.31 & 0.0010 \\
\hline 0902 & $\mathbf{S}$ & 3.36 & 0.0026 \\
\hline 1001 & ssw & 1.59 & 0.0012 \\
\hline 1101 & sW & 1.27 & 0.0010 \\
\hline 1201 & WSW & 3.95 & 0.0031 \\
\hline 1301 & $w$ & 1.80 & 0.0014 \\
\hline 1401 & WNW & 1.50 & 0.0012 \\
\hline 1501 & NW & 1.79 & 0.0014 \\
\hline 1602 & NNW & 1.63 & 0.0013 \\
\hline & \multicolumn{2}{|c|}{ Maximum Site Perimeter Dose $=$} & 0.0035 \\
\hline
\end{tabular}

*CEDE = Committed Effective Dose Equivalent, the total dose equivalent recieved over a 50 year period following the intake of a radionuclide.

Note: CEDE included the inhalation and submersion pathways. ICRP Publication No. 30 dose conversion factors used. 
Table 6-2

BNL Site Environmental Report for Calendar Year 1994

Ar-41 and 0-15 Site Boundary Dose Equivalents

\begin{tabular}{lccc}
\hline Sector & $\begin{array}{c}\text { Ar-41 } \\
\text { (mrem/yr) }\end{array}$ & $\begin{array}{c}\text { O-15 } \\
\text { (mrem/yr) }\end{array}$ & $\begin{array}{c}\text { Total } \\
\text { (mrem/yr) }\end{array}$ \\
\hline N & 0.0490 & 0.0040 & 0.0530 \\
NNW & 0.0330 & 0.0029 & 0.0359 \\
NW & 0.0320 & 0.0025 & 0.0345 \\
WMW & 0.0330 & 0.0025 & 0.0355 \\
W & 0.0360 & 0.0037 & 0.0397 \\
WSW & 0.0450 & 0.0032 & 0.0482 \\
SW & 0.0540 & 0.0039 & 0.0579 \\
SSW & 0.0510 & 0.0040 & 0.0550 \\
S & 0.0570 & 0.0050 & 0.0620 \\
SSE & 0.0740 & 0.0065 & 0.0805 \\
SE & 0.0760 & 0.0075 & 0.0835 \\
ESE & 0.0850 & 0.0082 & 0.0932 \\
E & 0.0560 & 0.0064 & 0.0624 \\
ENE & 0.0510 & 0.0630 & 0.1140 \\
NE & 0.0950 & 0.0091 & 0.1041 \\
NNE & 0.1100 & 0.0086 & 0.1186 \\
& & & \\
\hline & & &
\end{tabular}

Note: All values are individual dose equivalent rates at a distance of $1,550 \mathrm{~m}$ from the center of the BNL site. 
Table 6-3

BNL Site Environmental Report for Calendar Year 1994

Collective Dose - Radioactive Airborme Emissions

\begin{tabular}{|c|c|c|c|c|c|c|c|c|}
\hline Nuclide & $\begin{array}{l}\text { Total Ci } \\
\text { Released }\end{array}$ & $\underset{\text { (p-rem/yr) }}{\text { BLIP }}$ & $\begin{array}{c}\text { HFBR } \\
\text { (p-rem/yr) }\end{array}$ & $\begin{array}{c}\text { BMRR } \\
\text { (p-rem/yr) }\end{array}$ & $\underset{\text { (p-rem/yr) }}{801 \mathrm{NA}}$ & $\underset{\text { (p-rem/yr) }}{\text { Incin. }}$ & $\begin{array}{c}\text { Booster } \\
\text { (p-rem/yr) }\end{array}$ & $\begin{array}{c}\text { Total } \\
\text { (p-rem/yr) }\end{array}$ \\
\hline$A r-41$ & $2.00 E+03$ & & & $3.45 E+00$ & & & & $3.45 E+00$ \\
\hline As-74 & 2.17E-04 & & & & $2.50 E-06$ & & & $2.50 \mathrm{E}-06$ \\
\hline $\mathrm{Ba}-128$ & 1.60E-06 & & 8.38E-08 & & & & & 8.38E-08 \\
\hline $\mathrm{Be}-7$ & 2.07E-05 & & 2.22E-07 & & 5.43E-07 & & 4.90E-04 & 4.91E-04 \\
\hline$B r-77$ & $9.19 \mathrm{E}-03$ & & & & $4.51 E-04$ & & & 4.51E-04 \\
\hline Br-82 & $1.36 \mathrm{E}-03$ & & 6.01E-05 & & $6.68 \mathrm{E}-06$ & & & $6.68 \mathrm{E}-05$ \\
\hline$c-11$ & $9.50 \mathrm{E}-02$ & & 4.91E-03 & & 5.71E-04 & & $5.48 E-03$ & 1.10E-02 \\
\hline Co-57 & $3.35 E-04$ & & & & & 2.37E-04 & & 2.37E-04 \\
\hline Co-60 & $1.12 E-06$ & & & & $5.66 \mathrm{E}-05$ & & & 5.66E-05 \\
\hline Cs-137 & 4.30E-05 & $3.29 E-13$ & $4.29 \mathrm{E}-14$ & & $3.59 E-12$ & & & $3.96 \mathrm{E}-12$ \\
\hline $\mathrm{Ga}-68$ & $1.99 E-04$ & & & & $1.52 E-06$ & & & 1.52E-06 \\
\hline $\mathrm{H}-3$ & $8.08 E+01$ & $3.14 E-08$ & $2.74 E-02$ & & & $2.74 E-07$ & 1.30E-06 & 2.74E-02 \\
\hline $1-124$ & $6.15 E-04$ & & & & $1.14 E-04$ & & & $1.14 \mathrm{E}-04$ \\
\hline $\mid-125$ & $5.10 \mathrm{E}-04$ & & & & & $1.55 E-04$ & & $1.55 \mathrm{E}-04$ \\
\hline I-126 & 2.27E-03 & & 4.72E-07 & & $4.22 \mathrm{E}-04$ & & & 4.22E-04 \\
\hline $\mid-131$ & $7.40 \mathrm{E}-06$ & & $1.38 E-06$ & & & & & $1.38 \mathrm{E}-06$ \\
\hline $\mid-132$ & 1.36E-06 & & 5.21E-09 & & & & & 5.21E-09 \\
\hline $1-133$ & 1.56E-05 & & 4.99E-05 & & & & & 4.99E-05 \\
\hline I-134 & 1.88E-05 & & $2.25 \mathrm{E}-08$ & & & & & 2.25E-08 \\
\hline $1-135$ & $1.32 E-05$ & & 1.24E-07 & & & & & 1.24E-07 \\
\hline $\mathrm{Mn}-54$ & $3.80 \mathrm{E}-06$ & $1.06 \mathrm{E}-05$ & & & $5.24 \mathrm{E}-06$ & & & 1.58E-05 \\
\hline $\mathrm{N}-13$ & $2.60 E+02$ & & & & & & 7.14E-04 & 7.14E-04 \\
\hline $0-15$ & $3.90 E+02$ & 7.17E-05 & & & & & 2.69E-05 & 9.86E-05 \\
\hline$R b-84$ & 9.21E-06 & & & & 1.24E-06 & & & 1.24E-06 \\
\hline S-35 & 4.00E-05 & & & & & $1.86 \mathrm{E}-07$ & & 1.86E-07 \\
\hline Sb-124 & 6.64E-05 & & & & $9.74 E-05$ & & & $9.74 \mathrm{E}-05$ \\
\hline Se-75 & 1.35E-04 & & & & & & & $0.00 E+00$ \\
\hline Sr-85 & $1.00 E-06$ & & & & & 8.39E-08 & & 8.39E-08 \\
\hline Zr-89 & 9.58E-07 & 3.05E-07 & & & & & & 3.05E-07 \\
\hline Total & & 8.26E-05 & $3.24 \mathrm{E}-02$ & $3.45 E+00$ & 1.73E-03 & 3.93E-04 & 6.71E-03 & $3.49 \mathrm{E}+00$ \\
\hline
\end{tabular}



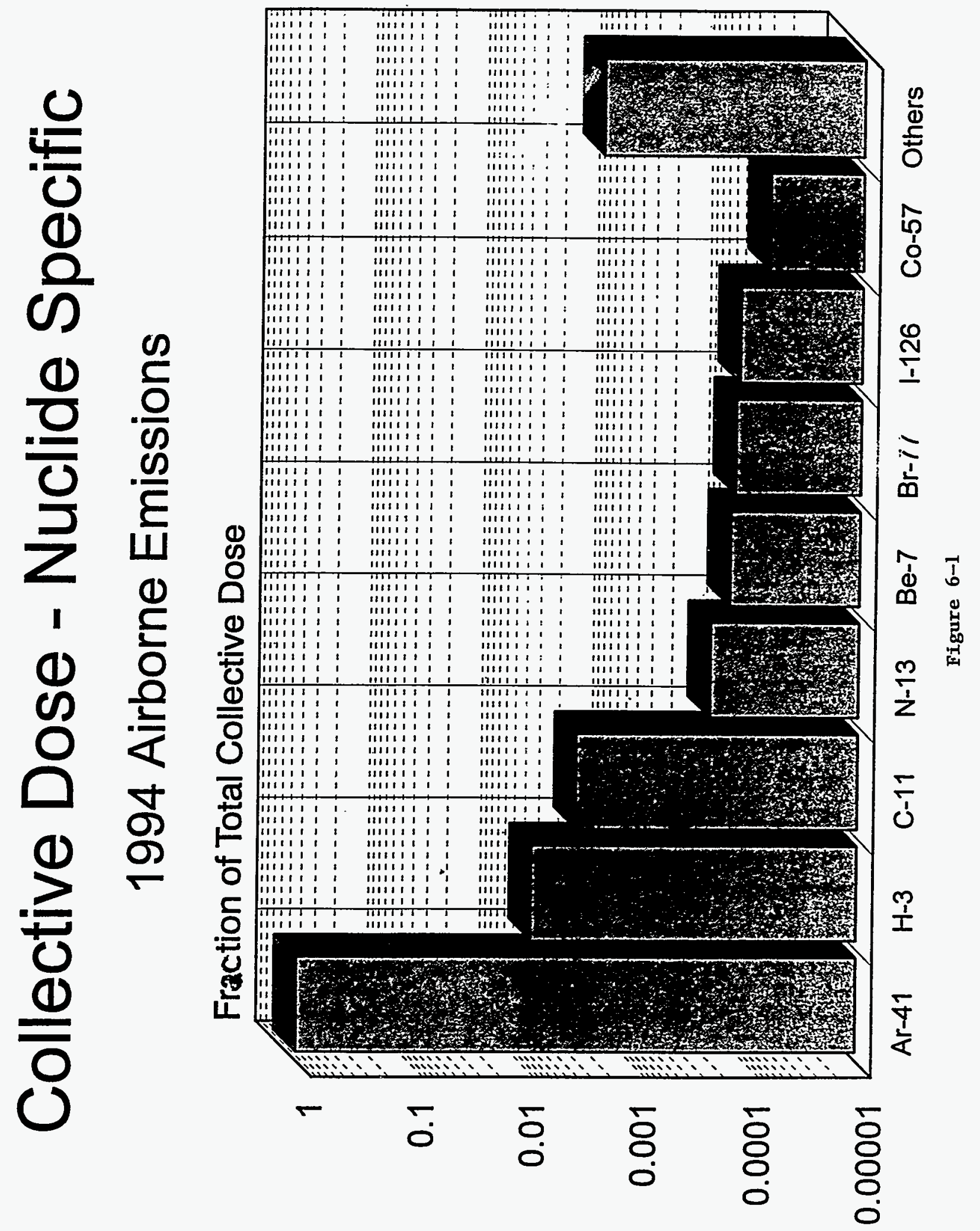


\section{Fraction of Collective Dose}

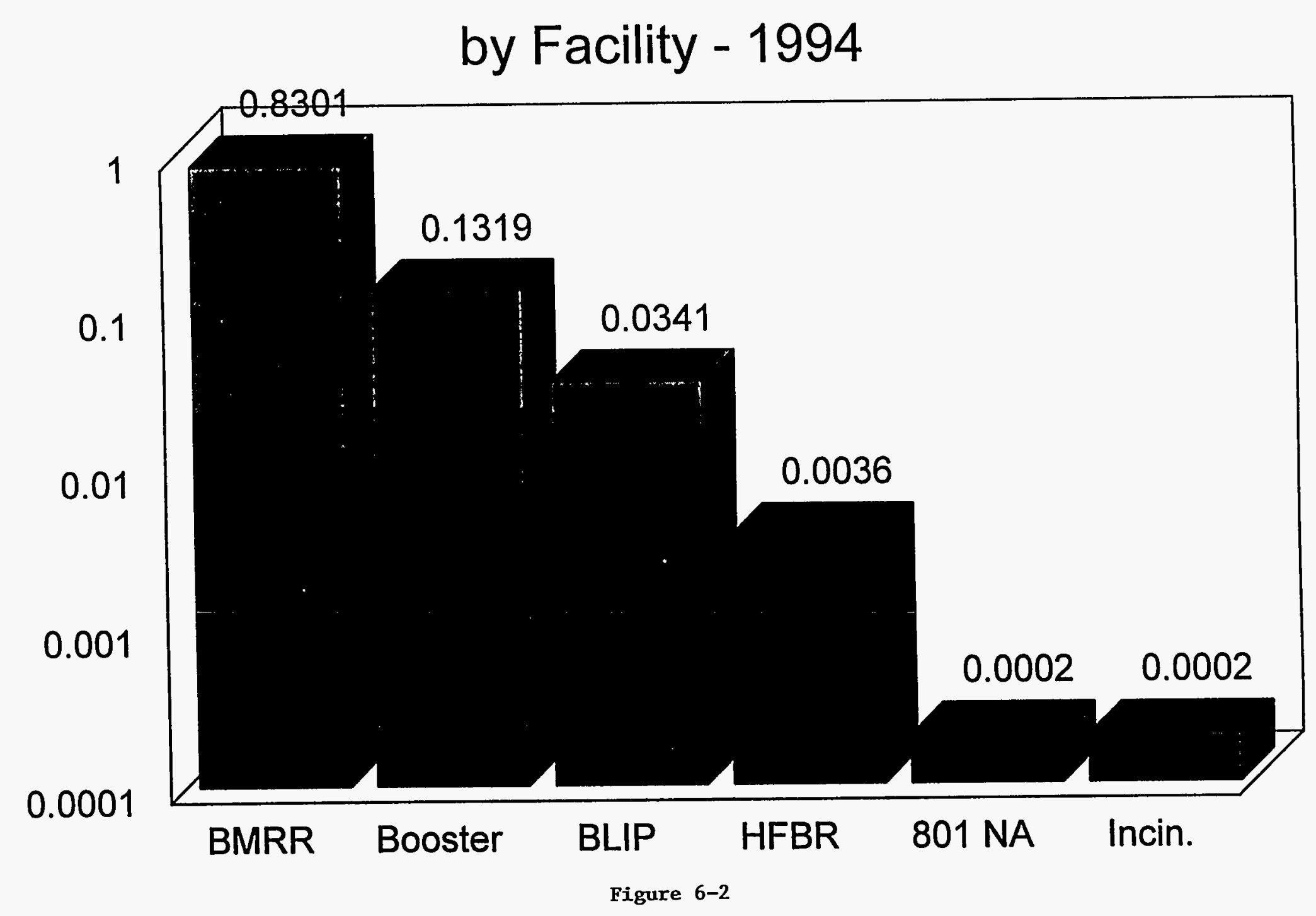


Table 6 - 4

BNL Site Environmental Report for Calendar Year 1994

Collective and Indivdual Committed Effective Dose

Equivalent (CEDE) From the Water Pathway

\begin{tabular}{llcc}
\hline Pathway & Nuclide & $\begin{array}{c}\text { Maximum } \\
\text { Individual } \\
\text { CEDE (mrem) }\end{array}$ & $\begin{array}{c}\text { Collective } \\
\text { CEDE } \\
\text { (person-mrem) }\end{array}$ \\
\hline $\begin{array}{l}\text { Drinking } \\
\text { Water }\end{array}$ & $\mathrm{H}-3$ & 0.10 & 52 \\
Fish & Cs-137 & 0.32 & 200 \\
& Sr-90 & 0.48 & 300 \\
$\begin{array}{l}\text { All Ingestion } \\
\text { Pathways }\end{array}$ & & 0.90 & 552 \\
\hline
\end{tabular}


The cesium-137 concentrations in fish samples collected from Donahue's Pond are reported in Table 4-16. Using the method described in Appendix B, the maximum individual committed dose equivalent was calculated to be $0.8 \mathrm{mrem} 10.008$ $\mathrm{mSv}$ ). The population collective dose equivalent due to cesium-137 and $\mathrm{Sr}-90$ combined was calculated to be 0.499 person-rem (0.005 person-Sv). The water and fish pathway dosimetric results are summarized in Table 6-4.

\subsection{Maximum Individual Effective Dose Equivalent}

The maximum committed effective dose equivalent to a hypothetical individual residing at the site boundary during 1994 was $1.04 \mathrm{mrem}$ (0.0104 msv) (see Table 6-5). This dose is a total value which includes the dose resulting from air inhalation, water ingestion, and fish consumption. This value is conservative due to the fish dose from Donahue's Pond. (The committed effective dose equivalent due to fish ingestion accounts for $83 \%$ of the maximally exposed individual's calculated dose.) The 1.04 mrem individual dose value can be compared to the expected dose equivalent received from local natural background sources, approximately $60 \mathrm{mrem}$. The calculated maximum individual dose is equal to $1.7 \%$ of the dose that a local resident could expect to receive even if no Iaboratory operations were conducted.

\subsection{Collective (Population) Dose Equivalent}

The collective (population) dose equivalent (total population dose) beyond the site boundary, within a radius of $80 \mathrm{~km}$, attributed to Laboratory operations during 1994, was 4.04 person-rem (0.040 person-Sv) and was obtained by the summation of the doses from the pathways discussed previously in this report. This data is summarized in Table 6-5.

The collective dose equivalent to the population within an $80-\mathrm{km}$ radius of the Laboratory, due to external radiation from natural background, amounts to about 291,000 person-rem/yr (2,910 person-Sv/yr), to which about 97,000 person-rem/yr ( 970 person-Sv/yr) should be added for internal radioactivity from natural sources. 
Table 6-5

BNL Site Environmental Report for Calendar Year 1994

Collective Dose from All Pathways

\begin{tabular}{lcccrc}
\hline & $\begin{array}{c}\text { Maximum } \\
\text { Individual } \\
\text { CEDE (mrem) }\end{array}$ & $\begin{array}{c}\text { Annual } \\
\text { Background } \\
\text { Dose Equiv. } \\
\text { (mrem) }\end{array}$ & $\begin{array}{c}\text { Maximum } \\
\text { Individual } \\
\text { Annual Dose } \\
\text { Limit (mrem) }\end{array}$ & $\begin{array}{c}\text { Collective } \\
\text { CEDE } \\
\text { (person-mrem) }\end{array}$ & $\begin{array}{c}\text { Collective } \\
\text { Background } \\
\text { Dose Equiv. } \\
\text { (person-mrem) }\end{array}$ \\
\hline Air (a) & 0.14 & 58 & 10 & 3,490 & $2.9 E+08$ \\
Water & 0.10 & ND & 4 & 52 & ND \\
Fish & 0.80 & 0.206 & NA & 500 & $1.0 E+02$ \\
All Pathways & 1.04 & 58 & 100 & 4,042 & $2.9 E+08$ \\
\hline
\end{tabular}

(a) Direct exposure from plume passage included in air component.

ND: Not Detected.

NA: Not Applicable. 


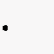




\subsection{LABORATORY QUATITY ASSURANCE - s. I. K. Briggs}

The EM program, which includes surveillance monitoring as well as compliance monitoring, utilizes an on-site Analytical Services Laboratory as well as off-site contractor laboratories for radiological and nonradiological analyses. Standard Operating Procedure's are established for the calibration of instrumentation, analysis of samples, and performance of quality control checks. Depending on the analytical method, quality control checks include analysis of blanks or background concentrations, use of Amersham or National Institute for standards and Technology (NIST) traceable standards, and analysis of reference check standards, spiked samples, and duplicate samples. The supervisors review all analytical and quality control results before the data is reported and incorporated into the database. In addition, both laboratories are certified by the NYSDOH Environmental Laboratory Approval Program (ELAP).

\subsection{Radiological Analyses}

The S\&EP Division Analytical Services Iaboratory performs radiological analysis of both environmental and facility samples for gross alpha, gross beta, gamma, tritium and strontium-90. The laboratory participates in the DOE Environmental Measurements Iaboratory (EMI) QA Program and the EPA Nuclear Radiation Assessment Division, Environmental Monitoring Systems Laboratory, Las Vegas (EMSL-LV) Intercomparison Study. The laboratory is certified by NYSDOH ELAP for potable and non potable analysis of gross alpha and beta, photon emitters, tritium, and strontium 89 and 90 environmental samples, and analyzes proficiency samples as part of the EIAP certification program. The results of these studies are presented in Tables $7-1$ through $7-3$, respectively.

Twenty-one of thirty-six EML analyses were within $\pm 10 \%$ and showing excellent agreement with the known value; thirteen of thirty-six were within $\pm 30 \%$ demonstrating good agreement; and two analyses fell outside the acceptance limits of $\pm 50 \%$. Further investigation of these unacceptable EMI analyses revealed a high energy component (i.e., cobalt-60, cesium-137) which interfered with the tritium calculation. Distillation of the sample would have precluded this, therefore a corrective action was implemented requiring distillation of all samples that show a high energy component in the analysis spectrum. EMSL-LV intercomparisons resulted in excellent agreement for three of the twenty-five analyses, within $1 \sigma$ of the known value; good agreement for eight analyses, within $2 \sigma$ of the known; six of twenty-five analyses between 2 and $3 \sigma$; and the remaining eight sample analyses $>3 \sigma$. Investigation of the unacceptable analyses showed three of the eight analyses were within 2 and $3 \sigma$ of the grand average, implying an error in the known value. One isotope was not detected by our instrumentation. An investigation of the QC data for the batches containing the four remaining unacceptable analyses showed no problem associated with the sample preparation, analytical process, or data calculations. Lastly, the radiological results from the EIAP proficiency test for gross alpha and beta showed excellent agreement for two of the four analyses, within 10\% of the known value, and the two remaining analyses showed good agreement, within $20 \%$.

Figures 7-1 and 7-2 summarize the internal quality control program for the radiological instruments. Figure $7-1$ shows the annual mean and 99\% confidence interval for the efficiencies of the alpha, beta, and tritium analyzers as determined by a daily calibration standard. It is noted that the counting time differs for tritium analysis of $7 \mathrm{ml}$ environmental and $1 \mathrm{ml}$ facility samples which contributed to the difference in efficiency shown. Figure 7-2 compares the mean and 99\% confidence intervals of the cesium-137 energy for each gamma detector as measured by a daily calibration standard. The plot shows the theoretical energy of $661.65 \mathrm{KeV}$ with a solid line, and illustrates the excellent performance of each detector, $\pm 0.68 \mathrm{KeV}$, which is well within the acceptance band of $\pm I \mathrm{KeV}$ highlighted on the plot. 
Table 7-1

BNL Site Environmental Report for Calendar Year 1994

BNL Quality Assessment Program Results

Environmental Measurements Laboratory

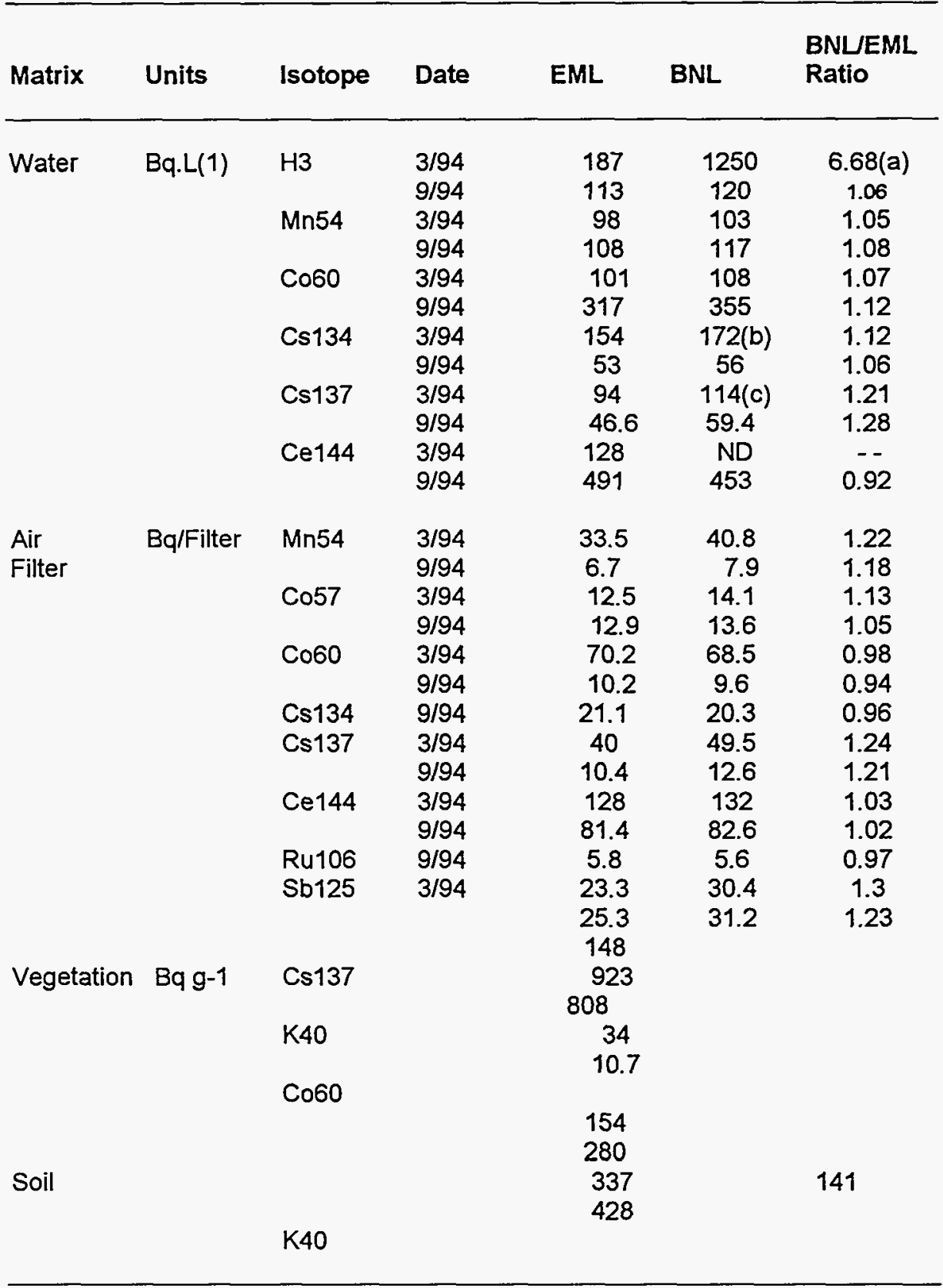

ND: Not Detected

(a) Outside acceptance limits

(b) Not reported to EML

(c) BNL result shown was corrected due to data entry error in electronic submission of data 
Table 7-2

BNL Site Environmental Report for Galendar Year 1994

BNL Quality Assessment Program Results

Environmental Monitoring Systems Laboratory (EMSL-LV)

\begin{tabular}{|c|c|c|c|c|c|c|}
\hline Matrix & Units & Isotope & Date & EMSL & BNL & $\begin{array}{l}\text { BNL/EML } \\
\text { Ratio }\end{array}$ \\
\hline \multirow[t]{9}{*}{ Water } & $\mathrm{pCi} \cdot \mathrm{L}^{-1}$ & $\begin{array}{l}\text { Gross } \\
\text { Alpha }\end{array}$ & $\begin{array}{r}1 / 94 \\
7 / 94 \\
10 / 94\end{array}$ & $\begin{array}{l}15.0 \\
32.0 \\
57\end{array}$ & $\begin{array}{c}9.33 \\
26.7 \\
38.2^{b}\end{array}$ & $\begin{array}{l}.62 \\
.83 \\
.67\end{array}$ \\
\hline & & $\begin{array}{l}\text { Gross } \\
\text { Beta }\end{array}$ & $\begin{array}{r}1 / 94 \\
7 / 94 \\
10 / 94\end{array}$ & $\begin{array}{l}62 \\
10 \\
23\end{array}$ & $\begin{array}{l}46 \\
22.7 \\
20.9^{b}\end{array}$ & $\begin{array}{c}.74 \\
2.27^{\mathrm{a}} \\
.91\end{array}$ \\
\hline & & $\mathrm{H}^{3}$ & $\begin{array}{r}3 / 94 \\
11 / 94\end{array}$ & $\begin{array}{l}4936 \\
9951\end{array}$ & $\begin{array}{l}5443 \\
9442\end{array}$ & $\begin{array}{r}1.10 \\
.95\end{array}$ \\
\hline & & $\mathrm{Co}^{60}$ & $\begin{array}{r}6 / 94 \\
11 / 94\end{array}$ & $\begin{array}{l}50 \\
59\end{array}$ & $\begin{array}{l}56.7 \\
64.3\end{array}$ & $\begin{array}{l}1.13 \\
1.09\end{array}$ \\
\hline & & $\mathrm{Cs}^{134}$ & $\begin{array}{r}6 / 94 \\
11 / 94\end{array}$ & $\begin{array}{l}40 \\
24\end{array}$ & $\begin{array}{l}35.7 \\
27\end{array}$ & $\begin{array}{r}.89 \\
1.13\end{array}$ \\
\hline & & $\mathrm{Cs}^{137}$ & $\begin{array}{r}6 / 94 \\
11 / 94\end{array}$ & $\begin{array}{l}49 \\
49\end{array}$ & $\begin{array}{l}64 \\
65.7\end{array}$ & $\begin{array}{l}1.31^{\mathrm{a}} \\
1.34^{\mathrm{d}}\end{array}$ \\
\hline & & $\mathrm{Zn}^{65}$ & $\begin{array}{r}6 / 94 \\
11 / 94\end{array}$ & $\begin{array}{l}134 \\
100\end{array}$ & $\begin{array}{l}159.3 \\
119\end{array}$ & $\begin{array}{l}1.19^{\mathrm{a}} \\
1.19^{\mathrm{a}}\end{array}$ \\
\hline & & $\mathrm{Ba}^{133}$ & $\begin{array}{r}6 / 94 \\
11 / 94\end{array}$ & $\begin{array}{l}98.0 \\
73.0\end{array}$ & $\begin{array}{l}96.3 \\
84.0\end{array}$ & $\begin{array}{r}.98 \\
1.15\end{array}$ \\
\hline & & $\mathrm{Ru}^{106}$ & $6 / 94$ & 252 & 274.7 & 1.09 \\
\hline Air & pCi/Filter & $\begin{array}{l}\text { Alpha } \\
\text { Beta } \\
\mathrm{Cs}^{137} \\
\mathrm{Sr} \mathbf{r}^{90}\end{array}$ & $\begin{array}{l}8 / 94 \\
8 / 94 \\
8 / 94 \\
8 / 94\end{array}$ & $\begin{array}{l}35.0 \\
56.0 \\
15.0 \\
20.0\end{array}$ & $\begin{array}{l}42.3 \\
68.7 \\
26.7 \\
\text { NA }\end{array}$ & $\begin{array}{c}1.20 \\
1.23 \\
1.78^{d} \\
--\end{array}$ \\
\hline Milk & $\mathrm{pCi} \cdot \mathrm{L}^{-1}$ & $\begin{array}{l}\mathrm{I}^{131} \\
\mathrm{Cs}{ }^{137} \\
\mathrm{Sr}{ }^{90}\end{array}$ & $\begin{array}{l}9 / 94 \\
9 / 94 \\
9 / 94\end{array}$ & $\begin{array}{r}75.0 \\
59.0 \\
1.0\end{array}$ & $\begin{array}{l}\text { ND } \\
65.3 \\
\text { NA }\end{array}$ & $\begin{array}{c}-- \\
1.10 \\
--\end{array}$ \\
\hline & $\mathrm{mg} \bullet \mathrm{L}$ & K & $9 / 94$ & 1715.0 & 1896 & $1.11^{\mathrm{a}}$ \\
\hline
\end{tabular}

ND: Not Detected

a Outside acceptance limits

b Not reported to EML

c BNL result shown was corrected due to data entry error in electronic

submission of data

d Determined to be an outlier 
Table 7-3

BNL Potable Water Radiochemistry Proficiency Test Results

Environmental Laboratory Approval Program

\begin{tabular}{|c|c|c|c|c|}
\hline Analyte & Date & $\begin{array}{c}\text { ELAP } \\
\left(\mathrm{DCI} \mathrm{LL}^{-1}\right)\end{array}$ & $\begin{array}{l}\mathrm{BNL} \\
\left(\mathrm{PC} I \cdot \mathrm{L}^{-1}\right)\end{array}$ & $\begin{array}{l}\text { BNL/ELAP } \\
\text { Ratio }\end{array}$ \\
\hline Gross Alpha & $12 / 94$ & $\begin{array}{l}7.94 \\
49.6\end{array}$ & $\begin{array}{l}8.11 \\
40.1\end{array}$ & $\begin{array}{r}1.02 \\
.81\end{array}$ \\
\hline Gross Beta & $12 / 94$ & $\begin{array}{l}10.4 \\
59.4\end{array}$ & $\begin{array}{r}9.5 \\
68.0\end{array}$ & $\begin{array}{r}.91 \\
1.14\end{array}$ \\
\hline
\end{tabular}




\section{Calibration Standard Summary}

Alpha, Beta, and Tritium Efficiency

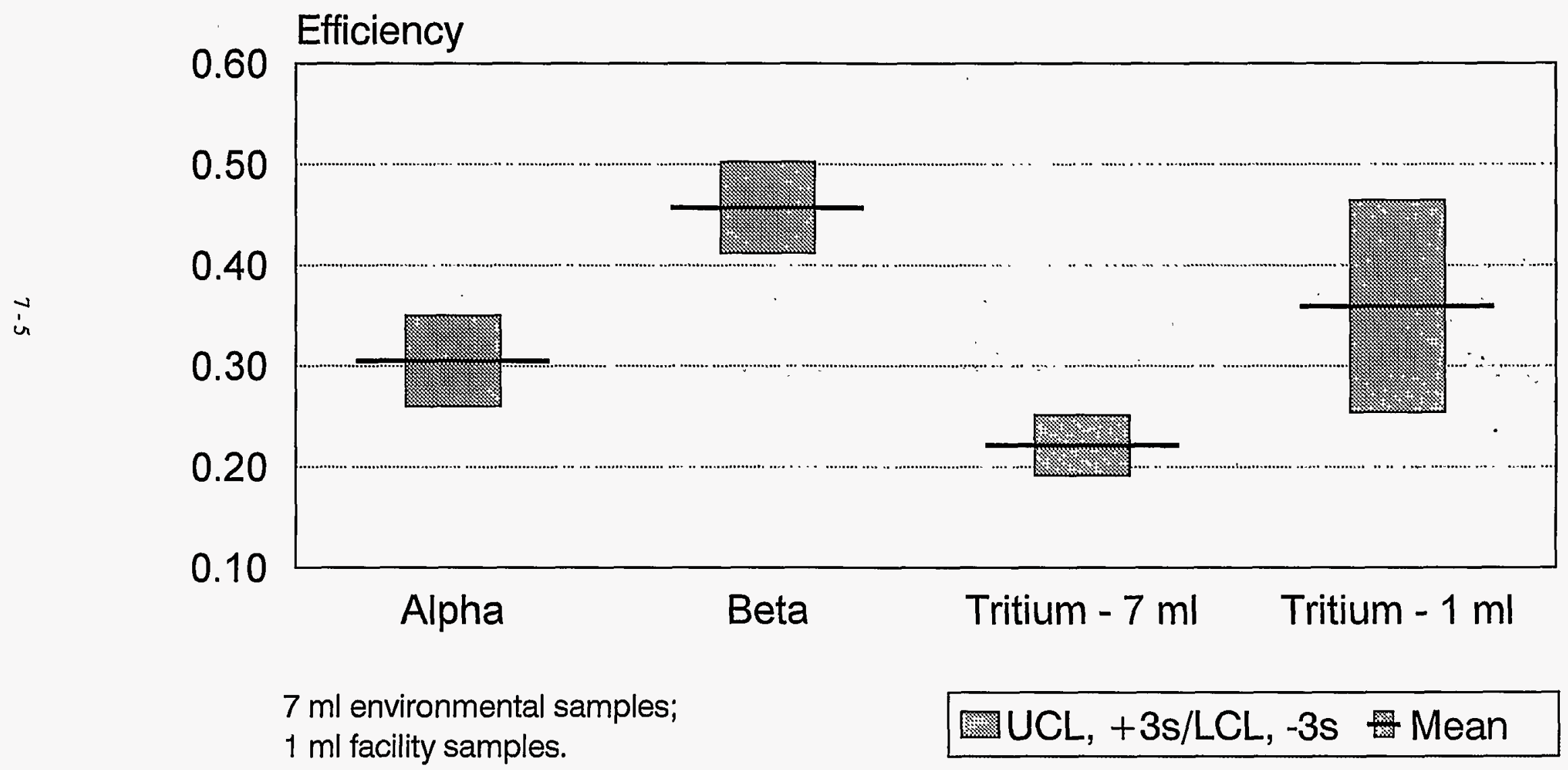

Figure 7-1 


\section{Gamma Calibration Standard Summary Cs137 Energy}

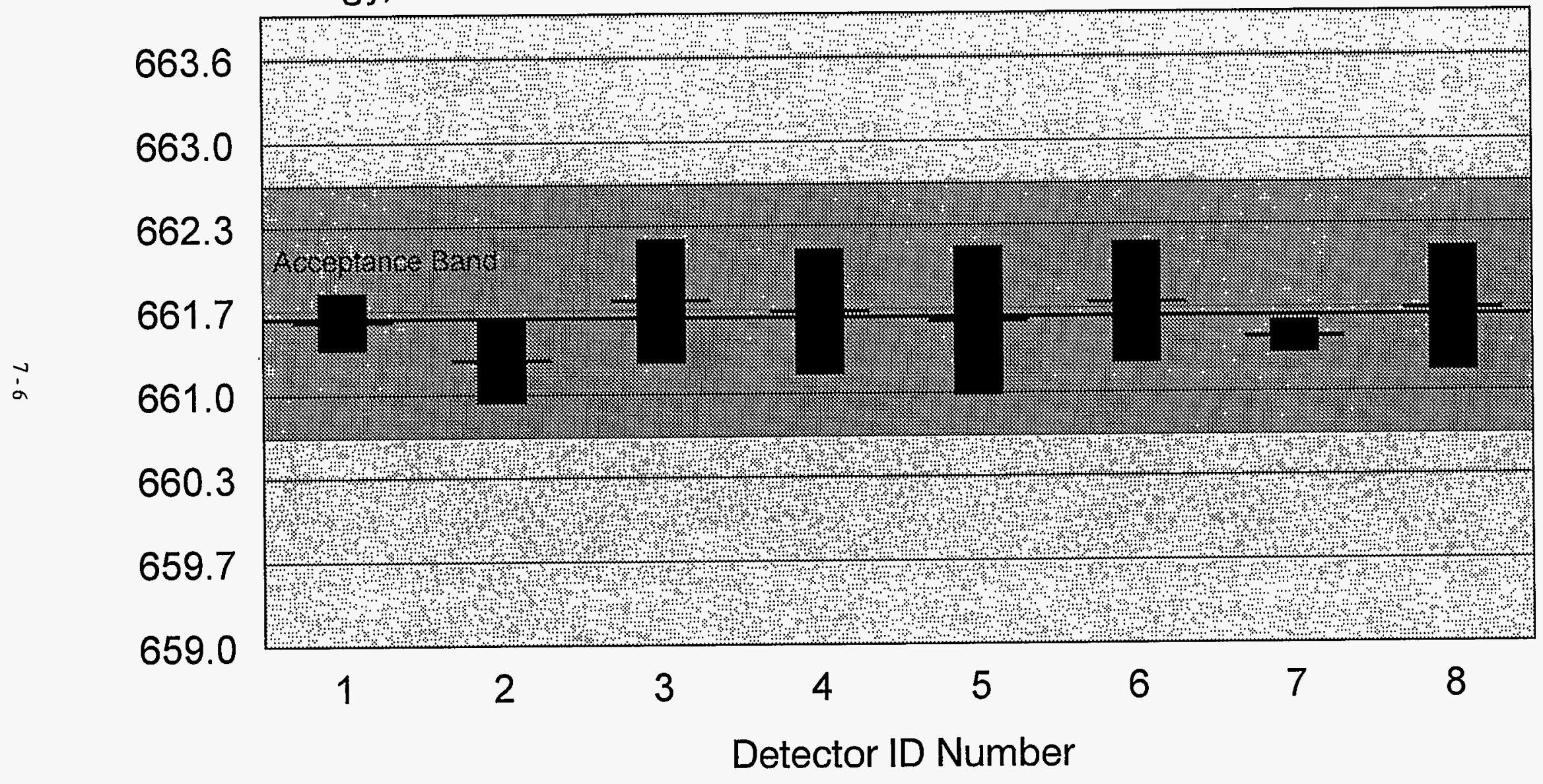


Between January and May 1994, the laboratory tested and implemented a strontium-90 method. Routine sample analyses began in March after final instrument calibration. Figure 7-3 compares the mean and 998 confidence interval of the deviation from the calibration standard for each of the detectors. The plot shows that the mean percent deviation from the calibration standards was within $\pm 5 \%$ and the $99 \%$ confidence interval was $\pm 8 \%$.

During December of 1994, an on-site audit of the radiological analytical processes was conducted by NYSDOH. Of the fifteen nonconformances noted, five required no corrective action after additional information was provided to ELAP, five pertained to sample preparation of which four related to tritium distiliation, three concerned analysis methodology, and two were associated with sample collection. A corrective action plan was developed by the Analytical Services Laboratory Supervisor and accepted by NYSDOH EIAP.

As part of the SCDHS program to monitor residential wells, an independent comparison of the BNI tritium results was performed. Duplicate field samples were collected and sent to two different laboratories for analysis; BNL and another NYSDOH certified laboratory. The data is plotted in Figure 7-4 and a linear regression analysis shows an intercept of $154 \mathrm{pCi} / \mathrm{L}$, a slope of 0.79 , and a correlation of 0.72 .

\subsection{Nonradiological Analyses}

The S\&EP Analytical Laboratory is certified by NYSDOH ELAP for metals and anions under environmental analyses of potable water and specific purgeable organic compounds under environmental analyses of non-potable water. These compounds are BTX, ethyl-benzene, chloroform, DCA, DCE, TCA, TCE, and PCE. The results of organic and inorganic proficiency samples analyzed for this certification program are presented in Tables 7-4 and 7-5, respectively.

Excellent agreement, within $\pm 10 \%$, was noted in twelve of twenty organic analysis tests, two tests fell within $\pm 20 \%$ of the known value showing good agreement, and six analyses were deemed unacceptable. Investigation into these unacceptable analyses revealed low recovery of an internal standard coupled with an autosampler problem causing non-uniform loss of volatiles. Corrective actions included monitoring of internal standards and hardware replacement of the autosampler. Results from the inorganic proficiency samples showed excellent agreement, within $\pm 10 \%$, in forty-seven of the fifty-two analyses with forty-five analyses actually being within 5\% of the known value; and good agreement, within $\pm 15 \%$, in the remaining five.

Figure 7-5 presents the annual mean and $99 \%$ confidence interval of the reference check and calibration check sample recoveries analyzed in each metals or anions batch. The results show the anions to be $\pm 10 \%$ and the metals $\pm 15.5 \%$ of the target value, with the exception of mercury which measured $\pm 19 \%$. The shaded areas on the plot shows the acceptance band for the various analytes. Figure 7-6 summarizes the recoveries of the organic reference check data by presenting the mean and $99 \%$ confidence interval for each of the primary volatile organic compounds and two PCB controls. The figure shows variability within $\pm 16 \%$ of the mean for the volatile organic compounds. The PCB controls showed a $16 \%$ negative bias and 138 variability for Aroclor 1254, and a 41\% variability about the mean for Aroclor 1260. Investigation into the PCB quality control data revealed a bias in the preparation of standards. Resulting corrective actions include evaluation of the PCB quality control program and implementation of improvements. Figure 7-7 presents the surrogate and spike recovery summary for the gas chromatography-mass spectroscopy method. As shown, the method performance was well within the acceptance band of $\pm 15 \%$ for the surrogates and $\pm 25 \%$ for the spikes. Figure 7-8 provides the mean and 99\% confidence interval of the spike recoveries for the ion chromatography and atomic absorption methods used for inorganic analyses. All spikes, except for one zinc sample, was within the $\pm 25 \%$ acceptance limit. 


\section{Strontium 90 Calibration Summary \\ Percent Deviation from Standards}

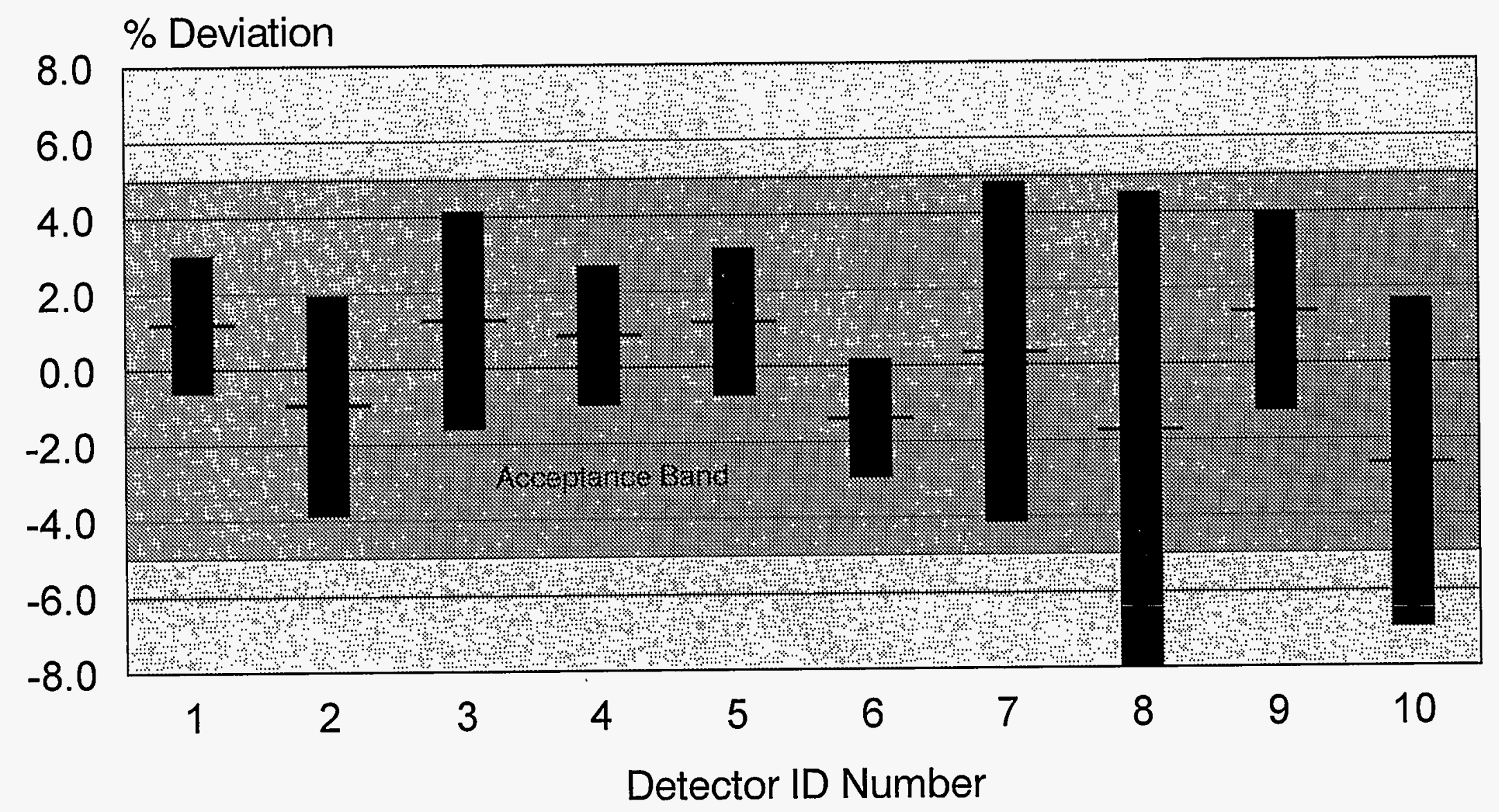

Figure 7-3

uCL, $+3 s / L C L,-3 s=$ Mean 


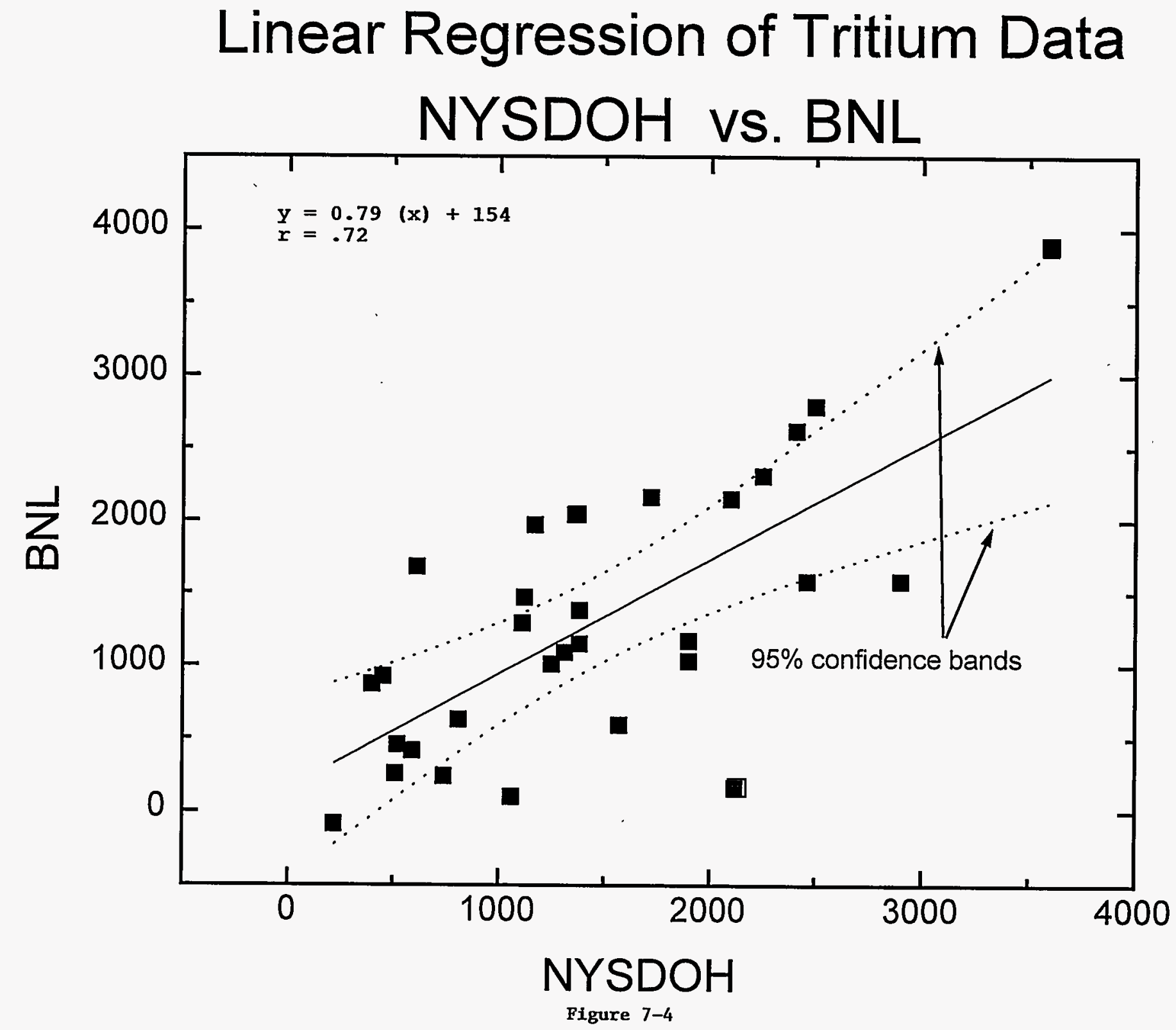


Table 7-4

BNL Site Environmental Report for Calendar Year 1994

BNL Non-potable Water Chemistry Proficiency Test Results Environmental Laboratory Approval Program

\begin{tabular}{|c|c|c|c|c|}
\hline Analyte & Date & $\begin{array}{l}\text { ELAP BNL } \\
\left(\mu g \cdot L^{-1}\right)\end{array}$ & $\left(\mu g \cdot I^{-1}\right)$ & $\begin{array}{c}\text { BNL/BLAP } \\
\text { Ratio } \\
\end{array}$ \\
\hline \multirow[t]{4}{*}{ Ethyl Benzene } & $1 / 94$ & 21.9 & 22.1 & 1.01 \\
\hline & & 28.0 & 27.5 & .98 \\
\hline & $7 / 94$ & 11.6 & 16.0 & $1.37^{\mathrm{a}}$ \\
\hline & & 76.9 & 106.0 & $1.38^{\mathrm{a}}$ \\
\hline \multirow[t]{4}{*}{ Total XYlenes } & $1 / 94$ & 17.3 & 20.2 & 1.17 \\
\hline & & 26.2 & 29.4 & 1.12 \\
\hline & $7 / 94$ & 20.6 & 30.1 & $1.46^{\mathrm{a}}$ \\
\hline & & 53.3 & 77.6 & $1.45^{\mathrm{a}}$ \\
\hline \multirow[t]{4}{*}{ Chloroform } & $1 / 94$ & 18.4 & 17.8 & .97 \\
\hline & & 25.5 & 24.3 & .95 \\
\hline & $7 / 94$ & 20.6 & 19.9 & .96 \\
\hline & & 35.8 & 37.1 & 1.03 \\
\hline \multirow[t]{4}{*}{$1,1,-$ Dichloroethane } & $1 / 94$ & 21.1 & 19.9 & .94 \\
\hline & & 33.9 & 31.1 & .92 \\
\hline & $7 / 94$ & 15.1 & 16.0 & 1.06 \\
\hline & & 48.8 & 51.6 & 1.06 \\
\hline \multirow{4}{*}{$\begin{array}{l}1,1,1- \\
\text { Trichloroethane }\end{array}$} & $1 / 94$ & 16.1 & 15.8 & .98 \\
\hline & & 38.1 & 36.0 & .94 \\
\hline & $7 / 94$ & 29.5 & 39.4 & $1.34^{a}$ \\
\hline & & 73.6 & 98.4 & $1.34^{\mathrm{a}}$ \\
\hline
\end{tabular}

a Outside acceptance limits 
Table 7-5

BNL Potable Water Chemistry Proficiency Test Results Environmental Laboratory Approval Program

\begin{tabular}{|c|c|c|c|c|}
\hline Analyte & Date & $\begin{array}{c}\text { ELAP } \\
\left(\mu g \cdot L^{-1}\right)\end{array}$ & $\begin{array}{c}\text { BNL } \\
\left(\mu g \cdot L^{-1}\right)\end{array}$ & $\begin{array}{l}\text { BNL/ELAP } \\
\text { Ratio }\end{array}$ \\
\hline Cloride & $\begin{array}{c}4 / 94 \\
10 / 94\end{array}$ & $\begin{array}{c}8.05 \\
150.0 \\
40.3 \\
140.0\end{array}$ & $\begin{array}{c}7.96 \\
147.0 \\
38.2 \\
137.0\end{array}$ & $\begin{array}{l}.99 \\
.98 \\
.95 \\
.98\end{array}$ \\
\hline Nitrate (as N) & $\begin{array}{c}4 / 94 \\
10 / 94\end{array}$ & $\begin{array}{l}.997 \\
4.99 \\
2.68 \\
4.98\end{array}$ & $\begin{array}{l}1.01 \\
4.83 \\
2.64 \\
4.98\end{array}$ & $\begin{array}{r}1.01 \\
.97 \\
.99 \\
1.00\end{array}$ \\
\hline Sulfate & $\begin{array}{c}4 / 94 \\
10 / 94\end{array}$ & $\begin{array}{r}30.6 \\
160.0 \\
180.0 \\
59.4\end{array}$ & $\begin{array}{r}30.0 \\
158.0 \\
181.0 \\
58.6\end{array}$ & $\begin{array}{r}.98 \\
.99 \\
1.01 \\
.99\end{array}$ \\
\hline Cadmium & $\begin{array}{c}4 / 94 \\
10 / 94\end{array}$ & $\begin{array}{r}6.0 \\
10.0 \\
7.0 \\
3.0\end{array}$ & $\begin{array}{c}6.30 \\
10.3 \\
7.30 \\
3.11\end{array}$ & $\begin{array}{l}1.05 \\
1.03 \\
1.04 \\
1.04\end{array}$ \\
\hline Copper & $\begin{array}{c}4 / 94 \\
10 / 94\end{array}$ & $\begin{array}{r}200.0 \\
600.0 \\
1000.0 \\
100.0\end{array}$ & $\begin{array}{r}202.0 \\
599.0 \\
975.0 \\
97.0\end{array}$ & $\begin{array}{r}1.01 \\
1.00 \\
.98 \\
.97\end{array}$ \\
\hline Lead & $\begin{array}{c}4 / 94 \\
10 / 94\end{array}$ & $\begin{array}{r}8.0 \\
30.0 \\
6.0 \\
36.0\end{array}$ & $\begin{array}{c}8.45 \\
34.6 \\
6.28 \\
37.0\end{array}$ & $\begin{array}{l}1.06 \\
1.15 \\
1.05 \\
1.03\end{array}$ \\
\hline Manganese & $\begin{array}{r}4 / 94 \\
10 / 94\end{array}$ & $\begin{array}{r}101.0 \\
303.0 \\
202.0 \\
94.1\end{array}$ & $\begin{array}{r}103.0 \\
302.0 \\
204.0 \\
94.0\end{array}$ & $\begin{array}{l}1.02 \\
1.00 \\
1.01 \\
1.00\end{array}$ \\
\hline Silver & $\begin{array}{r}4 / 94 \\
10 / 94\end{array}$ & $\begin{array}{l}23.8 \\
49.1 \\
16.2 \\
45.9\end{array}$ & $\begin{array}{l}25.0 \\
50.0 \\
15.7 \\
46.0\end{array}$ & $\begin{array}{r}1.05 \\
1.02 \\
.97 \\
1.00\end{array}$ \\
\hline Zinc & $\begin{array}{r}4 / 94 \\
10 / 94\end{array}$ & $\begin{array}{r}162.0 \\
2020.0 \\
103.0 \\
1210.0\end{array}$ & $\begin{array}{r}163.0 \\
2070.0 \\
102.0 \\
1230.0\end{array}$ & $\begin{array}{r}1.01 \\
1.02 \\
.99 \\
1.02\end{array}$ \\
\hline Chromium & $\begin{array}{c}4 / 94 \\
10 / 94\end{array}$ & $\begin{array}{r}40.0 \\
100.0 \\
70.0 \\
50.0\end{array}$ & $\begin{array}{r}45.2 \\
112.0 \\
72.2 \\
51.2\end{array}$ & $\begin{array}{l}1.13 \\
1.12 \\
1.03 \\
1.02\end{array}$ \\
\hline Iron & $\begin{array}{c}4 / 94 \\
10 / 94\end{array}$ & $\begin{array}{l}182.0 \\
401.0 \\
154.0 \\
364.0\end{array}$ & $\begin{array}{l}181.0 \\
397.0 \\
154.0 \\
374.0\end{array}$ & $\begin{array}{r}.99 \\
.99 \\
1.00 \\
1.03\end{array}$ \\
\hline Sodium & $\begin{array}{c}4 / 94 \\
10 / 94 \\
4 / 94 \\
10 / 94\end{array}$ & $\begin{array}{r}2.45 \\
6.14 \\
6.79 \\
3.91 \\
818.0 \\
1510.0 \\
565.0 \\
387.0\end{array}$ & $\begin{array}{r}2.18 \\
6.06 \\
7.60 \\
4.06 \\
789.0 \\
1540.0 \\
603.0 \\
385.0\end{array}$ & $\begin{array}{r}.89 \\
.99 \\
1.12 \\
1.04 \\
.96 \\
1.02 \\
1.07 \\
.99\end{array}$ \\
\hline
\end{tabular}




\section{Reference Check Sample Summary Inorganic Analysis}

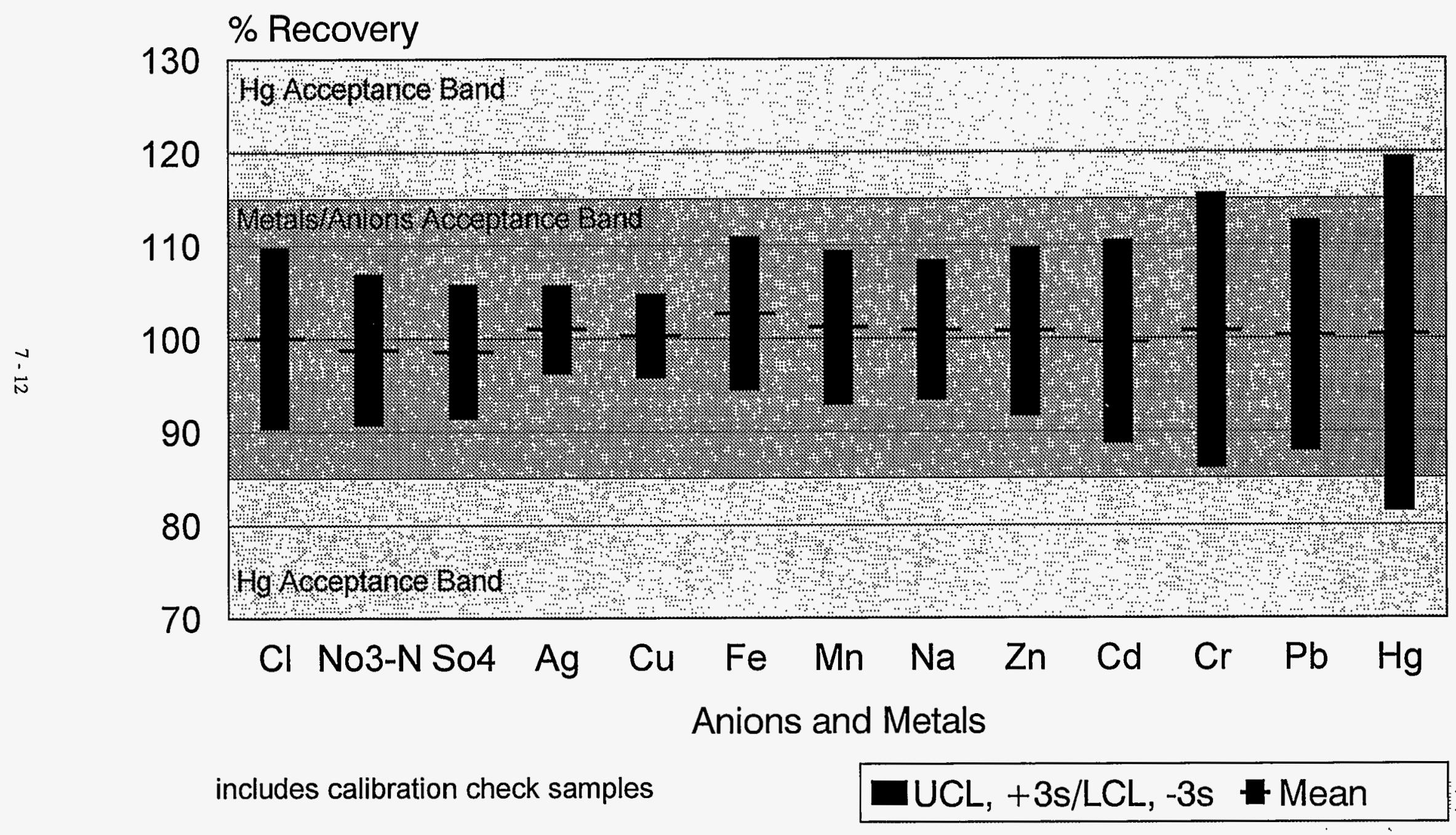

Figure 7-5 


\section{Reference Check Sample Summary Organic Analysis}

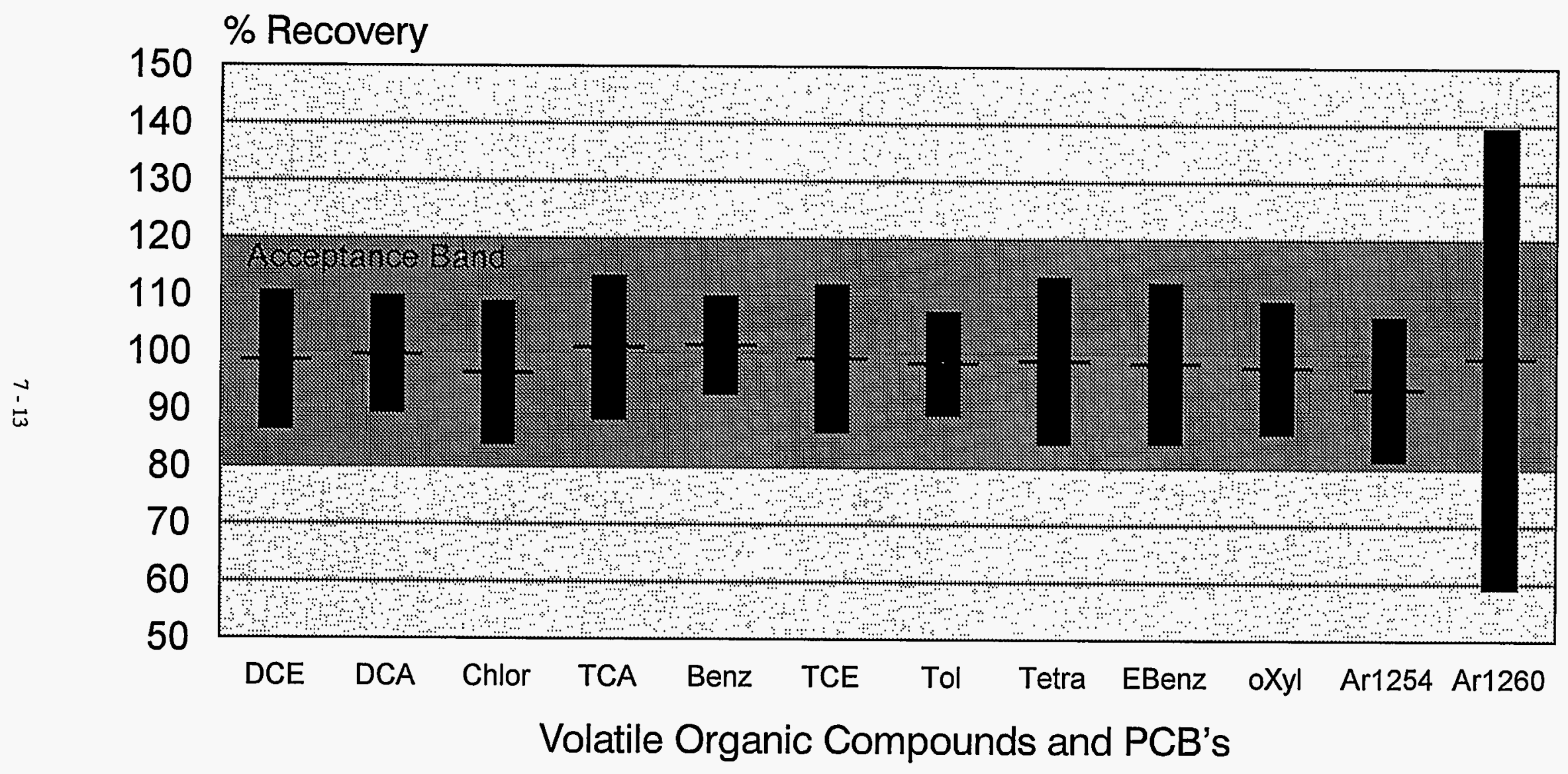

UUCL, +3s/LCL, -3s $\quad$ Mean 


\section{Surrogate and Spike Recoveries Summary Organic Analysis}

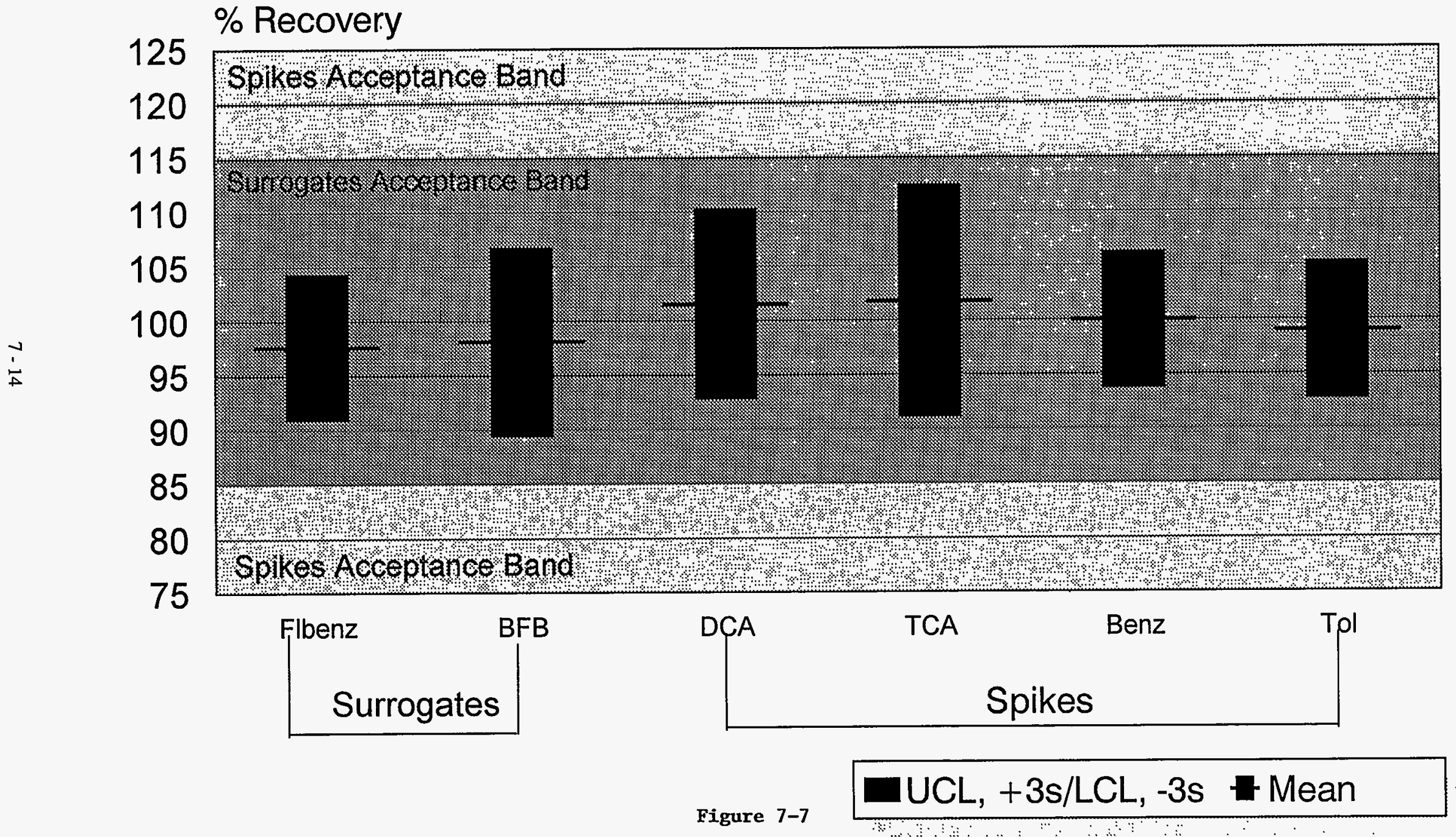




\section{Spike Recoveries Summary Inorganic Analysis}

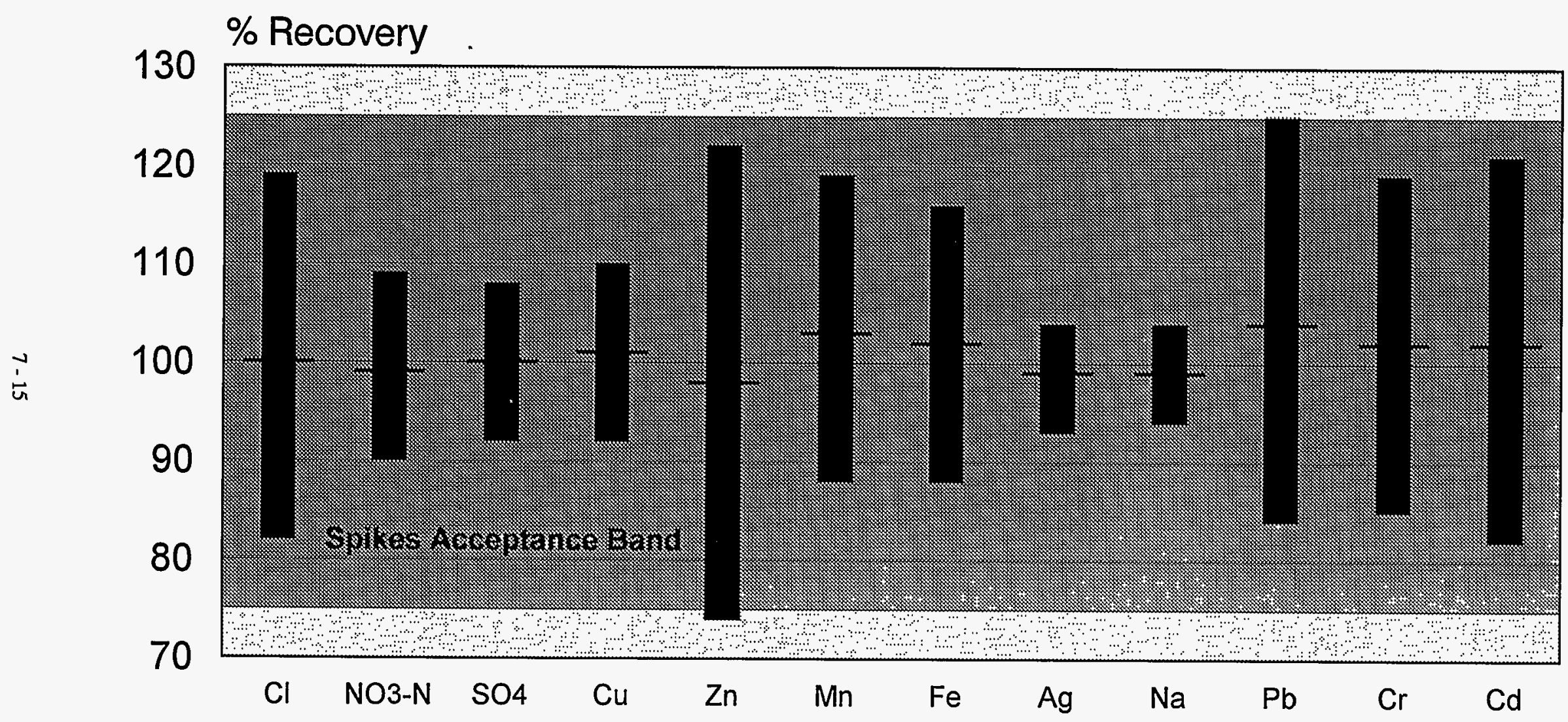

Figure 7-8 $\square$ UCL, +3s/LCL, -3s $\neq$ Mean 


\subsection{Contractor Laboratories}

Samples collected for regulatory compliance purposes such as SPDES discharge monitoring reports, water Treatment Plant monthly reports, and the CSF semiannual report are analyzed by off-site contractor laboratories certified in the respective analytes of interest. Contractors are also used to augment the capabilities of the on-site laboratories, for example strontium-90 and Toxic Characteristic Leachate Procedure (TCLP), as necessary to offset workload demands placed on the S\&EP Division laboratory. The respective laboratory supervisor specifies the contract requirements for each analytical method and ensures the incoming data package complies with those specifications before the data is reported. Audits of these commercial laboratories are performed periodically by the supervisor and $Q A$ officer to ensure competence in analytical methodology and implementation of a comprehensive $Q A$ program.

The contract laboratory responsible for analyzing the spDEs samples is required to participate in the NPDES Performance Evaluation study. The results of this audit are presented in Table 7-6. Fifteen of the seventeen analyses showed excellent agreement, within 10\%. The fathead minnow growth (IC25) analysis was acceptable at $+56 \%$, however the total suspended solids analyses was unacceptable at $+48 \%$. Investigation into the total suspended solids analysis revealed a problem with the homogenization and aliquot measurement of this sample resulting in a corrective action which adds a wetting agent in future analyses.

This same contractor participated in the Environmental Monitoring systems Laboratory (EMSI-CI) Water Pollution Performance Evaluation study \#33. The results given in Table 7-7 show excellent agreement, within the warning limits, for twenty of twenty four analyses, one sample outside the warning limit, and three samples outside the acceptance limits. A QC review by the contractor revealed a transcription error for the zinc analysis, yet no attributable cause for either phenols or nickel. 
Table 7-6

BNL National Pollution Discharge Elimination System (NPDES) Performance Evaluation Report

\begin{tabular}{|c|c|c|c|c|c|}
\hline Analyte & Units & Date & NPDES & BNL & $\begin{array}{l}\text { BNL/NPDES } \\
\text { Ratio }\end{array}$ \\
\hline $\mathrm{Cu}$ & $\mu \mathrm{g} \cdot \mathrm{L}^{-1}$ & $4 / 94$ & 98 & 94.9 & .97 \\
\hline $\mathrm{Fe}$ & $\mu \mathrm{g} \cdot \mathrm{L}^{-1}$ & $4 / 94$ & 310 & 309.0 & 1.00 \\
\hline $\mathrm{Pb}$ & $\mu \mathrm{g} \cdot \mathrm{L}^{-1}$ & $4 / 94$ & 110 & 109.0 & .99 \\
\hline $\mathrm{Zn}$ & $\mu \mathrm{g} \cdot \mathrm{L}^{-1}$ & $4 / 94$ & 171 & 189.0 & 1.10 \\
\hline $\mathrm{pH}$ & $\mathrm{pH}$ units & $4 / 94$ & 6.20 & 6.17 & 1.00 \\
\hline TSS & $\mathrm{mg} \cdot \mathrm{L}^{-1}$ & $4 / 94$ & 50 & 74.0 & $1.48^{a}$ \\
\hline Ammonia-N & $\mathrm{mg} \cdot \mathrm{L}^{-1}$ & $4 / 94$ & 12 & 12.3 & 1.03 \\
\hline $\mathrm{NO}_{3}-\mathrm{N}$ & $\mathrm{mg} \cdot \mathrm{L}^{-1}$ & $4 / 94$ & 39.2 & 37.2 & .95 \\
\hline Kjeldahl-N & $\mathrm{mg} \cdot \mathrm{L}^{-1}$ & $4 / 94$ & 29.1 & 28.4 & .98 \\
\hline 5-Day BOD & $\mathrm{mg} \cdot \mathrm{L}^{-1}$ & $4 / 94$ & 70.9 & 64.0 & .90 \\
\hline $\begin{array}{l}\text { Total } \\
\text { Residual } \mathrm{Cl}\end{array}$ & $\mathrm{mg} \cdot \mathrm{L}^{-1}$ & $4 / 94$ & .320 & .29 & .91 \\
\hline
\end{tabular}

Fathead Minnow

Chronic Data -

$\begin{array}{llllll}\text { Survival NOEC } & \% & 4 / 94 & 25.0 & 25.0 & 1.00 \\ \text { Growth IC25 } & \% & 4 / 94 & 37.4 & 58.5 & 1.56 \\ \text { Growth NOEC } & \% & 4 / 94 & 25.0 & 25.0 & 1.00\end{array}$

Cerlodaphnia

Chronic Data -

$\begin{array}{lllllr}\text { Survival NOEC } & \% & 4 / 94 & 25.0 & 25.0 & 1.00 \\ \text { Reprod. IC25 } & \% & 4 / 94 & 27.5 & 26.9 & .98 \\ \text { Reprod. NOEC } & \% & 4 / 94 & 25.0 & 25.0 & 1.00\end{array}$

a Outside acceptance limit of $\pm 15 \%$ 
Table 7-7

BNL Site Environmental Report for Calendar Year 1994

BNL $^{a}$ Water Pollution Performance Evaluation Study 非33

USEPA Environmental Monitoring Systems Laboratory (EMSL-CI)

\begin{tabular}{|c|c|c|c|c|c|}
\hline Analyte & Units & Date & $\underline{E M S L-C 1}$ & BNL & $\begin{array}{l}\text { BNL/EMSL-C1 } \\
\text { Ratio }\end{array}$ \\
\hline $\mathrm{Cu}$ & $\mu g \cdot L^{-1}$ & $11 / 94$ & $\begin{array}{r}33.6 \\
187.0\end{array}$ & $\begin{array}{r}32.1 \\
187.0\end{array}$ & $\begin{array}{r}.96 \\
1.00\end{array}$ \\
\hline $\mathrm{Fe}$ & $\mu g \cdot L^{-1}$ & $11 / 94$ & $\begin{array}{r}64.5 \\
1300.0\end{array}$ & $\begin{array}{r}66.4 \\
1293.0\end{array}$ & $\begin{array}{r}1.03 \\
.99\end{array}$ \\
\hline $\mathrm{Ni}$ & $\mu \mathrm{g} \cdot \mathrm{L}^{-1}$ & $11 / 94$ & $\begin{array}{r}265.0 \\
1080.0\end{array}$ & $\begin{array}{r}287.0 \\
1210.0\end{array}$ & $\begin{array}{l}1.08 \\
1.12^{b}\end{array}$ \\
\hline $\mathrm{Pb}$ & $\mu \mathrm{g} \cdot \mathrm{L}^{-1}$ & $11 / 94$ & $\begin{array}{r}645.0 \\
2900.0\end{array}$ & $\begin{array}{r}648.0 \\
2876.0\end{array}$ & $\begin{array}{r}1.00 \\
.99\end{array}$ \\
\hline $\mathrm{Zn}$ & $\mu g \cdot L^{-1}$ & $11 / 94$ & $\begin{array}{r}31.9 \\
726.0\end{array}$ & $\begin{array}{l}35.6 \\
67.0\end{array}$ & $\begin{array}{l}1.11 \\
.09^{b}\end{array}$ \\
\hline Ag & $\mu \mathrm{g} \cdot \mathrm{L}^{-1}$ & $11 / 94$ & $\begin{array}{r}84.0 \\
410.0\end{array}$ & $\begin{array}{r}81.5 \\
414.0\end{array}$ & $\begin{array}{r}.97 \\
1.01\end{array}$ \\
\hline Ammonia-N & $\mathrm{mg} \cdot \mathrm{L}^{-1}$ & $11 / 94$ & $\begin{array}{r}6.30 \\
.55\end{array}$ & $\begin{array}{r}6.37 \\
.57\end{array}$ & $\begin{array}{l}1.01 \\
1.04\end{array}$ \\
\hline $\mathrm{NO}_{3}-\mathrm{N}$ & $\mathrm{mg} \cdot \mathrm{L}^{-1}$ & $11 / 94$ & $\begin{array}{l}.86 \\
.27\end{array}$ & $\begin{array}{l}.87 \\
.30\end{array}$ & $\begin{array}{l}1.01 \\
1.11\end{array}$ \\
\hline Kjeldahl-N & $m g \bullet L^{-1}$ & $11 / 94$ & $\begin{array}{r}1.60 \\
12.0\end{array}$ & $\begin{array}{l}1.60 \\
12.1\end{array}$ & $\begin{array}{l}1.00 \\
1.01\end{array}$ \\
\hline Total Cyanide & $\mathrm{mg} \cdot \mathrm{L}^{-1}$ & $11 / 94$ & $\begin{array}{l}.49 \\
.21\end{array}$ & $\begin{array}{l}.47 \\
.20\end{array}$ & $\begin{array}{l}.96 \\
.95\end{array}$ \\
\hline Oil \& Grease & $\mathrm{mg} \cdot \mathrm{L}^{-1}$ & $11 / 94$ & $\begin{array}{l}43.0 \\
14.0\end{array}$ & $\begin{array}{l}34.0 \\
14.0\end{array}$ & $\begin{array}{r}.79 \\
1.00\end{array}$ \\
\hline Total Phenolics & $\mathrm{mg} \cdot \mathrm{L}^{-1}$ & $11 / 94$ & $\begin{array}{r}1.48 \\
.913\end{array}$ & $\begin{array}{l}1.98 \\
1.36\end{array}$ & $\begin{array}{l}1.34^{c} \\
1.48^{b}\end{array}$ \\
\hline
\end{tabular}

analysis performed by contractor laboratory

b Outside acceptance limits

c Outside warning limits 


\section{APPENDIX A}

\section{A.1 Glossary of Terms}

AGS

$\mathrm{AOC}$

AUI

BHO

BLIP

BNL

BETX

$\mathrm{BOD}_{5}$

CAA

CAAA

CBS

CERCLA

$\mathrm{CH}$

CO

CSF

CY

CWA

DAS

DAT

DCA

DCE

DCG

DMR

DOE

DOT

ECL

EDB

ECG

EM

EML

EMS

EMSL-LV

E\&OG

EPA

EPIP

ES\&H

HFBR

HWME

IAG

LEPC

LINAC

MDL

MLD

MPF

MRC

MRR

NA

NPDES

ND

NEPA

NESHAPS

NR

NS

NSLS

NYCRR

NYS

NYS AWQS

NYSDEC
- Alternating Gradient Synchrotron

- Area of Concern

- Associated Universities Inc.

- Brookhaven Area Office

- Brookhaven LINAC Isotope Production Facility

- Brookhaven National Laboratory

- Benzene Ethylbenzene Toluene Xylene

- Biochemica1 Oxygen Demand

- Clean Air Act

- Clean Air Act Amendments

- Chemical Bulk Storage

- Comprehensive Environmental Response, Compensation \& Liability Act

- Chicago

- Certificates to Operate

- Central Steam Facility

- Calendar Year

- Clean Water Act

- Department of Applied Science

- Department of Applied Technology

- Dichloroethane

- Dichloroethylene

- Derived Concentration Guide

- Discharge Monitoring Report

- Department of Energy

- Department of Transportation

- Environmental Conservation Law

- Ethylene Dibromide

- Environmental Compliance Group

- Environmental Monitoring

- Environment Measurements Laboratory

- Environmental Management Section

- Environmental Measurements Systems Laboratory - Las Vegas

- Engineering \& Operations Group

- Environmental Protection Agency

- Environmental Protection Implementation Plan (EPIP)

- Environmental, Safety, and Health

- High Flux Beam Reactor

- Hazardous Waste Management Facility

- Interagency Agreement

- Local Emergency Planning Committee

- Linear Accelerator

- Minimum Detection Limit

- Milion Liters per Day

- Major Petroleum Facility

- Medical Research Center

- Medical Research Reactor

- Not Analyzed

- National Pollutant Discharge Elimination System

- Not Detected

- National Environmental Policy Act

- National Emission Standards for Hazardous Air Pollutants

- Not Reported

- Not Sampled

- National Synchrotron Light Source

- New York Code of Rules and Regulations

- New York State

- New York State Ambient Water Quality Standard

- New York State Department of Environmental Conservation 


\section{A.1 Glossary of Terms (Continued)}

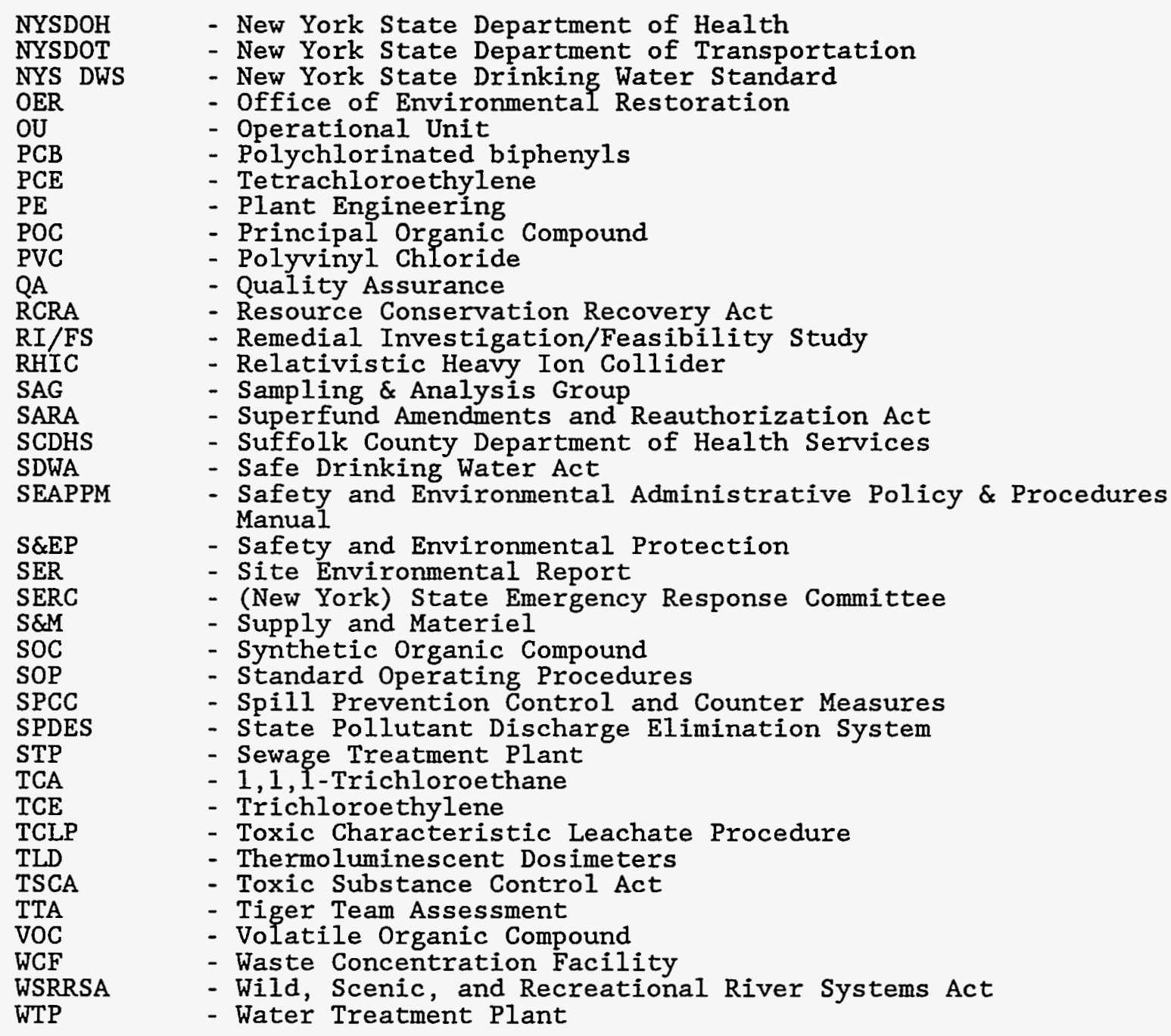




\section{A.2 Glossary of Units}

\begin{tabular}{|c|c|}
\hline $\begin{array}{l}\mathrm{CiMW}^{-1} \mathrm{~h}^{-1} \\
\mathrm{~cm} \\
\mathrm{~cm}^{3} \\
\mathrm{~cm}^{2} / \mathrm{d} \\
\mathrm{m}^{3} / \mathrm{min} \\
\mathrm{d} \\
\mathrm{gal} \\
\mathrm{GBq} \\
\mathrm{GeV} \\
\mathrm{GeV} / \mathrm{amu} \\
\mathrm{gph} \\
\mathrm{ha} \\
\mathrm{kg} / \mathrm{yr} \\
\mathrm{km} \\
\mathrm{L} / \mathrm{d} \\
\mathrm{m} \\
\mathrm{mCi} \\
\mathrm{MeV} \\
\mathrm{mg} / \mathrm{L} \\
\mathrm{mI} \\
\mathrm{MLD} \\
\mathrm{mrem} \\
\mathrm{mrem} / \mathrm{yr} \\
\mathrm{mSv} \\
\mathrm{mSv} / \mathrm{yr} \\
\mathrm{MW} \\
\mathrm{nCi} / \mathrm{L} \\
\mathrm{pCi} / \mathrm{kg} \\
\mathrm{pCi} / \mathrm{L} \\
\mathrm{pCi} / \mathrm{m}^{3} \\
\mathrm{pH} \\
\mathrm{rem} \\
\mathrm{Sv} \\
\mathrm{TBq} \\
\mu \mathrm{Ci} \\
\mu \mathrm{Ci} / \mathrm{L} \\
\mu \mathrm{g} / \mathrm{L}\end{array}$ & 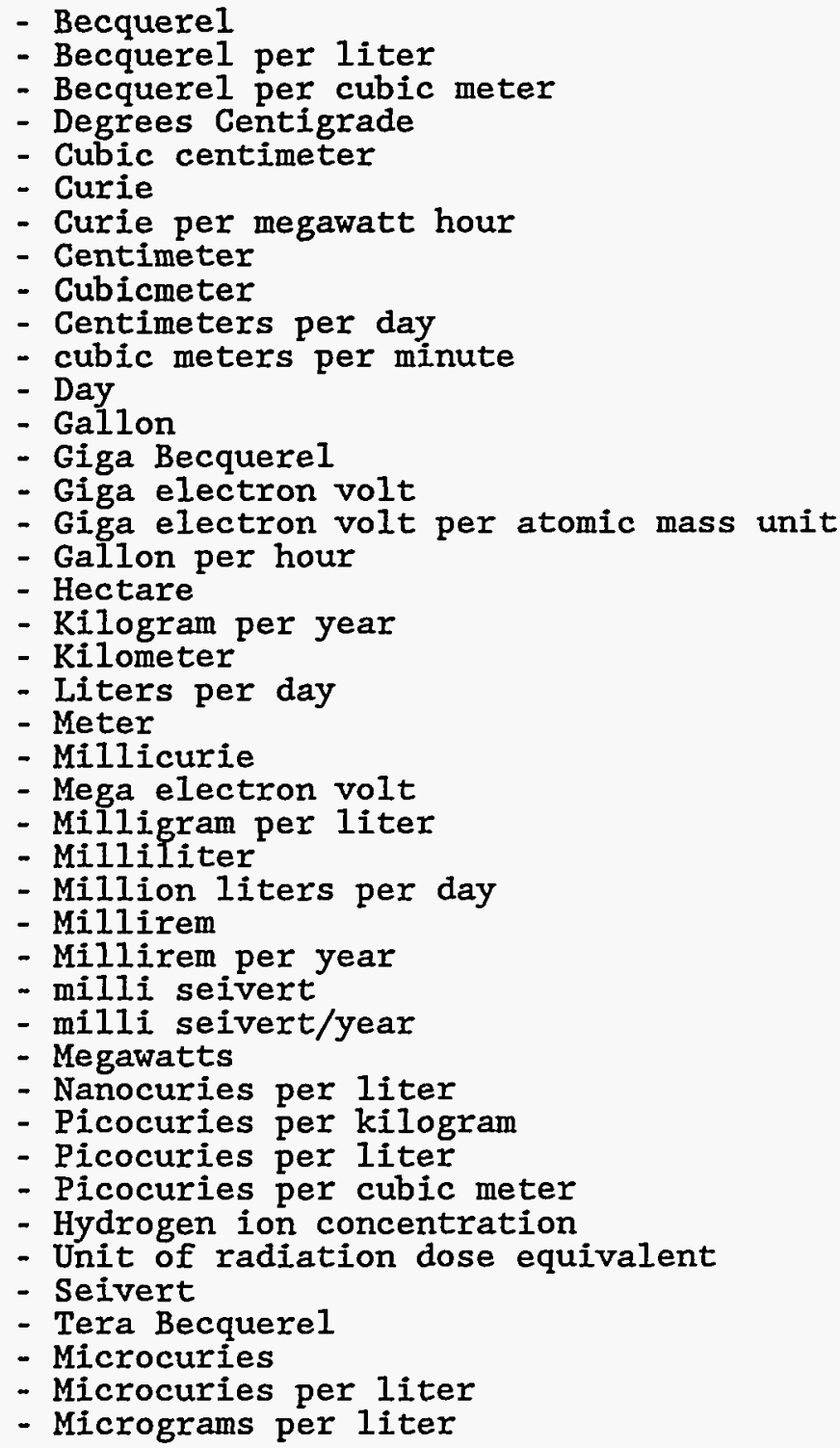 \\
\hline
\end{tabular}




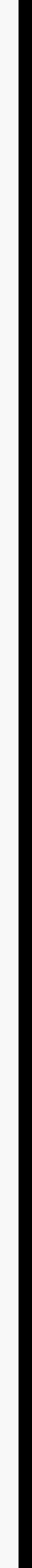


S. S. Chalasani, R. R. Gaschott, and G. I. Schroeder

\section{METHODOLOGIES}

1. Methodology for Dose Equivalent Calculations - Atmospheric Release Pathway

Dispersion was calculated for release elevations as listed in Table 4-1, at each of the 16 directional sectors, and for 6 distance increments (site boundary, $1.6-16 \mathrm{~km}, 16-32 \mathrm{~km}, 32-48 \mathrm{~km}, 48-64 \mathrm{~km}$, and $64-80 \mathrm{~km}$ ) from the center of the site using CAP88. The 1990 site meteorology as measured at 10 and 100 meter elevations was used to calculate the annual average dispersion for the midpoint of a given sector and distance. The radionuclide specific release rates (Ci/yr) from the HFBR stack, the Chemistry Building roof vent, the Van de Graaff roof vent, the BLIP stack, and the Hazardous Waste Management Incinerator stack were used to determine the annual emission rate for each radionuclide. The site boundary and collective data were obtained from the CAP88 computer code printout. The CAP88 calculates the total dose due to contributions from the submersion, ingestion, shoreline, and recreational pathways as a result of an atmospheric release. In 1990, two percent of the tritium atmospheric release from the 100 m stack was added to the 10 meter tritium source term in an effort to account for down-draft at the 100 meter stack.

2. Method for Tritium Dose Equivalent Calculations - Potable Water Ingestion Pathway

The method used to calculate the maximum individual committed effective dose equivalent and the collective dose equivalent are present along with the basic assumptions used in the calculation. For the maximum individual, the highest annual average tritium concentration, as measured from a single potable well was used to calculate the total quantity of tritium ingested via the drinking water pathway. For the collective dose equivalent calculation, the annual average tritium concentration was obtained by averaging all positive results from potable wells which were in the demographic region adjacent to the Laboratory. The annual intake of tritium via the drinking water pathway was calculated from the following equation:

$$
\mathrm{AI}=1 \times 10^{-6} \mathrm{C} \cdot \mathrm{IR} \cdot \mathrm{T}
$$

where: $\mathrm{AI}=$ Activity Intake, $\mu \mathrm{Ci}$

$\mathrm{C}=$ annual average water concentration, $\mathrm{pCi} / \mathrm{L}$

$I R=$ Ingestion Rate (2) $L / d$

$T=$ Time, $365 \mathrm{~d}$

The committed effective dose equivalent was calculated from the following equation:

$$
\mathrm{H}=\mathrm{AI} \cdot \mathrm{DCF} \cdot \mathrm{P}
$$

where: $\mathrm{H}=$ committed effective dose equivalent, rem

$\mathrm{AI}=$ Activity Intake, $\mu \mathrm{Ci}$

$\mathrm{DCF}=$ Dose Conversion Factor, Rem $/ \mu \mathrm{Ci}$ (6.3E-5 rem $/ \mu \mathrm{Ci}$ )

$P=$ Population at risk 
To determine the maximum individual dose, the population parameter was set to unity. For the collective dose calculation, the population at risk in this area was assumed to be approximately 500 .

\section{Methodology for Dose Equivalent Calculations - Fish Ingestion Pathway}

In order to estimate the collective dose equivalent from the fish consumption pathway, the following procedure was utilized:

a. Radionuclide data for fish samples were all converted to $\mathrm{pCi} / \mathrm{kg}$ wet weight, as this is the form in which the fish is used.

b. The average fish consumption for an individual who does recreational fishing in the Peconic River was based on a study done by the NYSDEC which suggests that the consumption rate is $7 \mathrm{~kg} / \mathrm{yr} .{ }^{42}$

c. Committed Dose Equivalent Tables ${ }^{43}$ were used to get the 50 year Committed Dose Equivalent Factor - rem/ $\mu \mathrm{Ci}$ intake.

identified were:

The factors for the ingestion pathway for the radionuclides

$$
\begin{aligned}
& { }^{3} \mathrm{H}: \quad 6.3 \mathrm{E}-05 \mathrm{rem} / \mu \mathrm{Ci} \text { intake } \\
& { }^{90} \mathrm{Sr}: \quad 1.3 \mathrm{E}-01 \mathrm{rem} / \mu \mathrm{Ci} \text { intake } \\
& { }^{137} \mathrm{Cs} \text { : } \quad 5.0 \mathrm{E}-02 \mathrm{rem} / \mu \mathrm{Ci} \text { intake }
\end{aligned}
$$

d. Calculation:

Intake $(7 \mathrm{~kg} / \mathrm{yr}) \times$ Activity in flesh $\mu \mathrm{Ci} / \mathrm{kg}$

$\mathrm{x}$ Factor rem $/ \mu \mathrm{Ci}$ intake $=$ rem

e. Because there is a cesium-137 background as determined by the control location data, this background was subtracted from all data prior to use for dosimetric purposes.

f. As the strontium-90 analyses of fish samples were delayed, an estimate of strontium-90 concentrations in fish for 1992 were obtained by determining a cesium-137: strontium-90 ratio from cesium-137 and strontium-90 data of previous years. This factor was then used to estimate the strontium-90 concentration for use in dosimetric assessment.

\section{Data Processing}

Analytical results of the environmental and effluent monitoring programs are reported in tables that accompany the text. The data presented in these tables were generated as described below.

First, gross alpha, beta, and tritium results are reported as the net measured quantity. When only one sample was analyzed, results could be positive, zero, or negative. When the average concentration is reported, the average was computed by averaging the volume-weighted measured quantity. Because measured quantities were used throughout the report for these parameters, the reader should examine Appendix $C$ to determine the typical analytical sensitivity for a particular parameter prior to deciding the importance of a result. Data which are less than the Minimum Detection Concentration (MDC) of the analytical technique should not be considered as positive results. Only data which exceed the MDC were used as positive results. 
Second, gamma spectroscopy, strontium-90, and chemical analytical results were not converted to the new data presentation format; measured concentrations that were less than or equal to the MDC, while reported, were not used to compute average concentration levels. AlI MDC values were evaluated as if the results were zero. This explains occasional instances where the MDC is several times larger than the calculated annual average concentration.

Finally, if an analysis was performed and the result was less than the MDC of the system, the concentration was generally reported as not detected (ND). Appendix $C$ presents typical MDCs for the analyses performed on environmental and effluent samples.

The following is a list of typical Minimum Detectable Limits (MDL) and Concentrations for the various analyses performed on environmental and effluent samples.

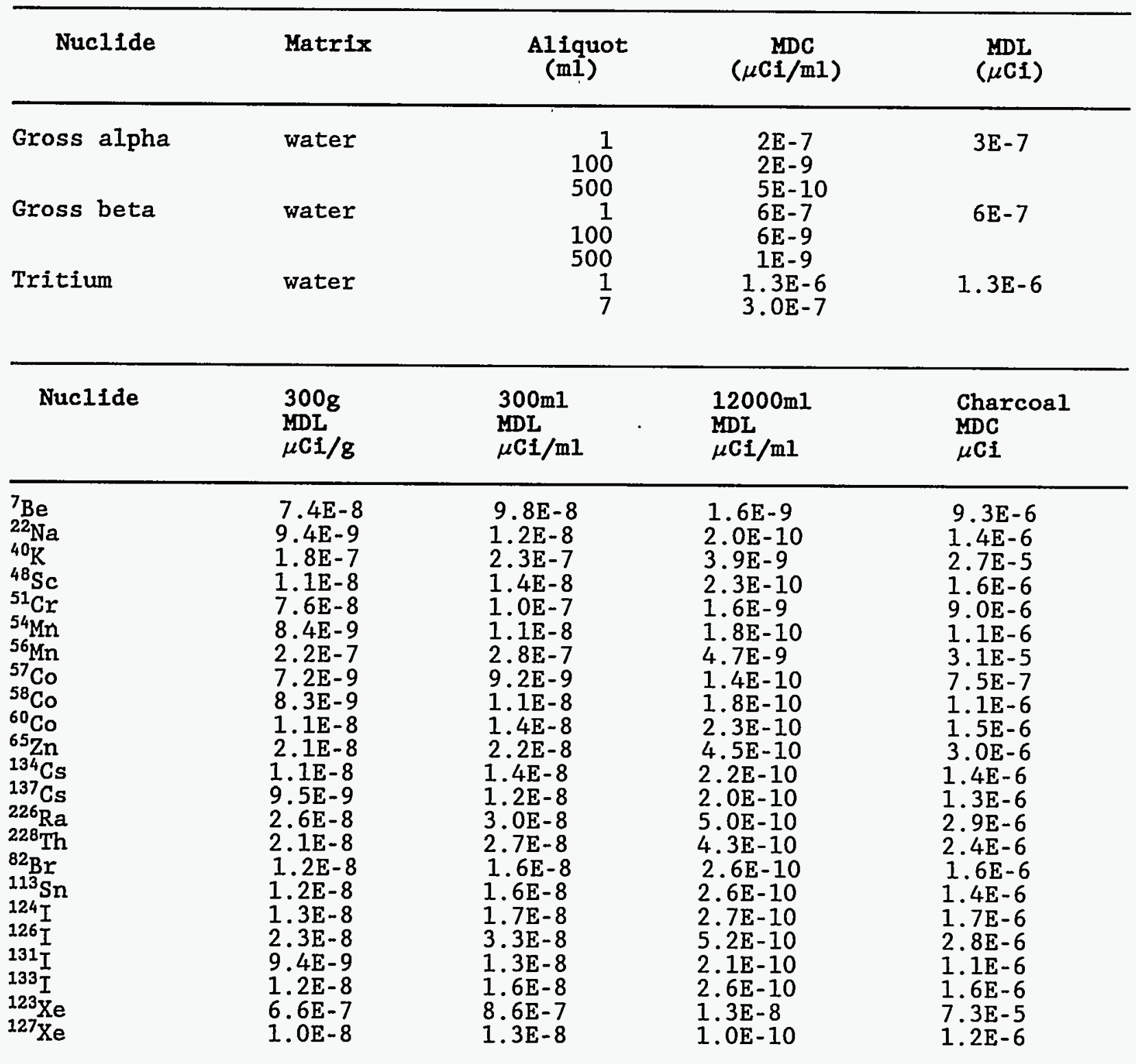


(All concentration values

in $\mathrm{mg} / \mathrm{L}$ except where noted)

BNL

OFF-SITE

$\mathrm{Ag}$
$\mathrm{Cd}$
$\mathrm{Cr}$
$\mathrm{Cu}$
$\mathrm{Fe}$
$\mathrm{Hg}$
$\mathrm{Mn}$
$\mathrm{Na}$
$\mathrm{Pb}$
$\mathrm{Zn}$
$\mathrm{Ammonia}-\mathrm{N}$
Nitrite-N
Nitrate-N
Specific Conductance
Chlorides
Sulfates
1,1,1-trichloroethane
trichloroethylene
tetrachloroethylene
chloroform
chlorodibromomethane
bromodichloromethane
bromoform
benzene
toluene
xylene

$\begin{array}{ll}0.025 & 0.010 \\ 0.0005 & 0.005 \\ 0.005 & 0.010 \\ 0.050 & 0.025 \\ 0.075 & 0.100 \\ 0.0002 & 0.0002 \\ 0.050 & 0.015 \\ 1.0 & 5.0 \\ 0.005 & 0.003 \\ 0.02 & 0.020 \\ \mathrm{NA} & 0.02 \\ \mathrm{NA} & 0.01 \\ 1.0 & \mathrm{NA} \\ 10 \mu \mathrm{Nmhos} / \mathrm{cm} & \mathrm{NA} \\ 4.0 & \mathrm{NA} \\ 4.0 & \mathrm{NA} \\ 0.002 & 0.005 \\ 0.002 & 0.005 \\ 0.002 & 0.005 \\ 0.002 & 0.005 \\ 0.002 & 0.005 \\ 0.002 & 0.005 \\ 0.002 & 0.005 \\ 0.002 & 0.005 \\ 0.002 & 0.005 \\ 0.002 & 0.005\end{array}$




\section{APPENDIX $C$}

INSTRUMENTATION AND ANALYTICAL METHODS

\section{S: S. Chalasani and R. R. Gaschott}

The analytical laboratory of S\&EP Division is divided into 1) radiological, and 2) nonradiological sections to facilitate analysis of specific parameters in each category. The following analytes are analyzed in each category.

1) Radiological: Gross alpha, gross beta, gamma, tritium, and strontium-90.

2) Nonradiological: Purgeable aromatics, Purgeable halocarbons, PCBs, anions, and metals.

A brief description of methods and instrumentation for each category is given below. Only validated and regulatory referenced methods are used during the analysis. All samples are collected and preserved by trained technicians according to appropriate referenced methods. Well qualified and trained analysts are involved in performing different analysis. The analytical laboratory is certified by NYSDOH for all radiological and nonradiological parameters, except for PCBs. The radiological laboratory participates in:

\section{1a) Gross Alpha and Gross Beta Analysis - Water Matrix}

Water samples are collected in one liter polyethylene containers. No preservatives are added prior to sample collection. If the samples are effluent or surface stream samples from Locations DA, EA, HM, or HQ or Building 535B daily process samples then $100 \mathrm{ml}$ are extracted for analysis. Ground water samples are typically analyzed using a $500 \mathrm{ml}$ aliquot. Due to high iron content, $100 \mathrm{ml}$ aliquots of ground water samples from the landfill areas may be used in this analysis. The aliquot is evaporated to near dryness in a glass beaker. The beaker is rinsed to remove the solids and the combined solids and rinsate are transferred to a $5 \mathrm{~cm}$ diameter planchet. The planchettes are evaporated to dryness, allowed to cool and then are counted in a gas flow proportional counter for 50 minutes. Samples are normally processed in batch mode. The first sample of each batch is a background that is subtracted from the raw data prior to computation of net concentration. System performance is checked daily with an americium-241 and chlorine-36 source.

\section{1b) Gross Alpha and Gross Beta Analysis - Air Particulate Matrix}

Air particulate samples are collected on $50 \mathrm{~mm}$ filters at a nominal flow rate of 15 liters per minute. At the end of the collection period, particulate filters are returned to the analytical laboratory for assay. Filter papers are counted twice in a gas flow proportional counter for 50 minutes. The first count occurs immediately upon receipt in the analytical laboratory. This count is used to screen the samples for unusual levels of air particulate activity. The filters are then recounted approximately one week later. The week delay permits decay of the short-lived radon/thoron daughters. The second analysis is used for environmental assessments. The first sample of each batch is a blank filter paper that is subtracted from the raw data prior to computation of net concentration. System performance is checked daily with an americium-241 and chlorine-36 source.

\section{1c) Tritium Analysis - Water Matrix}

Water samples are collected in one liter polyethylene containers. No preservatives are added prior to sample collection. If the samples are effluent or surface stream samples from Locations DA, EA, HM, or HQ or Building 535B daily process samples then $1 \mathrm{ml}$ is extracted for analysis. Ground water and potable water samples are typically analyzed using a $7 \mathrm{ml}$ aliquot. Liquid scintillation cocktail is then added to the sample aliquot so that the final volume in the liquid scintillation counting vial is 1 or $7 \mathrm{ml}$ of sample plus $10 \mathrm{ml}$ of cocktail. Samples are then counted in a low background liquid scintillation counter for 50 
to 100 minutes. Samples are normally processed in batch mode. The first sample of each batch is a background that is subtracted from the raw data prior to computation of net concentration. The second sample in each batch is a standard that is used to compute system performance and efficiency. Each sample is also checked for quenching. Corrections for background, quenching, and current system efficiency for the sample matrix and size are factored into the final net concentrations for each sample.

\section{1d) Tritium Analysis - Air Matrix}

Ambient and facility tritium air concentrations are measured by drawing the air at a rate of approximately $200 \mathrm{cc} / \mathrm{m}$ through a desiccant. At the end of each collection period, typically one week, the desiccant is brought to the analytical laboratory for processing. The desiccant is dried in a glass manifold system. Effluent samples have dedicated glassware as do environmental samples. The off gas containing moisture from the sampled air is collected by means of a liquid nitrogen trap. This water is then assayed for tritium content. A $7 \mathrm{ml}$ aliquot is used for analysis. Liquid scintillation cocktail is then added to the sample aliquot so that the final volume in the liquid scintillation counting vial is 17 ml. Samples are then counted in a low background liquid scintillation counter for 100 minutes. Samples are normally processed in batch mode. The first sample of each batch is a background that is subtracted from the raw data prior to computation of net concentration. The second sample in each batch is a standard that is used to compute system performance and efficiency. Each sample is also checked for quenching. Corrections for background, water recovery, air sample volume, quenching, and current system efficiency for the sample matrix and size are factored into the final net concentrations for each sample.

\section{1e) Strontium-90 Analysis}

Strontium-90 analyses are currently performed on water, soil, and aquatic biota samples. Water samples are processed in house using an EPA procedure adjusted in sample volume and counting time to meet MSL requirements. The procedure uses a ion-exchange column separation and isolation of the strontium-90 in a strontium carrier. Samples are prepared in batches. Chemical recovery is determined for each sample by the recovery of strontium carbonate. The use of batch blanks and counting system factors are used to verify the performance of the analytical system. The samples are counted twice to determine the strontium90 and yttrium-90 ingrowth.

Samples of solids are shipped to a contractor laboratory for analysis of strontium-90. The analysis proceeds by using the HASL-300 procedure which utilizes wet chemistry techniques to isolate strontium-90 from the sample. Samples are counted twice to verify strontium-90 and yttrium-90 ingrowth. Chemical recoveries are determined by a combination of gravimetric and strontium85 standard addition techniques. Samples are typically process in a batch. Backgrounds and system performance are verified with each batch. Chemical recoveries for both strontium-90 and yttrium-90 are determined for each sample.

\section{1f) Gamma Spectroscopy Analysis}

Surface, potable, and ground water surveillance samples are typically 12 liter samples that are placed in polyethylene bottles without preservatives. Samples are then passed through a mixed bed ion exchange column at a rate of 20 $\mathrm{cc} / \mathrm{m}$ until all 12 liters have passed through the column. The column is then removed, placed in a teflon coated aluminum can, and counted for 50,000 seconds. Where effluent sampling is performed in a flow proportional manner, $10 \mathrm{cc}$ aliquots are passed through the mixed bed column on an as needed basis. Typically samples sizes for this type of sample tend to approach the 50 to 100 liter size. Air particulate filter papers are counted directly on the detector for 10,000 seconds. Charcoal filter canisters are also counted directly on the detector with a count time of 10,000 seconds. Soil, vegetation, and aquatic 
biota are all processed following collection. Typically, $50 \mathrm{~g}, 100 \mathrm{~g}$, or $300 \mathrm{~g}$ aliquots are taken, placed in a teflon lined canister, and directly counted. For gamma spectroscopy analyses, backgrounds are collected once per week and system performance is verified daily. Analytical results reflect net activity that has been corrected for background and system response of the detection medium.

\section{2a) Purgeable Aromatics and Purgeable Halocarbons}

Water samples are collected in $40 \mathrm{ml}$ glass vials with removable teflonlined caps without any headspace and stored at $4^{\circ} \mathrm{C}$ and analyzed within 14 days.

Ten (10) purgeable compounds (benzene, toluene, ethyl benzene, total xylenes, chloroform, 1,1-dichloroethane, 1,1-dichloroethylene, tetrachloroethylene, 1,1,1-trichloroethane, and trichloroethylene) are analyzed under this category following EPA Method 624 protocols using GC/MS. These ten compounds were chosen as the target compounds since they are known or suspected to be present in the monitoring wells based on the DOE survey of the site in 1988 and a comprehensive analysis of 51 new monitoring wells using EPA's Contract Laboratory Program (CLP) ${ }^{41}$ procedures in 1989. There are currently two HewlettPackard GCMS instruments. One instrument is exclusively used for the analysis of purgeable compounds and the other for screening extractables and other extraneous compounds in non-routine samples. Since ground water under BNL is classified as a sole source aquifer, the detection limits reported for the compounds are close to drinking water standards.

The method involves purging a $25 \mathrm{ml}$ aliquot of the sample with ultra pure helium in a specially designed sparger using Purge and Trap technique. Each sample is spiked with known concentration of internal standards and surrogates before purging to facilitate identification, quantitation, and determination of the extraction efficiency of analytes from the matrix. The purged analytes are trapped on to a specially designed trap and thermally desorbed on to the DB -624 megabore capillary chromatographic column by back flushing the trap with helium. The compounds are separated into individual compounds with a temperature program of the GC and enter the mass spectrometer where they undergo fragmentation to give characteristic mass spectra. The unknown compounds are identified by comparing their mass spectra and retention times with reference compounds, and quantitated by internal standard method. The quantitation data is supported by extensive amount of $\mathrm{QA} / \mathrm{QC}$ such as tuning mass spectrometer to meet bromofluorobenzene criteria, initial and continuing calibrations verifying daily response factors, method blanks, surrogate recoveries, duplicate analysis, matrix spike and matrix spike duplicate analysis and performing reference standard analysis to verify the daily working standard.

\section{2b) PCB Analysis}

Samples are collected in 50-100 ml glass containers with teflon-lined lid and stored at $4^{\circ} \mathrm{C}$ and analyzed within $14^{\text {days. }}$

Transformer oil, mineral oil, hydraulic fluid, waste oil, and spill wipe samples are analyzed for PCBs using gas chromatography-electron capture detector (GC-ECD) method. This method is similar to EPA SW-846 method 8080 and is targeted to identify and quantitate seven different mixtures of PCB congeners in the samples.

The method consists of diluting a known weight of the sample with isooctane and removing the interfering compounds with one or more aliquots of concentrated sulfuric acid till the acid layer is almost colorless. All the oil matrix along with other interfering polar compounds are selectively removed from the sample, leaving PCBs in isooctane solvent.

There are two GC-ECD instruments for the analysis of PCBs. Each GC-ECD instrument is calibrated with different concentrations of each PCB mixture to establish linearity. The PCBs found in the samples are identified and quantitated by comparing the retention times and chromatographic patterns with 
the standards. Methods blanks, duplicates, spikes, and reference standards are run as part of $Q A / Q C$.

\section{2c) Anions}

Chloride, nitrate- $\mathrm{N}$, and sulfate are analyzed using Dionex Ion-chromatography (IC) with ion suppression and conductivity detection technique.

Monitoring well samples are collected in $500-1000 \mathrm{ml}$ polypropylene bottles, cooled to $4^{\circ} \mathrm{C}$, and analyzed within 28 days. For nitrate analysis in drinking water analysis, samples are supposed to be analyzed within 48 hrs. However, even though holding times were exceeded for nitrate analysis of monitoring well samples, it is expected that the depletion of nitrate will be negligible.

The anions are passed through an anion-exchange polymer column and eluted with carbonate/bicarbonate solution. Then the eluent passes through a ionsuppressing column where the background contribution from the eluent is suppressed, leaving the target anions to be detected by conductivity meter.

Initially, the IC system is calibrated with standards to define the working range of the system. The target anions in the samples are identified and quantitated by comparing the retention times and areas with the standards. Method blanks, duplicates, replicates, spikes, and reference standards are routinely analyzed as a part of QA/QC.

\section{2d) Metals}

Samples are collected in $1000 \mathrm{ml}$ polypropylene bottles and stabilized with ultra-pure nitric acid to a $\mathrm{pH}$ of $<2$. The samples are analyzed within 6 months, except for mercury, in which case the samples are analyzed within 26 days.

Cadmium, chromium, lead (furnace), copper, iron, manganese, silver, sodium, zinc (flame), and mercury (manual cold vapor) are analyzed with Perkin-Elmer atomic absorption spectrometer. Using the flame technique, the sample containing the target element is nebulized and atomized in an oxy-acetylene flame. At the same time, a beam of light from a element-specific hollow cathode lamp corresponding to the absorption frequency of target element is passed through the flame. The atomized element absorbs the energy specific to that element from the cathode lamp and the intensity of absorption is proportional to the concentration of the element in the sample. Calibration curves are run to establish the linearity of the system and samples are quantitated by comparing with standards.

Using the furnace technique, chemical interference is eliminated in two stages: first by heating the sample at 105 - $110^{\circ} \mathrm{C}$ to remove moisture and then at $600-900^{\circ} \mathrm{C}$ to burn out any organic matrix. Final atomization is achieved by heating the furnace to $2400-2700^{\circ} \mathrm{C}$. The rest of the technique is similar to the flame method mentioned above. Using this furnace technique, sub-ppb detection limits are possible for water samples.

Using cold vapor technique for mercury, a $100 \mathrm{ml}$ aliquot of the sample is digested with potassium permanganate/persulfate oxidizing solution at $95^{\circ} \mathrm{C}$ for 2 hours to oxidize any organically-bound and/or monovalent mercury to mercury (II) ion state. Excess oxidizing agent is destroyed with hydroxylamine hydrochloride. The mercuric ion later is reduced to elemental mercury with excess stannous chloride which is purged with helium into the absorption cell. The absorption is directly proportional to the concentration of mercury in the sample.

All the above mentioned atomic absorption techniques involve initial calibrations to define the calibration range, continuing calibrations, method blanks, duplicates, replicates, matrix spikes, and reference standard analysis as a part of $\mathrm{QA} / \mathrm{QC}$. 


\section{APPENDIX D}

\section{REFERENCES}

1. United States Department of Energy, "Radiation Protection of the Public and the Environment", DOE Order 5400.5, February 1990.

2. "Safe Drinking Water Act", New York State-Section 1414 (e): Aquifer Underlying Nassau and Suffolk Counties (NYS) designated as a sole source [U.S. EPA 42 USCA Section 3004-3 (e)].

3. "Safe Drinking Water Act:, Title XIV: Safety of Public Water Systems; Part C: Protection of Underground Sources of Drinking Water".

4. New York State of Environmental Conservation. Water Quality Regulations: NYCRR, Title 6, Chapter X, Part 703.6, Effluent Standards and/or Limitations for Discharges to Class GA Waters.

5. United States Environmental Protection Agency, Environmental Radiation Data Report 59, July - September, 1990, EPA 520/5-91-025, March 1991.

6. United States Environmental Protection Agency, Environmental Radiation Data Report 60, October - December, 1990, EPA 520/5-91-026, June 1991.

7. United States Environmental Protection Agency, Environmental Radiation Data Report 61, January - March, 1990 EPA 520/5-90-031, September 1990.

8. United States Environmental Protection Agency, Environmental Radiation Data Report 62, April - June, 1990, EPA 520/5-91-044, December 1990.

9. Brookhaven National Laboratory Environmental Monitoring Reports 1971-1987, Safety and Environmental Protection Division, BNL Report Nos. $17874,18625,19977,21320,22627,50813,51031,51252,51417,51697$, 51827, 51884, 51993, 52088, 52152, 52207, 52264.

10. Chapter 1 State Sanitary Code NYSDOH Part 5, Drinking Water Supplies Subpart 5-1 (Revised and adopted January 9, 1989).

11. New York State Department of Environmental Conservation, Classification and Standards Governing the Quality and Purity of Waters of New York State, Parts 700-703, 1978 .

12. United States Environmental Protection Agency, "National Interim Primary Drinking Water Regulations," 1975, Amended February 19, 1988.

13. United States Department of Energy, "Quality Assurance," Order No. 5700.6C, September 1986.

14. Brookhaven National Laboratory, "Quality Assurance Manual, " Revised March 1989.

15. Brookhaven National Laboratory, "Safety and Environmental Protection Quality Assurance Program Document", Revised May 1989.

16. Long Island Lighting Company Population Estimates, 1994.

17. Nagle, C. M., Climatology of Brookhaven National Laboratory: 1949-1973, BNL Report No. 50466, November 1975.

18. Nagle, C. M., "Climatology of Brookhaven National Laboratory: 1974 through 1977." BNL-50857, May, 1978. 
19. Warren, M. A., W. de Laguna, and N. J. Lusczynski, "Hydrology of Brookhaven National Laboratory and Vicinity," Geological Survey Bulletin $1156-\mathrm{C}, 1968$.

20. Cohen, P. H. et al., Atlas of Long Island Water Resources, New York State Resources Bulletin No. 62, 1969.

21. Clearlock, D. B. and A. F. Reisenauer, "Site-wide Ground Water Flow Studies for Brookhaven National Laboratory," BNL Informal Report, December 1971.

22. H2M, Holzmacher, McLendon, and P. C. Murrel, in Association with Roux Associates, Aquifer Evaluation and Program Design for Restoration. Submitted to BNL, June 1985.

23. Koppelman, L. Long Island Waste Treatment Management Plan, Vol. I and II, July 1978 .

24. Scheibel, Michael S. 1990. "Review of New York State Endangered Species Potentially Impacted by Construction of the RHIC at Brookhaven National Laboratory", Letter to Gerald C. Kinne, September 24, 1990.

25. Corin, Leonard P. 1990. "Review of Federally Threatened or Endangered Species Potentially Impacted by Construction of the RHIC at Brookhaven National Laboratory", Letter to Gerald C. Kinne, September 25, 1990.

26. New York Oil Spill, Control and Compensation Act, New York Navigation Law Article 12 .

27. New York State Environmental Conservation Law, Article 70 Part 621, Uniform Procedures Act.

28. Letter from C. J. Daggett (U. S. Environmental Protection Agency Region II) to D. Schweller (U. S. Department of Energy Brookhaven Area Office), Reference: PCB-Contaminated Fuel; Subject: U. S. Environmental Protection Agency Final Approval, January 21, 1986.

29. 6 NYCRR Part 596: Registration of Hazardous Substance Bulk Storage Tanks, July 1988 .

30. "Tiger Team Assessment of the Brookhaven National Laboratory", U. S. Department of Energy. DOE/EH-0140, June 1990.

31. Action Plan for the Tiger Team Assessment Report, Brookhaven National Laboratory, BNL 52258, Revision 3, October 15, 1990.

32. United States Department of Energy, "General Environmental Protection Program", Order 5400.1, November 1988.

33. Schroeder, G. L., and R. P. Miltenberger, "Brookhaven National Laboratory Environmental Monitoring Plan", 1991.

34. Personal Communications, L. Mausner, Medical Department, BNL, 1986.

35. Energy Research and Development Administration, Brookhaven National Laboratory, Final Environmental Impact Statement, July 1977.

36. Brookhaven National Laboratory, "Safety Manual", OSHA Guide 6.1.0, 1984.

37. Denham, D. M., et al., "A CaF2:Dy Thermoluminescent Dosimeter for Environmental Monitoring", BNWL-SA-4191, 1972. 
38. Budnitz, R. J., A. V Nero, D. J. Murphy, and R. Graven, "Instrumentation for Environmental Monitoring," Volume 1, Radiation, Second Edition, Lawrence Berkeley Laboratory, 1983.

39. United States Environmental Protection Agency Regulations on National Emission Standards for Hazardous Air Pollutants, 40 CFR 61 - Revised Federal Register Vol. 54, No. 240, December 1989.

40. National Council on Radiation Protection and Measurements, Recommendations on Limits for Exposure to Ionizing Radiation, NCRP Report No. 91, 1987.

41. "Compendium of Superfund Field Operations Methods", December 1987, U. S. Environmental Protection Agency, Washington, D.C.

42. New York State Department of Environmental Conservation, Personal Communication, Dr. F. Panek, 1985.

43. United States Department of Energy, "Internal Dose Conversion Factors for Calculation of Dose to the Public", July 1988 . 
Internal Distribution:

Department

ADD

AGS

BIOLOGI

BOOSTER

CEIMMISTRY

$\operatorname{cs}$

DAS

DAT

DIRECTOR'S

OFFICE

INSTRUMENTATION

MEDICAI

\section{Person}

S. Musolino

S. Ozaki

E. Lessard

D. I. Lowenstein

W. Sims

F. Wm studier

N. Tempel

W. Weng

C. Creutz

N. Satterley

R. Spellman

P. Carr

C. Krishna

J. Davenport

W. Becker

R. Bari

M. Bebon

M. Blume

M. Brooks

M. Davis

H. Grahn

T. Kirk

D. McWhan

M. Sakitt

N. Samios

R. Setlow

V. Radeka

D. Grabowski

D. Joel

G. Meinken
Department

NSLS

OER

OMC

PE

P\&GA

PHY

PUBLIC AFEAIRS

RD

S\&EP

S\&M

AUI

\section{Person}

N. Gmur

T. Dickinson

M. Hart

w. Gunther

B. Breitenstein

M. Sacker

W. Chaloupka

J. Medaris

E. Murphy

J. Laurie

B. Style

P. Bond

C. Carlson

J. Collins

K. Einfeldt

J. Throwe

A. Baittinger
D. Rorer

N. Houvener

W. Casey

J. Deitz

L. Emma

F. Marotta

R. Miltenberger

M. O'Brien

0 . White Safety

Representatives

M. Guacci

J. Hudis

L. Willis 
External Distribution:

\section{Dow Distribution:}

Office of Environmental Guidance and Compliance (EH-23) - 5 copies

office of Environmental Audit (EH-24) - 2 copies

Office of NEPA Project Assistance (EH-25) - 2 copies

Chicago Operations Office - 10 copies

Brookhaven Area Office - 10 copies

H. McCammon, Office of Health and Environmental Research - 1 copy

\section{ERA Distribution: (2 copies each)}

P. Giardina, Radiation Safety Program, U.S. EPA Region II

W. Gunther, U. S. EPA, Office of Radiological Programs, Washington, DC

J. Logsdon, U. S. EPA, Office of Radiological Safety Program

\section{New York State:}

R. Aldrich, NYS Department of Health (DOH)

R. Becherer, NYSDEC

R. Schneck, NYSDEC

R. Cowen, NYSDEC

C. Hamilton, NYSDEC

\section{Suffolk County:}

J. Baier, Suffolk County Department of Health Services (SCDHS)

M. Hibberd, SCDHS

D. Moran, SCDHS

J. Pim, SCDHS

P. Ponturo, SCDHS

G. Tarulli, SCDHS

M. Trent, SCDHS

G. Proios, Suffolk County Executive office

M. LoGrande, suffolk county Water Authority

R. Corwin, Suffolk County water Authority

\section{U.S. Congressman:}

M. Forbes

\section{General Distribution:}

B. Balke, Lawrence Livermore Laboratory

P. E. Bramson, Batelle Pantex

D. Brekke, Sandia National Laboratory

Hue-Su Hwang, Sandia National Laboratory

D. A. Cirrincione, Rocky Flats Plant

J. D. Cossairt, Eermilab

I. M. Eisenne, Environmental Measurements Laboratory

N. W. Golchert, Argonne National Laboratory

D. W. Grobe, Fermilab

W. R. Hansen, Los Alamos Scientific Laboratory

J. D. Heffner, Savannah River Laboratory

D. L. Hoff, Idaho National Engineering Laboratory

J. Hunter, Rutgers University

R. E. Jaquish, Pacific Northwest Laboratory 


\section{General Distribution: (cont'd)}

I. Koppelman, Nassau-Suffolk Regional Planning Board

B. Nemickas, United States Geological Survey

E. O'Connell, State University of New York, stony Brook

P. Rohwer, Oak Ridge National Laboratory

J. D. Sage, Bettis Atomic Power Laboratory

A. R. Seepo, Schnectady Naval Reactors office

I. Soholt, Los Alamos Scientific Laboratory

J. Soldat, Pacific Northwest Laboratory

R. K. Woodruff, Pacific Northwest Laboratory

J. Stencel, Princeton Plasma Physics Laboratory

NOTE: Additional reports are distributed to interested parties responding to the BNL press release that announces the issuance of the report. 
T- - $-\cdots$ 
